Historic, Archive Document

Do not assume content reflects current scientific knowledge, policies, or practices. 



\section{Wood's Lawn Grasses}

\section{To Make a Lawn}

Start the lawn as early as possible to give the grass a chance to become well establishod before the spring growth of weeds.

Remember when making a lawn that it is to last for years and be an ornament to are sown.

Plow or dig the sonl deeply. break up the lumps and apply either 4 pounds of Vigoro (the complese plant food) to each 100 square feet. or W o o d's $\mathbf{H}$ i g hGrade Sheep Manure at the rate of 10 pounds per 100 square feet. Work into the sosl, raking and cross raking until the soil is finely pulverized. Do not use fresh atable manure as it adds to the abundant supply of weeds and coarse grasses already in the soil. Sow the seeds broadcast. half one way and half at rught angles to give an even distribution. Sow when the air is calm: sowing in the wind causes an uneven stand Cover lightly by raking or rolling with a light roller Do not cover the seeds too deeply.

Start cutring when the young grass is about two inches high, and continue to cut regularly through the growing season. It not only keeps the grass trimlooking by preventing it from running to seed, but helps the root growth, and untold quantities of weeds. the seeda of which are naturally in your soil. will be prevented from sending up seed stalks. This rids your lawn of annual weeds and weakens the biennial and perennial ones.

Some weeds and coarse grasses yield only to individual attention. Cut them out wherever they appear (thcy may be taken out with a lawn weeder-see page 89), and scatter a few grass seeds to occupy the bare spots.

Two or three times a year, preferably when the days are cool, apply two pounds of Vigoro for each 100 square feet.

\section{Renewing Old Lawns}

A lawn can be kept thick and flourishing if at intervals the soil is stirred with a sharp rake snd more seeds sown. This should be done just after the grass has becu cut, or during a rainy spell. If rolled immediately after sowing the seeds will be better covered. Every spring and fall fresh seeds should be sown over the lawn to fill in bare spots and thicken the growth.

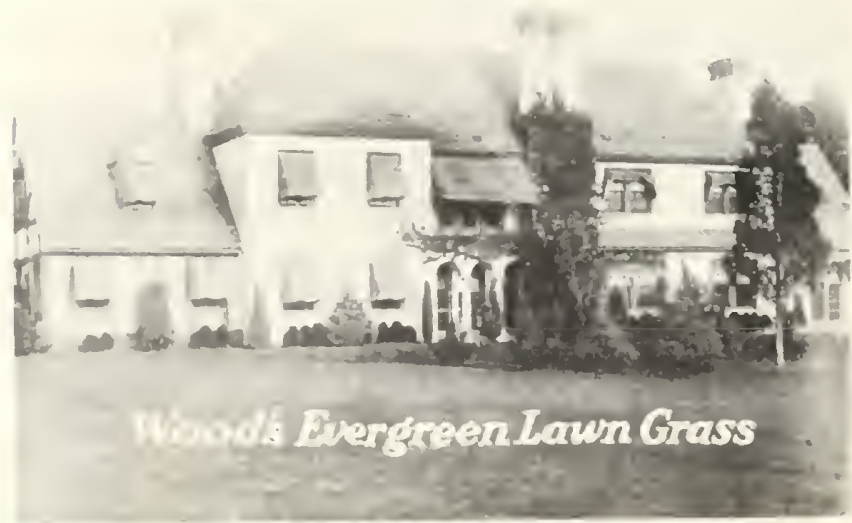

\section{Wood's Evergreen Lawn Grass}

1 lb. sows 200 square feet; 90 to 100 lbs. sow an acre

Our Fivcrgreen Lawn Grass is a mixture of grasses that are adapted to lawn makıng. and contains none of the conrse grasses nor those that grow in tufts or clumps. No one gran makes an ideal lawn grass, so we have put into our Evergreen a well-balanced mixture of grasses that are at their best during different months of the year, will give a beautiful green growth at all seasons, and will make a rich, deep grcen, vclvety lawn in ss short a time as possible. For years we have cxperimented with various grasses and combinations of grasses that are nuited so lawn making, and offer a lawn grass mixture that will give a thick and luxurinnt iurf, provided you follow the instructions given above and give your lawn the care and attention it deacrves.

In Virgina and further north, in the westcrly section of the Carolinas and fursher west. sow Wood'. Evergreen Lawn Grass; in other parts of the South Wood's Dixie Lawn Grans will be found more satisfactory.

By mail postpaid, 1 lb. $60 \mathrm{cta}$. : 5 lbs. \$2.55; 10 lbs. \$4.85; 25 lbs. $\$ 11.40$; $501 \mathrm{bs} . \$ 21.25$.

Nol postpaid, 1 lb. 50 cts.; 5 to 24 lbs. 45 cts. per lb. ; 25 to 99 lbs. 42 ets. per lb.; $100 \mathrm{lbs}$, and over $40 \mathrm{cts}$. per lb.

\section{Wood's Dixie Lawn Grass}

\section{Ilb. sows 200 square feet; 90 to $100 \mathrm{lbs}$. sow one acre}

This mixture is the result of a close and intimate study of grases suited to lawn making and such as are adapted to Southern soils and climate. Every grass suitable for lawn making will not stand the extreme heat and drought so often experienced in the South. so in selecting grasses for this mixture we have taken only those that will give a velvety green lawn under the most trying conditions of summer heat and drought when lawns often become brown and parched. In the easterly section of the Carolinas, and throughout the other states of the far South sow Wood's Dixio Lawn Grass; in Virginia and further north and in the westerly aection of the Carolinas and further west sow Wood's Evergreen Lawn Grass. By mail postpaid, 1 lb. 50 cts.; 5 lbs. \$2.20; 10 lbs. \$4.15; 25 lbs. $\$ 9.90 ; 50$ ibs. $\$ 18.75$.

Not postpaid, lb. $40 \mathrm{cts}$; 5 to 24 lbs. $38 \mathrm{cts}$. per lb.; 25 to 99 lbs. $37 \mathrm{cts}$. per lb.; 100 lbs. and over 35 cts. per lb.

\section{Shady Park Lawn Grass}

The problem of growing fine grass in shady locations has always been a difficult one. Only a few grasses will grow satisfactorily under such conditions. Among the grasses best adapted to this purpose are Poa Trivialis and Red Fescue. These grassea should be the base of all mixtures for shady lawns and woods. Shady Park Lawn Grass contains a large proportion of these two grasses besides other adapted turf-making grasses that will blend and make a thick velvety sod. By mail postpaid, 1 lb. $60 \mathrm{cts} . ; 5$ lbs. $\$ 2.55 ; 10$ lbs. $\$ 4.85 ; 25$ lbs. $\$ 11.40$; 50 Ibs. $\$ 21.25$.

Not postpaid, lb. $50 \mathrm{cts}$; 5 to 24 lbs. $45 \mathrm{cts}$. per lb.; 25 to 99 lbs. $42 \mathrm{cts}$. per lb.; $100 \mathrm{lbs}$. and over $40 \mathrm{cts}$. per lb.

\section{Wood's Emerald Park Lawn Grass}

A blended mixture of fine quick growing grasses that are adapted to the Middl and South Atlantic States. It contains no Bermuda Grass, carpet grass, nu any of the coarse grasses, nor those that grow in tufts. It is a good, all-rouni general purpose lawn grass mixture.

By mail postpaid, lb. 45 cts.; 5 lbs. \$2.10; 10 lbs.\$3.95; 25 lbs. \$9.15 50 lbs. $\$ 17.25$

Not post paid, lb. 38 cts.; 5 to 24 lbs., 36 cts. per lb.; 25 to 99 lbs., 34 ct per lb.; 100 lbs. and over, 32 cts. per lb.

\section{White Dutch Clover}

\section{For Lawns}

Makes a small, close, compact growth, covering the ground like a carpet. Sow either in the spring or fall. When sown by itself, sow 5 to 6 pounds per acre: it is better, however. sown in mixture with other grasses.
paid, lb. $50 \mathrm{cts} . ; 5 \mathrm{lbs}$ \$2.30; $10 \mathrm{lbs} . \$ 4.35 ; 25 \mathrm{lbs}$. $\$ 10.15$.

Not prepaid, lb. 43 cts.; 5 lbs. \$2.00; 10 lbs. \$4.00.

\section{Wood's Fair Green Fertilizer}

A complete grass food, a nalyzi ng 8 per cent ammonia. 7 per cent available phosphoric acid. 5 per cent potash. that will produce quickly a fine green turf. Apply two pounds to 100 square feet of lawn: on large areas apply 400 pounds to the acre.

100-lb. bag \$3.25: ton $\$ 60.00$.

\section{Wood's High Grade Sheep Manure}

A pure natural manure that will give quick results on lawns, roses and pot plants. It is a well-balanced plant food that will promote a rapid and steady growth. It is dried and pulverized, clean and easily handled, no weeds, straw and refuse. Do not use stable manure on your lawn-it is disagreeable to handle. is unsightly, but worse still, it fills the ground with weeds that will be hard to get rid of that are naturally of stronger growth than grasses, and will choke out the grass if allowed to remain and spread. besides making the lawn unsightly.

On new lawns apply 10 lbs, to 100 square feet: as a top dressing, 10 lbs. to 200 square feet.

Not prepaid, 25 lbs., 85 cts.; 50 lbs., $\$ 1.40 ; 100$ lbs., $\$ 2.50 ; 500$ lbs., $\$ 11.75$; ton; $\$ 45.00$.

\section{Vigoro}

\section{A Complete Food for Lawns, Shrubs, Gardens and Trees}

A good lawn requires proper nourishment, for grass, like human beings. must be fed. Vigoro is fine for flowers, vegetables. shrubs and trees, and supplies a well-balanced plant food that will give the grass a quick and vigorous start and weep the lawn healthy, velvety and green. A liberal use of Vigoro helps to develop a strong root growth and practically insures a beautiful lawn the first season. It is clean, odorless, can be applied by hand like sowing grass seeds. and costs onl y 20 to $25 \mathrm{cts}$. for 100 square feet. In the spring or fall apply $4 \mathrm{lbs}$ per 100 squa re feet and every six or eight weeks during the summer apply hal this quantity. 5-lb. package, 50 cts. (by mail postpaid, 70 cts.); 25-lb. bas, $\$ 1.75 ; 50 \mathrm{lbs}$. $\$ 3.00 ; 100$ lbs. $\$ 5.00$. Freight allowed on 100 lbs. or more. 


\section{W SEEDS}

\section{T. W. WOOD \& SONS, SEEDSMEN W. WOOD \& SONS, RICHMOND, VA.}

Our Guarantee Wood's Seeds are thorogghly recleaned, tested and of the highest quality We guarantee them to be as represented in purity, germination, weed seed content and origin up to the full amount of the purchase price. Owing to many fac tors over which we have no control, such as weather, soll and seeding conditions, we can-

not guarantee a crop. stay in business and grow. But we cannot control planting and cultural methods and weather and soil conditions, all of which affect the outturn of crops.
Please forward the following as per terms of your Descriptive Catalog to

Name

(Ladies, please prefix Miss or Mrs.; the latter use husband's initials. Write name and address very plainly.)

Post Office

State

R. . D. No.

Box. No.

County

Express Office (If different

Frels Topot..

If different

State

State you want goods shipped

by pli ; an $\bar{X}$ in proper space. \begin{tabular}{|l|l} 
Parcel Post. & Express. \\
\hline
\end{tabular}

Frolght.
AMOUNT ENCLOSED

Dato

P. O. Order

Express Order

Check or Draft

Cash

Stamps

Total
Do not write in this space

Prices, especially field seeds, onion sets, fertlizers and poultry foods, are subject to market changes.

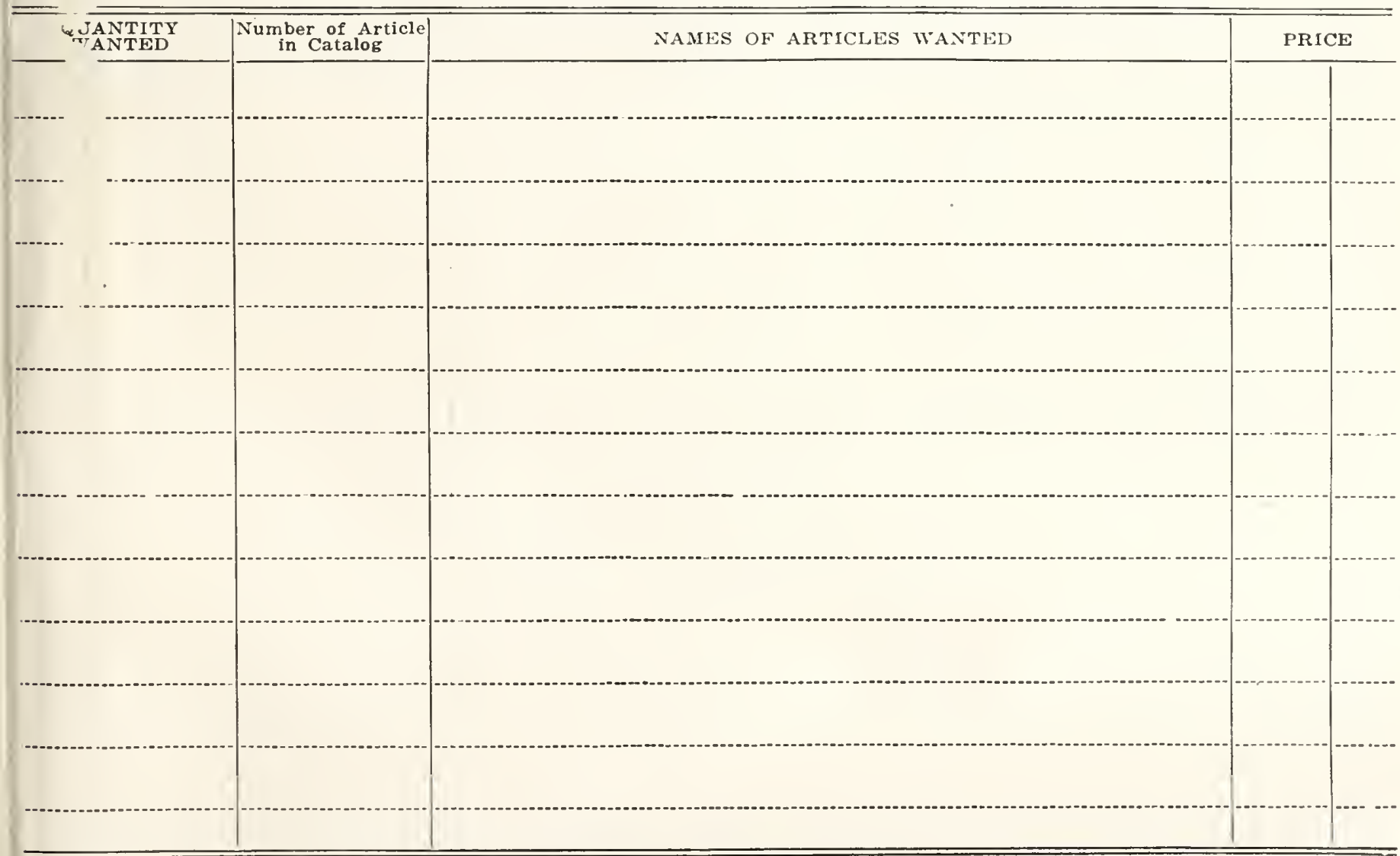




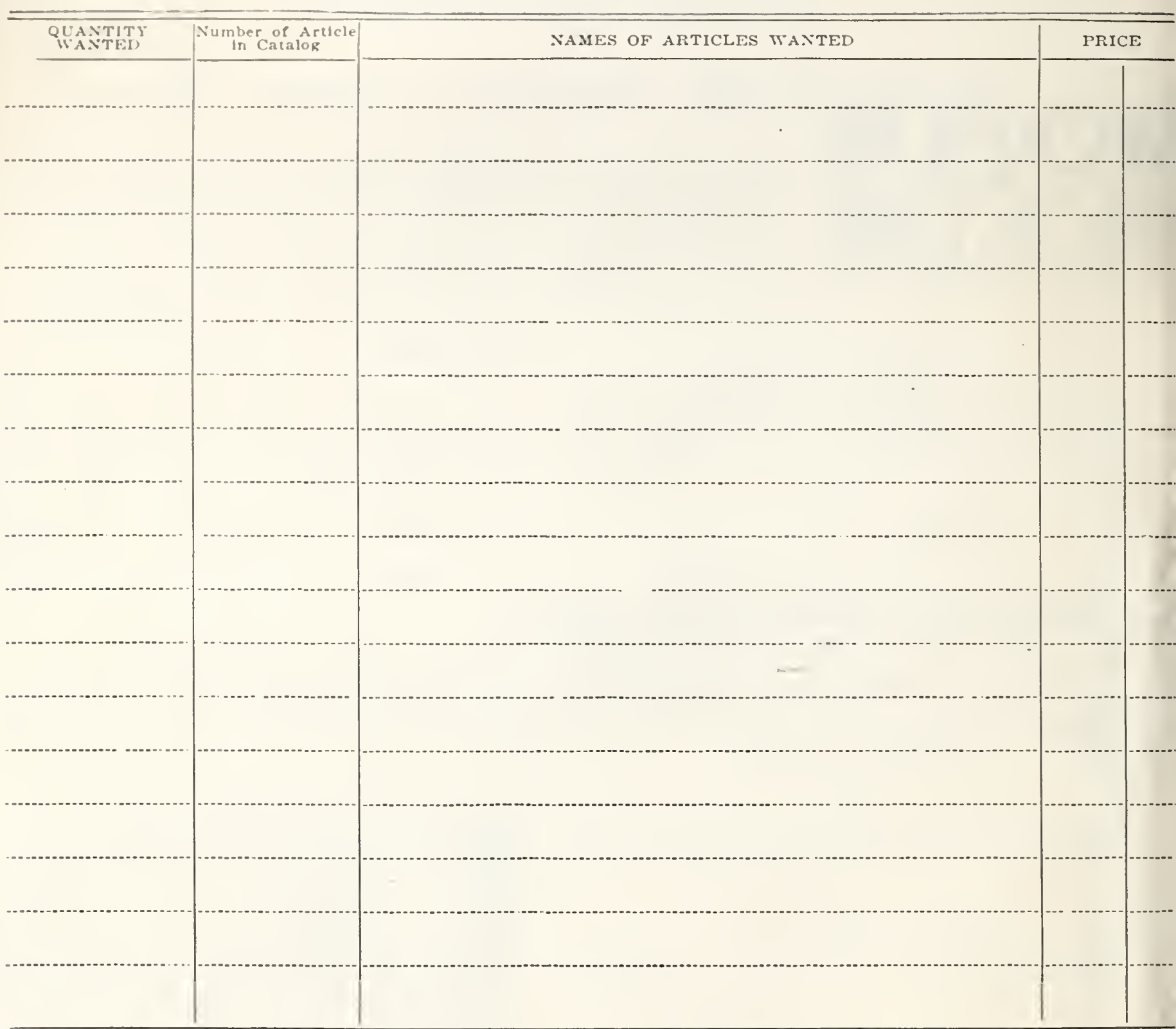

Eindly give bolow the names of any friends or nelghbors who you think would be interested in recelving our catalog:

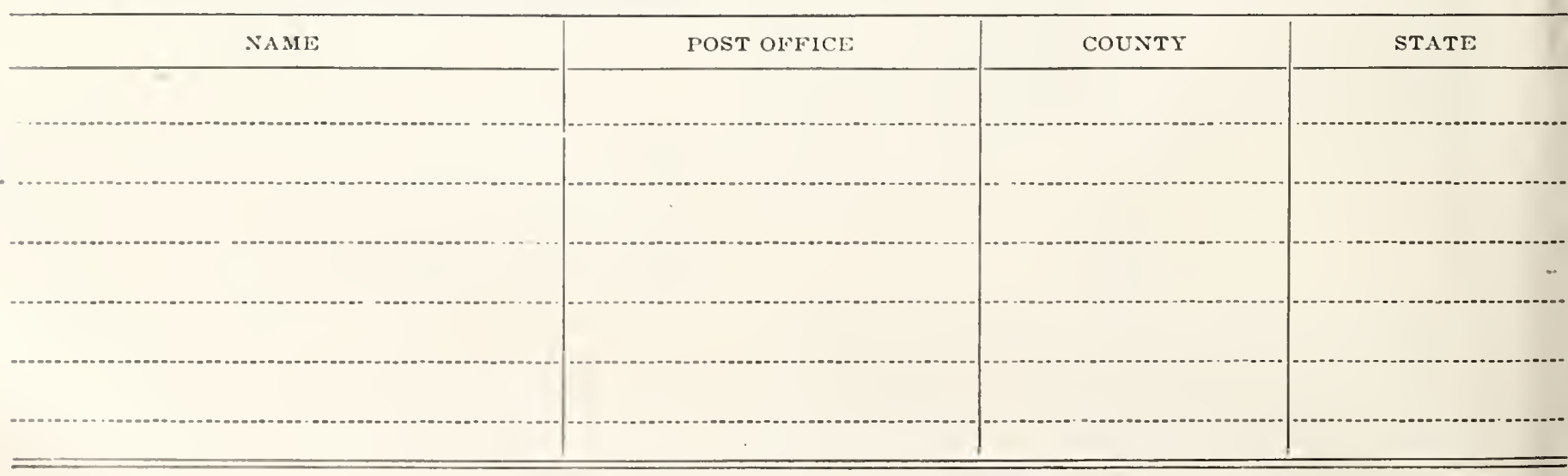




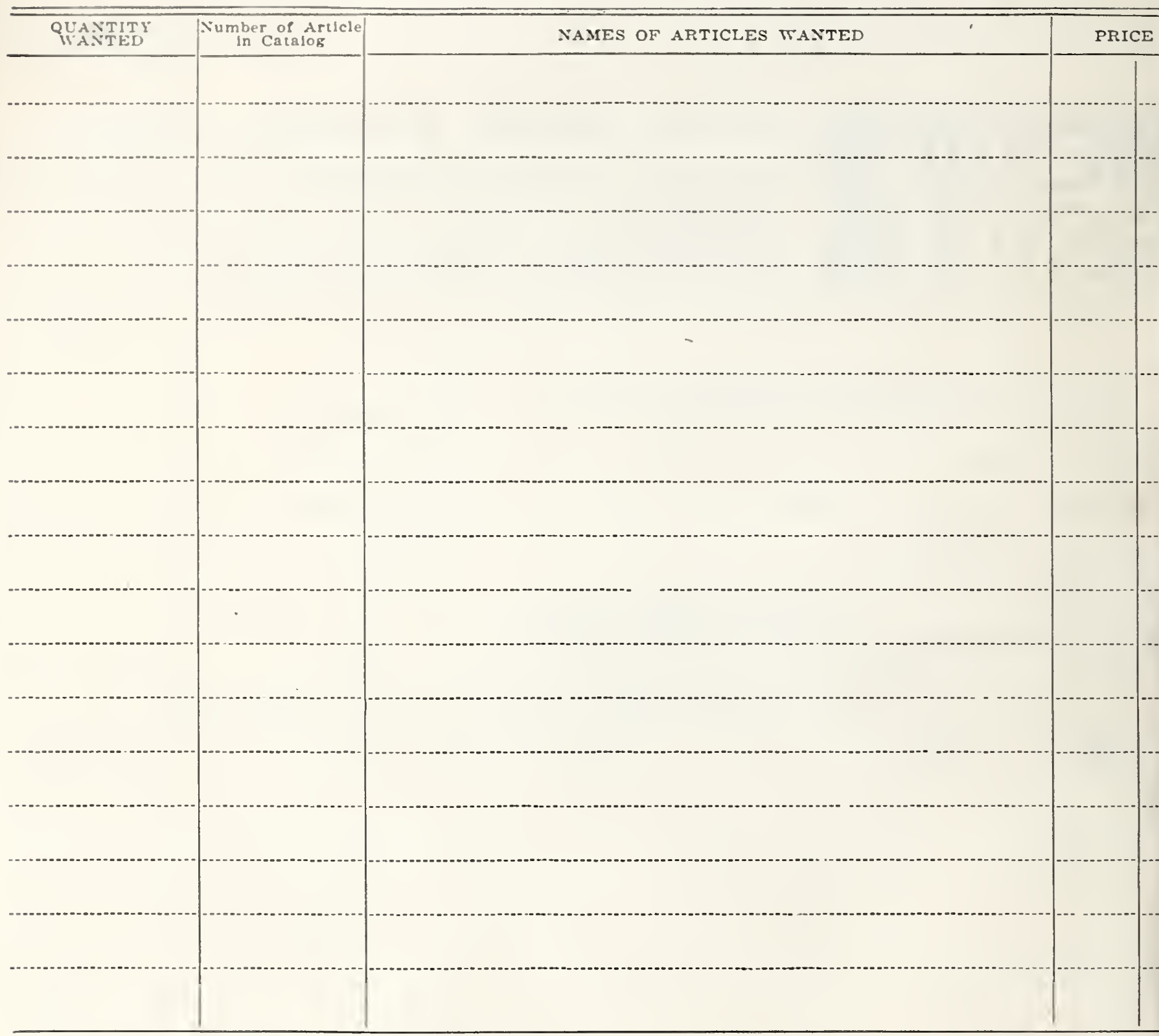

Findy glve below the names of ang friends or neighbors who you think would be interested in receiving our catalog:

\begin{tabular}{c} 
NAME \\
\hline POST OFFICE
\end{tabular}




\section{The House That Good Seeds Built}

At the right is a picture of the one-story building in which we began business-one room, $12 \times 24$ feet. Below are pictures of our present plant, except that our two branch stores, one warehouse and printing plant are not shown. We have grown because nearly two hundred thousand seed planters know that WOOD'S SEEDS are GOOD SEEDS, and that we will not send them seeds unless they are first class in every particular. All WOOD'S SEEDS are carefully analyzed for purity and tested for germination. Should any lot fall below our high standard in either purity or germination, it is immediately discarded. We will not sell you any but High Grade Seeds.

SAVE ON YOUR SEED BILL-1930 was not a profitable year for the farmer and he will need to save wherever possible. You can save on your seed bill by buying

Wood's Seeds, for we have made prices low to meet this condition. You will get high grade tested seeds, but at lower prices.

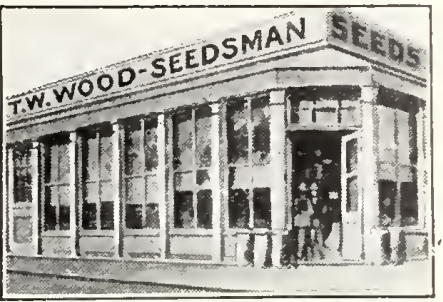

WOOD'S CROP SPECIAI, issued regularly during the planting season,

gives you, just at the right time, suggestions about what to plant, and keeps you informed about the current prices of field seeds. Write for it-it is free and we want you to have it.

We cordially thank our many friends for the splendid business with which they have favored us.

We hope you will continue to favor us, and on our part promise prompt attention, fair treatment and seeds that will grow.

January 1, 1931.

Very truly yours,

T. W. WOOD \& SONS.

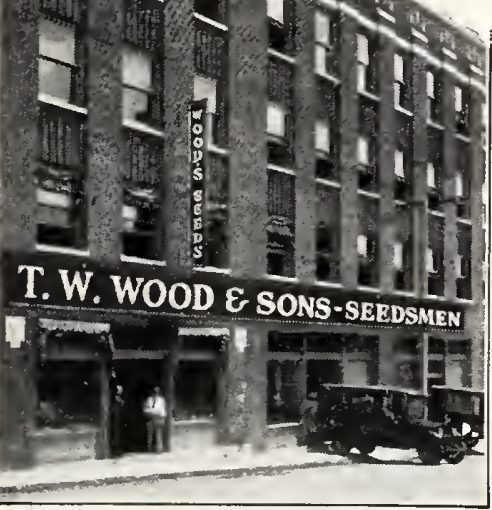

Offices, Salesroom, Parcel Post and Express Department

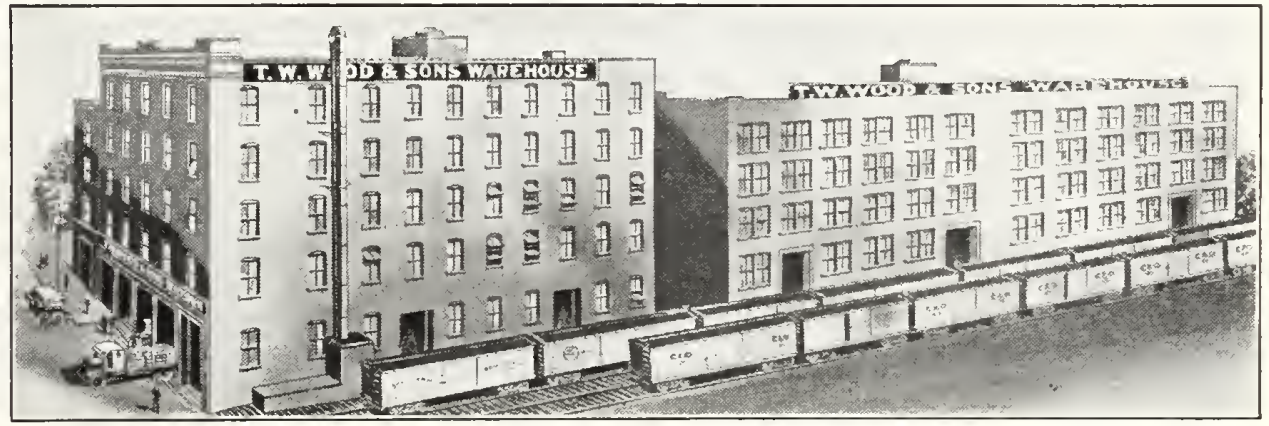

Freight Shipping Department, Poultry Food Plant, and Seed Testing Laboratory

\section{GENERAL INFORMATION AND TERMS OF SALE}

How to Send Money $\overline{\mathbf{C}} \mathbf{\text { H}} \mathbf{\mathbf { E }} \mathbf{C} \mathbf{x}$, postd be sent by BANK ORDER, EXPRESS MONEY ORDER ORTOFFICE MT ON EY LETTER; in case they go astray in the mails they can be traced and duplicates secured. Always register letters containing currency. Postage stamps in small amounts are satisfactory. We prefer $5 \mathrm{c}, 10 \mathrm{c}$ and $20 \mathrm{c}$ denominations. Customers who have no regular account with us will lindly remit the amount with their orders, or name business references, as customary, before opening new accounts.

C. O. D. Shipments Shipping C. O. D. only adds to the cost, lection. If you prefer shipment C. O. D. remit with your order one-haif the amcunt of the bill. Iinder no circumstances will we ship plants and other períshable goods C. O. $\mathrm{D}$.

Your Name and Address -Always be sure to give both: either unsigned or we have hundreds of orders you have not received the seeds you ordered probably yours is among them.

Fluctuation in Prices - Some time must necessarily elapse this between the writing and printing of this catalog and the time it reaches you. In the meantime the market prices of some varieties, particularly field seeds, may have changed. As far as possible, these price changes will be printed in our CROP SPECIAL, a copy of which, quoting current prices, will be sent you free on request. At any time we will be glad to quote vou firm prices. cr we will fill your order at the lowest prevailing prices, whether higher or lower than as printed in this catalog. If prices are lower you get the benefit of the decline: if higher. we wilt of course. be compelled to charge the prevailing price at the time the order is received.

Bags - There is no extra charge for bags in which to ship angthing offered in this catalog.
Postpaid Prices on Garden Seeds means that garden be delivered to your door if you live on seeds so quoted will any postoffice in the United States at postpaid prices. This applies will ship by express and prepay express charges. Shipment by express is safer than by parcel post.

\section{Postpaid Prices on Field Seeds} W Apply to Va.. N. $\mathrm{C}_{\text {. }}$

Postage to Other States: To S. C., Ga., Ky., Tenn., Ohio, Ind., N. Y., New England and Mich., add 2c per pound to postpaid prices.

To Ala., Ark., Fla, Ill., Iowa, La., Miss., Mo. and Wis., add $4 \mathrm{c}$ per pound to postpaid prices.

To Texas, Okla., Kan. and Neb., add $6 \mathrm{c}$ per pcund to postpaid prices.

EXAMPLE: If you live in South Carolina, the fourth zone from Richmond, you would add 2 c per pound to our "postpaid" price. If your order is for 25 lbs. Dwarf Essex Rape, quking the cost $\$ 3.50$ for 25 lbs. delivered at your postoffice.

OUR GUARANTEE.- Wood's Seeds are thoroughly recleaned, tested and of the very highest quality. We guarantee them to be as represented in purity, germination, weed seed content and origin up to the full amount of purchase price. Owing to so many factors over which we have no control, such as weather, soil and seeding conditions, we cannot guarantee the crop.

We offer you the best seeds because it is the fair thing to do and because we want to stav in business and grow. But we cannot control planting and cultural methods and weather and soil conditions, all of which affect the outturn of crops. 


\section{THE PLANTER'S TIME TABLE}

\begin{tabular}{|c|c|c|c|c|c|c|c|}
\hline Variety & When to Plant & $\begin{array}{l}\text { Stity } \\
\text { Feet. }\end{array}$ & $\begin{array}{l}\text { Qu } \\
\text { or }\end{array}$ & & w. & & \\
\hline 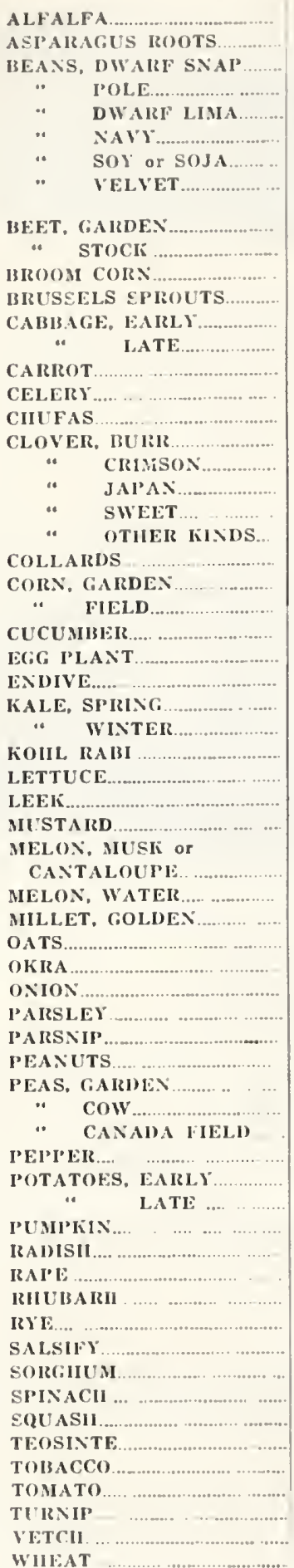 & $\begin{array}{l}\text { March to August. } \\
\text { April, May, June. } \\
\text { May and June. } \\
\text { March to July. } \\
\text { Jan. to June., Sept., Oct. } \\
\text { April to July. } \\
\text { March to August. } \\
\text { Feb., Mar. and April. } \\
\text { April to July. } \\
\text { July to November. } \\
\text { July to October. } \\
\text { March and April. } \\
\text { April, May-Aug. to Nov. } \\
\text { Feb., Mar. Aug. to Nov. } \\
\text { March to August. } \\
\text { April to early August. } \\
\text { April to July. } \\
\text { April to July. } \\
\text { Feb., Mar., April. } \\
\text { March to Sept. } \\
\text { Feb. to Apr., Aug. to Oct. } \\
\text { Feb., Mar., Aug. to Oct. } \\
\text { March to May, Aug., Sept. } \\
\text { Feb. to May. July to Oct. } \\
\text { Feb., March, Sept. } \\
\text { Feb., Mar., Apr., Sept., Oct. }\end{array}$ & 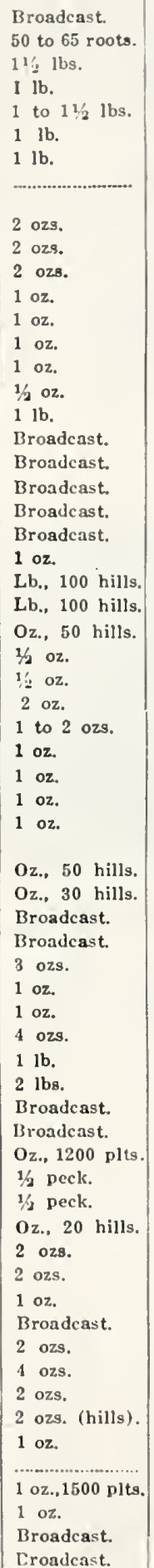 & 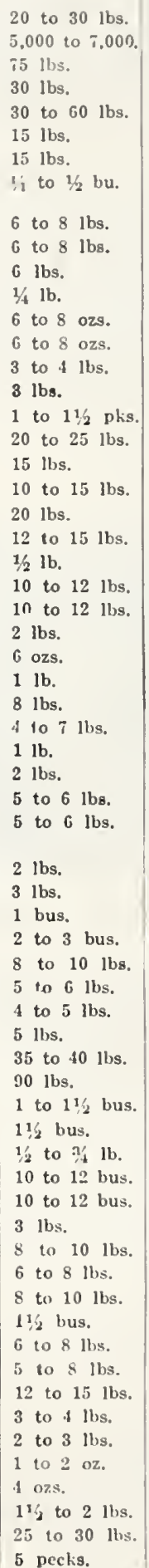 & $\begin{array}{l}15 \text { to } 18 \text { ins. } \\
2 \text { to } 2 \frac{1}{2} \text { feet. } \\
31 / 2 \text { feet. } \\
21 / 2 \text { to } 3 \text { feet. } \\
21 / 2 \text { to } 3 \text { fect. } \\
3 \text { feet. } \\
12 \text { to } 24 \text { ins. } \\
2 \text { to } 4 \text { feet. } \\
21 / 2 \text { to } 3 \text { feet. } \\
\text { rroadcast. } \\
\text { Eroadcast. } \\
\text { Broadcast. } \\
\text { Broadcast. } \\
\text { Broadcast. } \\
21 / 2 \text { to } 3 \text { feet. } \\
3 \text { feet. } \\
31 / 2 \text { to } 4 \text { feet. } \\
4 \text { feet. } \\
3 \text { fcet. } \\
18 \text { inches. } \\
18 \text { to } 24 \text { ins. } \\
18 \text { inches. } \\
18 \text { inches. } \\
8 \text { to } 12 \text { ins. } \\
18 \text { ins. } \\
12 \text { to } 18 \text { ins. }\end{array}$ & $\begin{array}{l}\text { Broadcast. } \\
18 \text { to } 24 \text { ins. } \\
3 \text { inches. } \\
3 \text { to } 4 \text { feet. } \\
15 \text { to } 18 \text { ins. } \\
1 \text { foot. } \\
6 \text { inches. } \\
2 \div 2 \text { to } 3 \text { feet. }\end{array}$ & 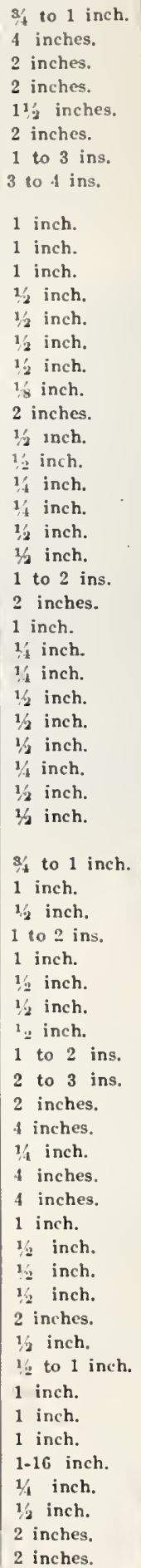 & $48 \mathrm{lbs}$. \\
\hline
\end{tabular}




\section{Wood's New Varieties and Specialties}

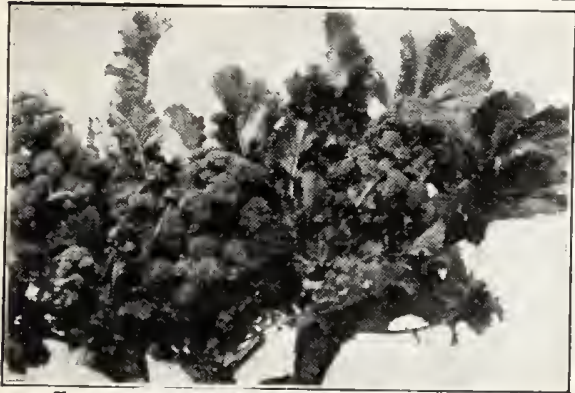

Green Sprouting Italian Broccoll.
No. 86. Green Sprouting Italian Broccoli -In the South, where we dearly OUR STOCr WAS Iove "greens," this new -arlety DIRECT FROM ITATY

should have a hearty welcome. It is distinct from th heading broccoli we have heretofore grown and which more nearly resembles cauliflower. It is of rapid growth and at the center of the plant a large head or a compact cluster of flower buas is produced. These are ready for use as soon as they are fully developed. After this as delicious as the first cutting many sprouts, four to six inches long, which are just use other sprouts will be prodi If these are cut as they become large enough for greens are sprouts will be produced for eight to ten weeks. These when cooked as greens are as delicious as cauliflower. To have them early plant in a hot bed when you plant cabbage and set out when large enough; or plant outside in April, transplanting them 2 feet apart in 3-foot rows. Cut the sprouts before the heads breas into flower, otherwise they will shoot to seed. If you grow for market break sprouts in bunches and ship in crates. In cities where there is an Italian popula. tion it is in constant demand. Pkt. 10c; $1 / 2$ oz. $35 \mathrm{c} ; 0 z .65 \mathrm{c} ; 1 / 41 \mathrm{~b} . \$ 2.25 ; 1 \mathrm{~b}$. $\$ 8.00$;

\section{Two Outstanding Yellow Corns for the Highlands}

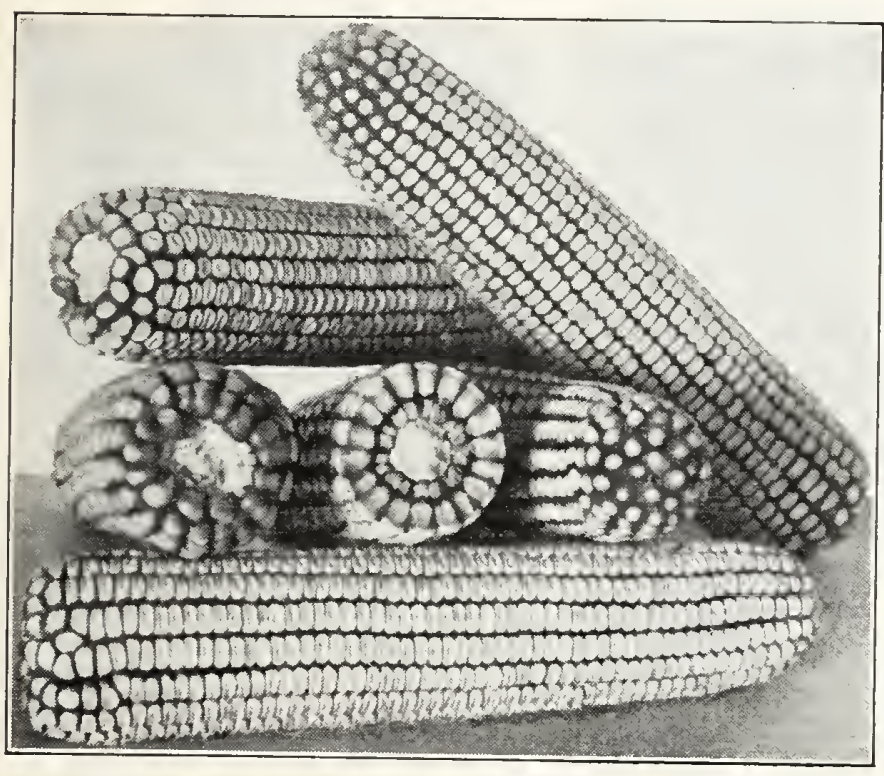

Golden Queen Corn.

\section{Golden Queen}

100-DAY CORN FOR ALTITUDES OF 1,000 TO 2,500 FEET. Heavy Yields of Large, Beautiful Ears. Outstanding Show Corn.

Mr. W. H. Byrne, Extension Agronomist of the Virginia Agrcultural and Mechanical College, Blacksburg, Va., says: "From two years experimenting with many varieties of corn in Grayson and Montomery Counties, Golden oueen proved one of thayson yellow corns adapted to Southwest Virginia.. It has of the best 10 to 11 inches, medium cob, is early, matures in 133 days and stood at the top of the test in yield."

F. F. Minton, who has farmed successfully for 36 years in Southwest Virginia, says: "For altitudes from 1,000 to 2,500 feet Golden Queen is superior to any corn I have ever seen. For the rich val. leys of Southwest Virginia, Tennessee, North Carolina, West virginia, and Maryland this corn should make 65 bushels of sound corn to the acre. It will mature sound corn in 100 days."

Golden Queen is the highest yielding early yellow corn for altitudes of 1,000 to 2,500 feet. The ears are $101 / 2$ inches long, have well filled tips and butts, straight rows, good grain closely placed on a medium cob. The ears are held nicely, medium high and medium erect. The stalks are sturdy, ten feet tall and free of smut and disease. It makes roasting ears in about 90 days, maturing in 100 to 110 days. It is two weeks earlier than Reid's Yellow Dent and three weeks earlier than Boone County, outyielding both on poor land.

We secured our Golden Queen Corn from the pioneer breeder of this variety. It is the same strain that won three grand championships in three successive years. By mail postpaid, qt. $35 \mathrm{c} ; 1 / 2$ peck 90c; peck $\$ 1.55 ; 1 / 2$ bushel $\$ 2.80$; bushel $\$ 5.25$.

Not postpaid, $1 / 2$ peck $65 \mathrm{c}$; peck $\$ 1.15 ; 1 / 2$ bushel $\$ 2.10$; bushel $\$ 4.00 ; 5$-bushel lots $\$ 3.90$ per bushel.

\section{Early Clarage Yellow Dent}

Matures in 80 to 90 Days; Holds World's Record Yield for Altitudes of 2,000 or More Feet.

Clarage is the ideal corn for growing in high altitudes for early feed or hogging down, or for planting late on land to be put in wheat. It is two weeks earlier than Golden oueen, month earlier than either Reid's Yellow Dent and Boon County, maturing in 80 to 90 days.

Clarage holds the World's Record Yield, 176 bushels por acre, on ten acres. It makes two good sound ears to the stalk; the ears are about 8 inches long, hold their size well to the tip, grains wide and deep, rows straight and close, butts and tips well covered and cob small but sound. It is carefully lent feeding corn.

Ira B. McKenzie, an authority on mountain corns, says clarage is the best corn for altitudes of 2,000 or more feet because it matures in 90 days and makes two good medium ears to the stalk, with a deep grain and small cob."

Our clarage was grown by a breeder who has won many prizes and sweepstakes with it. He says: "Clarage always matures here at an altitude of 2,300 feet, yieldin? 70 bu -hels to the acre, as high as any large corn. By mail postpaid qt. $35 \mathrm{c}$; $1 / 2$ peck $90 \mathrm{c}$; peck $\$ 1.55: 1 / 2$ bushel $\$ 2.80 ;$ bushel $\$ 5.25$. Not postpaid, $1 / 2$ peck $65 \mathrm{c}$; peck $\$ 1.15 ; 1 / 2$ bushei $\$ 2.10$; bushel $\$ 4.00$; 5-bushel lots $\$ 3.90$ per bushel.

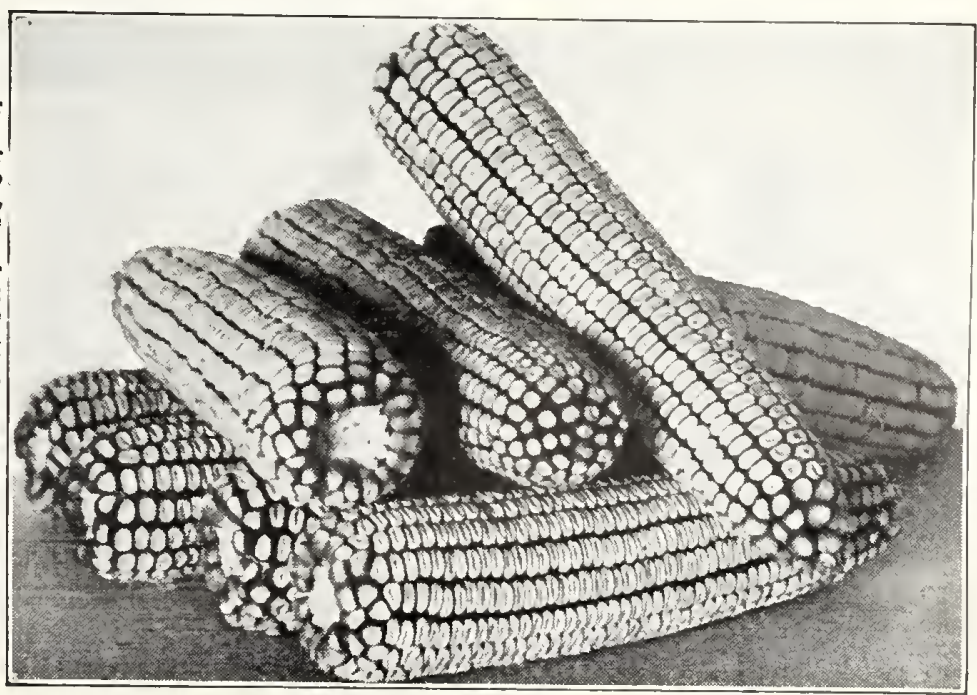

Sarly Clarage Yellow Dent Corn. 


\section{Wood's New Varieties and Specialties}

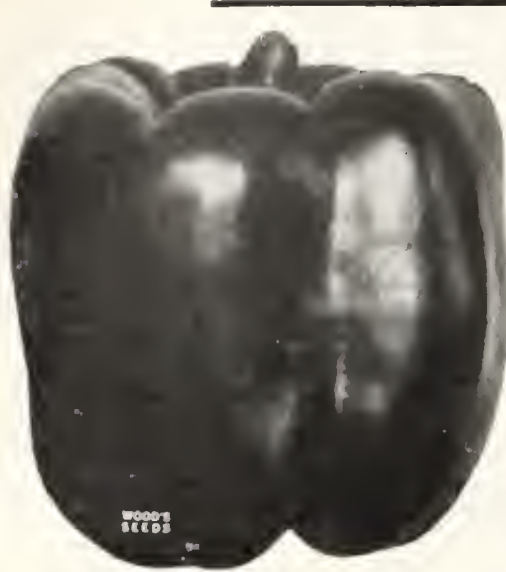

California Wonder Pepper.

\section{Shogoin Salad Turnip}

A!thougl grown principally for salad, like Soutliern Prize and Seven Top, it makes a pure white turnip 2 to 3 inches in diameter, somewhat between a flat and globe shape. Its most attractive features are its resistance to lice attacks and that it can be grown in hot weather. The leaves grow upright, about two feet high when fully developed, but should be cut before it attaius full growth. Early cutling will allow another and probably two cuttings later. During a warm growing seasou it will be leady to cut in about four weeks. Pkt, 5c; 0z. 10c; 1/1 1b, 25c; 1b, 75c ; $2 \mathrm{lbs} . \$ 1.25 ; 5$ lbs. $\$ 2.90$ postpala.

\section{Hollybrook Luscious}

\section{Cantaloupe}

There is only one objection to $\boldsymbol{F o l l y -}$ brook Luscious-1t grows too large to be profitable for market growers, frequently 15 lbs, or more. The best about it is 1ts wonderful flavor-equal to a Honey Dew -and that a single melon is enough for a good sized family. Dou't fail to plant it you will be delfghted with the flavor and surprised how large they grow. No melou could be more higlily recommended for the hoine garden. It continues bearing till late in the season and holds its fine quality to the very last. Pkt. 10c: oz. 20c 2 ozs. 35c; $1 / 4$ lb. 60c; 1b. $\$ 2.00 ; 5$ lbs. $\$ 8.75$ postpald
No. 357. California Wonder Pepper

In size it compares with Chluese Giant, about 4 inches across by $41 / 2$ to 5 inches long, bat in thickness of flesh there is no other pepper to compare with it. With most of them the flesh is a quarter of an inch thick, but a thickuess of three-eighths of au inch is quite common. This is its outstandiug point of excellence, for such thickness ot flesh is not found in any other pepper. It is medium early in maturity, bot produces good slzed green peppers nearly as early as the earliest. The quality is of the finest, being sweet, crisp, teuder and never hot. A good bearer and a wouderful long distance shipper. Every home gardener and market grower should plant it. Pkt. 10c; 1/2 oz. 35c; oz. $60 \mathrm{c} ; 1 / 4 \mathrm{lb} . \$ 2.00 ; 1 \mathrm{~b}$. $\$ 7.00$.

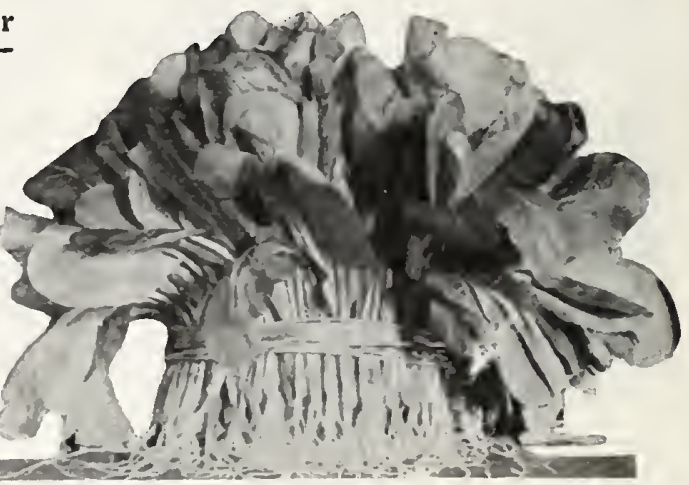

Mustard Spinach.

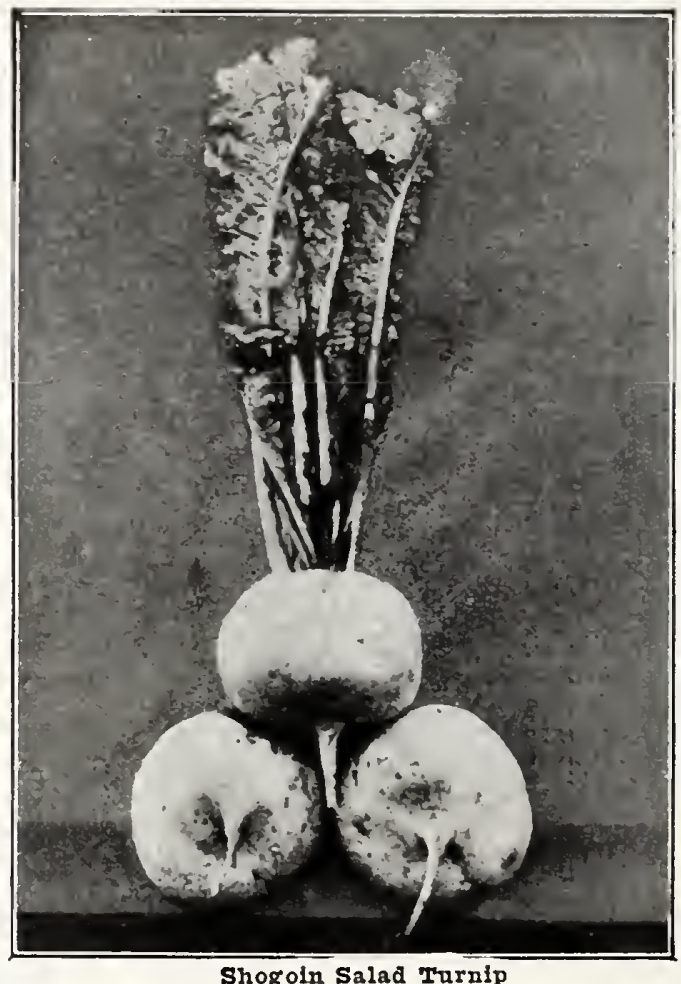

Mustard Spinach

SOMETIMES SOLD AS TE N D E R GREEN.-A mild mustard with a spinach flavor that can be grown in three to four weeks: can be orown in almost any season of the year, even during the hot summer months - it is virtually an all-season plaut. The leaves are cooked aud prepared for the table the same as spinach, mustard aud turnip salad and makes greens equal to the best of them. We suggest a planting every two weeks daring the summer to have a continuous supply of delicious greens. Pkt. 10c; oz. 15c; $1 / 4$ lb. 35c; 1b. $\$ 1.00 ; 2$ lbs. $\$ 1.75 ; 5$ lbs. $\$ 4.00$ postpaid.

\section{Free Flower Seeds}

To enconrage the growing of these home beautifiers, we will give free the following flower seeds witl orders for seeds in packets and onuces received before May Ist, provided you call for them witl your order. Please order by unmber.

COILECTION No, 1-Free with an order for packets and ounces a inounting to $\$ 1.00$ or more: one packet eacli of five separate varieties of easily grown annual flower seeds of our selection.

COIIECTION No. 2-Free with an order for packets and onnces amountiug to $\$ 2.00$ or more: one packet each of twelve separate varieties of flower seeds of our selectiou.

These collections are put up before our busy season opens and cannot be changed. only one collection can be allowed with each order.

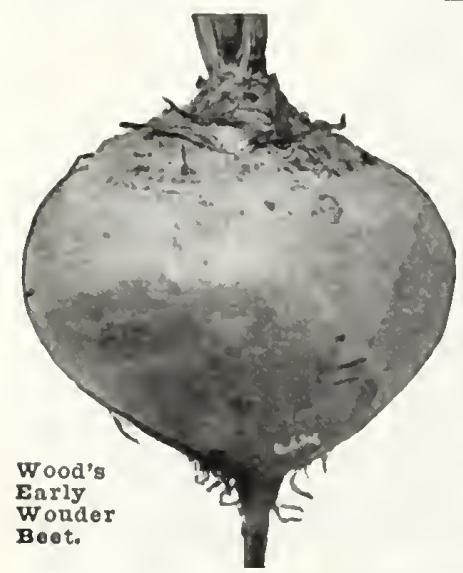

No. 407. Wood's Earliest Prolific Squash

-Yon will need only about half as many squash plants in your garden if yon plant wood's Farliest Prollfic because they will yield as many or more squashes, but each souach will contain about double as much flesh. They are thick from stem to blossom end, no depression around the steul and scarcely any between the scallops. This means more flesh, less waste and they are easier to prepare. These advantages will appeal to the home gardener, but its extreme earliness will appeal especially to those who grow for the early market. A Floriàn grower writes that he grew over 400 crates to the acre and that in every market to which he slipped, Wood's Earliest Proliflc brought from $25 \mathrm{c}$ to 50c per crate more than other varieties. Pkt. 10c;

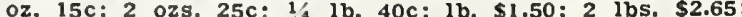

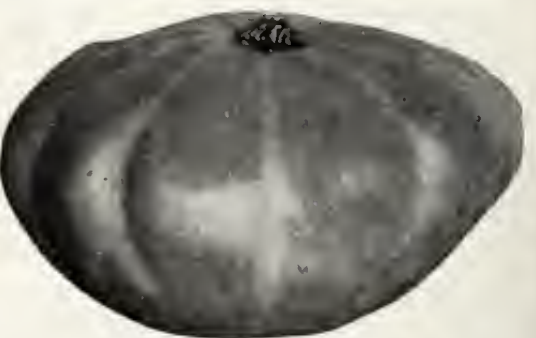

Wood's Sarliest Prolific Squash 5 lbs. $\$ 6.35: 10 \mathrm{lbs}, \$ 11.70$ postpaid.

No. 67. Wood's Early Wonder Beet -If earliness is desired, you luave it in Wood's Early Wonder, for it is even earlier than Crosby's Egyptian: but in addition to earliness, you have most excellent quality as well. It is of the blood turnip type, aniform in size, shape and color, is always smooth, is never strinzy, and is a good keever. The flesh is a deep rich ref, sweet, crisp and tellder. Although bred primarily for market growers, its many flne qualities commend it highly to the home gardeuer. Pkt. 10c; oz. 15c 2 ozs. $25 \mathrm{c} ; 1 / 4 \mathrm{~b}$. 35c; $1 \mathrm{~b}$. $\$ 1.15 ; 2$ lbs. $\$ 2.00 ; 5$ lbs. $\$ 4.00 ; 10$ lbs. $\$ 8.85$ postpaid. 


\section{Wood's High-Grade Garden Seeds}

\section{"BY MAIL POSTPAID" and "NOT PREPAID"}

GARDEN SEEDS quoted "by mail postpaid" in this catalog will be delivered, all transportation charges prepaid, to any post office in the United States. Or, if you prefer, we will ship by express and prepay charges. Shipment by express is safer than by parcel post.

FIELD SEEDS quoted "by mail postpaid" will be delivered to any post office in Virginia, North Carolina, West Virginia, Maryland, Delaware, New Jersey and Pennsylvania. On the field seed pages will be found under the heading "Postpaid Prices" the a mounts to be added for postage on orders to other states, making it easy to tell exactly what Wood's Seeds will cost you delivered at your door.

When quoted "NOT PREPAID" we deliver at our expense to the post office, express office or freight depot in Richmond, you to pay transportation charges only.
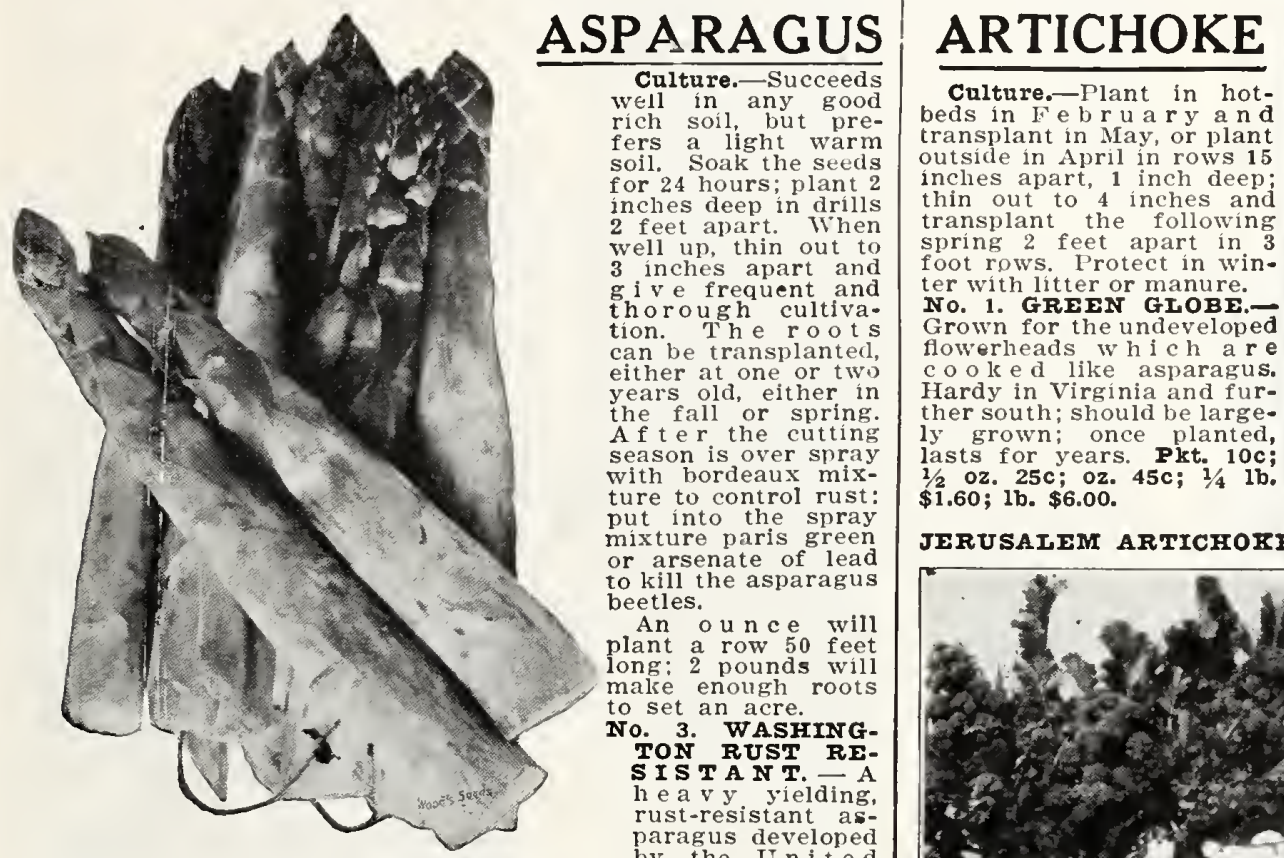
mixture to control rust: put into the spray or arsenate of lead to kill the asparagus beetles.

An oun e will plant a row 50 feet long: 2 pounds will make enough

No. 3. WASHINGTON RUST RI SISTA T T. A hea $v y$ yielding. rust-resistant as. paragus developed by the United States Department of Agriculture; produces extra large, green slightly tinted with purple at the tips. No other variety green slightly tinted with purple at the tips, No other variety
is as free from rust. Pkt. 10c; oz. 15c; $1 / 4 \mathrm{lb}$. 40c; $1 \mathrm{~b} . \$ 1.40 ; 2$ lbs. $\$ 2.50$; 5 lbs. $\$ 5.90$ postpaid.

No. 5. GIANT ARGENTEUIL.-In earliness and size of stalk this is a most superior asparagus. Very tender whether grown as green asparagus or when earthed up to blanch grower and large yielder of fine, thick. tender stalks. Pkt. 5c; oz. $10 \mathrm{c} ; 1 / 4$ 1b. 30c; $1 \mathrm{~b}$. $\$ 1.00 ; 2$ lbs. $\$ 1.75 ; 5$ lbs. $\$ 4.00$ postpaia.

No. 4. PAIMETTO.-A very early and prolific variety, producing an abundance of large, thick, very tender stalks. The deep green stalks are of the best quality. Palmetto has for many years been the old reliable standby with asparagus growers. Pkt. 5c; oz. $10 \mathrm{c} ; 2$ ozs. 15c; $1 / 4$ lb. $25 \mathrm{c} ; 1 \mathrm{~b} .75 \mathrm{c} ; 2$ lbs. $\$ 1.25 ; 5$ lbs. $\$ 2.90$ postpaid.

\section{ASPARAGUS ROOTS}

CULTURE.-Dig or plow cut a trench 15 to 18 inches deep. put in plenty of well-rotted manure, covering it with a few inches of soil, then set the roots $11 / 2$ to 2 feet apart and cover
with 4 inclies of soil. In the fall, cut off and burn the top growth plcw or throw down the earth and give a good application of stable manure, Early in the spring fork this in and apply ground animal bone. If white asparagus is wanted draw earth around the stalks as they grow. Do not continue cutting too feet: 5,000 to 7.000 will plant an acre

WASHINGTON RUST-RESISTANT. - Two-year-old roots. By mail postpaid, 35c per dozen; 50 for $\$ 1.15 ; \$ 2.00$ per 100 .

Not postpaid, 30c per dozen; 50 for $\$ 1.00 ; \$ 1.75$ per $100 ; \$ 12.00$ per 1,000 .

PALMETTO.-Two-year-old roots. By mail postpaid, $30 \mathrm{c}$ per dozen; 50 for $95 e ; \$ 1.65$ per 100 .

Not pestpaid, 25c per dozen; 50 for 80c; $\$ 1.40$ per $100 ; \$ 10.00$ per 1,000 . 2 lbs. $\$ 15.00$ postpaid.

on the stalks are produced small cabbage-like heads that are as great a delicacy as to July. transplanting $11 / 2$ feet apart, and cultivate like cableaves to glve the heads more favor and delicacy are greatly improved. If you have never sure to try some; you will be surprised how easily they can be grown and what a delicious dish they make. 1 ounce produces 2,000 plants. Pkt. $10 \mathrm{c}$;
oz. $25 \mathrm{c} ; 1 / 4$ lb. $75 \mathrm{c}$; lb. $\$ 2.50$; 2 ibs. $\$ 4.50$ yostpaid.

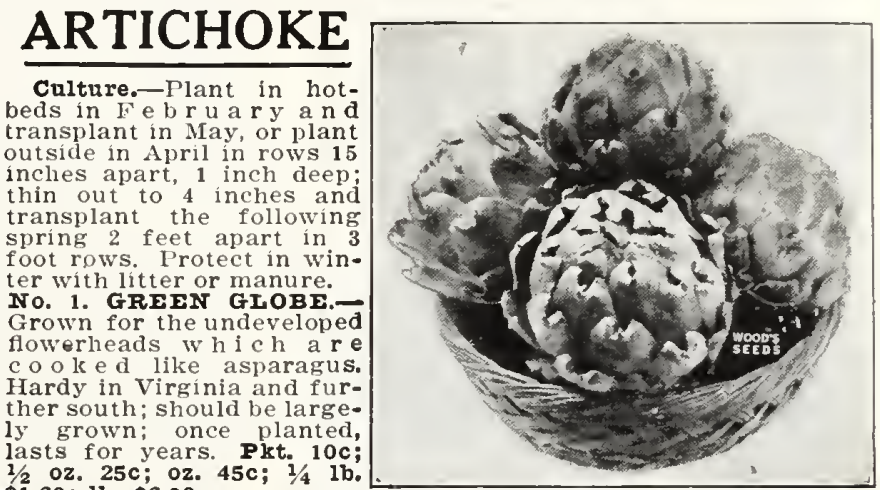

Green Globe Artichoke.

JERUSALEM ARTICHOKE ROOTS.-See page 77.

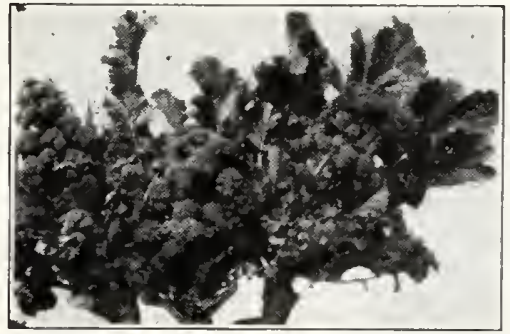

\section{BROCCOLI}

No. 85. EARIY WHITE CAPE.

cauliforver, but taller the heads more divided, hardier and s ands greater extremes ou have not been successful with cauliflower, try cauliflower. Pkt. $10 \mathrm{0c} 1 / 2$ 0z. $25 \mathrm{c} ;$ oz. $40 \mathrm{c} ; 2$ ozs. Calabrese Green Sprouting Broccoli. $75 \mathrm{c} ; 3 / 41 \mathrm{~b}$. $\$ 1.40 ; 1 \mathrm{~b} . \$ 5$. No. 86. CALABRESE GREEN SPROUTING ITAIIAN.-Distinct from White Cape, being more like cauliflower, requires the same culture and is served like it. Clusters of sprouts are produced to produce sprouts throughout a long season. These should be to grow and will yield an abundance of greens for a long time.

Pkt. 10 c; $1 / 2$ oz. $35 \mathrm{c} ;$ oz. $65 \mathrm{c} ; 2$ ozs. $\$ 1.20 ; 1 / 41 \mathrm{~b} . \$ 2.25 ; 1 \mathrm{~b} . \$ 8.00$;

No. 84. ITALIAN SALAD BROCCOII.

grown in Delaware, Maryland and the Eastern shore of Virginia. salad like Seven Top Turnip. Pkt. 5c; oz. 20c; $1 / 41 \mathrm{~b} .60 \mathrm{c} ; 1 \mathrm{~b} . \$ 2.00$.

\section{No. 87. BRUSSELS SPROUTS}

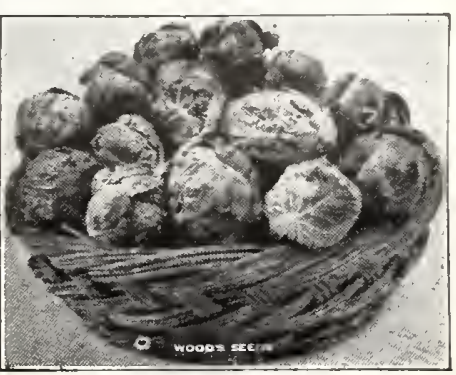

Brussels Sprouts. 


\section{Green Podded Varieties}

CULTURE.-Beans are sensltlve to both cold and wet, so do not
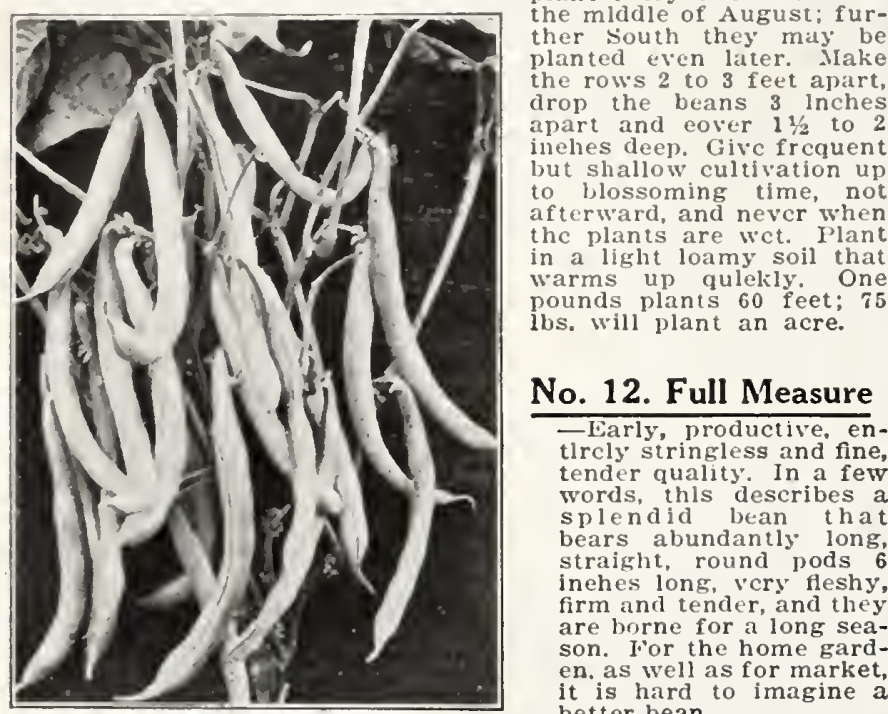

No. 14. Giant Stringless Green Pod
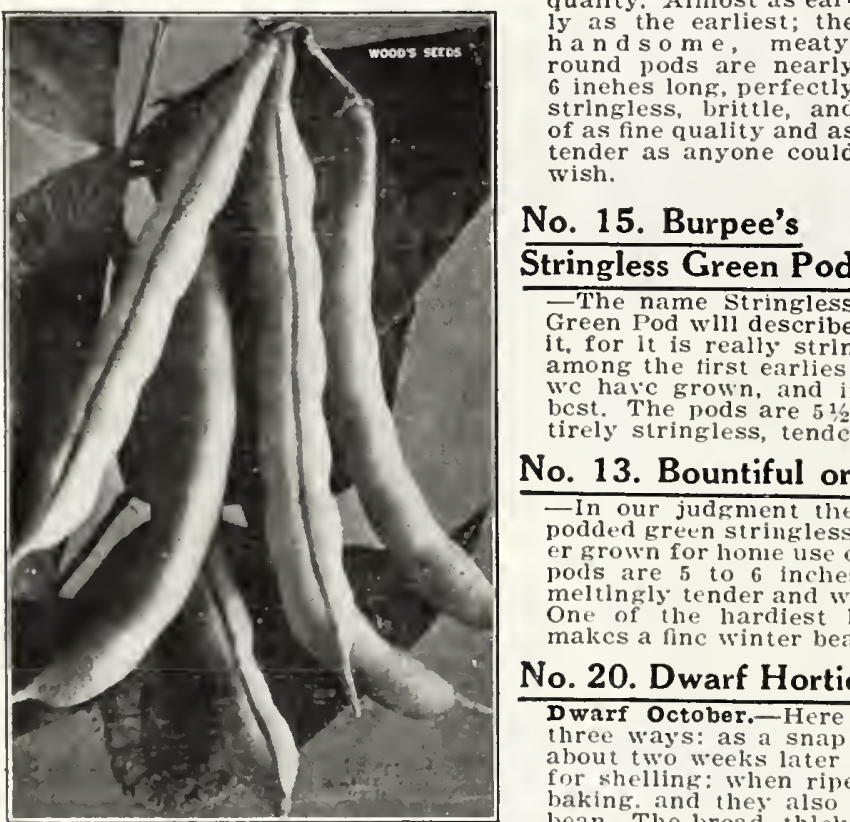

pods are nearly

inches long, perfectly of as fine quality and as

tender as anyone could

No. 15. Burpee's Stringless Green Pod The name Stringless

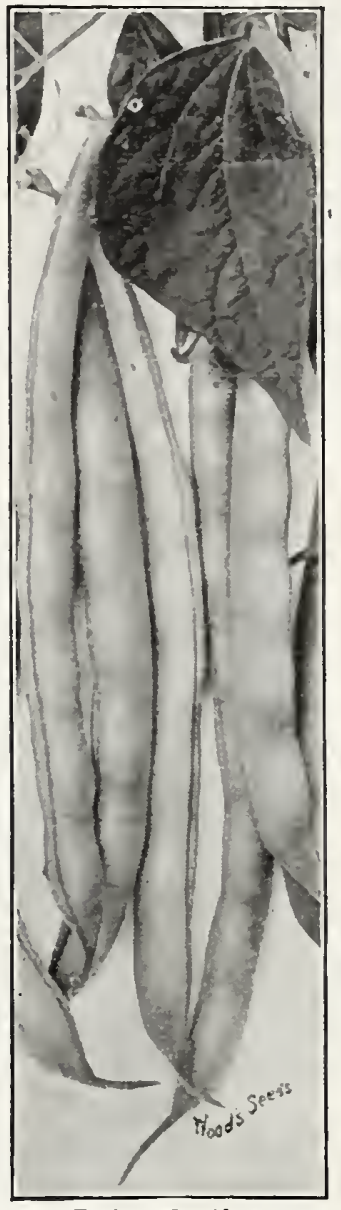

Red Valentine

No. 10. Extra Early Red Valentine - - o bean will stand adverse weather In unfitrs better than Red Valentine. tain to make a crop than most any orh作 , been eonstanty er it was, for it has pods are round, tender and of

No. 19. Tennessee Green Pod

or Brown Bunch.-A favorite wherever grown and in some parts of the South and largest pods of any bush rrceular in shape but of exNo. 17. Refugee, or 1,000 to 1 Probably the most prolific of all beans. nehes lons are of good flavor stringCSS when voung, and are fine for eanning and pieklimg. Refugee is a good bean for planting both early and lase, but they are more generally planted for No. 11. Black Valentine $-T^{\mathrm{h}} \mathrm{e}$ est of all beans; will stand more frost than any other sort. On this account partieularly" reeommended for market growers. The pods are long, straight, fusely and present a verveturaetive appearanee. Not reeommended for the IING OF THE EARIIES. - Same as Black Valentine.

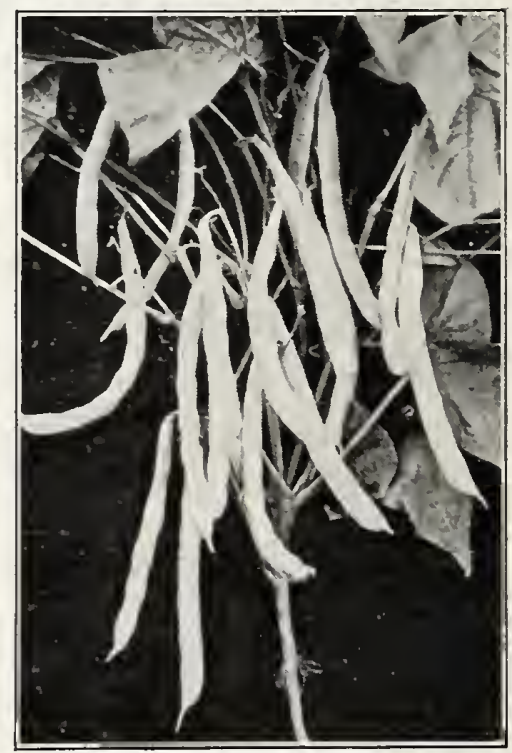

Bountiful or Early Six Weeks Beans

No. 13. Bountiful or Early Six Weeks

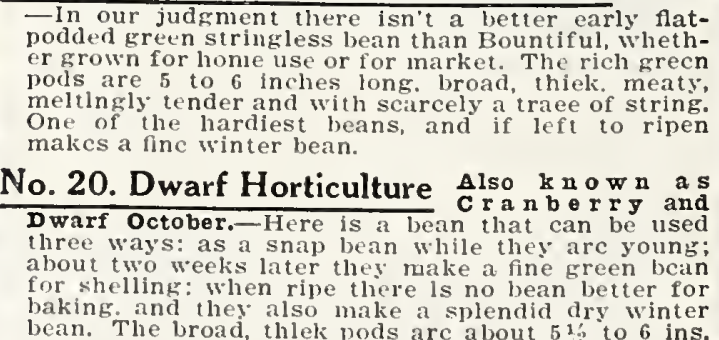

Stringless Green Pod Beans

it. for lt is really stringless. In earliness it ranks among the first earlies; it is as prolitic as any bean The pods are 5 to inches long, round, en-

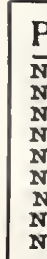

\section{PRICES}

No.10. Extra Early Red Valentine.

No, 11. Black Valentine

No. 12. Ful1 Measure

No. 13 Bonntlfnl or Early six weols

No. 14. Glant Stringless Green Pod.

No. 15. Burpeo's Stringless Green Pod.

No 17. Refugee, or 1,000 to

No. 19. Tennessee Green Po
BY MAIL POSTPAID

Pkt. 1/2 lb. Lb. 2 lbs. $5 \mathrm{lbs}$

Pkt.

$10 \mathrm{c}$

$10 \mathrm{c}$

$10 \mathrm{c}$
$10 \mathrm{c}$
$10 \mathrm{c}$

$10 \mathrm{c}$.

$10 \mathrm{c}$
$25 \mathrm{c} \ldots$. .40c. . .650. . \$ \$1.35.

$20 \mathrm{c} \ldots .35 \mathrm{c}, \ldots 60 \mathrm{c} \ldots 1.30$

$25 \mathrm{c} \ldots .40 \mathrm{4} \ldots 70 \mathrm{7} \ldots, \ldots, 1.55$

25c ...40c . .70c ... 1.45

$25 c \ldots 40 c \quad 70 c \quad 1.45 \ldots$

25c $40 \mathrm{c} 70 \mathrm{c}, 1.40$.

25c 40c 65c

25c...40c...70c.... 1.45

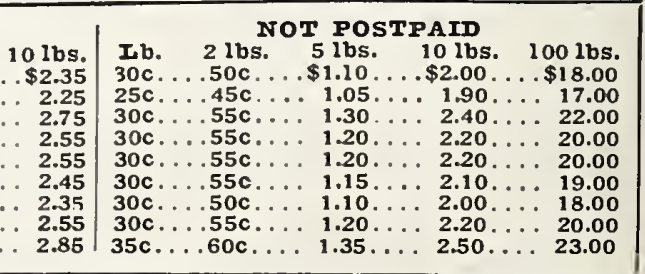




\begin{tabular}{|l|}
\hline INOCULATETHIS \\
SEED WITH \\
STIMUGERM \\
\hline
\end{tabular}

\section{Bush or Snap Beans}

Yellow or Wax Podded Varieties
Fifty pounds may 100-pound price
No. 33. Surecrop Stringless Wax

Resembles Currie's Rust Proof but even hardier, more rust proof, and stringless at practically all stages of growth. The rich, yellow, thick and meaty pods meas-

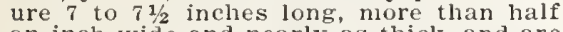
an inch wide and nearly as thick, and are produced in great abundance. Very early the vines are strong and vigorous. I'roductiveness is one of its strongest points. surecrop stringless 11 ax is one of the biggest yielding of all the wax beans, and has the advantage of being very early. In hardiness it probably excels all other wax beans, a distinct advantage where early planting is practiced. In many reamong the best of the wax podded varieties.

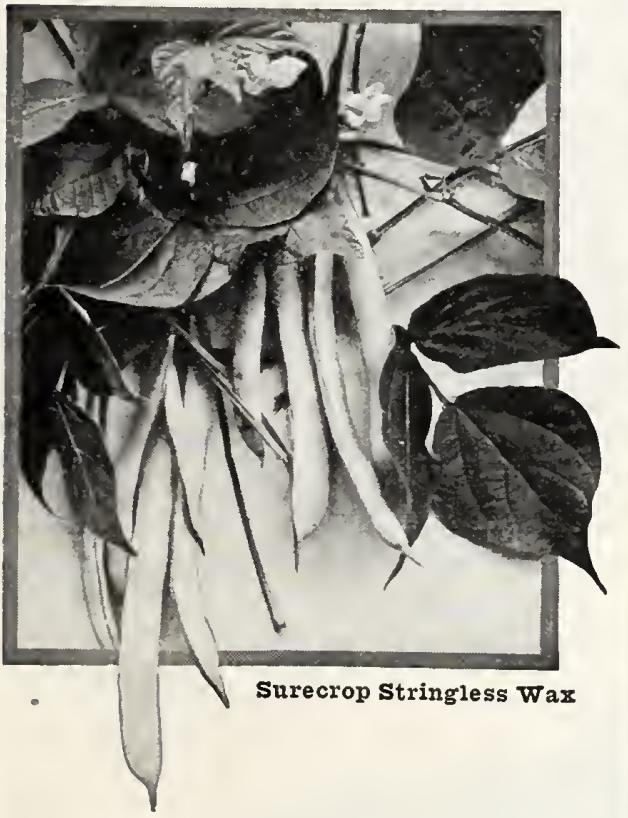

No. 29. Round Pod Brittle Wax

If splendid quality made a bean popular this should be our best seller among wax beans. It is a handsome midseason wax bean; a profuse bearer of meaty, stringless, tender round pods $51 / 2$ to 6 inches long: a fine bear in every way for the home garden and for home cannilly. Quite hardy and very prolific; it would satisfactory entirely stringless wax bean for the private garden.

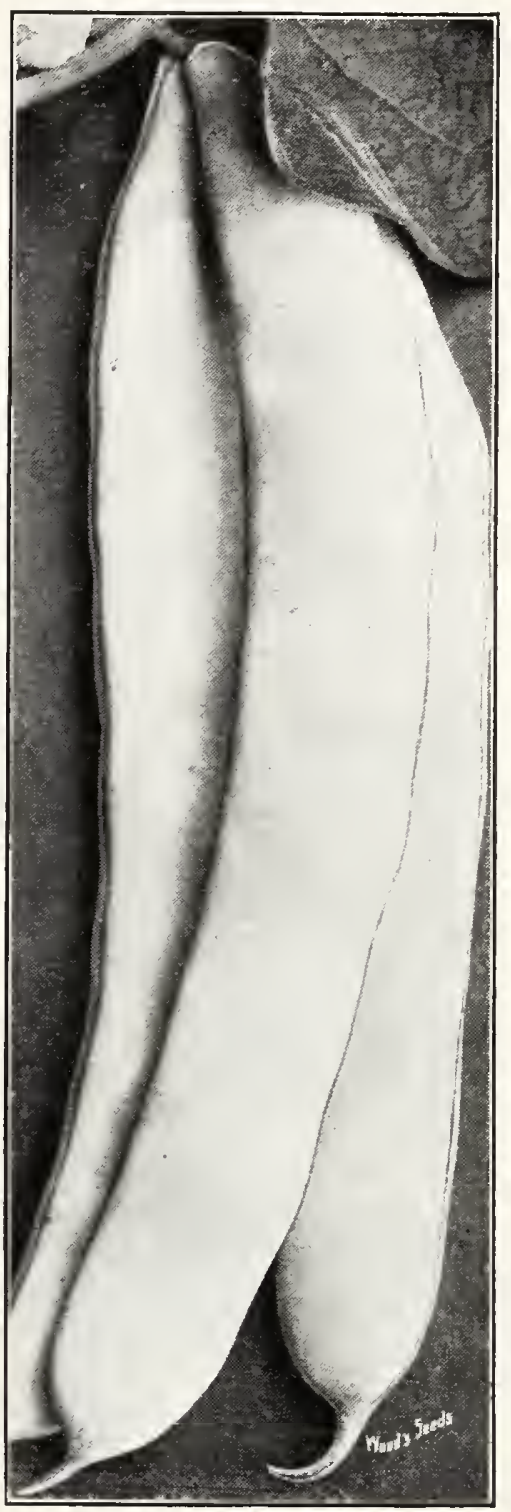

Rustless Golden Wax.

No. 28. Pencil Pod Black Wax--The best strain of black wax beans and has all bean for the home garden and nearly market. The pods are 6 to 7 inches long, round and of a uniform rich yellow color: tender, absolutely stringless, very brittle, feshy, exceedingly fine grained and without fibre. It is the finest strain of Black profusely and throughout a long stasun.

No. 26. Rustless Golden Wax

A vigorous wonderfully productive bean of excellent quality. Its unusual vigor tendrils which at first eive it the appearof a runing lean but it later assumes the true bush form. This vigorous yield and its long iearing season. Th handsome pods are uniformly large, $41 / 2$ of fibre, fleshy, very l,rittle and tender also makes a good bean to dry for winter use.

No. 30. Currie's Rust Proof Wax

An abundant bearer of crisp, tender stringless almost rust proof pods, $51 / 2$ to $G$ inches long, straight and of a beautiful golden color; comes early and presents a most attractive appearance. A vigorous ductive. A favorite with market growers.

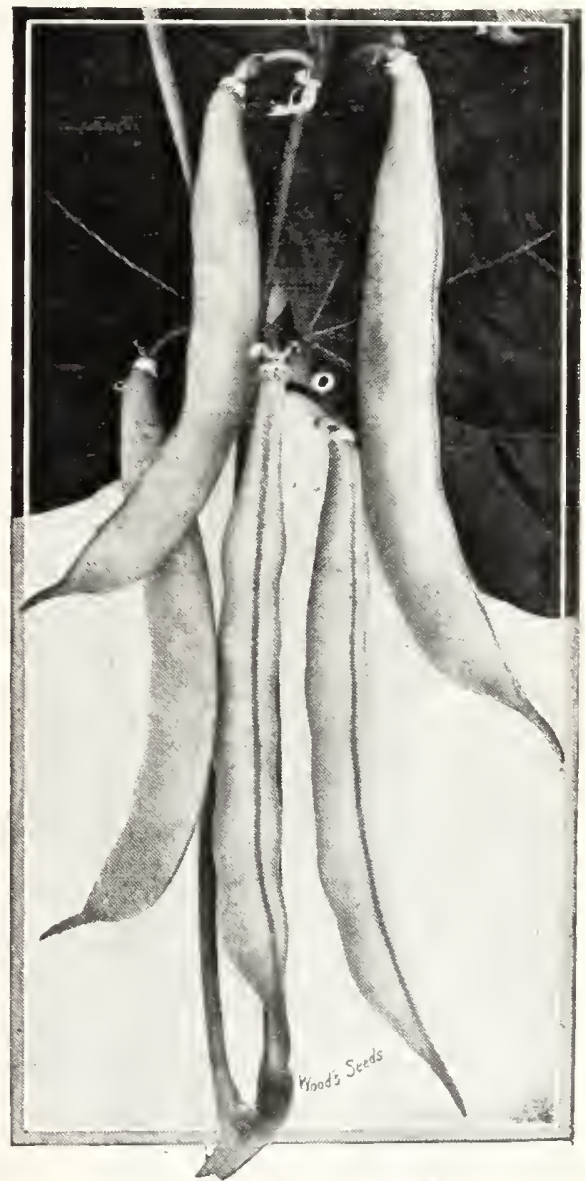

Pencil Pod Black Wax.

BY MAIT POSTPAID

\section{PRICES}

No. 26-Rustless Golden Wax

No. 28-Pencil Pod Black Wax

No. 29-Ronnt Pod Brittle Wux

No. 30-Currie's Rust Proof Wax

No. 33-Surecrop Stringless Wax

\section{Pzt. 1/2 1b. $1 \mathrm{lb} .2 \mathrm{lbs}$. 5 lbs.}

$10 \mathrm{c} \ldots 25 \mathrm{c} \ldots 40 \mathrm{c} \ldots 70 \mathrm{c} \ldots \$ 1.45 \ldots .2 .55$

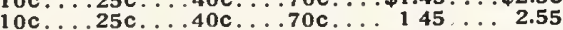

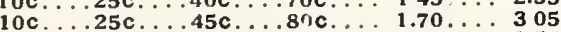

$10 c \ldots 25 c \ldots .40 c \ldots .70 c \ldots .1 .45 \ldots 22.55$

\begin{tabular}{|c|c|c|c|c|}
\hline \multicolumn{5}{|c|}{ NOT PREPAID } \\
\hline $1 \mathrm{lb}$. & 2 lbs. & 5 lbs. & $10 \mathrm{lbs}$. & 100 lbs. \\
\hline $\begin{array}{l}30 \\
30 \\
35 \\
30\end{array}$ & $\begin{array}{l}55 \mathrm{c} \\
65 \mathrm{c} \\
55 \mathrm{c}\end{array}$ & 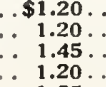 & $\begin{array}{r}\quad \$ 2.20 \\
\because \quad 2.20 \\
\therefore \quad 270 \\
\therefore \quad 2.20\end{array}$ & $\begin{array}{r}\quad \$ 20.00 \\
\because \quad 20.00 \\
\therefore \quad 2500 \\
\therefore \quad 20.00\end{array}$ \\
\hline & $.55 c$ & . 1.25 & 2.30 & 21.00 \\
\hline
\end{tabular}




\section{Dwarf or Bush Lima and Butter Beans}

CUエTURE.

\section{Small Seeded or Butter Bean Varieties}

No. 37. Wood's Prolific Bush Lima - Since we introduced this fine bean (ill other bush lima varietses. It is growth

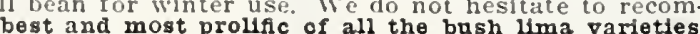
No. 38. Henderson's Bush Lima -The original dwarf or bush butter bean, a 's Bur ty a

No. 42. Jackson Wonder Bush Lima Also known as Florida Bush Butter Butter Bean. This bean origlnated in the South where many gardeners prefer it to all other kinds of bush limas, claiming that it is the best bearer of them all. and high and carry quite a load of pods that contain 3 to 4 beans each. It begins bearing

\section{Large Seeded Bush Limas}

No. 41. Wilson Bush Lima -The Wrilson is the very latest improvement in the . can be counted on one side of the plant. These pods will average more than five by any large limit beans. The plant is strong and holds the pods well off the ground, pther larke bush limas, it was ready for picking nearly ten days earier than any other, yet it continued in bearing for a long season. On account of the luxuriant than ordinary. In eariiness, abundance of yicld and long bearing season, the Wilson

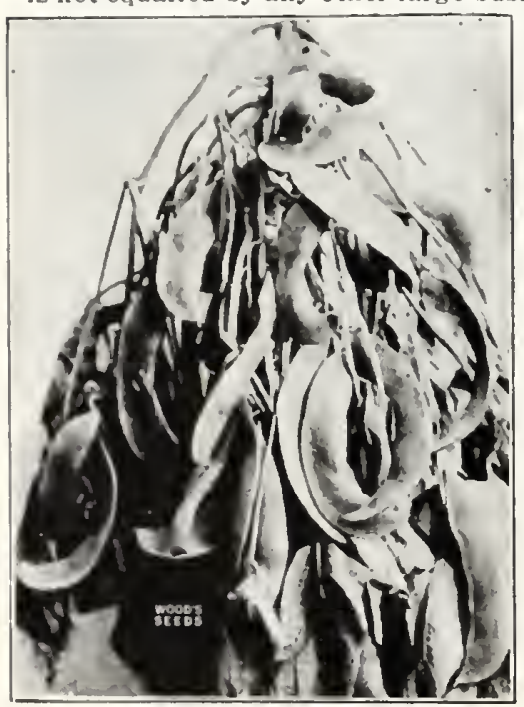

wils on Bush IIma \begin{tabular}{l} 
Wood's Prolific Bush Lima Beans. \\
No. 40. Burpee's Bush Lima The bush type of the well-known large white pole \\
\hline
\end{tabular} formly dwarf and erect, branch vigorously and are immense vielders, the pods carrying three to five large beans. The pods are well filled with very large beans identical in size and buttery, luscious flavor that has made the large white pole lima so universally popu-

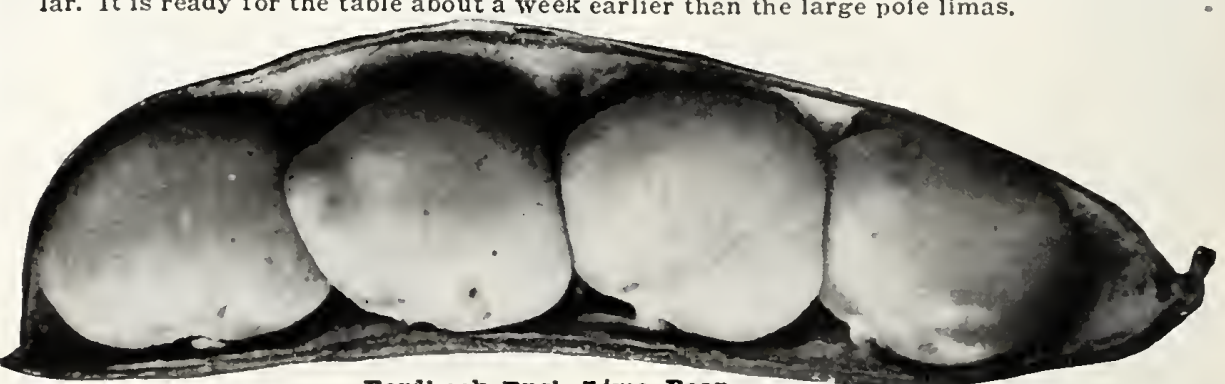

Fordhook Bush Iima Bean

No. 39. Fordhook Bush Lima -The dwarf form of the popular "potato lima." the ground, so that they are not injured by being beaten to the ground by the wind or rain. Very prolific, the pods, which are produced in clusters, each contain four or five large, fat beans of exceptionally fine quality. They are packed so closely together in the pods that they are fiattened on the ends, and are very easily shelled. The green creen threen.

\section{PRICES}

No.37. Wood's Prollfio Bush IIma.

No. 38. Henderson's Bush Iima

No. 39. Fordhook Bush IIma

No. 40. Burpo'sush Lima

No. 41. Wllson Bush ILlma.

No.42. Jackeon Wonder Bush rima.
BY MAIT POSTPAID

Ib. 2 1b8. $51 \mathrm{bs}, 101 \mathrm{bs}$.

Pkt. 1/21b.

$100 \ldots 250$

$100 \ldots 30 \mathrm{c} \ldots 50 \mathrm{c} \ldots 85 \mathrm{c} \ldots 1.45$

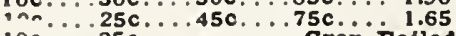

$10 \mathrm{c} \ldots 25 \mathrm{c}$

$45 \mathrm{c} \ldots . .75 \mathrm{c} \ldots . .65 \ldots .2 .95$

400...700... Crop Falled $1.45 \ldots 2.55$

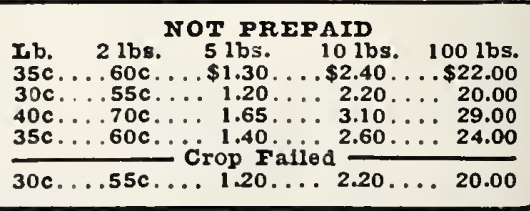




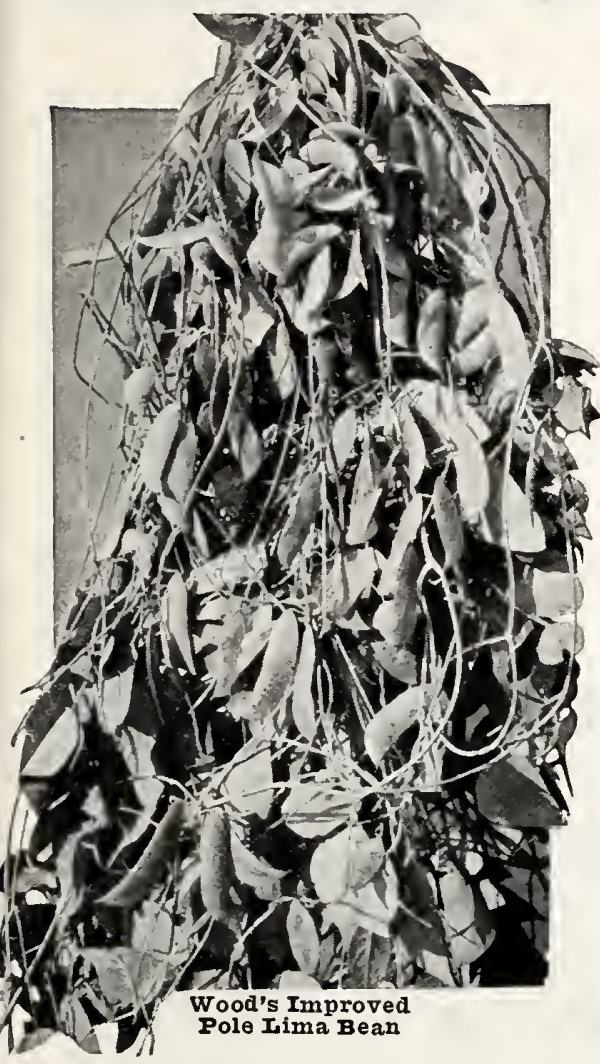

No. 45. Nancy Davis or Striped Creaseback -A vigorous and productive bean that bears quantities of fat, round, fleshy pods nearly eight inches long. A fine bean for either the home gar den ol market particularly for growing in corn. Of extra good quality and stays in condition as snaps longer than any pole bean.

No. 48. Fat Horse or White Creaseback -One of the earliest and at the same time on of the most preductive pole beans, bearin round, fleshy pods in large clusters. The seeds are pure white.

No. 49. McCaslan - A heavy bearer of large, meaty stringless snaps of delicious flavor. Bears all the season if closely picked.

No.50. Cut Short or Cornfield-May be used shelled green or dried for winter use. meaty pods are 4 inches long and crowded No. 51. L . Good bean for the small garden. beans, or dry beans either for snaps, shell ( 5 to 7 inches leng) are borne in large clusters long, broad, thick, fleshy and entirely stringless, Flavor rich and buttery.

\section{Pole Lima and Butter Beans}

No. 57. Wood's Improved Pole Lima (Butter Bean)-This improved variety is of eans are larger and it is earlier than any of the other pole ommon to find clusters of pods ready to pull at one time No. 59. Florida Speckled Butter Bean -Calico Bean.

61. Carpinteria Large Pole Lima the finest

o. 60. Ford's Mammoth Podded Po'e Lima the large yielders among the pole limas as well as be anusually large, each containing four or five beans of the finest quality. The vines o. 62. Large White Pole Lima The old reliable and well-known variety. A fav$x$ inches long, big and broad, and the beans are large and of superior quality.

\section{Pole or Cornfield Beans}

\section{PRICES \\ POIEIIMA and BUTTER BEANS}

No. 57. Wood's Improved Plrt. $1 / 21 \mathrm{~b}$.

No. 58. Small Pole Iima . 10c..25c... No. 59. Florida Speckled

No. 60. Ford's Mamimoth

No.61. Caminteriamoth $\ldots 10 \mathrm{c} \ldots 25 \mathrm{c} \ldots 45 \mathrm{c}$

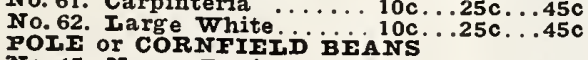

No. 45. Nancy Davis ....10c . 25c . .40c

No. 46. October or Horticil. $10 \mathrm{c} \ldots 25 \mathrm{c} \ldots 40 \mathrm{c}$

No.47. Tentucky Wonder.

No. 48. White Creaseback.
No. 49. McCaslan .......

No. 51. Cut Short

Wax $10 c \ldots 25$ feet long. 3 to 4 feet apart, in 4 -foot rovs and plant five planted in the cornfield and allowed pole. They may also troublesome to grow than busl beans, but they are of lant 100 hills; 30 pounds to the acre.

No. 46. October or Horticultural

(Wren's Igg or Speckled Cranberry).-The pods are $51 / 2$ to 6 inches long and when young are beans for use as snaps, for shelling when green, and for drying for winter use. A splendid beall flavor.

No. 47. Kentucky Wonder or Old

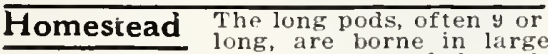
from the top to the bottom of the pole round, crisp and tender. If gathered as they mature they continue bearing throughout the season.

No. 52. Golden Cluster Wax - ir ed i u $\mathrm{m}$ hardy and continues in bearing for a long sea-
son. Pods, 6 to 8 inches long, are borne in clus-
ters, are broad, thick, fleshy. tender and of the
best flavor. The beans are white and make an
excellent dry bean for winter. No. 53. Scarlet Runners $-\tau$ seful as a vegeinental purposes, producing sprays of bright
scarlet flowers.
CUITURs.-Pole beans are more sensitive to cold than the

\section{:}
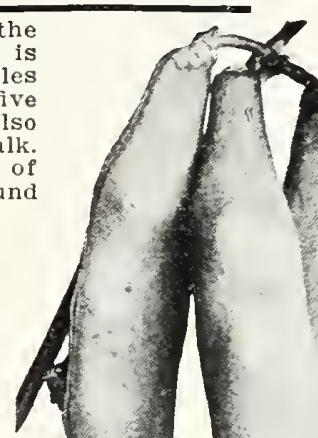

NOT PREPAID

2 lbs. 5 lbs. 10 lbs. Lb. 2 lbs. 5 lbs. 10 lbs. 100 lbs.

.

c..70c... $1.45 \ldots 2.5530 \mathrm{c} \ldots 55 \mathrm{c} \ldots 1.20$

.70c... 1.45 .

$2.5530 \mathrm{c} \ldots 55 \mathrm{c} \ldots 1.25$

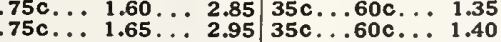

$75 \mathrm{c} \ldots 1.60$.

$.70 \mathrm{c} \ldots 1.45$

$.65 c \ldots 1.35$

$65 \mathrm{c} \ldots 1.35$

$.65 \mathrm{c} \ldots 1.35$

$70 \mathrm{c} \ldots 1.40$

$.70 \mathrm{c} \ldots 1.55$

\begin{tabular}{l|lll}
2.95 & $35 c \ldots 60 c \ldots$ & 1.40 \\
2.85 & $35 c \ldots .60 c \ldots$. & 1.35
\end{tabular}

$2.5530 \mathrm{c} \ldots 55 \mathrm{c} \ldots \quad 1.20$

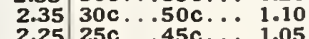

2.25
$25 \mathrm{c}$
2.35
$30 \mathrm{c}$.

$2.6530 \mathrm{c}$

2.35 30c . . 55c... 1.25

$2.4530 \mathrm{c} \ldots 55 \mathrm{c} \ldots 1.15$

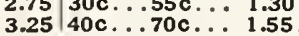

$2.20 \ldots 20.00$

$2.20 \ldots 20.00$

$2.50 \ldots 23.00$

$2.60 \ldots 24.00$
$2.50 \ldots 23.00$

2.00

1.90 .

2.00 .

2.00 .

2.10 .

2.40
2.90 .

20.00

18.00

17.00

21.00

18.00

19.00

22.00
27.00

\section{9}




\title{
Garden Beets
}

CUTTURE- For the earliest beets plant in a hot bed and trans (larch and make suceessive fur store as recommended on page 15 for storlng carrots. One ounee will plant 50 feet of row. 6 to lbs. one aere.
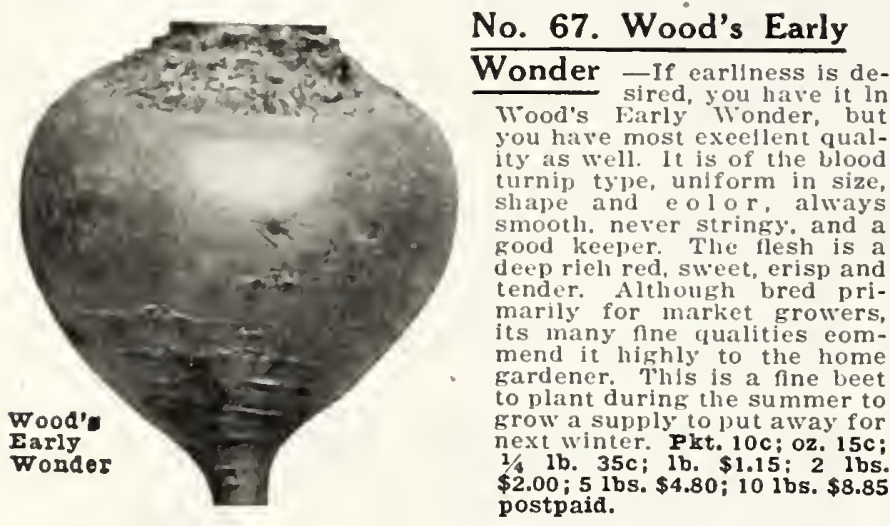

No. 73. Detroit Dark Red use or market. Almost globe root blood-red eolor without light rings. A good beet for both early and late pianting. The quallty is fine Pkt. 5c; oz. 10c; 5 lbs. $\$ 4.00 ; 10$ lbs; $\$ 7.50 \$ 1.75$ pala.

\section{No. 71. Extra Early}

Egyptian -in earliness no wlth Extra early Egyptlan its earliness adapting it for first early erop and for forcing. It is about ten days earnip, makes fine, smooth, aimost flat, very dark-red beets about two inehes In diameter: firm, erisp and tender: has very small tops. Prt. 5c; oz. lbs. $\$ 1.45 ; 5$ lbs. $\$ 3.40 ; 10$ ibs. $\$ 6.15$ postpaid.

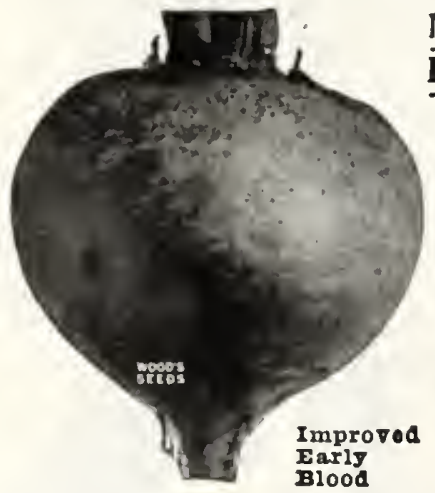

No. 70. Improved Early Blood -If you are in doubt you will net wo brong in plantyou wlll net go wrong in planting the Improved liarly Blood demand shows that lt has given unvarying satlsfation and has the indorsement of a large maJorlty of our eustomers. Not as early as the Extra Early Egyptian, but superior in quality. Of uniform size, with smooth skin free from fibrous rcots. Color and erlsp Ideal fer May, June and July to make beets for winter. A fine keeper. Pkt. 5c: oz. 10c: $1 / 4$ lb. 25c: $1 \mathrm{~b}$. $85 \mathrm{c} ; 2$ lbs. $\$ 1.45 ; 5$
10 lbs. $\$ 6.15$ postpad.

No. 76. Swiss Chard SPINACH BEET or SEA FATE.-A ter cuttlngt real cut-and-come again salad. for af-

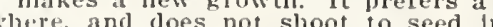
Boll, lut grows anyther an loes not shoot to seed in hot oz. $10 \mathrm{c} ; 1 / \mathrm{lb}$. $30 \mathrm{c}$; lb. $\$ 1.00 ; 2$ lbs. $\$ 1.75 ; 5$ lbs, $\$ 4.00$ postpaid.

\begin{abstract}
No. 68. Wood's Crimson
Clobe If asked to name the garden we would unhesitatingly name Crimson Globe. That it has made many fast friends is proved by the faet that fully three-fourths of our general orders eall for the Crimson Globe in varying quantitles. The shape is neariy a perfect globe about 10 Inehes around with smooth skin free from roetlets: the flesh is a rich biood red, nicely ringed, never stringy. and always tender and sweet. l'lant it for your main erop and again in June or July to have beets for next winter. Pkt. 5c; $\$ 1.50 ; 5$ lbs. $\$ 3.65 ; 10$ lbs, $\$ 6.35$ postpaid.
\end{abstract}
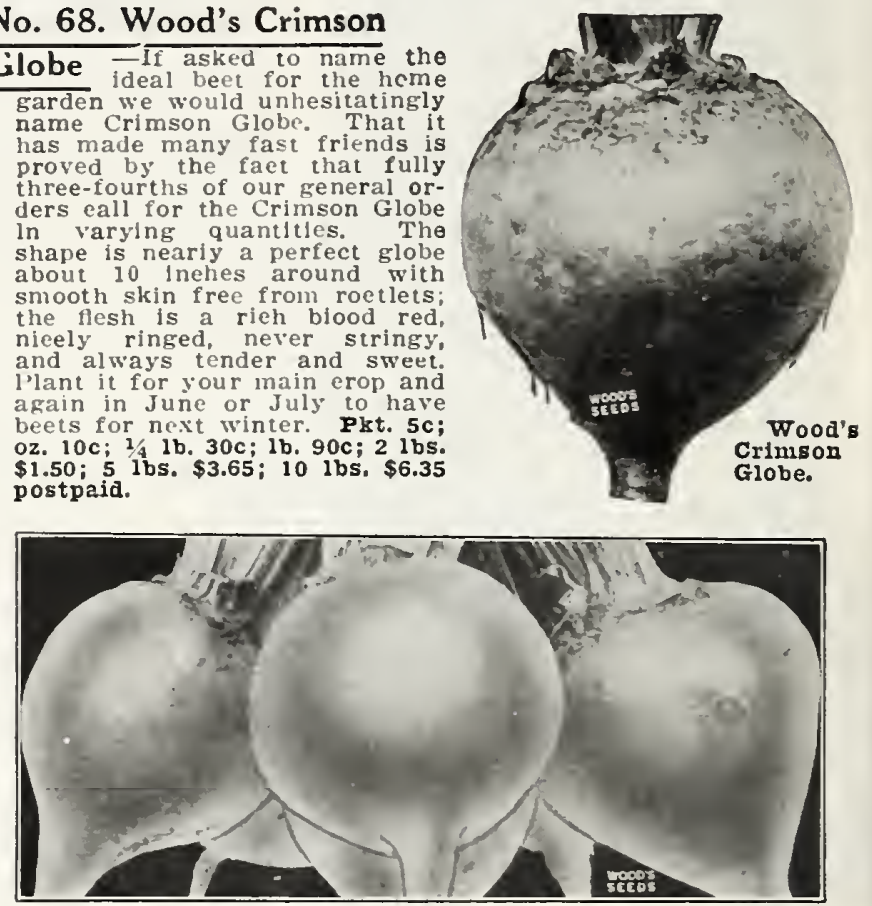

Crosby's Egyptian

No. 69. Crosby's Egyptian - Te recommend Cros by's earliness good sliape, good eolor and good quality. The color is bright red good shape, good eolor and good qualts. The color is der. ve have a ness, fine sliape and color we believe eannot be surpassed. Pkt. 5c: oz. 10c; $1 / 4$ lb. 30c; 1b. $90 \mathrm{c} ; 2$ lbs. $\$ 1.50 ; 5$ lbs. $\$ 3.65 ; 10$ 1bs. $\$ 6.35$ postpaid.

\section{No. 74. Edmand's Blood Turnip}

- Although quite early and muel used for early planting. the Ed$m$ a nd' $s$ is generally grown for main erop and for putting away for winter, for whieh purpose it is partieulariy good. The beets are nearly round smooth and exeellent keepers. Skin and tlesh deep red; erisp and sweet. We reeommend Edmand's for quality. It is a partieularly fine en. Pkt. 5c; oz. 10c; 1/1b. 30c; ib.' $90 \mathrm{cz} ; 2$ lbs; $\$ 1.50 ; 5$ ibs. $\$ 3.65 ; 10$ ibs. $\$ 6.35$ postpaid,

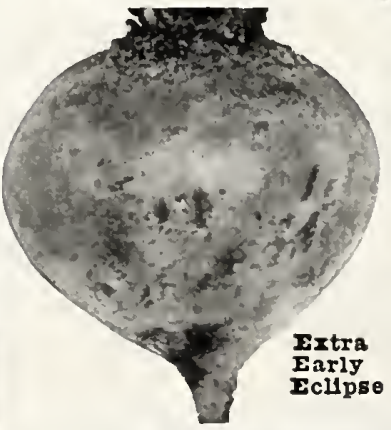

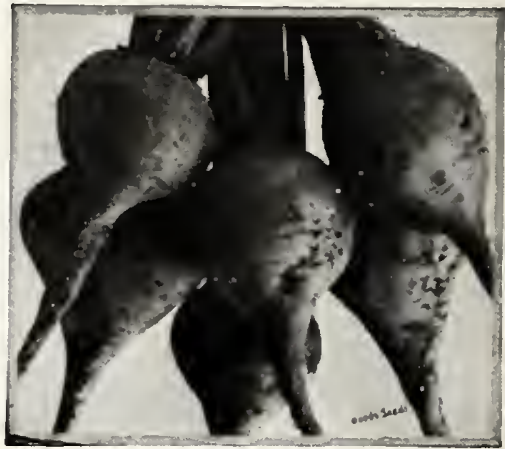

Edmand's Blood Turnip

No. 72. Extra Early Eclipse - An espeeially desirable, very early beet, making handsome smooth, round roots with small top and small tap-root, and nearly as early as the lixtra Early Egyptlan. Color, bright deep red, flesh fine gralned, sweet and tender, espeeially when young but holds peially older. home garden, but also does splendidiy when planted late to make beets for putting away for winter. Pkt. 5c; oz. 10c; $1 / 4$ 1b. 25c; 10 1bs. $\$ 6.15$ postpaid. 


\section{Stock Beets or Mangels}

FACTS ABOUT MANGEIS OR STOCK BEFTS

They make a splendid winter feed for cattle, sheep, hogs and poultry.

They increase the milk flow of dairy cows.

They yield larger crops than turnips and rutabagas and are higher in feeding value.

They keep stock and poultry in fine healthy condition.

They produce an immense yield of succulent and healthy food at low cost.

When fed in combination with grain, mangels are worth almost as much, pound for pound, as grain, for they aid digestion and assimilation.

They increase the value of other feeds when fed in combination, besides the uutritive value of the roots themselves.

CUITURE.-Flantings should be made beginning at corn plant ing time till the midule of June, soaking the seeds for twelty four hours before planting. Make the rows 2 to $21 / 2$ feet apart, the drills one inch deep on lands that have plenty of moisture il the subscil; on dry and sandy soil they should be planted deeper. Shallow sowings germinate better and give a larger proportion of vigorous plants. Thin out to stand 8 inches apart in the row
young plants may be transplanted to fill up vacancies. Cultivat as soon after planting as possible. As soon as frosts occur, di the roots, cut off the tops and pile on a well drained situatior, covering with straw or corn stalks and an inch of earth. As it gets colder increase the covering to prevent freezing. Gradual covering prevents heating. They are acrid when first dug, but if kept till January they will be sweet and succulent. Always feed with some dry roughage. They should have a fertilizer contain
ing a good per cent of potasl. 6 to 8 lbs. will plant an acre.

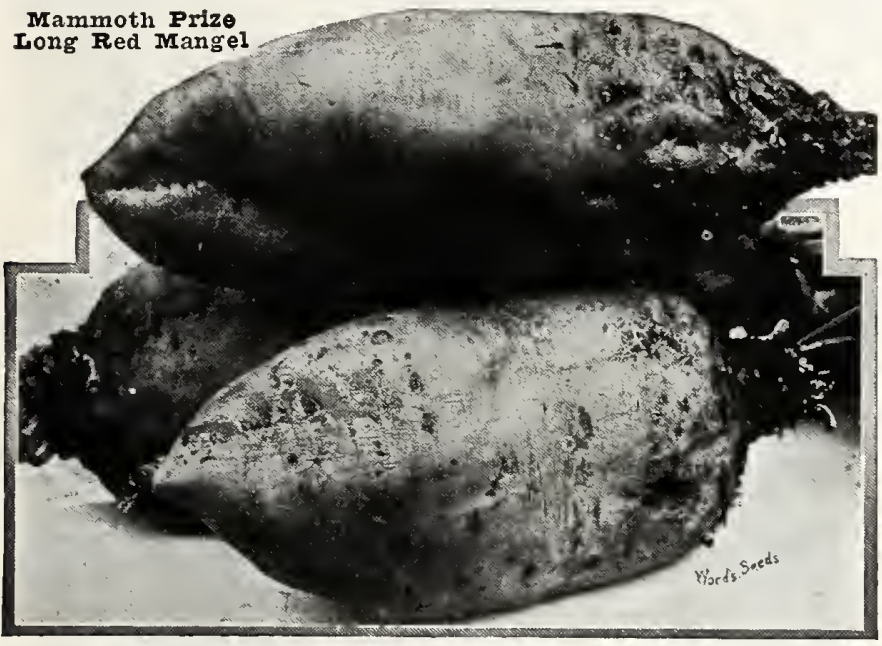

No. 80. Mammoth Prize Long Red - No other mangel this variety in yield. can compare with have been made on good land and under thorough cultivaticn. The roots of en weigh twenty to under thorough cultivaticn. grows well anove ground, is easily pulled; the deep red roots are straight, well formed and solid. A fine keeper and, at a low cost, will supply an abundance of succulent green food for soils. Oz. $10 \mathrm{c} ; 1 / 41 \mathrm{~b} .20 \mathrm{c} ; 1 \mathrm{~b} .60 \mathrm{c} ; 2$ 1bs. $\$ 1.00 ; 51 \mathrm{bs} . \$ 2.25 ; 101 \mathrm{bs}$. $\$ 4.10 ; 25$ lbs. $\$ 9.25$ postpaid.

No. 82. Golden Tankard The best known and most and especially recommended for the dairyman on account of its milk producing properties and the richer quality of the milk. The flesh is firm and solid, rich golden yellow color. On acccunt of its peculiar shape they can be grown closer in the rows than most mangels, increasing the yield per acre con-
siderably. Grows well above ground and easily pulled. Yields siderably. Grows well above ground and easily pulled. Yields lbs. $\$ 1.00 ; 5$ lbs. $\$ 2.25 ; 10$ lbs. $\$ 4.10 ; 25$ lbs. $\$ 9.25$ postpaid.

No.83. Silesian Sugar - Although this variety does not described abcre, the feeding value, pound for pound, is fully half as much again greater on account of its high percentage of sugar content. The roots grow partly out of the ground and can be harvested with less labor and expense. Recommended especially for fattening cattle, but is equally ivell adapted for $\$ 1.00 ; 5$ lbs. $\$ 2.25 ; 10$ lbs. $\$ 4.10 ; 25$ ibs. $\$ 9.25$ postpaid.

\section{Cauliflower}

CUITURE.-Cauliflower requires the same treatment and cultivation as cabbage and can be grown both early and late. No mer and protection during cold weatler.

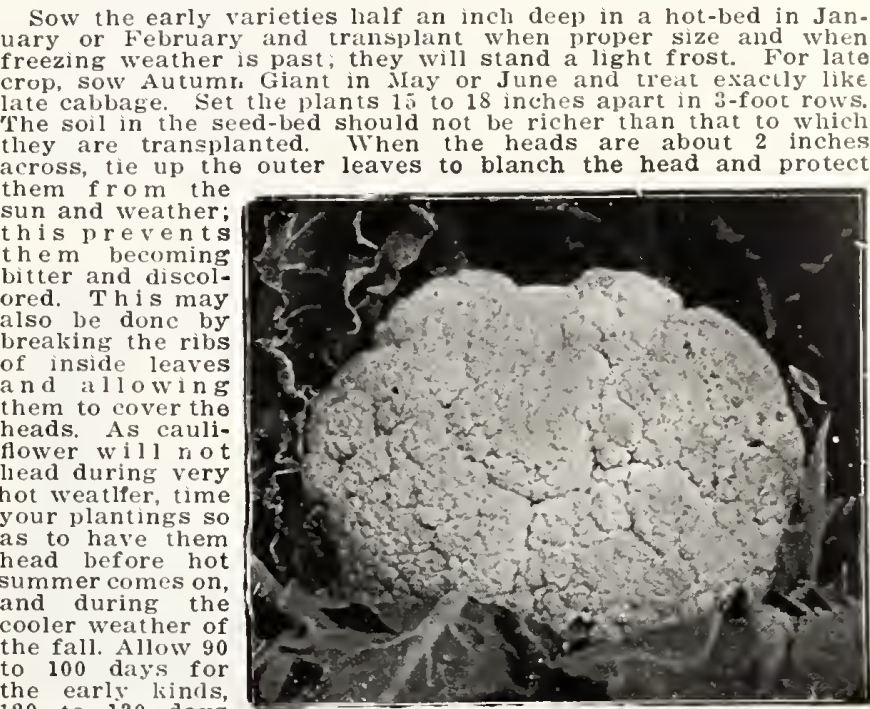

120 to 130 days Wood's Earliest Snowball Cauliflower.

sure to transplant to a rich, well-fertilized. moist soil, or give head is hard and com and frequent crillive

No. 128. Wood's Earliest Snowball

Southern growers and our strann is an any

adaptcd for forcing as for growing out of doors. Plat. 20c: $1 / 4$ oz. $65 \mathrm{c} ; 1 / 2$ oz. $\$ 1.25$; oz. $\$ 2.00 ; 1 / 41 \mathrm{~b} . \$ 7.00 ; 1 \mathrm{~b} . \$ 25.00$ postpaid. No. 129. Extra Early Dwarf Erfurt -A first-class

to our Snowball. Produces large, white, close, firm heads of $1 / 4$ 0z. 55c; $1 / 2$ oz. $\$ 1.00 ; 02$. $\$ 1.75 ; 1 / 41 b . \$ 6.00 ; 1 b . \$ 22.00$ postpaid. No. 130. Autumn Giant -A valuable late variety. adfall heading. The heads are laros and white and reming for fit for use. Plant in May or June and grow like late cabbage. $1 / 2$ oz. $25 \mathrm{c}$; oz. $40 \mathrm{c} ; 2$ ozs. $75 \mathrm{c}$; $1 / 4$ 1b. $\$ 1.35$; $1 \mathrm{~b}$. $\$ 5.00$ postpaid.

CAULIFLOWER PIANTS.-Ready January, February and March. 50 for 75 cts.; $\$ 1.25$ per 100 postpaid. Not prepaid, 50 for 65 cts.; $\$ 1.10$ per $100 ; \$ 9.00$ per 1,000 .

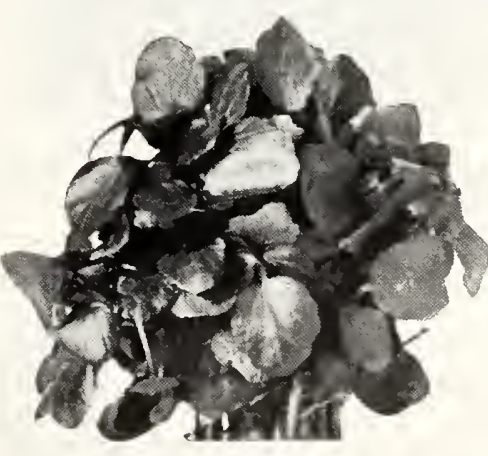

Water Cress.

\section{CRESS}

No. 187. WATER CRESS. along the edges or one rapid the young plants It not only makes a de plant, but purifles the $35 \mathrm{c} ; 2$ ozs. $60 \mathrm{c} ; 1 / 41 \mathrm{~b}$ $\$ 1.00$; lb. $\$ 3.50$ postpald.

No. 188. CURIED CRESS.-Can be sown either in the spring or fall. The plants are cut and tied in bunches in the same man ner as water cress. Sow in drills one foct apart. One ounce will sow about 200 feet of drill. Fkt. 5c; oz. 10c; $1 / 4$ lb. 30c 1b. $90 \mathrm{9} ; 2$ lbs. $\$ 1.50$ postpaid. 


\section{Wood's High-Grade Cabbage}

COTTURE- Then transplantlng cabbage plants from the seed chaber dug and well ther amonia The soll lin the seed lied should not be rlcher than the soil where set the plants as decp is the llrst leaf stems, glve frequent and set the flifeles apart in $21 / 2$ to 3 foot rows: the plants

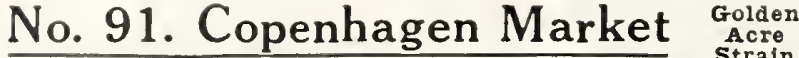 The Earllest of All the Round-Headed Cabbages}

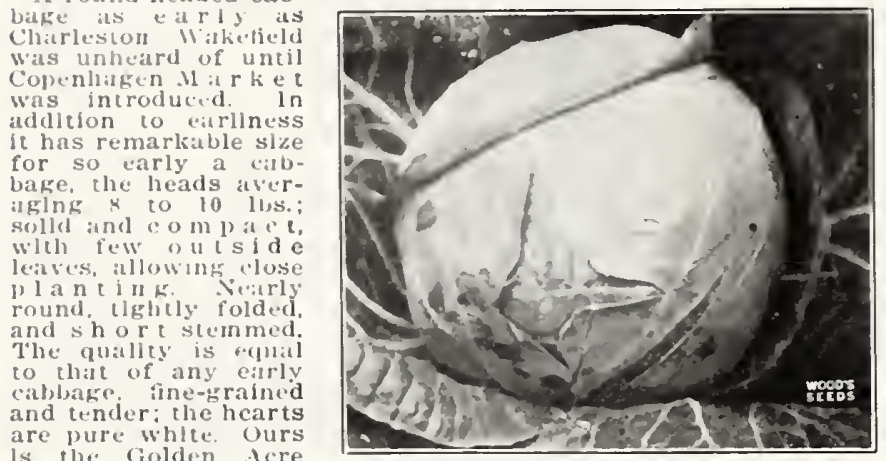

Pkt. $10 \mathrm{c} ; \mathrm{oz}$.

Copenhagen Market Cabbage. 30c; $1 / 4$ 1b. $\$ 1.00 ; 1$ b. $\$ 3.50 ; 2$ lbs. $\$ 6.30 ; 5$ lbs. $\$ 15.25$ postpaid.

No. 99. Early Drumhead -A most excellent, sure-heading . second early cabbagc of as nine top, solid 'risp and tender. Especially" adapted for the home
rarden. Pkt. 5c; oz. 20c; 2 ozs. 35c; 1/4 1b. 65c; $1 \mathrm{~b} . \$ 2.25 ; 2$ lbs. $\$ 4.00 ; 5$ 1bs. $\$ 9.80$ postpaid.

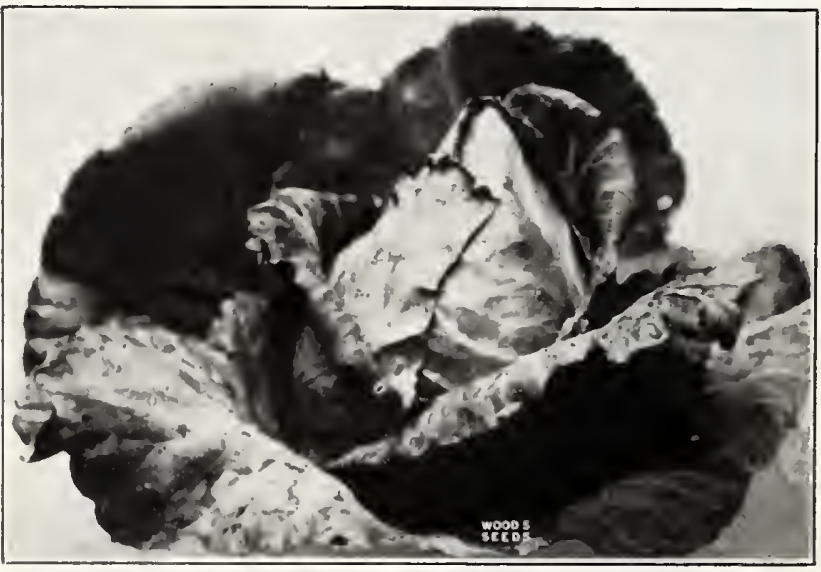

No. 93. Wood's Selected Early Jersey Wakefield Extra Early, Sureheading and Solid

More Than 100,000 Satisfied Planters Can Testify to the Fine Quality of Our Well-Bred Wakefield Earliness, hardiness, solldity, good size, nnlformity, fine qualIty-these characterlstles go to make Wood's selected barly
Jersey lliakefleld the most unlversally planted of all early cabJersey Wiakcfleld the most unlversally planted of all early cab-
bages. It is frown In nearly every garden in the South and

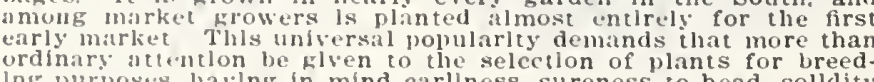
and unlformity of growtl and maturlty. In our Wakcfields this yoars, and we helfive we have as good and unlform a straln as 2 lbs. $\$ 4.90 ; 5$ 1bs. $\$ 11.50 ; 10$ lbs. $\$ 21.50$ postpaid.
PIANTING DATES (For the Vicinity of Richmona.)

spring Planting.- Sow the early varieties in boxes indoors $\mathrm{cr}$ in hot bed in January. February or Mlarch: for a summer crop Irom April to June.

Winter Cabbage.-Sow the late varletles in Aprll, May or June and transplant when large enough.

FOR CABBAGE WORMS.-A mixture of one pound arsenate of lead to seven pounds hydrated or air-slaked lime dusted on the cabbage at frequent intervals as the heads are forming wil klll the worm and will not impair the cabbage for human food.

\section{No.90. Wood's Extra Early \\ The Earliest of All Cabbages}

grow for home use grow for home use
or for market, you or for market, you II'ood's Extra Lar ly. for it is the cultivation and in every way one of the most desirable extra early varie. eminentlo an early cabbage it has slze. it is large than the Jersey not quefield, though not quite so solid. earlier. The qual ity is good, has few loose leaves, and nearly every Hardy, resisting cold and unfavorable conditions that often attend early

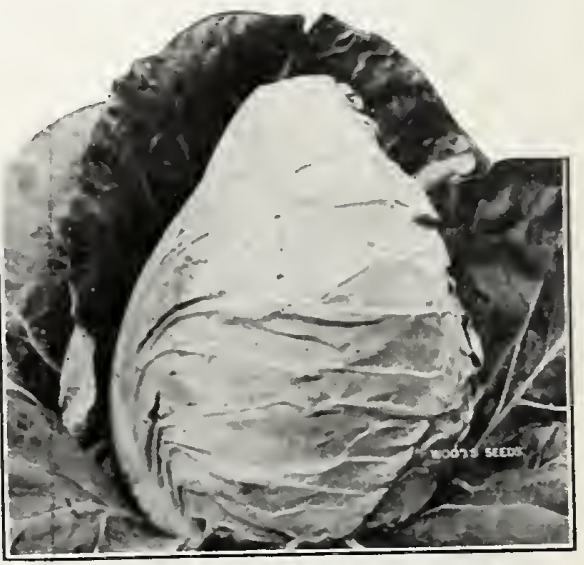
postpaid.

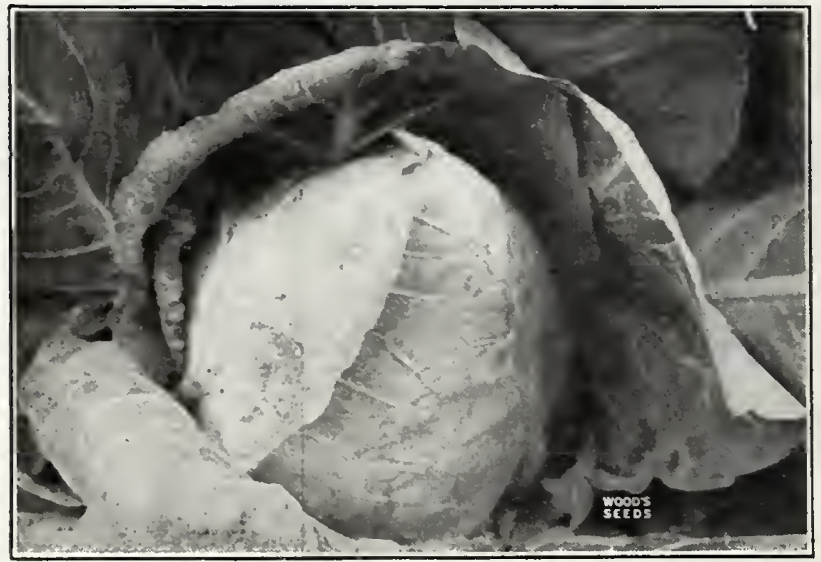

No. 94. Wood's Charleston Wakefield Fine Size, Fine Quality, Uniform

Sometimes called Iong Island wakefield.-Every gardener enfoy's a feeling of security when he plants our selccted Charleston TTakefield, for it is a thoroughbred. About a week later than our just as solld with less polnted and thicker heads it has earliness, hardiness, fine size and finc quality. These are the outstanding traits of character that have made our Selected Charleston Waliefield so popular with Southern gardeners. Pkt. 10c; oz. 30c; 2 ozs. 50c; $1 / 4$ lb. $80 \mathrm{c}$; 1 b. $\$ 2.75$; 2 lbs. $\$ 4.90 ; 5$ lbs. $\$ 11.50$; 10 lbs. $\$ 21.50$ postpaid.

The Wood's Selected Early Jersey Wakefield Cabbage I got from you last season was eight or ten days earlier than anything I have even planted. Being a few days earler makes a big difference for market. WADE I. MIZEII,
Hallifax County, 


\section{No. 96. All Head Early}

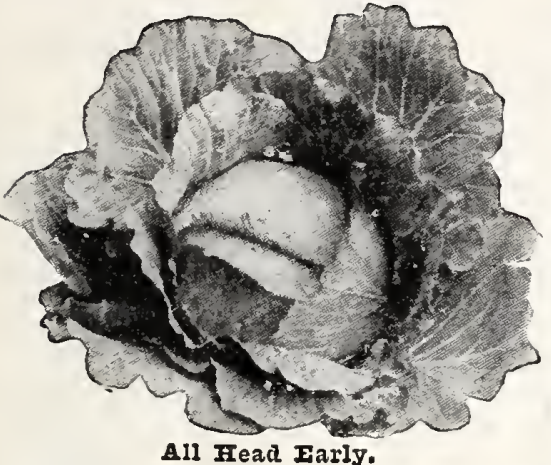

All Fead Early.
A Fine Cabbage to
Follow wakefield -All Head is a thoroughbred and leads all the second early varieties in size. It large heading cab bages, considering its earliness we large. It makes deep flat head, solid and un if or $m$ in or, is a dependabl header, is compact. with $1 \mathrm{ew}$ outside Plrt. 5c. ozs. $40 \mathrm{c} ; 1 / 4$ lb. $70 \mathrm{c}$; lb. $\$ 2.50 ; 2$ lbs. $\$ 4.50 ; 5$ ibs. $\$ 10.75$ postpaia.

No. 97. All Seasons -One of the very best, either for early or late planting. Heads very large and round Very solid and of the best quality, keeping as The plant is very vigorous and sure-heading. Remarkable for stand hot sun and dry weather, an excellent keeper. This cabbage every garden, Pkt. 5c; $02.20 \mathrm{c} ; 2$ ozs. $35 \mathrm{c} ; 1 / 4$ lb. $65 \mathrm{c}$; 1b. $\$ 2.25 ; 2$ lbs. $\$ 4.00$; 5 lbs. $\$ 9.80$ postpaid.
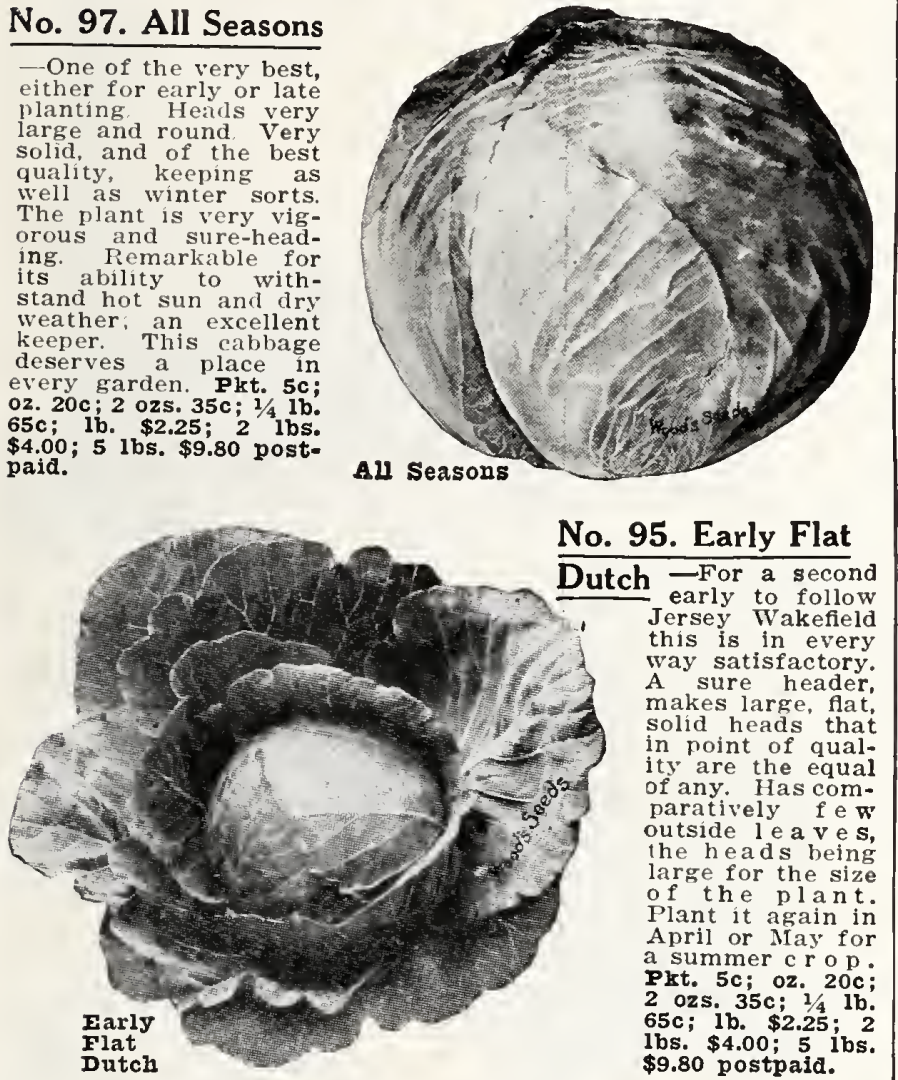

No. 95. Early Flat Dutch -For a second early to follow this is in every way satisfactory A sure header, makes large, flat, solid heads that in noint of qual. ity are the equal para ive comoutside leaves, the heads being large for the size of the plant. April or May for Aprimor c r o p Pkt. 5c; oz. 20c: 2 ozs $35 \mathrm{c}$ : $1 / 4 \mathrm{lb}$. lbs. $\$ 4.00 ; 5$ ibs. $\$ 9.80$ postpaid.

No. 100. Henderson's Succession

-A splendid sor t whether grown for medium early, midsummer or the late crop, and keeps well Heads deep and solid and of the finheads become solid before they are fulthe surest headers among the midseason varieties. Pkt. $35 \mathrm{c} ; 1 / 4$ 1b. $65 \mathrm{c} ; 1 \mathrm{~b}$ $\$ 2.25 ; 2$ lbs. $\$ 400$; 5 lbs. $\$ 9.80$ postpaid.

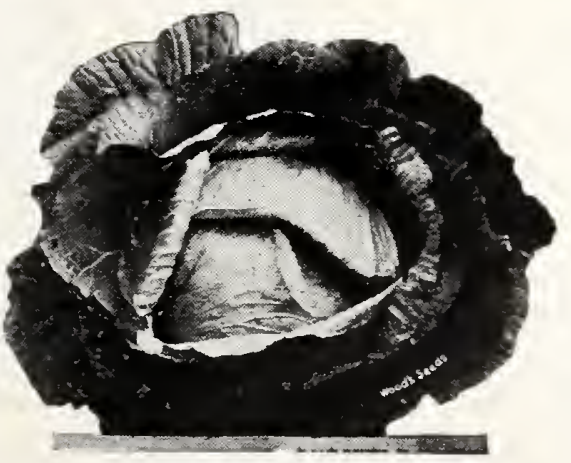

Henderson's Succession.

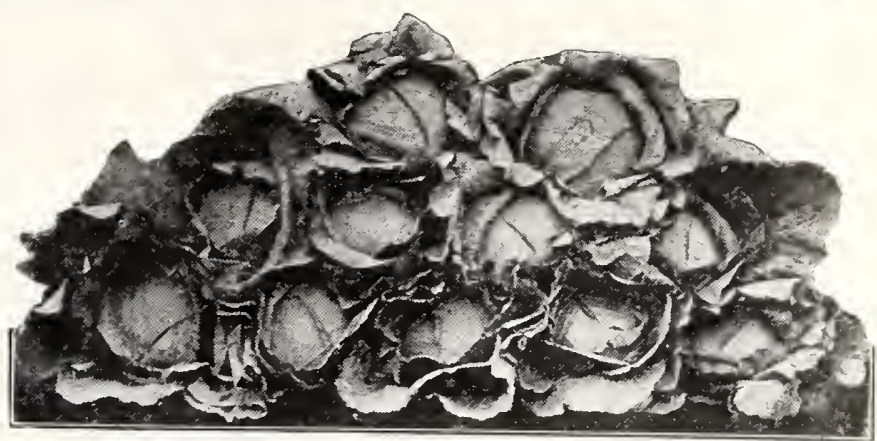

No. 98. Henderson's Early Summer -Although introyears ago, it still holds its place as an duced a number of bage. Forms large, fat round solid heads weighing 8 to 10 los., and is a sure and reliable header. Comes in about 10 days early cabbage Pkt. 5c; oz. 20c; 2 ozs. 35c; $1 / 41 \mathrm{~b}, 65 \mathrm{c} ; 1 \mathrm{~b} . \$ 2.25$; 2 lbs. $\$ 4.00 ; 5$ lbs. $\$ 9.80$ postpaid.

No. 106. Danish Ballhead short Originator's Strain Grown in Denmark. -The heaviest cabbage for its size we have e ver grown: ceedingly solid and h a r d: handsome, very hardy, a sure her and one of the an ideal cabbage for storing for winter. ozs. $50 \mathrm{c} ; 1 / 1 \mathrm{~b}, 85 \mathrm{c}$; lb. $\$ 3.00 ; 2$ lbs. $\$ 5.40 ; 5$ lbs. $\$ 13.10$ postpala.
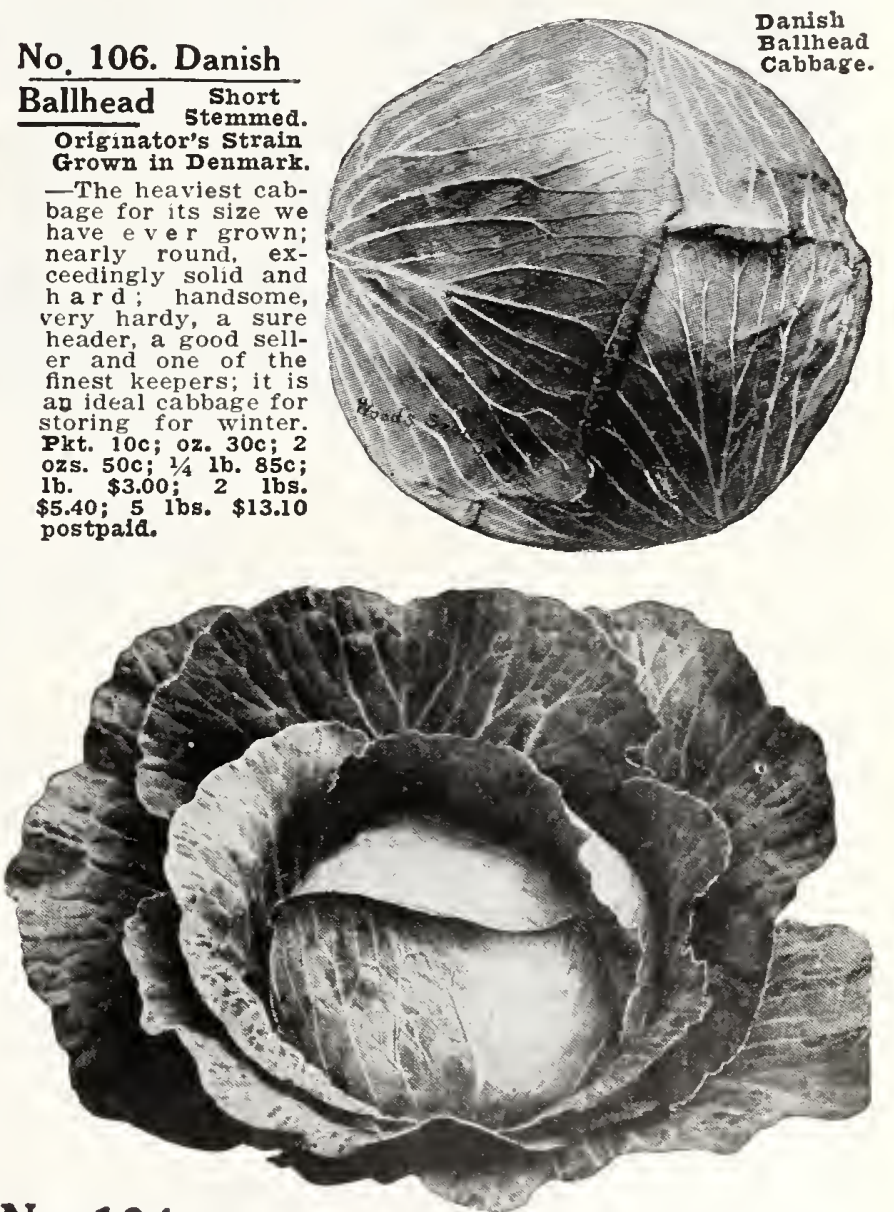

No. 104. Wood's Prize Head Iate Flat Datch Wood's Prize Head Late Flat Dutch This is beyond question the finest strain of Late Flat Dutch to selecting and breeding up our stock to have taken great pains in It is a thoroughbred, and will meet every demand for a first-class sure-heading, hard-heading, long-keeping cabbage of the very highest quality. It has all the good qualities that go to make the finest type of winter cabbage. We do not believe a better $10 \mathrm{c}$; 0z. 30c: 2 ozs. 50c; $1 / 4$ lb. $80 \mathrm{c} ; 1 \mathrm{~b}$. $\$ 2.75 ; 2$ lbs. $\$ 4.90 ; 5$ lbs. $\$ 11.50$; 10 lbs. $\$ 21.50$ postpaid. finest keepers: it is 


\section{Cabbage -- Continued}

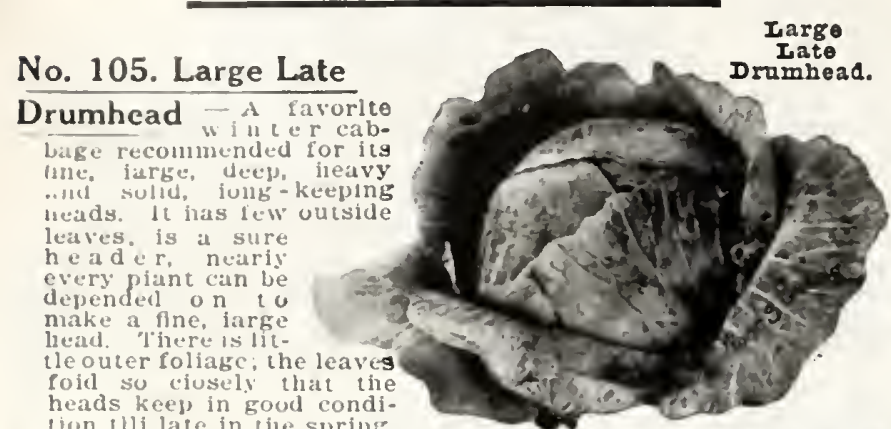

Plkt. $5 \mathrm{c} ;$ oz. $20 \mathrm{c} ; 2$ ozs. $35 \mathrm{c} ; 1 / 4$ 1b. $65 \mathrm{c} ; 1 \mathrm{~b} . \$ 2.25 ; 2$ lbs. $\$ 4.00 ; 5$ Ibs. $\$ \$ .80$ postpald.

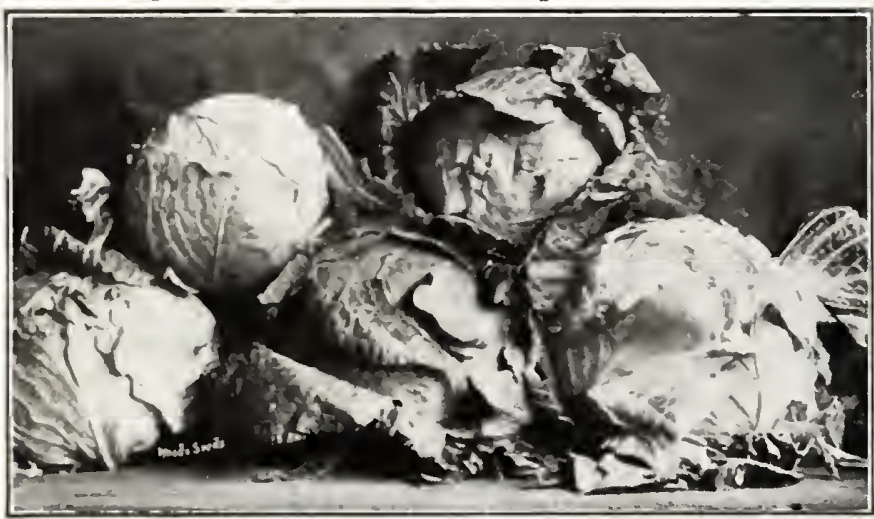

Surehead Cabbage.

No. 102. Surehead-As its name indleates, this is a sure

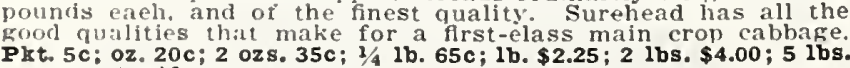
$\$ 9.80$ postpald.

No. 103. Large Late Flat Dutch - A good straln of this Makes good, large, solid, flat heads that keep well into the Winter. Pkt. $5 \mathrm{c} ;$ oz. $20 \mathrm{c} ; 2$
$\$ 4.00 ; 5$ lbs. $\$ 9.80$ postpald.

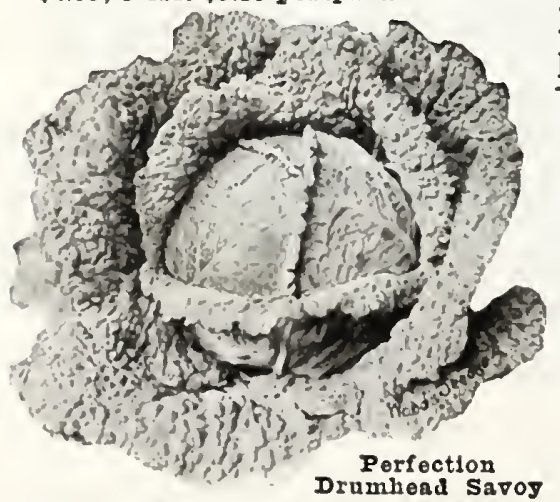

No. 107. Perfection Drumhead Savoy - Should be grown in every garden. No other winter eabbage ean compare with it in f touehed by frost when it is equal to eauliflower. If you grow them one you want to be withfinest solid hard heads do not plant till May. June cr early in July. as it will not head up hard during very hot Drumbead Saroy 30c: 2 ozs. 50c; $1 / 4$ lb. 列 $\$ 2.75 ; 2$ lbs. $\$ 4.90 ; 5$ lbs. $\$ 12.00$ postpald.

No. 108. Red Mammoth - The iargest and surest headlng ing. The ineals are large round, very sclid and attraetlve. Fkt. 10c; oz. $30 \mathrm{c} ; 2$ ozs. $50 \mathrm{c} ; 1 / 41 \mathrm{~b} .85 \mathrm{c} ; 1 \mathrm{~b} . \$ 3.00 ; 2$ lbs. $\$ 5.40$ postpald.

Cabbage Plants Jorsey Wakefleld, ready February till June. $\$ 3.50$ per $1,000$.
Late Vnrietios.--Ready from June till September. $45 \mathrm{c}$ per 100
postpald. Not prepald, 35c por $100 ; \$ 3.00$ per 1,000 .

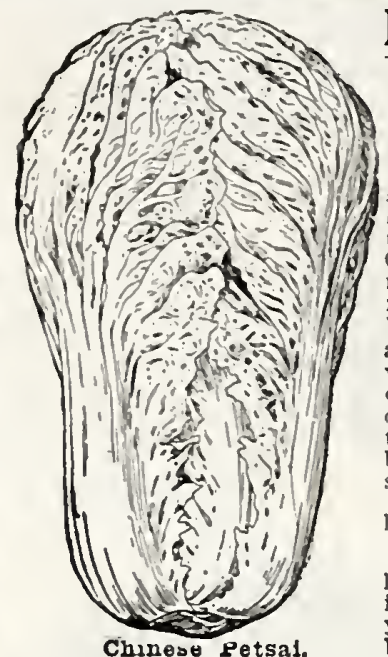

No. 114.Chinese Petsai or Celery Cabbage

A wonderful salad plant, growing 15 or 16 inches high, sollewlial re-
sembllng eos lettuce or probabiy more like swiss ehard. It yields an unCut up like cabbage and served salad. mayonnaise or Frencin dressing, it makes a splendid eole-slaw. Cau be bolied like eabbage if cooked quickly and served with cream sauce, but is without the strong flavor and odor of cabbage. The hearts blanch to a tuee and more beautiful than eabbage-elery leaf ineluding the out ide ones, is delieate and tender.

Be sure to plant some just to know ow good it is.

Snw early in the sprlng and again In July and August, transplanting 18 inehes anart in $216-$ foct rows. Time your spring planting so it will hear before hot weather: it heads in 80 40c; $1 / 4$ 1b. $70 \mathrm{c} ; 1 \mathrm{~b} . \$ 2.50 ; 2$ lbs. $\$ 4.50 ; 5$ lbs. $\$ 10.75$ postpald.

\section{CORN SALAD} or FETTICUS A very delightful salad that ean be served like let-
tuee or eooked like spinach. For summer use plant from fall plantings during August and September to proMake the drills a foot
apart, cover the seeds half an ineh, press the soil firm:

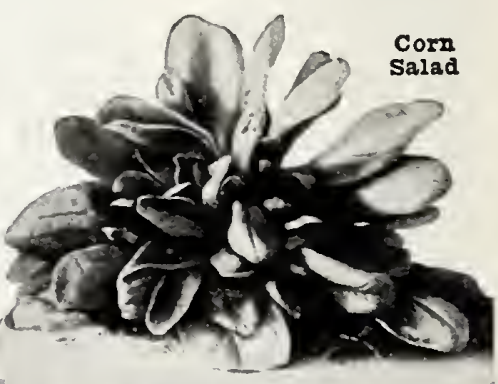
Pkt. 5c; oz. 15c; 2 ozs. 25c; $1 / 41 \mathrm{~b}$. 40c; $1 \mathrm{~b}$. $\$ 1.252 \mathrm{lbs}$. $\$ 2.20$ postpaid.

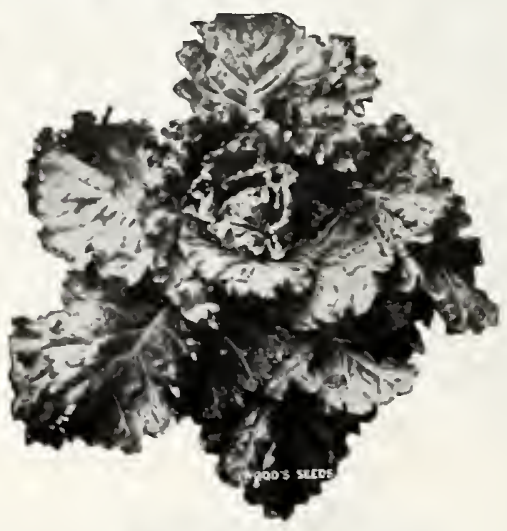

COLLARDS

One of the most popular Southern vegetables: largely used in place of and easier to grow than cabbage, ean be grown on poorer soil and withstands insect attaeks better Although often planted during the spring and summer, the princlpal plantings are made in June. July and August, transplanted 2 feet apart quent eultivation. A most excellent vegetable for the late fall. winter and early spring. The flavor is improved by
frost. Cultivate lilie late eabbage.

NO. 143. NORTH CAROIINA SHORT STEM.-A deeided imprevement, and has proved very popular wherever grcwn. Has short stem, large spreading leaves, very hardy, withstanding drought $10 c ; 1 / 41$ b. 30c; lb. $\$ 1.00 ; 2$ lbs. $\$ 1.75 ; 5$ lbs. $\$ 4.00$ postpaja.

No. 145. WHITE, or CABBAGE COIIARD.-Called eabbage-eollard beeause of its buneining habit and general resemblance to a eabbage, lixtremely hardy and grows on the poorest solls. 1b. 85c; 2 lbs. $\$ 1.45 ; 5$ lbs. $\$ 3.40$ postpald.

No. 144. GEORGIA or SOUTHERN.-Stands cold weather and aiverse conditions splendidiy and grows on land too poor to make a erop of cablvage. Most Southern gardeners would not feel 2 ozs. 15c; $1 / 4$ 1b. 25c; 1b. 75 c; 2 lbs. $\$ 1.25 ; 5$ lbs. $\$ 2.90$ postpaid.

COLIARD PIANTS - Rearly June, July and August, 40c per 100 postpald. Not postpala, 30c por $100 ; \$ 2.50$ per 1,000 . 


\section{Carrots}

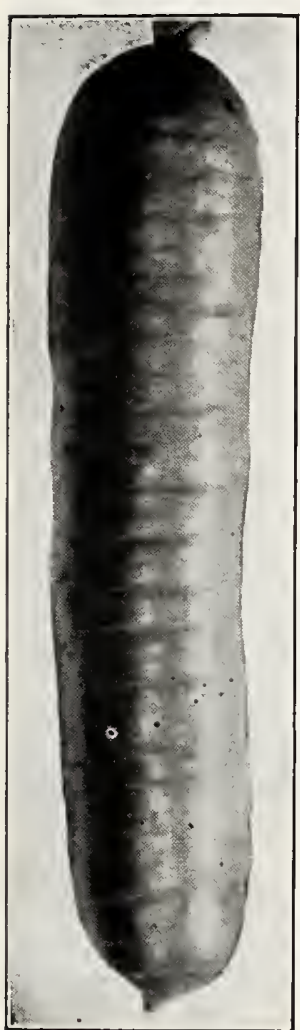

Wood's Scarlet Intermediate.

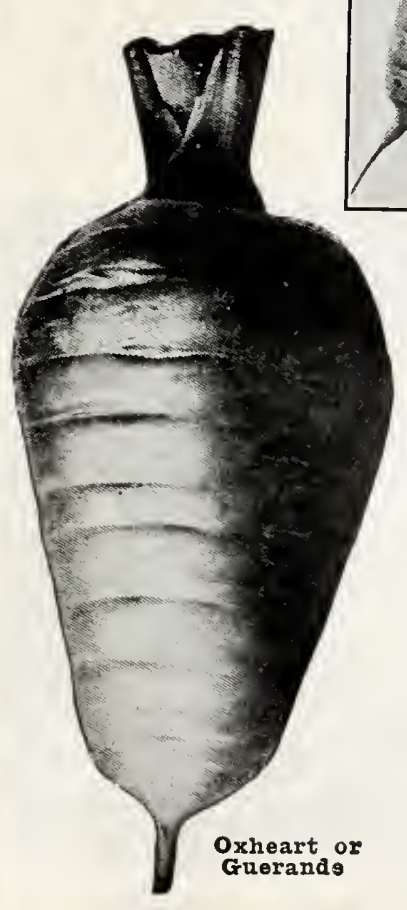

CUITURP.-Sow in a light, rich, deeplyworked soil as early as you can work the ground, in drills 12 inches apart and $1 / 2$ nch deep ; press the soil firmly after plantinches apart in the row. For field culture, make the drills 18 to 24 inches apart; later sowings should be made in July and August for a late crop to store for winter. In dry weather soak the seeds before sowing. To store for winter, pack in dry earth or sand in the cellar or put them outside on a well-drained situation, covering with a few inches of straw and 6 to 8 inches of earth 100 feet of drill; 3 to 4 pounds to the acre.

No. 119. Wood's Srarlet

Intermediate - The fincst carrot for all Early Scarlet dium early, but makes the size and type of root generally in demand: smooth and handsome, six to seven inches long, 116 inches thick, holding its thickness to the small tap root, and has that rich, bright orange color so much preferred. Pkt. $10 \mathrm{c} ; 0 z .20 \mathrm{c} ; 1 / 4$ Ib. 50c; 1b. $\$ 1.50 ; 2$ lbs. $\$ 2.65 ; 5$ lbs. $\$ 6.35$ postpaid.

No. 117. Early Scarlet Horn -The earliest variety in our list. The roots are 3 to $31 / 2$ inches long, $11 / 2$ inches thick at the shoulder tapering to inch at the bottom. It has scarcely any core, is fine grained and sweet flavored. Color, bright orange scarlet. Pkt. $10 \mathrm{c} ; 02.15 \mathrm{c} ; 2$ ozS. $25 \mathrm{c}$; $1 / 4$ lb. 35c; 1b. $\$ 1.25$; 2 lbs. $\$ 2.20 ; 5$ lbs. $\$ 5.20$ postpaid.

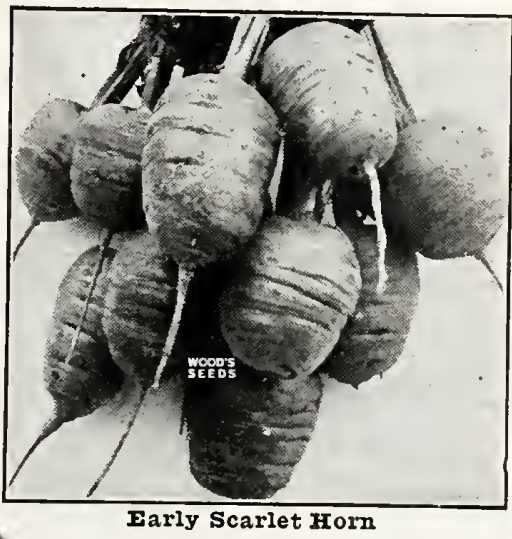

No. 118. Oxheart or

Guerande -One of the heaviest for stiff and heavy soils. to 5 inches long, about $31 \%$ to inches thick at top nearly oval shape: flesh at top, nearly oval shape; flesh bright orange, fine grained and sweet. Of the finest table quality and equally good ductive variety and easy to pull. Pkt. 5c; 0z. 10c; $1 / 4$ 1b. 30c; Ib. $90 \mathrm{c} ; 2$ lbs. $\$ 1.50$; 5 lbs. $\$ 3.65$ postpaid.

No. 123. Improved Long

Orange -Especially fine for light smooth, tapering roots of a deep orange color: free from side roots and superior in every respect; medium late, but can be used before attaining full size. A fine winter sort for table, mar$1 / 4$ lb. $30 \mathrm{c} ; 1 \mathrm{~b}$. $90 \mathrm{c} ; 2$ Ibs. $\$ 1.50$; 5 Ibs. $\$ 3.65$ postpaid.
No. 120. Danvers Half Long -There is hardly a class of not grow a good crop of Danvers carrot, for it thrives on a greater variety of soils than any other variety, and is one of the most productive. The roots are about 7 inches long, smooth and handsome; deep orange color; medium and tender. Pkt. 5c; oz. 10c; $1 / 41 \mathrm{~b} .30 \mathrm{c}$; lb. $\$ 1.00 ; 2$ lbs. $\$ 1.75 ; 5$ lbs. $\$ 4.00$ postpaid.

No. 122. Chantenay or Model -A fine, handsome, medium early carrot that can be used while quite young; those

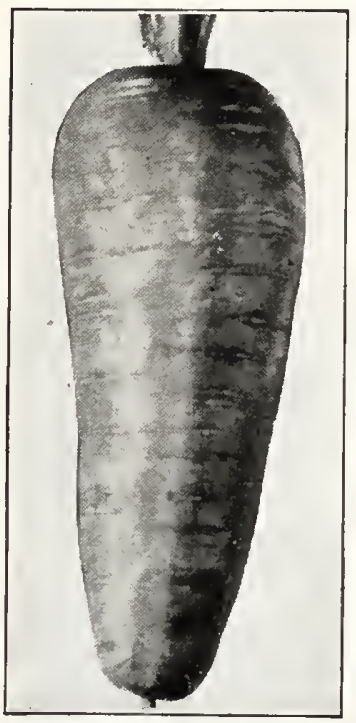
$p$ u l le d first out the row and a 110 w those remaining more room for full development. When full grown, they are about long, 2 to $21 /$ inches across at the top, tapering toa blunt end. They are $s u g$ ar y and tender, fin e grained and heary core so objectionable in many carrots. It is a easy to har-

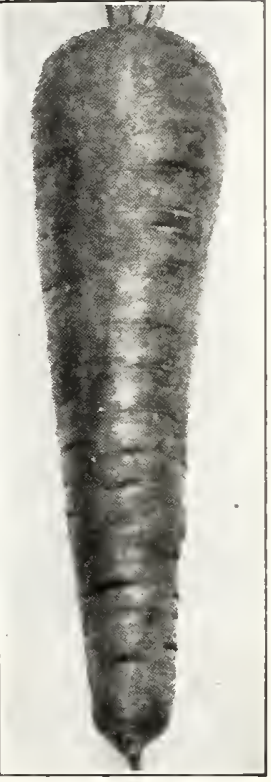
vest, and in

Danvers Half Iong first-class carrot. Plet. 5c; oz. 10c: $1 / 4$ Ib. 30c; Ib. $\$ 1.00 ; 2$ lbs. $\$ 1.75 ; 5$ Ibs. $\$ 4.00$ postpaid.

Chantenay or Model.

\section{Stock-Feeding Carrots}

Carrots make a fine alterative food for horses, cattle and hogs. They are rich in sugar and starch, and make a wholesome addition when fed with corn and fodder. Plant in March, April and May in rows $2 \frac{1 / 2}{2}$ to 3 feet apart. Three to 4 pounds will plant an acre.

No. 125. Improved White Belgian-A big yielder, averaglength, but is easily pulled, as about a third of its length grows above ground. Holds its size well throughout its length tapering gradually at base. Pkt. 5c; 0z. 10c; $1 / 4$ 1b. 25c; 1b. 75c; 2 ibs. $\$ 1.25$ 5 lbs. $\$ 2.90$ postpaid.

No. 124. Large Yellow Belgian $-\mathrm{A}$ good keeper and large a foot or more in length; yellow fiesh and yellow skin. Yellow carrots are preferred by many who claim they are more nutritious. Easily pulled, makes an excellent stock food and is a heavy cropper. Pkt. 5c; oz. 10c; $1 / 4$ 1b. 25c; 1b. $75 \mathrm{c} ; 2$ lbs. $\$ 1.25 ; 5$ lbs. $\$ 2.90$ postpaid.

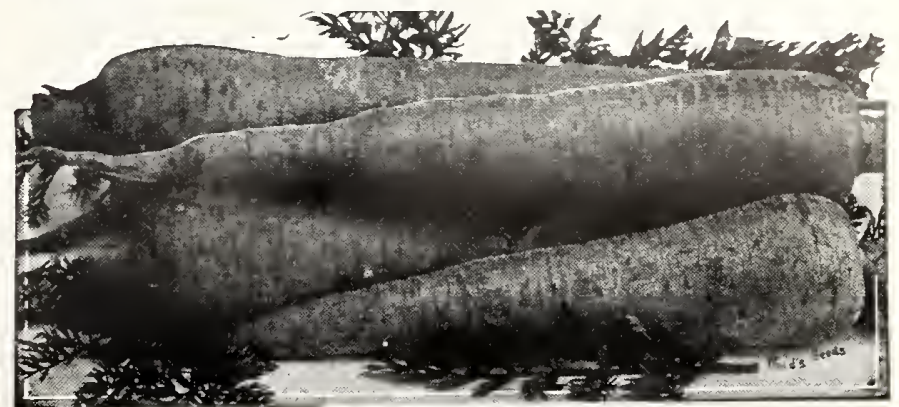

Improved Iong Orange 


\section{CELERY}

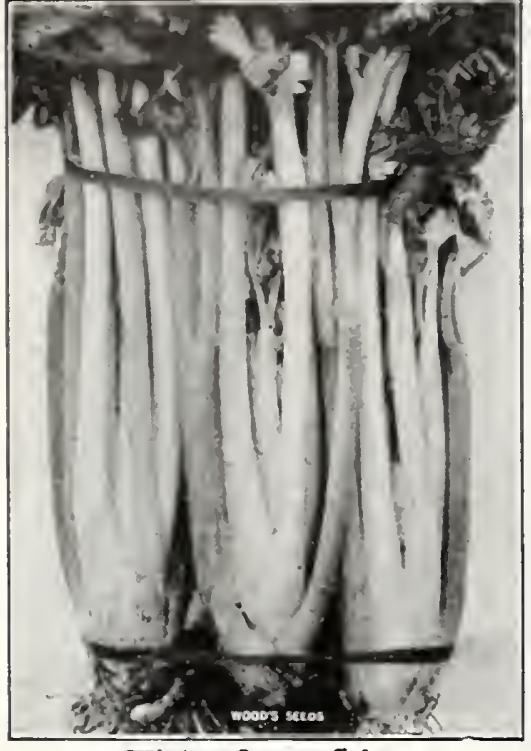

Winter Queen Celery
CUITURE.

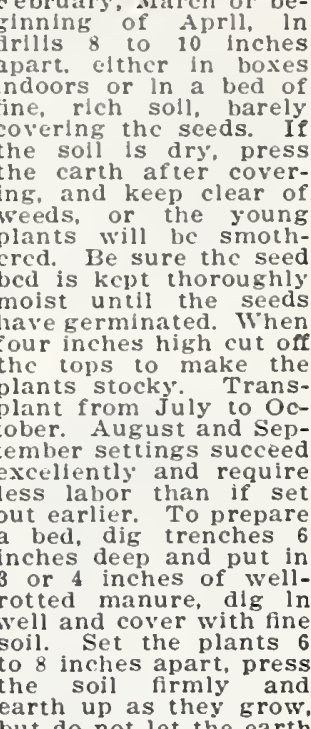

but do not let the earth

get into the heart of gere weather comes on, cover gradually with leaves, hay or straw, and place boards on top: water-proof felt paper is also used. Celerlae needs no apart. Celery sceds germinate slowly; soak for 24 to 36 hours

\section{Self-Blanching Celeries}

The ease with which they are (n every home garden. Plant the self-blanching kinds for earliest use, and the winter varieNo. 137. Improved White Plume - The earliest celery

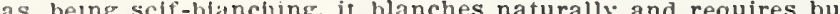

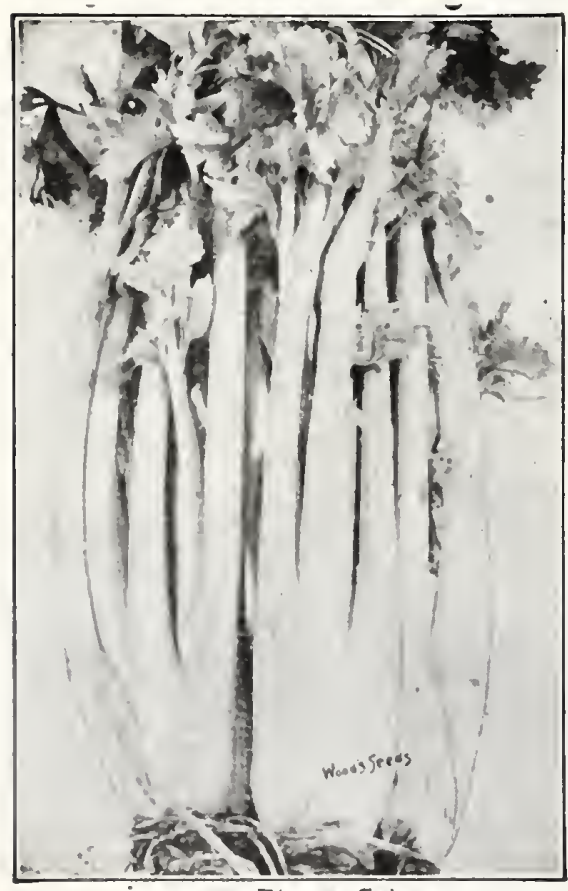
thite, the solld stalks are thick and crisp and have a rlch and A fine celery for late summer and e a r 1 y oz, 25c: 2 ozs. 45c; $1 / 4$ 1b. 80c; 1b. $\$ 3.00$; 2 1bs. $\$ 5.40 ; 5$ lbs. $\$ 13.10$ postpaid.

No. 138 Golden Self-Blanching

Grown in France from orfinator's stock. Excels all garden varietles in sweetness, and fine nutty flavor It has broad, heavy
staks that blanch easily to a rick appetizing, golden yel-
low ours is the
oritinal big - hartcd strain than wh l c h therc is not better low stalk is rarely grown Golden Sclffor its deliclous nutness, a bsence of $60 \mathrm{c} ; 1 / 4$ 1b. $\$ 2.00$; $1 \mathrm{~b}$. 5 ibs. $\$ 36.50$ postpaid.

\section{Winter Celeries}

of firmer texture, more comblanchlng kinds, and consequently better kcepers. For of your planting be one of the and Golden Self-Blanching, but ter that one of the Winter va-
rieties be planted. The rarie-

THE MOST PROFITABIE ACRE ON YOUR FARM is that deroted to the garden, provided you plant good seedsWOOD'S TESTED SEEDS. Othors may be as good, but there are none botter, and wood's Seeds cost less.

\section{No. 136. Giant Pascal}

-The large, thlek stalks are solid, crisp and of rich, nutand quickly. The heart is creamy yellow. It is an ideal ter for late fall and winis a selection from Golden Self-Blanching and inlserits many of its fine qualities and keeps better. It blanches

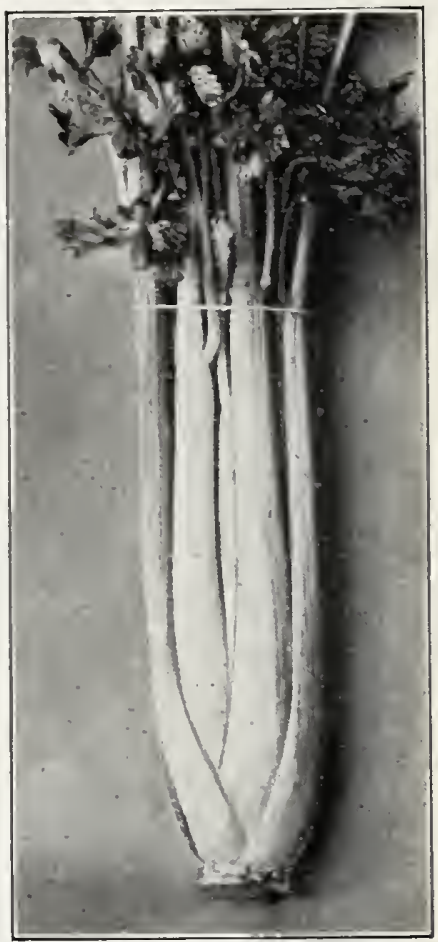

Glant Pascal Celery. easily, makes large, extra heavy stalks with very large hcarts.

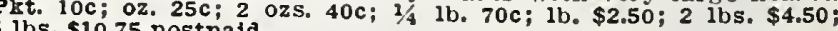
No. 135. Winter Queen-A splendid winter celery with an a beautiful, compact plant with perfectly heart. It makes blanches creamy white, crlsp and brittle, and the flavor is particularly attractive. Hardy and a splendid keeper. Pkt. $10 c$; Oz. $25 \mathrm{c} ; 2$ ozs. $40 \mathrm{c} ; 1 / 4$ lb. $70 \mathrm{c} ; 1 \mathrm{~b} . \$ 2.50 ; 2$ lbs. $\$ 4.50 ; 5$ lbs. $\$ 10.75$

No. 141. Celeriac or Turnip Rooted Celery -Grown exclusively for its roots which are fine for soups and stews or cooked and sliced as a salad. The roots keep all winter lf packed in damp sand or put into kilns like beets, carrots and turnips. Plant and cultivate like celery except it does not require earthing up. Plst. 10c; oz. $25 \mathrm{c} ; 2$ ozs. $40 \mathrm{c}$;
$1 / 4 \mathrm{lb}$. 70c; $1 \mathrm{~b} . \$ 2.50 ; 2 \mathrm{bs} . \$ 4.50 ; 5$ lbs. $\$ 10.75$ postpaid.

Celery Plants -Giant Pascal, winter Queen and White mail postpaid, 75c per 100. Not prepaid, 60c per 100; $\$ 5.00$ per 1,000 .

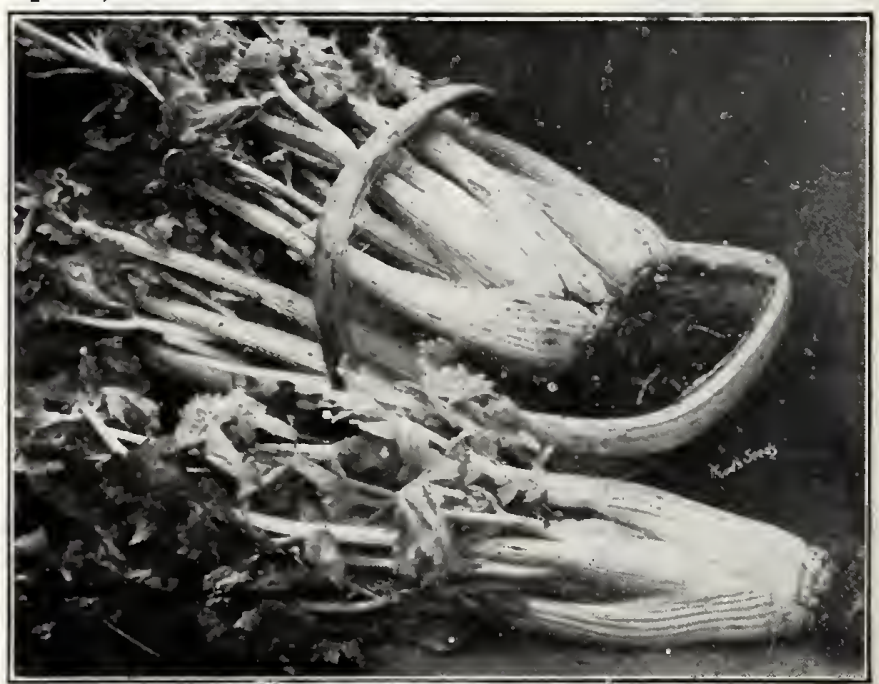

Golden Self-Blanching Celery. 


\section{Cucumber}

COIJURz.-To have the earliest cucumbers, start in pots, small paper boxes, berry boxes or on pieces of sod, grass side down so that they can be readily transplanted without checking the growth. For the general crop, plant in the open ground as soon as the weather becomes selcled warm, about the end of April or during May, not over an inch deep, in hills about four feet apart each way. The hills should be prcviously prepared by nixing well-rotted manule with the soil. Put about ten seeds in cach hill, and when all danger of insects is past thin out to four plants, and give frequent but shallow cultivation. The fruit should be gathered whether wanted or not, for if left to ripen on the vinc it destroys its productiveness. For pickling, plant in June or July. One ounce will plant 50 hills; two pounds acre.

No. 199. Everbearing -Although very early, it continues the vines will bear liuits at every stage of growth as well as blossoms; the small, perfectly shaped fruils make fine pickles. Desiratle for the home garden; cnormously prolific. Pkt. 10c oz. $15 \mathrm{c} ; 2$ ozs. $25 \mathrm{c} ; 1 / 4$ lb. $40 \mathrm{c} ; 1 \mathrm{~b} . \$ 1.25 ; 2$ lis. $\$ 2.20 ; 5$ lbs. $\$ 5.00$ postpaid.

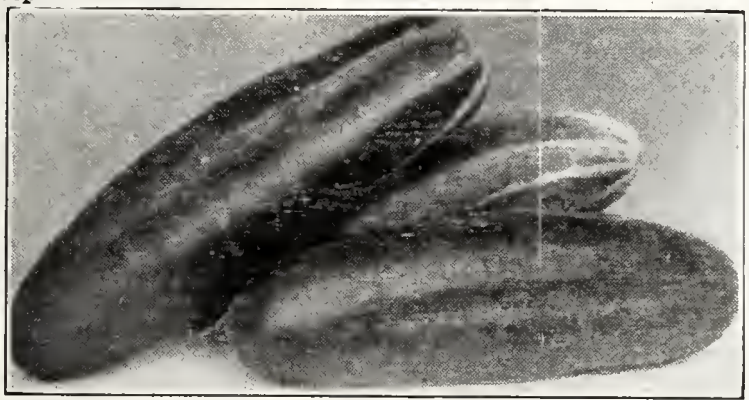

Early Fortune Cucumber

No. 194. Early Fortune $\rightarrow$ No cucumber holds lts dark green almost dead ripe. It is decidedly early, makes fruits about 9 lnches long, and is crisp and tender; a fine ylelder. Pkt. 10c; oz. $15 \mathrm{c} ; 2$ ozs. $25 \mathrm{c} ; 1$ 1b. 35c; $1 \mathrm{~b}$. $\$ 1.15 ; 2$ lbs. $\$ 2.00 ; 5$ lbs. $\$ 4.80$; 10 lbs. $\$ 8.85$ postpaía.

No. 200. Japanese Climbing -Ideal for growing on poles room in the garden; bcars quickly and sets its fruit censtantly throughout the season. Of extra fine quality dark green color Pkt. $10 \mathrm{c}$; oz. $15 \mathrm{c} ; 2$ ozs. $25 \mathrm{c} ; 1 / 4$ 1b. $45 \mathrm{c} ; 1 \mathrm{~b} . \$ 1.50 ; 2$ lbs. $\$ 2.65$; 5 lbs. $\$ 6.00$ postpatd

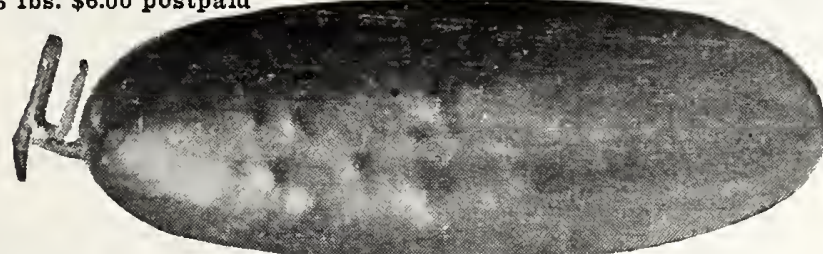

No. 191. Early White Spine Arlington Strain. - An extra lific, bears fruits 8 to 9 inches long, smooth and of a deep, rich culor; excellent for pickles. Pkt. 5c; oz. 10c; $1 / 41$ 1b. 30c; 1b. $\$ 1.00$; 2 lbs. $\$ 1.75 ; 5$ lbs. $\$ 4.00$ postpald.

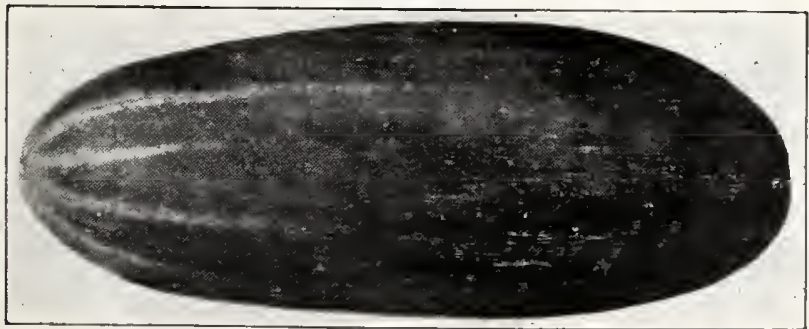

Staggreen Cucumber

No. 192. Staygreen -The earliest white spine varlety; a fruits 7 to 8 inches $10 n g$ that are a beautiful dark green color from end to end; earliness, productiveness. fine color and uniform shape ale its strong points of excellcnce. Pkt 10c; 0 . $15 \mathrm{c}: 2$ ozs.
postpatd.
No. 190. Wood's Ideal Write Spine - Our Ideal requirement for a firstclaurement whether grown in the private garden or for shipping to luarket It is early prolilic and produces a crop of large, symmetrica friats of an intense riels deep green color shading holds its color well, is ideal fcr slieing, and is affected by the hot sun less than any we have ever grown. It is ideal for slicing; firm, cool and crisp the flavor is rePkt. 10c; oz. 20c; 2 ozs $30 \mathrm{c} ; 1 / 41 \mathrm{~b} .50 \mathrm{c} ; 1 \mathrm{~b} . \$ 1.50 ; 2$ lbs. $\$ 2.65 ; 5$ lbs. $\$ 6.35$ postpaid.

No. 198. Early Green Cluster -Very early, beartwo ing in clusters of two and three. If liept gathered, the vines wil through a long season. The cucumbers are bright green, short and thickjust the right size and shape for pickles. Pkt. 5c; oz. 10c; $1 / 41 \mathrm{~b}, 30 \mathrm{c} ; 1 \mathrm{~b}$ $\$ 1.00 ; 2$ lbs. $\$ 1.75 ; 5$ 1bs. $\$ 4.00$ postpaid.

No. 197. Green Prolific or Earfy short grems.-An grown principally for pickling. Fruits 4 to is inches long when in table condition: dark green and of fine quality. Will bear through a long season if kept gathered. Pkt. 5c; oz. 10c; $1 / 4$ 1b. $30 \mathrm{c} ; 1 \mathrm{~b} . \$ 1.00 ; 2$ lbs. $\$ 1.75 ; 5$ lbs. $\$ 4.00$ postpald.

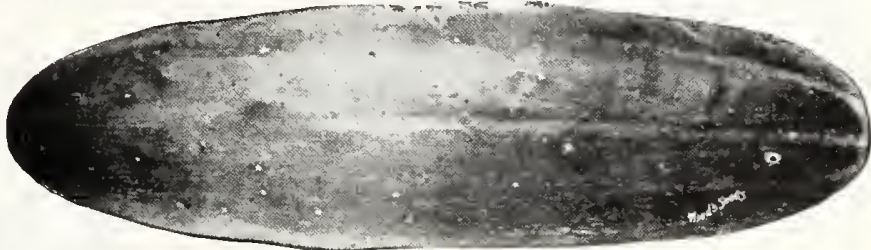

No. 195. Davis Perfect $\rightarrow$ A handsome, extra long, inwith almost transparent fenkely dark green cuc u m b e r flavor. The vine growth is vigorous, it is a generous yielder and is one of the best blight reslsters. It holds its fine color till almost dead ripe. Pkt. 1uc; oz. 15c; 2 ozs. 25c; $1 / 4$ lb. 40c; 1b. $\$ 1.25 ; 2$ lbs. $\$ 2.20 ; 5$ lbs. $\$ 5.00$ postpaid.

No. 193. Klondike-Deep green and holds its color well. 8 hardly affected by hot sun; very prolific. Pkt. 5c; oz. 10c; $1 / 4$ 1b. $30 c ; 1 b . \$ 1.00 ; 2$ lbs. $\$ 1.75 ; 5$ lbs. $\$ 4.00$ postpafd.

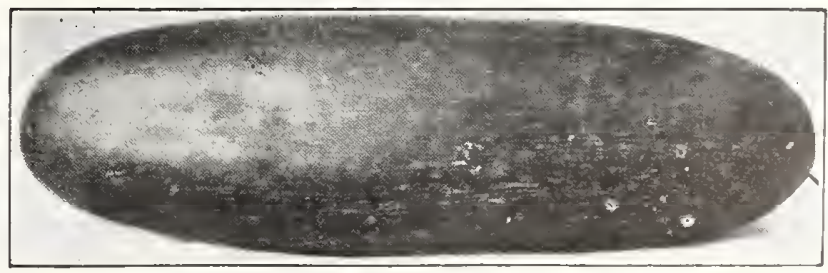

No. 196. Improved Long Gieen (Inndon Iong Green)that produces uniformly slender dark green fruits about 12 inches long. The young frults are just right for pickles, the larger ones for slicing; the rlpe fruits make the best sweet pickles. Firm ozs. $25 \mathrm{c} ; 1 / 4 \mathrm{lb}$. $40 \mathrm{c} ; 1 \mathrm{~b} . \$ 1.25 ; 2$ lbs, $\$ 2.20 ; 5$ lbs. $\$ 5.00$ postpaid.

No 201. Gherkin or BURR.-Grown exclusively for pickllng 20c; 2 oz8. 30c; $1 / 4$ lb. 50c; 1b. $\$ 1.75 ; 2$ lbs. $\$ 3.10$ postpaid. 


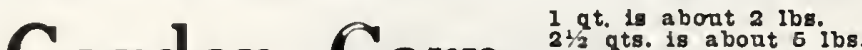 \\ Garden Corn \\ Order 50 Ibs. at $100-1 \mathrm{~b}$. rates.}

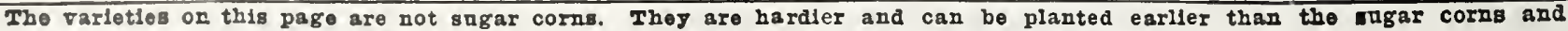
make excellent roasting ears before the sugar corns are ready.

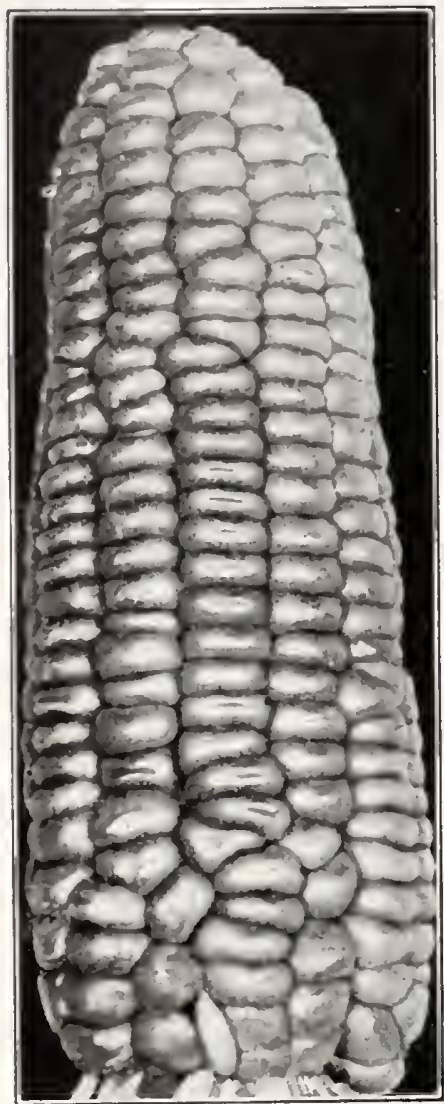

Bland's Extra Early
CUエTURI.-Corn prcfers a rlch, warm, well-manured soil, but excellent garden corn may be ralsed on any good soll that has been deeply and thoroughly workcd before planting. Plant the early varietles the last of tlll the ground ls thoroughly warm, otherw'lse they are liable to rot. Give frequent and thorough but shallow cultlvation, and continue plantings at intervals of about two weeks till $J$ uly or early in August for a succession of roasting ears throughout the season. plant during $\mathbf{J} u l y$ or early in August for late roasting ears. One pound will plant 100 hills; 10 to if No. 150. Bland's Extra Early Corne earllest of all the Garden the earliest of all garden corns, fully a week earlier than Extra Early Adams. No corn we have ever offered has had such constant and growing demand; practically every general order calls for Bland's Wxtra carly. It makes an attractive ear of good slzc and fine quality; the gardeners and take a pride in having the earliest garden in vour ncighgardeners and take a pride in having the earliest garden in tour ncighthe private gardener, but to those who grow for market, for in earliness it ls ahead of any garden corn in cultivation and the size and appearance of the ear should make it a ready seller.

Iave you ever had roasting ears on your table by June 25 th or earler? You can do it by planting Bland's Ixtra Early, and they will be good sized tender ears. Follow your planting of Bland's with Trucker's Favorite to make big roasting ears.

No. 151. Trucker's Favorite - There is no early garden corn so Trucker's Favorite. It makes an attractive ear about 10 inches long. with a good depth of plump, tender, sweet grains that many prefer to
sugar corn. It is much hardier than any sugar corn and can be planted wogks earlier, and is ready for the table or market in about 65 days. Unfortunately, since we introduced Trucker's Favorite the namc seems to have appealed to many seedsmen as a good one, and it has been applicd to many other corns. If ou ordered Trucker's Favorite from hach. To have the real Trucker's Favorite corn order from us, who originated it.

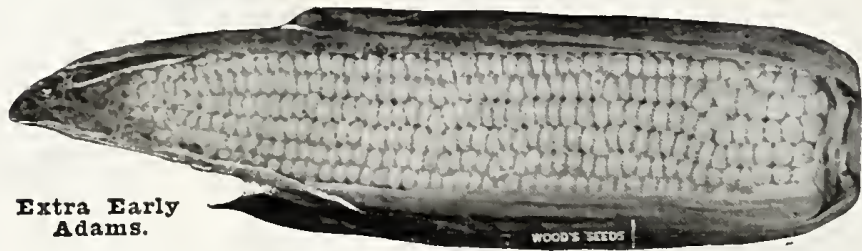

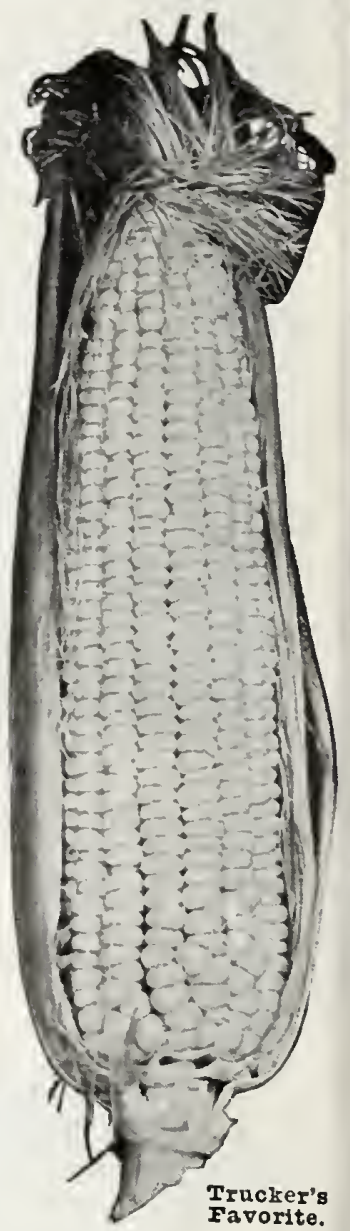

No. 155. Norfolk Market -Not as early as Ideal or Blg ear averamin about 9 inches long and whon at roasting ear stage are tender and milly it is hard ler than any of the sugar corns, withstands cold ground better and can be planted much earlier. A good early corn, but not as ears it makes a good yielding corn for feeding.

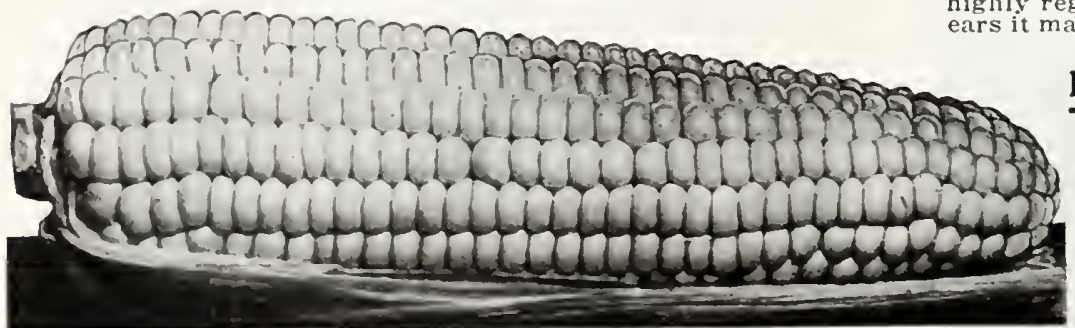

Ideal or Big Early Adams

\section{No. 154. Ideal or Big Early Adams}

- Intermediate as to earliness and size of ear, between Bland's Extra Farly and Trucker's Fayorite. It is hardicr than any of the sugar corns and can be planted earlier. The cars measure 9 to 10 inches long, wlth 12 or morc rows of round white grains to the ear. Grows about 6 feet high, allowing close planting; early and hardy, allowing early planting. Early and before the bigger-eared Trucker's Favorite.

\section{PRICES}

No. 150. Bland's Extra Early

No. 151. Truckers' Favorite.

No. 152. Extra Early Adams.

No. 154. Ideal or Bif Early Adams.

No. 155. Norfolk Market
BY MATI POSTPATD

Plt.

Ib. 2 lbs, 5 lbs, 10 Ibs.

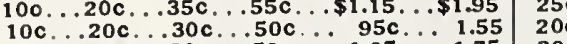

$100 \ldots 200 \ldots 30 \mathrm{c} \ldots 50 \mathrm{c} \ldots 1.05 \ldots 1.7520 \mathrm{c}$

$10 \mathrm{c} \ldots 20 \mathrm{c} \ldots 30 \mathrm{c} \ldots 500 \ldots 95 \mathrm{c} \ldots 1.5520 \mathrm{c}$

\section{NOT PREPAID}

2 lbs, 5 lbs, $10 \mathrm{Ibs}, 100 \mathrm{Ibs}$

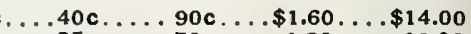
$.35 \mathrm{c} \ldots \ldots 70 \mathrm{~F} \ldots 1.20 \ldots 10.00$ $.35 \mathrm{c} \ldots 80 \mathrm{c} \ldots 1.40 \ldots 12.00$ $35 c \ldots \ldots 70 c \ldots . .1 .20 \ldots 10.00$ 


\section{Sweet or Sugar Corns \\ Sweet or Sugar Corns 5}

Do not plant sweet corn till the ground is thoroughly warm.

No. 158. Premo Extra Early $-T_{\text {he }}$ of all Sweet Corns, as early as Extra Early Adams. Remarkably hardy for a sweet corn, sweet varieties. Considering its extreme earliness, the ears are remarkably large, usually two to the stalk. In quality and sweetness it is all that can be desired.

No. 163. Golden or Bantam Evergreen

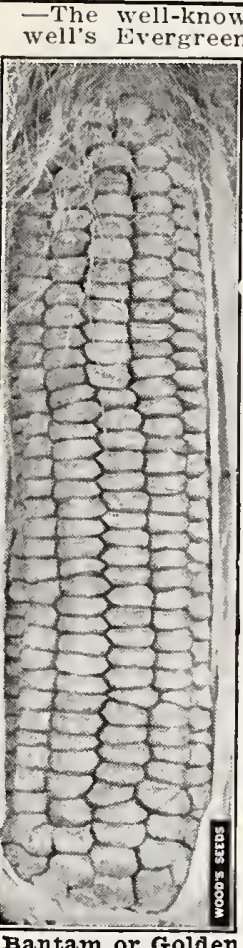
ere crossed and gave complete blend that combined the best characterthat has the color and deliciously sweet flavor and the Golden Bantam and tenderness Stowell's Evergreen. The ears are larger than to 14 rows of deep, sug ary, rich yellow grains. green we are sure you will like it, for it has both size and quality.

\section{No. 160. Golden}

Bantam - T h e earliest est yellow-grained sugar corn. Although the ears are not large, this is more liciously sweet flavor and tenderness. The ears are about 6 inches long, and at least two ears are
borne on each stalk. Can corn.

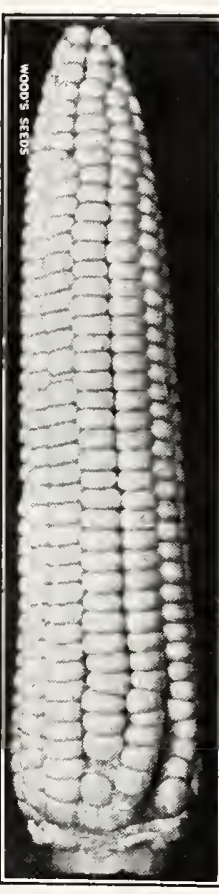

No. 166. Stowell's Evergreen -A favcorn for home use, market and canning. Aside from the size of the ears, which are large and well filled, its strong point is that it remains in the green state for such a long season. Grains are deep and svergreen.

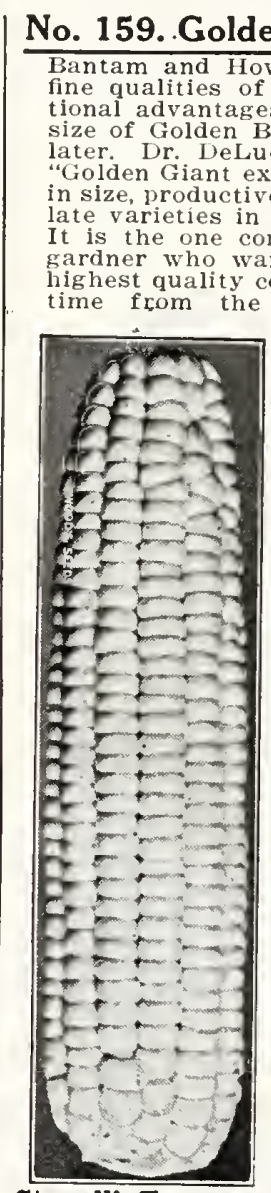

Stowell's Ivergreen
No. 164. Country

\section{Gentleman -One}

Vored late sweet

with a small cob dense

ly covered with irresular

of the best quality.

inches long,

two or more

fit

son.

cause of its peg

grains. The practically

Country opinion among gardeners is that est and most satisfactory of the later va-

No. 162. Black Mexican -Although grains are bluish-black, they are remarkderness and in The ears, usually eight rowed surpass it. eight inches long and are less subject to atFor family use we recommend it highly to follow the first early varieties.

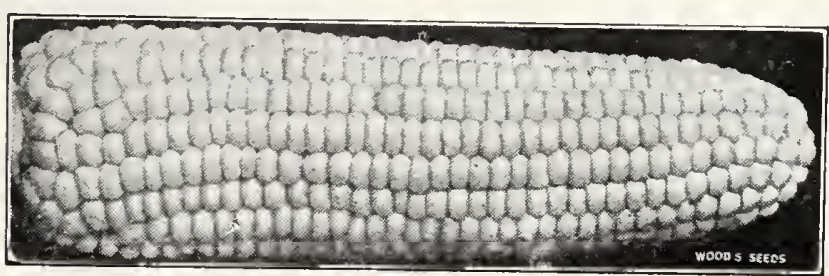

Howling Mob.

No. 161. Howling Mob - Not extra early but extra good early corn to come in after the extra early kinds like sremo Extra Early and Golden Bantam. The ears are quite large, 7 to 8 inches long, with 12 to 14 rows of tender, pure white grains that are deliciously sweet. Usually two ears are borne to the

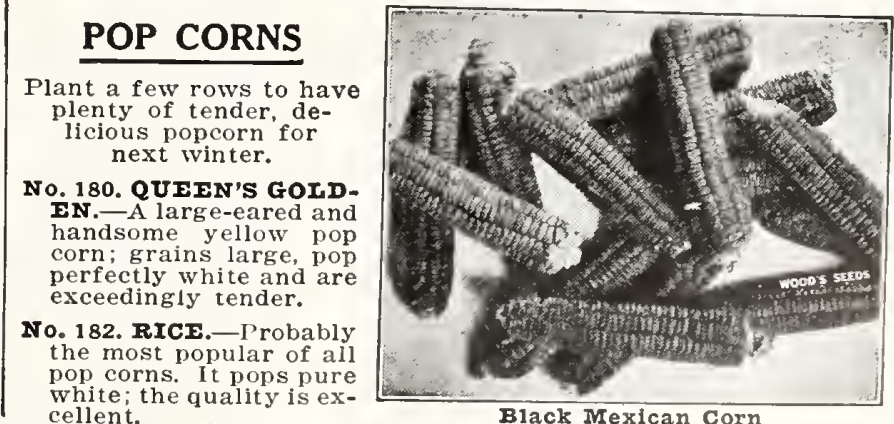

\section{PRICES}

Pkt. 1/\% ID MAII POSTPAID

No. 158. Premo Fxtra Early ........... 10c...20c...35c

No. 159. Golden Giant

No. 160. Golden Bantam

No. 161. Howling Mob

No. 163. Golden or Bantam

No. 164. Country Gentleman

No. 166. Stowell's

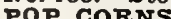

No. 180. Queen's Golden.

No. 182. Rice
$10 \mathrm{c} \ldots . .20 \mathrm{c} . .30 \mathrm{c}$.
2 lbs. $51 \mathrm{bs}$.

$65 \mathrm{c} \ldots \$ 1.25$

$65 c \ldots 1.35$

600.1 .30

$60 c .1 .30$

$65 \mathrm{c} \ldots 1.35$

$80 \mathrm{c} \ldots . .1 .70$

$650 \ldots .1 .35$

$50 \mathrm{c} \ldots . .00$

$50 \mathrm{c} \ldots 1.00$
10 1bs.

$\$ 2.35$

2.35

2.25
2.25

2.25
2.35

3.05

2.35

1.65

1.65

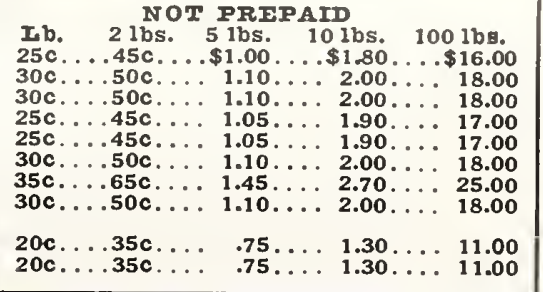




\section{EGG PLANT}

CUITURE.-l'lant in hopbed in February or March and keep and not checked. When 2 inches lutrit box or in the beds 3 to 4 Iusect Remedles, - lor cut worm use polsoned bran or polsened paper around the stem when setting out. Dust with siug shot to protect from bugs.

No. 206. Black Beauty ozs. $75 \mathrm{c} ; 3 / 4$ lb. $\$ 1.35$ lb. $\$ 5.00 ; 2$ lbs. $\$ 9.20$; 5 lbs. $\$ 22.00$ postpald.

No.208. New York Improved Purple

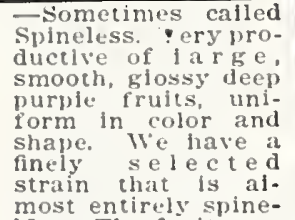

most entirely spine-

Black Beanty Egg Plant
thick, broad at the

$1 / 4$ lb. $\$ 1.35 ; 1 b . \$ 5.00 ; 2$ lbs. $\$ 9.20 ; 5$ lbs. $\$ 22.00$, postpald.

EGG PIANTS.-Rcady May 1st till July. 30c per dozen; 50 for $80 c$; $\$ 1.40$ per 100 postpald. Not postpald, 25c per dozen; 50 for $70 \mathrm{OC} ; \$ 1.25$
800 page 38 .

\section{ENDIVE}

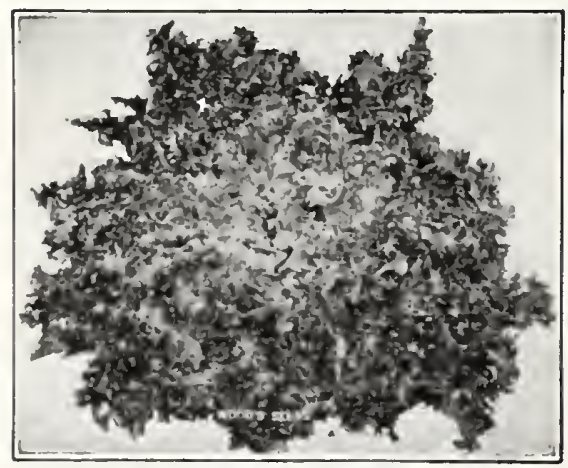

Green Curled Endive.

\section{GOURDS}

Plant in lills after frost is past and cultivate like squash. Leave 3 or 4 plants to the hill.

No. 216. DIPPER. For minking dippers. Pkt. 5 cts.; oz. 20 cts.
No. 214. NEST-EG . - 1 gocd nest-cgg; lasts for years. Prt. 5 cts; ; oz, 20 cts. oz. $15 \mathrm{c} ; 1 / 41 \mathrm{lb}, 40 \mathrm{c}$.

\section{HORSE RADISH ROOTS}

Ready November 1 st till June, 40 cts, per doz.; 50 for 85 cts. $\$ 1.50$ per 100 postpald. Not prepald, $35 \mathrm{cts}$. per doz.; 50 for $75 \mathrm{cts}$. $\$ 1.40$ per 100 ; 500 for $\$ 6.50$; $\$ 12.00$ per 1,000 .

\section{KALE or BORECOLE}

COITURE.-Spring or Smooth Kale sown in February or March makes greens earlier than the winter sorts. The Siberian and Scotch are generally sown from August 15 th to October 15 th, but are irequentiy sown in the spring with satisfactory results. Sow efther broadcast or in drills 18 inches apart, and give some cultivation, and they will yold greens throughout the winter. 4 to 5 ibs. in drills; sow 5 to 7 , lbs. Scotch Kale to the acre: 2 ounces to 100 feet of drill.

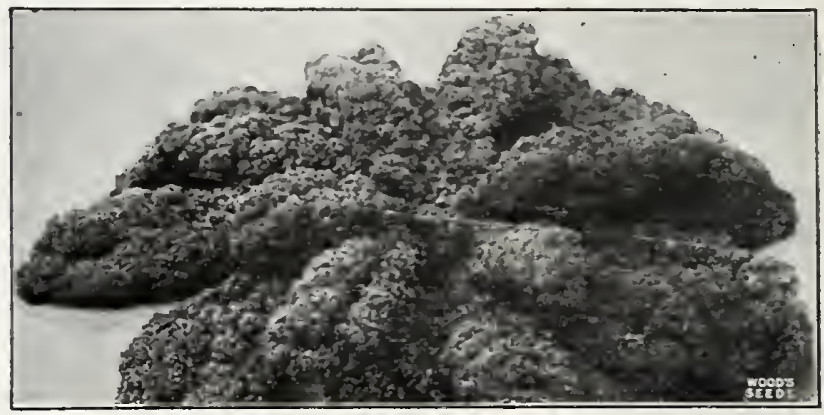

Dwarf Curled Scotch or Norfolk Kale

No. 219. Early Curled Siberian GIUE RALE or DWARF hardy, vigorous, spreading green kale, with a distinctive biuish ting, The edges the. is hardy enough to stand zero weather. Siow to run to seed. Pkt. $5 \mathrm{c}$; oz. $10 \mathrm{c} ; 2$ ozs. $15 \mathrm{c} ; 1 / 4 \mathrm{lb} .25 \mathrm{c} ; 1 \mathrm{~b} .75 \mathrm{c} ; 2$ lbs. $\$ 1.25 ; 5$ lbs. $\$ 2.90 ; 10$ lbs. $\$ 5.35$, postpaid.

No. 221. Dwarf Curled Scotch or Norfolk The most and denseiy curied variety. Hardier than cabbage, standing aimost zero temperature and is improved by frosi; curied like curled parsley. It is low growing and spreading. about a foot high: the leaves are bright green and are produced in great $\$ 3.65 ; 10$ lbs. $\$ 6.35$, postpald.

No. 222. Spring Kale SPRING SPROUTS or HANOVER Kale. A hardy, quick-growing, smooth-ieaved variety. Sow at intervals of ten days. so as aiways to have it young and tender. Pkt. 5c; $2 / 4$ 1b. 10c; 1b. 35c; 2 ibs. 60c; 5 lbs. $\$ 1.25 ; 10$ lbs. $\$ 2.25$, postpald.

\section{KOHL RABI}

The edible part is the turnip-shaped bulb that grows above ground. Com-
bines the flavors of the cabbage and turnip and makes a splendid dish if used when 2 to 3 inches thick. Sow in drills as early as the ground can be worked, thinning out to stand 5 to 6 inches in the row. For a succession, For fall use, plant in August or early September. Kolnl rabi should be more

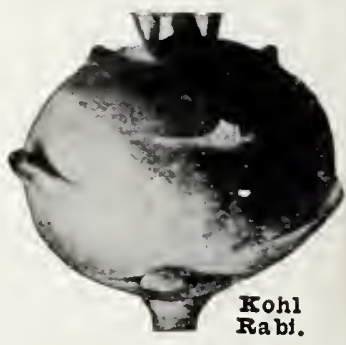
generally grown.

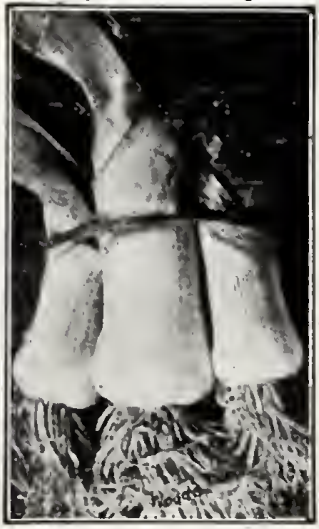

Large Flag Leek.
NO. 225. EARIY WHITE VIENNA.The best and earliest variety; flesh white and rery tender; the qualley Oz. 20c; 2 ozs. 35c; $1 / 4$ ib. 60c; 1b. $\$ 2.00$; 2 lbs. $\$ 3.50$.

\section{LEEK}

CUTTURE--Superior to onions for soup flavoring, etc. Sow eariy in the spring in a light, rich, moist soil in drilis half an incil deep. When 6 or 8 inches high, trim off the tops and roots and transplant 4 to 6 inches apart in one-foot rows setting the plants in the ground up to their center leaves, and earth up to blanch the necks. Sowings should also be made in September and transplanted outside in the fall or early soring. One ounce will sow about 100 feet of drili.

No. 227. IARGE FIAG.-Hardy, productive and of the best quality. $60 \mathrm{c} ; 1 \mathrm{~b}$. $\$ 2.00 ; 2$ lbs. $\$ 3.50$. 


\section{Lettuce}

CUITURב.-For quality lettuce requires quick growth; that means rich soil, plenty of water and clean and thorough cultivation to have crisp and tender heads. Make your first plantings in boxes or hot-beds and harden by exposure: later plant outside in boxes or hot-beds and harden by exposure: later plant outside inch rows and thin out. The curled varieties planted thickly make a beautiful border, the rows being thinned out by pulling as wanted. For a constant supply plant every three weeks-lettuce may plants: 2 pounds will make plants enough for an acre.

\section{No. 230. Wood's Cabbage Lettuce}

\section{If asked to name the most satisfactory all-round lettuce} would unhesitatingly name Wood's Cabbage. For more than thirty

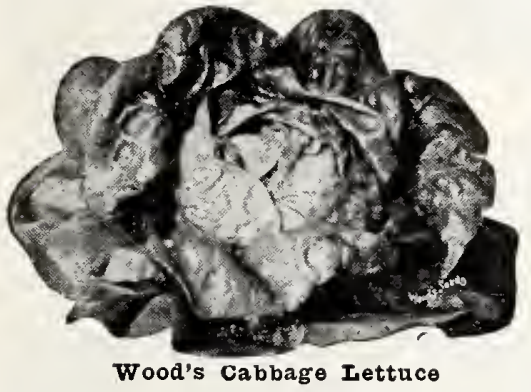
est, and in the meantime we have not found a more all-season letin the early spring, in fall and it is fine for forcing in hot bed, making a niedium large firm ly. The quality is excellent, the flavor sweet and buttery. Iou will like it. Pkt. 10c; 0z. 20c: 2 Ozs. 30c; $1 / 4$ 1b. 50c;
lb. $\$ 1.75 ; 2$ 1bs. $\$ 3.10 ; 5$ lbs. $\$ 7.40$ postpaid.

No. 235. Early Curled Simpson -A sure cropper even tions. Makes a well-blanched curly loose head: and tender. Fspecially adapted for sowing thickly in rows and cutting when young. Should be grown in every home garden. Plit. 5c; oz. $15 \mathrm{c} ; 2$ ozs. $25 \mathrm{c} ; 1 / 4$ lb. $40 \mathrm{c} ; 1 \mathrm{~b} . \$ 1.35 ; 2$ lbs. $\$ 2.40 ; 5$ lbs. $\$ 5.65$ postpaid.

No. 239. Crisp-as-Ice -Neither extra early nor extra Iarge, but a fine lettuce for the prieven in hot weather. In delicate flavor and tenderness no other is suand brittle as to fully justify the name. The heads are hard with rich creamy yellow hearts that are exceedinglv tenflavor. Slow to start to seed. Pkt. 10c; oz. 20c:

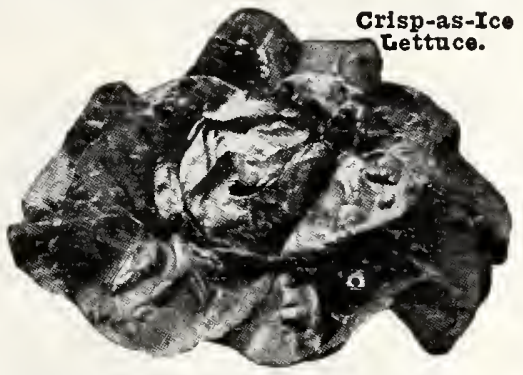

2 ozs. 30c; $1 / 4$ lb. $50 \mathrm{c} ; 1 \mathrm{~b} . \$ 1.75 ; 2$ lbs. $\$ 3.10 ; 5$ lbs. $\$ 7.40$ postpald.

No. 240. Cos or Romaine -Celery Iettuce. Has no equal cal heads which, if tied up blanch quality. whorms long, conias celery. MIakes fine heads even in hot whte, and as crisp and has a distinct quality that makes a pleather. Very sweet other varieties. Try it to convince yourself how well it merits a place in your garden. Pkt. 5c; 0z. $15 \mathrm{c} ; 2$ ozs. $25 \mathrm{c} ; 1 / 4$ 1b. 45c; 1b. $\$ 1.50 ; 2$ ibs. $\$ 2.65 ; 5$ lbs. $\$ 6.35$ postpaid.

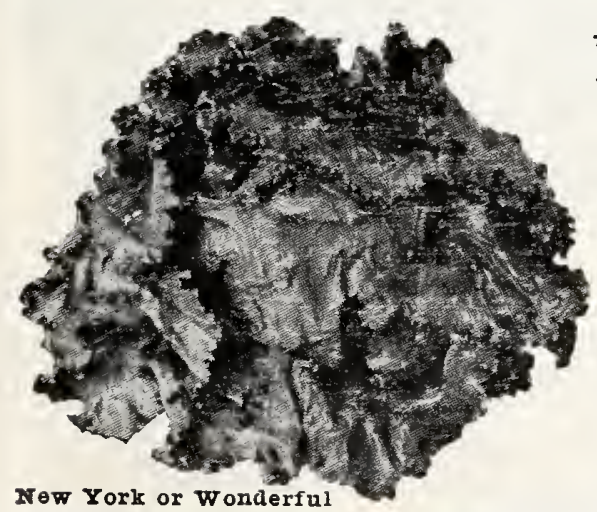

No. 232. New

York wonderful or A big head lettuce as solid and crisp as a cabbage. The hear is crea my white, with no trace of bit terness. It is a hotweather lettuce for spring summer and early fall planting but for fall planting we prefer our sure anc reliable header and slow to 10c; 0z. 20c; 2 ozs. $35 \mathrm{c}$; $1 / 4$ ib. 60c; $1 \mathrm{~b}$. $\$ 2.00$; 2 lbs. $\$ 3.50$ 5 lbs. $\$ 8.40$ postpaia.
No. 237. Summer Allheart -No lettuce with Allheart for heading in hot weathlarge compact, finely is there a sunmer le t t u c e of better quality. Its ability to weather places it in a $10 \mathrm{c}$; 0z. 20c; 2 ozs. $30 \mathrm{c}$ $1 / 4$ 1b. $50 \mathrm{c} ; 1 \mathrm{~b}$. $\$ 1.75$; 2 1bs. $\$ 3.10$; 5 lbs. $\$ 7.40$ postpaid.

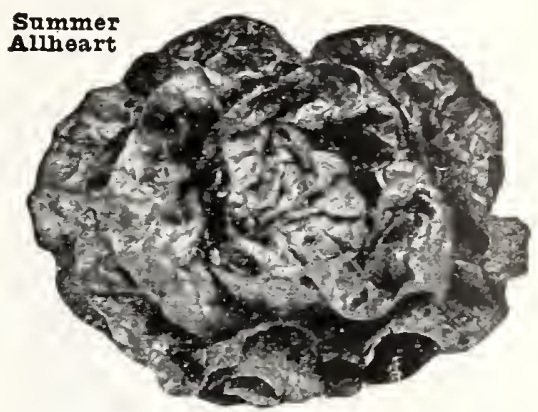

No. 233. California Cream Butter

buttery flarored. Pkt. 5c; oz. 15c; 2 ozs. 25c; 1/4 1b. 40c; 1b. $\$ 1.35 ; 2$ lbs. $\$ 2.40 ; 5$ lbs. $\$ 5.65$ postpaid.

No. 242. Iceberg - No lettuce is more crisp, especially the sure and reliable header even in summer. Forms a large, com crisp and delicious. Pkt. 10c; oz. 20c; 2 ozs. 30c; 1/4 1b. 45c; 1b. $\$ 1.65 ; 2$ lbs. $\$ 2.95 ; 5$ lbs. $\$ 7.00$ postpaid.

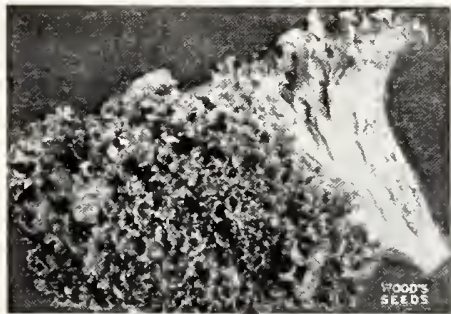

Grand Raplds Iettuce
No. 238. Grand Rapids

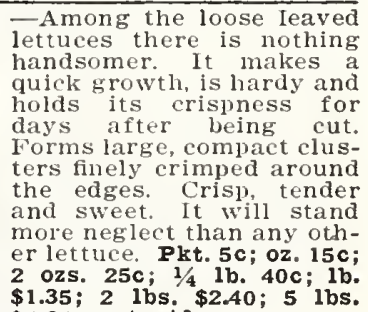
$\$ 5.65$ postpaid.
No. 234. Black Seeded Simpson -A fine lettuce to plant

der, semi-solid, erisp head. If you have not been successful with head lettuce, try Black Seeded Simpson. Pkt. 5c; oz. 15c 2 ozs. $25 \mathrm{c} ; 1 / 4$ 1b. 40c; 1b. $\$ 1.35 ; 2$ lbs. $\$ 2.40 ; 5$ lbs. $\$ 5.65$ postpaid.

No. 236. Improved Hanson

-One of the best summer solid, compact head, exceed ingly crisp, tender and sweet and blanches well: extremely slow to shoot to seed. A sure better than most heading varieties. Very much like Iceberg, except that it is larger ly lighter. Pkt. 5c; oz. 15c; 2 ozs. $25 \mathrm{c} ; 1 / 4$ lb. $40 \mathrm{c} ; 1 \mathrm{~b}$. $\$ 1.35$; 2 lbs. $\$ 2.40 ; 5$ ibs. $\$ 5.65$ postpaid.

No. 241. Chicken Lettuce

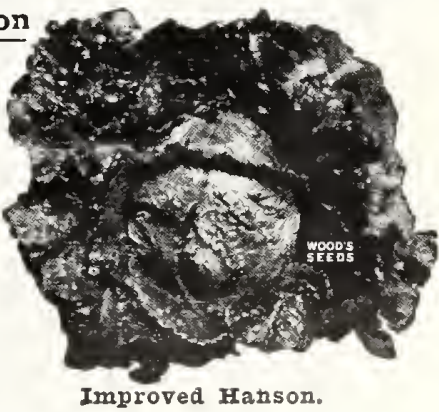

-Unlike any lettuce you

have ever grown, one that will yield more chicken feed than

with leaves that may be pulled like kale. After cutting

lb. $\$ 1.50 ; 2$ lbs. $\$ 2.65 ; 5$ lbs. $\$ 6.35$ postpaid.

\section{No. 231. Wood's Improved Big Boston}

did lotuch praise ceannot be given our grand stratnof fall use, or under canvas, and always makes large, buttery heads with thoroughly blanched hearts. The heads are extra large, firm blanched. Pkt. 5c; oz. 15c; 2 ozs. 25c; 1/4 1b. 40c; 1b. $\$ 1.25 ; 2$ lbs. $\$ 2.20$; 5 lbs. $\$ 5.20$ postpaid.

Lettuce Plants - Wood's Cabbage and Big Boston. Ready 100 postpaid. Not prepala, 35 cts. per $100, \$ 3.00$ per 1,000 . 


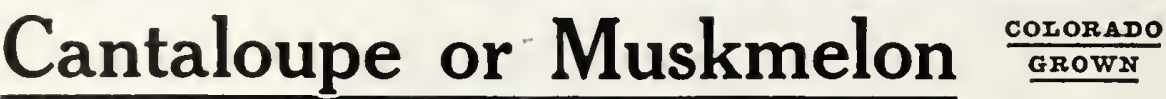

CULTURD.- Prepare hlls, 4 to $6 \mathrm{feet}$ apart, In a rlch, moder-

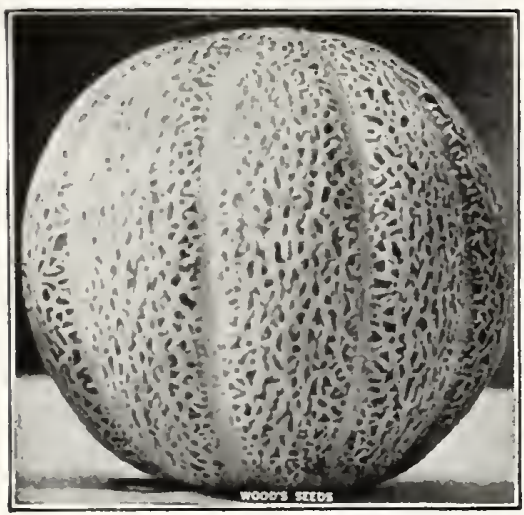

No. 247. Extra Early

Extra Early Hanover

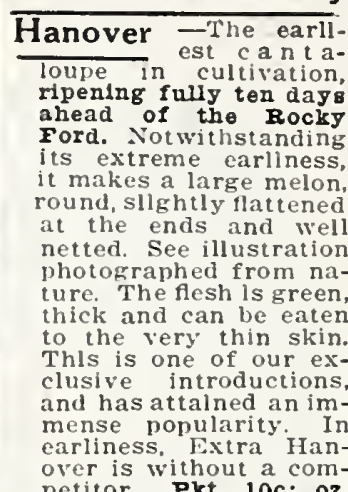

petitor. Pkt. $10 \mathrm{c}$; oz. $60 \mathrm{c} ; 1 \mathrm{~b} . \$ 2.00 ; 2$ 1bs. $\$ 3.50 ; 5$ lbs. $\$ 8.40$ postpaid.

No. 253. Gold Lined Rocky Ford - Whether

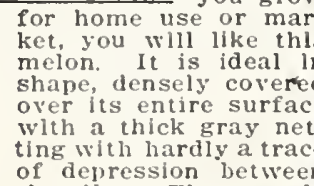
the slices, The meat ls deliclously sweet and Juicy and can be eaten Fiesh is green with a gold margln next to the seed cavity. Highly oz. $10 \mathrm{c} ; 1 / \mathrm{b}$. $35 \mathrm{c}$; $1 \mathrm{~b}$

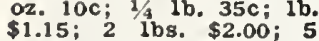
ibs. $\$ 4.80$ postpald.

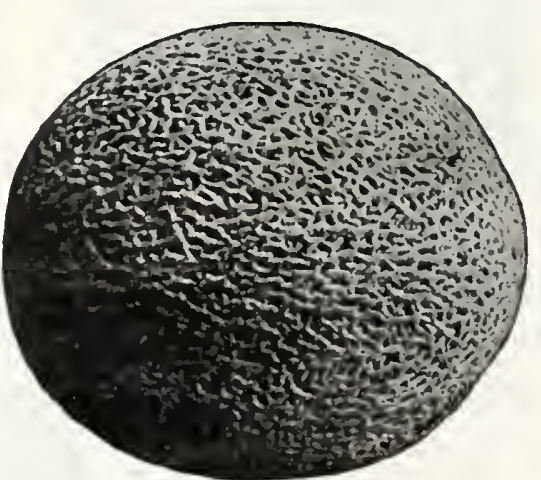

Gold Iined Rocky Ford

No. 261. Hollybrook Luscious -For flavor and size com-

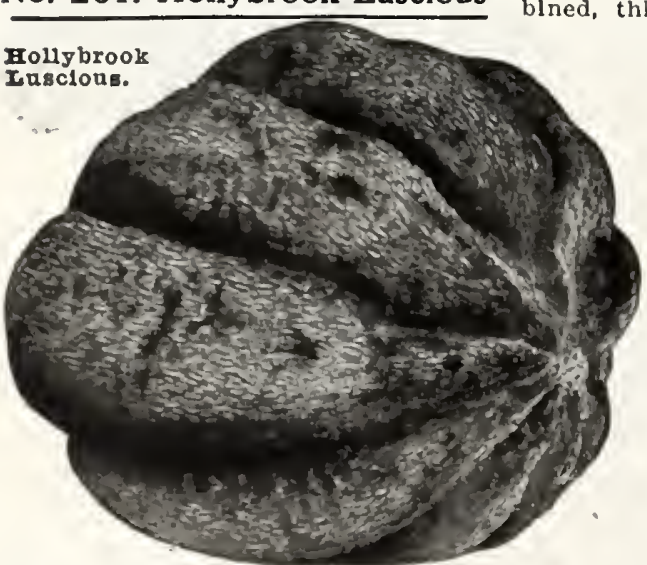
all melons Too la $\mathrm{rge}$ to be profitable or market-they often welgh 15 to $20 \mathrm{lbs}$. - they are ldeal for melon is enough for a family. The flavor is equal to that of a IIoney Dew melon. Contlnues bearlng tlll cold weather and holds its splendld quallty up to the very last. No melon could be more mended for the Pkt. 10c; oz, 20c; 2 ozs. 35c; 1/4 1b. 60c; 1b. $\$ 2.00 ; 2$ lbs. $\$ 3.50$; 5 lbs. $\$ 8.40$ postpald.

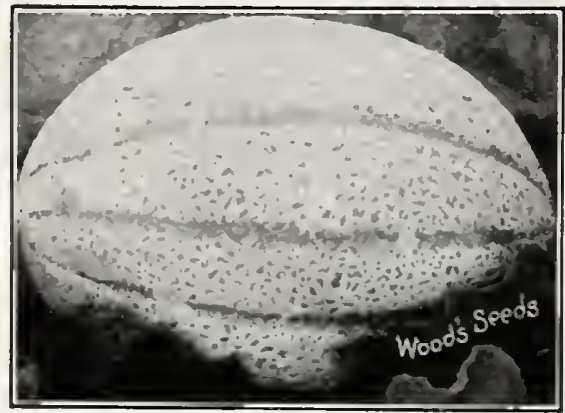

No. 260. Hale's Best-A salmon the Rock y F ord type; about ten days later and larger than Tood's Early Rocky ted iv $i$ in scarcely any rib. The quality. is deliciously sureet and spicy. On the Richmond $m$ arket they bring top prices: Oz. $\$ 15 \mathrm{i}, 2 \mathrm{bs}, \$ 2.50$ 5 ibs. $\$ 5.90$ postpaid. Hale's Best

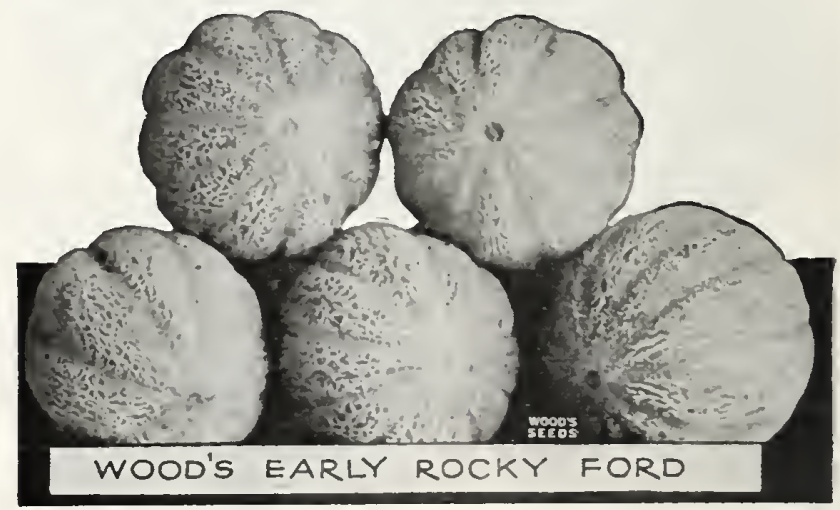

No. 250. Wood's Early Rocky Ford -A strain of Rocky earliness. It is a week to ten days earlier than Rocky Ford, is like it in shape. but a llttle larger. The melons are heavily netted, have small seed cavity, firm and thick green flesh, and are attractive in both shape and color. The flavor is deliciously sweet and spicy. It is early, prolific and of fine quality. This is just the melon to follow our Extra Early Hanover. It has that spi in the on," 5 lbs. $\$ 6.35$ postpaid.

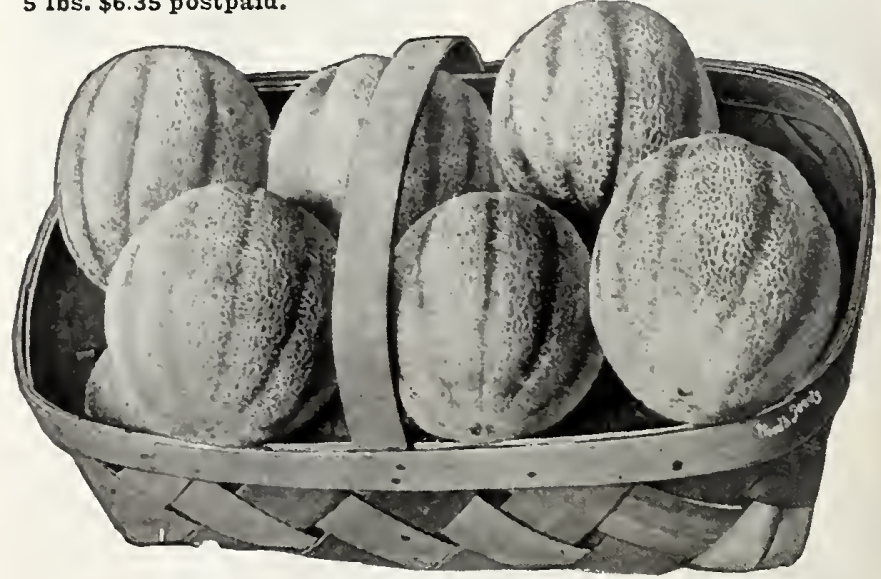

Wood's Early Knight Cantaloupe.

No. 249. Wood's Early Knight (Maryland or Sweet Air.)next to our Extra Eariy Hanover and Early Rocky Ford. It is a happy combinatlon of earliness, productiveness and quality. The melons are nearly oval shaped, densely netted, of good size ith thick brlght green hesh that is very luscious and ripens

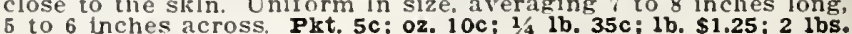
$\$ 2.20 ; 5$ lbs. $\$ 5.20$ postpaid. 


\section{-Formerly called Hoo- doo. One of the fin- est of the orange- fleshed melons; de- liciously sweet and spicy. The flesh is down to the thin firm rind. The ribs are distinet, with an exceptionally fi $\mathrm{rm}$ and $d$ en s e netting which covers the en- tire melon. Makes a vigorous vine, con sequently is disease resistant and a pro- lific bearer. Plrt. 5c oz. $10 \mathrm{c} ; 1 / 4$ 1b. $35 \mathrm{c}$; 5 ibs. $\$ 5.20$ postpaid.}

No. 255. Hearts of Gold

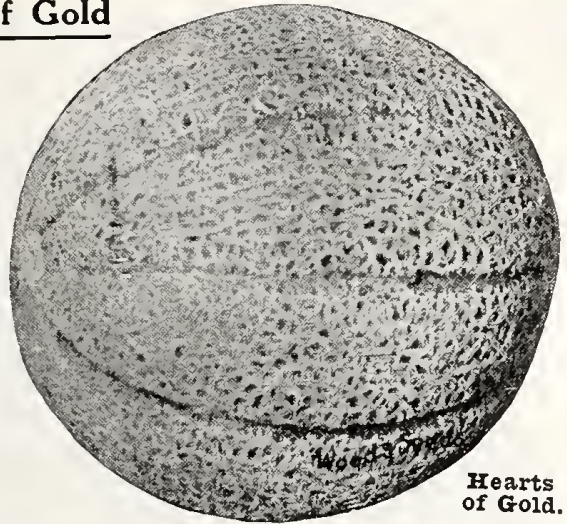

Rocky Ford

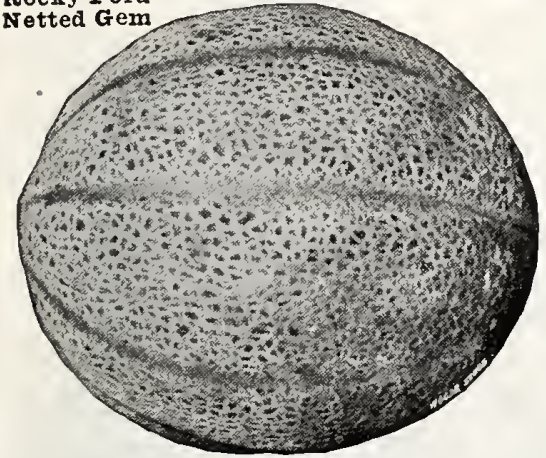

No. 252. Rocky Ford Netted Gem

-The standard of excellence a n o n
green - fleshed melons. The flesh is thick, with a small cavity; very sweet ard has that spicy flavor that makes cantaloupe so delicious. Oval shaped, covered iv it hine netting and uniform in size and shape. from selected mel ons and should not

be confused with cheap seeds saved from the run of the field. Pkt. 5c; oz. $10 \mathrm{c} ; 1 / 4$ 1b. 30c; 1b. $\$ 1.00 ; 2$ lbs. $\$ 1.75 ; 51 \mathrm{bs}$. $\$ 4.00$ postpaid.

\section{No. 257. Tip-Top}

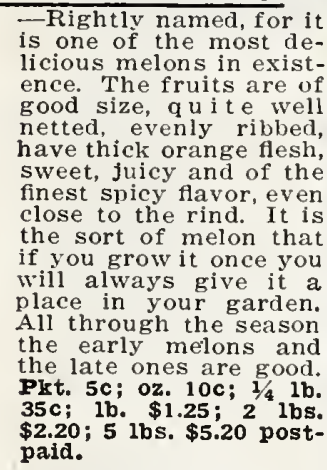

No. 254. Extra Early Hackensack -Similar Hackensack, but not so large, nearly two weeks earlier and has the same deliciously sweet and sugary flaher. The netting is juicy and sweet. The fiesh is light green.

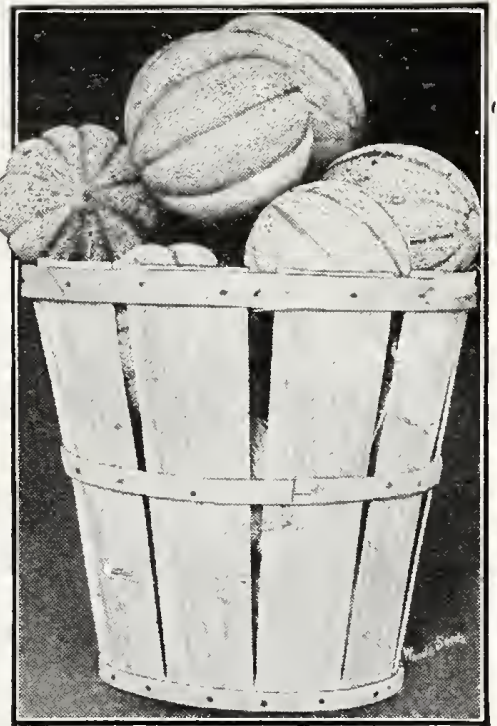

Tip Top Cantaloupe

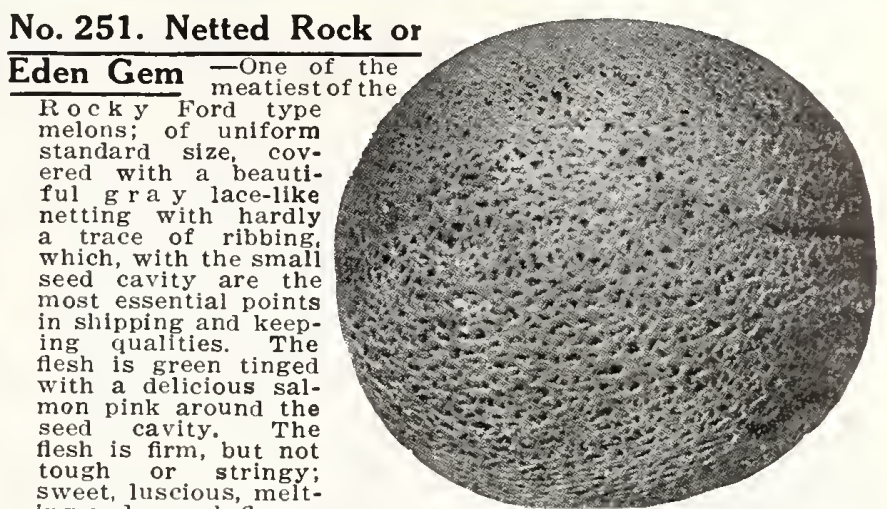

ing and superious, meltA heavy yielder. Pkt.

lb. $\$ 1.15 ; 2$ ibs. $\$ 2.00 ; 5$ lbs. $\$ 4.80$ postpaid.

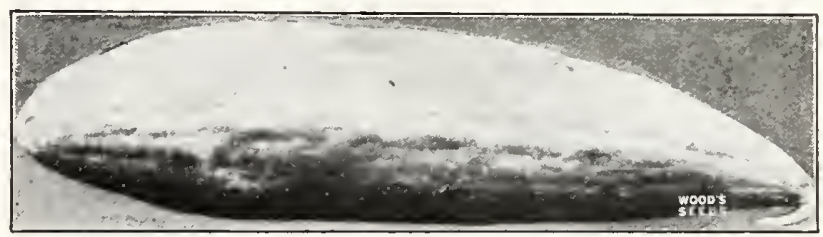

No. 262. Banana - When first introduced this was a curiosi15 to 20 inches long by four to six inches in diameter; has thick orange flesh with delightfully sweet flavor. Plst. 5c; oz. 10c; No. 259. Large

\section{Hackensack}

or TURK'S CAP.-This is the type of melon once called muskmelon. The fruits are large, nearly round, flattened at the ends; has wide slices; is densely netsweet and juicy. Recommended only for the home garden and nearby market. Prt. 5c; oz. 10c; $1 / 4$ 1b. 35c; 1b. $\$ 1.15 ; 2$ lbs. \$2.00; 5 lbs. $\$ 4.80$ postpaid.

No. 263. Glass

Melon or M A N G O. sweet For preserving. sweet pickles, m a n- Irarge Fackensack Iusk Melon. peppers, pies, and may be sliced and fried like egg-plant. Plrt. $10 \mathrm{c}$; 0z. $20 \mathrm{c} ; 2$ ozs. $35 \mathrm{c} ; 1 / 4$ 1b. $60 \mathrm{c} ; 1 \mathrm{~b}$. $\$ 1.75 ; 2$ bs. $\$ 3.10 ; 5$ lbs. $\$ 7.40$ postpaid.

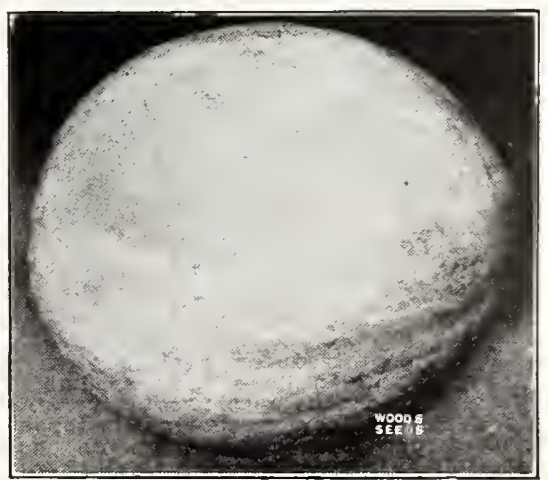

Honey Dew Melon.
No. 245. Honey Dew -it is certainly ew wh e $n$ ( up and will keep for mature pull when the blossom end is slightly soft, and $k$ e e $p$ a
few days before serving. The flesh is good right up to the rind distinct from the flavor of a cantaloupe. Pkt. 10c; oz. 15c; $1 / 41 \mathrm{~b}$. 40c; $1 \mathrm{~b}, \$ 1.40 ; 2$ postpaid. 


\section{Wood's ${ }_{\text {GROWN }}^{\text {SOUTHER }}$ Water Melon Seeds}

OULTURE.- Prepare hills 8 or 10 leet apart each way by work. rotted manure, or poultrs droppings-rich kround fires the plants a good start before insects attack them. well up, thin out, learing three strong plants to One ounce will plant 30 lillls; 3 lbs. one acre.

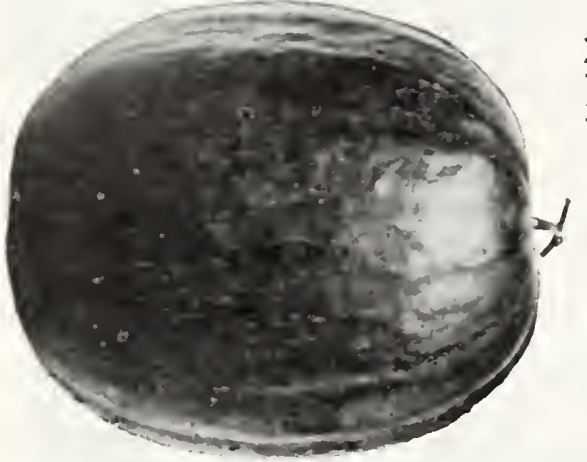

No. 275. Stone Mountain $-\mathrm{Sin}$ ? duetion of our imTreved st $\mathrm{r}$ a in o watermeion lias aroused so mueh in terest as stone near the base of Stone Mountain Confederate Memorlal. and immediately bec a me immensely popular, espeeially among thos e who prefer round melons. The introllucer says: "It is the finest of all, the sweetest of all and the largest of all; when once eaten it is not forEotten." The melons are round, of the riehest dark green color lave medium rind and the riehest scarlet flesil with the fiver and sweetest flavor without white hearts or stringiness. On thoof melon ind they roy to 50 to 80 pounds, solid througl and almost all heart. Pixt. 10c; 0z. 15c; $1 / 4$ 1b. 45c; 1b. $\$ 1.50$; 2 lbs. $\$ 2.65 ; 5$ lbs. $\$ 6.35$.

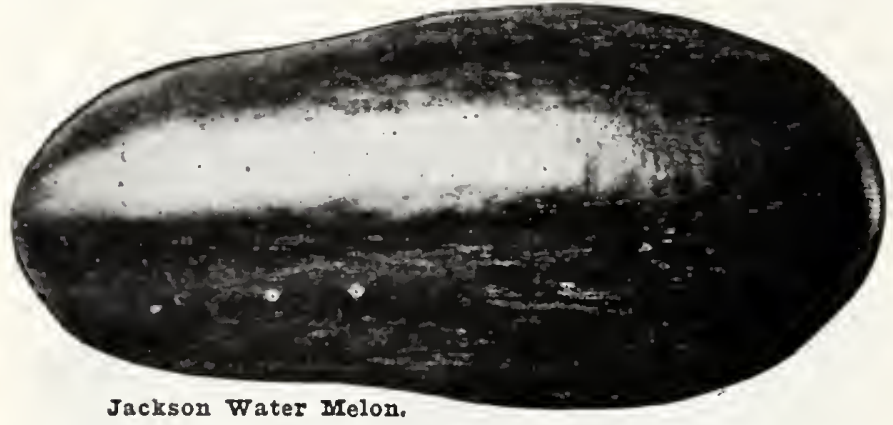

No. 278. Jackson -If asked to name the sweetest melon for o. 278. Jackson hom use, we would name the Jackson Other kinds may be larger. but none ean compare with it in dellelous sweetness. A long melon with mottled green skin. firm, red meat, and ripens close to the rlnd. Pkt. 10c; oz. 15c;

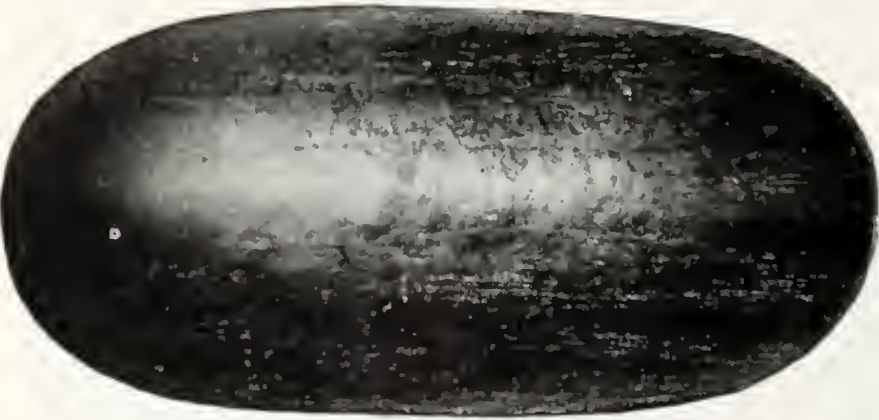

Halbert Honey

No. 280. Halbert Honey -The introducer describes this

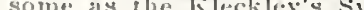
long enriy melon, with dark, rich, glossy green rind, crimson fiesh and sweetness that is unsurpassed. Fine for home use nnd home market, but not well sulted for shipplng. Pkt.
oz. 10c; 34 1b. 30c; 1 b. $\$ 1.00 ; 2$ bs. $\$ 1.75 ; 5$ bs. $\$ 4.00$ postpala.

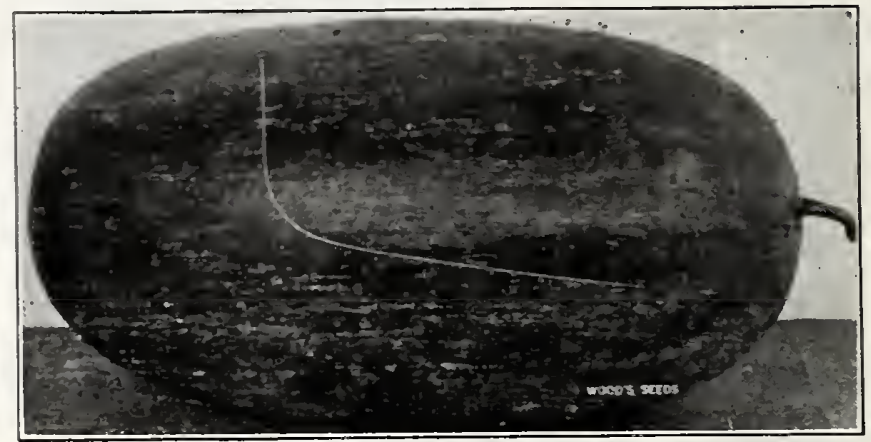

No. 269. Improved Kleckley's Sweet or Monte Cristo

Sometimes sold as "Wondermelon."-This improved strain has the same red flesin, delicious sweetness and all the other spiendid qualities that made lileekley's Sweet such a favorite. The improvement has been made along the line of size and shipping quatities. It is not at all unusual to have them weigh 50 pounds, ret the rind is thin, but so tough that mproved $5 \mathrm{c}$; oz. 10c; $1 / 41 \mathrm{~b}$. 30c; 1b. $\$ 1.00 ; 2$ lbs. $\$ 1.75 ; 5$ bs. $\$ 4.00$ postpaid.

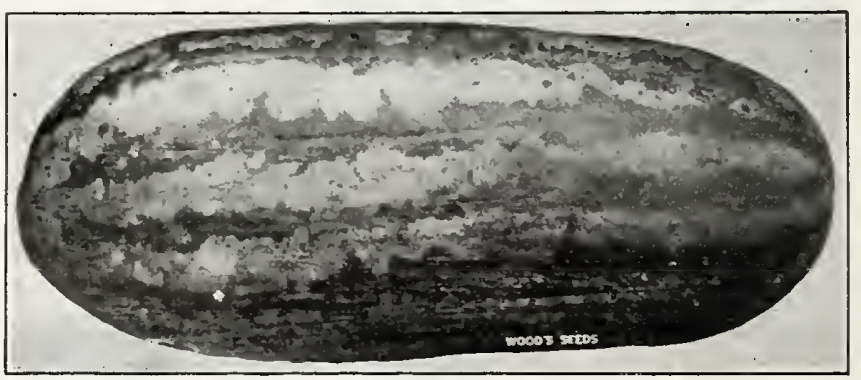

No. 279. Improved Georoia or Augusta Rattlesnake -The old Rattlesnake has alway's been regarded as a fine melcu. Our strain is the result of careful selection by an experienced melon grower through many years of careful and watchful work. The rind is thin and tough, the flesh deep. scarlet, the flavor unsurpassed by any other sort. We recom. mend it both for shipping and home use. Our mproved staek Pkt. 5c: oz. $10 \mathrm{c} ; 2$ ozs. $15 \mathrm{c} ; 1 / 4$ b. $25 \mathrm{c} ; 1 \mathrm{~b}$. $85 \mathrm{c} ; 2$ lbs. $\$ 1.45 ; 5$ ibs. $\$ 3.40$ postpaid.

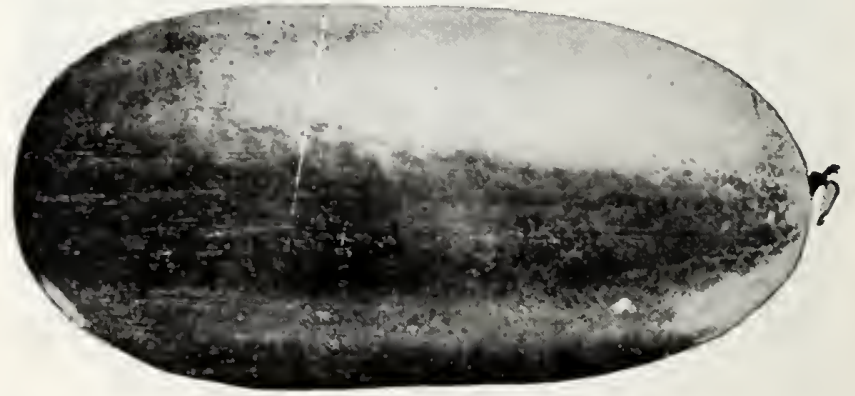

Irish Gray watermelon

No. 270. Irish Gray -In sweetness it is like Kleckley's in shape, size and in productiveness it compares with Tom Watson. The thin rind is so tough it will not burst frcm rough treatment in transit; its keeping quality will appeal to silippers who have experienced losses on account of glutted markets. The eolor is a distinct mottled greenish grey; the nish is red, sweet, crisp and free from stringiness. Aithough a grand shipper, it is equaliy fine for the home garden. Pkt. 5c: $02.10 \mathrm{c} ; 1 / 41 \mathrm{~b}$. $30 \mathrm{c} ; 1 \mathrm{~b}$. $\$ 1.00 ; 2$ lbs. $\$ 1.75 ; 5$ bs. $\$ 4.00$ postpaid. 


\section{Wood's $\underset{\text { SOUTHERN }}{\text { CROWN }}$ Water Melon Seeds}

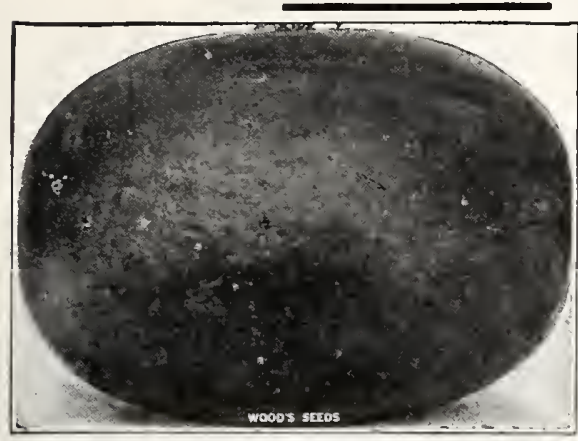

No. 274. Extra Early Dark Icing

An exira early and extra good melon for home use and One of the most delicious of melsugary to the very thin $r$ ind. The fruits ripen earlier than almost any other melon. Pkt. $5 \mathrm{c} ;$ oz. 10c; $1 / 4$ 1b. 30c; $1 \mathrm{~b}$. $\$ 1.00 ;{ }^{2}$ $\$ 4.00$ postpaid.
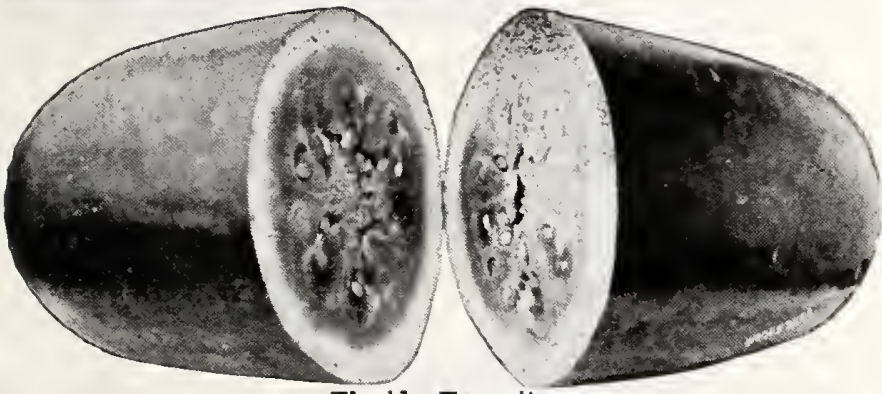

No. 271. Florida Favorite (or Pearson).-A splendid, large home melon and its long melon; comes early, is a fine ciously sweet to the thin firm rind. The quality and favor are extra fine. Plst. 5c; oz. 10c; 2 ozs. $15 \mathrm{c} ; 1 / 4 \mathrm{lb} .25 \mathrm{c} ; 1 \mathrm{~b} .85 \mathrm{c} ; 2$ lbs. $\$ 1.45 ; 5$ lbs. $\$ 3.40$ postpald.

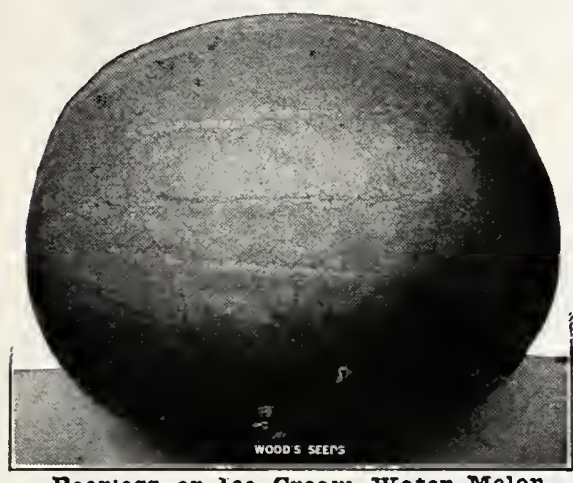

Peersess or Ice Creanı Water Melon.
No. 281. Peerless or Ice Cream For home garden or for market gardeners who sell direct to consumers the Peerless has no superior among oval - shaped melons; of good size, color light green, veined with darker green; deep rich red meat of the most delicious sweetness, and solid to the center. The vin e is quice vigorous and productive and the Pkt. 5c; oz. 10c: 2 ozs. $15 c ; 1 / 1 \mathrm{~b}, 25 \mathrm{c}:$ lb. $85 \mathrm{c} ; 2$ lbs. $\$ 1.45$ 5 ibs. $\$ 3.40$ postpaid.

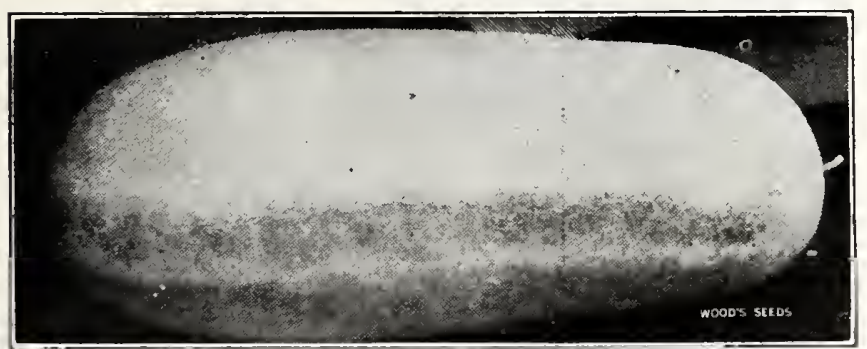

No. 276. Thurmond Gray -A heavy producer of large tractive appearance, fine quality and bright red, solid meat that ripens close to the tough thin rind and is free of strings. The thick greenish-gray color makes it hard to sunburn and it is wilt resistant. It is a wonderful market melon, ranking with Irish Gray and Tom Watson as a shipper, but it has the fine sugary quality so necessary in a home garden melon. It is about as early as Irish Gray. Pkt. 5c: oz. 10c: $1 / 4$ 1b. 30c; 1b. 90c; 2 lbs. $\$ 1.50 ; 5$ lbs. $\$ 3.65$; 10 lbs. $\$ 6.35$ postpaid.

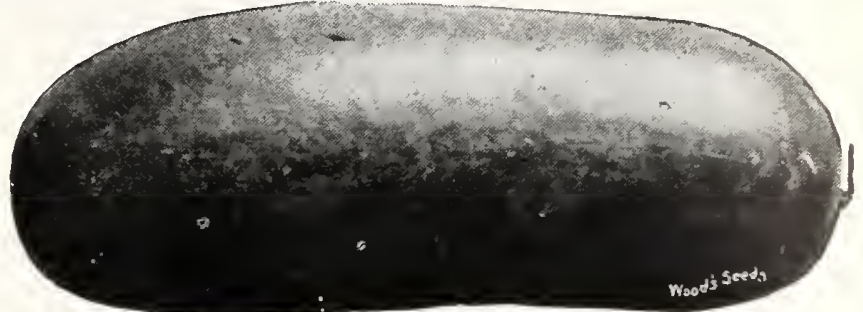

Tom Watson Water Melon.

No. 277. Tom Watson - The most popular shipping melon grown. The melons are large, long a tougher rind, giving it exceptionally fine shipping qualities. The flesh is rich red solid sweet and luscious and ripens close up to the rind Althourh a shipping melon, its fine qual. ity commends it to the home gardener. Pkt. 5c; oz. 10c; 2 ozs. $15 \mathrm{c} ; 1 / 4$ lb. $25 \mathrm{c} ; 1 \mathrm{~b} .85 \mathrm{c} ; 2$ lbs. $\$ 1.45 ; 5$ lbs. $\$ 3.40 ; 10$ lbs. $\$ 6.15$ postpaid.

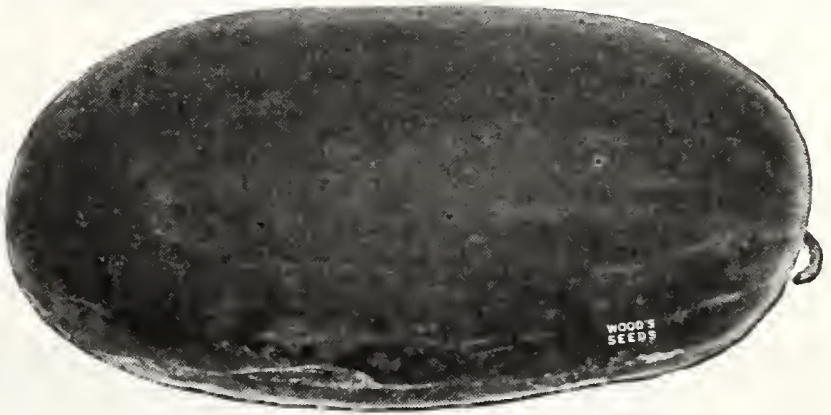

Alabama Sweets Water Melon.

No. 273. Alabama Sweets -A very large and attractive oblong melon of the type now skin is very dark green, with still darker stripes: the flesh is bright red, solid, very sweet and wefgh forty to fifty pounds. Pkt. 5c; oz. 10c; 2 ozs. 15c; $1 / 4 \mathrm{~b}$. $25 \mathrm{c}$; 1b. $85 \mathrm{c}$; 2 lbs. $\$ 1.45 ; 5$ lbs. $\$ 3.40$ postpaid.

Our melon seeds are saved from large melons grown express. 17 for seeds. Do not plant Northern and Western grown seeds if you want the finest watermelons.

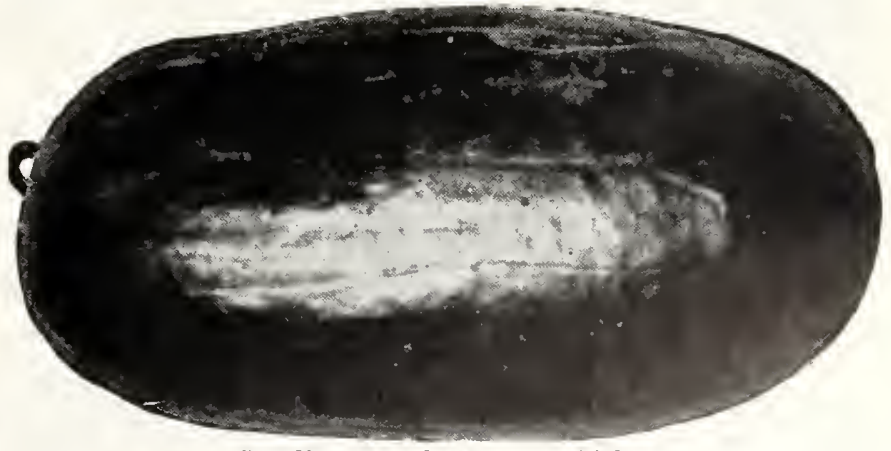

Carolina Bradfold Water Melon

No. 272. Carolina Bradford-The Bradford is one of the nearby market distances. It is a favorite above all others in sections where it has been grown. Makes a strong. healthy and very productive vine. The melons are large, elongated; rind dark green with darker stripe: flesh red, remarkab tender and sweet. 15c; $1 / 4$ lb. $25 \mathrm{c}$; 1b. $85 \mathrm{c} ; 2$ lbs. $\$ 1.45 ; 5$ lbs. $\$ 3.40$ postpaid.

No. 284. Preserving Citron $-M$ a k e $s$ excellent preserves stock feeding. Keeps for a long time. Pkt. 5c; oz. 10c; $1 / 4$ 1b. 30c; lb. $\$ 1.00 ; 2$ lbs. $\$ 1.75 ; 5$ lbs. $\$ 4.00$ postpaid. 


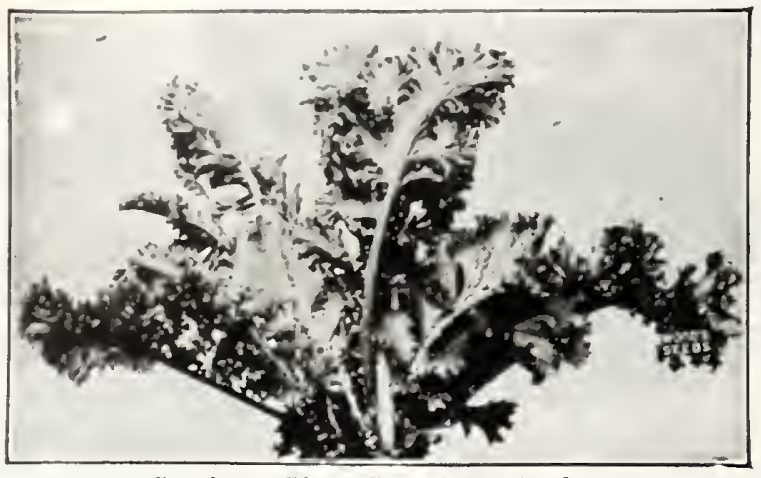

Southern Giant Curled Mustard

\section{MUSTARD}

CUITURE.

No. 291. Mustard Spinach-1

No. 290. Southern Giant Curled

- Popular with South. mass of leaves beautifully ruffled, curled and crimped around used as a salad like lettuce or cooked like spinach, Pkt. 5c; oz. $10 \mathrm{c} ; 2$ ozs. $15 \mathrm{c} ; 1 / 4$ lb. 20c; $1 \mathrm{~b} .65 \mathrm{c} ; 2$ lbs. $\$ 1.10 ; 5$ lbs. $\$ 2.40$; No. 292. Chinese Broad Leaved Makes a large and tenwithont bltter taste. Ready six weeks from sowing: sweet and oz. 10c; 2 ozs. $15 \mathrm{c} ; 1 / 4$ lb. 25c; 1b. $75 \mathrm{c} ; 2$ lbs. $\$ 1.25 ; 5$ lbs. $\$ 2.90$ postpald.

\section{NASTURTIUM or INDIAN CRESS}

Serves a triple purpose, the flowers for decoration the leares for garnishing and salads, and the green seed-pods for pickles.

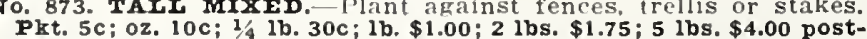
pald

No. 856. DWARF IIIXED.- Fine for beds and borders. Pkt. 5c; oz. $10 \mathrm{c} ; 1 / 4 \mathrm{lb} .30 \mathrm{c} ; 1 \mathrm{~b} . \$ 1.00 ; 2$ lbs. $\$ 1.75 ; 5$ lbs. $\$ 4.00$ postpald.

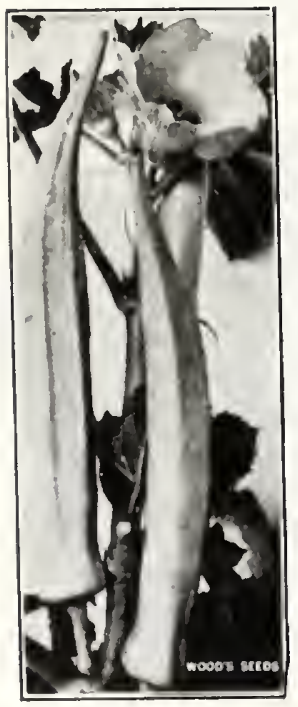

\section{OKRA or GUMBO}

CUITURE.-When the ground has beme thickly in drills $3 \mathrm{ft}$, apart string them and hang in the shade to dry
or they may be pickled like cucumbers or
canned. One ounce will sow 30 feet of drill No. 295. Kleckley's Favorite -Pro thick, lleshy pods of exceptional tender ness and flavor. $21 / 2$ to 3 feet high. clos
ointed. buring pods at each leaf-joint (tiom, and car eng the thickness well throughout the arlety. Pkt. $5 \mathrm{c} ; 02.10 \mathrm{c} ; 1 / 4$ 1b. 20c; 1b. 65c; 2 lbs. $\$ 1.10 ; 5$ lbs. $\$ 2.40$ postpaid.

No. 296. White Velvet-Bears round pods without ridges $11 \mathrm{ke}$ other varletles The extra large nods are produced in $20 c$ : 1 b. $65 \mathrm{c} ; 2$ lbs. $\$ 1.10 ; 5$ lbs. $\$ 2.40$ postpald.

No. 297. Improved Dwarf Green Prolific -Dwarf, but immensety producand are borne throllghout the season. Pkt. $5 \mathrm{c} ; \mathrm{oz} .10 \mathrm{c} ; 1 / 4 \mathrm{~b}$. 20
lb. $65 \mathrm{c} ; 2$ lbs. $\$ 1.10 ; 5$ bs. $\$ 2.40$ postpald.

No. 298. Perkins Mammoth Long Green - Wonderfully

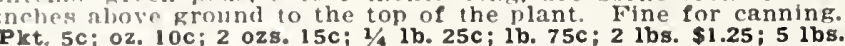
Prt, $5 \mathrm{c}$; 02. $10 \mathrm{c}$.
$\$ 2.90$ postpald.

\section{ONION SETS}

Bushel Prices Quoted on Request.

CUITURE.-Plant 4 inches apart, in rows half an inch deep and 1 foot between the rows, but do not cover the sets entirely, except Potato Onions. Which should be planted in rows 2 feet luant as earlyches apartin the row, and covered about one inch they" will be ready" for the table several weeks earlier than onions grown from seeos. All varleties can be set out in the fall as

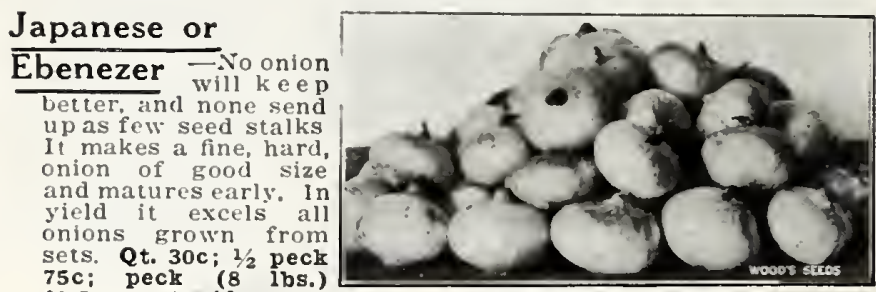

75c: peck $(8$

Not postpaid, qt. 20c; 1/2 peck 55c; peck (8 lbs.) $90 \mathrm{c}$.

YELIOW DANVERS. - The most popular of all the yellow varietles: the large, handsome onions are ready early in the summer. Qt. 30c; $1 / 2$ peck 70c; peck (8 1bs.) $\$ 1.15$, postpaid. Not postpaid, qt. $20 \mathrm{c}^{2} 1 / 2$ peck $50 \mathrm{c}$; peck (8 lbs.) $85 \mathrm{c}$.

SIIVER SKIN.-Produces silvery white onions. The best white oninn for spring setting; mild flaror. Qt. 30c; ${ }^{2} 2$ peck 80c; peck (8 1bs.) \$1.30 postpaid.

Not postpaid, qt. $20 \mathrm{c}$; $1 / 2$ peck $60 \mathrm{c}$; peck (8 lbs.) $\$ 1.00$.

RED WETHERSFIEID. - The best all-purpose red onion; a big cropper, hardy and a good keeper. Qt. 30c; $1 / 2$ peck 70 ; peck (8 ibs.) $\$ 1.15$ postpald.

Not prepald, qt. $20 \mathrm{c} ; 1 / 2$ peck $50 \mathrm{c}$; peck ( $8 \mathrm{lbs}$.) $85 \mathrm{c}$.

YELIOW POTATO.- Makes large onions of mild flavor. The smultest seis produce one to two large onions: medium sized sets produce a number of medium to snall sets, the large onions ploduce a great many smali sets. They are produced postpaid, qt. $35 \mathrm{c} ; 1 / 2$ peck $\$ 1.00$; peck (8 lbs.) $\$ 1.70$.

Not postpaid, qt. $25 \mathrm{c}$; $1 / 2$ peck $80 \mathrm{c}$; peck (8 lbs.) $\$ 1.40$.

WHITE MULTIPLIER.-Fine for early spring bunching. Matures very early; the flesh is pure white and very mild. No
onion keeps better. Qt. 35c; $1 / 2$ peck $90 \mathrm{c}$; peck (8 1bs.) $\$ 1.55$ postpaid. Not postpaid, qt. $25 c ; 1 / 2$ peck $70 c$; peck (8 lbs.) $\$ 1.25$. EXTRA EARIY WHITE PEARI-For Fall planting only. Sow seeds in the spring to make sets to be put out next fall. See page

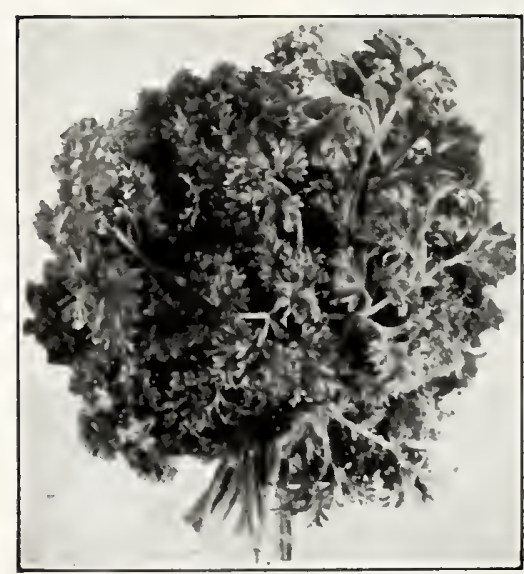

Champion Moss Curled Parsleg.

\section{PARSLEY}

CUITURE.-Sow in Febcuary Jarch or early in April half an inch deep, in rows a foot apart, pressing the soil after sowing. Slow rerminate, sometimes wo or three weeks in coming up. Germination may be hastened by soaking 24 to 36 hours before sowing. with boards to retain the moisture A few radisl seed should be sown in the row with parsley to mark the row and allow early cultivation. The radishes can be pulled early and will not interfere with the parsley. If dried crisp and rubbed to powder it may be bottled for use later. An ounce plants 100 feet. or by covering the rows

No. 314. Champion Moss Curled -The best and most beautifully curled and crimped, and is the best for garnishing and favoring. If cut when about 3 inches high, it starts a new grcwth that will be better curled and a brighter color. Makes an ornamental plant for edging walks. Pkt.
30c; 1b. 90c; 2 lbs. $\$ 1.50 ; 5$ lbs. $\$ 3.65$ postpaid.

No. 315. Plain or Single - Hardier than the curled and Nonger flavored; color very dark green; fine for flavoring soups, stews and garnishing, or they may be dried till crisp, rubbed to a powilb. 90c; 2 lbs. $\$ 1.50 ; 5$ 1bs. $\$ 3.65$ postpald. 


\section{Onion}

Plant $1 \mathrm{oz}$, to 100 feet of row; 5 to 6 lbs. to the acre.

cTI January or February plant 16 Inch deep in hotbeds or plant outside later. When the size of a goose quill hotbeds or plant outside later. When the size of a goose quil may also be made where the onions are to rrow thinning out to stand 3 to 4 inches apart, but the transplanting method saves seeds and at least two weedings and gives larger yields. Keep free of weeds.

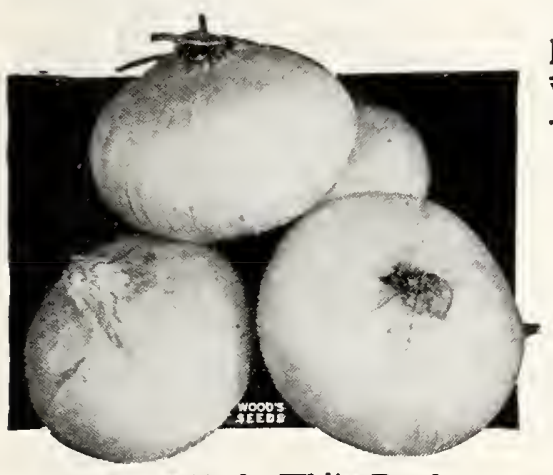

No. 309. Extra Early White Pearl $-\mathrm{T}$ h $\mathrm{e}$ of the white onions: makes good sized pcarly white bulbs, te nd e r, mild and of the best flavor. To make early sp ing onlons, sow March or early April; put out the sets next fall to make largc onions next spring bc fore any other kinds are ready. Splendid for pickling. Pkt. 10c; oz. $2 \mathrm{lbs}$. $\$ 4.90 ; 5$ ibs. $\$ 12.00$ postpaid.

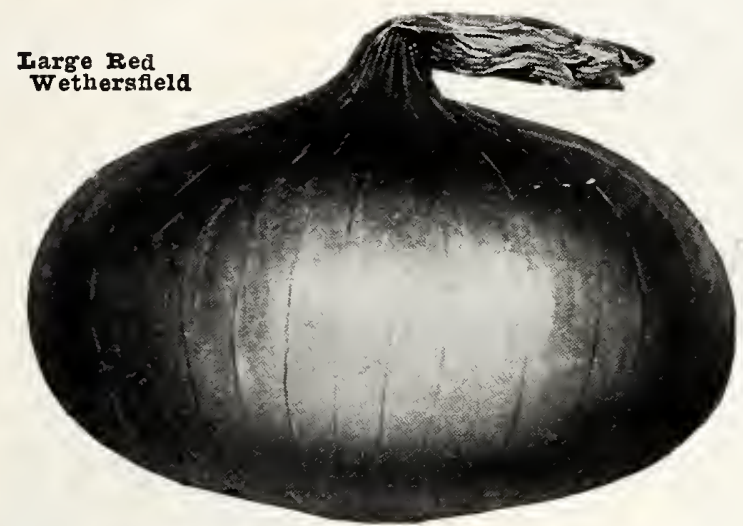

No. 301. Large Red Wethersfield -The bulbs are large, skin purplish red; flesh purplish white, very hardy and solid; an excellent keeper and a heavy cropper. $A$ good onion for poor and dry solls Pkt. 5c; oz. 15c; 1/4 1b. 50c; 1b. $\$ 1.75 ; 2$ lbs. $\$ 3.10 ; 5$ lbs. $\$ 7.40$ postpaid.

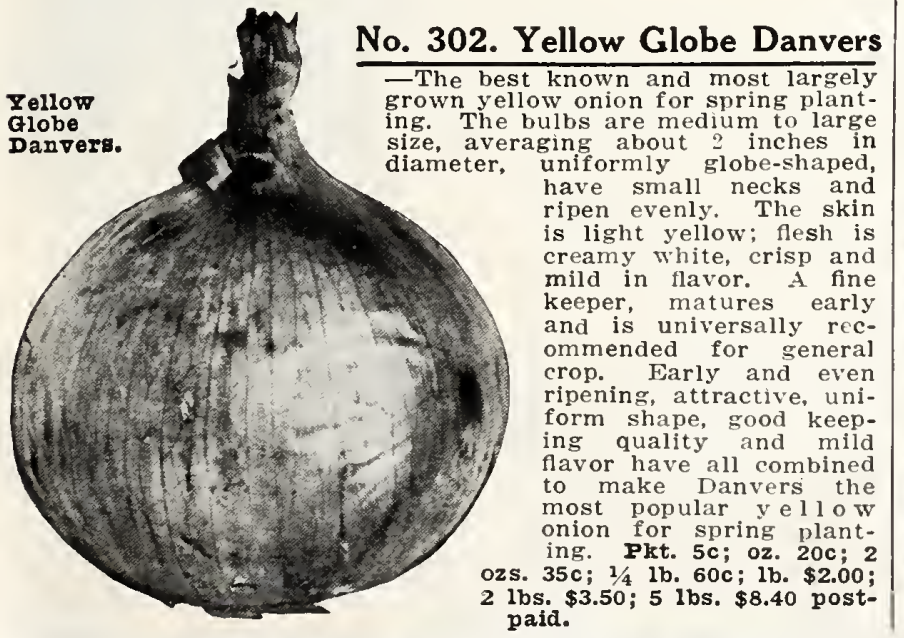

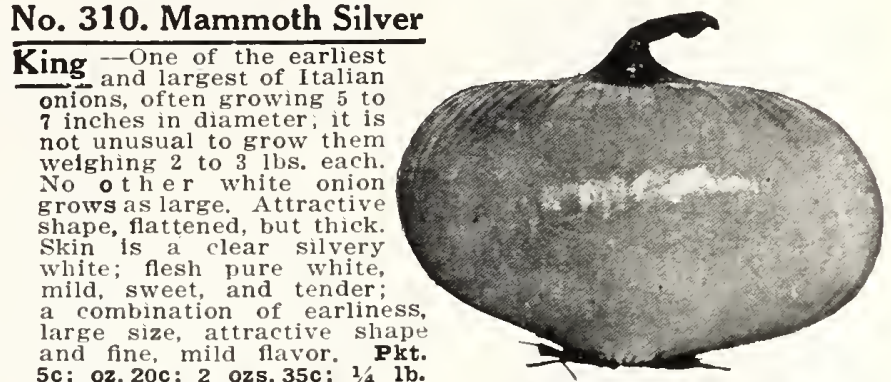

5c; oz. 20c; 2 ozs. 35c; 1 P $1 \mathrm{~b}$. $65 \mathrm{c} ; 1 \mathrm{~b} . \$ 2.25 ; 2$ lbs. $\$ 4.00$; 5 lbs. $\$ 9.80$ postpaid.

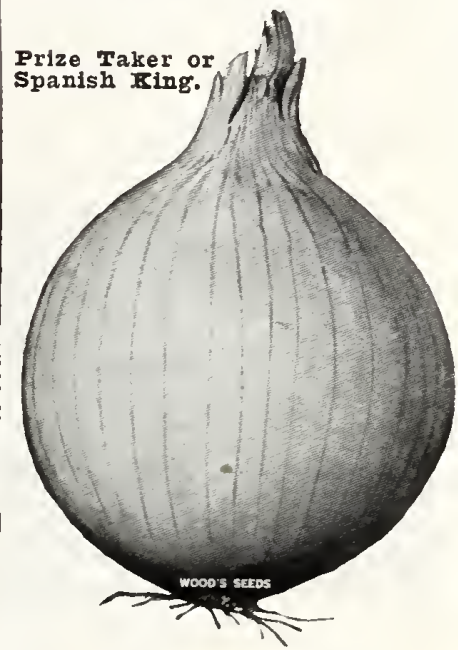

\section{No. 307. Copper King}

\section{-Attains an enormous size.} single onions having beell grown weighing four pounds. The skin is a reddish color: flesh white, very sweet, mild and tender. Enormous crops may be grown by following the transplanting method described above; plant early in the seed bed, transplant and have big onions in August. Plst. 10c;0z. 25c; 2 ozs. $40 \mathrm{c} ; 1 / 4$ lb. $70 \mathrm{c}$; $1 \mathrm{~b}$. $\$ 2.50$ 2 lbs. $\$ 4.50 ; 5$ lbs. \$10.75 postpaid.

No. 303. Silver Skin or White Portugal $-A$ be a u t1ful of good size, largely used for growing matured onions, for

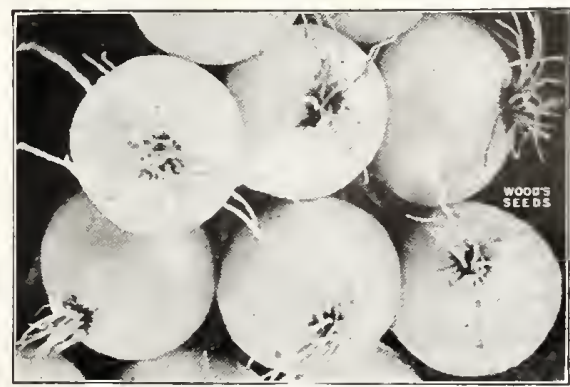

Silver Skin or White Portugal.
No. 308. Prize Taker fine flavor, like nearly al Spanish onions. The skin is pure white, sweet, mild and tender. Ripens up firm and hard; a good cropper and always uniformly globe shaped with small neck The roun plants can be used as a salad the half grown onions in carly summer and the ripe onions during the remainder 2 ozs. 35c; $1 / 4$ 1b. 60c; 1b. $\$ 2$ 2 lbs. $\$ 3.50 ; 5$ lbs. $\$ 8.40$ postpaid.

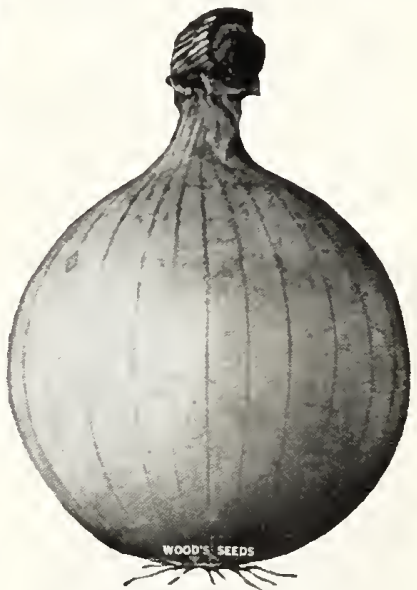

Copper IIng. or Spanish King - Large sets, for pickling. for bunching in the spring and for use as a salad when young. The flesh and skin are pure white, very mild makes a nlce, firm hard onlon, one that w $11 \mathrm{l} \mathrm{keep}$. The small bulbs make as good a plckling onion as our White Pearl. Pkt. 10c; $0 z$. $25 \mathrm{c} ; 2$ ozs. $40 \mathrm{c}$; 2 lbs. $\$ 4.50$ : 5 lbs. $\$ 10.75$ postpald. 


\section{Garden Peas - Early Varieties}

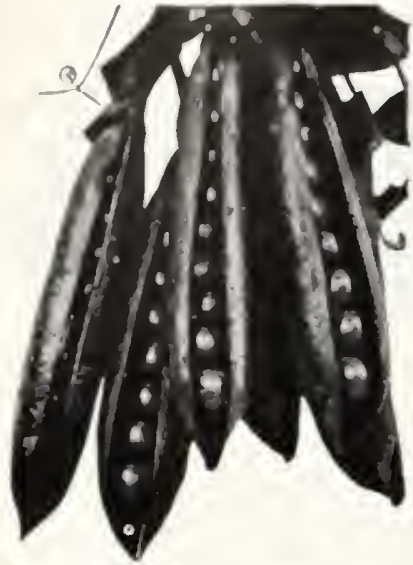

Pedigree Extra Early

No. 322. Large Podded Alaska or Ameer

No. 326. Petit Pois or French Peas llany gar

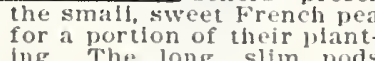

tender, dellicate qu a lit $y$

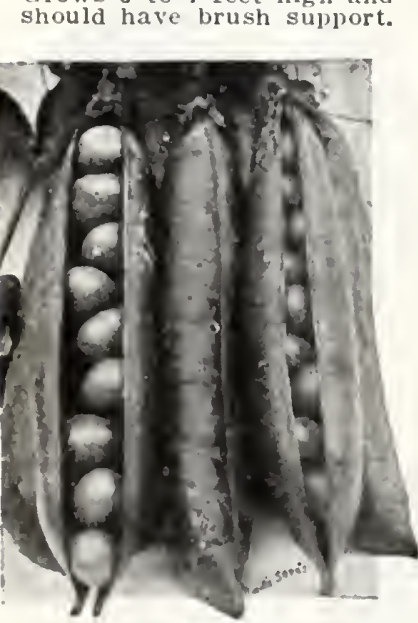

Thomas Iaxton
(Varieties marked with star (*) are wrinkled)

2 pounds will plant 100 foet of dril; 90 ponnds an acre.

CUITURE- Peas do best in a light, rich, loamy soll that has manured the previous season. Plant the smooth re not as hardy as the smooth kinds, and should be planted later, weeks-as late as August for a late crop. Plant 2 twcen the double rows; stake the tall varle- IYOCULATETHS Gather as fast as they arc fit
wise they wlll stop bearing. SEED IVITH STIMUGERM

No. 319. Wood's Pedigree Extra Early -This is all that a thorouglibred pea. The pods are well shaped and well filled pods retaining peas and areme earliness, wellfilled pods and great productlveness. $2 \frac{1 / 2}{1 / 2}$ eet high.

No. 320. Wood's Lightning Excelsior - No extra early our Lightning Excelsior: their hardiness adapts them for ver wrinkled varietes, but can be planted earlier and are ready for use earlier. l'rolific, grows $21 / 2$ feet high, strong, vigorous and
hardy, standing cold weather; ripens uniformly and ls one of the most productive extra early peas.

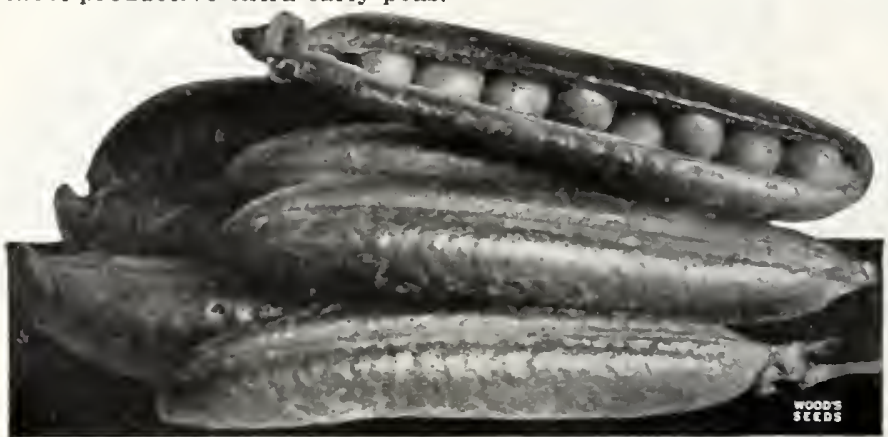

Iaxtonian Peas-Fandredfold Dark Green Strain

No. 329. Laxtonian* (Hundredfold strain. Sometimes called bination of earliness, productlveness and extra fine quality. A - rinkled pea, producing large, incensely dark green pods 4 inches long, contalning 6 to 8 large, luscious peas. There is no better extra carly wrinkled pea. Helght, 15 to 18 inches.

No. 323. Laxton's Progress* (Improved Iaxtonian)-The the latge podded wrlnkled peas, and ylelds better than any other pea of equal quality. Grows 15 inches high: the pods are peas.

No. 332. Thomas Laxton* -An exceptionally fine wrinnearly inches long that are packed the pod. It is only a few days later than the extra early smootl peas; is quite hardy and very prolific. The vines grow about 3 feet high. In qually, the peas are without a superior. Recom (uness, slze and fine quality.

No. 324. Nott's Excelsior*-Has all the good qualities of l'reinium Lem but ls a beter yjelder. The pods, about inclics ong contain 5 to 7 good sized, tender and delicious peas. A wonderful vielder and highly recommcnded for the home garden;

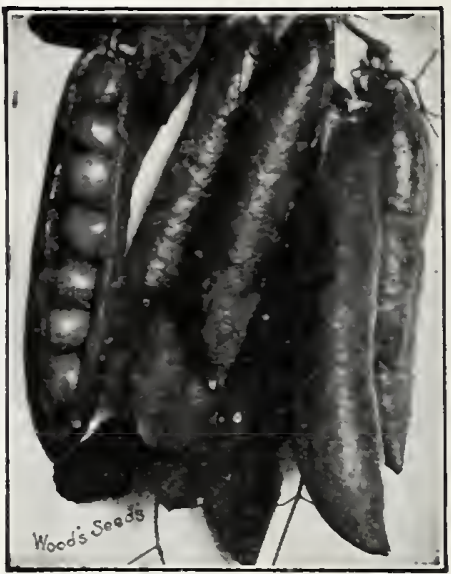

Iittle Marvel

No. 325. Little Marvel*

A splendid pea for the

It is a first rinted pea 18 to 20 nches high, heavily set with dark green pods closely crowded with 6 to 8 peas of extra fine flavor. A generus yielder, and the peas are who have heretofore planted American tionder and Premium Gem will find I itle IIarvel more satisfactory.

GRADUS OT PROSPERITYThomas Laxton is nore satfiactory.

AMERICA N WONDER Y You PREMIUM GEM

be far bettcr pleased with Marvel or Nott's Excelsior.

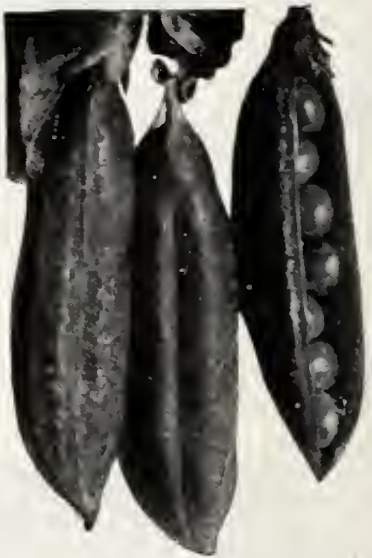

Nott's Excelsior

\section{PRICES}

No. 319. Wood's Pedigree Extra Early

No. 320. Wood's Ilghtning Excelslor.

No. 321, Extra Early Alaska.

No. 322 Targe Podaed Alask or meer.

No.323. Iaxton's Progress.

No.324. Nott's Excelsior.

No.325. Iittle Marvel

No. 326. Potit Pols or French Peas.

No.329. In 8 tonlan

No. 332 .
PRICES BX MAII POSTPAID

Pkt. $1 / \mathrm{g} 1 \mathrm{~b}$. Ib. $2 \mathrm{lbs}$. $5 \mathrm{lbs}$.

$10 \mathrm{c} \ldots .20 \mathrm{c} \ldots . .350 \ldots 600 \ldots . .25$

$10 \mathrm{c} \ldots 20 \mathrm{c} \ldots 35 \mathrm{.} \ldots 60 \mathrm{.} \ldots .20$

$10 \mathrm{c} \ldots .20 \mathrm{c} \ldots . .35 \mathrm{c} \ldots . .55 \mathrm{c} \ldots . .15$

$10 \mathrm{c} \ldots 20 \mathrm{c} \ldots 35 \mathrm{c} \ldots 60 \mathrm{c} \ldots 1.25$

$10 \mathrm{c} 25 \mathrm{c} 40 \mathrm{c} 770 \mathrm{c}$

$10 \mathrm{c} 20 \mathrm{c} \ldots 35 \mathrm{c}, \ldots 00 \ldots 135$

$10 \mathrm{c} \ldots 25 \mathrm{c} \ldots 40 \mathrm{c} \ldots 65 \mathrm{c} \ldots$.... 1.35

$100 \ldots 250 \ldots 40 c \ldots 65 \mathrm{c} \ldots . .1 .35$

$10 \mathrm{c} \ldots 25 \mathrm{c} \ldots . .400 \ldots 65 \mathrm{c} \ldots . .35$
Not Postpald

2 lbs. $51 \mathrm{bs}$. $101 \mathrm{bs}, 1001 \mathrm{bs}$.

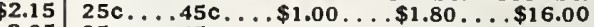
2.05 25c...45c ... .95 ... $1.70 \ldots .15 .00$ 1.95 25c...40c ... $.90 \ldots .1 .60 \ldots 14.00$ 2.15 25c...45c ... 1.00... 1.80 ... 16.00 2.45 30c ...55c... 1.15 ...2.10 . . 19.00 $2.2525 c \ldots .45 c \ldots .1 .05 \ldots \ldots 1.90 \ldots 17.00$ 2.35
2.35 $30 \mathrm{c} \ldots 50 \mathrm{~s} \ldots \ldots 1.10 \ldots 2.00 \ldots 18.00$ 2.35 30c...50c... $1.10 \ldots 2.00 \ldots 18.00$ $2 . 2 5 \longdiv { 2 5 c }$

1.05

17.00 


\section{Second Early and Late Peas}

\section{Varieties marked with a star (*) are wrinkled.}

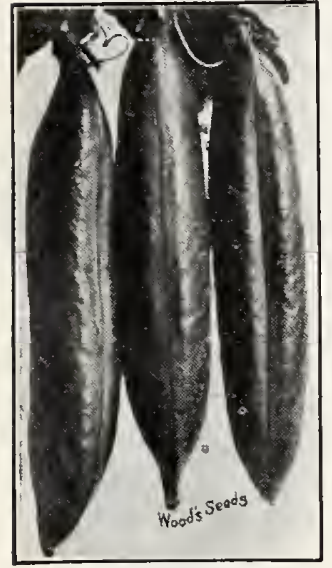

No. 337 Bliss Everbearing*

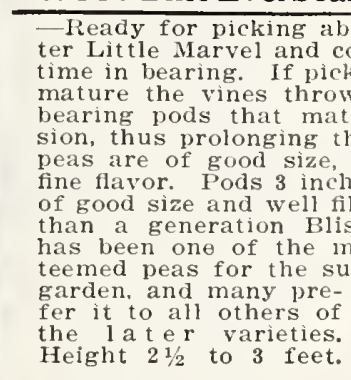

No. 345. Dwarf

Telephone or Daisy*

Dwarf Telephone

qualities of that fine pea. broad straight pods about $41 \%$ inches long. quite similar to pur Wood's Dark Green Telephone. The well-filled pods frequently contain 7 to 8 big. luscious sweet peas that melt in the mouth; $1 \frac{1 / 2}{2}$ feet high. no support.

No. 340. Champion of England*

-Universally admitted to be one of the best late peas. Highly prized by those who are
fond of a large, tender and luscious pea.

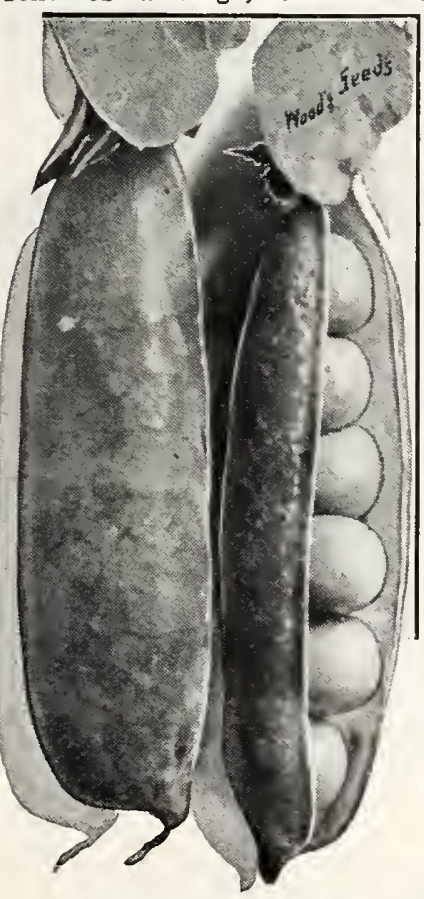

Champion of England

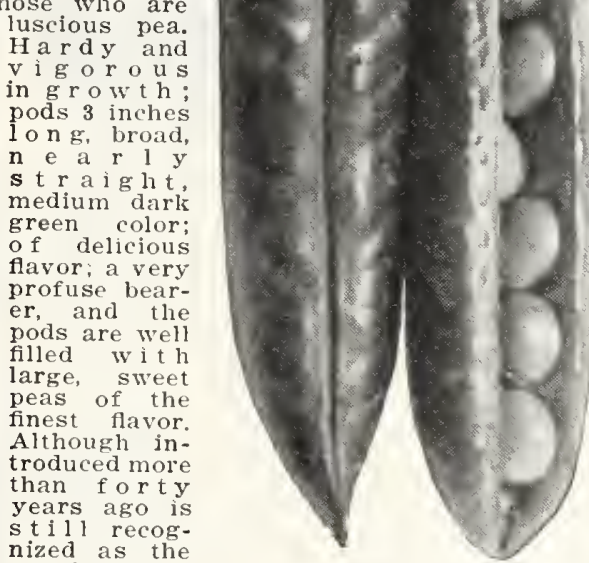

standard late Wood's Dark Green Telephone
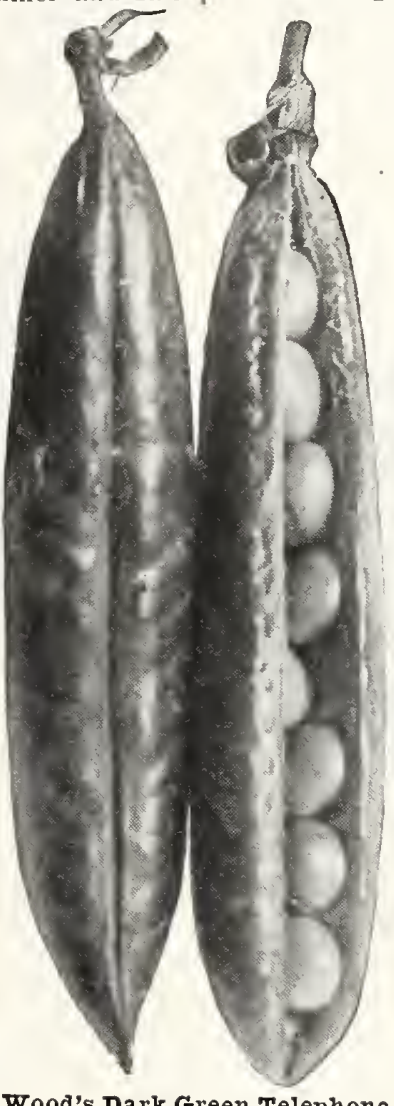

No. 342. Large White Marrowfat $-\mathrm{A}$ big yielder

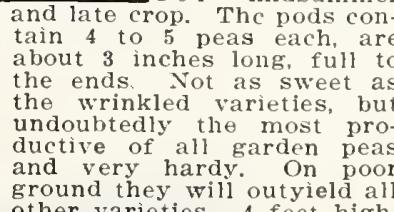
other varieties. 4 feet high.

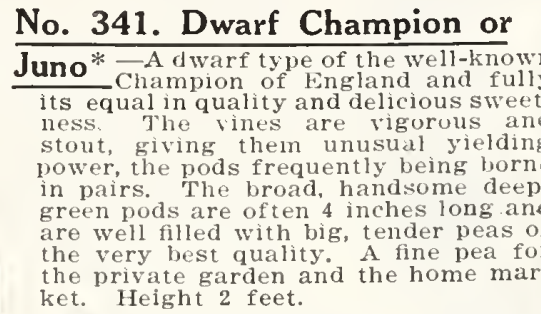

No. 339. Wood's Dark Green Telephone* - A highly bred of attractive ason pea ance and fine quality.

Our Dark Green Pod-

ded Telephone should

the light-colored Tele-
phones as generally

are longer and larger

green an

erally measure

inches lon

to capacit

to 8 peas

The vines grow 4 to

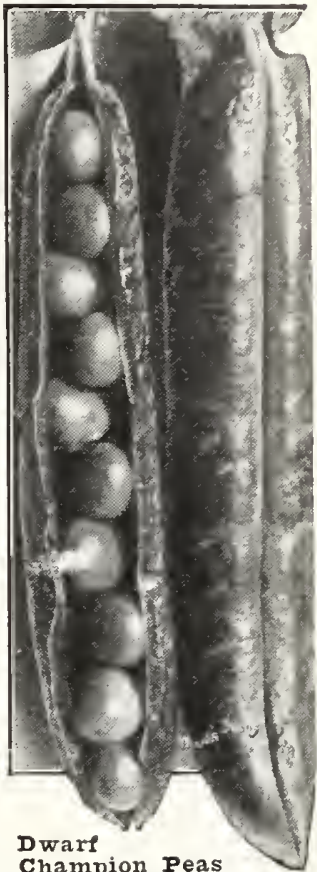

Champion Peas

abundant crop of fine, dark pods that picking.

Edible Podded or Salad Pea The finest type of sugar peas. Has no equal for sweetness and tenderness.

No. 344. Wood's Mammoth Luscious

Sugar

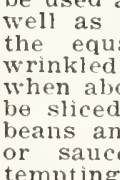

The poo

prod lon

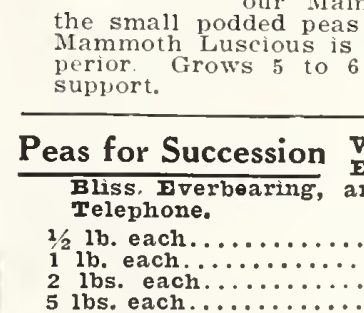

Bar

Wood's Pedigree Extra Whomas Laxton, Postpaid. P $75 \mathrm{c}$ $\$ 1.15$

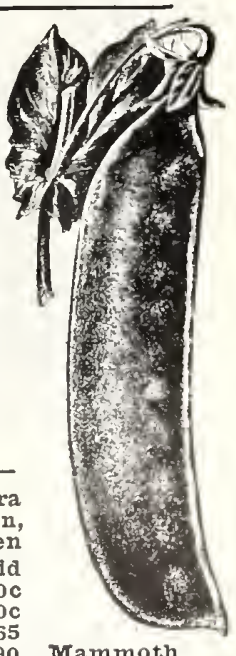

\$1.65

\section{PRICES}

No. 337. Bliss Everbearing

No. 337. Wiss 's Dark Green

No. 340. Champion of England.

To. 341 .

No. 342 .

No. 344 .

Champion of England.

Dwarf Champion or Juno...........

Large white Marrowfat $\ldots \ldots \ldots \ldots, 100$.

Dood's Mammoth
Pkt. BY MAII POSTPAID

Pkt. 1/21b. Lb. 2 lbs. 5 lbs. 10 lbs. Lb. $10 \mathrm{c} \ldots .25 \mathrm{c} \ldots . .40 \mathrm{c} \ldots 60 \mathrm{c} \ldots \$ 1.30 \ldots \$ 2.25$

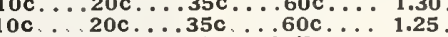

Crop failed

$100.25 \mathrm{c}$
$35 c \ldots . .55 c$
$45 c \ldots 80 c$

$40 \mathrm{c} . .65 \mathrm{c}$
1.10

1.70
NOT PREPAID

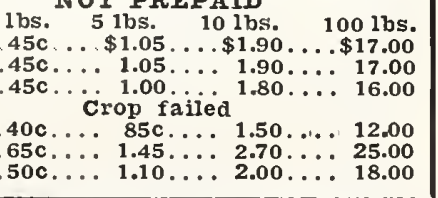




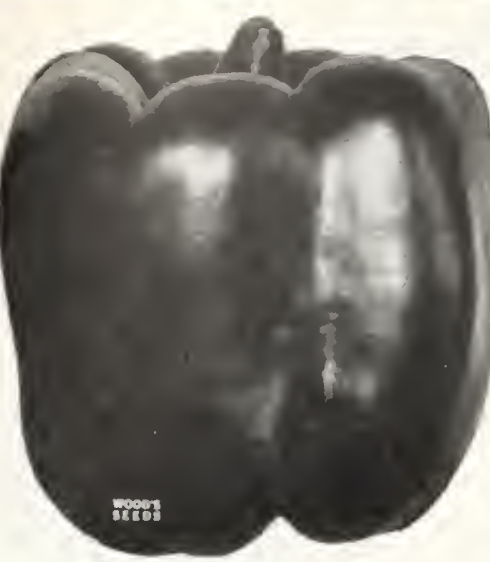

California Wonder Pepper

\section{Pepper}

One ounce will produce about 1,200 plants.

CUTTURE. - Plant in boxes in Feloruary or March, cover 1/

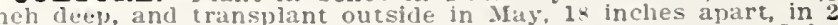
or 3-foot rows. When the ground becones warm, and until July, Jant outsidc for a late crol, Cultivate well and keep frec of the soll when the plants are six inches high, will materially inNo. 357. CAIIFORNIA WONDER-For description see page 3.

No. 353. Ruby Giant (Sometimes called world Beater)-A the chinese fiant and liuby King. It combines the large size and lyoductiveness of the Chinese Giant and the earliness, atalloet and matye used for stutling or sliced like cucumbers and served wh tomatoes. smooth and colors eventy all over. 5 lbs. \$15.25, postpaid.

No. 354. Ruby King $-A$ wonderfuliy productive pepper, to 4 inches across. The tiesh is so mild and sweet that it is used sliced in mixed salads. Its large size and thick flesh make it particularly fine lor stuffing with meats, rice, etc. The green O2. 30c; 2 ozs. 50c; $1 / 4$ 1b. $90 \mathrm{c} ; 1 \mathrm{~b}$. $\$ 3.25 ; 2$ bs. $\$ 5.90$, postpaid. No. 358. Long Red Cayenne - Very hot: used for pickling throf use yelder. The most universally grown hot oz. $30 \mathrm{c} ; 2$ oz $\$$. 50c; $1 / 4$ lb. $90 \mathrm{c} ; 1 \mathrm{~b} . \$ 3.25 ; 2$ lbs, $\$ 5.90$, postpaid.

No. 352. Large Sweet Bull Nose - A large pepper that ripens iruits with thick, mild flesh of for stulling. The plants grow pers are deep green. bright crim 2 ozs. $50 \mathrm{c} ; 1 / 4$ lb. $85 \mathrm{c}$; ib. $\$ 3.00$ 2 lbs. $\$ 5.40$, postpaid.

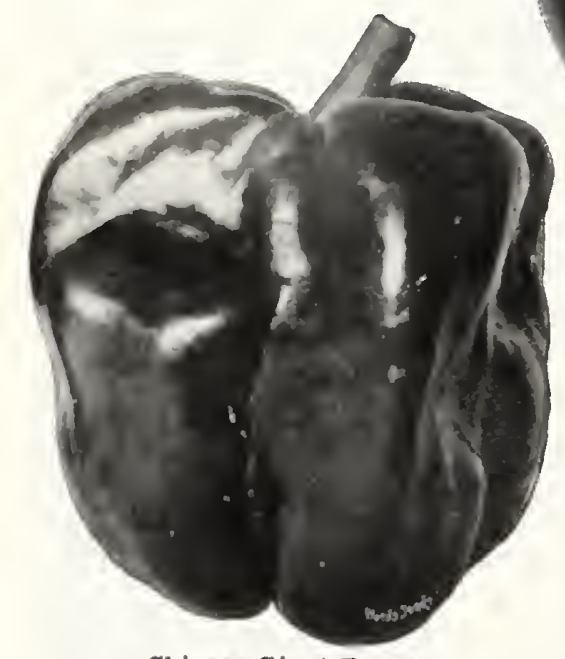

Chinese Glant Pepper

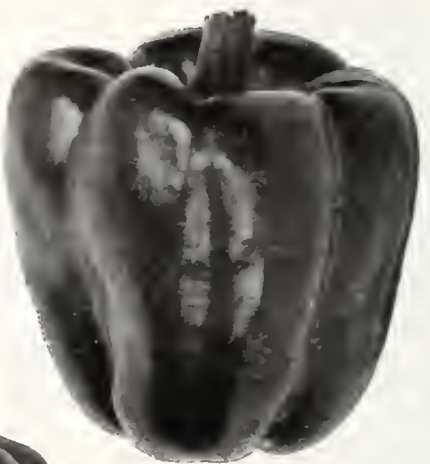

Large Sweet Bull Nose

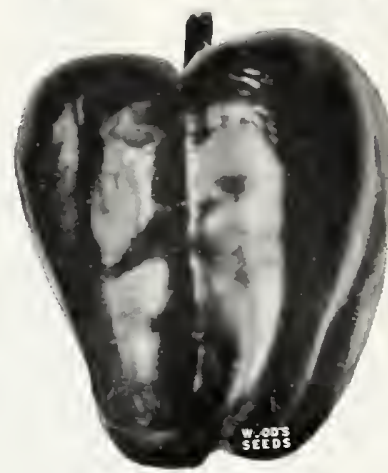

Royal Ring Pepper

No. 356. Early Neapolitan

Tho earliest of all good sweet peppers.-At full week earlier than any of the large bell peppers It is a wonderful bearer.

30 to 10 fruits being borne by a single plant. Alout 4 inches long by* 5 to 6 inches around; bright red, thick meated. very mild and 2 ozs. 50c; $1 / 4$ lb. $90 \mathrm{c} ; 1 \mathrm{~b}$. $\$ 3.25 ; 2$ lbs. $\$ 5.90 ; 5$ lbs. $\$ 14.25$, postpaid. No. 355. Pimento - Can be eaten raw like an apple, stuffed served as a salad, made into Spanish omelets, and for canning is especially fine: mooth and uniform in shape and size: an abun2 ozs. 50c; $1 / 4$ b. $85 \mathrm{c} ; 1 \mathrm{~b} . \$ 3.00 ; 2$ lbs. $\$ 5.40$, postpaid.

No. 351. Chinese Giant - The cnormous fruits usually measand to 5 incies long: it is vers prolific The strong stock plants about 2 feet high, bear an immense load of fruits, freplants, about 2 reet in a bunch. The flesh is thick, tender, sweet quenti hall a dozend a splendid stuffing pepper. Iild and frec of any fiery flavor. Pkt. 10c; 02.50c; 2 ozs. $90 \mathrm{c} ; 1 / 4$ 1b. $\$ 1.60 ; 1 \mathrm{~b} . \$ 5.75 ; 2$ lbs. $\$ 10.75$, postpaid.

PEPPER PIANTS.-Ruby king, Pimento and Cayenne. Ready Uay and June $30 \mathrm{c}$ per doz.; 50 for $70 \mathrm{c}$; $\$ 1.15$ per 100, postpaid. Not prepaid, 25c per doz.; 50 for $60 c$; $\$ 1.00$ per 100 . For complete list of vegetable Plants, see page 38 .

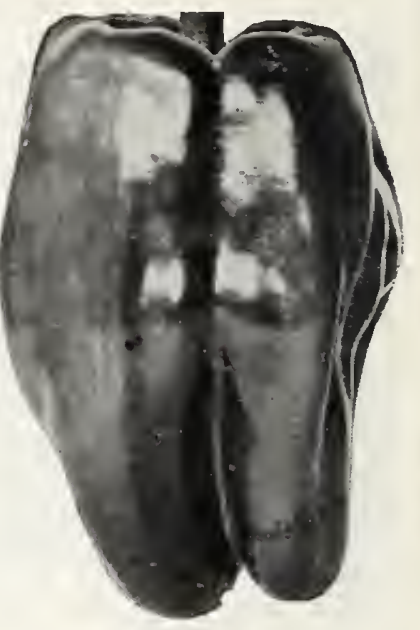

Ruby Giant Pepper No. 350. Royal King

-A grand pepper, making strong, stocky, plants that bear an astonishing number or fruits, extra large and as near perfect as a pepper can be: uniformly smooth and free from the irregularities found in many large peppers. The flesh is unusually perk and sweet; an idea pepper for stuffing with ads Pkt $10 c$ : $02,30 c$ : 2 ozs. $55 \mathrm{c} ; 1 / 4$ ib. $\$ 1.00 ; 1 \mathrm{~b}$. $\$ 3.50$; 2 lbs. $\$ 6.30$, postpaid.

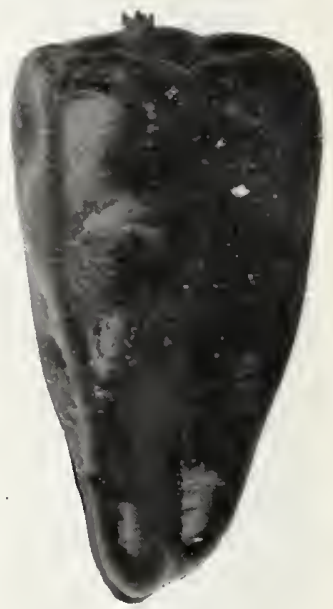

Early Neapolitan

\section{PARSNIP}

CULTURE- Plant as narly in the spring as the weather will permit Cut The 16 inch deep in a nd contmue planting till the nid in rows 18 incles apart, and when 2 nclue hiph thin oue to to 6 inches apart larsnips germinate slowly: spechally in dry weather: plant a few radish seeds sith them to mark cin le dug as wanted. or stored for wlinter use. Do not use fresh No. 317. Sugar or Hollow Crown $-A$ standard varlety, mak-

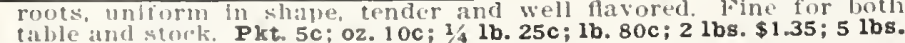
$\$ 3.15 ; 10$ 1 $1 \mathrm{~b} . \$ 5.75$, postpaid.

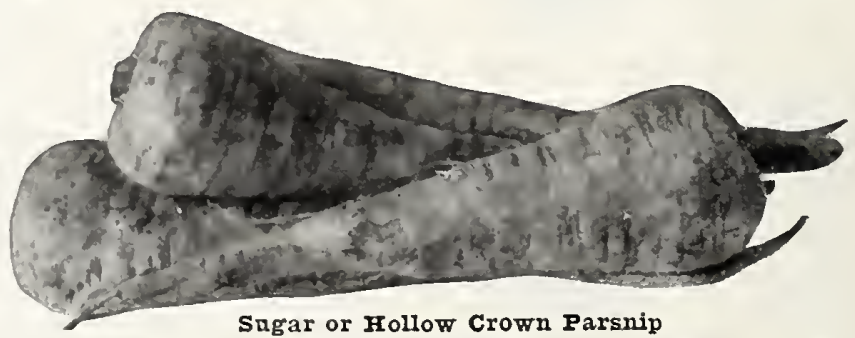




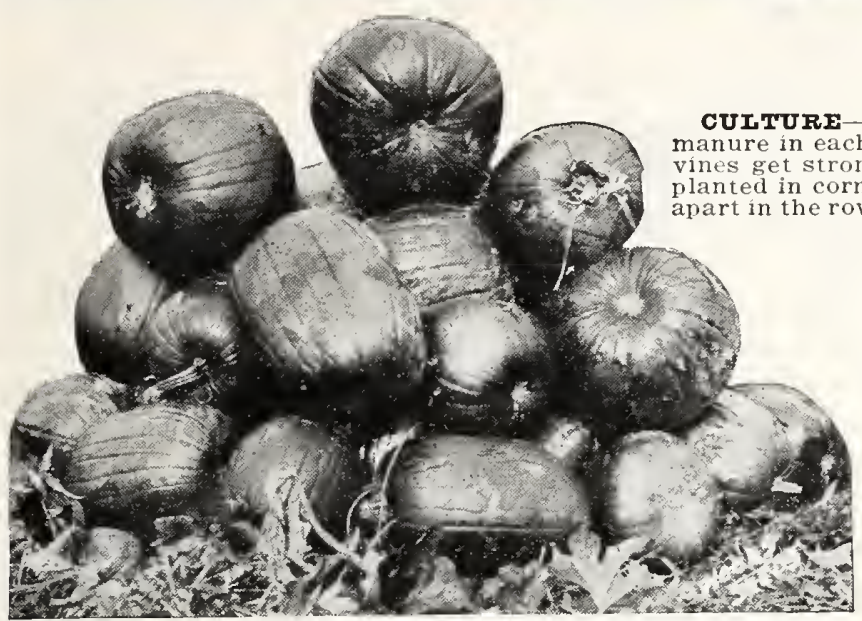

Virginia Mammoth Pumpkin \begin{tabular}{l} 
No. 365. Virginia Mammoth \\
\hline the have never grown a pumpkin \\
that combines so many good quali- \\
ties as the Virginia Hammoth. It \\
not only grows to an immense size, \\
but its keeping quality is most re- \\
markable. We have kept them in \\
fine condition for a whole year af- \\
ter they were taken from the field. \\
It is wndoubtedy the best and \\
most productive pumpkin for \\
Southern growers. Oval shaped, \\
the flesh thick, of fine flavor; \\
makes as delicious pumpkin pie as \\
anyone could wish. and is equally \\
good for stock feeding. Pkt. 1oc;
\end{tabular} oz. $15 \mathrm{c} ; 1 / 1 \mathrm{~b}, 50 \mathrm{c} ; 1 \mathrm{~b}, \$ 1.50 ; 2$ 1bs. $\$ 2.65 ; 5$ lbs. $\$ 6.35$, postpaid.

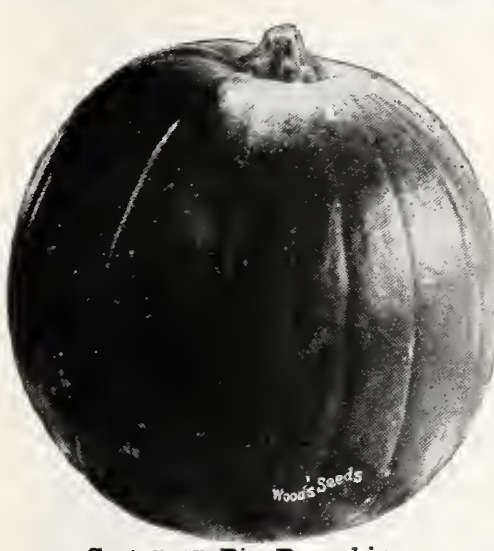

Sugar or Pie Pumpkin

No. 368. Tennessee Sweet Potato - The creamy thick, fine grained. very sweet and delicious and like the sweet potato in flavor. A first-class keeper and a good
yielder Pkt. 5c; oz. 10c; 1/4 1b. 30c; 1b. $\$ 1.00 ; 2$ 1bs. $\$ 1.75$; 5 lbs. $\$ 4.00$.

1 ounce will plant 20 hills; 3 pounds one acre. PUMPKIN

No. 369. King of the Mammoths -Sometimes called Jumbo beof all the pumpkins, sometimes weighing 100 pounds. They are bright yellow with hard, firm thick flesh that is tender, sweet and just the right quality for pumpkin pies, but makes fine stock food Grow some to
exlibit at your fair. Pkt. 100; oz. 15c; 1/4 1b. 40c; 1b. $\$ 1.25 ; 2$ lbs. $\$ 2.20$; 5 lbs. $\$ 5.20$, postpaid.

No. 367. Cashaw or Crookneck best flave very sweet and a good keeper. Pkt. 5c; oz, 10c; 1/41b. 30c; b. $\$ 1.00 ; 2$ lbs. $\$ 1.75 ; 5$ lbs. $\$ 4.00$, postpaid.

No. 370. Large Sweet Cheese -A fine pumpkin for both table and diameter; they are mottled green and yellow when young, fecoming creamy yellow when ripe. The flesh is yellow, extra thick, tender, sweet it is first class. Pkt. 5c; oz. 10c; 2 ozs. 15c; $1 / 41 \mathrm{~b}$. 25c; 1b. 65c; $21 \mathrm{lbs}$. $\$ 1.10$; 5 lbs. $\$ 2.40$, postpaid.

No. 366. Sugar or Pie -Not large, but one of the sweetest and best for pies; fine grained, dePkt. 5c; oz. 10c; 2 ozs. 15c; $1 / 4$ 1b. 25c; $1 \mathrm{~b} .90 \mathrm{9} ; 2$ 1bs. $\$ 1.50 ; 5$ 1bs. $\$ 3.65$, postpaid.

No. 371. Corn Field Pumpkin - For stock feeding; usually planted in cornfields, making $\$ 1.00 ; 5$ lbs. $\$ 2.25$, postpaid.

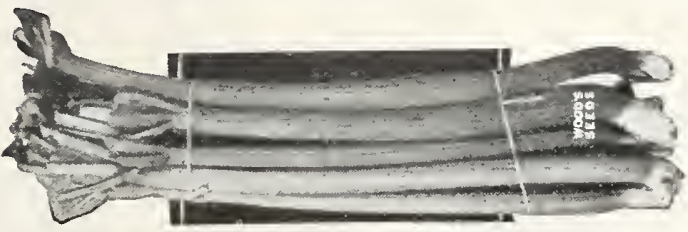

Rhubarb

\section{No. 397 RHUBARB PrANT}

Tre slsaded place, and when a few inches high thin to 12 inches apart, and in the fall or following not stand hot sun; a barrel placed over the plants gives ideal protection and will mak the plants yield longer and tender stalks. but it continues to produce for several years. Apply plenty of manure. Our rhubarb makes Pkt. 5c; oz. 15c; 2 ozs. 25c; $1 / 4$ 1b. $45 c ; 1 b . \$ 1.50$; 2 lbs. $\$ 2.65 ; 5$ lbs. $\$ 6.35$, postpaid.

Rhubarb Roots -20 c each; 3 for 50c; $\$ 1.50$ per doz., post-

\section{Salsify or Oyster Plant} $\$ 1.25$ per doz.; 50 for $\$ 4.50$.

1 ounce sows 50 feet of drill; 8 pounds one acre.

CUITURE.-Plant in March or April in rich, light, deeply worked soil, in rows 18 inches apart, and thin out to 4 to 6 inches. Do not use coarse or fresh manure, it makes the roots ill-shaped and un even. Cultivate often. Perfectly hardy and may remain out all winter. Can also be planted in liay and June if the season is young sprouts until they get established.

No. 399. Mammoth Sandwich Island - The most popular and far superior in size, weight and productiveness. A stron grower, with large, long, white tapering roots, without tendency
to branch. Pkt. 10c; oz. 20c; 2 ozs. 35c; 1/4 lb. 60c; 1b. $\$ 2.00 ; 2$ lbs. to branch. Pkt. $10 \mathrm{c} ;$ oz.
$\$ 3.50 ; 5$ lbs. $\$ 8.40$, postpaid.

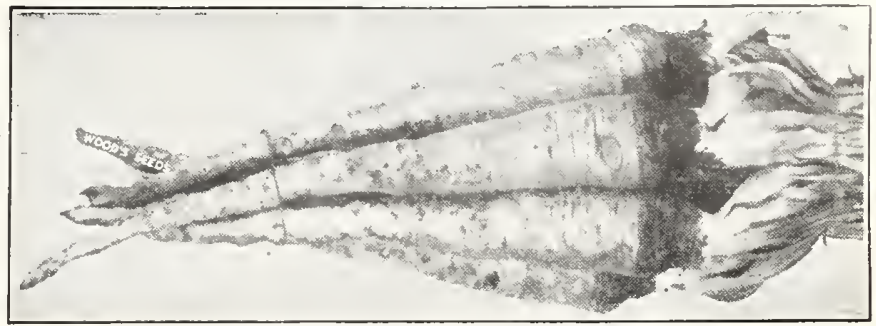

Mammoth Sandwich Island Salsify 


\section{RADISH}

1 ounce will plant 50 feet; 8 to 10 poands one acre.

CULTORE.To be tender and crisp, radishes must be grown auckIy, and thls requlres rlch soll and plenty of molsture Commencling wlth the tirst mild spell ln the spring, sow at intervals or etring

or (ave No. 378. Extra Early Scarlet Globe

generally be depended on to produce crisp.

Pkt, $5 \mathrm{c}$; 0z, 10c; 2 oz, $15 \mathrm{c} ; 1 / 4 \mathrm{~b}, 25 \mathrm{c} ; 1 \mathrm{~b}, 85 \mathrm{c}$; $2 \mathrm{lbs}$. $\$ 1.45 ; 5$ lbs. $\$ 3.40 ; 10$ lbs. $\$ 6.35$, postpaid

No. 375. Early Red or Scariet Turnip -sometimes Button.-No radish is more poluular for the home garden. A qulck growing, round, red radish, with small tops oz. $10 \mathrm{c} ; 2$ ozs. $15 \mathrm{c} ; 1 / 2$ 1b. 25c; 1 b. $75 \mathrm{c} ; 2$ lbs. $\$ 1.25 ; 5$ lbs. $\$ 2.90$; 10 lbs. $\$ 5.35$, postpala.

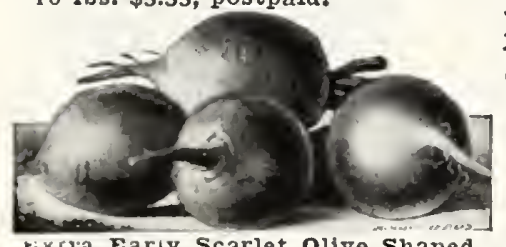

No. 379. Extra Early Scarlet Olive Shaped

kixcra Eariy Scarlet Olive Shaped.

Pkt. 5c; oz. 10c; 2 oz. $15 \mathrm{c} ; 1 / 4$ 1b. $25 \mathrm{c}$; 1b. $80 \mathrm{c} ; 2$ lbs. $\$ 1.35 ; 5$ lbs. $\$ 3.15 ; 10$ lbs. $\$ 5.75$, postpaid.

No. 376. Early White Tipped Scarlet Turnip or Sparkler. scarlet color relleved by the pure white tip makes this radish partlcularly attraetlve.

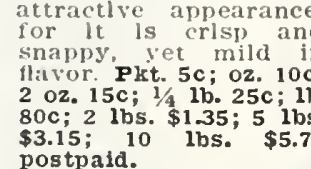
postpaid.

No. 380. Early White Turnip $\rightarrow$ A pure white that is partieularl lng during the summer roots. It is also adapt-

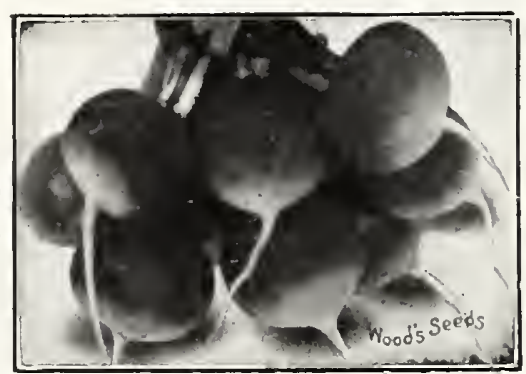
Parly White '1'pped Scarlet Turnip. $15 \mathrm{c} ; 1 / 4$ lb. $25 \mathrm{c} ;$ lb. $75 \mathrm{c} ; 2$ lbs. $\$ 1.25 ; 5$ lbs. $\$ 2.90 ; 10$ lbs. $\$ 5.35$, postpaid.

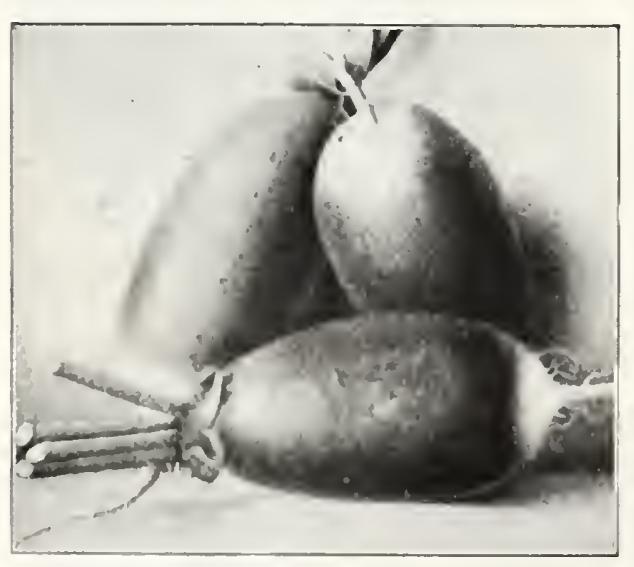

French Breakfast
White Strasburg.

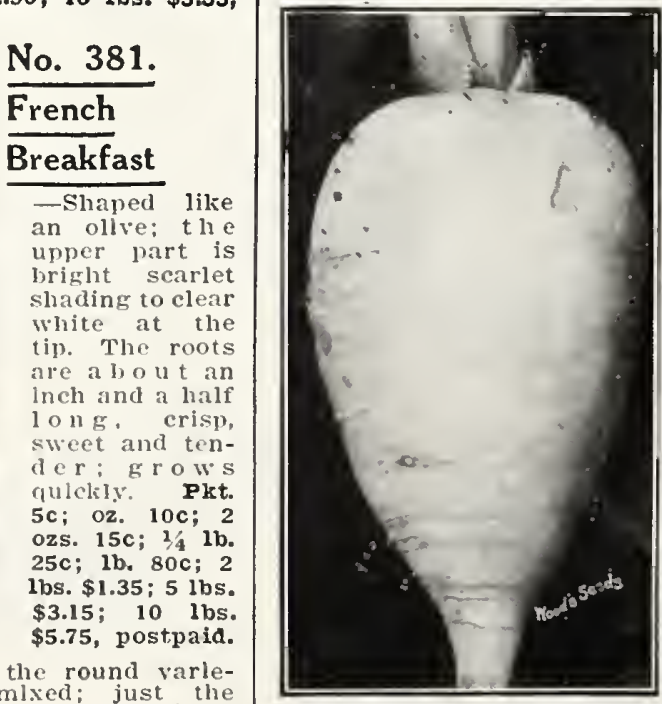

No. 387. Long White Icicle or IADY The finest early, pure white, long radish. On good soil they are ready in 20 to 25 days, and will remain crisp and tender longer than any first early variety. In quality and cttractiveness no long white radish can compare 10 ith lciele. Pkt. 5c; 0z. 10c; 2 oz $15 c ; 1 / 4$ lb. 25c; 1b. $75 c$; 2 lbs. $\$ 1.25 ; 5$ lbs, $\$ 290$ 10 bs. $\$ 5.35$, postpaid.

No. 385. Long Scarlet Summer

-No radish will keep as long nor grow as large and still remain firm and crisp. Fine for growing outdoors for summer use brientere tip. Pkt. $5 \mathrm{c}$; oz. $10 \mathrm{c} ; 2$ oz. $15 \mathrm{c} ; 2 / 42 \mathrm{~b} .25 \mathrm{c} ; 1 \mathrm{~b}$. $85 \mathrm{c} ; 2$ lbs. $\$ 1.45 ; 5$ lbs. $\$ 3.40$, postpaid.

No. 388. Brightest Long Scarlet

- A handsome radlsh that is ready in about 25 days after planting; bright scarlet with White tip: crisp, tender and $\$ 1.25 ; 5$ lbs. $\$ 2.90 ; 10$ lbs. $\$ 5.35$, postpaid.

No. 389. White Strasburg -A n excelradich severe heat and grows

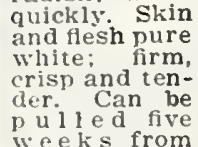

planting, but Iong Whit

etains its even then the roots are old and 1are Pkt 5c; 0z. 10c; 2 oz. 15c $1 / 4$ 1b. $25 \mathrm{c} ; 1 \mathrm{~b}, 80 \mathrm{c} ; 2$ lbs. $\$ 1.35$; 5 lbs. $\$ 3.15$, postpaid.

No. 390. Long Radishes

Mixed -A fine mixture of all the ing will give a continuous supply of crisp, tender radishes for a
long season. Pkt. 5c; oz. 10c; 2 ozs. 15c; $1 / 4$ lb. 25c; 1b. 75c; 2 lbs. $\$ 1.25 ; 5$ lbs. $\$ 2.90$, postpaid.

\section{WINTER RADISHES}

Plant during August or September, and when freezing weather comes on pack in sandy soil. deep, eool cellar, where they wil lieep all winter.

No. 382. Round Radishes Mixed tles mlxed just the 250;1b. 75c;2 lbs. $\$ 1.25 ; 5$ lbs. $\$ 2.90$, postpaid.

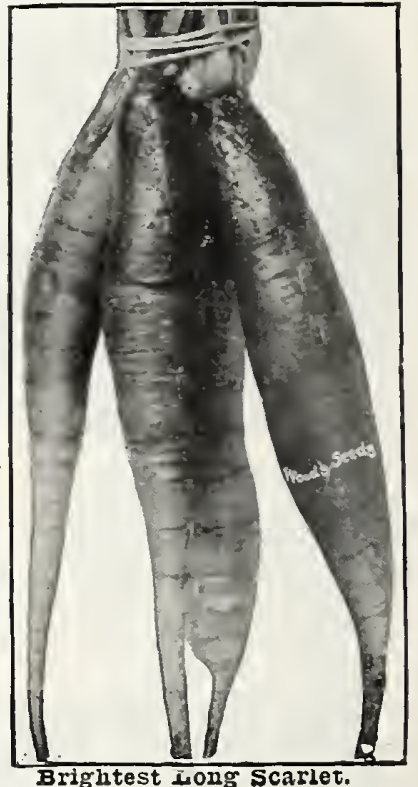

No. 392. Chinese or Celestial - 1 most excellent radish rith beautiful white skin and flesh: grows 6 to 8 inehes long; $21 / 2$ to 3 inches in diameter; crisp. Pkt. 5c; oz. $10 \mathrm{c} ; 2$ ozs. $15 \mathrm{c} ; 1 / 4 \mathrm{lb}$. $25 \mathrm{c}$; 1b. 85c; 2 lbs. $\$ 1.45 ; 5$ lbs. $\$ 3.40$, postpaid.

No. 393. Rose China Winter - A handsome radish growing about 5 inches long and $11 / 2$ to 2 inches across, holding its thickness to the botton. the flesh pure a deen rose color. the gent: splendid keepers pkt. 5c: $\$ 1.45 ; 5$ lbs. $\$ 3.40$, postpaid.

No. 394. Long Black Spanish - One of the latest and hardiest of radishes. The flesh is white, firm, pungent and of good flav-; oz. $10 \mathrm{c} ; 1 / 1 \mathrm{lb}$. $25 \mathrm{c}$; $1 \mathrm{~b}$. $85 \mathrm{c} ; 2 \mathrm{lbs}$. $\$ 1.45 ; 5$ lbs. $\$ 3.40$, postpaid. oz. $10 \mathrm{c} ; 1 / \mathrm{lb}$. 25c; $1 \mathrm{~b} .85 \mathrm{c} ; 2$ lbs. 


\section{SQUASH or CYMLING}

Summer Squash, 1 oz. plants 25 hills; 3 to 4 lbs. to an acre.

winter Squash, 1 oz. plants 10 hills; 3 to 4 lbs. to an acre.

Culture.-After danger of frost is past, plant in a warm wellpulverized, rich soll, mixing well-rotted manure in each hill. Plant about 1 inch deep, 8 or 10 seeds to the hill, the summer varieties 3 to 4 feet apart, the winter hill Do not bruise or break the stems of the winter squashes when gathering. Apply land plaster, air-slacked lime or paris green to keep off bugs: for the large squash bug, use Red Arrow Spray or Evergreen Spray.

No. 407. Wood's Earliest Prolific The earliest, the meatisquash. 10 days earlier than Early White Bush. - Note the

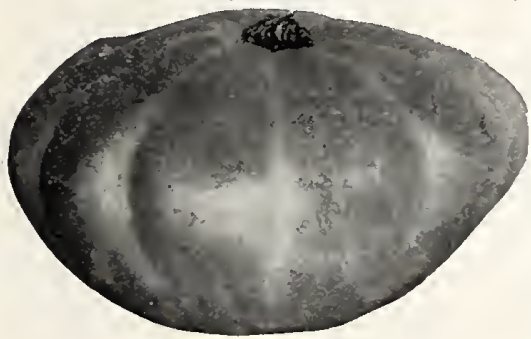

Wood's Earliest Prolific Squash thickness no depres-
sion around the stem sion around the stem
and absence of scallops; this means about double as much meat squashes: the y a $\mathrm{re}$ the table and with less waste, and the quality and flavor are extra about 2 feet high, are ver v vigorous and great producers. It is so much superior to squashes that o p e erence. Shippers throughout the South rould give it pref market to which they shipped our Earliest Prolific it commanded a premium of 25 or rieties. Pkt. 10c; oz. 15c; 2 ozs. $25 \mathrm{c} ; 1 / 4 \mathrm{~b}$; $40 \mathrm{c} ; 1 \mathrm{~b}$. $\$ 1.50 ; 2 \mathrm{lbs}$. $\$ 2.65 ; 5$; $1 \mathrm{bs}$. $\$ 6.35$, postpaid.

No. 409. Mammoth White Bush -Quite simEarly White Bush from which it was originally selected. It differs in being about a third larger and more uniform in shape; color a beautiful waxy white: the fruits are thick, the flesh tender and of the best quality. A very
prolific bearer. Pkt. 5c; oz. $10 \mathrm{c} ; 1 / 4$ lb. 30c; lb. $\$ 1.00$; 2 lbs. $\$ 1.70$; 5 1bs. $\$ 4.00$, postpaid.

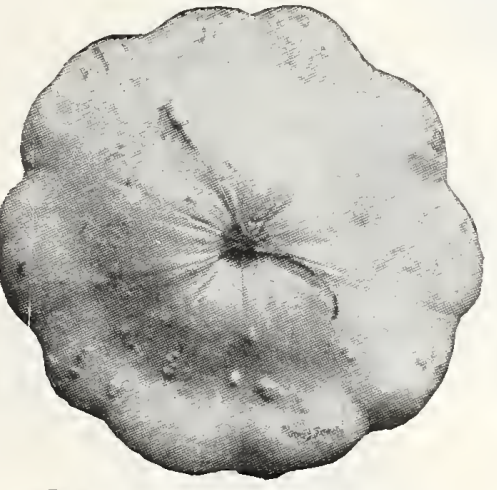

Mammoth White Bush Squash

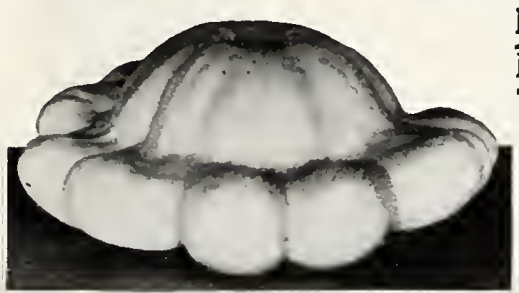

No. 408. Early White Bush Or PATTY - PAN til our Wood's Earliest Prolific was introduced Early White Bush was the standard squash for home use and market. The cream y wite squashes are about 8 around the edges and quite meaty. Pkt. 5c; Early White Bush Squash.

No. 410. Mammoth YeIIow Bush Gometimes called Except in the color of its fruits this is very similar to hasmoth White Bush. it the flesh is rich creamy yellow and of very fine quality It is of true bush form and a very abundant ylelder. Although the white variety is more generally grown many prefer the yellow because of its attractive color when cooked. Pkt. 5c; oz. 10c; $1 / 4$ 1b. 30c; 1b. $\$ 1.00$; 2 1bs. $\$ 1.70 ; 5$ lbs. $\$ 4.00$ postpald.

90c; 2 lbs. $\$ 1.50 ; 5$ lbs. $\$ 3.65$, postpaid.

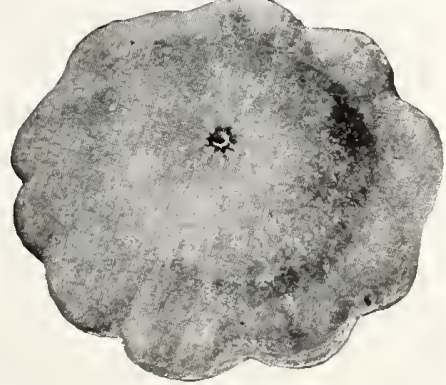

\section{No. 412. Golden Summer Crookneck}

habit

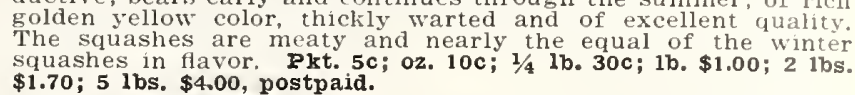
$\$ 1.70 ; 51 \mathrm{bs} . \$ 4.00$, postpaid.

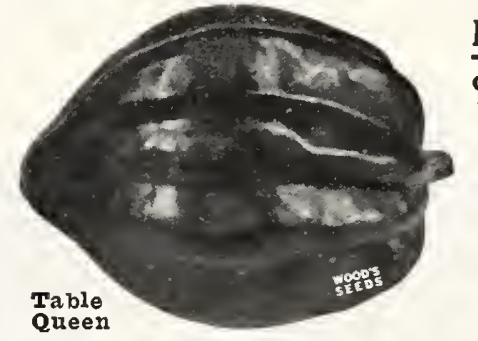

No. 415. Table Queen or Acorn Des Moines right for cutting in half baking orange, cooks dry: Hubbard winter squash: mously productive. Pkt. $10 \mathrm{c}$ Oz. $15 \mathrm{c}: 2$ ozs. $25 \mathrm{c} ; 1 / 4$ lb. $40 \mathrm{c}$ 1b. $\$ 1.50 ; 2$ 1bs. $\$ 2.65 ; 5$ 1bs. $\$ 6.35$, postpaid.

No. 411. Cocozelle or Italian Marrow -A bush varieduces squashes a foot long that are prepared for the table like eggplant. Use when about 8 inches long; very productive, ten$\$ 2.20 ; 5$ lbs. $\$ 5.20$, postpaid.

\section{WINTER SQUASH}

No. 413. Hubbard $\underset{m o s t}{- \text { The }}$ widely grown winter squash. orange flesh; fine grained, very dry, sweet and richly better for squash pies. Pkt. 5c; oz. $10 \mathrm{c} ; 1 / 4$ lb. $30 \mathrm{c} ; 1 \mathrm{~b}$. $\$ 1.00$; 2 lbs. $\$ 1.70$; 5 1bs. $\$ 4.00$, postpaid.

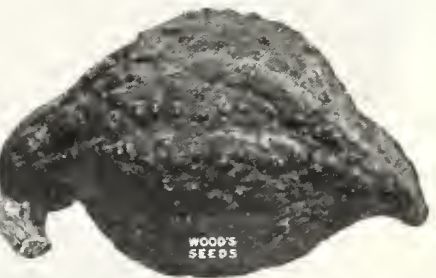

Hubbard Squash

No. 414. Delicious Rightly named, for the fine grained bright a hard burthin shell that makes it a good keeper. Pkt. 5c; oz. 10c; 1/4 1b. 35c; 1b. $\$ 1.25 ; 2$ lbs. $\$ 2.20 ; 5$ 1bs. $\$ 5.20$, postpaid.

\section{SPINACH}

culture.-For early summer use, sow early in fertilized soil, in drills i inch deep, $1 \frac{112}{2}$ to 2 feet between the rows. For wow from september to December 15. Requires but little cultivation. Two ounces will sow 100 feet one acre. The above applies to all varieties except New Zealand, which should not be planted until the ground is thoryield an abundant will

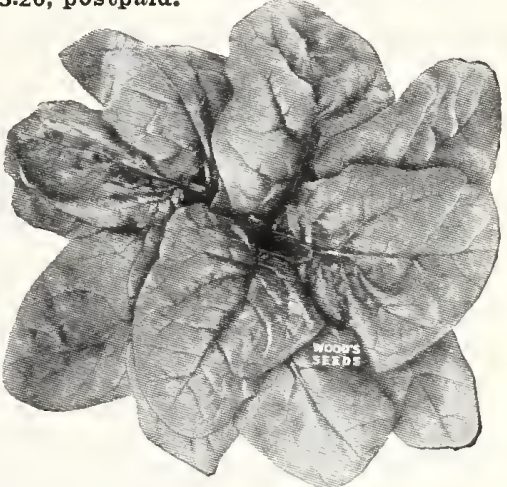

ply of delightful succulent greens right up to cold weather.

No. 403. Long Season

- Similar to the Norfolk Savoy, but of thick, tender and succulent dark green leaves, Pikt. 5c: oz. $10 \mathrm{c} ; 1 / 41 \mathrm{~b}$. $15 \mathrm{c} ; 1 \mathrm{~b} .40 \mathrm{c} ; 2 \mathrm{bs}$. $70 \mathrm{c} ; 5 \mathrm{lbs}$. $\$ 1.50 ; 10 \mathrm{lbs}$. $\$ 2.60$,

No. 405. Long Standing Bloomsdale

Bloomsdale strain. Plt $5 \mathrm{c}$; oz 10c: $1 / 1 \mathrm{~b}, 15 \mathrm{c} ; 1 \mathrm{~b}, 45 \mathrm{c} ; 2$ 1bs. $80 \mathrm{c}$ Bloomsdale strain. Pkt. 5c; oz. $10 \mathrm{c} ; 1 / 4$ 1b. $15 \mathrm{c} ; 1$
5 lbs. $\$ 1.75 ; 10$ lbs. $\$ 3.10 ; 25$ lbs. $\$ 6.60$, postpaid.

No. 402. Norfolk Savoy or Bloomsdale (Re-selected).and grows rapidly; leaves curled like a Savoy cabbage. Best for fall sowing. Pkt. $5 \mathrm{c}$; oz. $10 \mathrm{c} ; 1 / 41 \mathrm{~b} .15 \mathrm{c} ; 1 \mathrm{~b}$.

No. 404. New Zealand - Thrives during the hottest sum. poor, a single plant covering a space ar tender tips may be cut every few days; after cutting the plant puts out new growth and continues till frost. Soak for 24 hours and plant 4 seeds in hills 2 feet apart each way Pkt. 5c; 0z. 10c; $1 / 4$ 1b. 25c; 1b. 75c; 2 1bs. $\$ 1.25 ; 5$ 1bs. $\$ 2.90$, postpaid. 


\section{No. 437. Wood's Famous Brimmer Tomato}

First in Quality

First in Size

First in Productiveness

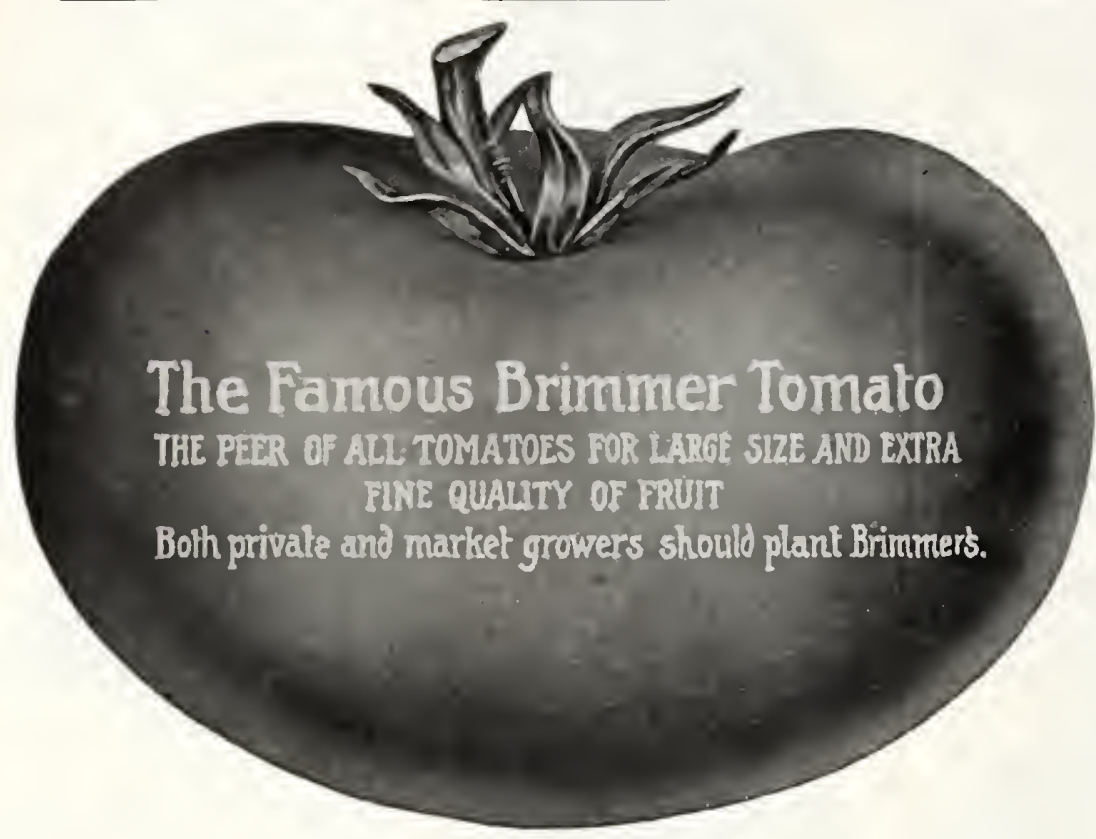

There is no tomato that can compare with Brimmer. Although it is the largest and most productive of all tomatoes, this statement refers particularly to the quality, flavor and meatiness of the frults that are without the acidity so objectionable in some varieties.

Quality -In the breeding of our Brimmer qualis our first consideration. The flavo may bous and tiey are so free of acid that they may be eaten with impunity by those to whom acid tomatoes bring distress.

Size and Weight -Brimmers measuring 15 to 16 inches in circumference Wouncis or more, are not at al unusual. They are all meat, have very few seeds and no core.

Productiveness -Although a few days late then the very early varieties, the enormous size and remarkable yield more than make up for the few days difference in earliness. The vines bear a tremendous load of fruits right up to frost, and the fruits are large till the end of the season.

HOW TO GROW BIG ERIMMERS.-To make the biggest tomatoes and the largest yield, train to a single stem, tie the vines up to strong five-foot stakes; this gives ample room for development plenty of sunlight, holds them off the ground and enables the vines to continue to yield a constant supply right up to frost.

Packet, $15 \mathrm{c} ; 1 / 4$ oz. 35c; $1 / 2$ 0z. $60 \mathrm{c} ; 0 \mathrm{z} . \$ 1.00 ; 1 / 4 \mathrm{bb}$ $\$ 3.50 ; 1 / 2$ lb. $\$ 6.50$; lb. $\$ 12.00$, postpaid.

\section{BRIMMER TOMATO PLANTS}

-Ready April, May, June and July.

HOT-BED PIANTS.-By mail postpaid, $30 \mathrm{c}$ per doz. 50 for $85 \mathrm{c} ; \$ 1.40$ per 100 . Not prepaid, $25 \mathrm{c}$ per doz. 50 for $75 \mathrm{C} ; \$ 1.25$ per 100 .

TRANSPLANTED PIANTS.-By mall postpaid, $40 \mathrm{c}$ per doz.; 50 for $\$ 1.10 ; \$ 1.90$ per 100 . Not prepaid, $35 \mathrm{c}$ per doz.; 50 for $\$ 1.00$; $\$ 1.75$ per 100 .

No. 424. Bonnie Best (Scarlet). - Not quite as early as later, but a more satisfactory tomato. A vigorous grower and enormously prolifle, agc which proteets the fruits from the is an intense scarup to the stem. It is round, slightly flattened at $\mathrm{s} \mathrm{t} \mathrm{em}$ endigb ut thieker
through than most through than most est characteristie is its remarkable unimoothness no the tind of 10 the kind of tomato either an early or a Bate erop and be
equally satlsfactory for hoth. Prof. Watts. In the Market Grow"rs Journal, says: "Bonnie Best grows in favor as one has more experience with it." Pkt. $10 \mathrm{c} ; 0 \mathrm{0z} .30 \mathrm{c} ; 1 / 4 \mathrm{lb}$. $\$ 1.00 ; 1 \mathrm{~b} . \$ 3.50 ; 2 \mathrm{lbs}$. $\$ 6.30 ; 5$ 1b8. $\$ 15.25$, postpaid.
No. 430. John Baer (Scarlet). - Not qulte as early its Spark's Larliana, though there are only a lew day's difference, but produces a heavier cropi uniformly large and more ateractle. The first fruits ripen among the earliest most extra early toThe fruits are

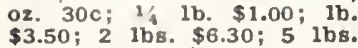
$\$ 15.25$, postpaid. and it continues to bear smooth, attractive and recarty tomato. Pkt. 10c:

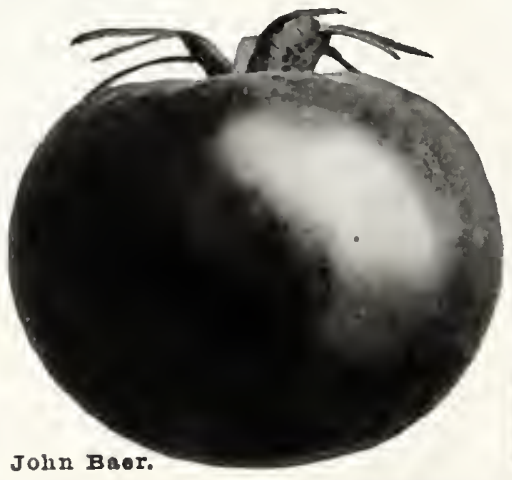

Wood's Improved Ponderosa

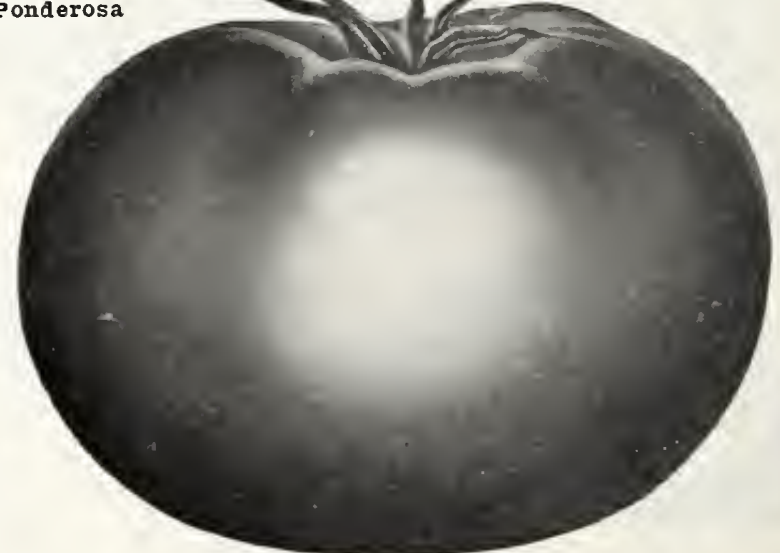

\section{No. 436. Wood's Improved Ponderosa}

Before our Brimmer was introdueed, Ponderosa was the tomato of outstanding merit in size as well as quality. Unfortunately. the old Ponderosa was rough and uneven. In our improved strail the tendency to produce rough fruits has been overcome withou in any wat sacrificing the many fine qualities that made this fine the exception of our Brimmer. l'onderosa is vithout doubt the largest meaticst and finest flavored tomato in eultivation, and is less acirl than most varteties. The plants ar healthy and luxurlant, quite blight resistant and continuous and abundant bearers. They are so vigorous that even in dry season. we have grown tomatoes of unusual size. The fruits are practically all meat with exceptionally few secds. If trained to a single stem tomatoes welghing a pound or more are not unusual lb. $\$ 6.00$, postpaid. 


\section{Wood's Pedigree Tomatoes}

1 ounce makes about 1,500 plants; 4 ounces will make plants for an acre.

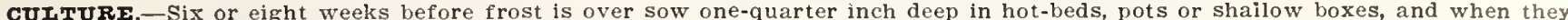

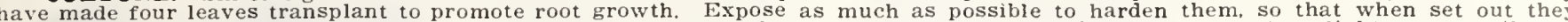

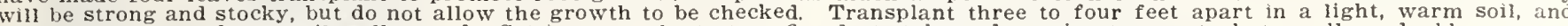

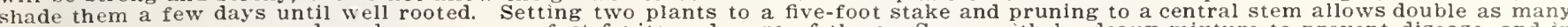

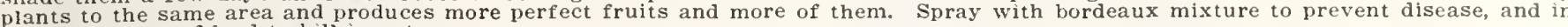
it put arsenate of lead to kill insects.

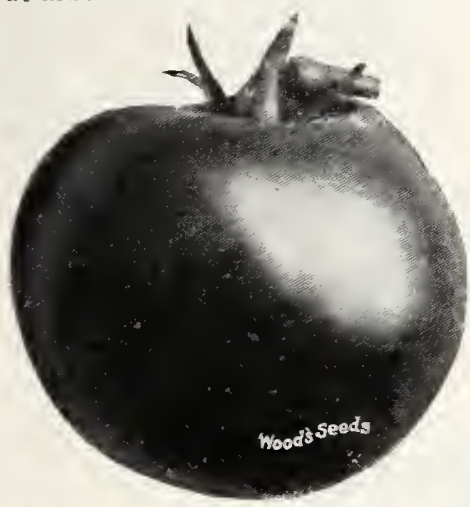

Marglobe Wilt-Resistant Tomato

\section{Reliable Wilt-Resistant Tomatoes}

Are you one, the thousands who have which were developed by the U. S Department of Agriculture. Our seeds were grown from planting stock supplied by them. There is no cure for wilt, which lives in the soil and invades the plant through its roots. The only remedy is to plant wilt-resistant varieties.

\section{No. 421. Norton Wilt-Resistant}

-Norton was developed from the Stone and ripens at the same season. It yields a heavy crop of large, smooth, solid red fruits that ripen slowly, therefore is a good keeper and a good shipper; it is also remarkably droughtresistant. An excellent tomato for the home garden, for canning and for the late market. Among late tomatoes, there is no finer longdistance shipper. Pkt. 10c; oz. 35c; 2 ozs. $60 \mathrm{c} ; 1 / 4$ 1b. $\$ 1.15 ; 1 \mathrm{~b} . \$ 4.00 ; 2$ lbs. $\$ 7.25 ; 5$ lbs. $\$ 17.50$; 10 lbs. $\$ 33.40$, postpaid.

No. 426. Marglobe Wilt-Resistant

-Probably no tomato has created such intense interest since the introduction of our Wood's Famous Brimmer. It wil-resistant tomato of the Globe type and exceeded all expectations. It is not oniy wilt-resistant, but is resistant to "nail-head rust" as well; is a splendid bearer, the fruits averaging one-half pound, firm, thick and mildly acid. Ripens perfectly, does not crack easily and is of very superior quality. The fruits are of good size, smooth, solid, deep from stem to blossom, and are borne in clusters of 5 to 7 fruits. Marglobe has proved its ability to withstand long periods of wet and unfavorable weather conditions. Pkt, 10c; $\$ 5.00$; 2 lbs, $\$ 9.20$; 5 lbs. $\$ 22.00$; 10 lbs. $\$ 42.25$, postpaid.

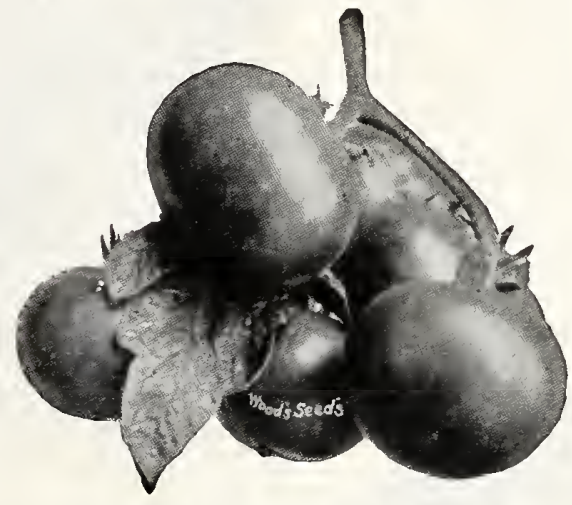

Norduke Wilt-Resistant Tomato

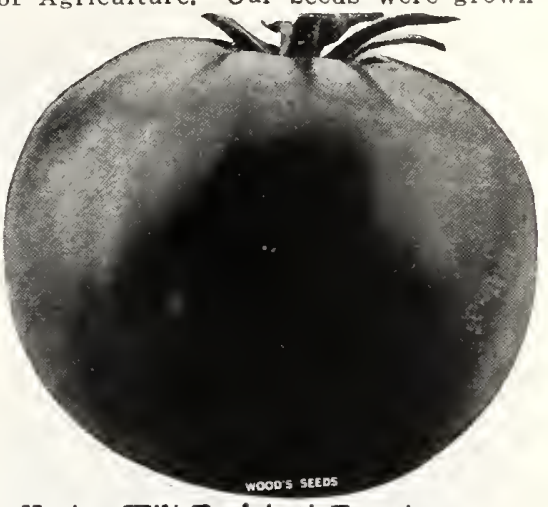

Norton Wilt-Resistant Tomato No. 429. Norduke Wilt-Resistant

-A notable wilt-resistant or "blight-proof" scarlet tomato for the home garden and nearby market that produces an abundant yield of smooth, solid, meaty fruits of good size. This is a tomato we can recommend highly because of its dependability to live and bear in wilt-infested soils. Slightly later than Norton. Some growers claim that Norduke is the best of all the vilt-resistant varieties: it certainly is a fine tomato, and any one who has had trouble on, account of wilt would do well to plant it. Norduke has proved its worth and dependability in thousands of gardens. Pkt. $10 \mathrm{c} ;$ oz. $40 \mathrm{c} ; 2$ ozs. $70 \mathrm{c} ; 1 / 41 \mathrm{~b} . \$ 1.25$; 1b. $\$ 4.50 ; 2$ lbs. $\$ 8.15 ; 5$ lbs. $\$ 19.75 ; 10$ lbs. $\$ 37.50$, postpaid.

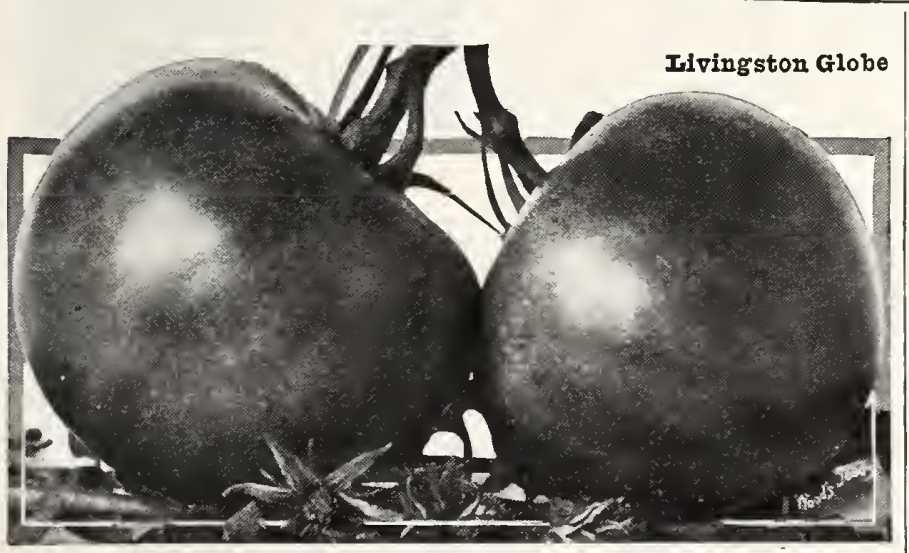

No. 433. Livingston Globe (Purplish Pink.)-A tomato of just after the very early kinds. Always smooth, firm fleshed, has but few seeds, and very productive. They are borne freely all over the vine, are uniform in size, solid and heavy and with hardly a trace of a core. Probably no other tomato is as nearly blight proof. A remarkably good keeper and colors up handsomely. We confidently believe that there is not a better $35 \mathrm{c} ; 2$ ozs. $60 \mathrm{c} ; 1 / 4 \mathrm{lb}$. $\$ 1.15 ; 1 \mathrm{~b} . \$ 4.00 ; 2$ lbs. $\$ 7.25 ; 5$ lbs. $\$ 17.50$; 10 lbs. $\$ 33.40$, postpaid.

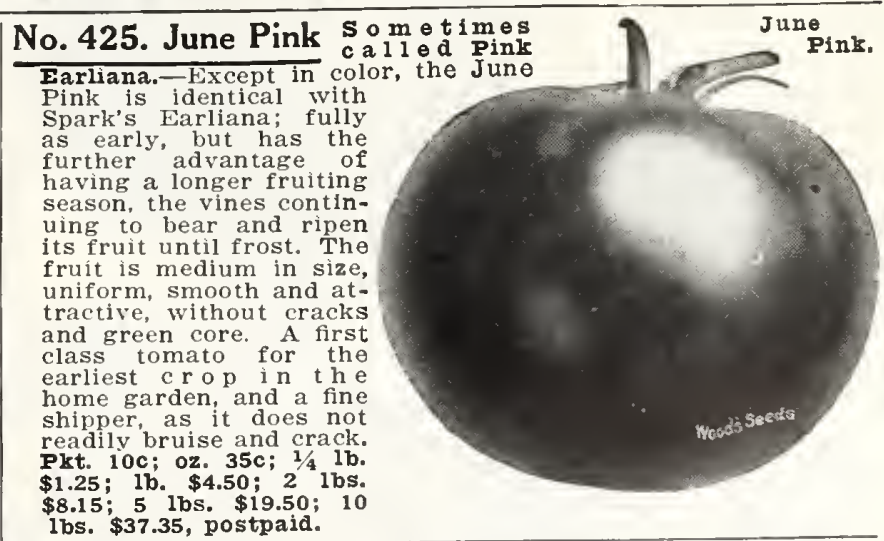

\section{YELLOW TOMATOES}

No. 439. Golden Queen or YELLOW TROPHY.-The handsomest of all the yellow tomatoes and highly esteemed for its delicate havor, meatiness and the vines bear profusely. Pkt. 10c; oz. 40c; 2 ozs. $70 \mathrm{c} ; 1 / 41 \mathrm{~b}$. $\$ 1.20$; 1b. $\$ 4.50 ; 2$ lbs. $\$ 8.15 ; 5$ lbs. $\$ 19.50$, postpaid.

No. 440. Yellow Plum -A fine preserving tomato; makes . 40. Lellow Plum small, uniform sized fruits of deli$80 \mathrm{c} ; 1 / 4$ lb. $\$ 1.40 ; 1 \mathrm{~b}$. $\$ 5.25 ; 2$ lbs. $\$ 9.90 ; 5$ lbs. $\$ 23.75$, postpaid. 


\section{Wood's Pedigree Tomatoes-Continued}

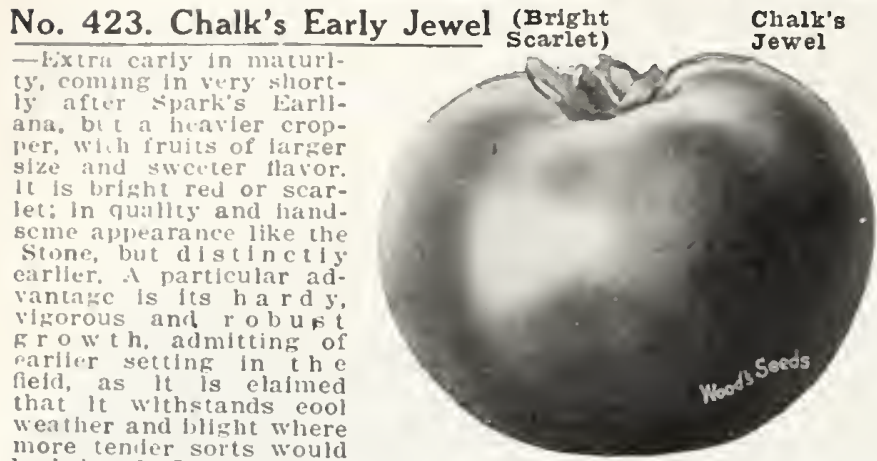

be injured. It continues bearlng through a long season. Pkt. 5 c oz. $25 \mathrm{c} ; 1 / 4$ lb. $85 \mathrm{c} ; 1 \mathrm{~b} . \$ 3.00 ; 2 \mathrm{lbs} . \$ 5.40 ; 5$ lbs. $\$ 13.10$, postpaid.

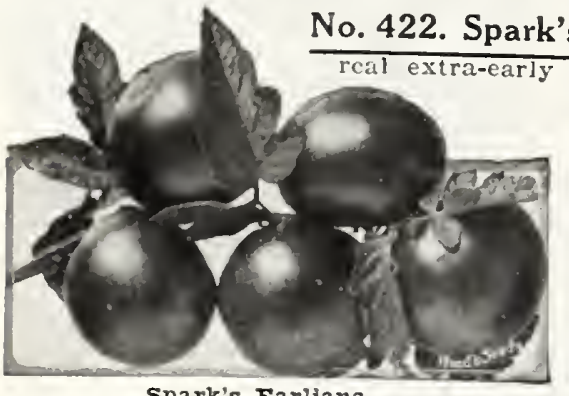

Spark's Earliana.

Tht lbs. $\$ 5.40 ; 5$ lbs. $\$ 3.0$ Pt. $5 \mathrm{c}$; oz. $25 \mathrm{c} ; 1 / 4$ lb. $85 \mathrm{c} ; 1 \mathrm{lb} . \$ 3.00 ; 2$ No. 428. Redfield Beauty (Parplish Pink.)-Beauty comes

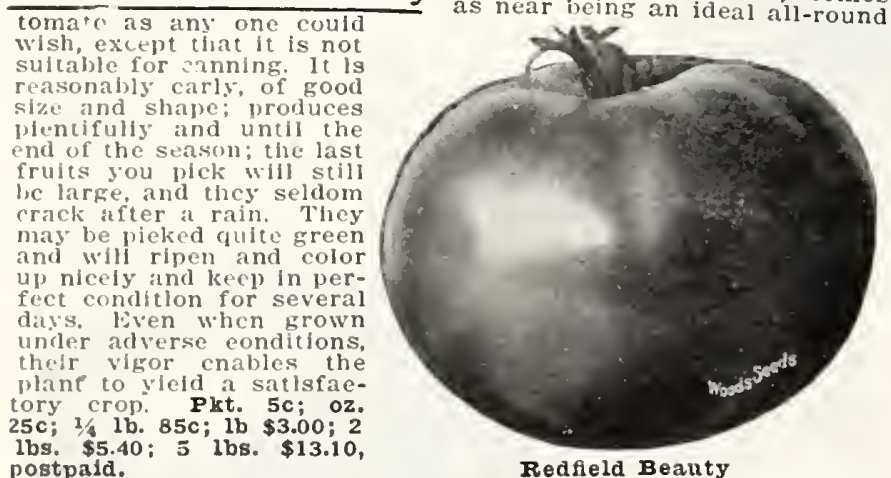

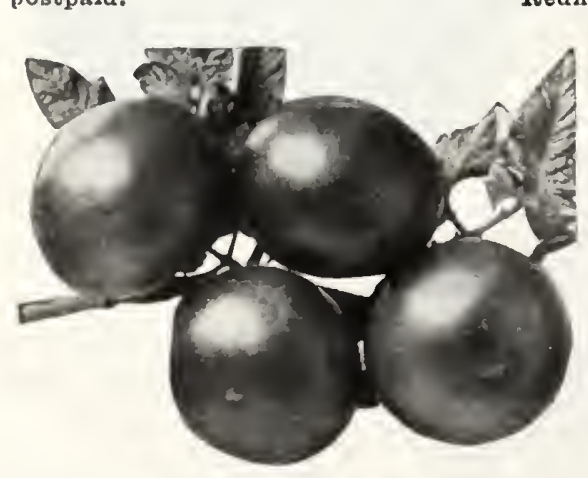

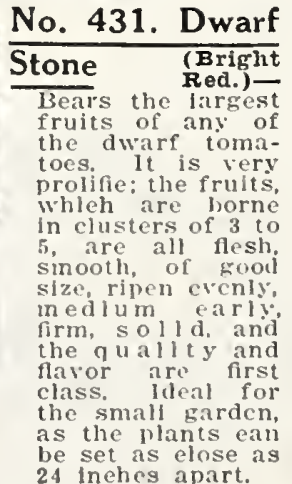

Dwarf stone

Pkt. 10c; oz. 40c; 2 ozs. $70 c$; $1 / 4$ lb. $\$ 1.25 ; 1$ b. $\$ 4.50 ; 2$ lbs. $\$ 8.15$; 5 lbs. $\$ 19.50$, postpald.
No. 434. Early Acme (Parplish Pink).-Through has been grown, none of supplanterl it in popular
favor, ard it is still on
of the best seliers. larly
and bears till eut off b. irust huldir size till the end of the
season. The tomatoes are round, smooth, solid. of cracks; borne in clusters of four or fivc: the quali.

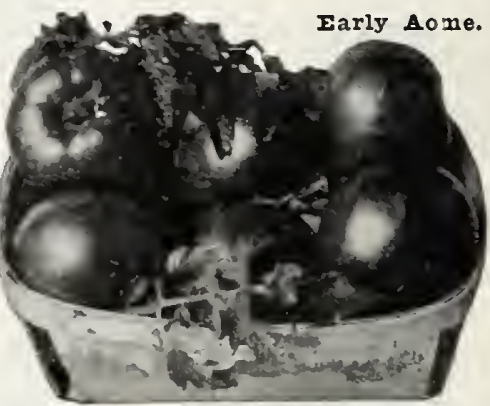
crltieism. Pkt. 5c; oz. $25 \mathrm{c} ; 1 / 4$ lb. $85 \mathrm{c}$; 1b. $\$ 3.00 ; 2$ lbs. $\$ 5.40 ; 51$ bs. $\$ 13.10$, postpaid.

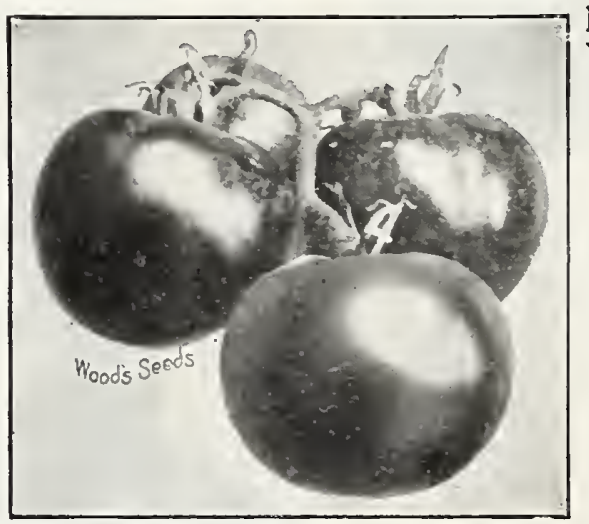

No. 438. Stone

(Bright Scarlet). One of the heaviest and most solid o of sood quality. Fine fcr main erop and deservedly one of the most popular tomatoes for home use, canning and the inarket. Is of large size, bright scarle eolur, smooth, solid up well under sum mer heat: $\boldsymbol{r}$ i pen evenly to the stem without eraeking and withstands ro and blight. It makes most attractive and salable fruits, firm $5 c ;$ oz. $25 \mathrm{c} ; 2$ ozs. $40 \mathrm{c} ; 1 / 4$ lb. $75 \mathrm{c} ; 1 \mathrm{~b} . \$ 2.65 ; 2$ lbs. $\$ 4.80 ; 5$ lbs $\$ 11.50 ; 10$ lbs, $\$ 22.00$, postpaid.

No. 435. Greater Baltimore (Blight Scarlet)-Even in unfaror Baltimore is a de. pendable tomato. It is a big yielder of good sized fruits, ends, firm and solid and free from ridges and cracks. and like it is a wouderful canner as well as a tine tomato for the home garden. It ripens evenly to the stem and is one of the big croppers among canning toma-
toes. Pkt. $5 \mathrm{c} ;$ oz. $25 \mathrm{c} ; 2$ oz. $40 \mathrm{c}$; $1 / 4$ ib. $75 \mathrm{c}$; $1 \mathrm{~b}$. $\$ 2.65$; 2 lbs. $\$ 4.80 ; 5$ lbs. $\$ 11.50 ; 10$ lbs. $\$ 22.00$, postpaid.

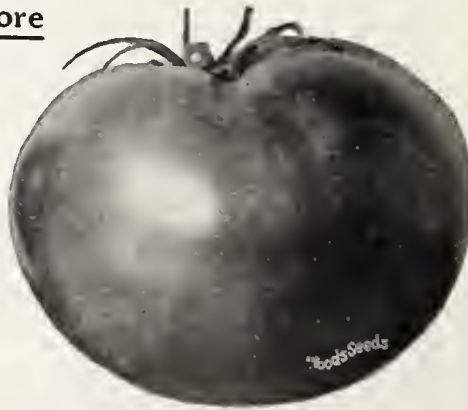

Greater Baltimore
Tomato Plants Ready after April 15 th. Bonuie Best. Earliana, June Pink, Stone, J'onderosa and Norduke Wil Resistant As it is not nossible always to have all varieties at the right size, we reserve the right to send a nother variety. We will. of eourse, send a variety as near as possible to the kind ordered. HOT-BED PLANTS

By mail postpaid. Not prepaid...................

BY mail postpaid.................. Per doz. Per 50 Per 100 Per 1,000

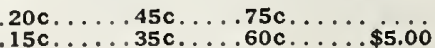
Not prepaid

$30 \mathrm{c} \ldots . .85 \mathrm{c} \ldots \$ 1.40 \ldots \ldots 10.00$

\section{BRIMMER TOMATO PLANTS}

Hot Bed Plants.-By mall postpald, $30 \mathrm{c}$ per doz,; 50 for $85 \mathrm{c}$ $\$ 1.40$ per 100 . Not postpald, $25 \mathrm{c}$ per doz.; 50 for $75 \mathrm{c} ; \$ 1.25$ per 100; $\$ 10.00$ per 1,000 .

Transplanted Plants. By mail postpaid, $40 \mathrm{c}$ per doz.; 50 for $\$ 1.10 ; \$ 1.90$ per 100 . Not postpaid, 35c per doz.; 50 for $\$ 1.00$ $\$ 1.75$ per 100; $\$ 15.00$ per 1,000 . 


\section{Turnip and Rutabaga}

CUITURF.-Spring sowings should be made as early as pos sible so that the turnips may make their size before hot weather otherwise they will become tough and bitter. For spring sowing there is mothing better than the Milans, 11 ood's Improved Red Top Globe, Purple Top Strapleaved and White Flat Dutch. Fo the regular crop, sow in July and August, the salad varieties in August or September. Sow either broadcast or in drills 2 feet apart, cover $1 / 2$ inch deep, and thin out to prevent overcrowding drills; 2 lbs. one acre broadcast; sow salad varieties 3 lbs. to acre. Milan Turnips - The Milans

to be desired in the uray of an

extra early garden turnip. They

are at least a week earlier than

any other; have small tops, so

that the rows can be planted

close together. The flesh i
clear ivory white; the skin is

perfectly smooth. They are

being of the most delicate fla-

vor. Medium size, flat shape.

There is nothing better for spring planting.

No. 445. EXTRA EARIY WHITE

MIIAN.-Pure white. Pkt. 5c

oz. 10c; $1 / 4$ 1b. 30c; 1b. $90 \mathrm{c} ; 2$ lbs.

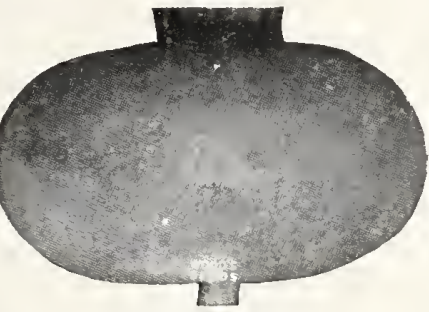

Mílan Turnıp
No. 446. EXTRA EARIY PURPIE TOP MILAN,-White with purple top. Pkt. 5c; oz. 10c; 1/4 1b. 30c; 1b. 90c; 2 1bs. $\$ 1.50$; 5 lbs. $\$ 3.65$, postpaid.

No. 450. Wood's Improved Red Top White Globe

-Handsome ap-

pearance and ex-

tra fine quality

for the universal popularity of our splendidly b red strain. Globeshaped, of good size; the upper part purple, the lower part pure white, with finegrained, tender pure white flesn. when about three in $\mathrm{ch}$ e $\mathrm{s}$ across bu t for stock feeding it should be grown to full

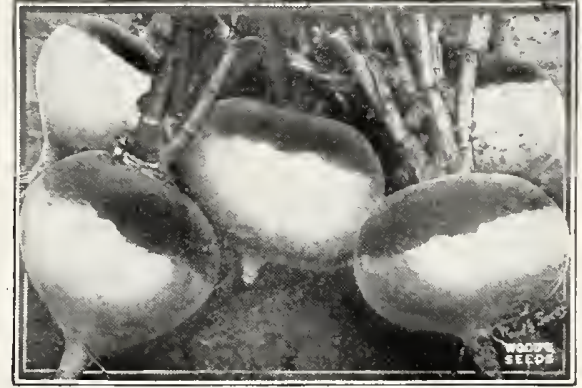

Wood's Improved Red Top Globe For the private garden and for market it has no superior heavy cropper, early and of extra good quality. Pkt. 5c oz. $10 \mathrm{c} ; 2$ ozs. $15 \mathrm{c} ; 1 / 4$

10 lbs. $\$ 5.35$, postpaid.

No. 449. MAMMOTH RED TOP WHITE GLOBE-Makes large clobe-shaped roots; white with purple tops. a big yielder - fine for the table, market and stock feeding. Pkt. 5 c; oz. $10 c ; 1 / 41 b$. $20 \mathrm{c} ; 1 \mathrm{~b} .65 \mathrm{c} ; 2$ 1bs. $\$ 1.10 ; 5$ 1bs. $\$ 2.40$, postpaid.

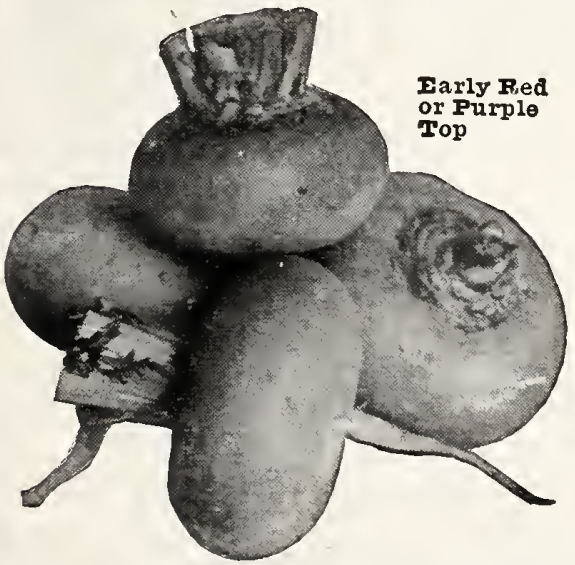

No. 447. $\mathbf{E}$ A R I $\mathbf{Y}$ TOP sw e e $t$ tender white turnip with purple top. A quick grow er; never stringy ; uniform in size and shape, an excellent table turnip and a good stock feed when full grown. Pkt. c; oz. 10c; $1 / 4$ 1b. $\$ 1.10 ; 51 \mathrm{bs}$. $\$ 2.40$, postpaid.

No. 448. I A R I Y W I I $\mathbf{T}$ I I A DUTCF. - The only this and Early Red or Purple Top is $\mathrm{Dutch}$ is pure Dutch is pure equally early and have the same good qualities. Pkt. 5c; oz. 10c; 1/4 1b. 20c; 1b. $65 \mathrm{c} ; 2$ lbs. $\$ 1.10 ; 5$ lbs. $\$ 2.40$, postpaid.

No. 451. IONG WHITE COWHORN.-A very productive turnip of excellent quality, fine grained and very sweet. Often grows $65 \mathrm{c} ; 2$ lbs. $\$ 1.10 ; 5$ lbs. $\$ 2.40$, postpaid.
No, 452, WFITE FGG.

pure white variety with small tops. Flesh 10c; 1/ 1b. 20c; 1b. 65c; 2 lbs. $\$ 1.10 ; 51 \mathrm{bs}$ $\$ 2.40$, postpaid.

No. 453. IARGE WHITE NORFOIK GIOBE.-Malies large

largely used for winter salad. Pkt. $5 \mathrm{c}$; oz. 10c; 1/4 1b. 20c; 1b. $65 c ; 2$ lbs. $\$ 1.10 ; 5$ lbs. $\$ 2.40$, postpaid.

No. 454. P O M R A N A N W I I T E G I O B E.-Extra large, round, white: fine for table and stock; a big yielder. On good land they often grow to ten pounds in
weight. For table use they are best when about 4 $100 ; 1 / 4$ 1b. $20 \mathrm{c} ; 1 \mathrm{~b} .65 \mathrm{c} ; 2$ bs. $\$ 1.10 ; 5$ lbs. $\$ 2.40$, postpaid.

No. 457. IARGE AMBER OR YEIIOW GLOBE.-Of large size, globe-shaped, with finegrained, solid, sweet and
tender yellow flesh. Fine for table and stock; a fine keeper, hardy and productive. 1b. $65 \mathrm{c} ; 2$ ibs. $\$ 1.10 ; 5$ lbs. $\$ 2.40$, postpaid.

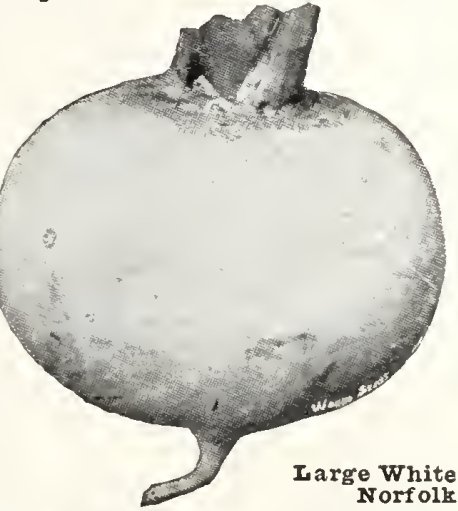

No. 456. PURPIE TOP YEIIOW ABERDERN.-A splendid keep er. Flesh is yellow, very solid, tender and sweet, Hardy and a 2 lbs. $\$ 1.10 ; 5$ lbs. $\$ 2.40$, postpaid.

No. 458. GOIDEN BAII or ORANGE JEIIY,-One of the sweetest and best yellow turnips: hardy; flesh is firm and of most 5 lbs. \$2.40, postpaid.

No. 461. MIXED TURNIP SEEDS.-A fine home garden mixture 1b. 65 c; 2 lbs. $\$ 1.10 ; 5$ lbs. $\$ 2.40$, postpaid.

\section{SALAD VARIETIES}

No. 562. SHOGOIN_Japanese Foliage Turnip. See page 3.

No. 459. SOUTHERN PRIZE or DIXIE.-Hardy and needs no protection; the most popular turnip grown for winter and spring salad. Pkt. 5

No. 460. SEVEN TOP.-A very hardy variety, grown exclusively for salad. Pkt. 5c; oz. $10 \mathrm{c} ; 1 / 41 \mathrm{~b} .20 \mathrm{c} ; 1 \mathrm{~b} .60 \mathrm{c} ; 2 \mathrm{lbs} . \$ 1.00 ; 5$ bs. $\$ 2.25$, postpaid.

\section{RUTABAGA or SWEDE}

CUITURE.-Plant in July or early in August, in drills 2 feet apart; thin out and keep clear of weeds.

No. 465. Wood's Improved Purple Top Yellow

An improved strain of the finest yellow-fleshed rutabaga grown

from roots selected for large size, uniformity in shape and

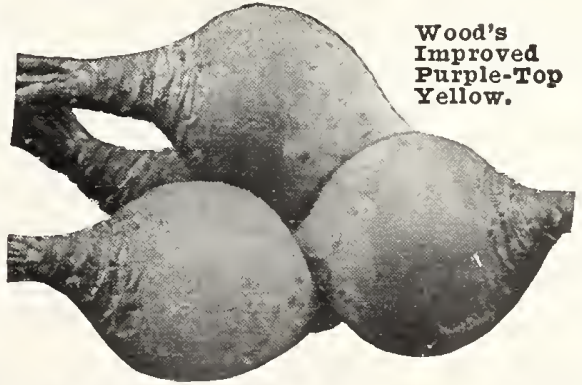
sweet, a good keeper and the best sliaped and most producthe table, and has high feeding value 5c: oz. 10c; $1 / 41 \mathrm{~b}$. $30 \mathrm{c}, 1 \mathrm{~h}, 75 \mathrm{c}$ $\$ 1.25 ; 5$ lbs. $\$ 3.15$, postpaid.

No. 466. $P \cup R P I E$ TOP YEIIOW.-The

old standard varie-

for table and stock. good keeper: hardy,

Pkt. 5c; 0z. 10c; 1/4 1b. 20c; 1b. 65c; 2 1bs. $\$ 1.10 ; 5$ 1bs. $\$ 2.40$, postpaid.

No. 455. WHITE SWERT GERMAN.-Fine for table and stock; flesh hard. firm and "sweet; a good keeper. Pkt. 5c; oz. 10c; $1 / 4$ 1b. $20 \mathrm{c}$; 1b. $65 \mathrm{c} ; 2$ lbs. $\$ 1.10 ; 5$ lbs. $\$ 2.40$, postpaid.

No. 467. IARGE WHITE or RUSSIAN.-The flesh is white, firm, sweet; grows large: fine for table and stock. Pkt. 5c; oz. 10c; $1 / 4$ lb. $20 c ; 1 b .65 c ; 2$ lbs. $\$ 1.10 ; 5$ lbs. $\$ 2.40$, postpaid. 


\section{GARDEN HERBS}

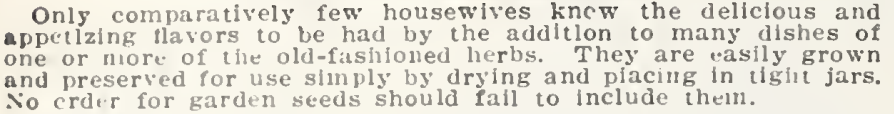

Caltare.-

cultivity

carefuliy prepared and well

eastry choked out by weels. Sow early in the spring. in drils

TO PRESERVE HERBS, the plants should be cut when in

bloom and wiled in the sun and thoroughly dried in the shade,

ling and medicinal quallites.

No. 475, ANISE.-An annual, cultivated principally for its seeds Whicl liate a picasint aromatic flavor. The leaves are also nitusear. Pkt. 5 cts.; oz. 15 cts.

No. 476. BAIM.-A perennial easily propagated by division of the roots or from seed. The leaf has a fragrant odor, some-
what similar to lemons, and is used for making balm tea for use in pevers. and a pleasant beverage called "balm wine." Pkt. 10c; 0z. 45c.

No. 477. SWEET BASII. The stems have a flavor somewhat simflar to that of cloves. Used for flavoring soups, stews,

No. 479. BORAGE.-A hädy annual. The leaves are used in salads, the flowers for bee pasturage. The bruised leav

No. 480. CARAW AY.-Cultivated for its seeds, which are used in confectionery, cakes, etc. "The leaves are sometimes used in soups. Can be sown will give a large yield of seed til? following season. Pkt. 5 cts.; oz. 15 cts.

No. 481. CATNIP, or CATMINT.-A hardy perennial, well known viuabie mifl nervine for infants and for seasoning. Can

Pzt. $10 \mathrm{c} ; 1 / 2$ oz. $40 \mathrm{c}$; oz. $75 \mathrm{c}$.

No. 482. CorIANDER.-A hardy annual, cultivated for its seed, which his an areable taste and is used in confectionery and to disguise the taste of medicine. Gather on a dry day, bruising the stems and leaves as ijtle as possible, for when injured they have a disagreeable odor which they impart to the seed.
Pkt. 5 cts.; oz. 15 cts.

No. 483. MAMMOTH DIIL.-An annual, cultivated for its seeds. which have an aromatic odor and a warm pungent taste. Used Pkt. 5 cts.; oz. 15 cts.; 1/4 1b. 35 cts.; 16 . \$1.00 postpaid.

10. 484. SWEET FENNEI.-A hardy perennial. Leaves are used $5 \mathrm{c} ;$ oz. $15 \mathrm{c}$

No. 485. HOREHOUND.-A perennial herb used in making cough sylups and lowenges and for flavoring candy. Plat. 10 cts.; $1 / 2$ oz. $25 \mathrm{cts}$; oz. $40 \mathrm{cts}$.

No. 486. IAVENDER.-A hardy perennial, used to make lavender water or dried and used as a perfume for linen, etc. Should be picked before it becomes dry, and dried quickly; germinates Prt. 5 cts.; oz. 20 cts.

No. 487. SWEET MARJORAN.-A perennial; the tender tops and deaves are used green for flavoring, but they

1. 488. ROSEMARY.-A hardy perennial for flavoring meats and soups and tor medicinal purposes. Plst. 10 cts.; $1 / 2$ oz. 25 cts.: oz. $40 \mathrm{cts}$.

No. 489. RUE.-A hardy perennial, thriving on poor soll. Used No. 490. SAGE.-One of the most popular perennial herbs, possesing some mcdicinal properties, but used princlpally for tlavorthe plant is coming into flower, and dry quickly in the shade. The plants will survive the winter and may be divided, when they will grow of and produce a second crop of superlor

No. 491. SUMmER SAVORY.-A hardy annual. The drled stems, oups. Pzt. 5 cts.; oz. 20 cts.

No. 493. THYMz.-A perennial, used both medicinally and for asoning. The yount leaves and tips are used for soups, front the leaves should bc dried for winter use. spring. Pkt. 10c; $1 / 2$ oz. $25 \mathrm{c}$; oz. $40 \mathrm{c}$

No. 494. WORMWOOD.-Tops and leaves, gathered and dried in uly and August, when the plant is 1 llower, are used for aromatic and tonic purposes, and as $\therefore$ worm medicine; also mouitry tonic; plant some in the chicken yard. Pkt. io cts.;

\section{Vegetable Plants and Roots}

In their proper seasons, we shall have large quantities of all the plants listed below, well grown and stocky and all grown their orders tilled the day after received, the weather permitting. They will be carefully packed and will carry long distances. Plants by mail at purchaser's risk. No charge for packing, etc. a vold lying over in express or post office on Sunday, no plants dercal. Should we be sold out of the variety ordered, we will
She whe send a nearly similar kind instcad. Special prices on 5,000 or
more plants. WE DO NOT SHIP PIANTS C. O. D.

ASPARAGUS ROOTS-See page 5.

EARIY CABBAGE PIANTS-Jersey Wakefield. Ready February, Mlarch, April and Mla. 50c per 100 postpaid. Not prepaid, 40c per $100 ; \$ 3.50$ per 1,000 .

EARIY CABBAGE PIANTS for Fall Setting. - Jersey and Charleston II akefield. Ready October and November. 45 cts.
per 100 postpaid. Not prepaid, $35 \mathrm{cts}$. per $100 ; \$ 3.00$ per 1,000 .

IATE CABBAGE PIANTS-Late Flat Dutch. Ready June, July and August. 45c per 100 postpaid. Not prepaid, 35c per 100 $\$ 3.00$ per 1,000

CAUIIFIOWER PIANTS-Ready February and March. 50 for $75 \mathrm{c} ; \$ 1.25$ per 100 , postpaid. Not prepaid, 50 for $65 \mathrm{c} ; \$ 1.10$ per $100 ; \$ 9.00$ per 1,000 .

CEIERY PIANTS.-Pascal, Winter Queen and White Plume Ready June, Juiy and August. 75 cts, per 100, postpaid. Not prepaid, 60 cts. per $100 ; \$ 5.00$ per 1,000 .

COIIARD PLANTS.-Ready June, July and August. 40c per 100 postpaid. Not prepaid, 30c per $100 ; \$ 2.50$ per 1,000 .

EGG PIANTS.-Ready May, June and July, 30 ctr, per doz. 50 for 80 cts.: $\$ 1.40$ per 100 postpaid. Not prepaid, 25 cts. per doz.; 50 for 70 cts.; $\$ 1.25$ per $100 ; \$ 10.00$ per 1,000 .

HORSE RADISH ROOTS.-Ready November ist till June. 40 cts. per doz.; 50 for 85 cts.; $\$ 1.50$ per 100 postpaid. Not prepaid, 35 cts. per doz.; 50 for 75 cts.; $\$ 1.40$ per 100 ; 500 for $\$ 6.50 ; \$ 12.00$ per 1,000 .

IETTUCE PLANTS-Wood's Cabbage, Big Boston and Iceberg. Peady lebruily. March, April, after September 15, October and November. $45 \mathrm{c}$ per 100 postpaid. Not prepaid, $35 \mathrm{c}$ per $100 ; \$ 3.00$ per 1,000 .

PEPPER PIANTS-Ruby King and Cayenne. Ready May and June. $30 \mathrm{c}$ per doz.; 50 for $70 \mathrm{c} ; \$ 1.15$ per 100 postpaid. Not prepaid, 25c per doz.; 50 for $60 c ; \$ 1.00$ per 100 .

RHUBARB ROOTS.-Ready November 1st, till May. 20 cts. each; 3 for 50 cts.; $\$ 1.50$ per doz. postpald. Not prepaid, 15 cts. each; 3 for 40 cts.; $\$ 1.25$ per doz.; 50 for $\$ 4.50$.

SWEET POTATO PIANTS- Fellow Nansemond, Hanover White Yam, Forto Rico and Nancy Hall. Ready May and June. 55c per 100 postpald. Not prepaid, $45 \mathrm{c}$ per $100 ; \$ 4.00$ per 1,000 .

HOT-BED TOMATO PIANTS-Bonnie Best, Earliana, June Pink, Stone, Ponderosa and Norduke Wilt Resistant. Ready April, May, June and July. 20c per doz.; 50 for $45 \mathrm{c} ; 75 \mathrm{c}$ per 100 postpaid. Not prepaid, $15 \mathrm{c}$ per doz.; 50 for $35 \mathrm{c} ; 60 \mathrm{c}$ per $100 ; \$ 5.00$ per 1,000 .

TRANSPIANTED TOMATO PIANTS - See Hot-Bed Plants for varieties, 30 cts. per doz.; 50 for 85 cts.; $\$ 1.40$ per 100 postpald. Not prepald. 25 cts. per doz.; 50 for 75 cts.; $\$ 1.25$ per $100 ; \$ 10.00$ per 1,000 .

BRIMMER TOMATO PIANTS-Fot Bed Plants, 30c per doz.; 50 for $85 \mathrm{c} ; \$ 1.40$ per 100 , postpaid. Not postpaid, $25 \mathrm{c}$ per doz.; 50 for $75 \mathrm{c} ; \$ 1.25$ per 100 .

Transplanted, 40c per doz.; 50 for $\$ 1.10 ; \$ 1.90$ per 100, postpaid. Not postpald, 35c per doz.; 50 for $\$ 1.00 ; \$ 1.75$ per 100 .

SAGE ROOTS. -20 cts. each, postpald. Not prepald, $15 \mathrm{cts}$. THYME ROOTs.

BIRD SEEDS Safeguard the health of your birds by reedWOOD'S SONGSTERS FOOD.-The highest grade of mixed bird seeds in the proper proportions. By mail postpaid, 1b. 25 ; 5 1bs. $85 \mathrm{c} ; 10$ lbs. $\$ 1.50$. Not prepaid, 1b. 15c; 5 lbs. 60c; 10 lbs. $\$ 1.15$ CANARY SEID.-By mail postpaid, 1b. 25c; $51 \mathrm{bs} .85 \mathrm{c} ; 101 \mathrm{bs}$ $\$ 1.50$. Not prepaid, 1b. $15 \mathrm{c} ; 5 \mathrm{lbs}, 60 \mathrm{c} ; 10 \mathrm{lbs}$. $\$ 1.15$.

HEMP SEED-By mall postpaid, 1b. 20c; 5 1bs. 70c; 10 lbs. $\$ 1.15$. Not prepaid, 1b. $12 \mathrm{c} ; 5$ lbs. $45 \mathrm{c} ; 10$ ibs. $80 \mathrm{c}$.

BIRD RAPE.-By mail postpaid, 1b. 20c; 5 lbs. 75c; 10 lbs. \$1.25. Not prepaid, 1b. $14 \mathrm{c} ; 5$ lbs. 50c; 10 ibs. $90 \mathrm{c}$.

BIRD MIIIET.-By mail postpaid, 1b. 20c; 5 lbs. 60c; 10 lbs, 95c. Not prepaid, 1b. $10 \mathrm{c} ; 5$ 1bs. 35c; $10 \mathrm{lbs}$. $60 \mathrm{c}$.

SUNFIOWER FOR FEEDING.-By mall postpaid, 1b. 20c; 5 lbs. $75 \mathrm{c} ; 10$ lbs. $\$ 1.25$. Not prepaid, 1b. $12 \mathrm{c} ; 5$ lbs. $50 \mathrm{c} ; 10$ lbs. $90 \mathrm{c}$. CUTTLEFISH BONE.-40 cts. per lb. postpaid. Not prepaid, 30 cts. per $1 \mathrm{~b}$. 


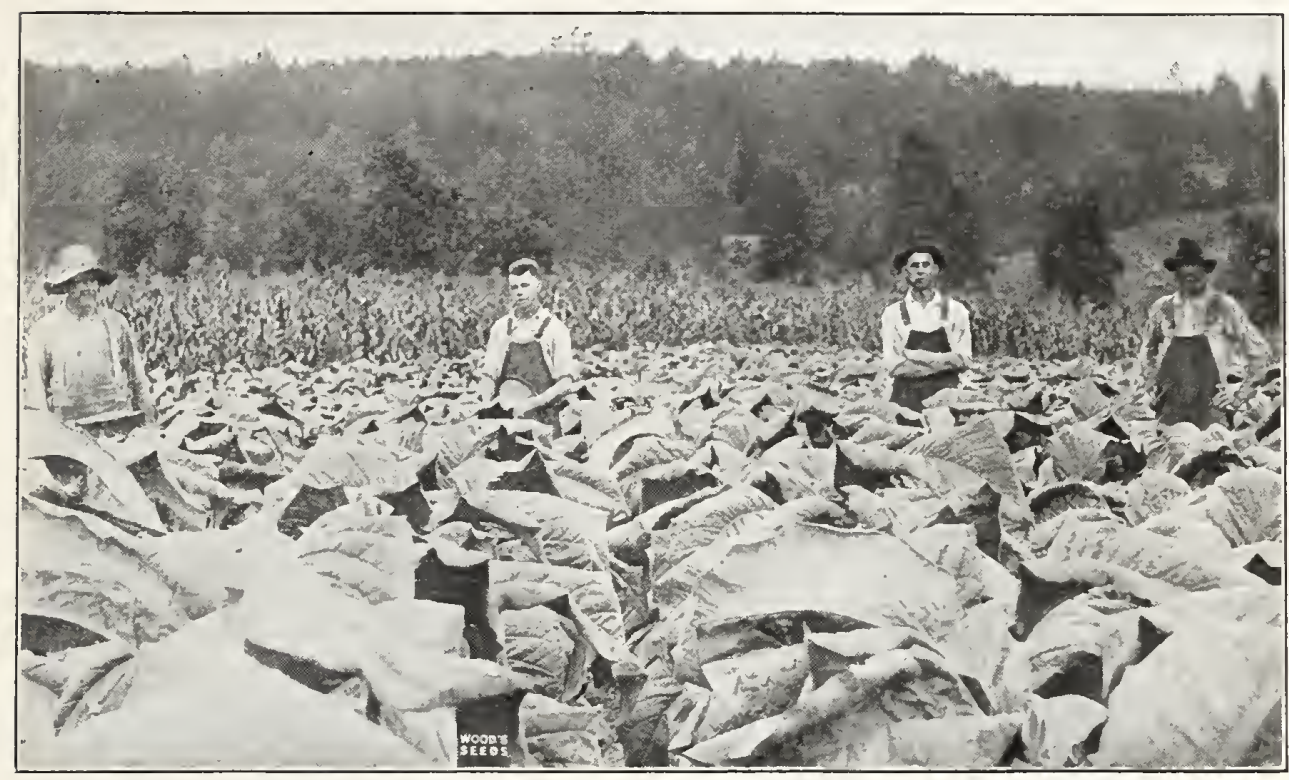

WOOD'S TOBACCO SFEDS are all treated as recommended by the Virginia Agricultural Experiment Station at Blacksburg. This treatment is to prevent wildfire, black fire, angular leas spot and other tobacco diseases.

CULTURE.-A very

land 15 best woods for plant beds, This the stroys grass, weeds and insects, adds fertility through the action ground in good are sown about Febr tected by plant-bed

enough and in $31 \%$-foot rows the plants. Constant care must be given, cultivating, suckering.

FOR TOBACCO WORMS AP ply either arsenate of lead or paris green with one of the dust guns offered on page 92. They apply the insecticides perfect$1 y$ and the cost is small when it is remembered that they will last for years.

\section{Select Varieties}

Each, pkt. $10 \mathrm{c} ;$ oz. $40 \mathrm{c} ; 1 / 4$ lb. $\$ 1.25 ; 1 \mathrm{~b} . \$ 4.00$ postpaid

No. 499. Bonanza -A broad-leaved bright tobacco that is es ern Carolinas and Georgia. Easy to cure and makes a rich leaf of good weight and bright color.

No. 500. Jamaica Wrapper -Adapted to the sandy soils of medium long leaf of good weight that cures a bright yellow.

No. 501. Adcock - One of the best tobaceos for poor land. set well apart on the stalk, exposing a greater surface to the sun, resulting in a more uniform ripening and more even crop. Best adapted to light gray or sandy soils; cures bright.

No. 502. Improved Gold Leaf -A fine, upright plant with well spaced, which allows uniform ripening. Cures easily to a high-grade bright leaf. Prefers a sandy soil.

No. 503. Warne - The leaf is long, of good breadth, silky and color, with fine silky quality.

No. 504. Improved Yellow Oronoko -For yellow wrapsmokers. Cures bright, or can be cured for dark filler. It has good width and fine length. Does best on light gray soils.

No. 505. Improved White Stem Oronoko -On light makes high-class bright leaf; on heavier soils, it makes mahogany or medium bright. The leaf has good length and width, cures easily and is of very fine quality.

No. 506. Improved Hester -The leaf is of good width and fine wrappers and cutters on light soils when flue cured, or goodbodied air-cured tobacco on heavier soils.

No. 517. Choice Havana -An Americanized Havana used long, fine quality leaf; very early. Best adapted to chocolate No. 508. White Burley -A heavy yielder of rich, bright be grown only on limestone soil.

No. 509. Cash -An excellent bright tobacco with a medium to allow the entire leaf to ripen. Especially well adapted to medium rich loam and sandy soils; cures easily.

\section{Standard Varieties}

Fach, pkt. 10c; oz. 35c; 1/4 1b. $\$ 1.00 ; 1 \mathrm{~b} . \$ 3.50$ postpata

No. 510. One Sucker -A heavy yielding dark tobacco, with fine texture. May be air, sun, flue or fre cured leaf, thick and of Turtlefoot. Does best on rich loam or clay soil.

No. 511. Big Oronoko - A dark tobaceo that adapts itself to heavy producer and of fine texture. The leaf is long, broad and tapering with small side ribs; has unusual weight and body, and may be cured red or black.

No. 512. Sweet, or Little Oronoko The best for sunfine chewing tobacco, wrappers and fillers. The leaf is long, narrow and very waxy. It may also be flue cured, making a rich, heavy mahogany. In the sun-cured section it is grown almost

No. 513. Blue Pryor - A large, long and broad leaf. Makes pers, strips and fillers, and a rich export tobacco. Best adapted No. 514. Yellow Pryor - On the sandy soils of the eastern long leaf, quite broad, of good weight, fine quality, and one that cures easily to the highest grade of bright tobacco; has good

No. 515. Medley Pryor good black wrappers, strips and fillers. The leaf is large and broad, hea
clay soils.

No. 520. Flanagan silky

No. 521. Virginia Sun Cured

No. 523. Lizard Tail

No. 524. Willow Leaf

No. 525. Famous

No. 526. Deer Tongue

either flue or sun cured.

No. 529. Hickory Pryor -On the sandy soils of the eastest class bright leaf. 


\section{Wood's High-Grade Flower Seeds}

Sow the Seeds

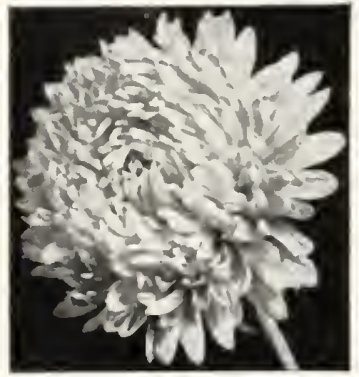

No. 609. White Beauty.

No. 610. Crimson Beauty.

No.611. Lavender Beanty.

No. 613. Purple Beanty.
No.612. Mixed Beauty.

victoria$$
\text { , }
$$

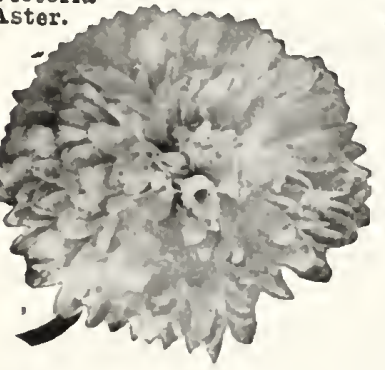

02. 35c.

VICTORIA

ASTER - A m a gnificent aster,distinguished b y and regular over-lapping of the petplant bears 20 to 30 very ers, 4 inches many delicate and so me gor gecus shades. 15 to 18 inches high.
0.615 . Mixed Colors. Prt. 10c; 1/8 oz. 25c. QUEEN OF THE MARKET.-The earliest

good size on
No. 623. Pink

No. 624. White

No. 625. Scarlet

No.626. Dark Blue
No. 627. All Colors Mixed

Each

Packet $10 \mathrm{c}$

$1 / 8$ oz. $20 \mathrm{c}$.

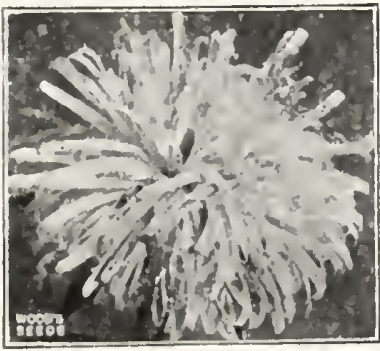

No. 605 OSTRICH

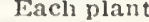

bears 25 to

long curled,

petals sug-

gestive of an
ostrich fea-
ther. All colther. All col Pkt. $10 \mathrm{c}$;

Ostrlch Feather Aster. $1 / 402.45 \mathrm{c}$.

No. 606. PERENNIAT ASTER (Michaelmas Daisy).-An cxccedingly showy perennial with single dalsy-like flowers: early CORNFLOWER ASTER.-Sec Stokesla.
The Soil best suited to flowers is a light rich loam, made as to lighten and make it friable. Many seeds are very small and HAIF HARDY and TENDER FLOWERS should not be sown or iransplanted outside until the weather is settled and warm. HARD SHELIED SEEDS like Canna Fiening Giory Brazilian and Japanese Morning Glory should have a hole filed thrcugh the outer shell, or soaked in warm water 36 hours before planting.

\section{$1 / 4$}

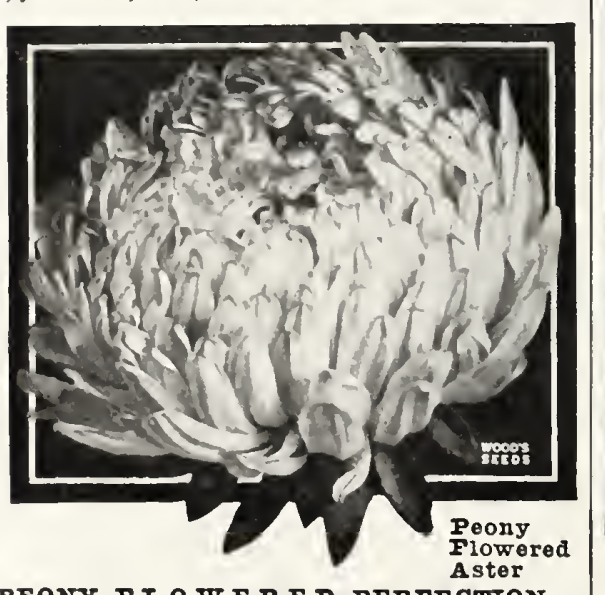

PEONY FIO WERED PERFECTION.-

Large, perfectly formed, brilliantly col-
ored. Very docible; 3 to 4 inches across. No. 603. MIXED CoIORS.-Pkt. 10c; 1, oz. $25 c$.

No.604. CFINA or QUIIIED ASTER.Flowers large, brilliant and of many beauPlat. 5c; $1 / 4$ oz. 20 c.

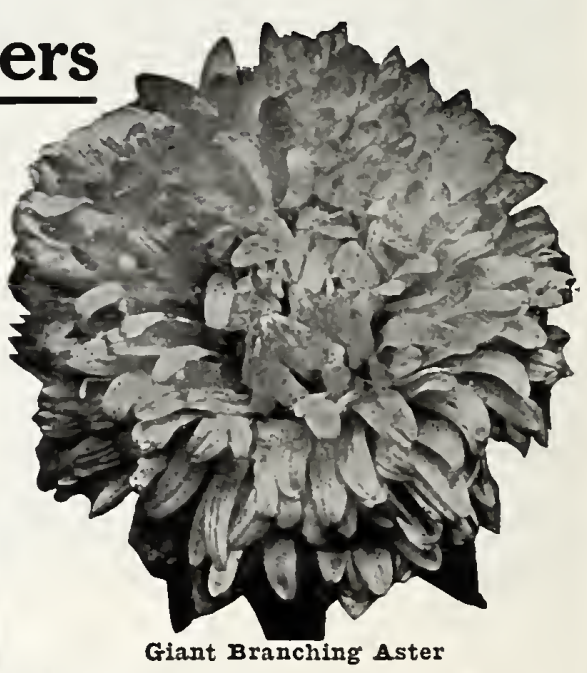

GIANT BRANCHING. - A beautiful late. lowering aster which bears on long stems in diameter. $11 / 2$ to 2 feet high. Branches freely. Pure White.-Pkt. 10c; $1 / 8$ oz, $25 \mathrm{c}$. No. 617. Pink.-Pkt. 10c; $1 / 8$ oz. $25 \mathrm{c}$.

No. 618. Dark Blue.-Pkt. 10c; 1/8 oz. 25c.

No. 619. Scarlet.-Pkt. $10 \mathrm{c} ; 1 / 8$ Oz. 25c.

No. 620. Mixed Colors,-Pkt. 10c; 1/8 0z. 25c.

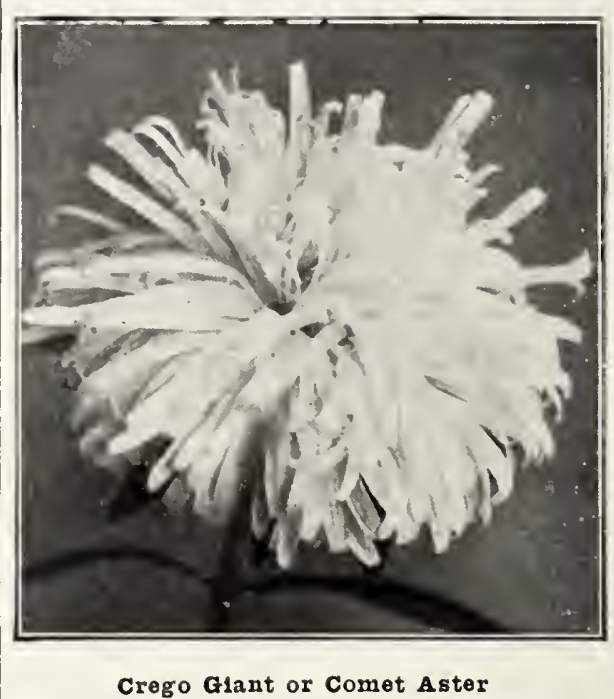

CREGo GIANT or COMET.-The flowers are of tmmense size, often 5 lnches across. The long wavy twisted petals give it the appearance of the finest Japanese chryNo. 630 . Crimson-Pkt. 10c; 1/8 02. $25 \mathrm{c}$. No. 631. Pink -Pht. 10c; $1 / 8$ oz. $25 \mathrm{c}$. No. 632. Dark Blne.-Pkt. $10 \mathrm{c} ; 1 / 8$ oz. $25 \mathrm{c}$. No. 633. Pure White.-Pkt. 10c; 1/8 oz. 250. No. 634. Muxed Colors-Plt. 100; 1/8 0z. 250. 
No. 550. Abronia $\rightarrow$ A tralling plant fragrant flowers. Splendid for rock work. Hardy annual. Pkt. 10 cts.; $1 / 4$ oz. 25 cts. No. 553. Abutilon (Bell $\mathrm{Flow}$ er, or ubearing bell-like flowers of many colors; suitin winter. Height, 2 to 4 feet. pkt. 20 cts. No. 556. Achillea (The Pearl).-A fine . June till frost: blooms the first season if sown early. Height, 2 feet. Pkt. 15 cts.

No. 559. Acroclinium--Ev e rl asting, white daisy-like flowers. Fine for borders and for winter bouquets. Hardy annual. 5 cts.; $1 / 4$ oz. 15 cts.

No. 562. Adlumia (Allegheng vine.)No An attractive climbr, with fern-like leaves and flesli-colored prove year by year. A shady situation suits it best. Hardy biennial. Height, 15 feet. Pkt. 10 cts.

ALLEGHENY VINE.--See Adlumia

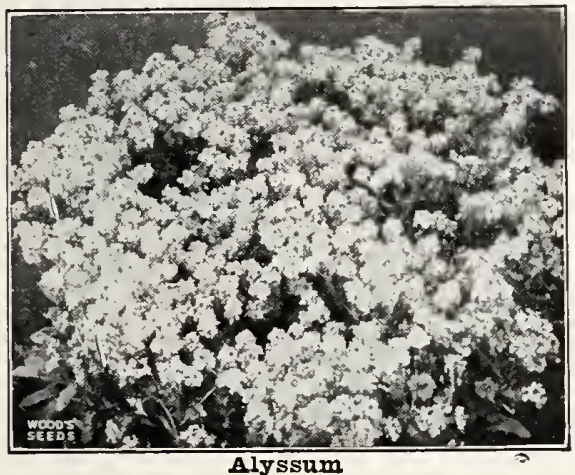

Alyssum - One of our finest hardy plants and fer cutting. Sow early for a pots tinuous bloom; cut away the faded blooms and others will come

No. 568. Iilac Queen. Nearly all summer it bears a wealth of beautiful deep lilac lav-
ender blooms. A splendid bedding and oorder plant. Very dwarf. Pkt. 10c; $1 / 4$ oz. $20 \mathrm{c} ; 1 / 2$ oz. 35c.

No. 569. Iittle Dorrit.-A gem for beds, borders, porch and window boxes, baskets and rockeries. Forms a perfect little bush, smothered with white blooms through summer till fall. Plt. 10 cts.; $1 / 4$ oz. 25 cts.; $1 / 2$ oz. 40 cts.

No. 570. Little Gem (Carpet of Snow.)There is no better border plant. Very dwarf; covers a circle of about

No. 571. Saxatile.-Brilliant golden yellow showy for perennial borders and beds; 9 incs the plo $10 \mathrm{cts} 1 / 40 z, 30 \mathrm{cts}$

No. 572. Sweet.-Hardy annual; covered With pure white fragrant blooms. The 5 cts.; $1 / 2$ oz. 20 cts.; oz. 30 cts.

No. 576. Amaranthus $\rightarrow$ Some have age, others beautiful clusters of brilliant flowers. Transplant 2 feet apart. Half

No. 579. Ampelopsis (Boston or Japrapid creeper with lovely green foliage which turns red in fall. Excellent for covering walls, outhouses, etc. Perennial
Height, 50 feet. Pkt. 10 cts.; $1 / 2$ oz. 20 cts No. 582. Anchusa - A strong growing bears an abundance of lovely gentian blue flowers during the entire season. cts.; $1 / 8$ oz. $20 \mathrm{cts}$.

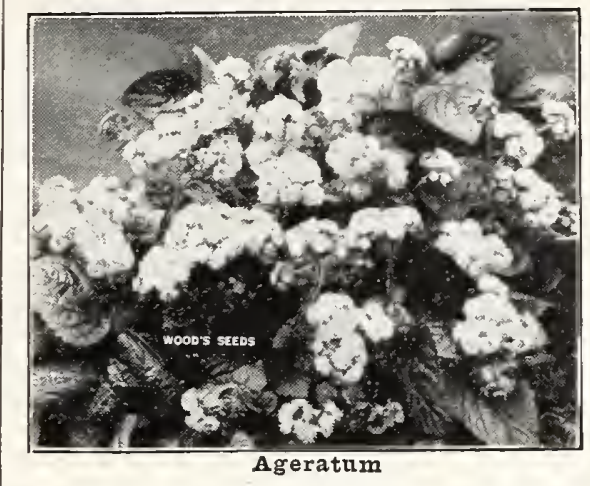

\section{Ageratum}

in summer and as pot-plants in winter No. 565. Dwarf Perfection Blue. Pkt. 10
cts.; $1 / 4$ oz. 25 cts.; $1 / 2$ oz. 40 cts. No. 564. Dwarf Mixed Colors. Pkt. 5 cts.;

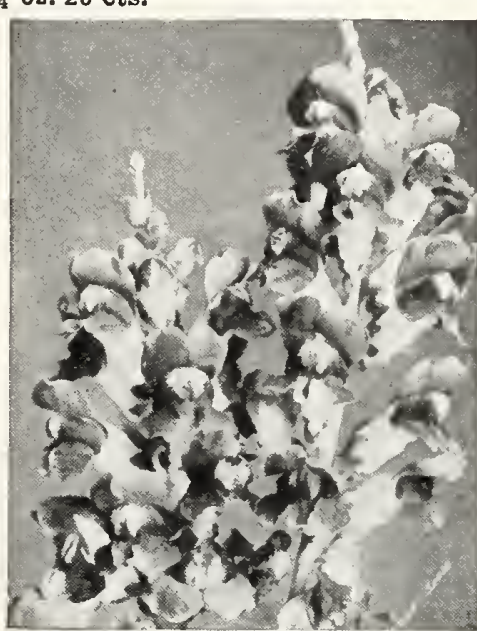

Antirrhinum or Snapdragon.

Antirrhinum (Snapdragon)-Showy and ducing brilli useful border plants, properennial. Height. 2 to 3 feet. A fine mixture of all colors. Pkt. 5c; $1 / 4$ oz. 25c; $1 / 2$ oz. $40 \mathrm{c}$.

Giant Flowered Snapdragon No. 585. Snow White. ] Each No. 586. Deep Pink. No. 587. Canary Yellow.
No. 588. Defiance Scarlet.
$1 / 4$
$1 / 4$
oz. $40 \mathrm{c}$.; No. 590. Wood's Brilliant Mixture.-Th individual blooms are extra large, closely fine. Pkt. $15 \mathrm{c} ; 1 / 4$ oz. 50c.

No. 598. Arabis Alpina (Rock Cress) ing and rockeries; fragrant white flowers. Height,
$20 \mathrm{cts}$.

No. 640. Balloon Vine (Iove-in-arapid climbers, with inflated ballconHeight, 10 feet. Pkt. 5c; oz. 20c.

No. 647. Balsam Pear-A gra ce bearing golden yellow fruits changing to
bright red when ripe. Height, 15 feet. Plst. $5 \mathrm{c} ; 1 / 2$ oz. $25 \mathrm{c}$; oz. $40 \mathrm{c}$.

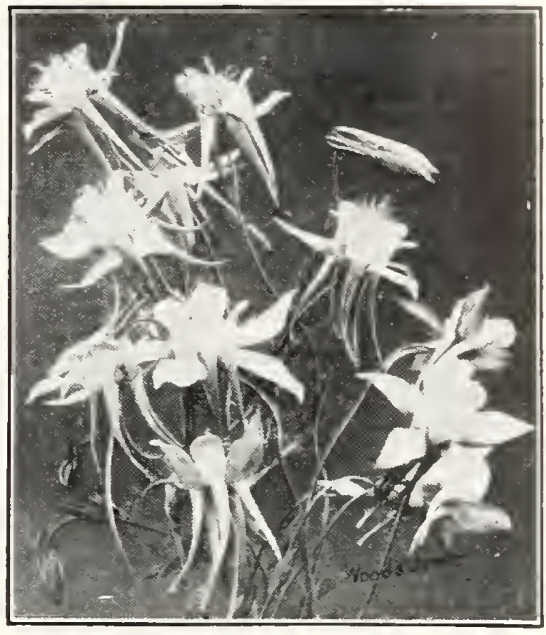

Aquilegla, or Columbine.

Aquilegia (Columbine).-H a r d y perenbearing numberless exquisite b100 $\mathrm{ms}$. No. 594. Long Spurred Hybrids. Mixed colors. Pkt. $10 \mathrm{cts}$; $1 / 8$ oz. $40 \mathrm{cts}$. No. 595. Single Blue, Rocky Mountain No. 596. Mixed Colors-Single and Double. Pkt. 10c; $1 / 4$ oz. $25 \mathrm{c}$

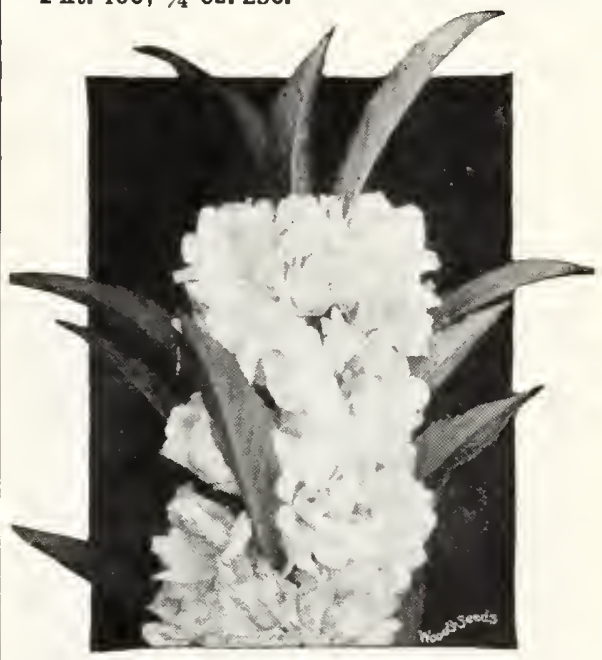

Balsam, or Touch-Me-Not

Balsam (Touch-Me-Not or Lady's Slipper)

and striped. Half hardy annual. Colors.-Pkt. 5c; $1 / 4$ oz. 20c; $1 / 2$ oz. 30c.

No. 646. Balsam Apple

Pkt. $5 \mathrm{c} ; 1 / 2$ oz. $25 \mathrm{c}$; oz. $40 \mathrm{c}$.

No. 650. Begoniavernon. - Fine for boxes, bearing immense quantities of brilliant scarlet blooms; foliage ornaTender perennial. Pkt. 15c; 1-16 oz. 50c.

No. 652. Brachycome (s w a n River flowering dwarf plants for edgings and small beds; bears pretty daisy-like flow-
ers. Half hardy annual. Height, 6 inches. Mixed colors. Pkt. 10c. 
No. 654. Bryonopsis

Pkt. $10 \mathrm{c}$.

BABY'S BREATH-See Gypsophila.

BACHELOR'S B U T T O N S.-See Globe

BELIIS. -

BIACK-EXED SUSAN.-See Thunbergla. BLUE BOTTLE.-See Centaurea cyanus.

BOSTON IVY.-See Ampeiopsis.

BURNING BUSH,-See Kochia.

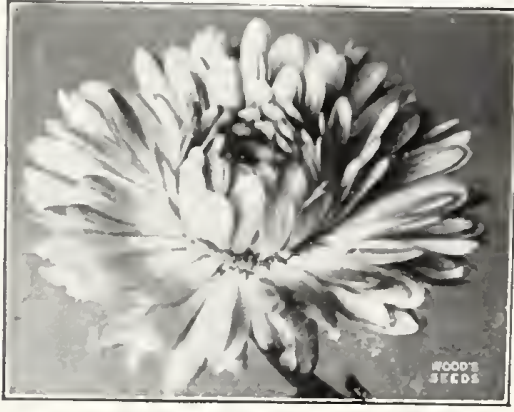

Calendula

Calendula

No. 659. Ball's Orange King.-Very large for lods, borders and cut flowers. Pkt. $10 \mathrm{c} ; 1 / 4$ oz. $25 \mathrm{c} ; 1 / 2$ oz. $40 \mathrm{c}$.

No. 661. Double Iemon Queen.-Long $1,0 z, 15 \mathrm{c} ; 1 / 0 z, 25 \mathrm{c} ; 0 \mathrm{z}, 40 \mathrm{c}$

No. 660. Double-Mixed Varieties. A fine mlxture of all the best varieties; all colors. Plt. $5 \mathrm{c} ; 1 / 2$ oz. $15 \mathrm{c} ;$ oz. $25 \mathrm{c}$.

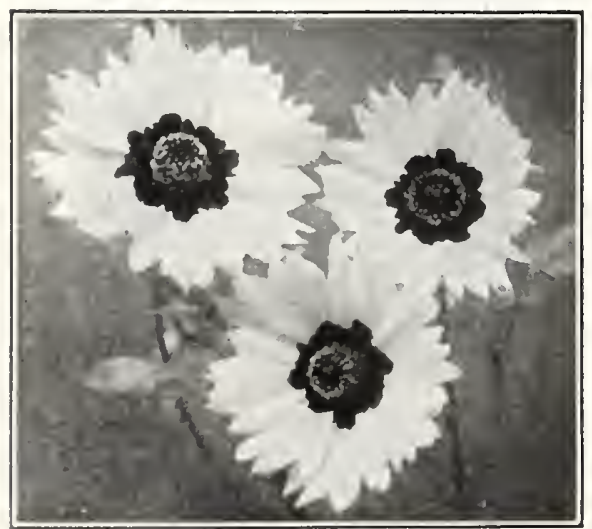

Callopsis or Coreopsis

Calliopsis - Bcautiful annuals. Excellent

To. 665. Crimson. Heisht 6 to 8 inehes. Pkt. $10 \mathrm{c} ; 1 / 4$ Oz. 20.

ITo. 666. Golden Ray.

Pkt. $10 \mathrm{C} ; 1 / 4 \mathrm{Oz} .20 \mathrm{c}$.

ITo.667. All Colors Mixed. Very rieh and

showy. Pkt. 5c; $1 / 20 z .20 \mathrm{c} ; 0 z .35 \mathrm{c}$.
No. 668. Coreopsis Ianceolata.-Bcautiful (')ulikl. Pkt. 10c; $1 / 4$ oz. 25c.

STIMUPIANT. A reil llower fertilizer in 10 tablets $15 \mathrm{c} ; 30$ tablets $25 \mathrm{c}$.

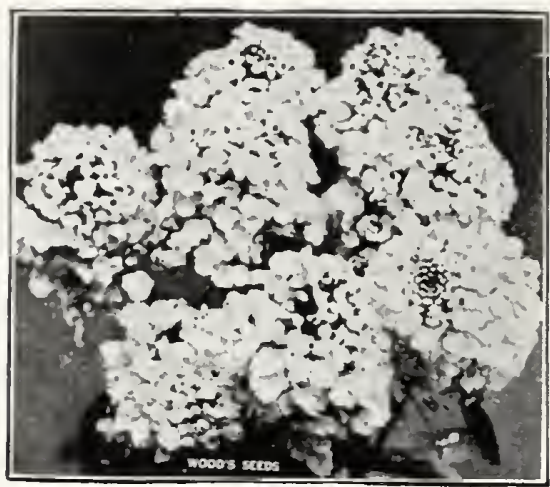

Candytuft.

\section{Candytuft - Ind}

No. 675. Dwarf white,

berlding. Pkt. $10 \mathrm{c} ; 1 / 2$ oz. $25 \mathrm{c}$ Dwarl Fink. Pkt. $10 \mathrm{c} ; 1 / 2$ oz. $25 \mathrm{c}$. . 677. Dwarf Lilac. Pkt. $10 \mathrm{c} ; 1 / 202.25 \mathrm{c}$. 20c; 0z, $30 \mathrm{c}$

No. 679. Giant Empress Hyacinth Flowered.

Makes fine eut flowers, and does exceed-

ingly well in beds and borders: eaeh plant bears several large flower spikes. Height No. 682. Iberis Sempervirens. - IIhite Per cnnial Candytuft. An early and prof

No. 673. Canary Flower $-A$ desirfrowing climber. lellow fringed flowers $1 / 2$ oz. $20 \mathrm{c}$.

Canna (Indian Shot)-Stately, orna-

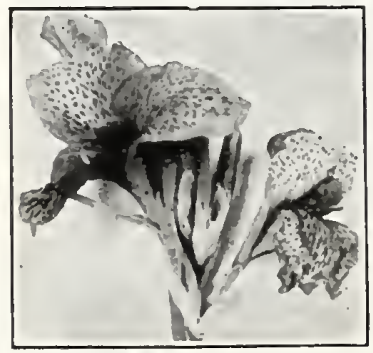

Canna.

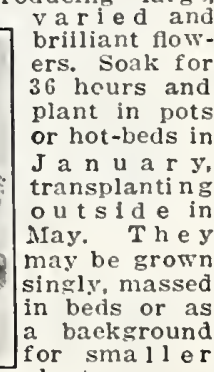
plants.

No. 685. Crozy's Iarge Flowerlng.-A fine the Laren varie tics. Pkt. 10c; oz. 30c.

Canna Roots.-See Bulbs, page 53.

\section{Canterbury}

Bells (Campanu. ha) Bcautiful hardy bicnnials
bearing a prefusion of bel1shaped flowers of exquisite colin a ricin, light scil. Height $21 / 2$ feet.

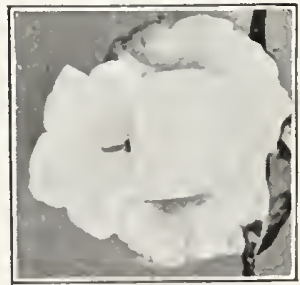

Canterburg Bells.

No. 688. Single.-Mixed colors. Plst. 5c $1 / 4$ Oz. $20 \mathrm{c}$.

No. 689. Double.-Mixed eolors. Pkt. 10c 棺 $02.20 \mathrm{c}$.

No. 703. Catchfly (Suene.)-Compact, linclies high, densely covered with white, plnk and red double flowers. IIardy an-
nual. Pkt. 10c; 1/ oz. 20c.
No. 693. Cardinal Climber - There is climber that for beauty, brillianee and rapidity of grow th can colmpare with Cardinal Climber. Grows 30 feet or more, eovered from midsummer till frost with round fiery, eardinal red flowers, $11 / 2$ inches in diameter, and borne in elusters of 5 to 7 each. Plant in a warm sunny plaee: file or eut a noteh in each seed to insure germination. Plst 15c; $1 / 4$ oz. 40c.

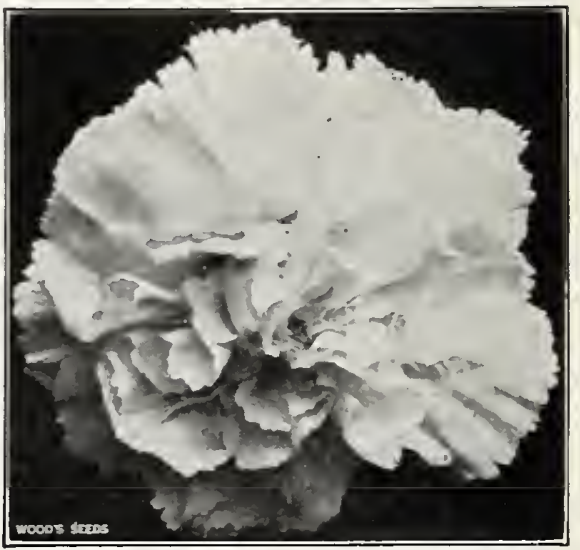

Carnation.

Carnation -General favorites for their sity of eolor. Exeelient bloomers and indispensable for wintcr-flowering. Half

No. 696. Marguerite.-Blooms in four months. Fine for bedding or pots. Dwarf. flowers very profusely; blooms double All colors. Fkt. $10 \mathrm{c}$; $1 / 4$ oz. $35 \mathrm{c}$.

No. 697. Chabaud's Perpetual.-Blooms in five montis, and continucs in greatest profusion indefinitely. Early and hardy. Many colors mixed. Pkt. 15c; 16 oz. 30c. No. 698. Finest German Double Mixed.-A splendid strain for bedding or pots. Pkt. $20 \mathrm{c}, 1 / 0 \mathrm{~s}, 50 \mathrm{c}$

No. 699. Double Carnations Mixed.-A splendid mixture. Pkt. 10c; $1 / 4$ oz. 50c.

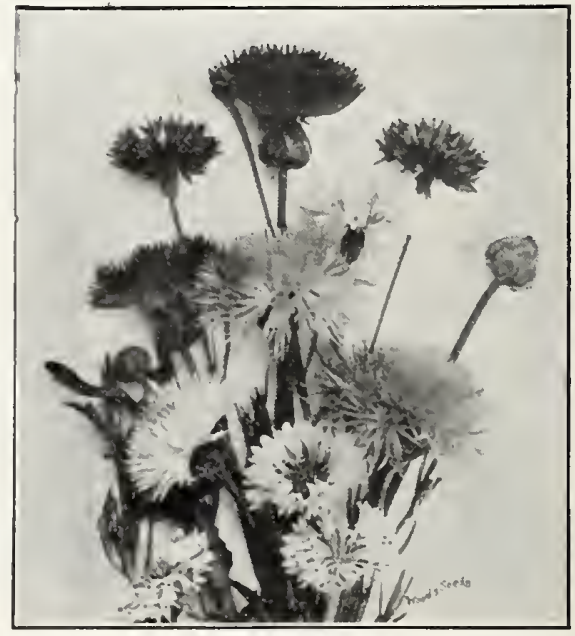

Centarrea-Cornflower or Ragged Robin.

Flowering Centaureas - Universal favflowers; deliciously scented, long stemmed, will last for days. Sometimes called Bachelor's Button. IIardy annual.

No. 711. Cyanus Double Blue.-Pkt. 10c; $1 / 4$ oz. $20 \mathrm{c} ; 1 / 2$ oz. 30c; oz. 50c.

2No. 712. Cyanus Double Mixed Colors.-Pkt. $5 \mathrm{c} ; 1 / 2$ oz. $25 \mathrm{c} ; \mathrm{oz} .40 \mathrm{c}$ 


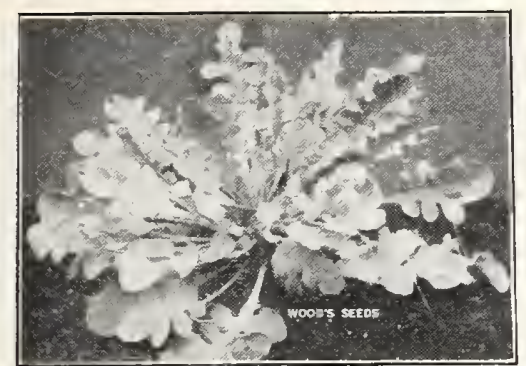

Dusty Miller Centaureas Half hardy for bedding, borders and hanging baskets. No. 706. G y m noc a r pa.-Delicately gracefully drooping, silver foliage. Prt. $5 \mathrm{c} ; 1 / 4$ oz. $20 \mathrm{c} ; 1 / 2$ oz. 35c.

No. 707. Candidissima-Foliage deeply cut; silvery white. Plst. 10c; $1 / 4$ oz. $40 \mathrm{c}$.

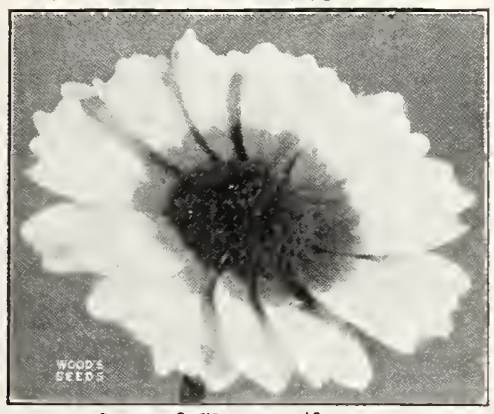

Annual Chrysanthemum

Chrysanthemum - Showy and effective nuals for borders and eut flowers thrifty and free blooming. Height, 1 to $11 / 2$ feet. No. 716. Japanese.-Perennial; bears fantastic incurved double flowers of the
types. All colors mixed. Plt. 15c.

No. 717. Eastern Star. Canary yellow shading deeper toward the base of petals dark brown center: lears profusely for months. Pkt. 10c; $1 / 4$ oz. 20c.

No. 718. Morning Star. - 3 to 4 inches across; deep yellow, shading to a pale sulphur: blooms from early summer till late fall. Splendid for cutting. Hardy annual. Height 10 inches Pkt. 10c; 1/4 oz. 20c. No. 719. Double Mixed Varieties.-Annual

No. 723. Clarkia

A hardy free
blooming, handsome
hardy annual plant
of easy cult re
Blooms throughout
the season in sun or
shade. Height, $11 / 2$
feet. Double mixed
colors. Plt. 5c; $1 / 4$
oz. 20c.

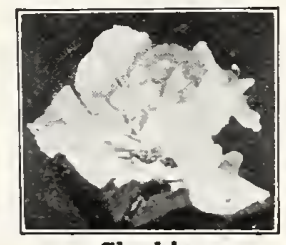
0z. $20 \mathrm{c}$

Clarkfa

No. 726. Clematis Paniculata

-Splendid

hardy perengrowing 12 to growing 12 to covered with a dense mass of pure white star-like fra that bloom for $\mathrm{sev}$ e r a weeks. A fine climber for porches, etc and very easi-

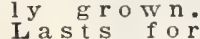
years and is ne v e r trousects. Pkt. 10c; $1 / 4$ oz. $30 \mathrm{c}$.
No. 727. Clematis Flammula - A vigorer with clusters of fragrant white flowNo. 731. Cobaea Scandens (Cathedral best climbers, with fine foliage and large. bell-shaped purple flowers. Grows rapidly, 20 to 30 feet. Plant in the house, outside in May.

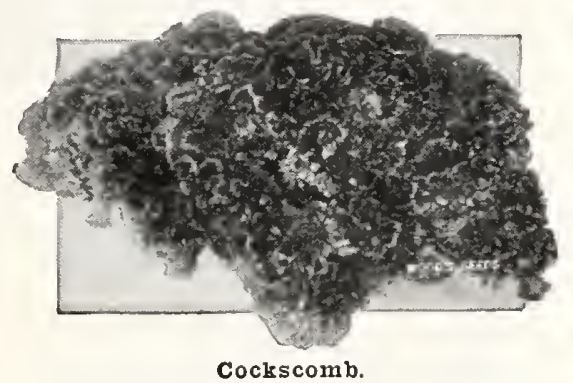

Cockscomb Easily grown annuals, fine plants and for drying for winter bouNo. 735. Celosia or Plumed Cockscomb.Mixed colors. Plt. 5c; $1 / 4$ oz. $20 \mathrm{c}$.

No. 736. Tall Mixed Colors.-Prt. $5 \mathrm{C} ; 1 / 4 \mathrm{oz}$. $25 \mathrm{c}$.

No.737. Dwarf Scarlet.-Pkt. 10c; 1/8 oz. 25c. No. 738. Dwarf Mixed Colors.-Fine for No. 739. Variegated Leaved Cockscomb -Entirely distinct from any other lea orange, green, etc., of the most brilliant with the nearly black-red velvety combs. A dwarf, compact grower, making an elegant bedding and border plant one of the Plt. 10c; 3 pkts. for 25 c.

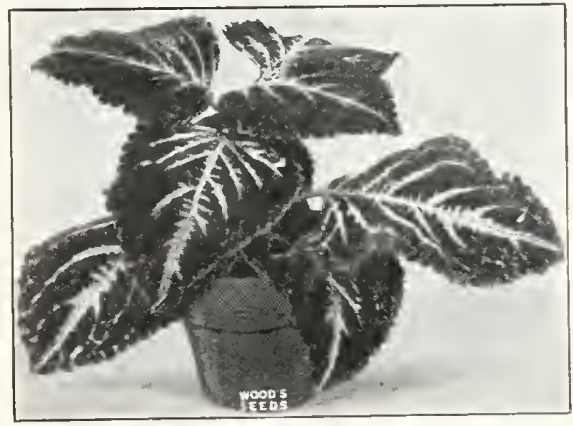

\section{Coleus}

No. 743. Coleus foliage plants. Indispensable for borders and bedding. Sow early indoors and transplant our seeds will produce an endess markings. Radiant Mixture-Plt. $10 \mathrm{c}$ : $1 / 8$ oz. $75 \mathrm{c} ; 1 / 4$ oz. $\$ 1.25$.

No. 744. Coleus Ornatus $\rightarrow S$ u $\mathrm{h}$ dirichness of color combinations ar a thousand, no two would irregularly spotted. marbled with blackish purp Pkt. 20c: 1 \% oz. \$1.25.

No. 745. Coleus Metallicus Thoroughthe leaves are very large, covered with
blisters and present a curious metallic blisters and present a curlous metalle appearance The ground color shades of
rich red bronze and copper. Pkt. 15c.

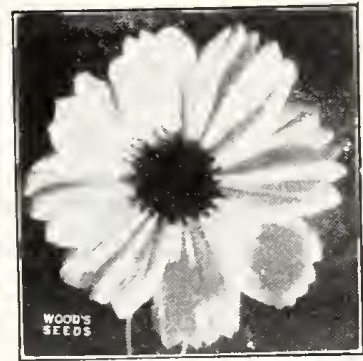

Cosmos eral times when a foot high ind

po. 750. Wood's superb Mixture.

$\mathrm{gr}$

remaining fresh for
$1 / 2$ oz. $30 \mathrm{c}$; oz. $50 \mathrm{c}$.

No. 751. Lady Lenox Giant Cosmos.

$$
\text { ever }
$$

ous, and yields a wealth of
hlooms. Keep a week witho
Plkt. 10c; 1/2 oz. 25c; oz. 40c.
No. 752. Early Flowering. Bcgin

as

est red. Plt. 10c; 1/2 oz. 30c; oz. 50c.
No. 760. Klondye Y 110 w. Gorgeou

in pots till the plants are well

No. 755. Mammoth Pure White Cosmos.Pkt. 5c; $1 / 2$ oz. $25 \mathrm{c} ;$ oz. $40 \mathrm{c}$.

No. 756. Mammoth Pink Cosmos.-Pkt. 5c $1 / 2$ oz. $25 \mathrm{c} ; \mathrm{oz} .40 \mathrm{c}$.

No. 757. Mammoth Deep Crimson-Plst. 5c No. 758. Mixed Cosmos.-A fine mixture o all colors. Pkt. $5 \mathrm{c} ; 1 / 2$ oz. $20 \mathrm{c}$; oz. $35 \mathrm{c}$.

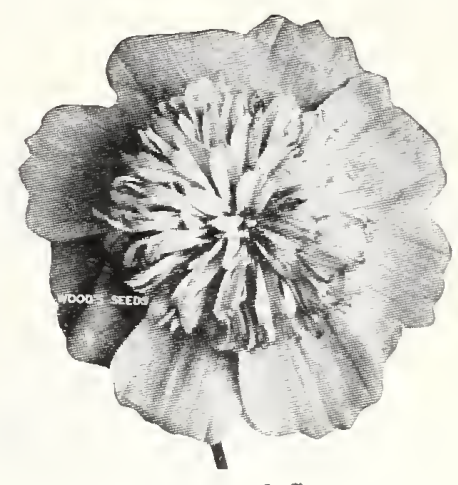

Double Crested Cosmos

Double Crested Cosmos

\author{
er-
ey
$y$
y
ie
4
n,
c;
}


No. 768. Cowslip (Primula veris).Pkt. 10c; 1/6 0z. 50c.

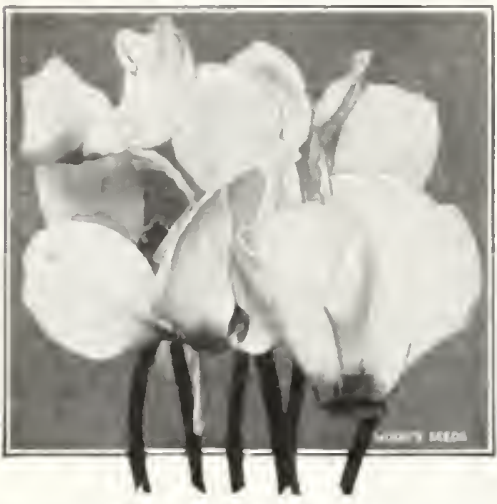

No. 770. Cyclamen

2 pkts. for $25 \mathrm{c}$.

Cypress Vine with

No. 773. White.-Pkt. 10c; $1 / 2$ oz. 20c; oz. 35c. No. 774. Scarlet.-Pkt. 10c; $1 / 2$ oz, 20c; oz. 35c. No. 775. Mixed Colors-Pkt. 5c; 1/2 oz. 20c; oz. $35 \mathrm{c}$.

CAIIFORNIA POPPY.-

CAMPANULA. - See Canterbury Bells.

CASTOR BEAN,

CATHEDRAI BELIS.-See Cobaea.

CELOSIA.

CHINESE BELI FLOWER.-Sce Abutilon

COLUMIBINE.

convorvurus. - See Morning Glory.

COREOPSIS

CORNFLOWER

CUP AND SAU CER.- Sce Canterbury Bell

\section{Dahlia}

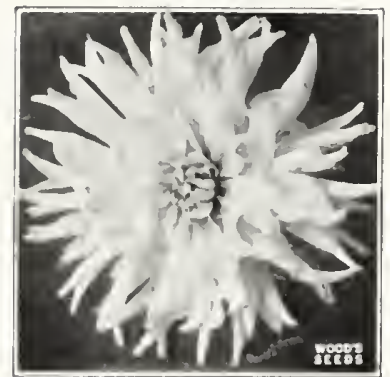

No. 780. Peony Flowered.

Pkt. 10c; 3 oz.

No. 781. Cactus Flowered.

Pkt. 15c; 1/6 oz. 60c.

No. 782. Double Mixed Colors.-All

ing, show and fincy varletles. Pkt No. 783. Single Mixed Colors.-A flne mix-

Plet. $5 \mathrm{c}$; 1 , oz. $25 \mathrm{c}$.

Dahua Bulbs.

53.

Daisy (Bellis perennis monstrosa).-The

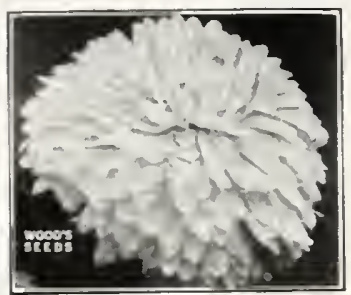

No. 786. Double Pink.-Pkt. 10c; 1/ oz. 40c. No. 787. Double Pure White.-Pkt. 10c: No. 788. Double Mixed Colors-Pkt. 10c; No. 790. African Daisy ( $D$ i in orpho-

Splendidly adapted
Pkt. 10c: 1 oz. $20 \mathrm{c}$.

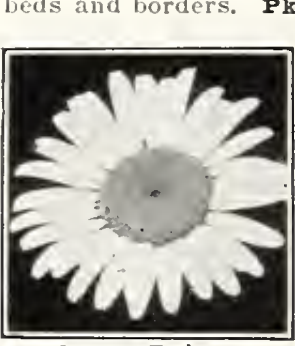

Shasta Daisy

No. 793.

Shasta Daisy Peerfectly $h$ ard y perennials, be aring across. Blooms for months and more freely. flowers remain we e ks after cuting. $\mathbf{P}$ t. $10 \mathrm{c} ; 1 / 8$ oz, $25 \mathrm{c}$.

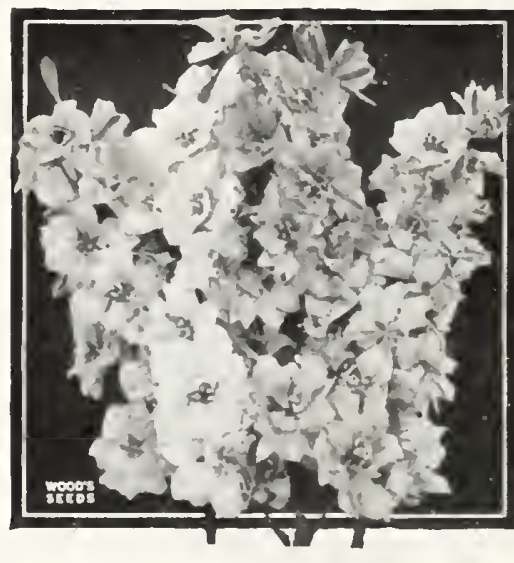

Delphinium

Delphinium Perennial Larkspur.

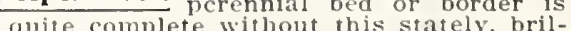

quite complete without this stately bril-

For the earllest blooms, plant in boxes

atcr to a rich, dccply worked soil. They Cut away the old flower spikes after loloomNo. 798. Belladonna-An exquisitc shade of turquolse bluc. Pkt. 20c; 3 pkts. for No. 799. Bellamosa. - Intense rich deep blue. Pkt. 20c; 3 pkts. for $50 \mathrm{c} ; 1, \mathrm{~B}$ oz. $65 \mathrm{c}$ No. 800. Mixed Colors, A fine mis

SWAN RIVER DAISY,-Sce Brachycome. DEVIL-IN-A-BUSF. - Sec Nigella. ETERNAL FIOWER EVENING GIORY.

IVERIASTINGS.-See Acroclinium, Globe Amaranth. Ilellchrysum and Job's Tears

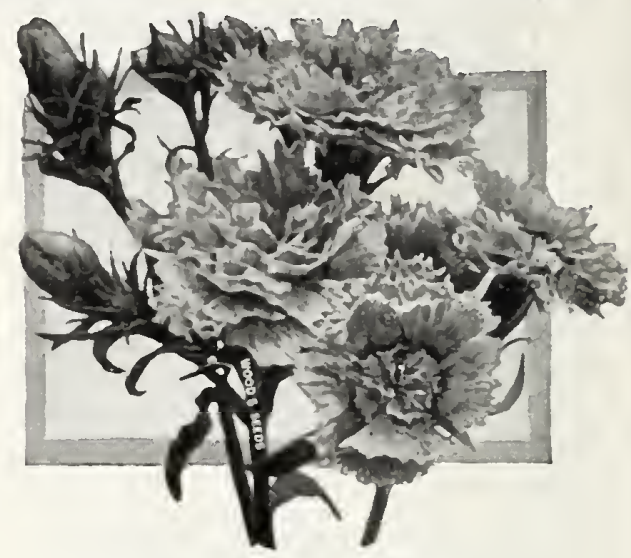

Wood's Superb Dianthus

\section{Dianthus or Pink $\underset{\text { or }}{\rightarrow \text { our }}$ our mos t} highly prized flowers for bedding and cut flowers. Sow early indoors and they will continue flowering the nest year Hardy annual.

WOOD'S SUPERB DIANTHUS M IX T U RE. -A magnificent mixture containing all the best varieties, both double and single, and producing unusually large and brilliant flowers in the fragrance, Pkt. $10 \mathrm{c} ; 1 / 4 \mathrm{oz}, 30 \mathrm{c} ; 1 / 2 \mathrm{Oz}$. 50c. No. 807. Double China or Indlan Pink.Finest colors mixed. Pzt. $5 \mathrm{c} ; 1 / 4$ oz. $20 \mathrm{c}$. No. 808. Double Japan Pink.-Flowers large. Brightest colors mixed. Pkt. 5c; 1/4 oz. $20 \mathrm{c}$ No. 809. Wood's Mixtare of Double Pinks.The very choicest double varieties. Colors Pkt. $5 \mathrm{c} ; 1 / 4$ oz. $25 \mathrm{c} ; 1 / 2$ oz, $40 \mathrm{c}$.

No. 810 . Wood's Mixture of Single Pinks.A mixture of the choicest single varieties. The flowers are handsome, extra 5c; $1 / 402.20 c ; 1 / 202.35 c$.

No. 811. Double Fringed.-Called the Marvelous Pink, because of its large wonderfully fringed double flowers, often 3 to 4 inches across. Bears constantly till frost. Pkt. 10c; $1 / 4$ oz. $30 \mathrm{c}$.

No. 812. Clove Pink. Hardy garden pink. Double and semi-double in many beautlful colors. Pkt. $10 \mathrm{c} ; 1 / 4$ oz. $40 \mathrm{c}$.

No. 813. Fireball-Brilliant scarlet double flower. Splendid for bedding and cut flowers. Pkt. 10c; 1/ oz. 25c.

No. 820. Didiscus (Blue Lace Flower.) irom July till frost. Fine cut flower and pot plant for winter. Hardy annual; 18 inches high. Pkt. 10c; 1, oz. 30c.

Digitalis (Foxglove).stately plants, with ornamental leaves and pendulous flowers.

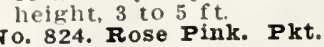
No. 824. Rose Pin.

No. 825 . White. Pkt. $10 \mathrm{c}$; $1 / 4$ oz, 30c.

No. 826. Purple. Pkt. 10c; $1 / 4$ oz. $30 \mathrm{c}$

No. 827. Mixed Colors. Pkt. $10 \mathrm{c}$; $1 / 4$ oz. $25 \mathrm{c}$.

No. 832. Dolichos

(Fyacinth Bean or Jack Bear)-Rapid cllmbers, bearlng large elustcrs of purple and white fowers, follow e d by pkt. 5c;oz. $20 \mathrm{c}$.

Pkt. 5c; oz. 20c.
DUSTY MIIIER. - See Centaurea.

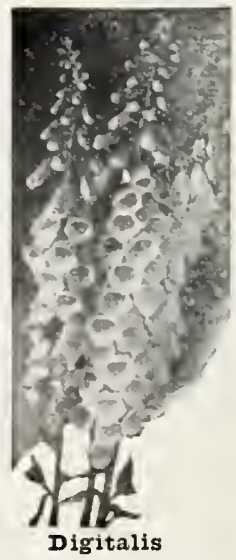




\section{ane The Need for Plant Food exis}

ACH plant, whether
a tiny grass plant or a stately tree, is an individual being with its peculiar complexities. To grow it successfully we must appreciate that in most cases it has been removed from its natural environment and placed under conditions different from those nature intended for it.

Like ourselves, plants are living beings - they breathe,

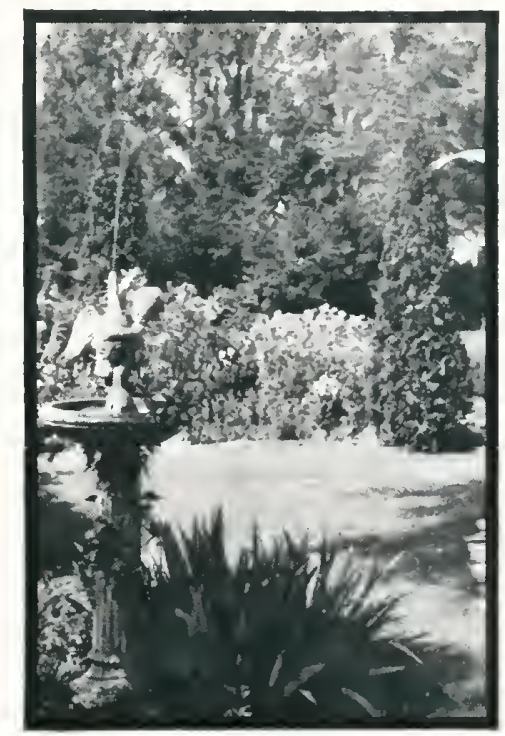
feed, grow, and reproduce.

To do this they must have food, moisture, air, light, and warmth. Anyone can grow them successfully if they provide the vital requisites all life must have.

The best seeds, plants, or bulbs will not grow satisfactorily in an impoverished soil. Failure is usually due to inadequate plant food in the soil. It took nature thousands of years to accumulate the small store of food contained in the few inches of surface soil. This is quickly consumed by growing plants, and unless additional food is supplied growth cannot continue.

\section{The Development of Vigoro}

Recognizing the need for a plant food which would supply all of the elements taken from nature's pantry, Swift $\&$ Company, after years of scienific research, exhaustive growing tests, and comparisons, developed Vigoro, a

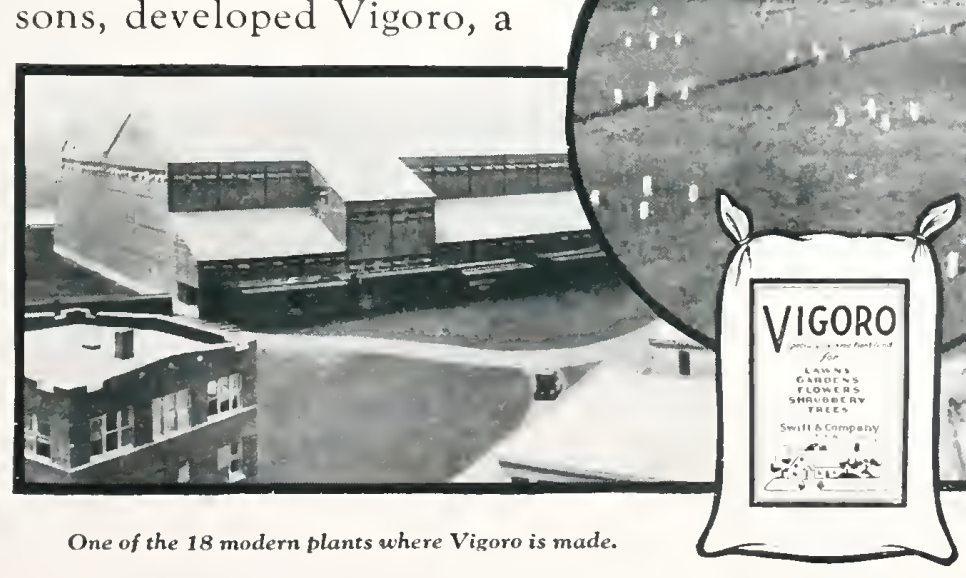

Center-A corner of one of Swift \& Company's experimesual plots. plant food which completely meets these requirements. Vigoro contains every element necessary, each in the right proportion, for full growth and beauty. When Vigoro is used, no other materials are needed. 


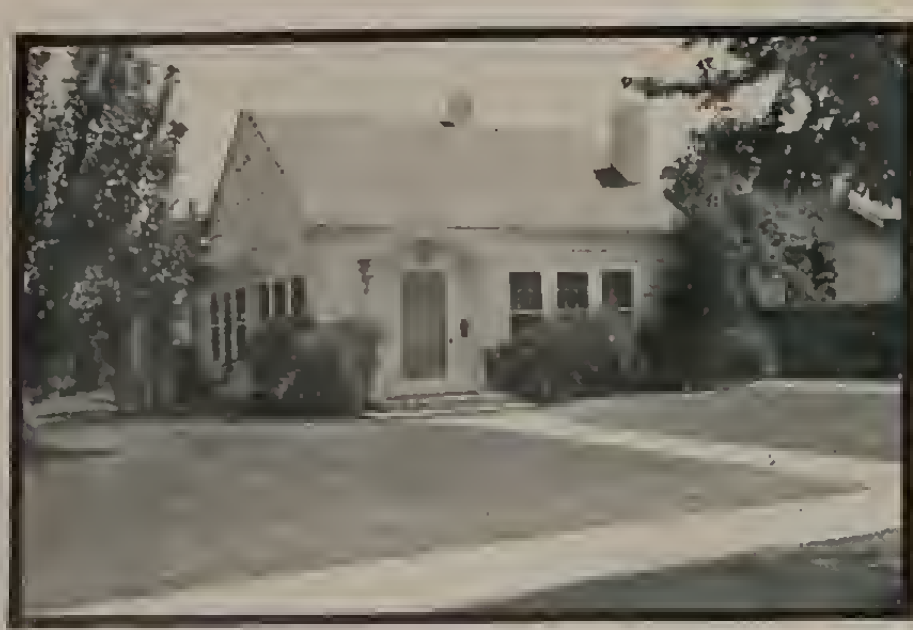

Rich-green, Velvety Lawns

To establish and maintain a beautiful lawn, regular feedin with a complete, balanced plan food is essential. Vigoro pro duces thick, springy turf and deep, extensive roots which choke out weeds and keep new ones fron becoming established. A portion of the abundant root growth produced by Vigoro normally decays each year, depositing humus in the soil, where it is needed. By feeding your lawn with Vigoro in spring, summer, and fall, you can season.

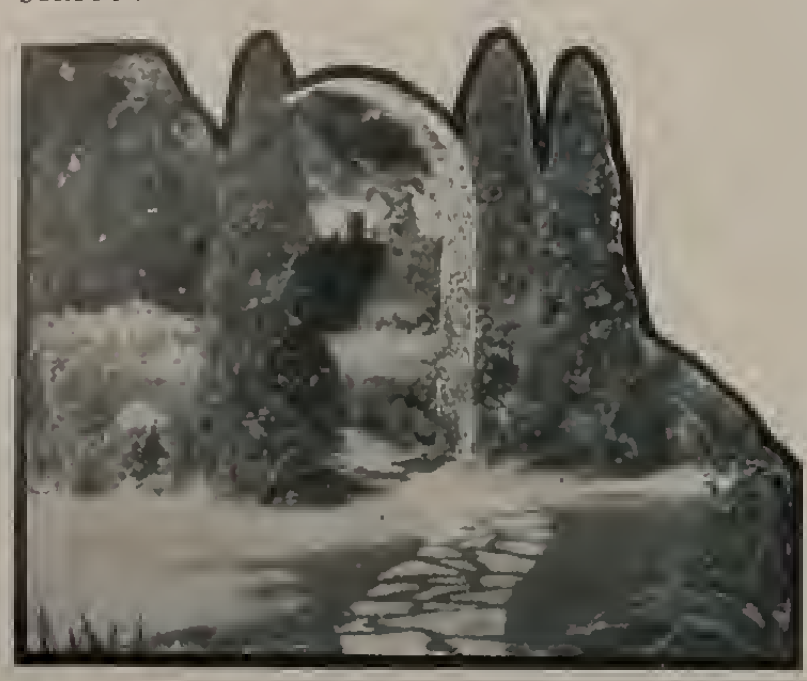

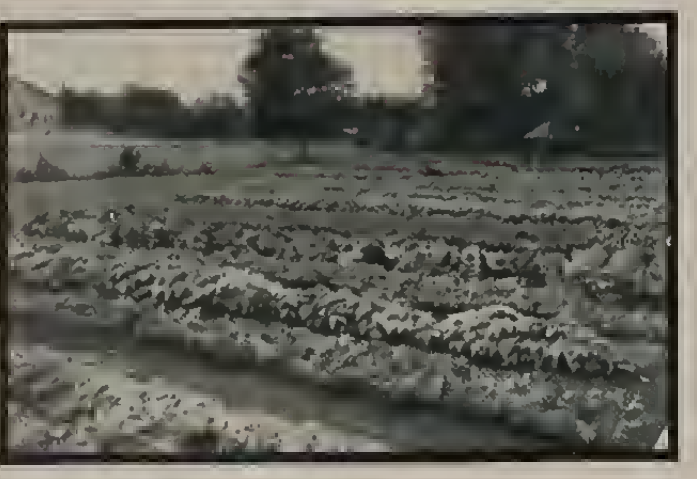

Early, Delicious Vegetables

A portion of the home grounds should be devoted to a vegetable garden. There are no other vegetables like those garden-fresh ones you grow yourself, and it's surprising how much food you can raise on a small plot. Vegetables are heavy feeders, and failure in growing them is usually due to a lack of plant food in the soil. Feed your vcgetables Vigoro nd they will be larger and better avored, crisper, and will mature much earlier. Work Vigoro into he soil at planting time and feed them again when they are half grown.

\section{All Plants Must Be Fed}

plants by their spindling stalks, yellowish and undersized leaves, It is sometimes too late to save plants when these symptom appear because they often fall victims of disease when they are in such a weakened condition. Avoid these symptoms by following a regular feeding program with Vigoro, the complete plant food. and poorly developed blossoms.
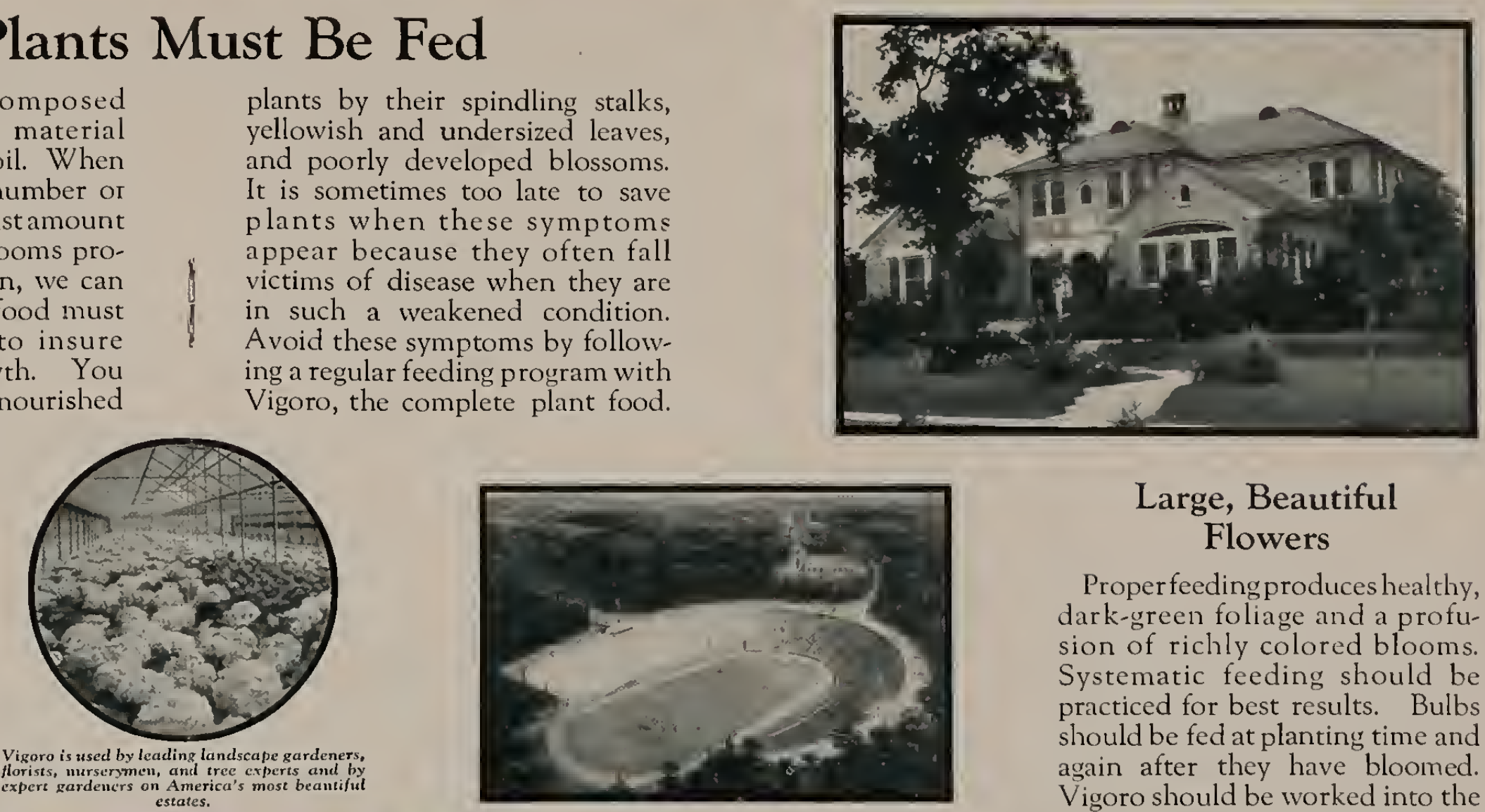

Luxuriant Shrubbery and Trees neglect than any other plants about the home. They are often planted in excavated soil from basements or forced to live with a portion of their root systems aperlaid with cement walks or overlaid with centront walks or pavens. Evill if properly fill gow and thrive if properly fed and watered. An application of Vigoro once each year is ordinarily sufficient for trees. Shrubs should be fed in early spring and again in late summer or early fall. Feeding them with Vigoro will produce and growth. Systematic feeding should be Perennials should be fed each year
Trees and shrubs are probably subjected to more abuse and maintain healthy, luxuriant
Large, Beautiful Flowers

Properfeeding produces healthy, dark-green foliage and a profusion of richly colored blooms. practiced for best results. Bulbs should be fed at planting time and again after they have bloomed. Vigoro should be worked into the soil before annuals and perennials are planted. Annuals should be fed again when buds appear. in early spring, summer, and early in early spring, summer, and early fall. Vigoro supplies all the fullest expression of their beauty.

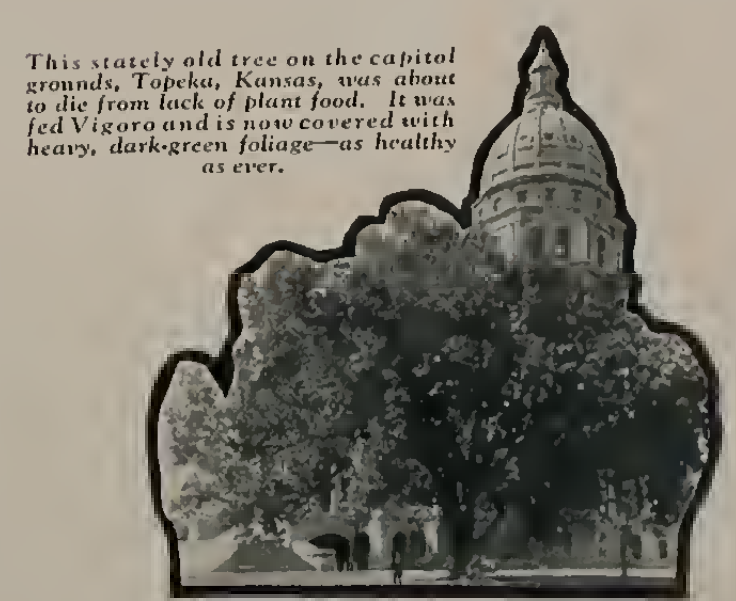
(a) 


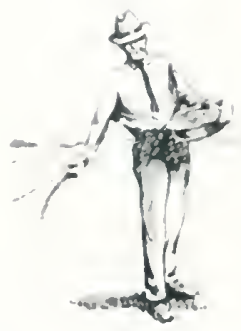

rowing by hand like grass neced.

\section{Vigoro Is Easy to Use

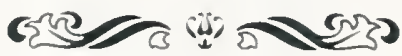

This illustrates method of broadcasting V'igoro on areas to he planted and of feeding established lawns. Four pounds should be applied evenly to every 100 square feet before seeds are sown and worked into the surface soil. On established lawns apply two to four pounds to every 100 square feet when the grass is dry, and soak it into the soil.

Vigoro should be mixed with the sail in the bottom of the hole or trench before planting shruhs, young trees, and other large plants; and in the bottom of the trench hefore planting bulbs, tubers, etc. Mix a level teaspoonful of Vigoro with each quart of soil in the bottom of the hole or trench, and the same amount with each quart of soil used in filling the hole or trench.

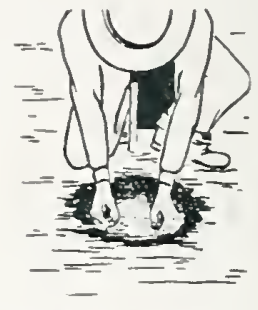

Mix Vigoro with soil in bottom of the hole or trench before planting.

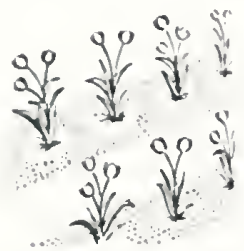

Applying alongside of row on both sider.

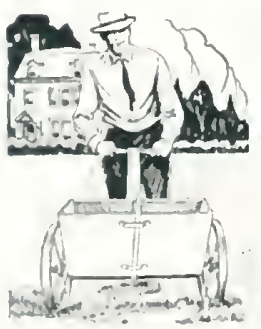

The Viguro Spreader saves time and insures uniform distribution.
This method is used in feeding vegetables, flowers, hedges, and other plants grown in row's. Two pounds of Vigoro should be applicd to every 50 feet of row and worked lightly into the soil on both sides and around the plants.
Feed shrubs, specimen plants, regetables grown in hills, etc., this way. Apply Vigoro in a circle starting a few inches away from the trunk or stem and extending out as far as the branches extend; then work it lightly into the soil.

\section{(3)}

The Vigoro Spreader applies Vigoro evenly and accurately, saves time and waste of plant food, and insures best results. It is especially valuable on large lawns but its many uses all year round and its very low cost make it an excellent investment for those with small grounds. There are three sizes for different-sized lawns.
To feed trees make holes under the drip of branches as illustrated here. Half fill the holes with Vigoro; then water and fill the holes with soil. Use one pound of Vigoro to each inch of circumference of the trunk of the tree, measuring it four feet above the ground.

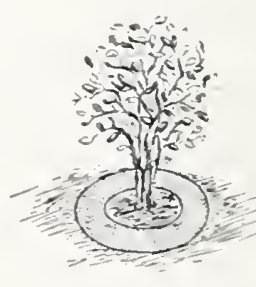

Applying Vigoro around the plant.

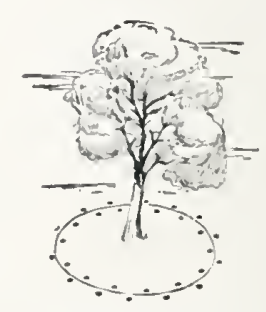

Mcthod of feeding established trees.

The Vigoro Spreader is made in three different sizes for different recjuirements. Ask us for descriptive folder and prices.

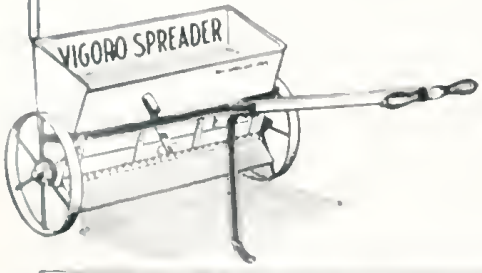

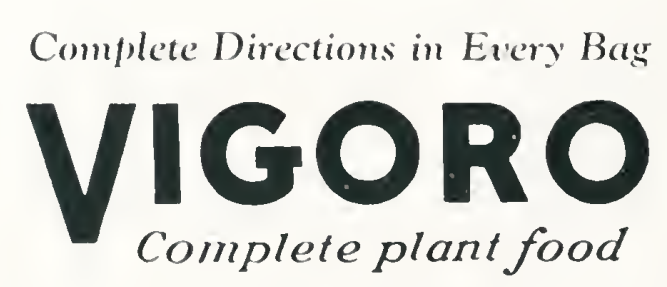

A product of Suift $\mathcal{B}$ Company
Prices

100-16. bag - $\$ 5.00$ $50-1 \mathrm{~b}$. bag -3.00 $25-\mathrm{lb}$. bag - 1.75 5-lb. pkg. - . .50 12-0z. pkg. - - . 10 Freighe will be al. lowed on 100 pounds. Prices on other sizes f. o. b. Richmond.

For Launs, Gardens, Flowers, Shrubbery, and Trees

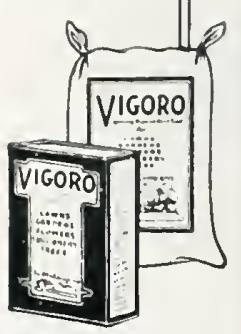




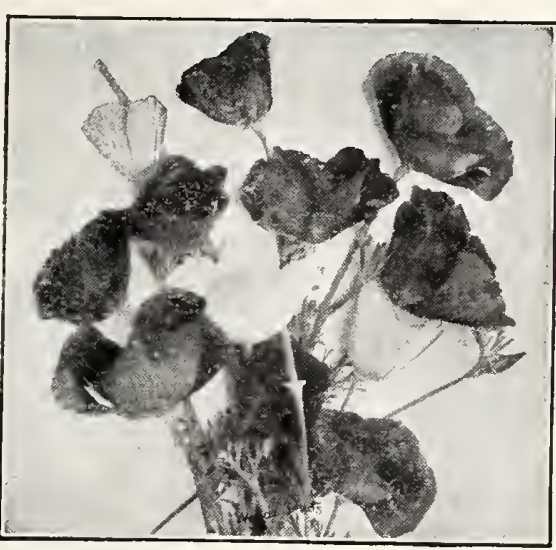

Escholtzla or California Poppy

Escholtzia (Callfornia P opp g).-Easily bright, poppy-shaped flowers from ucing till frost. A bed in full bloom makes a brilliant effect.

No. 835. Scarlet Beauty. Pkt. 10c; $1 / 4$ oz. 25c. No. 836. Golden West. Pkt. 10c; $1 / 2$ oz. $20 \mathrm{c}$. No. 837. All colors mixed. Prt. 5c; $1 / 2$ oz. $20 \mathrm{c}$; 0z. 30c.

No. 840. Bush Escholtzia, or Hunnemannia (Santa Barbara Poppy).-Bears large cup-shaped yellow flowers 3 inches across, on 12 -inch stems; the petals are crinkled like crushed satin; will keep for two weeks. Plt. 5c; $1 / 4$ oz. 20 .

Ferns - Decorative p lan t s ; keep moist. Tender perennial. Plst. isc.

No. 849. Feverfew $-\mathrm{Fr}$ e flowering succeeding in any garden soil, blooming till frost. Splendid for bedding and cut
flowers. White flower. Prt. 5c; $1 / 4$ oz. $20 c$. Forget-Me-Not (Myosotis)-Highly masses. If sown early will bloom the first season. Height, 6 to 9 inches. Hardy perennial.

No. 852. Rose Pink. Pkt. 10c; $1 / 8$ oz. $20 \mathrm{c}$. No. 853. Deep Blue, Plrt $10 \mathrm{c} ; 1 / 8$ oz. $20 \mathrm{c}$. No. 855. Mixed Colors. Pkt. 5c; $3 / 4$ 0z. $25 \mathrm{C}$

FIAX.-See Linum.

FLOSS FIOWER.-See Ageratum.

FOUNTAIN PLANT.-See Amaranthus. Four O'CLOCK.- See Marvel of Peru. FOXGIOVE.-See Digitalis.

Gaillardia Blanket -Showy and free blooming, remarkable. for the brilliancy, profusion ers, continuing in bloom all summer. Fine for bedding. borders and cutting

To. 860 . Grandiflora. - Hardy perennial; gorgeous flowers,

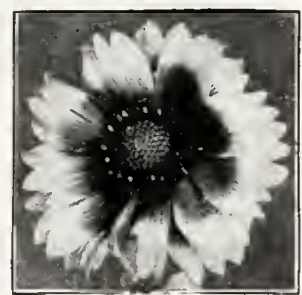

Gaillardia

across. Splendid for permanent beds and cutting. Pkt. 10c; $1 / 4$ oz. $25 \mathrm{c}$

No. 861. Mixed Colors. The most varied colors. Hardy annual. Pkt. 5c; $1 / 4$ oz. $20 \mathrm{c}$

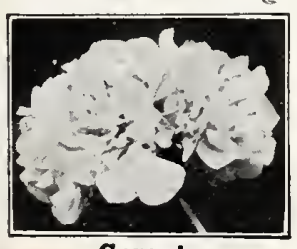

Geranium

\section{Geranium}

-There is no pot and bedding plant more popular. cession of bloom till frost, and then make a splendid house plant. The flowers are of

No. 866. Geum Mrs. Brad shaw. - Peren-

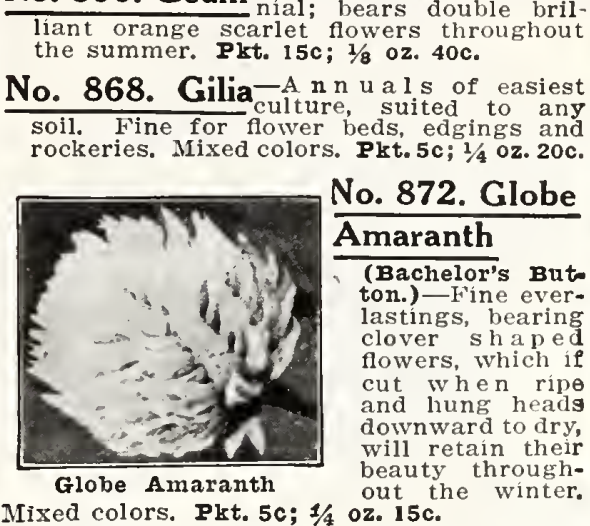

No. 875. Godetia -Showy and at-

annuals bearing an abundance of satiny cup shappecially if grown in poor dry soil: blooms continuously if the seed moved a re reearly in the spring, in a sunny place and cover one-fourth

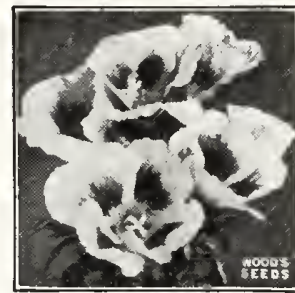

Godetia inch deep, One foot high. Mixed Colors.
Pkt. 5c; $1 / 2$ oz. 20c.

Gypsophila (Baby's Breath). Yields graceful sprays of pure white starshaped flowers; a fine cut flower and useNo. 878. Perennial. Plt. $10 \mathrm{c} ; 3 / 4$ oz. $20 \mathrm{c}$. No. 879. Annual. Prt. 5c; $1 / 2$ oz. $15 \mathrm{c} ;$ oz. $25 \mathrm{c}$.

GIIITLOWER-See Stocks.

GOMPHRENA.-See Globe Amaranth. GOURDS.-See page 20.

\section{Helichrysum}

(Strawflower or sternal Flower). - Everlasting; cut wh en about to open and dry for winter bouquets; many colors. For drying, cut the flowers when partly open with as long stems as possible. H a r dy annual. 2 feet high.

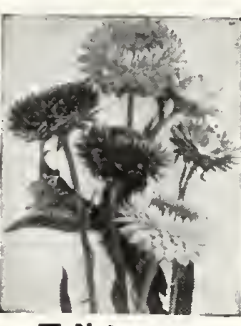

No. 884. Fireball. Scarlet. Pkt. 10c; $1 / 4$ oz

No. 885. Golden Ball. Pkt. 10c; $1 / 4$ oz. $25 \mathrm{c}$. No. 886. Mixed Colors. Plat. 5c; $1 / 4$ oz. $20 \mathrm{c}$.

\section{Hibiscus}

(Mallow Ma r. vel or Marsh. mallow) -From June till frost, these hardy ants bear big. blooms, of ten 6 inches across, the colors rangand shades of

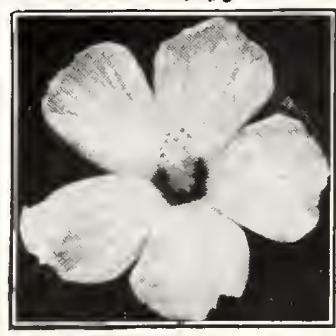

Mallow Marvel or Hibiscus No. 897. Mallow Marvels Mixed. Pkt. 10c; $1 / 4$ oz. $25 \mathrm{c}$.

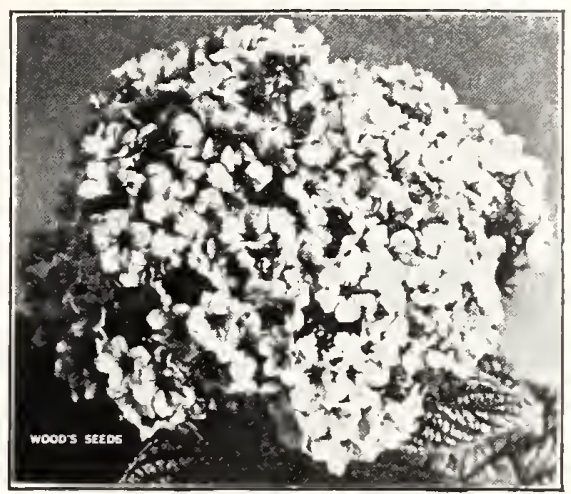

Heliotrope

\section{Heliotrope} feet.

No. 890. Iemoine's Giant.-Flowers double the size of older sorts. Pkt. 15c. Pkt. 10c. No. 891. Blue. -The deepest hite. Prt. 10c. No. 892. White. Spotless White. Plrt. 10c. No. 893. Mixed Colors.-Many
colors. Pkt. 10c; $1 / 8$ oz. 25c.

\section{Hollyhock}

\section{PERENNIAI HOLIYHOCKS}

No. 902. Double White. Plt. 10c; $1 / 4$ oz. 35c. No. 903. Double Pink. Plkt. $10 \mathrm{c} ; 1 / 4$ 0z. 35c. No. 904. Double Yellow. Prt. 10c; $1 / 4$ oz. 35c. No. 905. Double Scarlet. Pkt. 10c; 1/4 oz. 35c. No. 908. Double Mixed Colors. Pkt. 10c; Tro.

Aliegheny Hollyhocks.-The nearcrushed satin: seldom less than s incles across. Pkt. 10c; $1 / 4$ oz. 35 c.

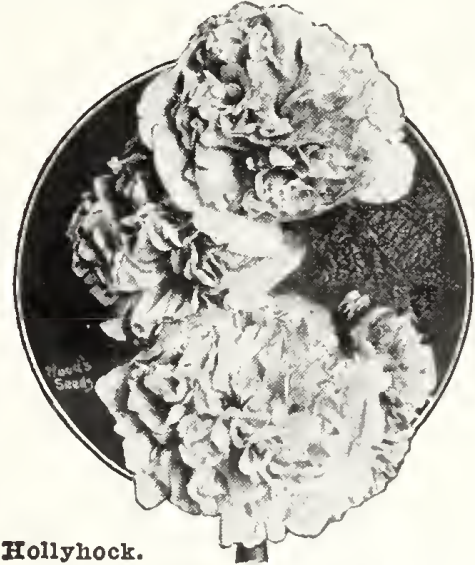

ANNUAI HOLIYHOCKS

August

frost in wonderftil $1 / 8$ oz. $25 \mathrm{c} ; 1 / 4$ oz, $40 \mathrm{c}$

No. 911. Single Everblooming.-Pkt. 5c $1 / 4$ oz. $20 \mathrm{c} ; 1 / 2$ oz. $30 \mathrm{c}$

No. 916. Humulus Japonicus (Japanese grown hardy annual climher, growing 15 to 20 feet Fine for covering porches, trellises and unsightly places. Pkt. Ec; $1 / 4$ Oz. $15 \mathrm{c}$. 
HELUANTHUS.

HUNNEMANLA.

HYACINTH BEAM.

No. 919. Ice Plant-

crles. Pkt. 5c; $1 / 402.15 \mathrm{c} ; 1 / 2$ oz. $25 \mathrm{c}$.

INDIAN SHOT.

I POMEA GRANDIFLORA,-See Moon-

IPOMEA QUAMOCIIT.-

IPOMEA SETOSA

IVY, JAPANESE or BOSTON.-See Ampe-

IVY, KENIIWORTH.

JACK AND THE BEAN STALK. - See

JACK BEAN. - See Dolichos.

No. 923. Job's Tears Orna m e ntal

ing for winter bouquets. liant early in

hlll. Helglit, 3 feet. Pkt. 5c; oz. $20 \mathrm{c}$.
No. 926. Kenilworth Ivy and $\mathrm{n}$ eharm-

boxes, baskets and roekeries. Lavender
and purple flower. Pkt. 10c; 1/8 oz. 25c.

No. 929. Kochia or Burning Bush

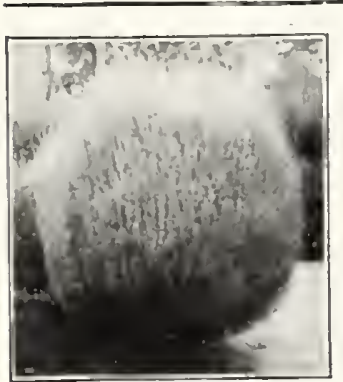

- (Mexican Fire

Fochla

growing, highly

nual formin:

perfeet pyramids

high, eovered

green branehes
whieh in the fal

turn to a deep

hedge. Thin out

to 18 ins. alpart. $15 \mathrm{c}$; oz. $25 \mathrm{c}$.

No. 933. Kudzu Vine $\underset{B \text { Jan }}{\text { Jack and the }}$.

vine of wonterful growth; at-

$3 / 4$ oz. $20 \mathrm{c} ; 1 / 2$ oz. $35 \mathrm{c}$.

Larkspur ( $A$ in n a 1

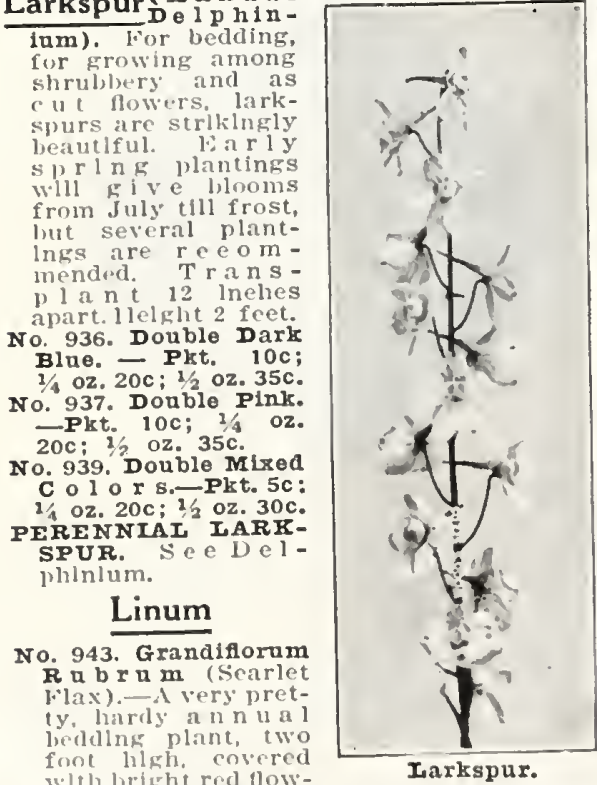

ers. Pkt. $5 \mathrm{c} ; 1 / 2$ oz. $15 c$.
No. 945 . Perennial Blue.

Iarkspur.

Pkt.

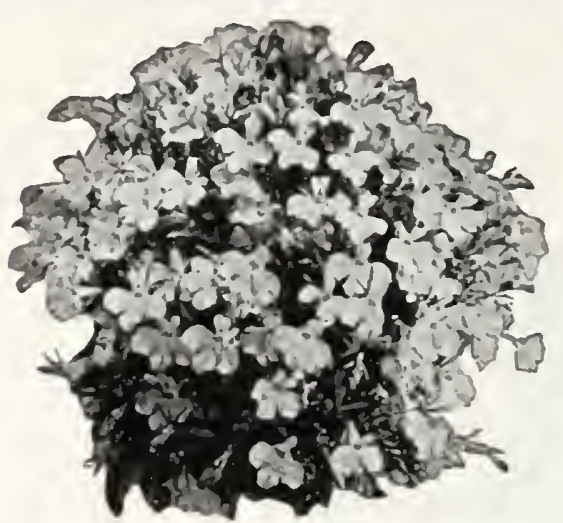

No. 948. Lobelia

and roekeries; ver

Pkt. 10c; $3 / 8$ 02. $25 \mathrm{c} ; 3 / 4$ oz. $40 \mathrm{c}$.

Lupins nuals and perennials.

\section{ANNUAI VARIETIES}

No. 952.-Blue. Pkt. 5c; $1 / 2$ O2. $15 \mathrm{c}$.

No. 955. Mixed Colors. Pkt. 5c: $1 / 2$
PERENNIAL VARIETIES

No. 956. -Blue. Prt. 10c; 1/4 02. 20c.

No. 957. Mixed Colors.-Pkt. 10c; $1 / 2$ oz. $25 \mathrm{c}$.

LACE FLOWER.-See Didiseus.

LADY'S SIIPPER.-See Balsam.

IATHYRUS IATIFOLIUS.-See Perennial

LOVE GROVE.-See Nemophila

LOVE IN A MIST.-See Nigella.

LOVE-IN-A-PUTF. - See Balloon Vine.

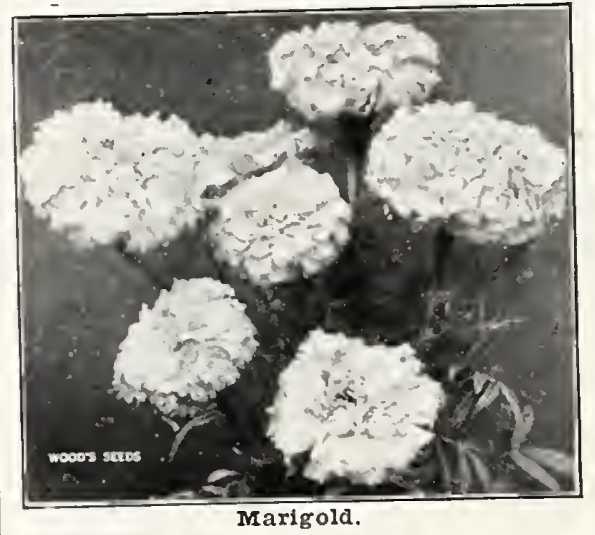

\section{Marigold}

No. 973. Marvel of Peru (rour

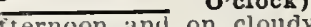
day. Flowers showy and in great profusion Hardy annual. Height 2 feet. Mixed eolors. Pkt. 5c; oz. 20c.

No. 985. Mimulus or Musk Plant.-An plant for hanging baskets, window-boxes. etc.; bright musk-scented foliage; numerMoonflower

(Evening Glory).-

elimbers with luxu-

rlant foliage; the

blooms, 4 to 6 inehes

in diameter, open in

eloudy days. Grows

30 feet or more. File

a hole in the sceds

hasten germination.

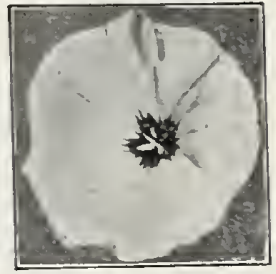

Moonflowe
No. 988. Grandiflora. - Bears hundreds of pure white fragrant flowers 5 to 6 inelues No. 989. Heavenly Blue.-A bout 15 feet hlgh, with exquisite azure blue flowers
that shade to white at the eenter. Pkt. 10c; $1 / 2$ oz. $40 \mathrm{c}$.

FLOWERING MAPLE.-See Abutilon. MARGUERITES.-See Carnation. POT MARIGOID.-See Calendula.

MARSHMALLOW.-See Hibiseus. MEXICAN FIRE PIANT.-See Koehia. IIIMOSA.-See Sensitive Plant. MOMORDICA.-See Balsam Apple and Pear. MOURNING BRIDE.-See Seabiosa. MYOSOTIS.-See Forget-Me-Not.

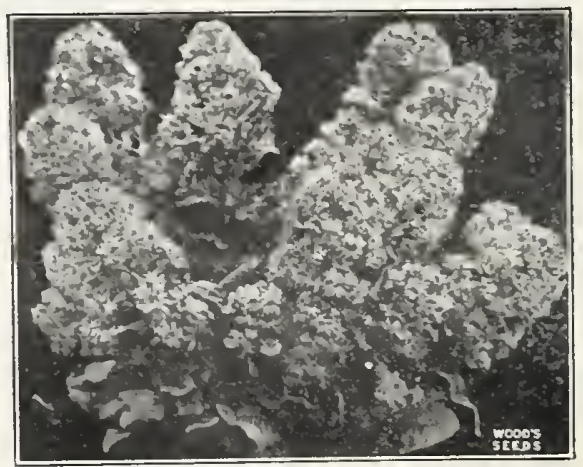

Wood's Superb Mignonette.

Mignonette Beginning in March, sow at intervals outside for a succession: in late summer sow
in pots or boxes for winter blooming. l'refers a cool location. Thin out to six inehes apart. Hardy annual. One foot high.

No. 976. Wood's Superb Mixture plant in boxes and transplant 18 inehes No. 960. African Double orange.-Pkt. 10c; No. 961 . African Double Lemon Queen. Pkt. $10 \mathrm{c} ; 1 / 4$ oz. $25 \mathrm{c}$.

No. 964. African Double Mixed.-All the $20 \mathrm{c}$.

No. 966. French Double Golden Ball.-Helght 1 foot. Pkt. $10 \mathrm{c}$ : $3 / 4$ oz. $25 \mathrm{c}$.

No. 968. Frencl Double Mixed.-A mlxtur No. 969. Miniature Marigold. Snlendid for beddin bedding, borders and pots. 6 inehes aeross plants 4 to 6 lnches $h l g h, 6$ inehes aeross,
covered wlith perfeetly double variegated
fowers. Pkt. 10c; $1 / 4$ oz. 30c.
- Made up of the newest and best sorts, all shades of color and varieties which produce the largest flower-spiles, some 12
to 15 inelies long. Deliciously fragrant. Pkt. 10c; $3 / 4$ oz. 20c; $1 / 2$ 02. 35c.

No. 977. Defiance.-Delieiously fragrant; fine for eutting, kepping fresh for days: flower spikes remarkably large. Pkt, 10=; $1 / 4$ oz. $20 \mathrm{c} ; 3 / 2$ oz. $30 \mathrm{c}$.

No. 978. Machet.-Bears massive spikes of very fragrant red flowers. Pkt. 10c; $1 / 40 z$. 20c; $1 / 2$ 02. $30 \mathrm{c}$. No. 982 . Sweet Mignonette.-Fragrant; large 


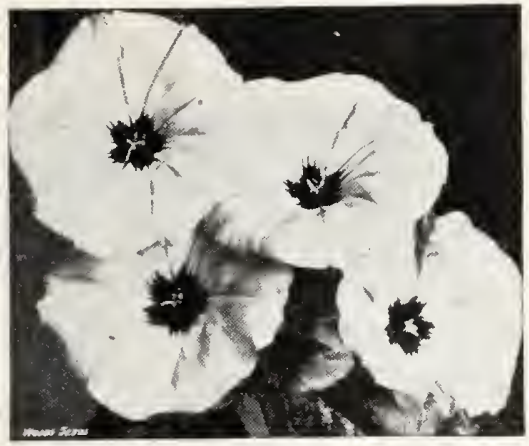

\section{Morning Glories}

No. 993. Brazilian (Ipomea setosa).-A luxuriant annual, growing 30 to 40 feet, and makes a thick shade. The flower ful rose color. Excellent for porches or arbors, covering an enormous space in a short time. Plat. 10c.; oz. 40c

No. 994. Morning Glory (Convolvulus).-All colors mixed. Pkt. 5c; oz, 15c.

No. 995. Bush Morning Glory. Tivelve inches high, peculiarly adapted for bedding, pot and window culture; blooms profusely. Mixed colors, Pkt. 5c; oz. 20c.

No. 1054. Nicotiana (Flowering Towith bloom all summer and fall: flowering a few weeks after sowing. Pkt. 10c; 1/8 oz.

No. 1061. Oxalis $\rightarrow$ Splendid lit t le colored flowers, for hanging-baskets, rockwork or edgings. Half hardy perennial. Pkt. 10c; $1 / 8$ oz. $40 \mathrm{c}$.

\section{JAPANESE MORNING GLORIES}

One of the grandest climbers, the flowers measuring 4 to 6 inches across in limitless variety of colors. The foliage is ornamental vivid mottled and checkered, some rich, yellow. Soak 24 hours before planting.

No. 998. Double Japanese.-Bears a wealth of blocm nearly all double. Pkt. 10c $1 / 8$ oz. $30 \mathrm{c}$.

No. 999. Fancy Fringed Japanese.-The flowers are as big as saucers, ruffled from fowers are as big as Plt. 10c; $1 / 2$ oz. 20c; oz. 35c.

No. 1000. Single Imperial Japanese.-The original variety. The wonderful colorings of both flowers and foliage

scription. Pkt. 5c; oz. 25c.

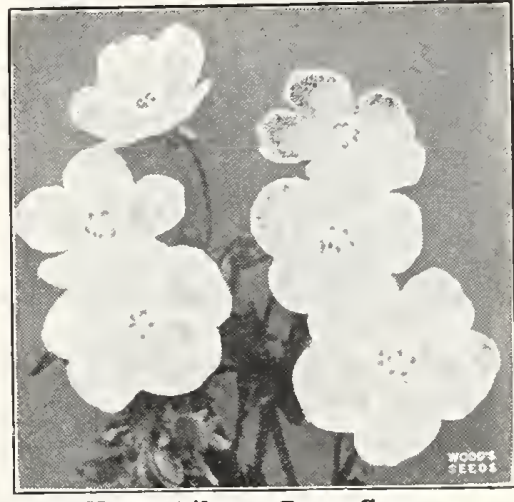

Nemophila or Iove Grove.

No. 1050. Nemophila (Iove Grove.)annual, 6 inches high, bearing its bright flowers in great profusion. Easily grown. Pkt. 10c; $1 / 4$ 0z. 25 c.

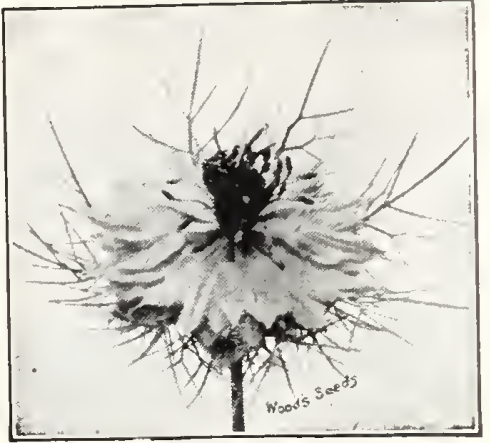

Nig'ella

No. 1058. Nigella (Love - In - a - Mist, or 1058. Nigella Devil - in - a - Bush.)Handsome flower, requiring but little care. Flowers bright and showy. Hardy
annual Height, 1 foot. IIixed colors, Pkt $5 \mathrm{c} ; 1 / 2 \mathrm{oz} .15 \mathrm{c}$.

No. 1088. Ornamental Pepper

-As a pot plant for house decoration during the winter, it is most effective and as easily grown as garden peppers. The blooms arc followed by innumerable bright scarlet berry-like fruits in the most wona lon profusion. The berries reir beauty and attractiveness. Pkt. $10 \mathrm{c}$.

CINOTHERA.-See Primrese (Evening) PAIMA ChRISTI.-See Ricinus. PELARGONIUM.-See Geranium.

PERIWINRIE.-See Vinca.

No. 1085. Passion Flower - Splendid annual climbers, be a ring attractive fringed flowers; derives its name from its resemblance to a cross. Height, 10 feet. Pkt. $10 \mathrm{c} ; 1 / 8$ oz. 25c。

\section{Wood's Peerless Nasturtiums}

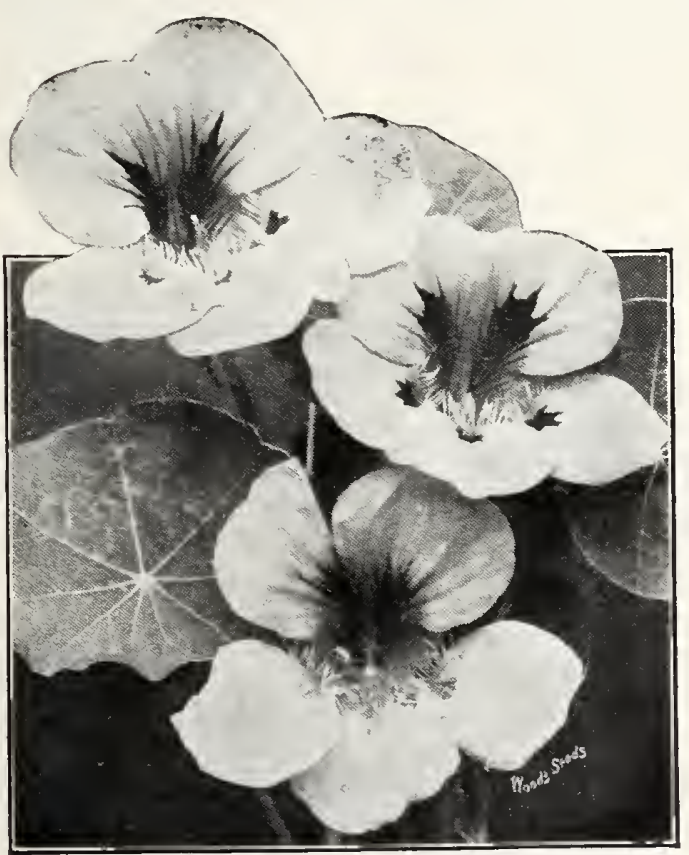

Wood's Peerless Kasturtiums

No annual will produce such a lavish profusion of blooms for so long a time, and such variety and brilliance of color as Nasturtiums. They bloom best in poor soil, the richer the soil the fewer the blooms. Hardy annual.

Wood's Peerless Mixtures We have put into these mixtures the est varieties of distinct merit. The colors vary from pearly white to almost black; every intermediate color is represented, giving the richest combination of colors ever offered in Nasturtiums.

No. 1010. Dwarf Peerless Mixture-Pkt. 10c; 0z. 20c; 1/4 1b. 50c; 1b. $\$ 1.50$ postpaid.

No. 1030. Tall Peerless Mixture.-PIt. 10c; oz. 20c; 1/4 1b. 50c; Ib. $\$ 1.50$ postpaid.

All Varieties offered below, unless otherwise quoted: Pkt. 5c; oz. 15c; $1 / 4$ Ib. 40c; 1b. $\$ 1.25$, postpaid.

Dwarf or Tom Thumb Nasturtiums

No. 1012. Chameleon.

No. 1014. Dark Scarlet (dark leaved).

No. 1015. Golden Yellow.

No.1016. Ivy Ieaved.

No. 1018. Creamy white.

No. 1019. Bright Rose.

No. 1020. Ruby Red.

No. 1021. Variegated Leaved.

Pltt. $10 \mathrm{c} ; 0 \mathrm{z} .20 \mathrm{c} ; 1 / 4$ 1b. $50 \mathrm{c}$.

\section{NASTURTTUM MIXTURES}

No. 1025. Dwarf, Mixed Colors. Pit. 5c; oz. 10c; $1 / 4$ 1b. 30c; 1b. $\$ 1.00$ postpaid. postpaid.

No. 1044. Lobb's Trailing Nasturtiums Flowers and foliage smaller more free flowering, more intensely brilliant and varied. Mixed colors. Pkt. 5c; 0z. 15c; $1 / 4$ Ib. $40 \mathrm{c}$; Ib. $\$ 1.25$ postpaid. 


\section{Wood's Royal Pansies}

Saved from plants selected for the leapty

Giant Pansies in Separate Colors TRIMARDEAU STRAINS

Each, pkt. 10c; 1/8 0z. 450; 1/4 0z. 75c.

No. 1064. Cardinal-Brillant brownish red

No. 1065. Emperor Frederick.-Dark red, with

No. 1066. Falry Queen.-Sky blue, with pure No. 1067. Faust, or sing of the Blacks.-Large No. 1068. Fire King.-Golden yellow, the upper No. 1069. Light Blue.-Lovely shade of sky i) iue. with dark eye; very dainty. No. 1070. Iord Beaconsfield.-The lower petals to white, tinted with purple in the upper petals. No. 1071. Snow Queen.-Beautiful, large, pure white; flowers

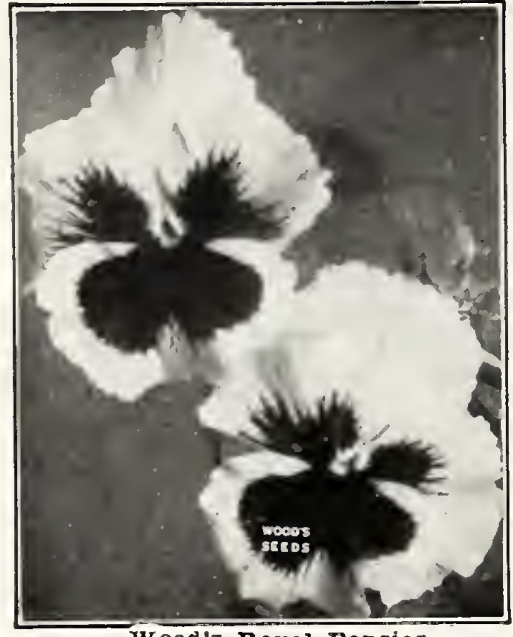

wood's Royal Pansies.

\section{Pansy Mixtures}

No. 1075. Wood's Royal Pansy Mixture.-A magnifieent mixture exeelling in an endless variety of the richest eolors. It eontains every conceivable color and eolor combination found in pansies. The blooms are large and of perfect form. Prt. 10c; $1 / 8$ oz. 50c; $1 / 4$ oz. $85 \mathrm{c} ; 1 / 2$ oz. $\$ 1.50 ;$ oz. $\$ 2.50$.

No. 1076. Wood's Ixhibition Pansy Mixture.The ricliest and liandsomest pansy mixture, obtain. The blooms average 2 to 3 inches across, of every imakinalle pansy eolor and combination of colors in endless variety. Pkt. $25 \mathrm{c} ; 3$ pkts. 60 c; $1 / 8$ oz. $\$ 1.00$.

No. 1077. Wood's Superb Frilled Pansy.-Each petal is frilled or curled, giving the appearance of a double pansy. This unusual formation adds reatly to its keeping quality. Pkt. 20c; 3 pkts. for 50c; $1 / 8$ oz. $85 \mathrm{c}$.

No. 1078. Giant Trimardeau Mixture.-A distinct strain with remarkably large blooms, generally marked With large blotches: the $35 \mathrm{c} ; 1 / 4 \mathrm{Oz}$. $65 \mathrm{c} ; 1 / 2 \mathrm{oz}$. $\$ 1.15$.

No. 1079. Irarge Flowering Mixed Pansies.-A rery superior mixture of all colors; rich and beautiful. Pkt. 5c; $1 / 4$ oz. 35c; $1 / 2$ oz. 60c.

No. 1080. TUFTED PANSIES (Viola Cornnta).-Not as large as the regular pansy, but have longer stems and bloom throughfrost. Mixed colors. Prt. $10 \mathrm{c} ; 1 / 4$ oz. $65 \mathrm{c}$.

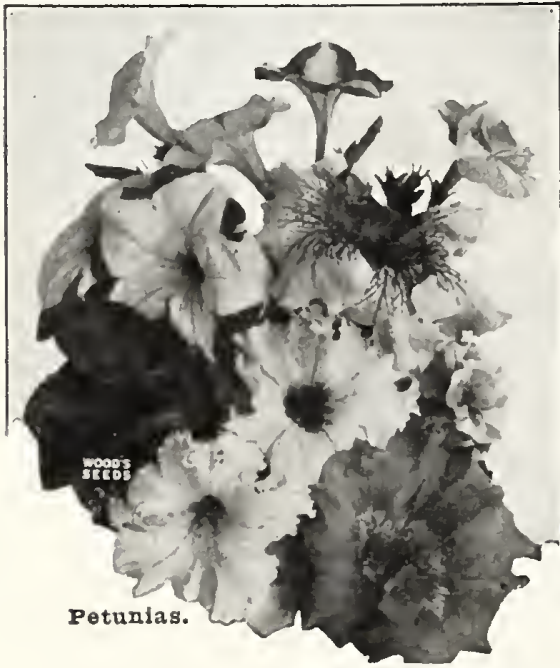

\section{PHLOX DRUMMONDII}

their many and brillantly eolored flowers. Sown in the open ground in the early spring No. 1115. Large Flowering Dwarf.-Fine for pots, bedding and borders. Brilliant in No. 116 d profuse in bloom. Height 6 inches. Mixed colors. Pkt. 10c; 1/8 0z. 35c. of the inost varied colors, distinctly with white. Flower's fringed. Pkt. 10c; 1/6 oz. $25 \mathrm{c}$.

Grandiflora Phlox LARGE FLowering.-Rcmarkable not only for the brillare as the ordinary phlox. Our laree-

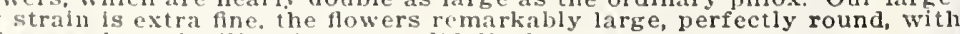
No. 1123. Grandiflora Pure White,-Pkt. 10c; 1/4 oz. 40c.

No. II24. Grandiflora Rose Pink - Plet. 10c; $1 / 402,40 c$

No. 1125. Grandiflora Scarlet.-Pkt. 10c; 1 ; Oz, 40c.

No. 1129. Wood's Grandiflora Phlox Mixture -A splendid mixture most brillant large-flowering varieties, the colors being well balanced. Pkt. 10c; 1/ 0z. 30c: $1 / 2$ oz. $55 \mathrm{c} ;$ oz. $\$ 1.00$

No. 1119. MIXED PHIOX. - A mixture of all colors to be found in phlox. The blooms are not ats litree as

\section{PETUNIA} No annual will give a greater profusion of bloom with so little care than petunias.
plant in a sunny position and they will bloom till frost. Grow them in pots, beds, borwar and porch boxes. For early flowers sow in boxes and transplant when weather is BAICONY PETUNIAS. - The dwarf plants are a mass of bloom throughout the summer. No. 1110. Balcony Mixed Colors. Each of above, pkt. $15 \mathrm{c} ; 2$ pkts. for $25 \mathrm{c} ; 1-16$ oz. $50 \mathrm{c}$.

1095. Wood's Superb Fringed Petunias. -The blooms are of ten 4 to 5 inches across, 1096. Wood's Bedding Petunias.-A splendid strain. Bred especially for bedding. The Se, bushy plants grow only eight inches high, blooming so profusely as to fairly hide No. 1097. Royal Purple.-Rich velvety purple or nearly blood red. Pkt. 10c; 16 oz. 50c.

1098. Rosy Morn.-Bears hundreds of rich, lasting blooms; brilliant rose color, with throats. Fine for beds and pots. Prt. 10c; 1/8 oz. 50c.

1102. Double Petunias.-A splendid strain. producing a large percentage of double flowers in bright colors, beautifully marked. Pkt. 30c.

No. 1103. Single Petunias. A choice mixture of all colors. Pkt. 5c; 1/4 0z. 35c; 1/2 0z. 60c.

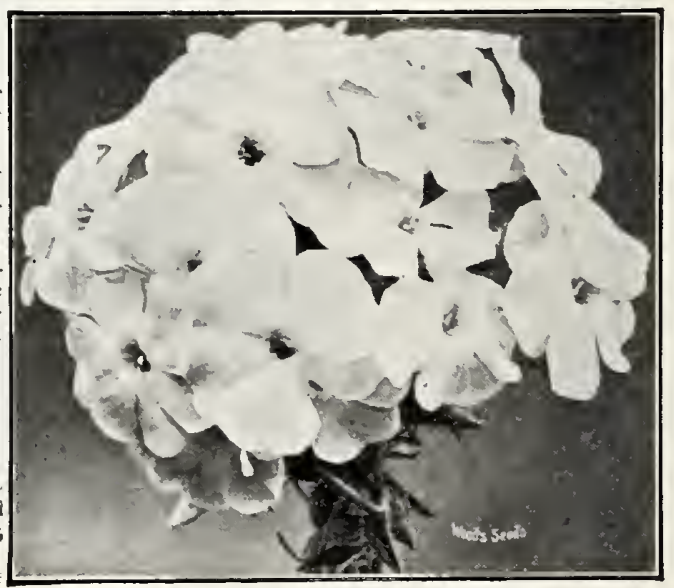

Wood's Grandiflora Phlox 


\section{Poppies}

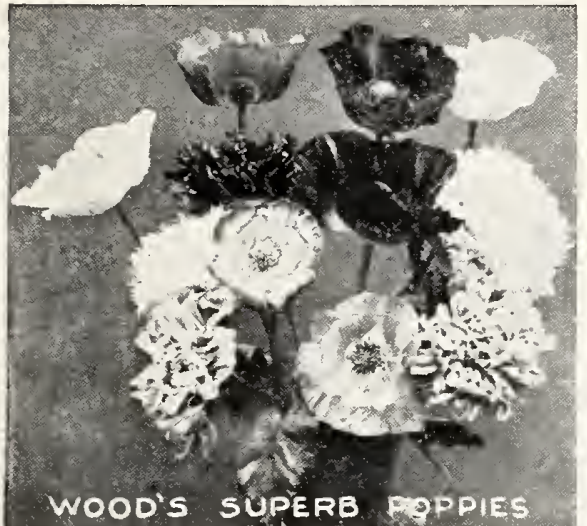

No. 1140. Wood's Superb Poppy Mixture -A grand mixture of all the gle annual poppies, all varieties and every color. The wonderful variety and brilliant $10 \mathrm{c} ; 1 / 2$ oz. $25 \mathrm{c}$; oz. $40 \mathrm{c}$.

\section{PERENNIAL POPPIES}

No. 1151. Iceland.-Resembles crushed satin; blooms continually from June to Oc3 to 4 years following. All colors mixed.
3 to Pkt. $10 \mathrm{c}$; $1 / 8$ oz. $20 \mathrm{c} ; 1 / 4$ oz. $35 \mathrm{c}$.

ORIENTAI POPPIES - In spectacular display they are only rivaled by the finest No. 1150. Oriental Mixed Colors.Pkt. 10c; $1 / 8$ oz. $20 \mathrm{c}$.

No. 1152. Oriental Pink.-Pkt. 15c; $1 / 8$ oz. 35c.

\section{Portulaca}

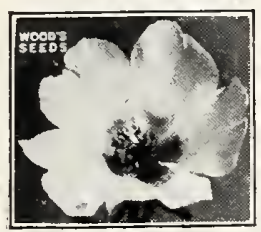

(MOSS FIOWER).

situation and produces fowers of al niost every color in great profusion. The deuble is especially weather is settled warm. Tender anNo. 1155. Single Mixed Colors.-Pkt. $5 \mathrm{c}$ $1 / 4$ oz, 20c: $1 / 20 z, 35 c$

No. 1156. Double Mixed Colors.-P rt. 10c; $1 / 8$ oz. $30 \mathrm{c} ; 1 / 4$ oz. 500 .

Primrose Chinese Primroses are among dow plants the finest winter flowering winsplendid for mixed bordeng

No. 1161. Primula Sinensis (Chinese Primrose).-Large flower, beautifully fringed and borne in great profusion. Sow in May or June, transplanting to pots. Mixed cclors. Pkt. 20c; 3 pkts. for pot

No. 1162. Evening Primrose. The 50c. known English Primrose. Flowers large, showe and fragrant. Pkt. 10c; 1 . large, PRIMUIA vERIs. - See Cowslip.

Pyrethrum -Golden Feather is fine for daisy-shap edging beds. Roseum bears for cut flowers. No. 1165. Golden foliage with white flowers: usually grown as an annual. 8 inches. Plt. 5c; $1 / 4$ grown No. 1166. Roseum (Painted Daisy)-Bright Nose pink. Ht. 2 feet. Pkt. $15 \mathrm{c} ; 1 / 8$ oz. $30 \mathrm{c}$. No. 1168. Ricinus (Castor Bean.) plants with palm-like leaves. Fine for backgrounds and centers for beds. Pkt. 5c; Oz. $15 \mathrm{c} ; 1 / 4 \mathrm{lb} .50 \mathrm{c}$.

RAGGED ROBIN.-See Centaurea Cyanus. ROCK CRESS.-See Arabis.
Hardy annuals and perennials of quick growth and easy culture, yielding a wealth of gorgeous bloom

where they are to bloom may be transplanted. Barely cover the seeds and press the soil firmly. Sow early in the spring, at intervals during the sumthe flowers regularly to insure a long blooming season.

\section{ANNUAL POPPIES}

No. 1141. Special Mixed Single Poppies.Contains only select varieties that will give a dazzling display of colors. Pkt. 5c; $1 / 2$ oz. 15c; oz. $25 \mathrm{c}$.

No. 1142. Special Mixed Double Poppies.An elegant collection into which we have put only those that will produce flowers colors. Pkt. 5c; $1 / 2$ oz. 15c; oz. 25c.

No. 1143. Flanders Poppy.-Vivid scarlet: sistent bloomers. Pkt. 10c; $1 / 4$ oz. $20 \mathrm{c}$.

No. 1144. Tulip.-Large single bright scarlet flowers; as dazzling as scarlet tulips massed beds. Pkt. 10c; $1 / 4$ oz. $20 \mathrm{c}$.

No. 1145. Shirley.-Remarkably brilliant and free-flowering. Range from pale rose to $1 / 4 \mathrm{oz} .15 \mathrm{c} ; 1 / 2 \mathrm{oz} .25 \mathrm{c}$.

No. 1146. Double Carnation-Flowered.-A magnificent fringed poppy of dazzling $1 / 2$ oz. 15c.

No. 1147. Double Peony-Flowered.-Splend large flow Mixed colors. Pkt. 5c; $1 / 2$ oz. 15 c

California Poppy.-See Escholtzia.

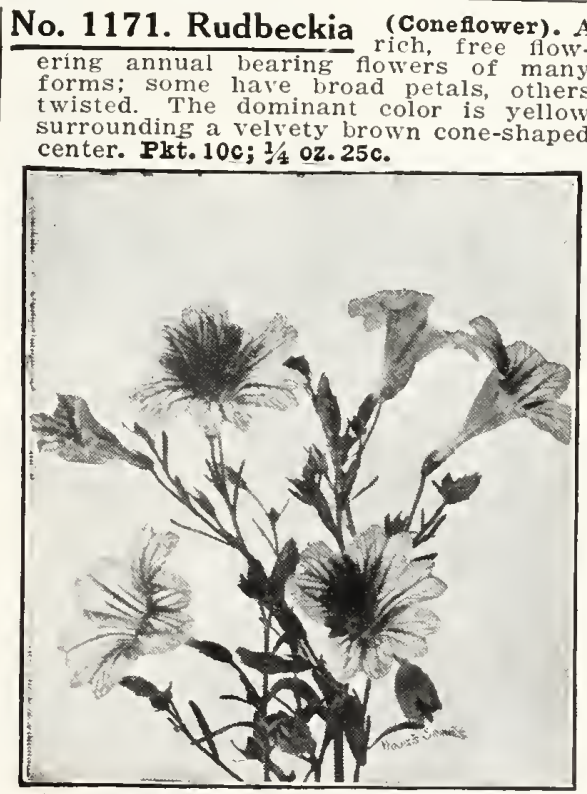

Salpiglossis or Painted Tongue

No. 1174. Salpiglossis - It w o u $1 \mathrm{~d}$ bed and border than salpiglossis with its richly colored, funnel-shaped flowersscarlet, crimson, yellow, buff, purple and blue-black. Sow indoors in February or March or outside later. Half hardy an
nual; height, 2 feet. Pkt. 10c; $1 / 4$ oz. 35c.

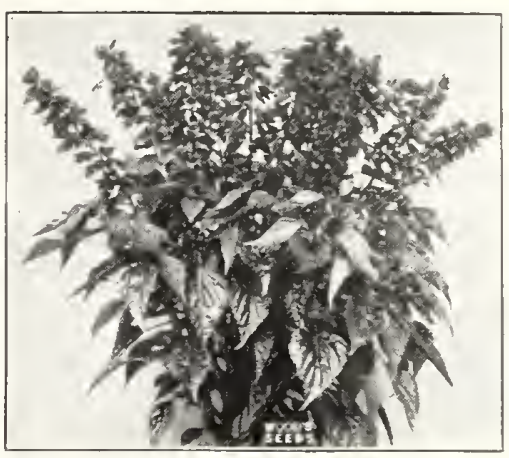

\section{SALVIA OR SCARLET SAGE}

A standard bedding and border plant.

No. 1179. Fireball or tense scarlet flowers. Plet. 15c; $1 / 8$ oz. No. 1180. Splendens (Scarlet Sage).-The standard variety. Pkt. 10c; $1 / 8$ oz. 30c; No. 1181. Salvia Patens.-Intense bright blue; extra large fl

SCARIET RUNNERS.

Scabiosa (Mourning Bride).-The longstemmed double blooms make

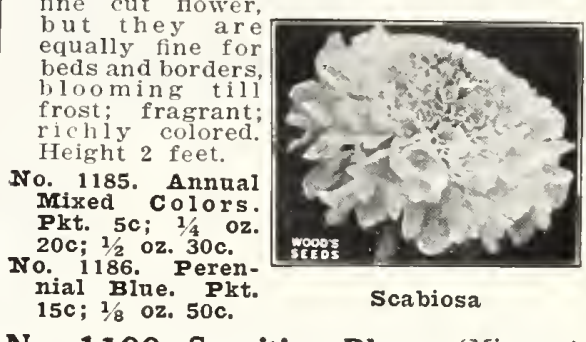

No. 1190. Sensitive Plant (Mimosa). plants with graceful and elegant foll-
age. The branches and leaves when ouched drool in a most interesting man ner. Easily grown. Tender
Height, I foot. Pkt. 5c; 1/4 oz. 20c.

No. 1193. Smilax

for days without witting. Soak for a
day and sow in a box in liarch and keep
moist. Slow to germinate. Plt. 10c; 1/4 oz
20c; $1 / 2$ oz. 30c. No. 1196 . Snow on the Mountain

-An exceedingly ornamental plant for
mixed border or as a background for low
growing plants. The foliage is light
green with white margin. 2 feet high
Hardy annual. Pkt. 10 ; $1 / 4$ oz. 20 c.

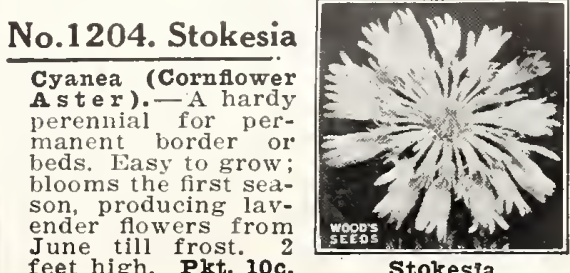




\section{Stocks}

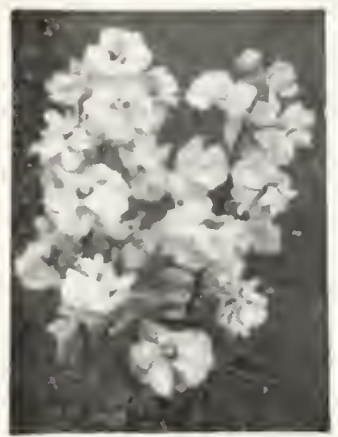

No. 1199. Cut-and Come-Again, or Princess Alice.

Stocks

olors. Pkt.10c No. 1200. Large Flowering Ten Weeks

Pkt. $10 \mathrm{c}$; 1's oz. $30 \mathrm{c}$; 1/4 oz. $50 \mathrm{c}$.

No. 1216. Sweet Rocket (Hesperis).

Pkt. 5c; $1 / 4$ oz. 20c.

No. 1218. Sweet Sultan

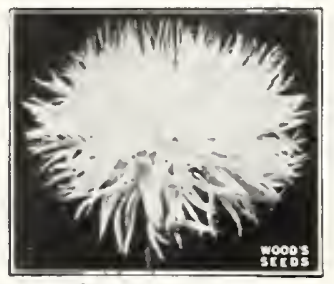

Sweet Sultan.

Gardy annual. Mixed colors. Pkt.

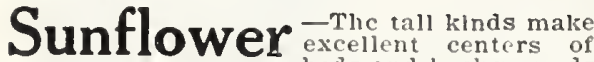

No. 1207. Red Sunflower.

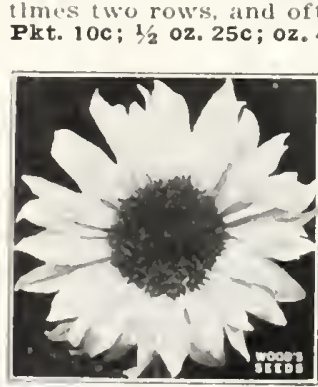

No. 1208. Miniat u re $S u n$. flower.

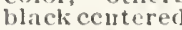

No. 1209. Double Chrysanthemum Flowerea or Japanese. - The most hcautlful of all Plden ycllow witl

\section{No. 1210. CaHfornia.}

ble flowers are extra
ligh. Pl. $5 \mathrm{c}$; oz. $20 \mathrm{c}$.

Mammoth Rassinn.

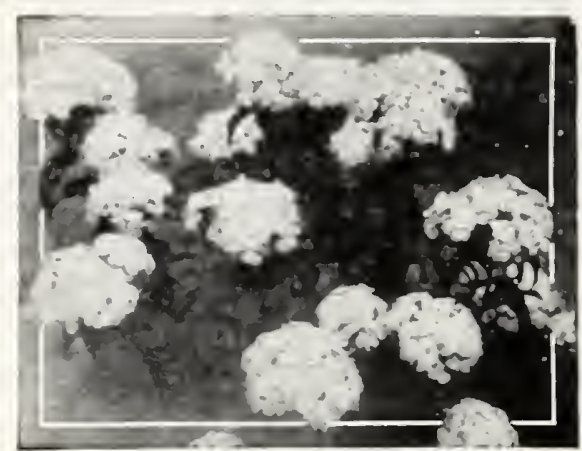

Sweet William.

\section{Sweet William}

o. 1222 singerennial Heikht No. 1223. Pink Beauty. Pkt. 10c: 1 oz. 250 . No. 1224. Scarlet Beauty. Plkt. 10c; $1 / 4$ oz. No. 1224. Scarlet Beauty. Pkt. 10c; $1 / 4$ oz. No. 1227. Single Mixed Colors. Pkt. 5c; No. 1233. Double. 11 All colors mixed. Pkt. $10 c$; $1 / 4$ oz. $25 \mathrm{c}$; $1 / 2$ oz. $40 \mathrm{c}$.

SIIENE.-See Catchfly.

SNAPDRAGON.-See Antirrhinum.

STRAWFLOWER.-See Hclichrysum.

SWEET AIYSSUM.-See Alyssum.

TOUCH-ME-NOT.-See Balsam.

No. 1236. Thunbergia (Black $E$ y 0 d rapid climber growing 4 to 6 feet high

splendid for trellises, fences, etc., bear-

ing beatiful

hardy annual. Pkt. 10c; $1 / 4$ oz. $30 c$.

No. 1239. Torenia Fournieri.

grown in

blue fowers with spots of indigo and yellow throats. 'Tender annual. Height, 1

\section{Verbena}

Annual for beds, bor-
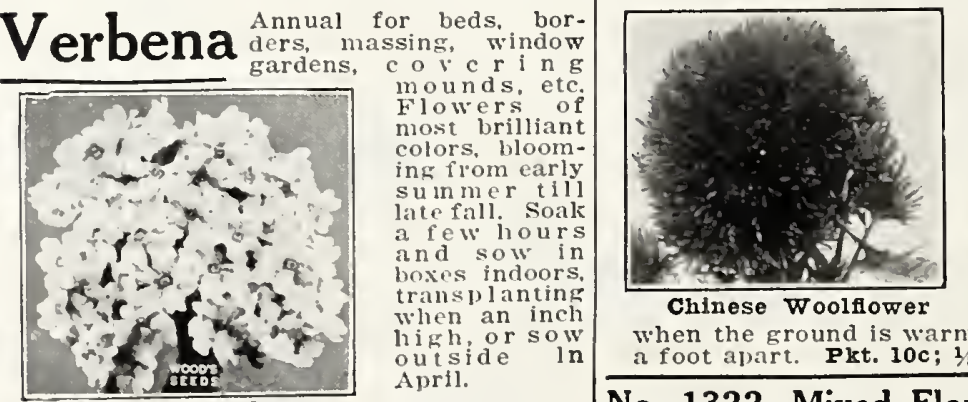
wigh or sow high, or sow Mammoth Verbena April.

No. 1245. Deflance Scarlet.-The most inloc; 1/4 oz. 40c; $1 \frac{2}{2}$ oz. $75 \mathrm{c}$.

No. 1246. Mammotl White. Extra large and very free blooming. Pkt. 10c; $1 / 4$ oz. $40 \mathrm{c}$.

No. 1247. Mammoth Pink. Pkt. 10c; $1 / 4$ oz. No. 1248. Mammoth Purple. Pkt. 10c; 14 oz. $40 \mathrm{c}$.

No. 1252. Mammoth Mixed. The finest and largest strain: the magnificent blooms are

Pkt. 10c; $1 / 4$ oz. $35 \mathrm{c} ; 3 / 2$ oz. 60c.

No. 1255. MIXED VERBENAS.-All colors $1,0 z, 25 c$; 15 oz, $40 c$.
No. 1260. Veronica (Speedwell)-A elegant hardy perennial of easy culure.

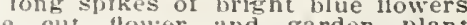
Pkt. 10c; 1 oz, 30c.

Vinca (Periwinkle.) - Splendid for bedind ding, window gardens, house plants in treats. Bear's large single flowers indoors and transplanted to a warm place, Whe bloom the same summer and fall; nates slowly. Tender perennial. Height,

No. 1264. Rosea,-link with crimson eye. Pkt. 10c: $1 / 4$ 02. 35c; $1 / 2$ oz, 60c.

o. 1265. Alba.-White, rose eve Pkt. 10c: 1/4 oz. 35c: $1 / 2$ oz. $60 \mathrm{c}$.

30c No. 1272. Virginian Stock -Beautiful ing annal for beds and edgings; succeeds nual. Pkt. 5c; íz oz. 20c; oz. 35c.

\section{Wallflower}

- Bears large spikes of deliciously ${ }^{\circ} \mathrm{r}$ a $\mathrm{g}$ a n $\mathrm{t}$
blooms. Üseful for beds, bord ers and winter and transplane. In the fall put into pots for hardy perennial. Height,

No. 1275. Annual Wallflower. $\mathrm{B}$ loo $\mathrm{m}$ s from July till frost if sown outside in April; blooms boxes. Pkt. 10c; $1 / 4$ oz. 25c.

No. 1276. Single. - A fine Pkt. 5c; $1 \frac{1}{4}$ oz. $15 \mathrm{c}$. No. 1277. Double. - V e r y $10 \mathrm{c} ; 1 / 8 \mathrm{oz}$. $60 \mathrm{c}$

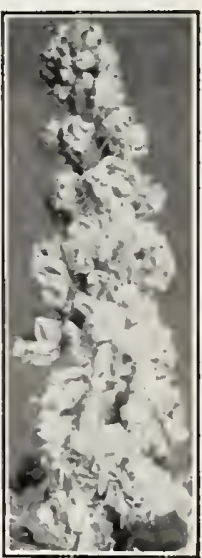

wallflower
VIRGIN'S BOWER.-See Clematls. No. 1282. Chinese Woolflower

- The large globe shaped flowers resemble balls of silky scarlet wool. The plants grow $21 / 2$ feet high and by midsummer
Chinese Woolflower

weeks $P$ la when the ground is warm and thin out to a foot apart. Pkt. 10c; 1 \% 02. 25c.

\section{No. 1322. Mixed Flower Seeds}

-A mixture of more than a hundred varieties of flowers for sowing amongst shrubbery, in fence corners, unsightly or out-of-the-way places. This mixture will give a constant suceession of bloom from day to day untll killed by frost, and does lot require the constant care and attento produce beautiful effects is in the case of flower beds. Frepare the ground rvell, scw the seeds but do not cover too deep, and let nature do the rest. Pkt. $5 \mathrm{c}$; 02. 20c; $2 / 4$ 1b. $65 \mathrm{c} ; 1 \mathrm{~b}$. $\$ 2.00$ postpaid.

STIMUPLANT WONDER GARDEN
An odorless, highly concentrated plant food in convenient tablet form. 10-tablet pkg. 150; 30 tablet pig. $25 \mathrm{c}$. 


\section{Wood's Giant Flowering Sweet Peas}

\section{AN OUNCE WIII PLANT 25 FEET OF ROW}

CUITURE.-Early planting is advised so that they may bloom before very hot weather. Dig the soil deeply to allow deep rooting. Open a trench four to six inches deep, in which plant the seeds early in February and cover with an inch of soil and press
it firmly. When up about two inches begin cultivating and gradually fill the trench until it is level. Do not allow the roots to become too dry; water at least twice a week. Be sure to gather the blooms, otherwise the vines will stop flowering.

FAII PIAN TING.-Sweet peas may also be started in October, Noyember and December, plantin

give them slight protection and they will become well rooted

Gather sweet pea blooms frequently; the more you cut them the better and longer they bloom.

\section{Wood's Spencer or Orchid Flowering Sweet Peas}

The Spencers offercd here have all proved their merit and represent the cream of the best varieties and a wide range of colors.

They are our selection from a long and confusing list of many hundreds of varieties.

AII VARIETIES-Pkt. $10 \mathrm{c} ; 0 \mathrm{z} .25 \mathrm{c} ; 1 / 41 \mathrm{~b} .75 \mathrm{c} ; 1 \mathrm{~b} . \$ 2.50$ postpaid.

No. 1330. Austin Frederick.-An exquisite shade o1 lavender the standard being a slightly deeper shade than the wings. A splendid extrat large flower nicely placed on long stiff stems, most of which bear four blooms.

No. 1329. Avalanche. - No pure white sweet pea makes as large a flower, nor blooms that will last as long; a strong grower and a profuse bloomer.

No. 1332. Crimson King.-Without exception the most magnificent crimson yet introduced.

bloomer with remarkably large rich deep crimson waved flowers carried on strong stems. Does not sunburn.

No. 1333. Dobbie's Cream.-The flowers are deep cream, are of unusual size, very much waved or crimped, the standards sometimes being double. A strong grower and profuse bloomer.

No. 1334. Fifrida Pearson.- Lovely blush pink, beautifully shaded. TV hen young the pink color seenis to have a bronze sheen. A large and magnificent flower, a fine bloomer, frequently four blooms to the stem.

No. 1331. Glen Eagles. - No lavender Sweet peas can compare with Glen Eagles. The blooms are beautifully waved and daintily frilled at the edges.

No. 1335. Hercules.-A splendid large rich pink waved flower, often more than two inclies across. Very much like the original Countess Spencer but a much finer and larger flower.

No. 1336. Mary Pickford.-A dainty cream pink with a slight suffusion of tifully waved; flowers very freely.

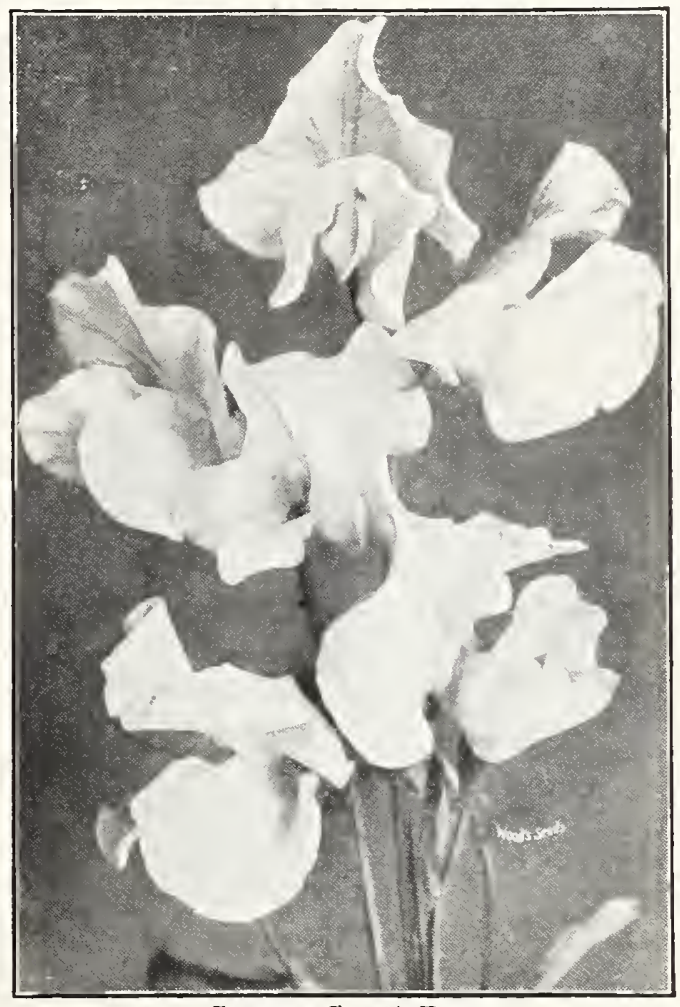

Spencer Sweet Peas.
No. 1337. Mrs. Tom Jones.-A mo

tractive bright delphinium blue. The

waved, of fine substance

tra long

No. 1338. R. F. Felton.-Bears all the lavender Spencers. The color is an exquisite soft lavender slight suffusion of rose.

No. 1339. Robert Sydenham.-The mos individual color in sweet peas, being are of immense size and exquisite place.

No. 1340. Royal Purple.-The name well describes the color-a rich royal purple which deepens as the flower ages. It is without doubt the introduced.

No. 1341. Royal Scot. The most brilliant cerise or orange scarlet. The large, finely waved blooms stand the ing. A strong plant and a free

No. 1342. Warrior.-Rich deep, pure maroon flushed with bronze. The blooms are remarkably large and will appreciate this fine flower.

No. 1343. What Joy.-An exceptionally beautiful waved flower. The color is a rich deep primrose yellow an exquisite and dainty flower.

No. 1344. Youth.-Not only beautiful, but delightfully fragrant. The color
is clear pure white with a well-defined pink edging.

\section{Sweet Peas in Mixtures}

\section{Grandiflora Sweel Peas}

No. 1374. Wood's Early Flowering Spencers or Winter Flowering.-Blooms bloom longer than other spencers, They are especia weeks earlier and remain in outdoor planting. We offer a well balanced mixture of many colors, Plt. 10c; oz. 35c;

No. 1376. Wood's Superb Spencer Mixture-The Spencers are the finest type mixture is a well balanced blend of colors from the purest white to the deepest maroon, one that will please the most exacting lover of sweet peas. It will give a lavish dis-
play in an almost endless range of color. Plt. 10c; oz. 20c; $1 / 4$ 1b. 60c; 1b. $\$ 1.75$, postpaid. No. 1375. Wood's Special Mixture-A peerless mixture of grandifora varieing varieties of every color, the colors being evenly distributed througliout. In di versity of color, size and beauty of flowers no other grandiflora sweet pea mixt
can surpass our "Special Mixture." Pkt. 5c; oz. 15c; 1/4 1b. 35c; 1b. $\$ 1.00$, postpaid.

No. 1377. Large Flowering Mixture-A very good mixture of standard grandi play. The colors are not as well balanced as in our "Special Mixture." Pkt. 5c; 0z. 10c; $1 / 4$ ib. 25c; 1b. 75c, postpaid.

No. 1378. Perennial or EverLastrigg swert PEAs.-Once planted, these ers early in the spring before the annual linds begin to flower. Perfectly hardy 8 to 10 feet high. Mixed colors. Pkt. 10c; $1 / 2$ oz. $30 \mathrm{c} ; 02.50 \mathrm{c} ; 1 / 41 \mathrm{~b}$. $\$ 1.50$.

No. 1379. Cupid Sweet Peas-Distinct from other sorts; 6 to 9 inches high, Very neat, compact and businy; very effective in beds and particularly attractive as a border plant. Pkt. 5c; oz. 15c; $1 / 4$ 1b. 50c; 1b. $\$ 1.50$, postpaid.

\section{AIL VARIETIES-Pkt. 5c; 0z. 10c;}

$1 / 4$ lb. 30c; 1b. $\$ 1.00$, postpaid.

No. 1370. America.-Crimson scarlet, striped No. 1360. Black Fnight.

No. 1361. Dorothy Eckford.-

No. 1363. Fon. Mrs. E. Kenyon.-

No. 1368. Janet scott.

bright pink.

No. 1364. King ENward VII.-Bright red or

No. 1365. Lady Grisel Hamilton.-The larNo. 1366. Iord Nelson or Brilliant Blue.-A No. 1359. Mrs. Walter Wright.-Rose purple; a profuse and contínuous bloomer.

No. 1367. Prima Donna.-A clear, soft pink; the stems usually bear three blooms. 


\section{Wood's Giant Zinnias}

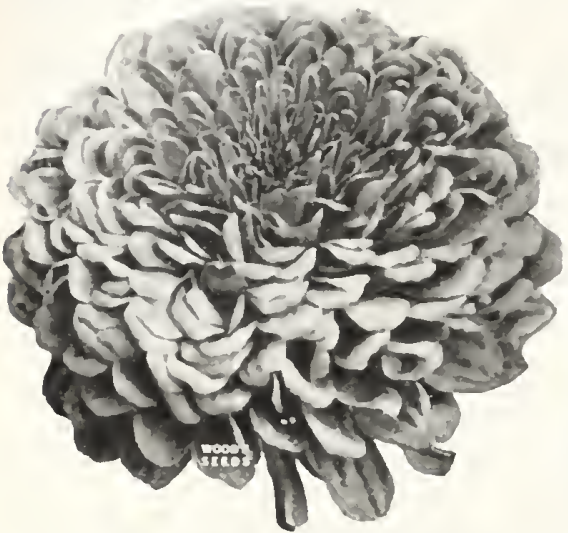

DAHLIA FLOWERED ZINNIAS

No. 1288. Exquisite

No, 1289. Golden State

Pkt. 15c: 1/4 oz, 50c.

No. 1290. Polar Bear

Pist. 15c

No. 1291. Crimson Monarch

No. 1298. Dahlia Flowered Mixed Colors Pint. elegrant mixture; all colors. $0 z . \$ 1.40$.
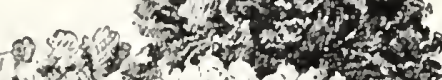
$1+10$
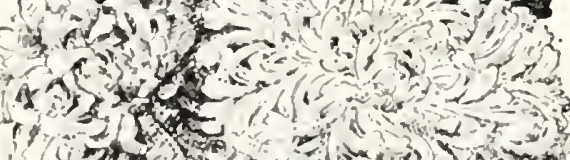

$$
\text { (is }
$$
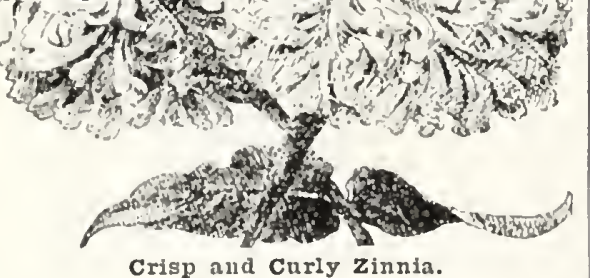

No. 1304. Crisp and Curly - Fntirely
POMPOM, or LILLIPUT ZINNIA

No. 1321. Pure White. Pkt. 10c; 1/4 oz. 30c.

No. 1322. Golden Yellow. Pkt. 10c; $1 / 40 z .30 \mathrm{c}$. No. 1323. Pink. Pkt. 10c; $1 / 4$ oz. 30c.

No, 1324. Scarlet. Pkt. $10 \mathrm{c} ; 1 / 4$ oz. 30c.

No.1327. All Colors Mixed. Pkt. 10c; $1 / 4 \mathrm{oz}$ $25 \mathrm{c}$

No. 1302. Double Striped or Zebra - A very beatiful strain with striped
fowers, large, perfectly double blooms of
various colors, some blotched, striped and
mottled. and different shades: hardly any
two plants with flowers alike. Pkt. 10c;
1/4 oz. 25c.

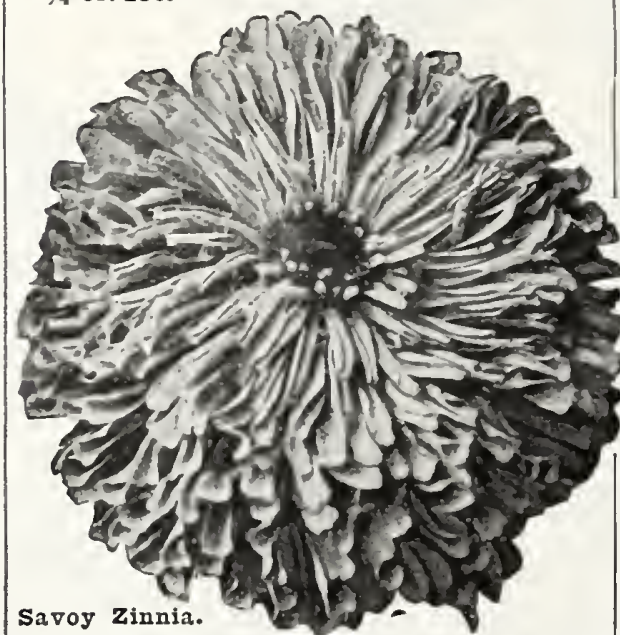

No. 1299. Savoy

blooms turn upward at the sides, forming
channels, of ten so pronounced as to form
quills like a quilled aster. The color is a
singular mixture of red and yellow,
deepening from golden yellow at the
center to dark red at the margin. Pkt.
loc; $1 / 40 z$. 40c.

No. 1300. Curled and Crested

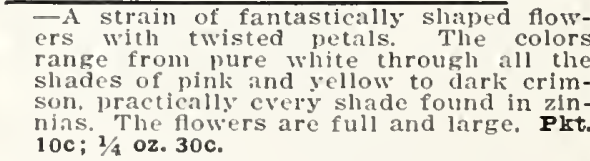

WOOD'S GIANT FLOWERED ZINNIA COIIECTION

This collection contains:

1 pkt. Graudiflora white ..........10c

pht. Grandifora Scarte

1 plet Grandiflora Pink $\ldots . . . \ldots \ldots$....

1 plrt. Grandiflora Deep Yeilow.......... 10c

1 pkt. Grandiflora Purple............10c

1 pkt. Dahlia Flowered Mixed Colors $10 \mathrm{c}$

All of the above for $50 \mathrm{c}$

$60 \mathrm{c}$

Order as Zimnia Collection No. 1320

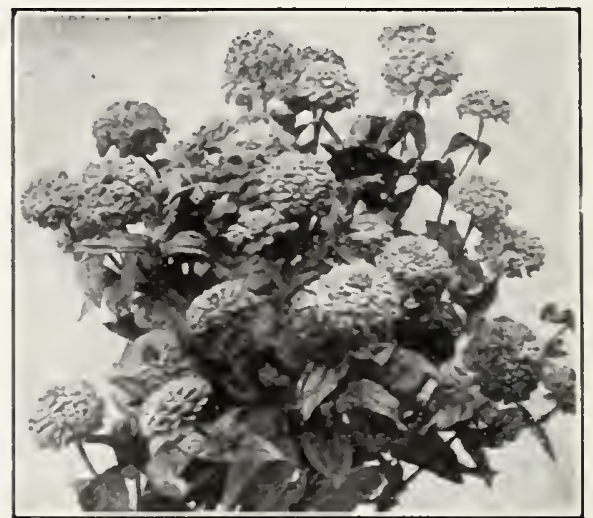

Wood's Grandiforz Glant Zinnlas

GRANDIFLORA GIANT ZINNIAS

-Giant in slze and perfectly double round and full flowered. It is not at all inusual for the flowers to measure 4 to 5 attractive in the garden they make fine and lasting cut flowers. Allow each plant 12 to 15 inclies to have the largest No. 1309. Grandiflora white.-Pkt. 10c; 1/. 02. 30c; 1 oz. 50c. Scarlet. - Pkt. Ioc; $1 / 4$ oz. 30c; $1 / 2$ oz. $50 \mathrm{c}$

o. 1311. Grandifiora Pink.-Pkt. 10c; $1 / 4$ oz. $30 \mathrm{c} 1 / 2$ oz. $50 \mathrm{c}$

12. Grandifiora Deep Yellow.-Pkt. 10c: 02 . 30c: $1 / 2$ 02. $50 \mathrm{c}$

o. 1313. Grandlfora Purple.-Pkt. 10c; 1/4 No. 1318. Grandifora Mixed Colors.-Pkt. 10c; $1 / 4$ oz. $25 \mathrm{c}$; $1 / 2$ oz. $45 \mathrm{c}$; oz. $75 \mathrm{c}$.

No. 1305. Tom Thumb -Very dwarf 18 inches high; excellent for beds and borders. Double; very bright colors. Pkt. 100 $1 / 4 \mathrm{oz} .30 \mathrm{c}$.

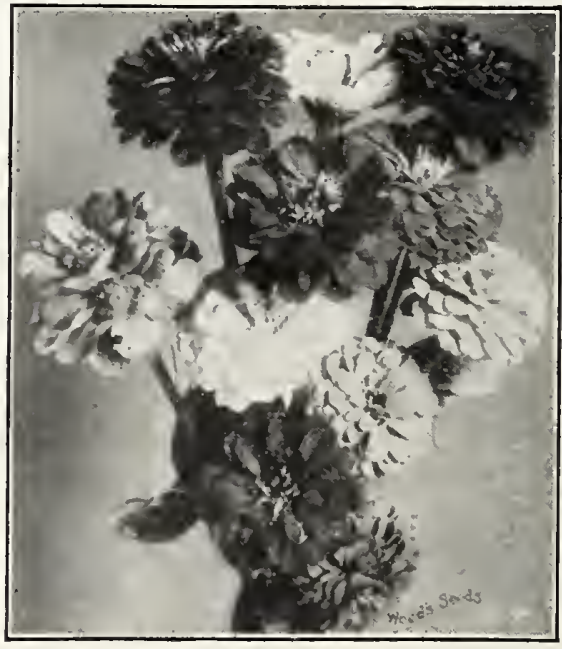

Double Zinnias

No. 1301. Double Mixed Zinnia

$A$ good mixturc of all colors. The blooms are not as large as those of our Grandiflora Giants, nor as brilliant, yet they are of good size and cover a wide range of colors. Put. 5c; $1 / 2$ oz. 25c; oz. $40 \mathrm{c}$. 


\section{Bulbs for Spring Planting}

\section{Cannas}

Gorgeous and cffective bedding p.l a $\mathrm{t}$ s. The $y, g r o w$ soil but respond quickly to $1 \mathrm{iberal}$ treatment. In groups or as b a ck g rounds for $\mathrm{smaller}$ plants they present a brilliant and con$\mathrm{t}$ in u ous dis-

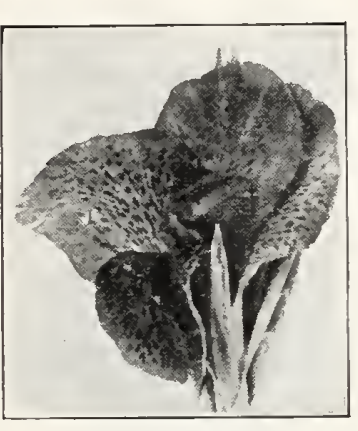

Eureka -4 feet. Without exception the Eureka finest white or cream colored canna The flowers are large and freely borne; green leaved. $20 \mathrm{c}$ each; 3 for 50c; 6 for 90c; $\$ 1.75$ per dozen postpaid.

Firebird $-3 \frac{1}{1 / 2}$ feet. Clear glistening scarpetals often $21 / 2$ inches across; green leaved. $15 \mathrm{c} \mathrm{each;} 3$ for $40 \mathrm{c}$; 6 for $70 \mathrm{c} ; \$ 1.30$ per dozen, postpaid.

Golden Gate -4 feet. Almost pure gold throats are richly rayed with orange crimson and apricot centering to the per dozen postpaid.

King Humbert -4 feet. The finest immense orchid-like flowers are orange scarlet: rose-tinted and margined at the base. Bronze leaved. 15c each; 3 for 40c; 6 for 70c; $\$ 1.30$ per dozen postpaid.

Mrs. Alfred Conard - The grandest of cannas. Produces magnificent heads of perfectly formed flowers of great size and wonderful substance. 20c each; 3 for 50c; 6 for 90c; $\$ 1.75$ per dozen postpaid.

The President -4 feet. The immense ing scarlet; no other scarlet a rich glowperior in the quality and quantity of blooms which are borne on strong, erect stalks. 20c each; 3 for $50 c$; 6 for $90 \mathrm{c}$; $\$ 1.75$ per dozen postpaid.

Wintzer's Colossal -5 feet. The largcannas sometimes est flowered of all striking vivid scarlet that holds its brilliancy. Green leaved. $15 \mathrm{c}$ each; 3 for 40c; 6 for 70c; $\$ 1.30$ per dozen postpaid.

Wyoming -5 feet. A beautiful shade of and strikingly beautiful. Bronze leaved. $15 \mathrm{c}$ each; 3 for $40 \mathrm{c}$; 6 for $70 \mathrm{c} ; \$ 1.30$ per dozen postpaid.

Yellow King Humbert -4 feet. Bears vellow flowers spotted with bright red: often 5 to 7 inches across, single petals 3 inches. 15c each; 3 for $40 c$; 6 for $70 c$; $\$ 1.30$ per dozen postpaid.

\section{Dahlias}

Plant in a sumny location when the ground is varm, covering the bulbs with 4 or 5 inches of earth.

Bashful Giant - An exquisite apricot strong stems; one of the largest of all $\$ 1.25$, postpaid.

Dakota - Autumn shades; a deep rich extra large erect flower. 40c each; 3 for
$\$ 1.00$, postpaid.

Edward Parrish $\rightarrow$ An attractive shade liandsome full flowers of fine size on stiff Emily Badetty - Mauvo rose, tipped ed with maroon; hard to describe. Often $50 \mathrm{c}$ each; 3 for $\$ 1.25$.

Jersey Beauty - Perfectly formed that blooms profusely and keep splendideach; 3 for $\$ 1.50$.

Lenore -A finely formed flower of splenpretty rose reflex; an abundant bloomer 40 c each; 3 for $\$ 1.00$.

Mrs. Carl Salbach -A lovely shade o

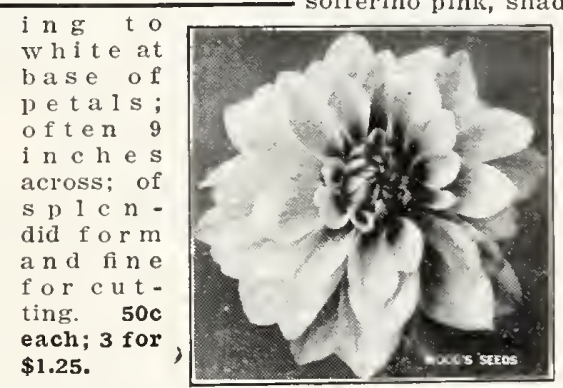

Mrs. de Ver Warner bloons, on long strong stems, are of perfect form; lovely bloomer. 50c each; 3 for $\$ 1.25$.

Oregon Beauty - Intense oriental red garnet suffusion. Remarkable for its unusual size and brilliant color; long
stemmed and a free bloomer. 40c each;
$\mathbf{3}$ for $\mathbf{\$ 1 . 0 0}$.

Sebastabol -A Burbank creation that its class and color; rich golden scarlet:
the flowers are borne freely on long stiff the flowers are borne freely on
stems. 60c each; 3 for $\$ 1.50$.

Mixed Dahlias -Our mixture is made types and colors. By mail, postpaid,
$25 \mathrm{c}$ each; 4 for $75 \mathrm{c}$; $\mathbf{1 . 7 5}$ per dozen. Not prepaid, 20c each; 4 for 60c; $\$ 1.60$ per dozen.

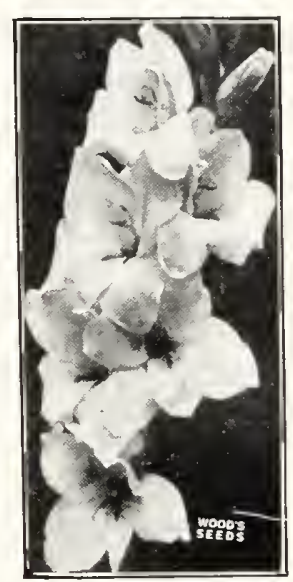

Gladiolas

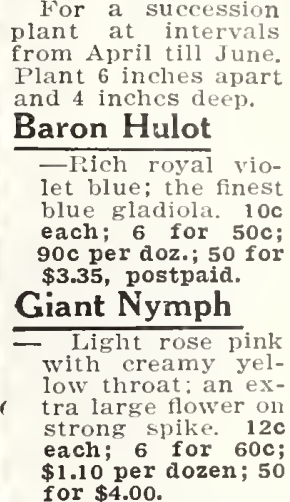

All our gladiolas are No. 1 first size bulbs

Golden Measure

$\$ 1.10$ per dozen; 50 for $\$ 4.00$.

Herada - Pure mauve, glistening and the throat The immense, blooms are carried on tall straight spikes.
$10 \mathrm{c}$ each; 6 for $50 \mathrm{c}$; $85 \mathrm{c}$ per dozen; 50 for $\$ 3.15$, postpaid.

Mrs. Francis King

milion; extra larg
well arranged on

cut flower. $7 \mathrm{c}$ each; 6 for $30 \mathrm{c} ; 55 \mathrm{c}$ per dozen; 50 for $\$ 2.00$, postpaid.

Le Marechal Foch -A large lily-like, tifully ruffled flower; pure rosy pink shading deep pink at edge. $7 \mathrm{c}$ each; 6
for 35c; 60c per dozen; 50 for $\$ 2.25$, postpaid.

Los Angeles -A soft shade of pink with throat; worthy of a place in any garden.
100 each; 6 for $50 \mathrm{c} ; 85 \mathrm{c}$ per doz.; 50 for $\$ 3.15$.

Mary Pickford -Distinct and beautiful; $8 \mathrm{c}$ each; 6 for $40 \mathrm{c} ; 75 \mathrm{c}$ per dozen; 50 for $\$ 2.75$.

Virginia (Scarlet Princeps).-An intense, tra fine and early bloomer make liant display. $10 \mathrm{c}$ each; 6 for $50 \mathrm{c}$; $90 \mathrm{c} \mathrm{per}$ dozen; 50 for $\$ 3.25$ postpaid.

\section{Mixed Gladiolas}

pure white to dark

By mail, postpaid, 6 for $35 \mathrm{c}$; dozen $60 \mathrm{c} ; 50$ for $\$ 2.00 ; \$ 3.50$ per 100 .

Not prepaid, 50c per doz.; 50 for $\$ 1.80$ $\$ 3.25$ per 100 .

\section{CALADIUMS (ELEPHANT'S EAR).-A} cially in lawns. To have the best res beds or groups, espeabundance of water and plenty of rich manure. When full grown. they stand 6 to 8 feet high, and bear immense lightgreen leaves 3 to 4 feet long by 2 to $2 \frac{1 / 2}{2}$ feet wide.

First Size Bulbs. - Over 11 inches in circumference. By mail, postpaid, 35c each. Not prepaid, 25c each; $\$ 2.50$ per doz.

\section{Fancy Leaved Caladiums} Superb foliage plants for window and porch boxes and shaded
places outdoors. Beautiful designs and gorgeous colorings. $30 \mathrm{c}$ each; 3 for $80 \mathrm{c}$.
Madeira Vine Root

space in a short time:

and multiply. By mail postpaid, 100 each; 6 for $50 c ; 90 c$ per dozen; 25 for $\$ 1.60$.

Not postpaid, 800 per dozen; 25 for $\$ 1.50$.

Tuberoses -One of the most delightfully fragrant summer or start in pots and set outside in May; give them plenty of

DOUBLE PEARI, extra large. By mail postpaid, 10c each; 3 for 200 ; 6 for $35 \mathrm{c} ; 60 \mathrm{c}$ per dozen; 25 for $\$ 1.10$.

Not prepald, 50c per dozen; 25 for $\$ 1.00 ; \$ 3.50$ per 100. 


\section{NURSERY STOCK}

Nurbery stock will be shipped by express or freight separate from seed orders.

Cannot be malled.

American Arborvitae

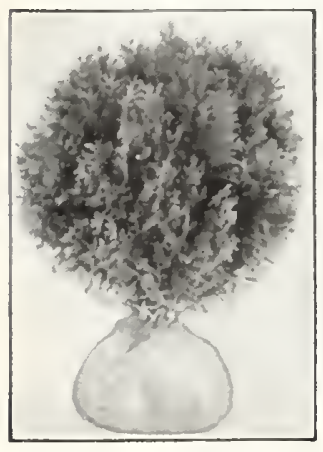

Globe Arborvitae

Globe

Arborvitae

\section{HARDY EVERGREENS}

2 to 3 feet, $\$ 1.50$ each; 3 to 4 feet,

Almost a per
fect globe; the
foliage is light

ally grown as

to 15 inches, $\$ 1.50$ eachi 15 to 18
$1 \mathrm{nch}$ es, $\$ 2.00$ each.

Hovey's Golden Arborvitae

riglat: the foliage briglit green. 15 to 18 Inches, $\$ 1.50$ each; 18 to 24 inches, $\$ 2.00$. Chinese Compact Arborvitae

l warf, compact, bright green foliage. 15 $\$ 1.75$ each.

Deodora Cedar - Popular trees for in clumps with dark-leaved evergreens. drooplng and very graceful. 18 to $\mathbf{2 4}$ inches, $\$ 1.75$ each; 3 to 4 feet, $\$ 3.50$.

Dupressa Juniper - Sometimes ealled

Very popular for borders and roek gar-
lens: the branches spread almost on the

Fround: has feathery, silver green foliage,
12 to 15 inches, $\$ 1.25$ each; 15 to 18 inches, $\$ 1,50$ each.

Stricta Juniper

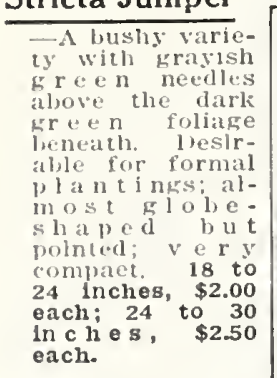

\section{Retinospora}

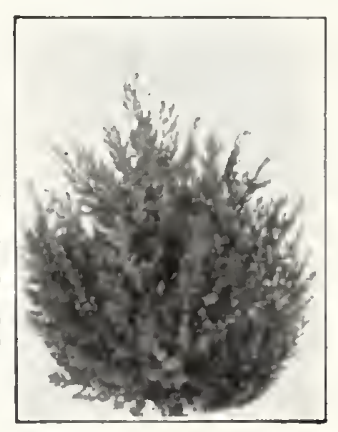

(Veitch's Silver

Stricta Juniper

tiful sllvery blue feathery foliage. I

mg, especlally when grown agamst dar 18 to 24 inches, $\$ 2.00$ each.

Norway Spruce

ak 18 to 24 inches, \$1.25; 24 to 30 inches, $\$ 1.50$ each.

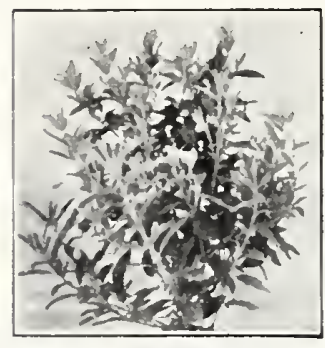

Azalea Iedifolla

Azalea IEDIant grower and profuse bloomer; ance of large bl $100 \mathrm{~ms}$ tinged with pink. This white azalea. 12 to 15 inches, $\$ 1.50$ each: 15 to 18 inches, \$1.75.

Cotoneaster HORI Z O N . TAIIS. - A low green shrub with a 1 most horizontal branehes, small shing green foliage and main on the plant all winter. Fine for rockery and bolder planting. 8 to 12 inches, $\$ 1.00$ each; $\$ 10.00$ per dozen.

\section{Bush Boxwood}

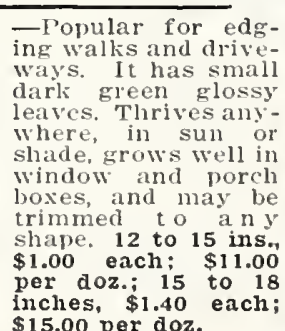

$\$ 15.00$ per doz.

\section{Dwarf Boxwood}

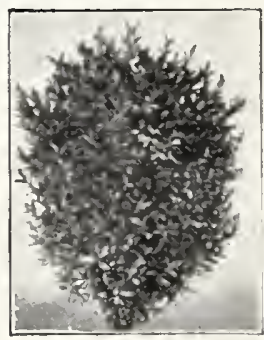

-The real old-fashioned kind; a slow always but very attractive variety that deep freen and vely dense. 4 to 6 inches,
$25 \mathrm{c}$ eacls: $\$ 2.00 \mathrm{doz}$. $\$ 15.00$ per 100 . 6 to 8 inches, $40 \mathrm{c}$ each; $\$ 4.00$ doz.; $\$ 30.00$ per 100 .

Nandina Domestica -A leafy Japanese thrive in any soil if the drainage is good.
It resembles a dwarf bamboo: the follage is pink tiplped in summer, bionzy red In winter. The white fowers are followed divarf and dense, being one of the dwarfIsh plants of Japanese gardens: graceful $\$ 1.00$ each; 18 to 24 inches, $\$ 1.50$ each.
BROAD-LEAVED EVERGREENS Cannot be malled.

\section{Abelia Grandiflora -A graceful shrub dart-shaped leaves that turn to a metallic}

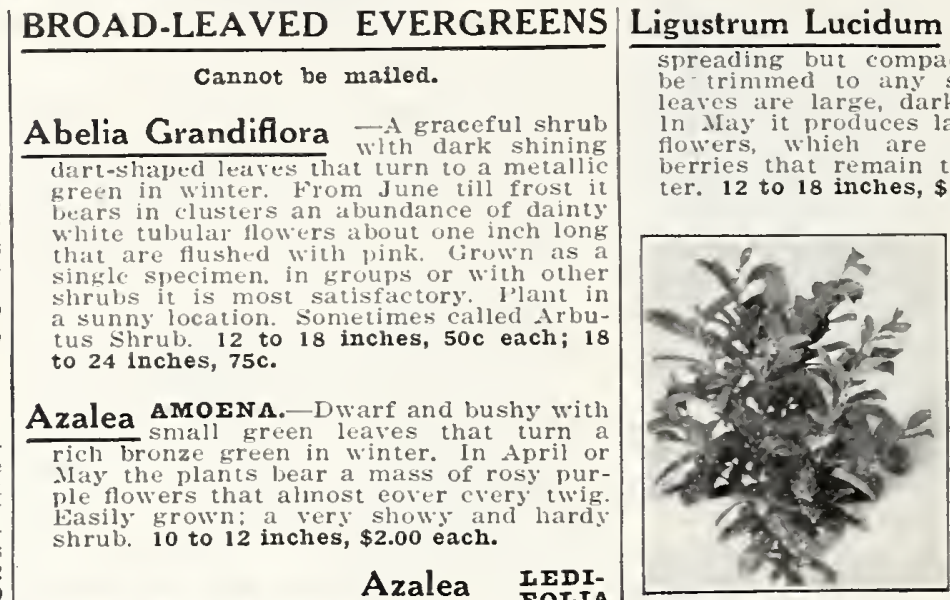

English Ianrel stoek, but there are so many conditlons
cannot guarantee nursery stock to live. Ligustrum Lucidum (Japanese Everspreading but compaet growth and can leares are large, dark green and glossy. in it produces large heads of white Wors, when are followed by black wies that remain throughout the windozen; 18 to 24 in che s, $\$ 1.50$ each; $\$ 15.00$ per dozen.

\section{English Laurel}

-Very beautiful with its broad sh in ing dark green foliage; a and thrives in any good garden soll Attains a height of 12 to 15 feet, with a cor $\mathrm{res}$ pon $\mathrm{d}-$ to 18 in $\mathrm{ch}$ e $\mathrm{s}$, $\$ 1.50$ each: 18 to 24 inches, $\$ 2.00$.

\section{FLOWERING SHRUBS}

If to be sent by mail add $10 \mathrm{c}$ each to cover postage.

Althea (Rose of Sharon).-Blooms abunAantly from July to September tall and upright and splendidly adapted for screens, hedges and shrub borders. Tre can $30 \mathrm{c}$ each; $\$ 3.25$ per dozen. 3 to 4 feet, $40 \mathrm{c}$ each; $\$ 4.35$ per dozen.

Barberry Thunbergi (Japanese Barberwhether grown sing ry). - Attractive The spray-like branches carry great quantities of small green foliage whieh clianges to bright red in the fall. During the winter it bears a mass of attractive bright red berries which remain all windoz. 18 to 24 inches, 35c each; $\$ 3.85$ doz.

Buddlei or Butterfly Bush $\underset{\text { grow ing }}{\mathrm{A}}$ shrub with long graceful spikes of delightfully fragrant flowers that are borne all sumnier. The top growth may freeze during severe winters, but it starts growth again in the spring. Cut away feet, 300 each; $\$ 3.00$ per doz. 3 to 4 feet, $40 \mathrm{c}$ each; $\$ 4.00$ per dozen.

Calycanthus - The flowers and young spicy odor, especially when crushed in the hand. The chocolate-colored flowers ar double, very fragrant, blooming in April or May, The foliage is luxuriant, $1 \frac{1}{2}$ to 2 feet, 30c each; $\$ 3.25$ per dozen. 2 to 3 feet, $40 \mathrm{c}$ each; $\$ 4.35$ per dozen.

Caryopteris (Blue splrea).--One of our that in the fall is covered with elusters of showr, bright blue flowers. Grows 3 of showy, bright blue fowers. Grows splendid low growing hedge. 12 to 18 inches, 35c each; $\$ 3.50$ per dozen.

Cornus or Dogwood The shrub that every Southern yard. The deep pink flow ered variety. 12 to 18 inches, $\$ 1.75$ each 18 to 24 inches, $\$ 2.25$ each; 2 to 3 feet, $\$ 3.00 ; 3$ to 4 feet, $\$ 4.00$ each. 
Flowering Crab (Bechtel's Double).-An Philadelphus Coronarius (Mock Orange). blooming shrub that bears long double pink fragrant blooms that resemble miniaand very hardy. 2 to 3 feet, $\$ 1.25$ each.

Crepe Myrtle - The best beloved South

so Hardy in ern shrub and deservedly ters of delicately fringed flowers through out the summer. It is usually grown as a single specimen, but makes a charming hedge. Pink and Iavender.-18 to 2 incies, 40c each; $\$ 4.00$ per dozen; 2 to 3 feet, 50c each; $\$ 5.00$ per dozen. Red-18 to 24 inches, $50 \mathrm{c} \mathrm{each;} \$ 5.50$ per do
to 3 feet, $75 \mathrm{c}$ each; $\$ 8.25$ per dozen.

Cydonia (Japanese Quince).-In April or ersbloom profusely. Grows about 8 feet high, spreading with glossy leaves.

Deutzia Watereri - In the spring and

bear a profusion of blooms. They are hardy and grow in all soils. Bears beautiful pink bell-shaped flowers. 3 to 5 feet, each; \$6.00 per dozen.

Forsythia or Golden Bell - Even be leaves appear forsythia yields a mas of brilliant yellow bell-shaped bloom INTERMEDIA. - The earliest bloomer. 2 to 3 feet, $30 \mathrm{c}$ each; $\$ 3.00$ per dozen. VIRIDISSIMA.-Deep yellow flowe
3 feet, 30 each; $\$ 3.00$ per dozen.

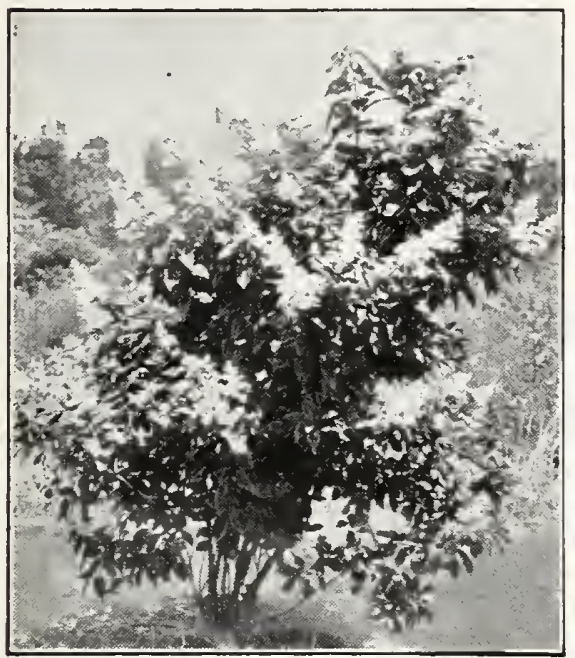

Hydrangea Paniculata

Hydrangea - Effective whether grown tubs: bears a wealth of bloom.
PANICUIATA GRANDIFIORA.

PANICUIATA GRANDIFIORA. - The later panicles or white blooms that 18 to 24 inches, $50 c$ each; $\$ 5.00$ per doz. 2 to 3 feet, $60 \mathrm{c}$ each; $\$ 6.00 \mathrm{doz}$.

OTASKA. - Produces large pink, some-

times blue. flower heads; usually grown

in tubs. Three-year-old plants, $75 \mathrm{c}$ each;

Hypericum Henryi (St. John's wort).

shrubs bearing an immense quantity of

large clear yellow flowers. Suits most any soil. 18 to 24 inches, 30c each; $\$ 3.00$ per dozen.

Lonicera Tartarica (Bush Honeysuckle). in Nlay and Jiune, followed by red berries that remain for several weeks. Grows 8 to per dozen. 3 to 4 feet, 50c each; $\$ 5.00$ per per dozer. shrub that has beauty, grace and fraed, showy flowers in May and June. Fine shrubs. 3 to 4 feet, $45 \mathrm{c}$ each; $\$ 4.50$ per dozen.

Rhodotypos (White Kerria).-A very orhandsome foliage: the branches are clus-

berries which remain through the wint
2 to 3 feet, 50c each; $\$ 5.00$ per dozen.

Spirea - Showy free flowering shrub

ANTHONY WATERER.

dense with bright crimson flowers. mer, 18 to 24 inches, $35 \mathrm{c}$ each; $\$ 3.50$ per dozen.

VAN HOUTTEI.-

ful bush with archin

covered from end to end with pur feet, $35 \mathrm{c}$ each; $\$ 3.50$ per dozen. 3 to 4 feet, $45 \mathrm{c}$ each; $\$ 4.50$ per dozen.

THUNBERGII - A beautiful shrub

numerous slender branches forming

dense, fcathery bush 3 to 5 feet high

masses cover fle flowers, borne in

of snow, 18 to 24 inches, $35 \mathrm{c}$ each; $\$ 3.50$ per dozen; 2 to 3 feet, $50 \mathrm{c}$ each; $\$ 5.00$ per dozen.

Symphoricarpos (Racemosus or Snowcalled st peter's berry).- Sometimes growing slirub with pink flowers and weary white berries that stay on the plan each; $\$ 3.50$ per dozen. 2 to 3 feet, $45 \mathrm{c} \mathrm{each}$ $\$ 4.50$ per dozen.

Syringa or Lilac (Vulgaris).-Both ornaand for cutting. One of the most beautiful and fragrant spring flowering shrubs. 2 to $75 \mathrm{c}$ each; $\$ 7.50$ per doz.

Viburnum Optulus (Snowball).

berry. Bears white flowers in May and June, followed by bright scarlet berries $35 \mathrm{c}$ each; $\$ 3.50$ per dozen. 2 to 3 feet, $75 \mathrm{c}$ each; $\$ 7.50$ per dozen.

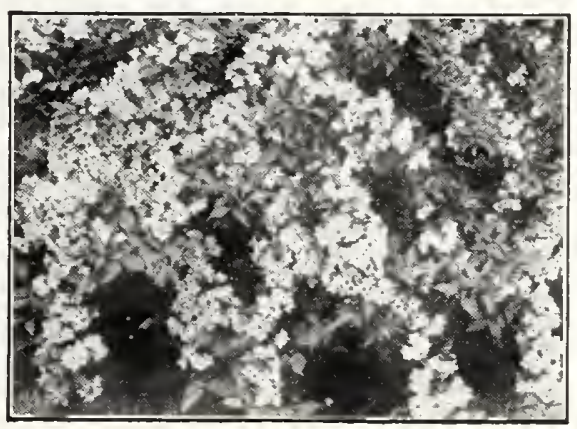

weigela

ARBOREA GRANDIFLORA.

during the fowers are profusely borne $\$ 4.00$ per dozen, 3 to 4 feet, $50 \mathrm{c}$ each; $\$ 5.00$ per dozen.

PURPUREA. $\$ 5.00$ per dozen.

URPUREA.-A generous bloomer; flowper dozen. 3 to 4 feet, $50 c$ each; $\$ 5.00$ per dozen.

\section{BABY RAMBLER ROSES}

Te offer white, pink and crimson Baby Ramblers at $50 \mathrm{c}$ each. If by mail, $60 \mathrm{c}$ each.
Weigela - Hardy free flowering

\section{HARDY ROSES}

Strong 2-year-old field grown. These are shipped dormant; no foliage.

Monthly or Tea Roses

$75 \mathrm{c}$ each. If by mail, $85 \mathrm{c}$ each.

FRANCISCA KRUGER.

RAISERIN AUGUSTA VICTORIA.

creamy white tin
PINK RADIANCE.

RED RADIANCE.

RED MAMAN COCHET.-Rich deep red and

SAFRANO.

SUNBURST

\section{Climbing Roses}

$50 \mathrm{c}$ each. If by mail, $60 \mathrm{c}$ each.

AMERICAN PILIAR. - The large

Alvers are borne in imme

CRIMSON RAMTIER.-The brigh

TAUSENDSCHOEN. - Tields large

of blooms, each cluster almost a

DR. VAN FLEET.-Long, pointed, deep pink

buds, bright pink when open with shell

\section{SHADE TREES \\ Catalpa Bungei.-The Globe Headed}

symmetrical rounded head resemble an each.

Judas Tree Red Bud.

(

feet, $65 \mathrm{c}$ each; $\$ 6.50$ per dozen.

DOGWOOD OR CORNUS.-See Flowering

Mimosa -An ornamental tre

foliage: low growing, 5 to 6 feet, $\$ 1.00$ each.

Lombardy Poplar

\section{branches low. Grow} $50 \mathrm{c}$ each: $\$ 5.00$ per dozen. 8 to 10 feet, $75 \mathrm{c}$ each; $\$ 7.50$ per dozen.

\section{HEDGE PLANTS}

Privet

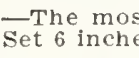

AMOOR RIVER.

the South. May be trimmed to any de$100 ; \$ 60.00$ per 1000 .

CAIIFORNIA.

inches, $\$ 7.00$ per $100 ; \$ 60.00$ per 1,000 . GRAPE VINES

All varieties $25 \mathrm{c}$ each; $\$ 2.50$ per dozen. If by mail, 35c each; $\$ 2.85$ per dozen.

CATAWBA

CONCORD.

pact; berries large and black.

NIAGARA.-Bunches very large and com-

pact; berries large, light greenish 


\section{Wood's Verified Origin Clover}

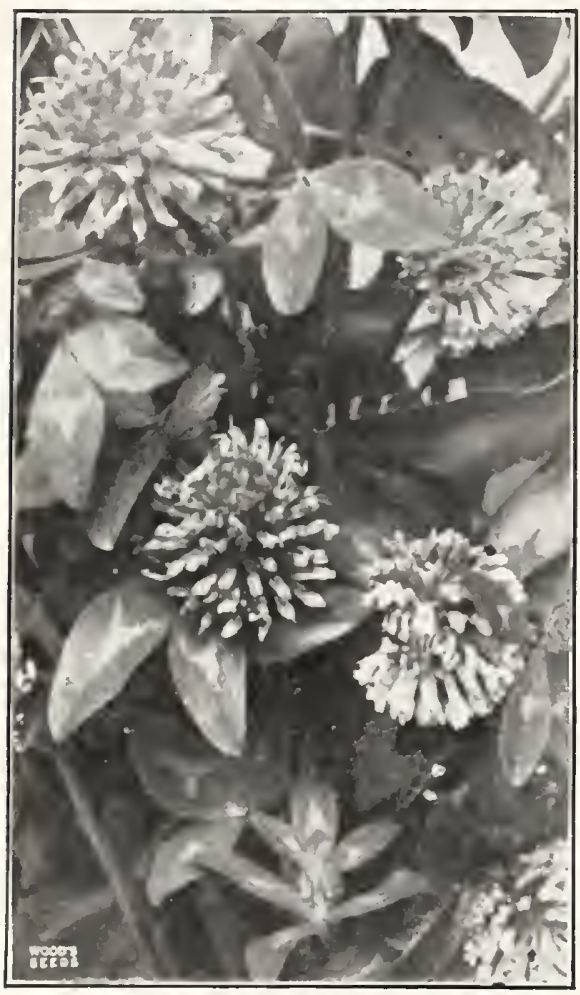

RED CLOVER

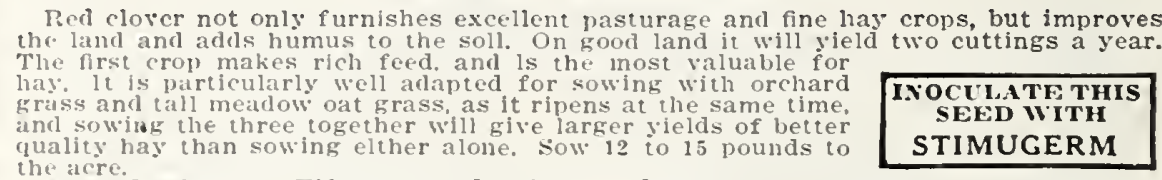

A Good Mixture.-Fifteen pounds of orchard grass, 12 pounds of tall meadow oat he aldition of 6 pounds of herd's grass or red top wlil increase the pasturage and the

\section{American Grown Red Clover}

Grown in Michigan, Ohio, fllinois and Missourl

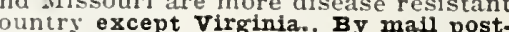
paid, 1b. $43 \mathrm{c} ; 5$ lbs. $\$ 1.90 ; 10$ lbs. $\$ 3.55 ; 25$ lbs. $\$ 8.15 ; 50$ lbs. $\$ 15.75$.

Not postpaid, 1b. 35c; 5 to 24 lbs. 32c per 2b.; 25 to 99 lbs. $30 \mathrm{c}$ per $1 \mathrm{~b} ; 100 \mathrm{lbs}$ and over 290 per 1b. No charge for bags.

\section{Virginia Northern Neck Red Clover}

The only disease resistant red clover and the best adapted for growing in the South. The supply this season is limited. ties disease resistant red clover adapted to the South. This is an isolated peninsula, has no railroads, and for more than 300 years has been forced to save its own clover a larfe, vigorous growth; not only stands cold winters, but can In inia Northern Veck clover showed a 100 per cent stand the second year, and a heavy growth, 24 inches high. Shenandoah Valley red clover, generally grown from West had a 50 per eent stand 18 inches tall, but the growth was very inferior and straggly The origin of our Northern Neck Red Clover is verlfied by the United States Department of Agriculture.

By mail postpaid, 1b. 45c; 5 lbs. $\$ 2.05$; 10 lbs. $\$ 3.85 ; 25$ lbs. $\$ 8.90 ; 50$ lbs $\$ 17.25$

Not postpaid, lb. $38 \mathrm{c} ; 5$ to 24 lbs. $35 \mathrm{c}$ per lb.; 25 to 99 lbs, $33 \mathrm{c}$ per lb.; 100 ibs. and over $32 \mathrm{c}$ per lb. No charge for bags.

\section{MAMMOTH, or SAPLING CLOVER}

\section{INOCVLATE THIS}

SELI WITI

STIMUGERM

o the clover and timothvi $A$ bushel weighs 60 pounds. By mail postpaid, 1b. 45c; 5 lbs. $\$ 1.90 ; 10$ lbs. $\$ 3.55 ; 25$ lbs. $\$ 8.15 ; 50$ lbs. Not postpald, lb, 35c; 5 to 24 lbs. $32 \mathrm{c}$ per $1 \mathrm{~b} .25$ to $99 \mathrm{lbs}$. 30c per b.; 100 lbs. and over, $29 \mathrm{c}$ per lb. No charge for bags.

\section{FOR YOUR PROTECTION}

NOTE THE TAG.-This tag is on every bag of clover seeds we ship, and tells where the seeas were grown. This is your protec-

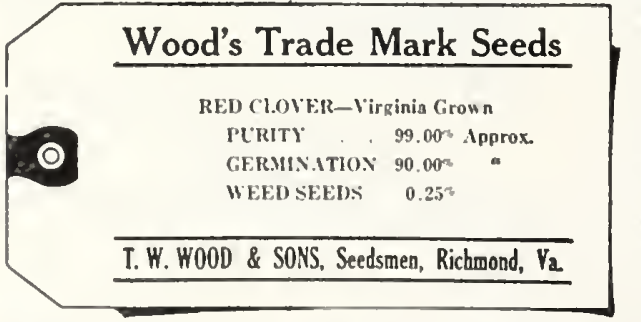
ion against forign grown seeds as well as seeds th a t a $\mathrm{r}$ i 0 adapted. Note the adapteal purity test to guara seods of which soeds, of which you already have more th a n germination test. If a lot that germinates 90 per cent is worth lot that germinates 60 per cent is too expensive at $\$ 10.00$ a bushel watch the germination test and don"t sow dead seeds.

Every bng of clover seods we send out carries this tag, and we guaranteo the purity and germination to be as tagged.

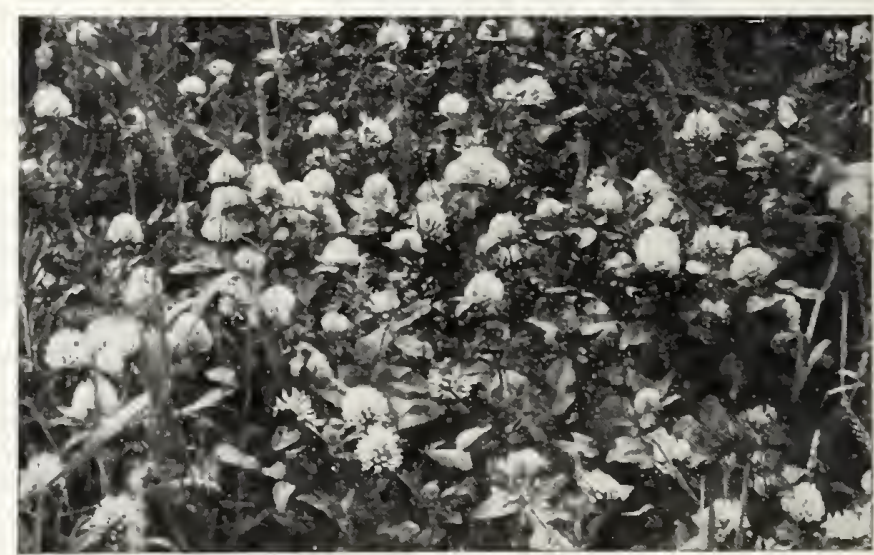

\section{ALSIKE CLOVER}

Alsikc clover has plenty of leaf, prows thicker is finer stemmed makes better hay and mole and better grazlng than red clover, and wlll grow on soils too acil too wet or too deficient in lime to produce a paying crop of other clovers. It is hardier and will stand uncut without deterioratios the quality of the hay better than other clovers. It is adipted to a varjety of soils, succeeding IXOCEIATE TIIS On light upland and loamy as well as on SEND WITI $\quad$ higher per cent of digestible protein. ParSTIMUGERM ticularly valuable for grazing, for it makes a thick undergrowth, greatly increasing in getting a stand of other clovers because your land is acid or moist, sow alsike. By mail postpaid, 1b. $40 \mathrm{c} ; 5$ lbs. $\$ 1.75 ; 10$ lbs. $\$ 3.25 ; 25$ lbs. $\$ 7.40 ; 50$ lbs. $\$ 14.25$

Not postuald, 1b. 33c; 5 to 24 lbs, $29 \mathrm{c}$ per $1 \mathrm{~b} . ; 25$ to 99 lbs. $27 \mathrm{c}$ per lb.; 100 lbs. and over, $26 \mathrm{c}$ per lb. No charge for bags. 
The Virginia Agricultural Fxperiment Station says: "The unfortunate use of unadapted varieties of alfalfa has probably caused more failures and discouraged more farmers than any one factor in the production of this crop."

Sow only on well-prepared land; kill the weeds by constant cultivation from plowing to seeding time. Sow on a deep, welldrained soll; alfalfa cannot live with its feet in water. Before sowing, inoculate the seeds with Stimugerm; it pays, and is an insurance against failure. You will find description of Stimugerm on page 75

Sow 20 to 30 pounds to the acre in March or April, covering one inch deep on light sandy soils, three-fourths to one inch deep on heavier soils. Our experience has been very satisfactory when alfalfa is sown on fall-sown grain. To insure an even distribution, sow with either a Cahoon Seed Sower or a Cy. clone Seeder. (se
weighs 60 pounds.

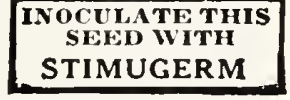

Watch the Tag. On every bag of alfalfa and clover seeds we Send out is a tag similar to the one illustrated on page 56. It tells where the seeds wele grown; it tells the germination and weed content. This tag is your protection
against poor, foreign and unadapted seeds. WATCH THE TAG.

\section{FACTS ABOUT ALFALFA}

Once established, it lasts for years.

Yields three to five cuttings of nutritious hay each season. Feeding value high - contains as much protein as wheat When fed with grain, it supplies the protein necessary for a balanced ration.

Does not exhaust the soil; it enriches it.

Claimed to add twice as much witrogen to the land as Red clover.

Requires but little care and attention.

It supplies its own nitrogen and stores it in the land to make bigger the crops that follow it.

ne of the farm's most profitable crops; it pays constant dividends.

\section{ALFALFA DEMANDS}

A well-prepared, fertile, well-drained soil.

A liberal application of lime.

Inoculation with Stimugerm.

Seeds that are adapted to the section where the crop is to be grown.

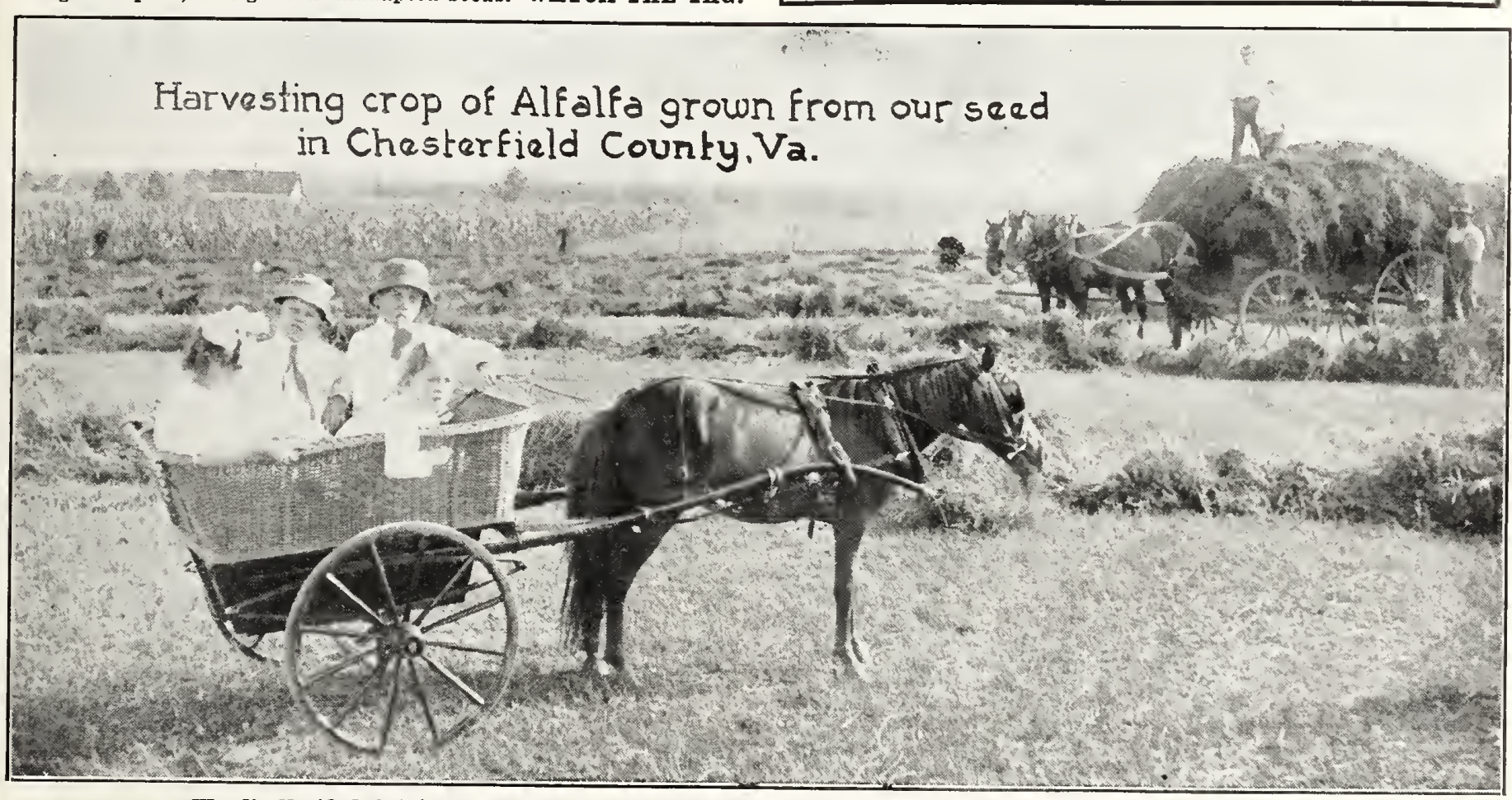

Wood's Verified Original. Guaranteed Origin-Purity Over 99 Per Cent-Germination Over 90 Per Cent.

GENUINE KANSAS ALFALFA -An alfalfa that can ters of Kansas will come through our winters splendidly. wn a test of alfalfas from many sources, made by the Virginia Agricultural Experiment Station, four plantings of Kansas alfalfa stood the winters better than any in their test and yielded more than $4 \frac{1}{2}$ tons per acre. It makes a quick spring growth and gives several cuttings each season. We recommend it for the Piedmont and Eastern sections. By mail postpaid, 1b. 40c; 5 1bs. $\$ 1.65 ; 101 \mathrm{bs}$. $\$ 3.05 ; 25$ lbs. $\$ 6.90 ; 501 \mathrm{bs}$. $\$ 13.25$. Not prepaid, $1 \mathrm{~b}$. $32 \mathrm{c} ; 5$ to 24 lbs, $27 \mathrm{c}$ per $1 \mathrm{~b}$.; 25 to 99 lbs. $25 \mathrm{c}$ per ib.; 100 lbs. and over, $24 \mathrm{c}$ per lb. No charge for bags.

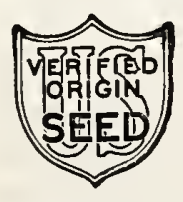

We are authorized distributors of VERI. FIED ORIGIN AIFALFA SEEDS under the direct supervision of the United States Department of Agriculture. A certificate showing the exact origin will accompany every bag or alf alf a we ship to $y$ ou. This is of creat importance because many alfalfas, both domestic and imported, are not adapted and bring loss and disappointment.
UTAH ALFALFA - Utah has a cold climate and the harsh alfalfa grown there. It is thoroughly depe confuse it with the cheap, tende origin. The hardiness of an alfalf uninjured through the winter depend very much on where it lbs. $\$ 7.40 ; 50$ lbs. $\$ 14.25$.

Not prepaid, 1b. 33c; 5 to 24 lbs. $29 \mathrm{c}$ per 1b.; 25 to 99 lbs. $27 \mathrm{c}$ per 1b.; 100 1bs. and over, $26 \mathrm{c}$ per $1 \mathrm{~b}$. No charge for bags.

GRIMM ALFALFA Montana Grown.-The hardiest of all that gives the plant a firm hold on the soll and preverts heavlower soils. $\mathbf{B y}$ mail postpaid, $1 \mathrm{~b}$. 55c; 5 1bs. $\$ 2.45 ; 10$ 1bs. $\$ 4.65$; 25 lbs. $\$ 10.90 ; 501 \mathrm{bs}$. $\$ 21.25$.

Not prepaid, 1b. $47 \mathrm{c}$; 5 to 24 lbs. $43 \mathrm{c}$ per 1b.; 25 to 99 lbs. 410 per $1 \mathrm{~b}$; 50 1bs. and over, $40 \mathrm{c}$ per $1 \mathrm{~b}$. No charge for bags. 


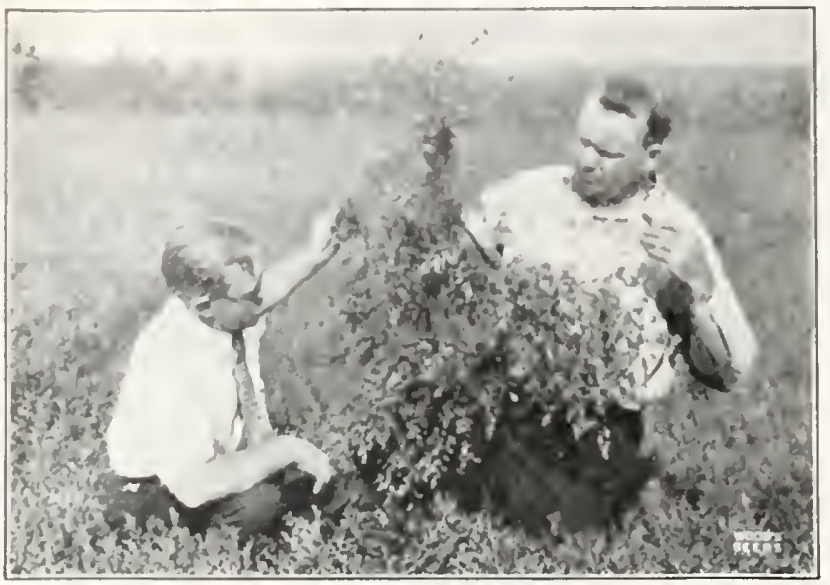

KOREAN LESPEDEZA

AN-EARLY DROUGHT RESISTANT SOII BUIIDER

The gtronge growth nenetrates about 8 inches deep, making rought resistant, and thrl

(woody stem holls it leaves well and produces a full crop the first season. It l,roadsast 10 to 15 lhs. to the aere during late freezes after a light 5 lbs. $\$ 2.30 ; 10$ lbs. $\$ 4.35 ; 25$ lbs. $\$ 10.15 ; 50$ lbs. $\$ 19.75$. Not prepaid, 1b. $43 \mathrm{c} ; 5$ to 24 lbs. $40 \mathrm{c}$ per lb.; 25 to 99 lbs. $38 \mathrm{c}$ per lb.; 100 lbs. and over, $37 \mathrm{c}$ per lb. No charge for bags.

\section{JAPAN CLOVER or LESPEDEZA}

A Good Mixture.

INOCYYATETIIS
SHHO WITII
STIMUGERM

JAPAN CLOVER-BY mail postpald, $1 \mathrm{~b}$. 35c; 5 lbs. $\$ 1.55 ; 10$ lbs. $\$ 2.85 ; 25 \mathrm{lbs} . \$ 6.40 ; 501 \mathrm{bs} . \$ 12.25$.

1b.; 100 lbs. and ovor, $22 \mathrm{c}$ per $1 \mathrm{~b}$. No charge for bags.

\section{WHITE DUTCH CLOVER}

\section{FOR IAWNS AND PASTURES}

Makes a small, close, compact growth, covering the ground like carpet. Sow elther in the spring or fall. When sown by itself

By mall postpald, 1 b. 50c; 5 lbs. $\$ 2.30 ; 10$ lbs. $\$ 4.35 ; 25$ lbs. $\$ 10.15$; $501 \mathrm{bs}$. $\$ 19.75$. $1 \mathrm{~b} .43 ; 5$ to $241 \mathrm{bs} .40 \mathrm{c}$ per $1 \mathrm{~b}$; ; 25 to $99 \mathrm{lbs}$. $38 \mathrm{c}$ per 1b.; 100 1bs. and over, $37 \mathrm{c}$ per lb. No charge for bags.

\section{SWEET CLOVER}

WHITE BOKHARA, OR MEIILOTUS ALBA

On lands too poor to grow

a paying crop of corn on

worn out called, waste land.

on land too siandy to grow

ans other crop, sow sweet
clover, and in a few years
the land will be in condition
cor gencral crops. It is adapt-
ed to a wide variety of solls;
is uscful for pasture, for for-
age, for ensilage, for bees,
for turning under to improve
the land. The deep roots
brcak up, aerate and drain
stiff subsoils and add humus.
Spring sowings will yield a
crop the following fall and
two crops tle following year.
A good plan is to cut the
crop for liay the fall after

seeding and pasture it the

grows 1 is to $2 \%$ feet ligh.

but if cut when 6 inches ligh

it stools out and makes a

more tender growth for graz-
ing. The second year it

grows 5 to 10 feet high, and

should be cut before blooming.

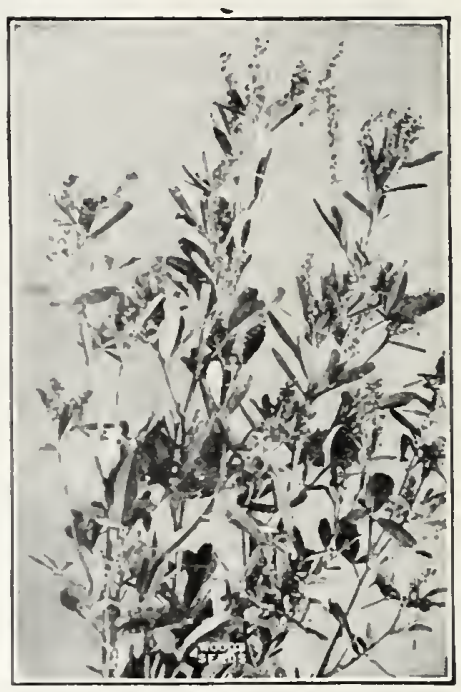

Sweet Clover.

Be sure to lime the land and inoculate the seeds.

\section{INOCULATE: THIS
SEFD WITH \\ STIMUGERM}

HUILED AND RECLEANED SWEET CIOVER. For sowing after March 15 th. lbs. $\$ 1.75 ; 25$ lbs. $\$ 3.65 ; 50$ lbs. $\$ 6.75$.

Not prepaid, $1 \mathrm{~b}, 18 \mathrm{c} ; 5$ to 24 lbs, $14 \mathrm{c}$ per $1 \mathrm{~b}$. 25 to $99 \mathrm{lbs}, 12 \mathrm{c}$ per 1b.; 100 lbs. and over, $11 \mathrm{c}$ per lb. No charge for bags.

UNFUIIED SWEET CIOVER.-Recommended by the Virginia Experiment station for sowing early-as early as February lst in Lastern Virginia. By mail postpaid, 1b. 25c; 5 lbs. 90c; Not 150,25 lbs. $\$ 3.15 ; 50$ 165. $\$ 5.75$.

to 99 lbs. $10 \mathrm{c}$ per 1b.; $100 \mathrm{lbs}$. and over, 9c per lb. No cliarge for bags.

Grundy County Sweet Clover - About two weeks earlier and makes a tiner hay. It is the hardiest of all sweet clovers and stands well in long dry spells in the summer. A splendid

HUIIED SEEDS-BY mail postpaid, 1b. 25c; 5 Ibs. $\$ 1.00 ; 10$ lbs. $1.75 ; 251 \mathrm{bs} . \$ 3.65 ; 50 \mathrm{lbs} . \$ 6.75$

Not prepaid, $1 \mathrm{~b}, 18 \mathrm{c} ; 5$ to 24 lbs, $14 \mathrm{c}$ per $1 \mathrm{~b} . ; 25$ to 99 lbs. $12 \mathrm{c}$ per lb.; 100 lbs. and over, $11 \mathrm{c}$ per 1b. No charge for bags.

BEGGAR WEED or Ilorida clover. A nitrogen-gatherer, by stock and is real a lua rich in protein and relished rens for pasture or liay; it is even more fattening than alfalfa and cowpeas: makes a fine cover crop, espccially for orchards.
Sow when frost is over 3 to 4 lbs, to the acre, in 3 -foot drills or 10 to 12 lbs; broad-

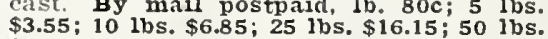
$\$ 31.25$.

Not prepald, 1b. 70c; 5 to 24 lbs, $65 \mathrm{c}$ per $1 \mathrm{~b} . ; 25$ to 99 1bs. $62 \mathrm{c}$ per lb.; 100 lbs. and over, 600 per lb. No charge for bags.

\section{WOOD'S DIXIE WHITE CLOVER}

This is one of the few plants that furnishes abundant grazing throtighout the year under severe Southern conditions. Neither hot, dry weather nor cold weather stop its growth. in a two-jear test at our experment station, tested with varicthe earliest to bloom, mill the most luxuriant winter and early spring growth, ten inches tall, and stood the hot, dry summers best.
it is relishcd by all llve stock, is adapted to practically every region and type soil in the south but does best on sand clay. I Is a perennial and spreads rapidly by reseeding. By mail postpaid Not prepaid, lb. $43 \mathrm{c} ; 5$ to 24 lbs. $40 \mathrm{c}$ per $1 \mathrm{~b}$; 25 to 99 lbs. $38 \mathrm{c}$ per 1b.; 100 lbs. and over $37 \mathrm{c}$ per lb. . No clarge for bags.

\section{CRIMSON CLOVER - Sow it on every picce of land that} will be unoccupied by another crop

improving your land. it "ill pay handsomely. By mail postpad, bc; 5 lbs, $\$ 1.00 ; 10$ lbs. $\$ 1.75 ; 25$ lbs. $\$ 3.65 ; 50$ lbs. $\$ 6.75$

Not prepaid, lb. $18 \mathrm{c} ; 5$ to 24 lbs. $14 \mathrm{c}$ per $1 \mathrm{~b}$.; 25 to 99 lbs. $12 \mathrm{c}$ per Ib.; 100 lbs. and over, $11 \mathrm{c}$ per lb. No charge for bags. 


\section{Wood's High-Grade Grass Seeds}

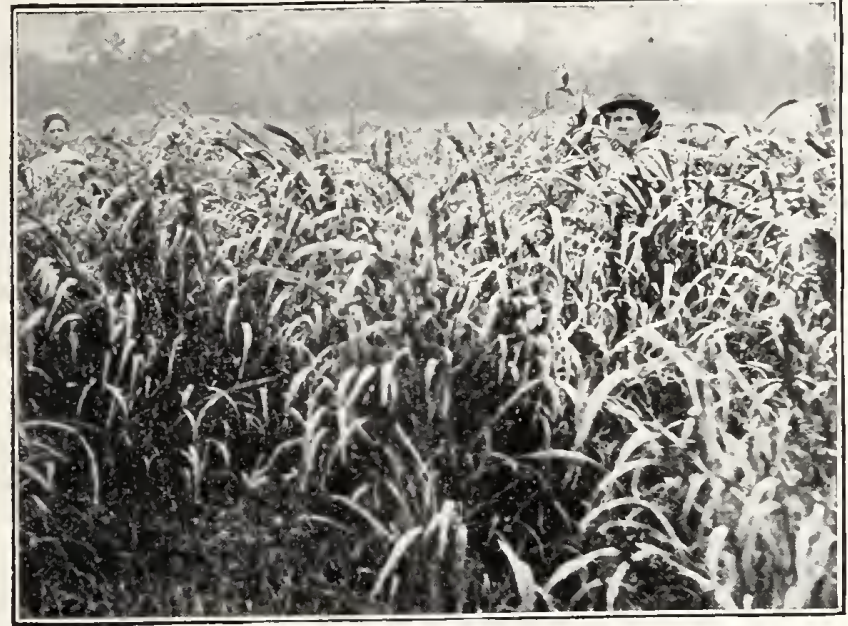

\section{Sudan Grass}

A Wonderful Quick-Growing Summer Hay Grass.

As big a yielder as Johnson grass, but it has none of the latter's objectionable features. for Sudan grass can never become a pest, for it is an annual with short fibrous roots that are killed - the entire plant, leaves, stems and heads,

largely supplant millet

as Sudan grass will give

hundred stems growing from

timothy in feeding value

thoroughly warm, either bry

high: when sown broadcast it grows four to five feet high. If

sown broadeast, the hay is finer and rather better than when

grown in rows. Cut when in bloom, for at that stage the feedin

value is highest; yet there

standing beyond the proper

growth it supports the pea rines and makes the cutting easie

and allows them to cure more quickly; the mixture will

better-balanced ration than either fed alone. When grown

cowpeas or soy beans make the sowing of Sudan grass after the heavy clay to light sand, will grow Sudan grass. Sow 5 to 6 lbs. postpaid, lb. 25c; 5 lbs. $\$ 1.00 ; 10$ lbs. $\$ 1.70 ; 25$ lbs. $\$ 3.65 ; 50$ lbs. $\$ 7.00$, Not prepaid, 1b. $17 \mathrm{c} ; 5$ to 24 lbs. $14 \mathrm{c}$ per $1 \mathrm{~b} . ; 25$ to 99 lbs. $12 \mathrm{c}$ per 1b.; $100 \mathrm{lbs}$. and over $11 \frac{1 / 2}{2}$ per $1 \mathrm{~b}$. No charge for bags.

\section{Paspalum Dilatatum, or Dallas Grass}

In the far South paspalum makes an all-the-year-round grazing and hay grass, but is recomnended for growing throughou cellent green feed and hay; stands close grazing and is no

jured by moderate frosts. It is hardy and thr

variety of soils except those that are very dry and sand

ennial, growing 3 to 5 feet high

starting early in the spring and remaining green till frost.

from the niddle of March till the midlle of April; farthe

By mail postpaid, 1b. 60c; 5 lbs. $\$ 2.60 ; 10 \mathrm{lbs}$. $\$ 4.95 ; 25 \mathrm{lbs} . \$ 11.65$; 50 lbs. $\$ 22.75$.

Not prepaid, lb. $50 \mathrm{c} ; 5$ to 24 lbs, $46 \mathrm{c}$ per lb.; 25 to 99 lbs, $44 \mathrm{c}$ per lb.; $100 \mathrm{lbs}$, and over $43 \mathrm{c}$ per $\mathrm{lb}$. No charge for bags.

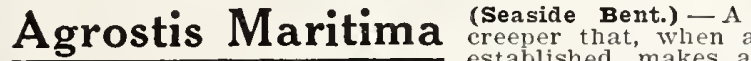

\footnotetext{
for grazing. It is adapted to he

and will stand almost any

ly by means of runners or stolons

green, forming a thick matted turf of fine te
dark green color. By mail postpaid, $1 \mathrm{~b}$. $\$ 1.50$.

Not postpaid, $\$ 1.40$ per $1 \mathrm{~b}$.
}

\section{BERMUDA GRASS}

By mail postpaid, 1b. 55c; 5 lbs. $\$ 2.30 ; 10$ lbs. $\$ 4.35 ; 251 \mathrm{bs} . \$ 10.15 ; 50 \mathrm{lbs}$ $\$ 19.75$.

Not prepaid, 1b. $45 \mathrm{c} ; 5$ to 24 1bs. $40 \mathrm{c}$ per lb.; 25 to 99 lbs. 38c per 1b.; 100 lbs. and over 37c per 1b. No charge for bags.

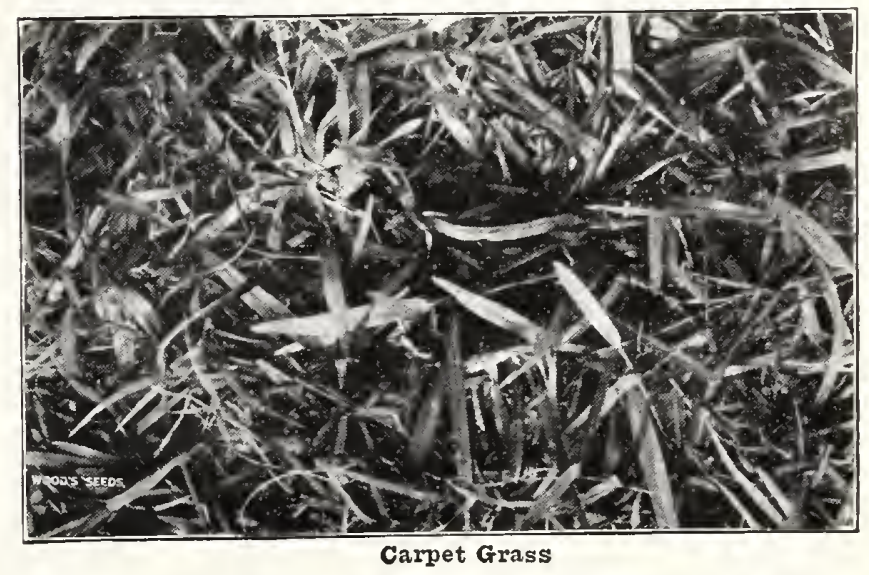

Carpet Grass $\quad$ The The Grass That Thrives on Close Grazgrazing one of the most valuable permanent the Atlantic Ocean and Gulf and approximately 125 to 150 with Bermuda grass, carpet grass is its equal in feeding value; more grazing. It is strictly a pasture grass and stands close more rapidly pet grass past

where

seeding is advisable. By mail postpaid, 1b. 55c; 5 lbs. $\$ 2.35 ; 10$ lbs. $\$ 4.45 ; 25$ lbs. $\$ 10.40 ; 50$ lbs. $\$ 20.25$

Not prepaid, 1b. $45 \mathrm{c} ; 5$ to 24 lbs. $41 \mathrm{c}$ per $1 \mathrm{~b}$; 25 to $99 \mathrm{lbs} .39 \mathrm{c}$ per South German Bent

contains a small percentage of Velret Bent. By mail postpaid Not postpaid, 1b. $\$ 1.00 ; 5$ to $241 \mathrm{bs} 95 \mathrm{c}$. $\$ 2$ r $1 \mathrm{~b}$; 25 to $991 \mathrm{bs}$. $92 \mathrm{c}$ per lb.; 100 1bs. and over $90 \mathrm{c}$ per $1 \mathrm{~b}$.. No charge for bags. Colonial Bent

$\$ 1.00 ; 5$ 1bs. $\$ 4.55 ; 10$ bs. $\$ 8.95 ; 25$ bs. $\$ 21.15 ; 50$ bs. $\$ 41.25$ Not prepaid, 1b. $90 \mathrm{c} ; 5$ to 24 lbs. $85 \mathrm{c}$ per 1b.; 25 to $991 \mathrm{bs} .82 \mathrm{c}$ per 1b.; $100 \mathrm{lbs}$. and over $80 \mathrm{c}$ per 1b. No charge for bag's.

Postpaid Prices Apply to Va., N. C., W. Va., Md., Del., POSTAGE TO OTHER STATES: To S. C., Ga., Ky., Tenn., Ohio, Ind., N. $\mathbf{Y} ., \mathrm{N}$ ew England and Mich., add $2 \mathrm{c}$ per pound to postpaid prices. To Ala., Ark., Fla., II., Iowa, La., Miss., Mo. and Wis., add To Texas, Okla., Kan. and $\mathrm{Neb.,} \mathrm{add} 6 \mathrm{c}$ per pound to postpaid prices. 
ORCHARD GRASS (The Great Pasture and Hay Grass.)-

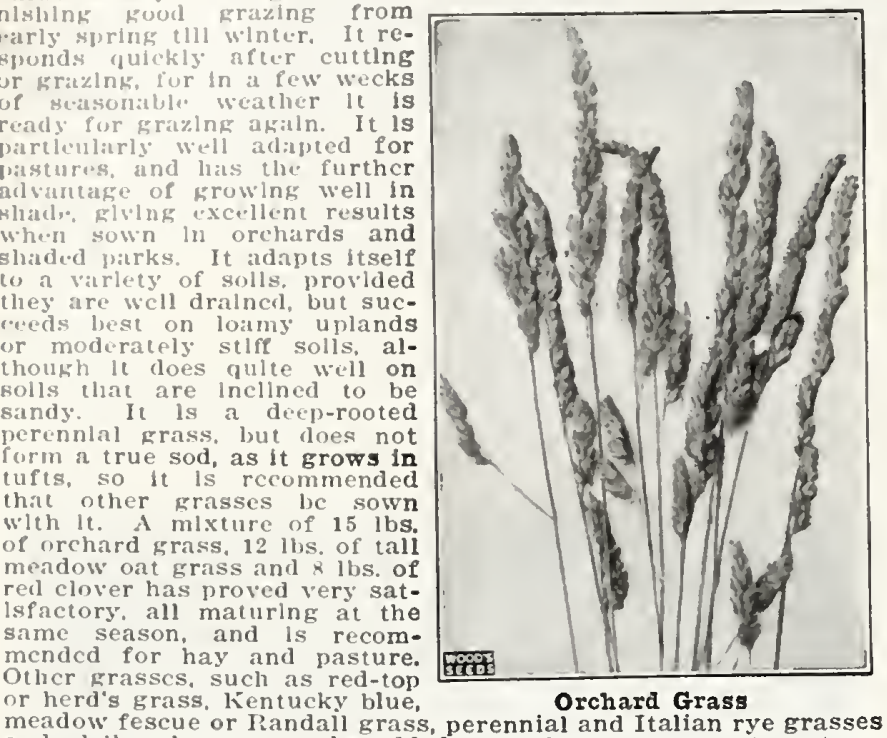

Present Price, TRADE-MARE BRAND:

By mall postpald, 1b. 30c; 5 lbs. $\$ 1.30 ; 10$ ibs. $\$ 2.35 ; 25$ lbs. $\$ 5.30$ 50 lbs. $\$ 10.25$.

Not prepala, 1b. 23c; 5 to 24 lbs. $20 \mathrm{c}$ per $1 \mathrm{~b}$.; 25 to $99 \mathrm{lbs} .18 \mathrm{1} / 2 \mathrm{c}$ per 1b.; $100 \mathrm{lbs}$. and over $18 \mathrm{c}$ per lb. No charge for bags.

\section{Meadow Fescue, or Randall Grass} A splcndid spring and summer grass, stands close grazing. . 列, 6 lbs. herd's

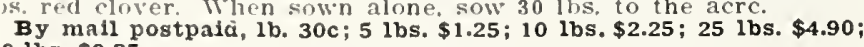

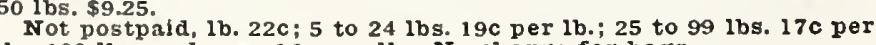
1b.; 100 lbs. and over $16 \mathrm{c}$ per 1b. No charge for bags.

Perennial Rye Grass more and more ispreciated as

By mall postpaid, 1 b. $25 \mathrm{c} ; 5$ lbs. $\$ 1.00 ; 10$ lbs. $\$ 1.75 ; 25$ lbs, \$3.65; 50 lbs. $\$ 6.75$; 5 to 24 lbs. $14 \mathrm{c}$ per lb.; 25 to 99 lbs. $12 \mathrm{c}$ per 1b.; 100 lbs. and over $11 \mathrm{c}$ per $1 \mathrm{~b}$. No clarge for bags.

Sheep Fescue

By mall postpald, 1b. 45c; 5 lbs. $\$ 1.95 ; 10$ lbs. $\$ 3.65 ; 25$ lbs. $\$ 8.40 ; 501$ bs. $\$ 16.25$.

Not prepald, 1b. $37 \mathrm{c} ; 5$ to 24 lbs. $33 \mathrm{c}$ per lb.; 25 to 99 lbs. 310 per lb.; 100 lbs. and over $30 \mathrm{c}$ per lb. No charge for bags.

\section{We Guarantec Purity and Germination}

Wood's High Grade Seeds are all tested for purlty and germination, and to onch bag is attaclied a tag giving percentage of germito your state Department of Agriculture for testing, and if they do not come up to the puity and germination as iabeled, your money will be lefunded immediately.
Chewing's Fescue wll stand more hard wear and trampling: the wiry creeping roots form a close and lasting turf. It grows on poor dry sandy acld soils, reslsts drought and does well $\mathrm{ln}$ sliaded pla for weeds to larly fine for lawns; once established it ls difficult for Weeds to 5 lbs. $\$ 2.35 ; 10.1 \mathrm{bs}, \$ 4.45 ; 25$ bs. $\$ 10.40 ; 501 \mathrm{bs}$. $\$ 20.25$.

Not prepaid, lb. $45 \mathrm{c} ; 5$ to 24 lbs. $41 \mathrm{c}$ per $1 \mathrm{~b}$; 25 to 99 lbs. $39 \mathrm{c}$ per lb.; $100 \mathrm{lbs}$. and over $38 \mathrm{c}$ per $\mathrm{lb}$. No charge for bags. Poa Trivialis fough stalked meadow Grass.)-A growth, productiveness and nutritious qualities. It starts carly in the spring and continues green till late in the fall, growing to pereer sueh a red op herd's rrass and hentuck bluc grass. A splcndid 5 1bs. $\$ 2.60 ; 10$ lbs. $\$ 4.95 ; 25$ lbs. $\$ 11.65 ; 50$ lbs. $\$ 22.75$.

Not prepaid, 1b. $50 \mathrm{c} ; 5$ to 24 lbs. $46 \mathrm{c}$ per $1 \mathrm{~b}$; 25 to 99 lbs. $44 \mathrm{c}$ per b. 100 lbs. and over $43 \mathrm{c}$ per lb. No charge for bags.

Hard Fescue pasture grasses, and on lands too dry, W in heat and long droughts. Soll $30 \mathrm{lbs}$, to the acre. By mail postpaid, lb $45 \mathrm{c} ; 5$ lbs. $\$ 1.95 ; 10$ lbs. $\$ 3.65 ; 25$ lbs. $\$ 8.40 ; 50$ lbs. $\$ 16.25$.

Tot prepaid, $1 \mathrm{~b}$. $37 \mathrm{c} ; 5$ to 24 lbs. $33 \mathrm{c}$ per $1 \mathrm{~b}$; 25 to 99 lbs. $31 \mathrm{c}$ per 1b.; $100 \mathrm{lbs}$. and over $30 \mathrm{c}$ per ll. No charge for bags.

TALL MEADOW OAT GRASS This grass $\begin{aligned} & \text { (Erass.) } \\ & \text { seems to }\end{aligned}$

make more leafage and grazing. a larger yield of hay and to
keep green longer, both during the winter and summer, than most rrasses. It is cspecially adapta-
ble to the South. It withstands the heat and drought of mid-sum-
mer and cold of winter; starts very carly in the spring and conlate in the fall. For hay it can be cut twice in a season, frequentmuch hay as timothy. Its nutritive qualities are first class: ripgrass and red clover. It is best adapted for good loamy uplands nearly all soils, and better than most other grasses on light and sandy soils. Sown with orchard
grass and red clover, sow 12 lbs. tall meadow oat grass, 15 lbs. or chard grass, and $8 \mathrm{lbs}$. red clover. The addition of 6 or 7 lbs. of lancy clean red top or herd's grass secd to the acre to this mixture yleld of grazing. When sown by itself, sow 25 to 30 lbs. to the

By mail postpaid, 1b. 35c; 5 lbs. $\$ 1.45 ; 10$ lbs. $\$ 2.65 ; 25$ lbs. $\$ 5.90$; 50 lbs. $\$ 11.25$.

Not prepaid, 1b. 26c; 10 to $24 \mathrm{lbs}$. $23 \mathrm{c}$ per $1 \mathrm{~b} . ; 25$ to $99 \mathrm{lbs}$. $21 \mathrm{c}$ per $1 \mathrm{~b}$.; charge for bags.

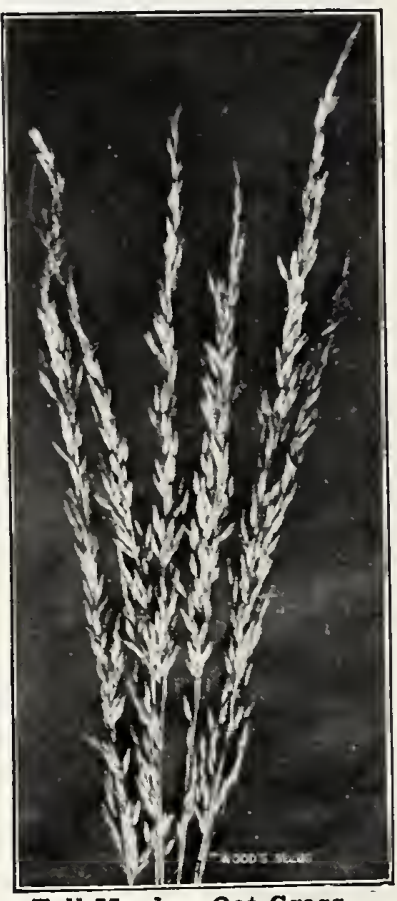

Tall Meadow Oat Grass

\section{Italian Rye Grass} adapted for rtch loamy soils or low grounds: does better in damp situations than most grasses. Recommended principally for fall eeding. Full description in our Fall Catalogue. Sow 30 to $35 \mathrm{lbs}$. to the acre. By mail postpald, 1b. 25c; 5 lbs. 85c; 10 lbs. $\$ 1.45$; 25 lbs. $\$ 2.90 ; 50$ lbs. $\$ 5.50$.

Not prepaid.1b. $15 \mathrm{c} ; 5$ to 24 lbs. $11 \mathrm{c}$ per lb.; 25 to $99 \mathrm{lbs}$. $9 \mathrm{c}$ per 1b.; $100 \mathrm{lbs}$. and over $8 \frac{1}{2} \mathrm{c}$ per lb. No charge for bags.

Postpaid Prices of Field Seeds Apply to Van, N. C., W. Postpaid Prices of Field Seeds Va., Md., Del., N. J.' and POSTAGE TO OTHER STATES: To S. C., Ga., Ky., Tenn., ohio, Ind., N. Y., New England and Mich., add $2 \mathrm{c}$ per pound to postpald prices.

To Ala., Ark., Fla., Ill. Iowa, Ia., Miss., Mo., and Wis., add 4c per pound to postpaid prices.

To Texas, Okla., Kan., and Neb., add $6 \mathrm{c}$ per pound; to Cuba, 10c per lb. to postpald prices. 


\section{KENTUCKY BLUE GRASS}

THE GRASS THAT MADE KENTUCKY FAMOUS. Sow 35 to $40 \mathrm{lbs}$, to the acre.

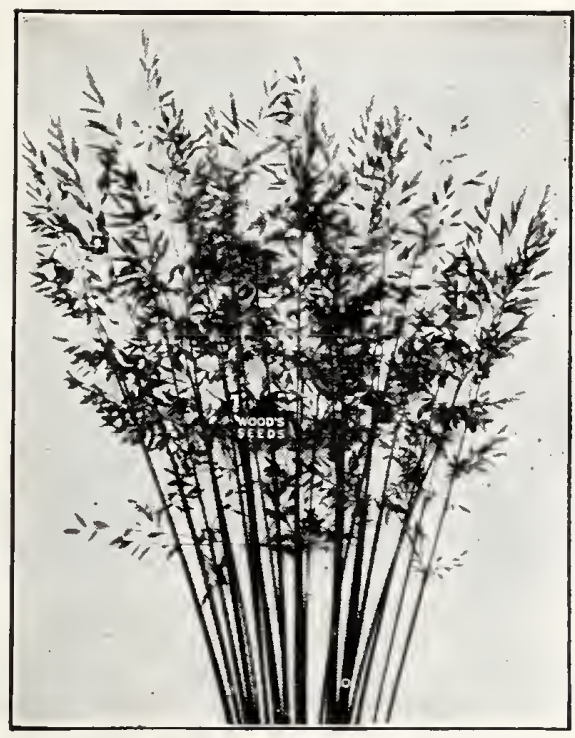

Kentucky Blue Grass.
On la nds that will grow Kentucis probauly no vilel $\mathrm{gras}^{\circ} \mathrm{t} \mathrm{h}$ at equals it for mak pasture, nor one tliat will yield a rleller, sweeter and pasture, Lxcept on very light salluy soils it should be included in al grass mixture It is one of the first to start up in the spring and gives the rery tinwinter.

Kentucky blue grass is hardy will withstand coldest weather. and the trampling hurt it as the roots hurt it as the roots stout and form a tough sod, but do not turn stock on it till the grass is strong and well established. A s it more to become well established, we suggest that it be sown with at least one other grass. If sown with a single grass use perennial rye grass, but a better mixture would be 15 bs. Ientucky blue, 5 lbs. red top or herds grass, 5 lbs. perennial rye
grass, 10 ibs. meadow fescue or Randall grass and 5 lbs. red grass,

Although slow to establish itself, Kentucky blue grass, once a stand is had on land to which it is adapted, lasts for many years, as the plants spread with their underground roots and will improve year to year, and rarely needs reseeding. A thick, well set sod of Kentucky blue grass makes an ideal pasture, and for constituents of all pasture mixtures.

Spring sowings of Kentilcky blue grass should be made from the middle of February till the midrle of April-the earlier the better to give it a good start before the weeds. Cover with a roller or brush. the roller aftords the best possible ccvering for all fine grass seeds as it does not cover them too deep and assures a firm seed bed.

Our special grass and clover nasture mixtures described on page 62 all contain a liheral nroportion of Kentucky blue grass. By mail postpaid, 1b. 55c; 5 lbs. $\$ 2.45 ; 10 \mathrm{lbs}$. $\$ 4.65 ; 25 \mathrm{lbs}$. $\$ 10.90$; 50 lbs. $\$ 21.25$.

Not postpaid. 1b. $47 \mathrm{c}$ : 5 to 24 lbs. $43 \mathrm{c}$ per $1 \mathrm{~b}$.; 25 to $99 \mathrm{lbs}$. $41 \mathrm{c}$ per lb.; $100 \mathrm{lbs}$. and over $40 \mathrm{c}$ per lb. No charge for bags.

\section{TIMOTHY}

The Most Extensively Grown Hay Grass-12 to $15 \mathrm{lbs}$. Sow an Acro

For hay, timothy is the best known and most extensively grown of all grasses. A stand is easily established it is inexpensive io sow it starts quickly and yields its best crop the year after it is sown, but the following year's sow, starts quick as lo nure. It stands up well, is easily cured and is heavy for its bulk, for which reascn it has proved the most profitable hay crop when grown for market. The yield on good land frequently runs from $11 / 2$ to 3 tons to the acre.

Timothy requires good land to make good creps-this applies particularly to timothy, for, unlike other grasses, it does not enrich the soil, but exhausts it, so that top-dressing with stable manure or fertilizer is advised; the fertilizer should contain a
sapling clover the clover will help to supply nitrogen.

Meadow fescue or Randall grass, red top or herds grass and sapling clover all mature at the same season as timothy, and are good grasses to sow with it for hay and grazing, increasing the yield of hay and the yield and value of the pasturage. A good mixture is 6 ibs timothy, 5 lbs. red top or

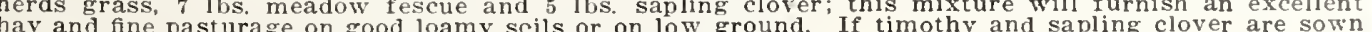
hay and fine pasturage on good loamy scils or on low gro.
together, mix 8 lbs. timothy and 6 lbs. sapling clover.

The common practice in the West of sowing timothy and red clover mixed is not recommended, as red clover ripens earlier than timothy and timothy is easily injured by early cutting and the hay shrinks in weight. The best time to cut is when it is in bloom; it is then easier te cure and its feeding value is highest.

Timothy grows best on clay or heavy loam, lowlands and in mountainous districts, but grows quite satisfactorily on any good loamy soil, provided there is abundant moisture.

TIMOTHY-Present price, TRADE-MARK BRAN D, by mail postpaid, lb. 25c; 5 lbs. 95 ; 10 lbs. $\$ 1.65$; 25 lbs. $\$ 3.65 ; 50$ lbs. $\$ 6.75$.

Not prepaid, $1 \mathrm{~b}$. i6c; 5 to 24 lbs, $13 \mathrm{c}$ per 1b, 25 to 99 lbs. $12 \mathrm{c}$ per lb.; 100 lbs. and over, $11 \mathrm{c}$ per lb. No charge for bags. ed fer sow ing on

\section{RED TOP, or HERDS GRASS}

THI BIUE GRASS OF THE ATIANTIC COAST grass is one or th most valuable an kemtucky blue ris on well as stirf upland grows better in moist most any other grass. stand and to get a and improves tating and increasing in Red top year herds cluded in all mixpermanent pasture or tent pasturage and Wer est a bsupplant ot her rillsides

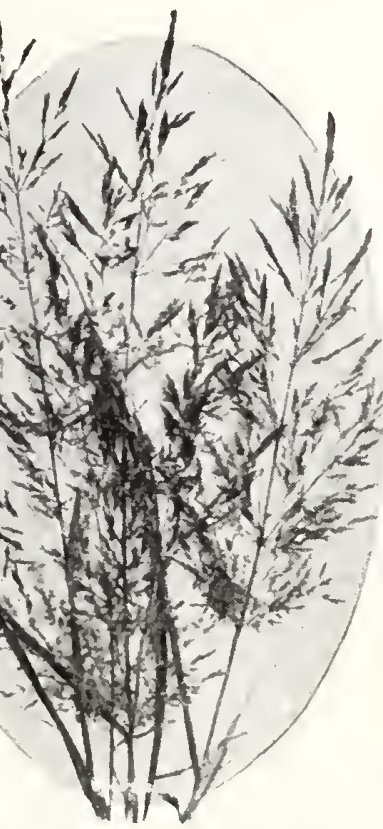

ed Top, or Herds Grass 


\section{Wood's Special Grass and Clover Mixtures SOW THEM FOR BIGGER AND BETTER GRASS CROPS}

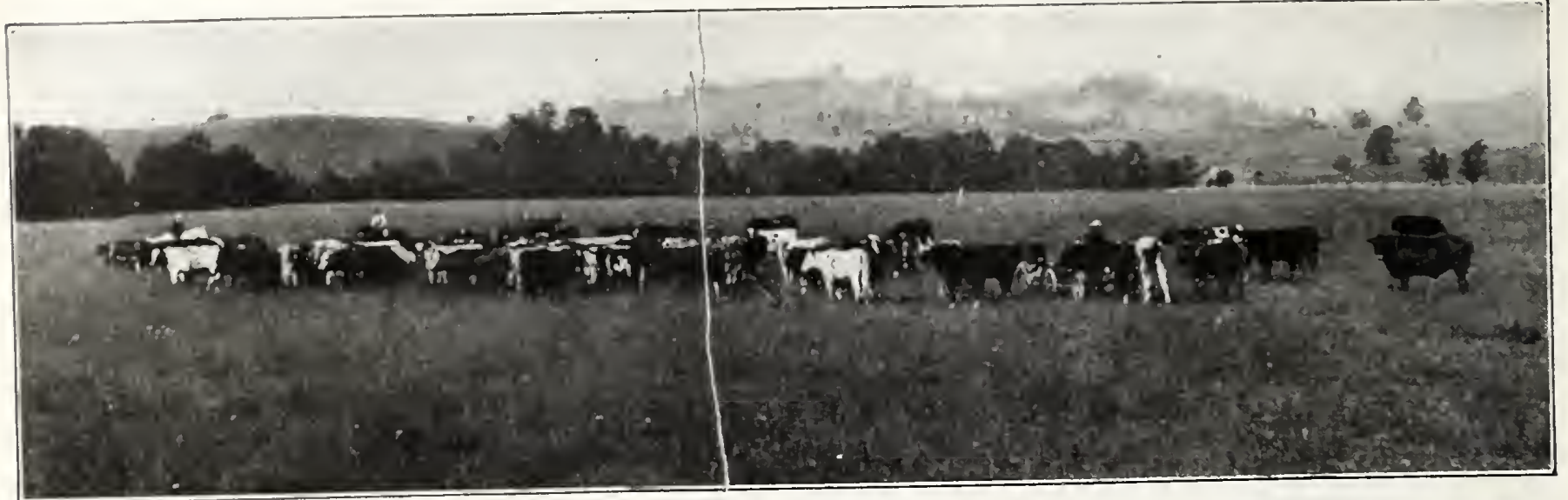

\section{WHY SOW MIXED GRASSES}

All anthoritles agree that a mixture of grasses will yiela a better crop than a single grass.

The greater the number of grasses in a mixture the

he stand, and a prowth is produced.

mixtandely than a singlo grass and help to keep out weeds.

Some grow in tufts and require other grasses to till in.

In pastures, mixtures yleld a constant succession of growth

from spring till fall.

Mixtures last for years.
Mixtures insure against fallure of any one grass.

Mixtures give more and better grazing for a longer season than a single grass.

Mixtures will give rou a chance for a crop in any season.

Mixtures insure a denser growth than the same number of seed of one or two varieties.

Grasses differ in the soils in which they yield the best results; they differ in the purposes to which each is best adapted; they differ in the season at which they are at their best.

Our erass mixtures are made up on formulas that long ex-

perience has proved are productive of the best results.

\section{PERMANENT PASTURE GRASS MIXTURES}

\section{SOW 30 TO 35 POUNDS TO THE ACRE}

MIXTURE NO. 1 - For light gravelly or sandy soils Composed of the following grasses and clovers:

Perennial Rye Grass

Alstre Clover

Tall Meadow oat Grass

Alfalfa

Alfalfa

Meadow Fescu

Japan Clover

$50 \mathrm{lbs}$. $\$ 12.75$.

Not postpald, 1b. 28c; 5 to 24 lbs. $25 \mathrm{c}$ per $1 \mathrm{~b}$; 25 to

\section{MIXTURE NO 2 - For good loam soil}

Composed of the following grasses and clovers:

Tal Meadow Oat Grass

Orchard Grass

Perennial Rye Grass

Perennial Rye Grass

wilte Clover

White Clover

Red Top or Herd's Grass

Tentucirg Blue Grags

Timothy

Carpet Grass

Paspalum or Dallas Grass

Alfalfa

By mall postpaid, 1b. 35c; 5 lbs. $\$ 1.55 ; 10$ lbs. $\$ 2.85 ; 25$ lbs. $\$ 6.60$; $501 \mathrm{bs} . \$ 12.75$

Not postuaid, lb, $28 \mathrm{c} ; 5$ to 24 lbs. $25 \mathrm{c}$ per 1b.; 25 to 99 lbs. $23 \mathrm{c}$ per lb.; $100 \mathrm{lbs}$. and over $22 \mathrm{c}$ per lb. No charge for bags.

Postpaid Prices of Fie'd Seeds -Apply to Va., N. C., W. Ponna. Tenn., Ohio, POSTAGE TO OTHER STATES: TOS. C., Ga., Ky." Tenn., Ohto, Ind., N. Y. New Eng and and Mlch.; add 2 cts. per pound to

To Ala., Ark., Fla., Ill., Iowa, Ian, Miss., Mo. and Wis. add 4 cts. per pound to postpald prices.

To Toxas, Okla. Kan. and Neb. add 6 cts per pound; to Cuba, $10 \mathrm{c}$ per lb. to postpald prices.

MIXTURE NO. 3-For heavy loam or clay soils Composed of the following grasses and clovers:

\section{Alsike Clover}

Orchard Grass

Red Top or Herd's Grass

White Clover

Red Fescire

Meadow Fescue

Italian Rye Grass

By mail postpaid, 1b, 35c; 5 lbs. $\$ 1.55 ; 10$ lbs. $\$ 2.85 ; 25$ lbs. $\$ 6.60$ 50 lbs. $\$ 12.75$.

Not postpaid, 1b. 28c; 5 to 24 lbs. 25c per 1b.: 25 to 99 lbs. 23c per lb.; 100 lbs. and over $22 \mathrm{c}$ per lb. No charge for bags.

MIXTURE NO. 4-For moist bottom land Composed of the following grasses and clovers: Kentucky Blue Grass

Kentuck

Timothy crass

Alsike Clover

Meadow Fescue Red Clover

Tall Meadow Oat Grass

Kentucky Blue Grass

Perennial Rye Grass

Timothy

1bs. $\$ 12.75$.

Not p12.75. per lb. $100 \mathrm{lbs}$. and over $22 \mathrm{c}$ per $1 \mathrm{~b}$. No charge for bags.

MIXTURE NO. 5 - For wet bottom land Composed of the following grasses and clovers:

Red Top or Herd's Grass

\section{Italian Rye Grass}

Meadow Fescue

Timothy

Alsike Clover

Kentucky Elue Grass clove

Sapling or Mama

White Clover

\section{Theadow Oat Grass}

作 50 lbs. $\$ 12.75$

Not postpaid, 1b. $28 \mathrm{c} ; 5$ to 24 lbs. $25 \mathrm{c}$ per lb.; 25 to 99 lbs. 230 Not postpaid, lb. $28 \mathrm{c}$. $22 \mathrm{per}$ lb. No charge for bags. 


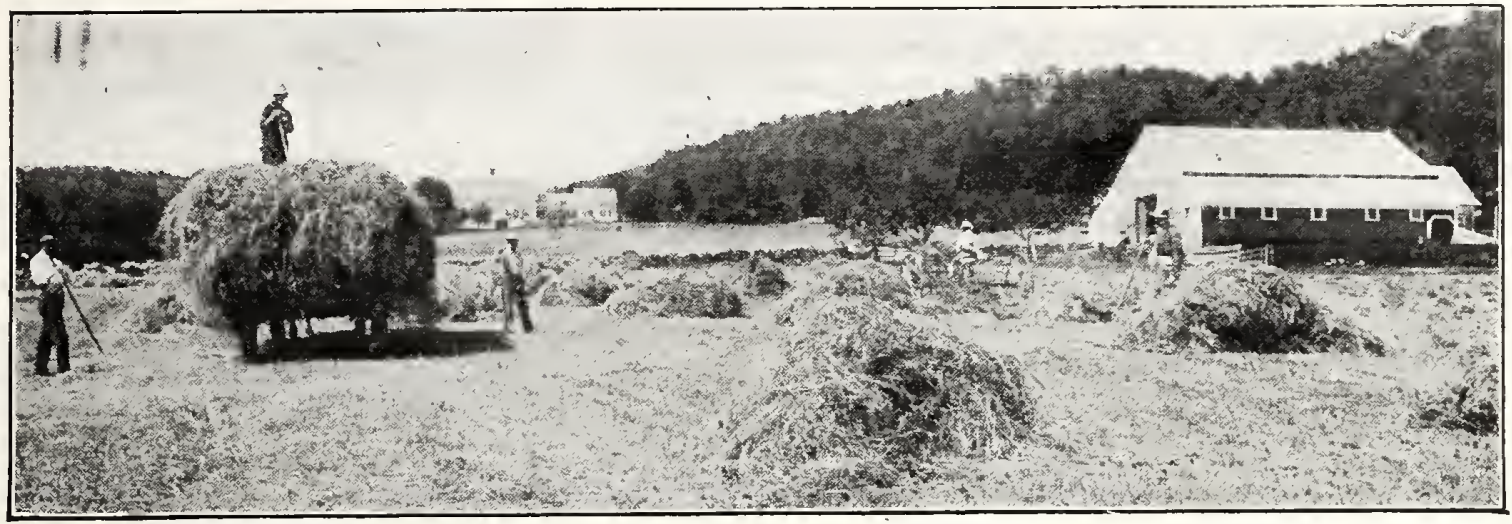

\section{HAY MIXTURES the acre \\ Will also make splendid pasturage}

Our Special Mixtures for mowing for hay are composed to prether for the frst cupally of grasses which ripen together for the frst cutting; but they also contain smaller proportions of other grasses which will increase considerably the second cutting, and also add very much to the pasturage yield, in case it is desired to use the fields for pasturage af terward. These grass mixtures afford splendid crops of hay of the finest quality and highest feeding value, and after being cut will give continuous and abundant pasturage of the richest and most nutritious character till winter comes. Flelds sown with these mixtures will last for years. May be used for hay exclusively, or for hay and pasturage as may be most needed.

MIXTURE NO. 6 - For light gravelly or sandy soils Composed of the following grasses and clovers:

Orchard Grass

Tall Meadow Oat Grass

Perennial Rye Grass

Red Fescue

Kentucky Blue Grass

Red Clover

Red Top or Herds Grass

Meadow Fescue

Alfalfa

$$
\text { Timothy }
$$

By mail postpaid, 1b. 35c; 5 lbs. $\$ 1.55 ; 10$ lbs. $\$ 2.85 ; 25$ lbs. $\$ 6.75$ 50 lbs. $\$ 13.00$

Not postpald, lb. 28c; 5 to 24 lbs. $25 \mathrm{c}$ per lb.; 25 to 99 lbs. 231/20 per lb.; $100 \mathrm{lbs}$. and over $23 \mathrm{c}$ per lb. No charge for bags.

\section{MIXTURE NO. 7 - For good loam soil}

Composed of the following grasses and clovers:

Tall Meadow Oat Grass

Meadow Fescue

Orchard Grass

Red Top or Herds Grass

Timothy

Fed Fescue

Kentucky Blue Grass

Perennial Rye Grass

Red Clover

Alsike Clover

Alfalfa

Italian Rye Grass

By mail postpaid, 1b. 35c; 5 lbs. $\$ 1.55 ; 10$ lbs. $\$ 2.85 ; 25$ lbs. $\$ 6.75$ 50 lbs. $\$ 13.00$

Not postpaid, lb. 28c; 5 to 24 lbs. $25 \mathrm{c}$ per lb.; 25 to 99 lbs. $231 / 2 \mathrm{c}$ per lb.; $100 \mathrm{lbs}$. and over $23 \mathrm{c}$ per lb. No charge for bags.

MIXTURE NO. 8 - For heavy loam or clay soils Composed of the following grasses and clovers:

Orchard Grass

Perennial Rye Grass

Tall Meadow Oat Grass

Kentucky Blue Grass

\section{Meadow Fescue}

Red Top or Herds Gras:

Red Clover

Alsike Clover

Timothy

Alfalfa

Sheep Fescue

By mail postpaid, 1b. 35c; 5 lbs. $\$ 1.55 ; 10$ lbs. $\$ 2.85 ; 25$ lbs. $\$ 6.75$ 50 lbs. $\$ 13.00$

Not postpaid, Ib. $28 \mathrm{c}$; 5 to 24 lbs. 250 per lb.; 25 to 99 lbs, $231 \% 0$ per lb.; $100 \mathrm{lbs}$. and over 23c per lb. No charge for bags.

\section{MIXTURE NO. 9 - For moist bottom land}

Composed of the following grasses and clovers:

Red Top or Herds Grass

Timothy

Meadow rescue

sapling Clover

Itallan Rye Grass

Alsike Clover

Kentucky Blue Gras:

Sheep Fescue

50 lbs. $\$ 13.00$

Not postpaid, 1b. $28 \mathrm{c} ; 5$ to 24 lbs. $25 \mathrm{c}$ per $1 \mathrm{~b}$.; 25 to 99 lbs. $231 / 2 \mathrm{c}$ per $1 \mathrm{~b}$.; 100 lbs. and over $23 \mathrm{c}$ per $1 \mathrm{~b}$. No charge for bags.

\section{Meadow Mixture No. 10}

A grass mixture that has particular value for permanent pasture. It is composed of an even greater variety of grasses than any of our other mixtures; is admirably adapted for both permanent pasture and for hay: makes a thick turf and gives a splendid yield of grass that will be relished by all kinds of
stock, and is adapted to a wider variety of soils than our other mixtures, each of which is prepared for lands of a certain char acter and for special purposes. We recommend it for sowing on inds of soils, except very light sandy

By mail postpaid, 1b. 40c; 5 lbs, $\$ 1.60 ; 10$ lbs. $\$ 2.95 ; 25$ lbs. $\$ 6.85$; 50 lbs. $\$ 13.25$.

Not prepaid, $1 \mathrm{~b}, 30 \mathrm{c} ; 5$ to 24 lbs, $26 \mathrm{c}$ per lb.; 25 to 99 lbs. $24 \mathrm{c}$ per lb.; 100 lbs. and over $23 \mathrm{c}$ per lb. No charge for bags.

\section{Wood's Golf Mixtures}

These mixtures are made up of grasses especially well adapted to Southern soils and climatic conditions. If not sure of which is best for your section, tell your troubles to our Golf Department.

\section{Wood's Putting Green Mixtures}

These mixtures are composed of the very finest dwarf-growing grasses, adapted and blended for different soils and climatic conditions. Sow at rate of 1 1/2 to 2 lbs. to each 100 square feet. Sections of Virginia, the Carolinas and the Southern States gen-
erally where Bent grass will not thrive. Price, 25-1b. lots, 39c 1b.; 50-1b. 10ts, 38c 1b.; 100-1b. lots, 37c 1b.

WOOD'S PUTTING GREEN MIXTURE "E"-For Pledmont and mountain sections of North Carolina and Virginia. Does not con50-1b. lots, 41c per 1b.; 100-1b. 1ots, $40 \mathrm{c}$ per $1 \mathrm{~b}$.

WOOD'S PUTTING GREEN MIXTURE "F"-A mixture for greens that can he given complete care and which will produce the finest Bent greens. Contains both Creeping and Coos Bay
Bents. Price on 25-1b. lots, 75c per 1b.; 50-1b. lots, 72c per 1b.; 100-lb. lots, $70 \mathrm{c}$ per $1 \mathrm{~b}$.

\section{Wood's Fair Green Mixtures}

Sow at rate of 100 to 150 pounds per acre on new falrways, or 60 o 75 pounds per acre in renovating old fairways.
We offer the following specially prepared mlxtures for different location

WOOD'S FAIR GREEN MIXTURE "A"-Especially prepared for the far Southern States. Contains both Bermuda grass and car-
pet grass. Price on 100-1b. 1ots, 32c per 1b.; 500-1b. 1ots, 31c per 1b. WOOD'S FAIR GREEN MIXTURE "B"-For Georgia, the Carolinas and Eastern Virginia. Contains a heavy proportion of Bermuda grass. Price, 100-1b. 1ots, 32c per 1b.; 500-1b. lots, $31 \mathrm{c}$ per $1 \mathrm{~b}$. WOOD'S FAIR GREEN MIXTURE "C"-For Piedmont and moun-

tein sections of North Carolina. Virginia and Northern sections.

Contains only grasses for these locations. Price on 100-1b. lots, $34 \mathrm{c}$ per $1 \mathrm{~b}$.; 500 -1b. lots, $33 \mathrm{c}$ per $1 \mathrm{~b}$.

We handle a complete line of golf club supplies-power, horse and hand mowers, sprinklers, hose, rollers, course markers, ball washers, tee markers, hoxes and stands, hole rims, putting cups and flags. Write for Golf Course Catalog. 


\section{Wood's Virginia Grown Ensilage Corns}

\section{THE SILO FILLERS}

Wood's Virginia Grown Ensilage Corns are bred up especially for ensilage purposes. They have the height of stalk and a luxuriant growth of broad, thick, succulent blade that will insure maximum tonnage. Our corns are ear selected, nubbed, recleaned, graded and tested.

The following varleties are recommended for the Atlantic Coast States and the Corn Belt.

\section{Wood's Pamunkey Ensilage}

The Heaviest Producer of All Ensilage Corns

Our Pamunkey Ensllage Corn Is bred for height of stalk, breadth the a thlekne inehes In diameter, wlth a good depth of grain. In tonnage of enas proved by reports from dalrymen and stockmen in every seetion By mall postpald, qt. 35c; $1 / 2$ peck $90 c$; peck $\$ 1.60 ; 1 / 2$ bushel $\$ 2.95$; bushel $\$ 5.50$.

Not postpald, $1 / 2$ peck $65 \mathrm{c}$; peck $\$ 1.20 ; 1 / 2$ brshel $\$ 2.25$; bushel $\$ 4.25$; 5 -bushel lots $\$ 4.00$ per bushel.

\section{Wood's Eureka Ensilage}

Eureka is more universally grown for ensllage than any other one variety. It is a double purpose eorn, for, aside from being a hrst-class ensliage corn, as a field variety it ranks high in yield. of fodder. It bears one to two ears to the stalk, the ears frequently over 12 inelies. The erains are nedium large flinty, elosely e It makes ensilare $\ln$ about 100 days. By mall postpald, qt. 35c $1 / 2$ peck 900 ; peck $\$ 1.55$; $1 / 2$ bushel $\$ 2.80$; bushel $\$ 5.25$.

Not postpald, $1 / 2$ peck $65 \mathrm{c}$; peck $\$ 1.15 ; 1 / 2$ bushel $\$ 2.10$; bushel $\$ 4.00$; 5-bushel lots $\$ 3.90$ per bushel.

\section{Wood's Virginia Ensilage}

The Delaware Experiment Station says: "For years Thood's Vir Ginfat Ensliage has outyielded all other varleties, and we eonside territory and a great in 100 days. By mall postpald, qt. 30c; 1/2 peck 80c; peck $\$ 1.30$ bushel $\$ 2.30$; bushel $\$ 4.25$.

Not postpald, $1 / 2$ peck $55 \mathrm{c}$; peck $90 \mathrm{c}$; $1 / 2$ bushel $\$ 1.60$; bushel $\$ 3.00$; 5-bushel lots $\$ 2.90$ per bushel

\section{Brandon Red Cob Ensilage}

\footnotetext{
Dig corn from one of our older ensilage varietles rown In the fertile James River Valley, breeding partleularly fo (n) iivege peck $\$ 1.25 ; 3 / 2$ bashel $\$ 2.20$; busliel $\$ 4.00$.

Not postpald, $1 / 2$ peck 50 c; peck 85 ; $1 / 2$ bushel $\$ 1.50$; bushel $\$ 2.75$ S-bushel lots $\$ 2.60$ per bushel
}

The following varietles are recommended for Ohio, New England, Now $\mathbf{Y}$ ork and other Northern States.

\section{Cocke's Prolific Ensilage}

The Maryland stace College say's: "IFood's Cocke's 'Prolifie aver(in state average was less than 7 tons. In il thirteen-year test it outyielded all Gther ensilage varleties. It is superior to other varieties beeause of Its ligher feeding value and beeause it makes so many ears, is Sy to handle and put through the eutier-box. The Dalry Husbandry Department or the indiana state Experi-

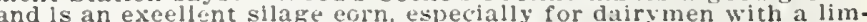
ited aereage for silage." By mail postpald, qt. 30c; $3 / 2$ peck $85 \mathrm{c}$; peck $\$ 1.50$; $1 / 2$ bushel $\$ 2.70$; bushe $\$ 5.00$.

Not postpaid, $1 / 2$ peck $60 \mathrm{c}$; peck $\$ 1.10$; $1 / 2$ bushel $\$ 2.00$; bushel $\$ 3.75$.

\section{Wood's Blue Mountain Ensilage}

An early selection from our Pamunkey Ensilage that will make good ears In the North. The grain and ear are both large and it 4. $1 / 2$ bushel $\$ 2.80$; bushel $\$ 5.25$. Not postpaid, $1 / 2$ peck $65 c$; peck $\$ 1.15 ; 1 / 2$ bushel $\$ 2.10$; bushel Wood's Virginia Pride Yellow Ensilage

The heaviest produeer of all the vellow ensilage varieties Irakes an 11 -ineh ear with deep grain: grows 13 feet insuring a high tonnate. At ensilage stare in 90 days, making the crop further north than other leavy under adverse eonditions will outyield most varieties. In the Mlaryland State College tests last season it ranked seeond. By mall postpald, qt. 30c; $1 / 2$ peck $75 \mathrm{c}$; peck $\$ 1.25 ; 1 / 2$ bushel $\$ 2.20$; bushel $\$ 4.00$. Not postpaid, $1 / 2$ peck 50c; peck 85c; 32 bushel $\$ 1.50$; bushel $\$ 2.75$ : 5-bushel lots $\$ 2.60$ per bushel.

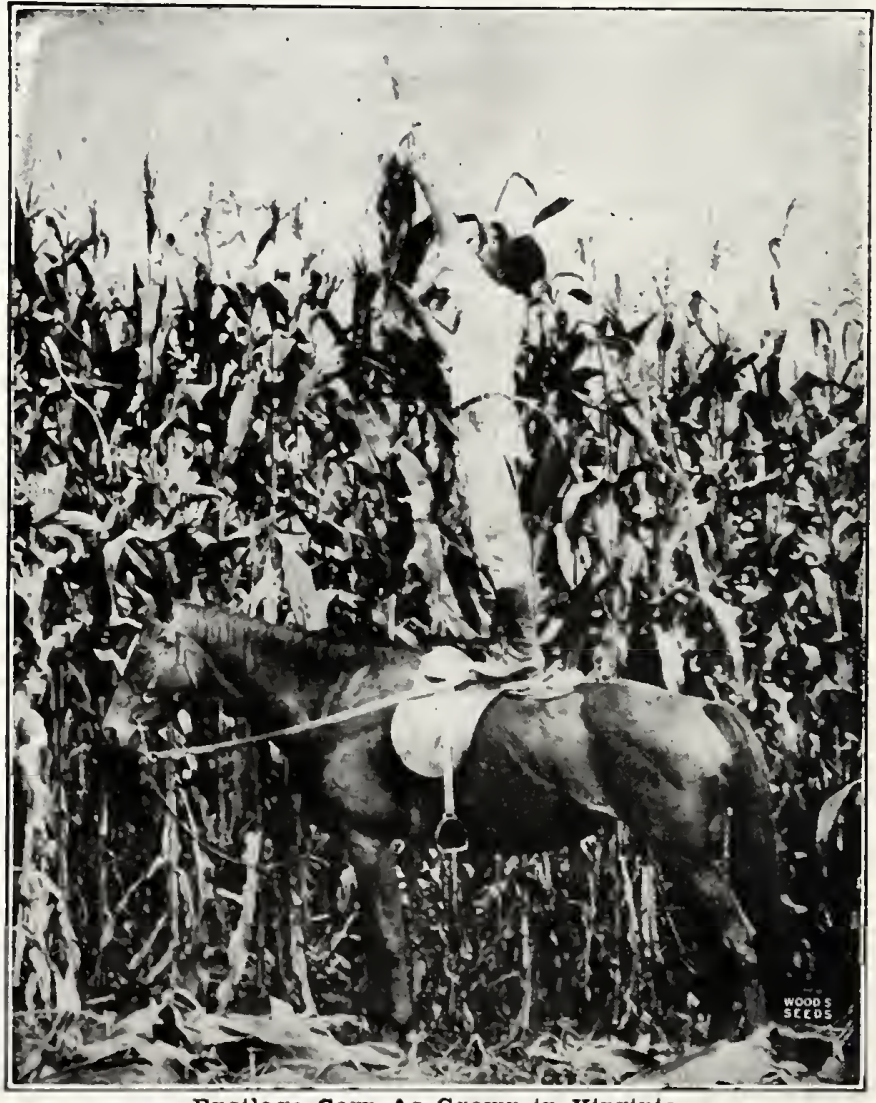

Ensllage Corn As Grown in Virginia. 


\section{WOOD'S SELECTED SEED CORNS}

1 peck $=14 \mathrm{lbs}$.

$1 / 2$ bushcl $=281 \mathrm{bs}$.

1 bushel $=56 \mathrm{lbs}$.

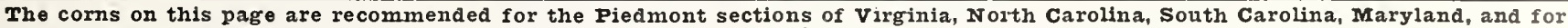
Kentucky, Tennessee, Delaware, and New Jersey.

\section{White Varieties}

\section{Wood's Improved White Dent}

For generations Wood's Improved White Dent has been the reliable old stand-by with southern corn growers, and its merits are generally recognized. It makes a single ear to the stalk, but they are long and heavy; the grains are quite wide, deep and firmly set on a medium sized cob. The size of the ear assures a good yield. It is a safe and reliable corn that year by year is being planted in increasing quantities as its dependalle and reliable qualities dre becoming recognized. The stalk is tall and
carries a good growth of fodder.

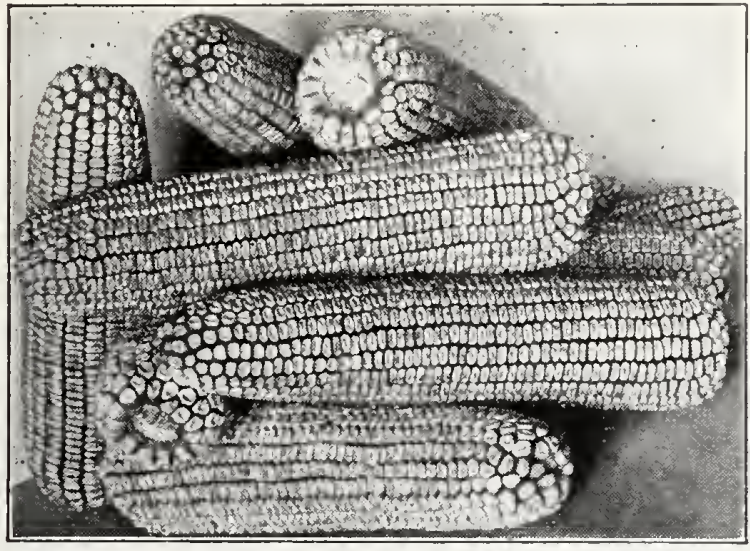

Boone County ed more attention from corn breeders other white corn; there is probably no otlor white prizes than any other white corn: there is probably no other white corn so exten-
sively planted. It is one of the big yielding single eal varieties. occasionally yielding over 100 bushels to the acre. Our pedigree stock was grown from certified seed, and is the strain that has won most of the important prizes for white corn in Virginia. It makes a 10 to 11 -foot stalk of medium size witl: a tair amount of fodder. The stalks bear one to two good ears, usually 10 to 11 inches long, that are carried 4 to 5 feet high. The grains are not flinty, so make good corn for feeding and milling. The ears are well filled at butt and tip; the grains are deep.

\section{Woodburn White Dent ${ }^{- \text {In the breeding of this }}$}

jectives-increased production and resistanc two definite ibIt is a vigorous growing white dent; the stalk is thick and leafy: grows 10 to 11 feet high; bears one to two good ears that are 11 to 12 inches long, well filled out at hut and tip, and does not shrivel like many big-eared corns. It matures in about 100 days. wrote of the most successful Prince Edward County corn growers bushels to the acre. A Chesterfield County farmer tells us he made better than 60 bushcls to the acre, but that his land was only medium.

\section{Weekley's Improved White Dent}

\section{Recommended a bove all other corns for Piedmont carolina by his}

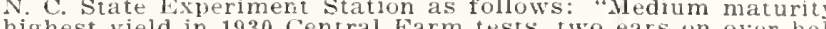

the stakts

butts and tips filted no other corn is more sound; medium

Iall

hank. It has a broad leaf and vigorous stocky stalk." Ou short wood's DIxIE. An excetionally well-bred corn that breeder. BIGGS' SEVEN EAR. 'The earliest of the prolific corns and a fine JoHNSON CoUNTY WHITE DENT.-Piant Boone County

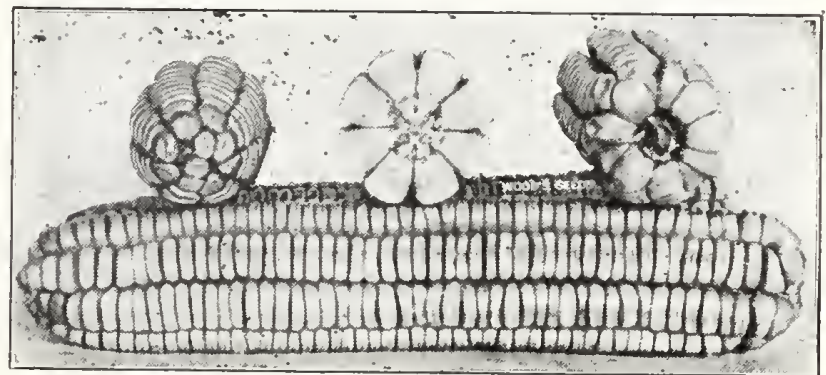

Hickory King ${ }^{-T h e}$ grain is so wide and deep and the will cover the end of a broken cob. It has been called the Poor Man's Corn bccause it can be depended upon
to produce a crop on poor, thin land. Or good land it bears two

How We Handle Seed Corn our seed corns are grown seed stocks and are field intom our own selected brought in to our warehouse, again inspected ear by ear, and every ear nubbed and tipped, shelled, recleaned, graded and tested for germination. This insures hlgh-grade seed corns of uniform quality.

\section{Yellow Varieties}

WOOD'S IMPROVFD GOIDEN DENT. A prime favorlte in all the REID'S YEI.OW DENT. A fint corn for the upland sections: maIUPRO in a D IDAMING. The ears are big and generally two to the

\section{Jarvis Golden Prolific}

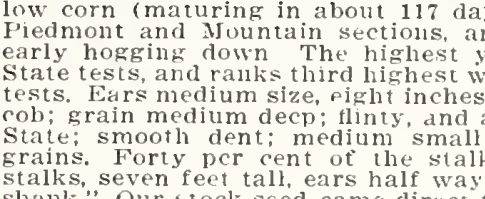

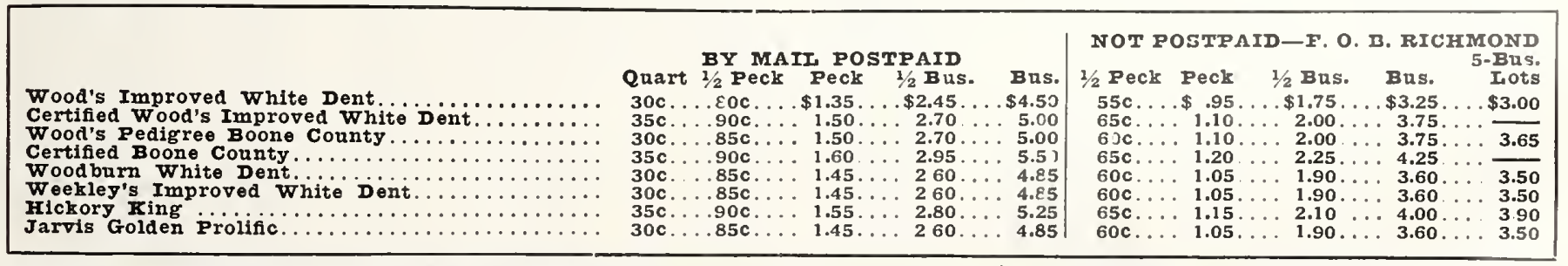




\section{White Varieties}

SOUTHERN SWOWFLAKE.

WOOD'S IMPROVED WHITE DENT.

HICKOR Y KING

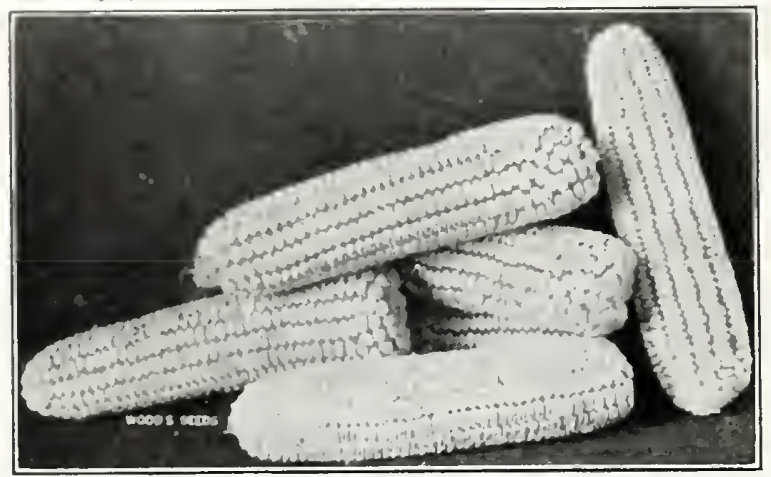

Biggs' Seven Ear

Wood's Dixie

Latham's Double

Mosby's Prolific

Cocke's Prolific
Douthit's Prolific Red Cob White Dent

Recommended by the S. C. Experinient station as the highest Ylelding corn for South Carolina. White grain on red eob: very pro-
ilfie, making two or more ears on two-thirds of the stalks: 1 linty and weevil resistant; ears eight inclies lung, good show type: deep grain, small cob; 70 lbs, ears shells 59 lbs. grain. Stalks nine to ten ture. Our stock seed comes direct from the breeder, the strain winHasting's Prolific The introducer claims that it 24 to 30 inches apart in the row avcrage land. and if planted six ears to the stalk can be had. The ears are well filled at both ends: the cols is small; the shuck is hcavy and covers Whatley's Prolific Red Cob White Dent A very prolifie late corn for the far South. Our stoek was ob-

\section{Yellow Varieties}

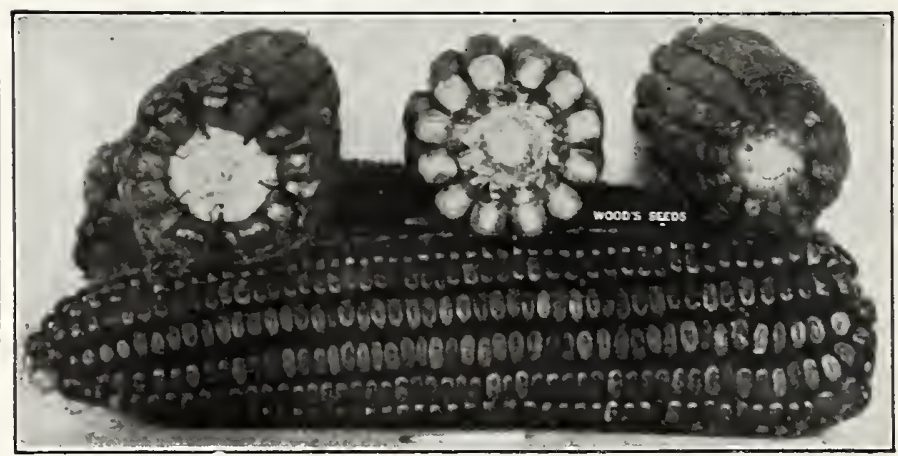

Wood's Improved Golden Dent

In the eoastal sections of the Atlantic Coast States from the Potomac River to Florida Golden Dent has a place that no other corn can fill. It is early enough to make a crop on land on which early potatoes have been grown; it can be hogged down much earlier than other Southern varieties, and it is used quite generally the early roasting ears. It makes a beautiful ear, and whether on are deep, medium wide and firmly set on a small cob. The shuck is elose and completely proteets the tip a ainst adverse weather. We have known it to be under water for a day and come out perfeetly sound. Our stock is well bred, the ears well flled out at both Wood's Virginia Yellow Dent

A week later than our Improved Golden Dent; bears one to two extra large ears to the stalk, with twenty rows of closely placed, very deep gratns, the butts and tips well eovered; medium dent; proved one of the biggest ylelding yellow eorns.

\begin{tabular}{|c|c|}
\hline & Quart $\begin{array}{l}\mathbf{B Y} \\
\mathbf{B Y}\end{array}$ \\
\hline 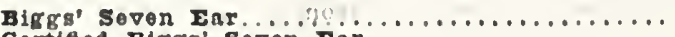 & $30 c \ldots 85$ \\
\hline Certifled Blggs' Soven Ear........ & 35c. \\
\hline Wood's Dixio $\ldots \ldots \ldots \ldots \ldots \ldots$ & $30 \mathrm{c}$. \\
\hline Certined Wood's Dixie........... & $35 \mathrm{c}$. \\
\hline 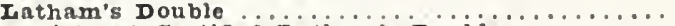 & 300 \\
\hline Reglstered Certifled Iatham's Double........... & 35c. \\
\hline Hasting's Prollfic $\ldots \ldots \ldots \ldots$ & 30c. \\
\hline Douthit's Proliflc Red Cob white Dent.......... & $30 \mathrm{c}$. \\
\hline 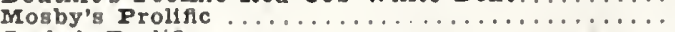 & \\
\hline Cocke's Prollfic & 300. \\
\hline Whatley's Prollfic Red Cob white Dent......... & $30 \mathrm{c} \ldots .85 \mathrm{c}$ \\
\hline 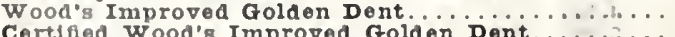 & $30 c \ldots 80 c$ \\
\hline 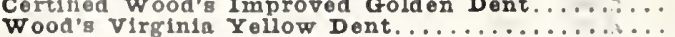 & $\begin{array}{l}35 \mathrm{c} \ldots .90 \mathrm{c} \\
30 \mathrm{c} \ldots .80 \mathrm{c}\end{array}$ \\
\hline
\end{tabular}

BY MAII POSTPAID Peck Peck $1 / 2$ Bus.

c...\$1.50 ...\$2.70

(800, $1.60 \ldots, 2.95$

$1.45 \ldots 2.60$

1.55

(1.45

. 1.55

$85 \mathrm{c} \ldots 1.50$

1.35

. 1.35

$85 \mathrm{c} \ldots 1.45$

1.40

$80 \mathrm{c} . . .1 .30$

\begin{tabular}{|c|c|c|c|c|c|}
\hline \multirow[b]{2}{*}{ Bus. } & \multicolumn{5}{|c|}{ NOT POSTPAID-F. O. B. RIOHMOND } \\
\hline & $1 / 2$ Peck & Peck & $1 / 2$ Bus. & Bus. & Iots \\
\hline $\begin{array}{r}\$ 5.00 \\
5.50\end{array}$ & $60 \mathrm{c} \ldots$ & $\$ 1.10$ &.$\$ 2.00$ & $\$ 3.75$ & $\$ 3.65$ \\
\hline 4.85 & & 1.05 & 1.90 . & $\begin{array}{l}4.25 \\
3.60\end{array}$ & 3.50 \\
\hline 5. & & 1.15 . & 2.10 . & 4.00 & \\
\hline 4.85 & $60 \mathrm{c}$ & 1.05 . & 1.90 & 3.60 & 3.50 \\
\hline 5.25 & 650. & 1.15 . & 2.10 . & 4.00 & 365 \\
\hline & 60c. & 1.10 . & 2.00 . & 3.75 & 3.65 \\
\hline $\begin{array}{l}4.85 \\
4.50\end{array}$ & $\begin{array}{l}60 c . \\
550 .\end{array}$ & $\begin{array}{r}1.05 \\
.95\end{array}$ & $\begin{array}{l}1.90 \\
1.75\end{array}$ & $\begin{array}{l}3.60 \\
3.25\end{array}$ & $\begin{array}{l}3.50 \\
3.15\end{array}$ \\
\hline 5.00 & $60 \mathrm{c}$. & 1.10 . & 2.00 & 3.75 & 3.65 \\
\hline & $60 \mathrm{c}$. & 1.05 & 1.90 & 3.60 & 3.50 \\
\hline 4.75 & $55 \mathrm{c}$ & 1.00 & 1.85 & 3.50 & $\mathbf{3 . 4 0}$ \\
\hline 5.25 & 65 & 1.15 & 2.10 & 4.0 & \\
\hline 4.25 & & .90 & 1.60 & $\mathbf{3 . 0 0}$ & 2.90 \\
\hline
\end{tabular}




\title{
WOOD'S SELECTED SEED CORNS \\ $1 / 2$ bushel $=28 \mathrm{lbs}$
}

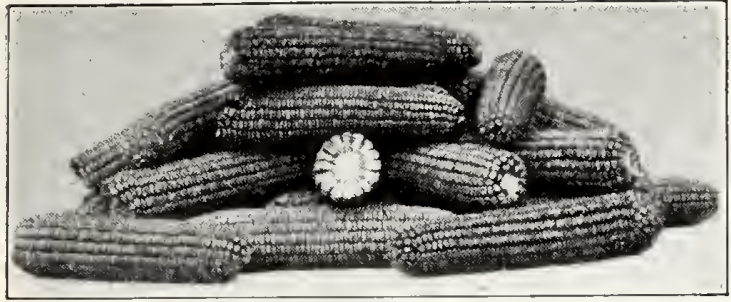

Early Clarage Yellow Dent.

2 FINE EARLY CORNS FOR THE

MOUNTAINS

\author{
Early Clarage Yellow Dent
}

\section{Golden Queen}

The corns on this page are recommended for the mountain sections of Virginia, North Carolina, West Virginia, Maryland, Tennessee, and Kentucky, and for Pennsylvania, Ohio and New York.

\section{Yellow Varieties}

JARVIS' GOLDEN PROI,IFIC. Highly recommended by the North Carolina Experiment Station See page 65.

EARIY CLARAGE YEIIOW DENT. A 90 -day yellow corn for GOIDEN QUExN. Makes sound corn in high altitudes in about GOIDEN QUDEN. Makes
100 days. See page 4.

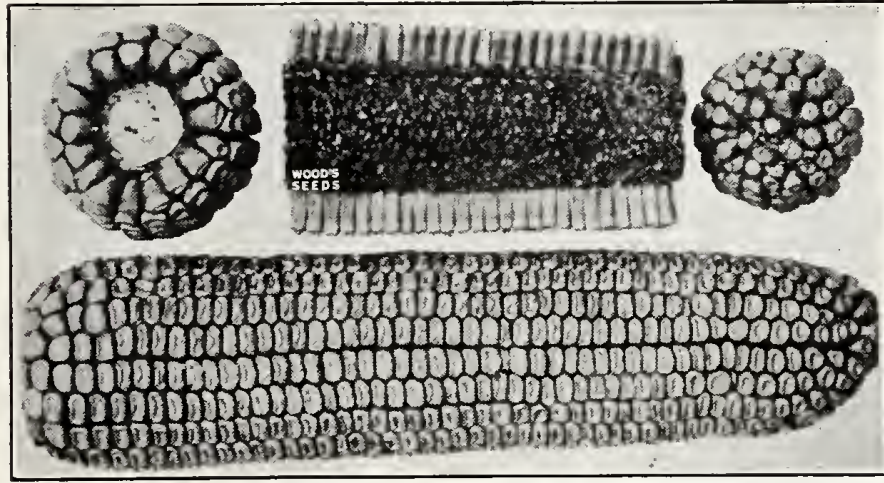

Reid's Yellow Dent ${ }^{- \text {In the }}$ piedmont or upland Reid's Yellow Reid's Yellow Dent has made a well-deserved reputation because of its large yields and superior type of ear. It is a big yielder on good loam and heavy land, making ears that average 9 to 10 inches long with 18 to 24 rows to the ear, and well filled out at butt and tip. It is a true dent corn, the grains are medium narrow, wedge-shaped, and the rows are so close that there is pracsize of the ear; makes one to two ears to the stalk.

Improved Leaming try overas a big yielding, early generally two big ears to the stalk with rarely a barren stalk. It does well on all soils but prefers light to medium soils. The It does well on all solis. but prefers light to medium solls, The age about 10 inches long with 18 to 20 rows to the ear. The color age about 10 inches long with 18 to 20 rows to the ear.
is a deep, reddish yellow. Matures in about 100 days.

Postpaid Prices Apply to Va., N. C., W. Va., Ma., Del., PosTAGT TO OT

Ohio, Ind., N. Y., Now England and Mich., add $2 c$ per ponnd

to postpaid prices. $4 c$ per pound to postpala prices.

To Texas, Okla., Kan. and Neb., add $6 \mathrm{c}$ per pound to postpaid prices.
HICKORY KING.

\section{White Varieties}

BOONE COUNTY.

JOHNSON COUNTY WHITE DENT.

Silver King

\section{days and mak}

ing its earlines

closely placed on

Early Harvest

eight inches long. In nine
ears, and meal in 110 days.

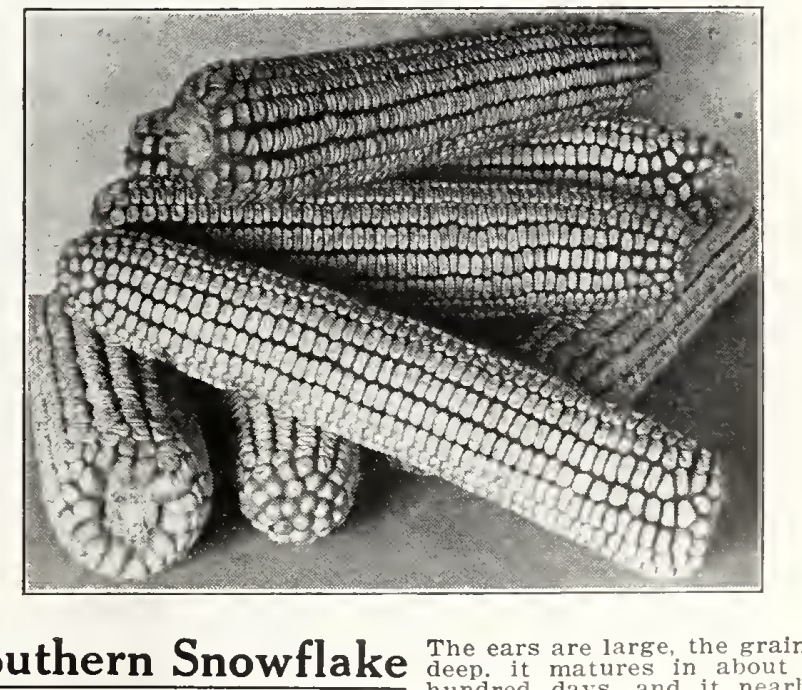

Southern Snowflake

always carries two ears to the

thin land that will not bring

planting.

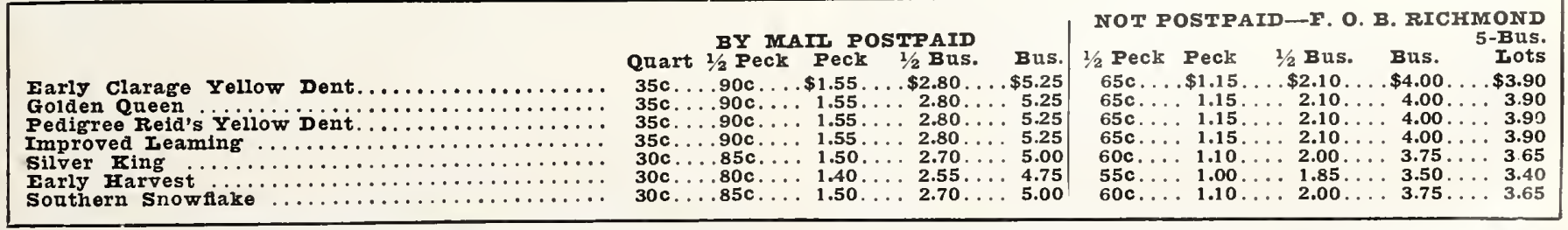




\section{Oats}

\section{Pedigree Fulghum Oats}

One of the most satisfactory of all oats for spring sowing. A heavy ylelder, rust-proof, has full heads and plump, heavy grain, and is one of the earliest. There is no variety more reliable for spring sowing than Fulghum.

By mail postpaid, peck 60c; $1 / 2$ bushel 95c; bushel

Not postpald, peck 35c; $1 / 2$ bushel 55c; bushel 95c; 10-bushel lots $92 \mathrm{c}$ per bushel. No charge for bags.

\section{Red Rust-Proof Oats} talned a prominent place in farming operations. Thls is partleuar true in the coast regton where other varieties have not proved altogether sittisfactory. bet where the red are cm inelined to rust. By mail postpaid, peck 55c; $1 / 2$ bushel $90 \mathrm{c}$; bushel $\$ 1.60$.
Not postpaid, peck 30c; $1 / 2$ bushel $50 \mathrm{c}$; bushel $85 \mathrm{c}$; 10-bushel lots $83 \mathrm{c}$ per bushel. No chargé for bags.

\section{WHAT OATS TO PLANT}

The oat is a cool season plant and requires early planting. If you can get them in early, the Gray winter and Red Rust Proof are recommended. If Irarch lst to $15 \mathrm{th}$, the earlier kinds, like Fulghum, in before Swealsh Select will no doubt give better results on account or Swedish Select will no
thelf earlfer maturity.

\section{Swedish Select Oats}

Those tho prefer a white oat for spring seeding will make no mistake in sowing swedish Select. One of the State Experiment Stations reports in a test covering several years an average yield of slightly more than 10 bushels to the acre more than fies tested, and that the proportion of kernel to the whole It has given especially good is not large in

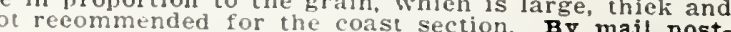
paid, peck 55c; $1 / 2$ bushel $90 \mathrm{c}$; bushel $\$ 1.60$.

Not postpaid, peck, 30c; $1 / 2$ bushel 50c; bushel $85 \mathrm{c}$; 10 -bushel lots $83 \mathrm{c}$ per bushel.

\section{Gray Winter or Turf Oats}

Probably the best reason for the wide popularity of Gray Winter Oats is their extreme hardiness, for there is no other oat that will stand sueh extreme cold. Another good clalm for their popularity is their stooling propensity, which aeeounts in part for the heavy yield. Their strong turfing and stooling characteristics give them advantages over all other oats for grazing purposes They have the further advantage of weicht; it is not unusual to have them weigh 35 to 40 pounds to the busliel. By mail postpaid, peck $65 \mathrm{c} ; 1 / 2$ bushel $\$ 1.05$; bushel $\$ 1.90$.

Not postpaia, peck 40c; $1 / 2$ bushel 65c; bushel $\$ 1.15 ; 10$-bushel lots $\$ 1.12$ per bushel.

\section{Burt, or Ninety-Day} Oats

If you have not seeded your ats by the first part of March. he Burt is a safe oat to plant, for cessful farmers it has proved its generall be depended upon to from heat. It makes a good yrain is free fromi rust, and what

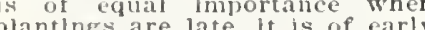
Early plantings can be De to put the same land

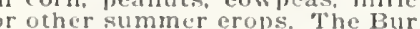
on the llight sindy solls of the Thurains (7) bushel $\$ 1.65$.

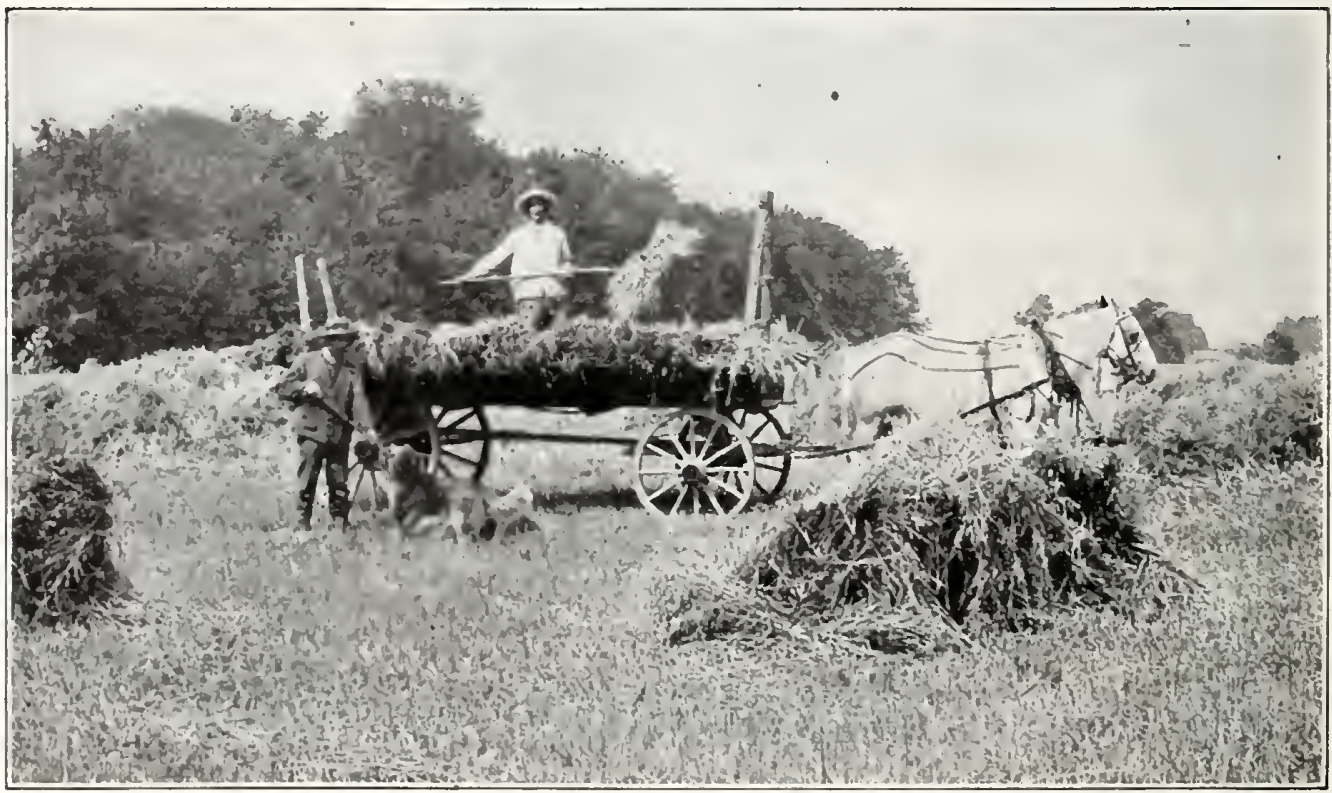

Not postpald, peck $35 \mathrm{c}$; 3

bushe1 55c; bushel 90c; 10-bushel lots 870 per bushel.

\section{White Spring Oats}

This varlety is gulte largely frown in this seetion, although the newer varletles offered by us are preferable, both as to yleld and
rellabllity. By mall postpald, peck $55 \mathrm{c}$; 16 bushel $90 \mathrm{c}$; buslel $\$ 1.55$. Not postpald, peck 30c; 1/2 bushel 50c; buslel 80c; 10-bushel lots 770 per bushel

Ceresan Controls Diseases

Sunflower seeds fed to pouttry make a real egg-produeer, being rlch in oil and proteln they make an ideal food during the moulting season; the leaves make excellent fodder; the whole plant makes time ensilage and hor feed Under favorable conditlons, 40 to 60 bushels can be busluels have been rrown on extra good land in an unusual season. When ripe and hard eut off the heads and pile loosely under eover and when cured they will thresh easily. plant and cultlvate like corn. By mall postpald, 1b. 25c; 5 1bs. 85c; 10 Ibs. $\$ 1.45 ; 25$ lbs. $\$ 2.90 ; 50$ 1bs. $\$ 5.50$.

Not prepaid, 1b. 15c; 10 to 24 lbs. $11 \mathrm{c}$ per 1b.; 25 to 99 lbs. $9 \mathrm{c}$ per $1 \mathrm{~b} . ; 100 \mathrm{lbs}$. and over $8 \frac{1}{2} \mathrm{c}$ per $1 \mathrm{~b}$. 


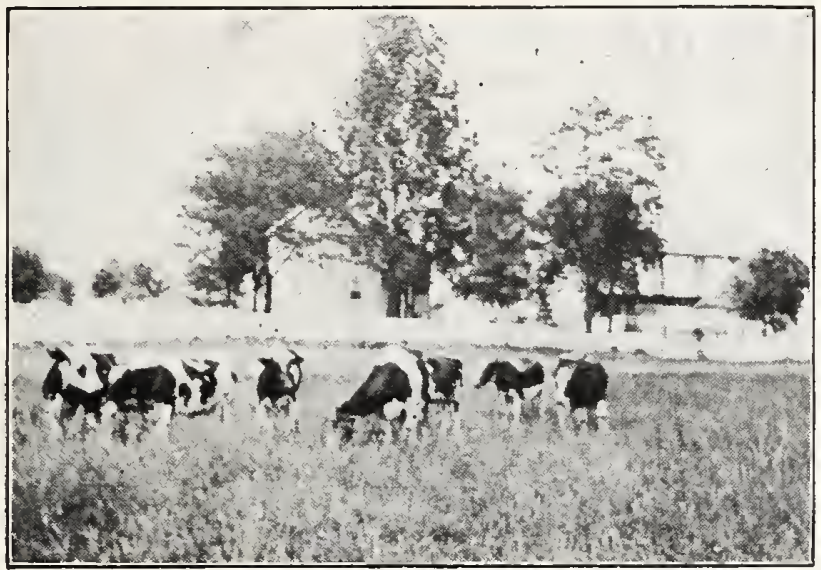

Wood's Spring Pasture Mixture

A mixture of spring barley, rye, oats, vetch and rape, com. bined in proper propcrtions to make a quick, early and nutritious spring and early summer pasture that will give an abundance of grazing before the grass and clover pastures are ready.
It makes a quick growth, is relished by all kinds of stock, and comes in before the natural pasture grasses have made sufficient growth to furnish grazing. Sow 2 to 3 hushels to the acre in postpaid, peck $75 \mathrm{c}: 1 / 2$ bushel $\$ 1.20$ : bushel $\$ 2.15$.

Not prepaid, peck $40 \mathrm{c}$ : $1 /$ bushel $70 \mathrm{c}$; bushel (40 lbs.) $\$ 1.25$; 5-bushel lots $\$ 1.20$ per bushel.

\section{Postpaid Prices on Field SeedApply to Va., N. c., w. Va.} POSTAGE TO OTHER STATES: To S. C., Ga., Ky., Tenn. Ohio, Ind., N. Y., New England and Mich., add $2 c$ per pound to postpaid prices.

To Ala., Ark., Fla., Ill., Iowa, Ia., Miss., Mo, axd W1s., add 4c per pound to postpald prices.

To Texas, Okla.. Kan. and Neb., add $6 \mathrm{c}$ per pound, to $\mathrm{Cuba} 10 \mathrm{c}$ per lb., to postpaid prices.

The Quickest Growing and Earliest Maturing Spring Grain Barley is the quint
grain and may be exp
medium land. and

\section{Beardless Spring Barley}

ripens in about 75 days. It makes a growth of about 27 inches
and makes a very good hay, It has strong straw and well-
filled heads. Our stock is free from bearded heads and the
hay can be fed to stock without fear of injury. By mail post-
paid, peck 90c; $1 / 2$ bushel $\$ 1.60 ;$ bushel $\$ 2.85$.
Not postpaid, peck 55c: $1 / 2$ bushel 95c; bushel (48 1bs.) $\$ 1.75$; Not postpaid, peck 55c: $1 / 2$ bushel $95 \mathrm{c}$
10-bushel lots and over $\$ 1.70$ per bushel.

Bearded Spring Barley - Heads up in about 65 days and ma-

than Beardless spring Barley. prove harmful when fed to stock. The grain should be ground bushel $\$ 2.35$.

Not postpaid, peck 40c; $1 / 2$ bushel 70c; bushel (48 lbs.) $\$ 1.25$; 10-bushel lots and over $\$ 1.20$ per bushel.

Treated Barley - We offer the aboye barleys treated with Cereblight and other diseases In additio and smut, rust, seeding

treatment with Ceresan stimulates the plant and increases the bushel is made.

\section{Dwarf Essex Rape}

\section{THE ECONOMICAL PASTURE CROP FATTENS SHEEP WITHOUT GRAIN}

\section{A Quick and Cheaply Grown Pasturage for Sheep; Hogs, Cattle and Poultry. \\ Ready in 6 to 8 Weeks from Sowing}

Bot it as early as possible-late March or early April is not too late 3 to 4 lbs. plant an acre in drills; 6 to 8 lbs. broadcast.

Formerly rape was grown especially for sheep and lambs, but in recent years it has been found equally good for providing pasture for all kinds of slock. It has been estimated to yield more than 10 tons of green forage per acre that, for fattening is claimed to be worth, pound for pound, double the value of clover. One of the lambs fed on rape alone was 7 to 8 lbs per month. Another experiment redion rape alone was 7 to 8 lbs. per month. Another experiin coln at the last working sowng of to libs. rape to the acre particularly profitable practice, as an enormous crop can be grown at a cost of about 50 to $60 \mathrm{cts}$. per acre. An acre of rape will easily pasture twenty hogs for two months.

Do not turn stock into a rape pasture when they are hungry, nor when the rane is wet. as it may induce bloating; allow them to remain a short while the first day, and increase the time each succeeding dav. Give stock access to salt twhile feeding nn rape: they should also have hay or straw convenient in case of bloat.

CULTURE:- Sow as mrly as the land can he made ready, thr earlier the better, but sowings as late as April have been very succcssful. Sow either broadcast or in drills 18 inches to 2 feet apart; when grown in drills and cultivated occasionally, the leave. Allow 8 to 10 weeks for it to attain its maximum growth.

Sow it again next fall to have grazing during the fall, winter and sprinz.

By mail rostraid, lb. 20c; 5 lbs. $75 \mathrm{c} ; 10$ lbs. $\$ 1.25 ; 25$ lbs. $\$ 2.40$ 50 lbs. $\$ 4.50$

Not prepaid, 1b. $12 \mathrm{c} ; 5$ to 24 lbs. 9c per 1b.; 25 to 99 lbs. $7 \mathrm{c}$ per lb.; 100 lbs. and over $61 / 2 \mathrm{c}$ per lb. No charge for bags.

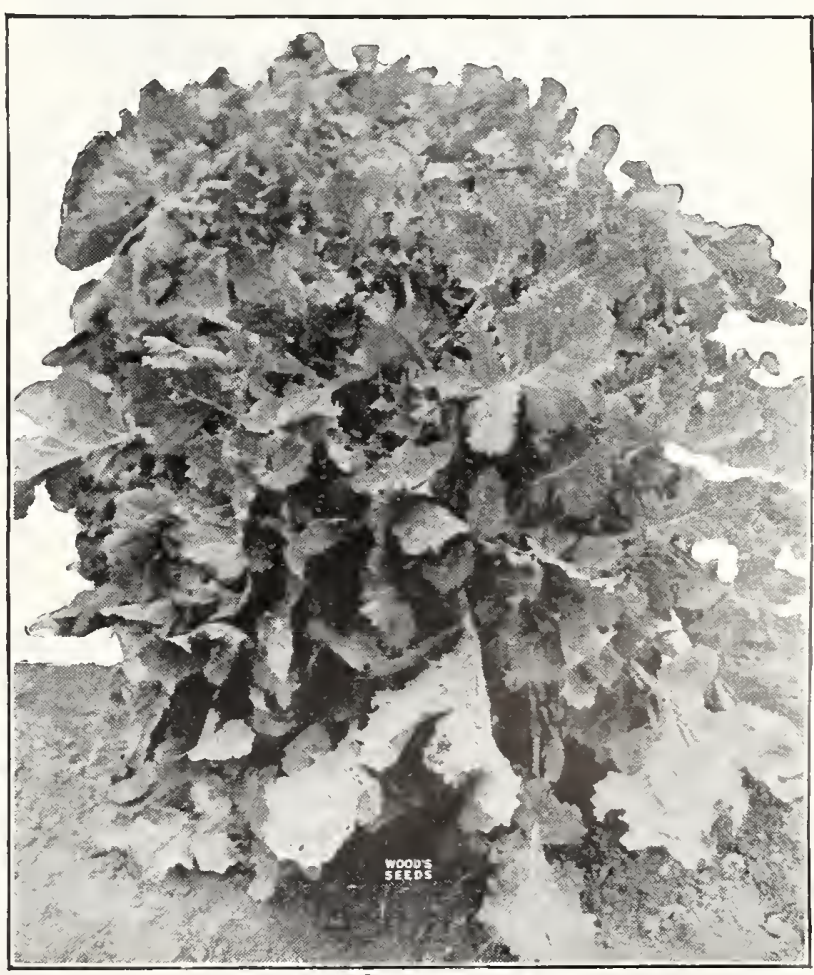

Dwarf Essex Rape. 


\section{Wood's Seed Potatoes}

Culture Potatoes thrive best in a sandy loam that contalns plenty of vegetable matter a clover sod or land that inches alvirt in three-foot rows, 4 inches deep for early plantBefore the plants appear a bove re planted. and be sure to work lt into the soil so not use stable manure, as It means scabby potatoes. Continue to spread.

\section{Irish Cobbler Potatoes}

Te belleve Te are safe in saying that 75 per cent of all the Trio popularity extra early potatoes planted tome arliness, but also on its repuacteristles is that it makes few if any very small potatoes praccoblifer. The tubers ire round to oval in shape, slightly fattened, have strong, well-developed eyes; the flesh ls pure white and

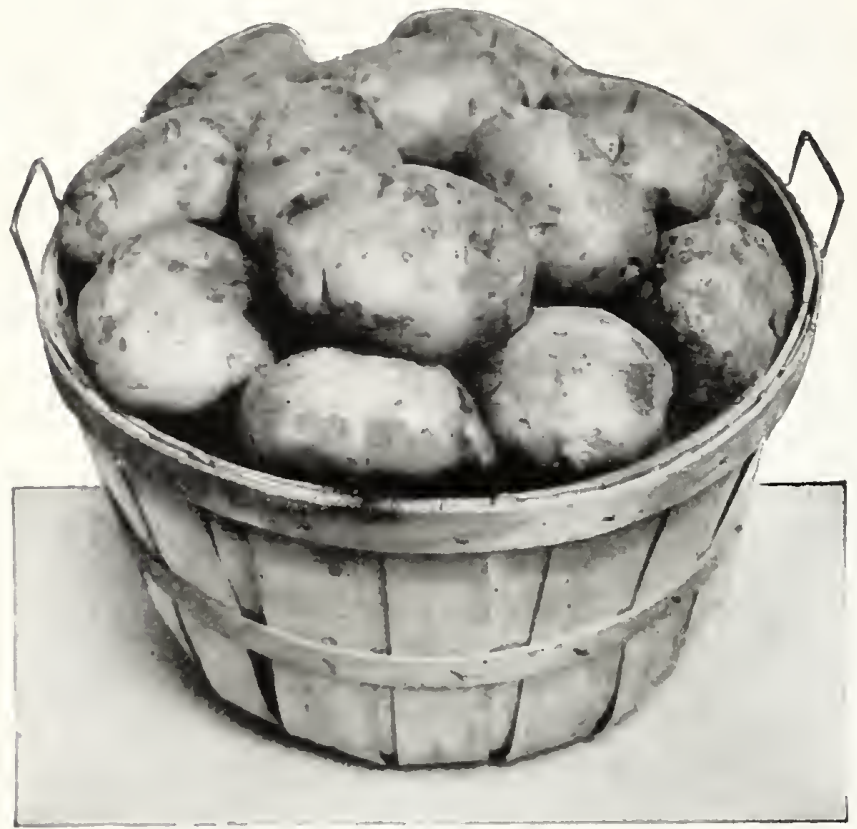

\section{Certified Irish Cobblers}

It is false cconomy to save fifty cents or a dollar a bag by huylng bor common potatoes when certificd seed can be hadthe most successful potato growers use nothing but certlfied done for horses, cattle, hogs, ete. The small additional cost of less dismase, more No. I potatoes and greater proft to the grower. lepry ten-pects big will carry the tag of the inspection authortplied to have then as pure as is humanly possible.

CERTIFIED MAINE GROWN COBBIERS.-Certified by the $\$ 1.20$; 15 bushel $\$ 2.05$; bushel $\$ 3.70$.

Not prepasd, $1 / 2$ peck $50 c$; peck $75 \mathrm{c}$; $1 / 2$ bushel $\$ 1.30$; bushel $\$ 2.40$; 10 -pecle bag (150 lbs.) $\$ 5.50$.

CERTIFIED PRINCE EDWARD ISLAND COBBIERS. GOV.NRment inspected and certified. By mall postpald, $1 / 2$ peck $75 \mathrm{c}$; peck $\$ 1.20$; 3/2 bushel $\$ 2.05$; bushel $\$ 3.70$

Not prepald, $1 / 2$ peck 50c: peck $75 \mathrm{c}$; $3 / 2$ bushel $\$ 1.30$; bushel $\$ 2.40$; 10 -peck bag (150 lbs.) \$5.50.
Spray Your Potatoes Potato planters who grow for market ther. know trotherence the increased lield and the better quality of the potatoes. For these same reasons, those who BORIEAUX MIXTURE is the recognized fungicide, preventing disease and stimulating the plants, invigorating then to yield ARSENATE OF IEAD AND PARIS GREEN are the universally Into bordeaux mixture and applied at a single spraying. SEMESAN BEI prevents diseases in potatoes and other seeds. SPRAY MATERLALS AND SPRAYERS are deseribed on pages 87 to 92 .

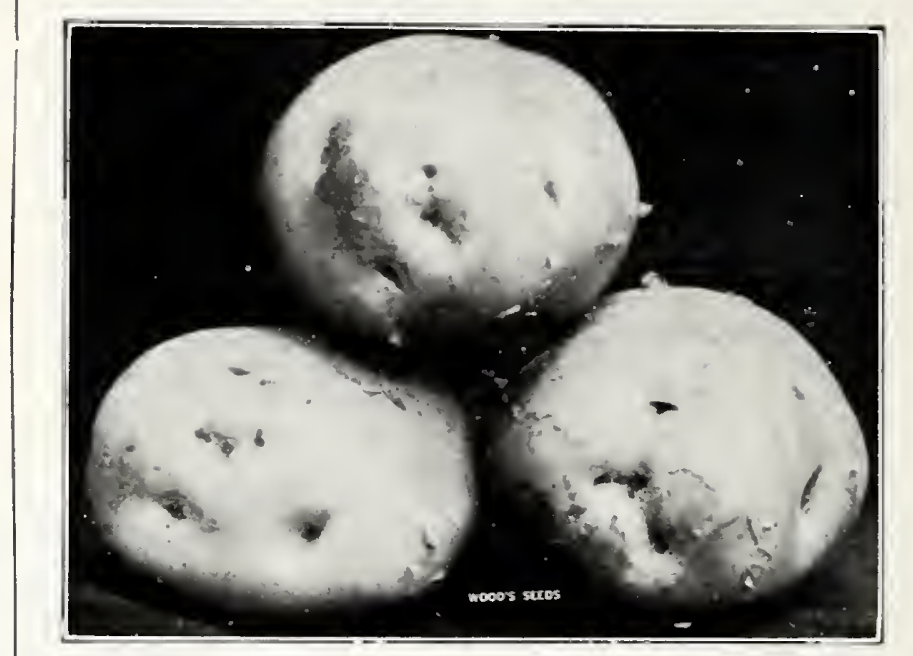

\section{Wood's Virginia 2nd Crop Cobblers}

\section{PEDIGREE STOCK GROWN FROM CERTIFIED SEED}

The experience of practlcally all large potato growers, an experience covering several years, provis conclusively that Virginla Second Crop potatoes, raised as a second crop from certifled Maine-grown stock, make larger yields and are stronger growers than Northern grown potatoes. They are smaller than Maine rown, cut to better advantage, and are more economical to plant.

Our stock was grown in the best potato growing section in Vircinia. We planted certified potatoes that had been grown under the rigid rules of the Maine Experiment Station. had been inwhen growing and after being harvested and certified yem as true Irish cobblers and free from disease. They are not as large as Maine-grown potatoes, but are just the size or cutting into two pieces or for planting whole. Thls season, on accunt of dry weather, our second crop Cobblers are smaller than usual. They are the right size for planting whole and will go

We recommend Virginia Second Crop Cohblers in the highest terms: they make sturdy, hardy plants and better ylelds than $1 / 2$ peck $70 \mathrm{c}$; peck $\$ 1.15$; $1 / 2$ bushel $\$ 1.90$; bushel $\$ 3.40$.

Not prepald, $1 / 2$ peck 45 c; peck 70 ; $1 / 2$ bushel $\$ 1.15$; bushel $\$ 2.10$; 10 -peck bag (150 lbs.) \$4.75.

\section{Selected Maine-Grown Cobblers}

We have secured a splendid supply of Cobblers, grown by competent and rellable growers. and grown from first-class seed stock. generally from certified seed. The price is lower than for certifled seel, but they are fine stock and ln every way dependable. By mad

postpald, $1 / 2$ peck $65 \mathrm{c}$; peck $\$ 1.10$; $1 / 2$ bushel $\$ 1.85$; bushel $\$ 3.30$.

Not prepald, $1 / 2$ peck $40 \mathrm{c}$; peck $65 \mathrm{c} ; 1 / 2$ bushel $\$ 1.10$; bushel $\$ 2.00$; 10-peck bag (150 lbs.) \$4.50. 


\section{Early Potatoes}

Red Bliss -To those who prefer a potato with a pink skin Red BISs and white flesh, or those who grow for markets Red Bliss. It is one of the very earliest, nearly round, peels without waste and a fine yielder. It is a sure and uniform cropper, a strong grower, is of good size, cooks white and mealy and measures up to every requirement of a firstclass first early potato. Its productivecommend it.

VIRGINIA 2nd CROP A better yielder than Northern grown, stronger grower and, on account of size, more economical to plant Smaller than usual this season because of dry weather, but the right size for planting whole and will plant further than prer potathan

By mail postpaid, $1 / 2$ peck $75 \mathrm{c}$; peck $\$ 1.20$; $2 / 2$ b u s hel $\$ 2.00$ bushel $\$ 3.60$.

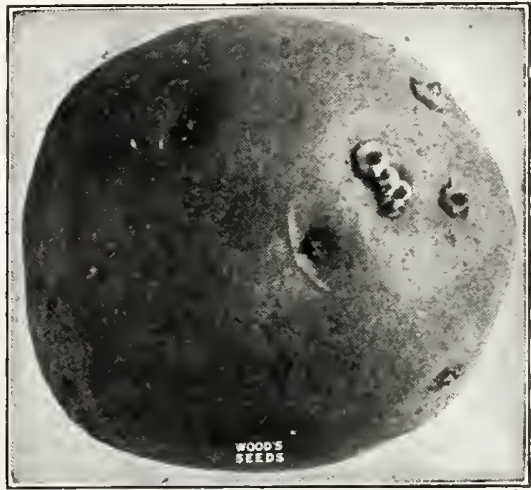

Red Bliss Potato
Not prepaid, $1 / 2$ peck $50 \mathrm{c}$; peck $75 \mathrm{c}$; $1 / 2$ bushel $\$ 1.25$; bushel $\$ 2.30$; 10 -peck bag (150 lbs.) $\$ 5.25$.

MAINE GROWN RED BIISS. Grown from selected planting stock and grown expressly for planting. By mail postpaid, $1 / 2$ peck $70 \mathrm{c}$; peck $\$ 1.15 ; 1 / 2$ bushel $\$ 1.90$; bushel $\$ 3.40$.

Not postpaid, $1 / 2$ peck $45 c$; peck 70c; $1 / 2$ bushel $\$ 1.15$; bushel $\$ 2.10$; 10-pecls bag (150 $\mathrm{lbs}$.) $\$ 4.75$.

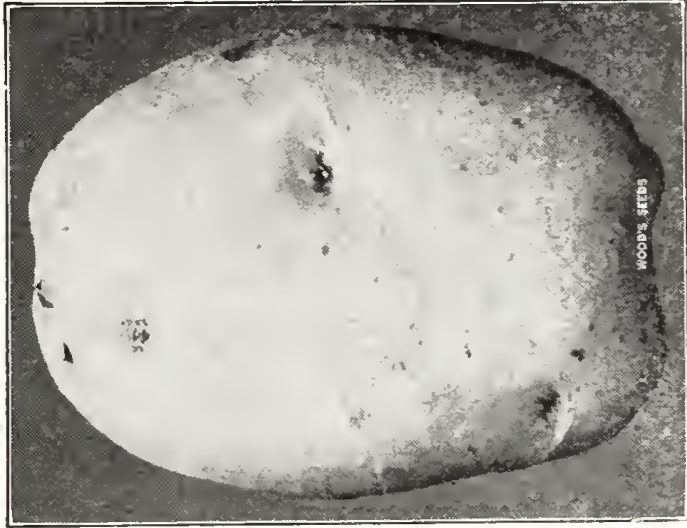

\section{Spaulding No. 4 Rose} NORTHERN GROWN Very mealy, dry and keens well. Spaulding No 4 was bred out of the old popular Early Rose, and is in every way a better potato, having a better shape, being shorter, thicker and larger and a $1 / 2$ bushel $\$ 1.85$; bushel $\$ 3.30$.

Not prepald, $1 / 2$ peck $40 \mathrm{c}$; peck $65 \mathrm{c}$; $3 / 2$ bashel $\$ 1.10$; bushel $\$ 2.00$; 10-peck bag (150 lbs.) $\$ 4.50$.

\section{2nd Early and Late Potatoes}

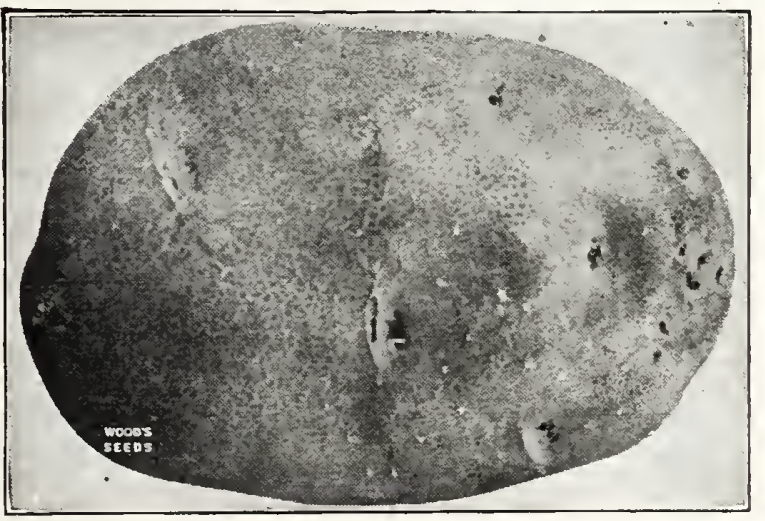

Green Mountain - Has the reputation of making big crops everywhere and on practically any kind of soil, producing uniformsmooth, oval-shaped potatoes with white skin, with very few small potatoes. Medium late; not suscepti-

CERTIFIED GREEN MOUNTAIN-By mail postpaid, $1 / 2$ peck $75 \mathrm{c}$; peck $\$ 1.20$; $1 / 2$ bushel $\$ 2.00$; bushel $\$ 3.60$

Not postpaid, $1 / 2$ peck $50 \mathrm{c}$; peck $75 \mathrm{c} ; 1 / 2$ bushel $\$ 1.25$; bushel $\$ 2.30$; 10 -peck bag ( 150 lbs.) $\$ 5.25$.

SFIFCTID GREEN MOUNTAIN.-By mail postpaid, 1/2 peck $65 \mathrm{c}$; peck $\$ 1.10 ; 1 / 2$ bushel $\$ 1.85$; bushel $\$ 3.30$

Not prepaid, $1 / 2$ peck $40 \mathrm{c}$; peck $65 \mathrm{c} ; 1 / 2$ bushel $\$ 1.10$; bushel $\$ 2.00$; 10-peck bag (150 lbs.) \$4.50.

Improved Peachblow Attractive in appearance at: a fine keeper. A dependakie ditions of drought and heat. The skin is slightly tinged with pink. By mall postpaid, $1 / 2$ peck $70 c$; peck $\$ 1.15 ; 1 / 2$ bushel $\$ 1.95$; bushel $\$ 3.50$.

Not prepaid, $1 / 2$ peck $45 \mathrm{c}$; peck $70 \mathrm{c}$; $1 / 2$ bushel $\$ 1.20$; bushel $\$ 2.20$; 10 -peck bag (150 lbs.) $\$ 5.00$.

\section{Sweet Potatoes}

-At the time this catalog is printed these cannot be quoted. Write for prices about April ist
Lookout Mountain - The wide popularity of Looloson and yet make satisfact to withstand a hot and dry seasize, smooth, oval in shape with white skin. $\mathbf{B y}$ mail postpaid, $1 / 2$ peck $75 \mathrm{c}$; peck $\$ 1.20$; $1 / 2$ bushel $\$ 2.00$; bushel $\$ 3.60$

Not prepaid, $1 / 2$ peck 50 ; peck 75 c; $1 / 2$ bushel $\$ 1.25$; bushel $\$ 2.30$; 10 -peck bag' (150 lbs.) \$5.25.

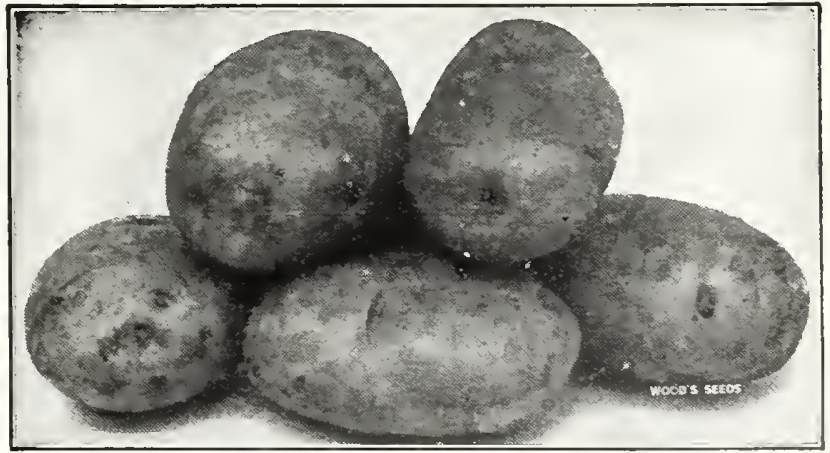

McCormick potatoes, peels without waste, and the quality is all that $\$ 1.15$ $1 / 2$ bushel $\$ 1.95 ;$ bushel $\$ 3.50$.

Not prepaid, $1 /$ peck $45 \mathrm{c}$; peck $70 \mathrm{c}$; $1 \frac{1}{2}$ bushel $\$ 1.20$; bushel $\$ 2.20$; $10-$ peck bag (150 lbs.) $\$ 5.00$.

\section{Potatoes for June and July Planting}

We carry in cold storage all the leading varieties so as to have them in sound, vigorous and unsprouted condition. Write for prices.

No. 304. Potato Planter -Adjustable to the depth you want No. 304. Potato Planter to plant; no springs to break; just a horse machine. By mail postpaid, $\$ 2.25$. Not prepaid, $\$ 2.00$. 


\section{Cow Peas}

1 peck $=15$ lbs.

$1 / 2$ bushel $=301 \mathrm{bs}$.

1 busbel = $60 \mathrm{lbs}$.

\section{THE SOUTH'S ECONOMICAL SOIL IMPROVING AND HAY CROP}

WHEN TO PLANT. Plan a grain drlll or In rows $2 t$ to

INOCUIATETHIS
SEED WITH
STIMUGERM

SOWING COW-PEAS WITH SOY-BEANS, TAFFIR CORN, SORGHUM AND SUDAN GRASS.-Cow-peas may be solv wit thall a bushel soy-beans or one peck kafir corn or sorghun SOWING COW-PEAS WITH MILIET.-New Era and IThipoorwll are the best kinds to sow with German millet-one The crop should be cut when the millet is ready. The peas will

Brabham slmilar to Whip By mall postpaid, qt. $30 \mathrm{c}$; 12 peck $85 \mathrm{c}$ disetse-resistant as Iron. By mall po
peck $\$ 1.45 ; 1 / 2$ bus. $\$ 2.60 ;$ bus. $\$ 4.85$.

Not postpald, $1 / 2$ peck $60 \mathrm{c}$; peck $\$ 1.00$; $1 / 2$ bus. $\$ 1.85$; bus. $\$ 3.50$ Whippoorwill sometimes called Shinney or speckled Peas. More largely grown than any other cow pea, probably of both hay and peas. Makes an upright growth, making it easy wanted. By mall postpald, qt. $30 \mathrm{c} ; 1 / 2$ peck $80 \mathrm{c} ;$ peck $\$ 1.40$; $1 / 2$ bus. $\$ 2.50$; bus. $\$ 4.60$.

Not postpald, $1 / 2$ peck 55 ; peck 95 ; $1 / 2$ bus. $\$ 1.75$; bus. $\$ 3.25$.

New Era -New Era ranks among the earliest, is of erect prowth, and the seeds are the smallest of all cowmakes lt easy to hariest and curc. By mail postpaid, qt. 30c; $1 / 2$ peck $80 \mathrm{c}$; peck $\$ 1.40 ; 1 / 2$ bus. $\$ 2.50$; bus. $\$ 4.60$.

Not postpald, $1 / 2$ peck 55 ; peck 95 c; $1 / 2$ bus. $\$ 1.75$; bus. $\$ 3.25$.

Groit $-A$ cross between Whippoorwlll and New Era that is as When grown whthout soy beans or other support, the mass of growth generally averages two feet or more orer the field. It
Is rust-reslstant. By mail postpaid, qt. 30c; $1 / 2$ peck $80 c$; peck $\$ 1.40 ; 1 / 2$ bus. $\$ 2.50$; bus. $\$ 4.60$.

Not postpala, $1 / 2$ peck 55c; peck 95c; $1 / 2$ bus. $\$ 1.75$; bus. $\$ 3.25$.

Mixed Cow-Peas -Grow thlcker, producing a better crop of tles. For soll-inuroving $1 \mathrm{t}$ is really an advantage to sow mlied peas. By mail postpald, qt. $25 \mathrm{c} ; 1 / 2$ peck $75 \mathrm{c}$; peck $\$ 1.30 ; \frac{1}{2}$ bus. $\$ 2.25$; bus. $\$ 4.10$.

Not postpald, $1 / 2$ peck 50c; peck $85 \mathrm{c} ; 1 / 2$ bus. $\$ 1.50 ;$ bus. $\$ 2.75$.

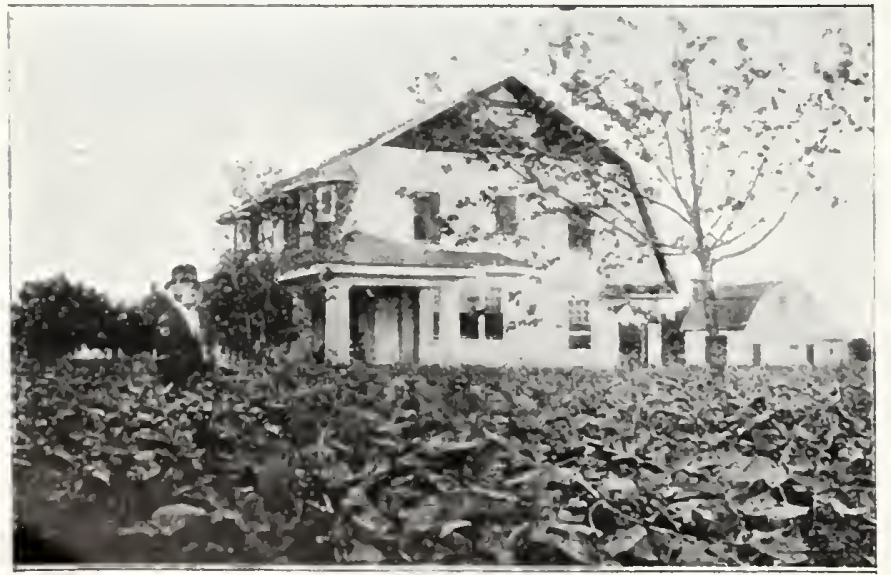

A fine growtli of Cow-Peas.

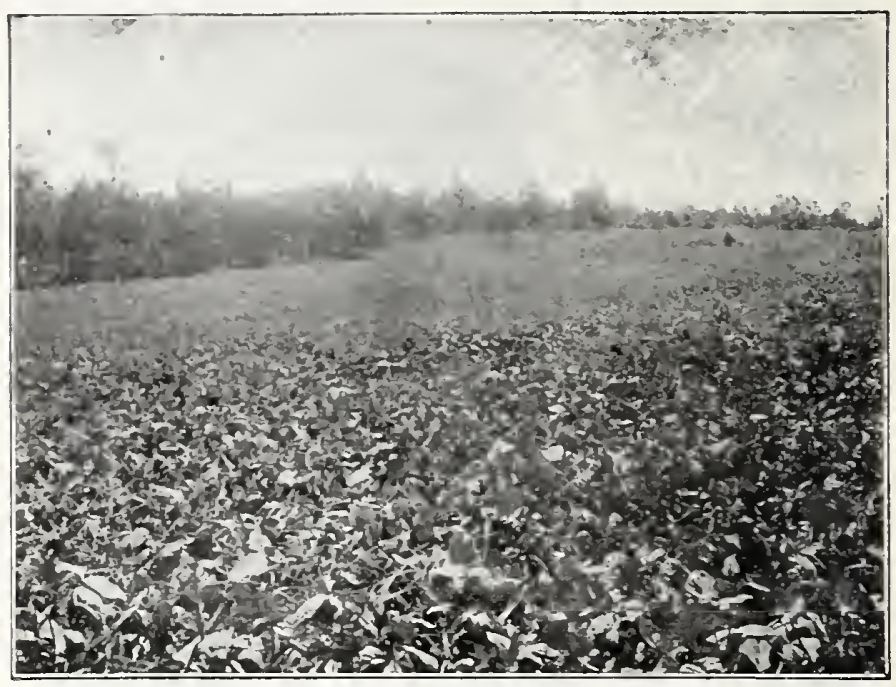

\section{FACTS ABOUT COW.PEAS}

Pound for pound, cow-pea hay is as valuable as clover hay. It is nearly equal in value to alfalfa and wheat bran.

It contains four times as much digestible protein as timothy hay. Horses and mules need no grain through the winter when fed cured cow-pea hay

The U. S. Department of Agriculture says: "No one thing can add more to the agricultural wealth of the South than the growing of cow-peas."

Makes a fine feed for work and beef stock and dalry cattlo.

cotton can be grown for three successive years after a cow-pea crop.

Wheat and oat lands put into cow-peas after harvest can be seeded to grain again in the fall, making two crops a year on the same land.

Does not require expenslve fertllizer, but adds nitrogen to the soll and improves its mechanlcal condition.

They can be grown on any soll that is not too wet.

There is no cheaper way to improve poor land than by growing cow-peas. They add nitrogen and improve the mochanical condition of the soil.

Iron -A vigorous grower, the vines growing 4 to 5 feet long, son. Wedium early, a prolific bearer, is never affected by rust, and makes a particularly fine hay. This pea seems to be immune to many diseases that attack some other varieties. $\mathbf{B y}$ mall postpald, qt. 30c; $1 / 2$ peck $80 \mathrm{c}$; peck $\$ 1.40 ; 1 / 2$ bus. $\$ 2.50$; bus. $\$ 4.60$.

Not postpaid, 1/2 peck 55c; peck 95c; $1 / 2$ bus. $\$ 1.75$; bus. $\$ 3.25$.

Black - On sandy soils it makes a fine growth and plenty of - peas, wut it does well under widely different conditions and soils. On heavy clay it makes a lieavy growth of vine, for pasturing logs. By mail postpaid, qt. 30c; $1 / 2$ peck $85 c$; Not postpaid, $1 / 2$ peck $60 \mathrm{c}$; peck $\$ 1.00$; $1 / 2$ bus. $\$ 1.85$; bus. $\$ 3.50$.

Clay - Tigorous in growth; of running habit. Very popular all through the southern States: a good variety for soil wli vonderful or l"nknown. hut it is somewhat earlier though the growth ls quite similar. By mail postpald, qt. 30c; $1 / 2$ peck 80c; peck $\$ 1.40 ; 1 \%$ bushel $\$ 2.50$; bushel $\$ 4.60$

Mixed Cow-Peas and Soy Beans - Tle beans, being of upVixed Cow-Peas and Soy Beans Fighe beans, sung of uplong pea vines, and not only make the harvesting easier, but the combination of cow-peas and soy beans makes a better hay By $1 \% a l l$ postpaid, qt. $25 \mathrm{c} ; 1 / 2$ peck $700 ;$ neck $\$ 1.20 ; 1 / 2$ bus. $\$ 2.05$; bot postpald, $1 / 2$ peck $45 c$; peck $75 c$; $1 / 2$ bus. $\$ 1.30$; bus. $\$ 2.40$. 


\section{Black Eye and other Edible Peas}

$1 \mathrm{peck}=15 \mathrm{lbs}$.

$1 / 2$ bushel $=301 \mathrm{bs}$

1 bushel $=60$ lbs.

\section{Black Eye Peas for Succession}

We recommend Extra Early Black Eye, Farly Ram's Horn Black Eye and Virginta Black Fye. Piant liberally to have plenty of dried peas for next winter.

Extra Early Black Eye Sometimes called six weeks Peas,ing ready for the table in about 65 to 70 days after planting. It is a prolific bearer of well-filled pods; the peas are not as large as Virginia Black Eye, but are distinctly earlier. The home gardener should grow them for an extra early supply of sweet, tenhigh price paid for the first black eye peas on the market. By mail postpaid, q t. 40c; $1 / 2$ peck $\$ 1.15$; peck $\$ 2.10 ; 1 / 2$ bushel $\$ 3.90$ bushel $\$ 7.35$.

Not postpaid, $1 / 2$ peck $90 c$; peck $\$ 1.65 ; 1 / 2$ bus. $\$ 3.15$; bus. $\$ 6.00$.

Early Ram's Horn Black Eye $-A l$ though called Early medium early, being ready in about 80 ways. It makes a large leafy growth and is prolific, with well-filled pods. Its popularity is largely due to the attractive appearance of the mapaid, qt. 35 c $1 / 2$ peck $\$ 1.00 ;$ peck $\$ 1.70 ; 1 / 2$ bus. $\$ 3.10 ;$ bus. $\$ 5.85$ paid, qt. 35 ; $1 / 2$ peck $\$ 1.00$; peck $\$ 1.70 ; 1 / 2$ is. $\$ 3.10$; bus. $\$ 5.8$.

Virginia Black Eye For the main crop thls has always all black eye most extensively grown of about 110 days, it has proved so thoroughly dependable that they are very generally grown to produce dry peas for winter use. The pods are long and well filled and are produced in great abundance. By mail postpaid, qt. 35c; $1 / 2$ peck 90c; peck $\$ 1.60 ; 1 / 2$ bushel $\$ 2.85$; bushel $\$ 5.35$.

Not postpaid, $1 / 2$ peck $65 \mathrm{c}$; peck $\$ 1.15$; $1 / 2$ bus. $\$ 2.10$; bus. $\$ 4.00$.

Gray Crowder Tnown in various sections as Taylor, Blue Whippoorwill, Gray Whippoorwill, Early Crowpod, and makes a larce yield of peas Matures early $B$ y mail postpaid, qt. 30c; $1 / 2$ peck 90c; peck $\$ 1.55 ; 1 / 2$ bushel $\$ 2.75$; us. $\$ 5.10$

Not postpaia, $1 / 2$ peck 65 ; peck $\$ 1.10$; 1/2 bus. $\$ 2.00$; bus. $\$ 3.75$.
Cream Crowder - Not only one of the earliest to mature, but flavored table peas. It is also excellent to use for a forage crop and soil-improver, as it makes a large growth of vines. bus. $\$ 10.35$.

Not postpaid, $1 / 2$ peck $\$ 1.30$; peck $\$ 2.40$; $1 / 2$ bus. $\$ 4.60$; bus. $\$ 9.00$.

Gallavant, Rice or Lady the peas are the smallest, but all the edible cow-peas-it probably should not be called a cow-
pea. They are prolific bearers and may be used either green or
dry. By mall postpaid, qt. 50c; $1 / 2$ peck $\$ 1.45 ;$ peck $\$ 2.70$. Not postpaid, $1 / 2$ peck $\$ 1.20$; peck $\$ 2.25$.

Postpaid Prices Apply to Va., N. C., W. Va., Ma., Del., POSTAGr TO OT N

Ohio, Ind., N. Y., New England and Mich., add $2 c$ per pound to postpaid prices.

To Ala., Ark., Fla., Ill., Iowa, La., Miss., Mo. and Wis., add 4c per pound to postpaid prices.

To Texas, Okla., Kan. and Neb., add $6 c$ per pound to postpaid prices.

Mung Beans -A real soll lmprover that grows on almost any forage; is free of disease and is not troubled by the Mlexican bean a hay that stock and makes 1 ts crop in 90 to 100 days, in plenty of time to put in fall crop on the same land. Plant in $3^{1 / 2}$ foot rows. 4 lbs. to the acre, the end of May or in June. By mall postpaid, 1b. 35c; 5 lbs. $\$ 1.30 ; 10$ lbs. $\$ 2.35 ; 25$ lbs. $\$ 5.15 ; 501 \mathrm{bs}$. $\$ 9.75$.

Not postpaid, 1b. $25 \mathrm{c} ; 5$ to 24 lbs. $20 \mathrm{c}$ per $1 \mathrm{~b}$.; 25 to $99 \mathrm{lbs} .18 \mathrm{c}$ per $\mathrm{lb}$; $100 \mathrm{lbs}$. and over $17 \mathrm{c}$ per lb. No charge for bags.

\section{Velvet Beans}

\section{A Fine Fall and Winter Grazing Crop}

Velvet beans make an enormous growth, larger than any other known forage plant, in the same length of time far surpassing cow-peas, and are especially desirable for lands where pea-wilt and nematode attack the cow-pea, as they are immune to these diseases. Velvet beans are usually planted a peck to half a bushel to the acre In rows 5 feet apart, $21 / 2$ to 3 feet apart in the row. As a soil immuch larger growth and so much heavier a mount of foliage. The proportion of nitrogen contained in the vines is about the same as cow-peas, but as the yield is so much greater, the total amounts of nitrogen and humus added to the soil are correspondingly larger. A crop of three tons will add as much nitrogen to the soil as will a ton of cotton-seed meal, while the amount of humus will be three a ton of cotton-
times as great.

Makes Nutritious Fall and Winter Grazing.-In the South, velvet beans are used very largely for winter grazing, and for that purpose is one of the best crops for the light soils and in the long season of the Gulf Coast and Florida. They should be allowed to grow until December, or until killed by frost, after which they can be grazed through the winter, as the vines, leaves and pods decay the slowly and remain palatable a long time. Early In the year, very materially to the productiveness of the soll.

Velvet beans are usually grown with corn. The corn is planted in five-foot rows, three feet apart in the rowi the beans planted between the corn. At INOCULATE THIS the last working beans are planted again in the SEED WITH middles between the rows of corn. When the STIMUGERM cattle turned in to graze.

\section{Osceola Velvet Beans}

The Osceola has given excellent results as a forage crop in Virginia, and even more northerly sections. In Virginia we have found it to make fully as mich growth of vine as the Early the same length of time. It also has the advantage of being free from the itching furze which makes other velvet beans rather reeable to pick.

Not postpaid, $1 / 2$ pecis 500 ; peck $80 c$; $1 / 2$ bus. $\$ 1.40$; bus. $\$ 2.60$.
The South's Wonderful Forage and Soil Improving Crop

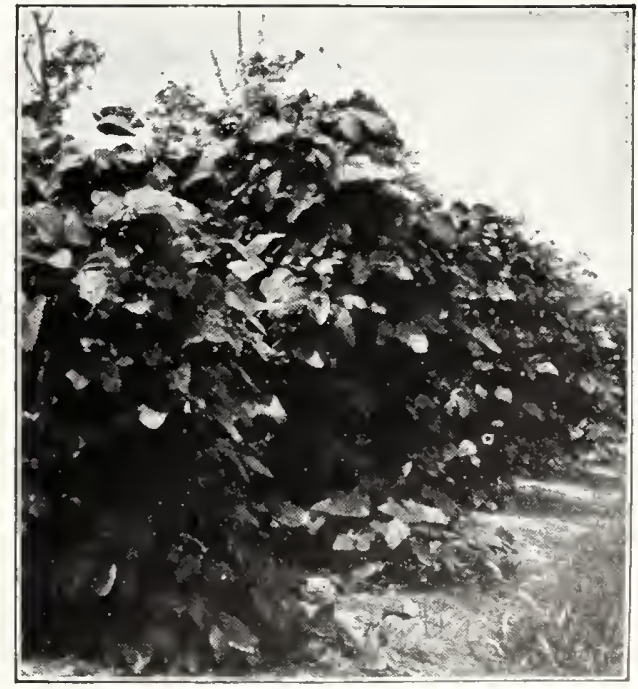

100 Day or Speckled Velvet Beans

100 Day or Speckled is one of the earliest varieties and can be grown farther North than the common velvet beans. South of Virginia they will mature in a season of average length. In more northerly secgrowth of vines for pasturing and finishing cattle, and a fine soilimprover. By mail po

Not postpaid, $1 / 2$ peck $35 \mathrm{c}$; peck $60 \mathrm{c}$; $1 / 2$ bus. $\$ 1.10$; bus. $\$ 2.00$; 5-bus. lots $\$ 1.90$ per bus. 


\section{Soy or Soja Beans ${ }^{1}$ pack $x=1$ ba. Soy or Soja Beans}

They make poor land good--they make good land better.

\section{WORTH KNOWING ABOUT SOY BEANS}

Thes will grow on all kinds of solls.

Soy bean hay is more nutritions than cow pea hay and stock Ag a milk and butter producer soy beans are equal to alfalfa and saperior to cotton seed meal

$A$ bushel of soy beans is worth more for feed than two bushels of coin.

They can be hogged down without any harvesting expense. When cut at the proper stage of growth the hay is equal to alfalfa for dalry cattle.

Soy bean meal or ground soy beans will take the place of meat scrap in poultry foods.

Drought and excesslve rainfall affect them less than cowpeas.

It 18 one of the easlest crops to grow and harvest.

They make a fine hog pasture.

They can be grown with cow-peas to hold the pea-vines ofr

the ground; will improve the quality of the hay and make 1t easler to care.

They increase the yleld of the following crop.

They make a rich and nutritlous hay and one of the cheapest. planting.

It is one of the South's most economical soll 1mprovers.

They require no fertllizers except acld phosphate.

FEEDING VAIUE. Soy bean hay contains a high per cent of protein, is superior to cow-peas in feeding value and as a milk and butter producer is equal to alfalfa and superior to cotton sced meal. The beans and bean meal contain about 35 per cent of digestible protein and stock eat them with relish and thrive on them. Hogs fed cn soy beans in combination with corn fatten much more economically than on corn alone-a bushel of soy corn. For feeding beef cattle expcriments have proved soy beans to be about 50 per cent greater value than cow-peas. They make an excellent winter feed fcr young cattle, sheep and horses hen fed with roughage.

CULTURE. Soy bcans may be planted either broadcast or in drilis. Usually a better crop is had when planted in drills and cultivated, and few crops leave the land cleaner and in better condition for the following crop. They grow equally well on light and heavy solls, but on heavy solls they should not be planted more than 1 to $11 / 2$ inches deep except ln ary seascns, On light sandy soils plant deeper, but not more than 3 inches in drilis about a peck to the acre. Plant in April, May or June.

Illini -Aithough bred primarily as a seed producer, it compares

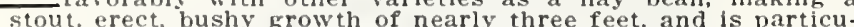
larly recommended for hogeing down. The pods are mostiy three a few inches of the ground to the tip of the stem. The oil content averayes over 18 per cent; very hardy and matures in about 105
lays. By mall postpald, qt. 30c; $1 / 2$ peck $75 c$; peck $\$ 1.25 ; 1 / 2$ bus. $\$ 2.15$; bus. $\$ 3.95$.

Not postpald, $1 / 2$ peck 50c; peck $80 \mathrm{c} ; 1 / 2$ bus. $\$ 1.40$; bus. $\$ 2.60$; 5 bus, and over, $\$ 2.50$ per brs.

Virginia -On account of Its abundant growth and large vield ensllage. As it is about twenty days earlier than Mammoth can be grown further North and throughout the corn The vines make a flne growth, are flled with pods, stand about three feet high, are casy to cut and easy to cure. The well for hav-making. By mall postpaid, qt. 35c; $1 / 2$ peck $85 \mathrm{c}$ Not postpald, $1 / 2$ peck 60 ; peck $\$ 1.00 ; 1 / 2$ bus. $\$ 1.85$; bus. $\$ 3.50$.

CERTIFIED VIRGINIA. Ccrtified by the Virginia Crop Improvement Association. By mall postpaid, qt. 40c; $1 / 2$ peck 90c; peck Not postpald, $2 / 2$ peck 65 ; peck $\$ 1.10$; 1/2 bushel $\$ 2.00$; bushel $\$ 3.75$.

Laredo -A bean of outstanding worth, particularly for makaro -maker it stands second to none. In a six-ycar tcst $1 / 2$ peck $\$ 1.00$; peck $\$ 1.75 ; 3 / 2$ bus. $\$ 3.10$; bus. $\$ 5.85$.

Not postpald, $f_{5}$ peck $75 \mathrm{c}$; peck $\$ 1.30 ; 1 / 2$ bus. $\$ 2.35$; bus. $\$ 4.50$; 5 -bus. lots $\$ 4.40$ per bus.

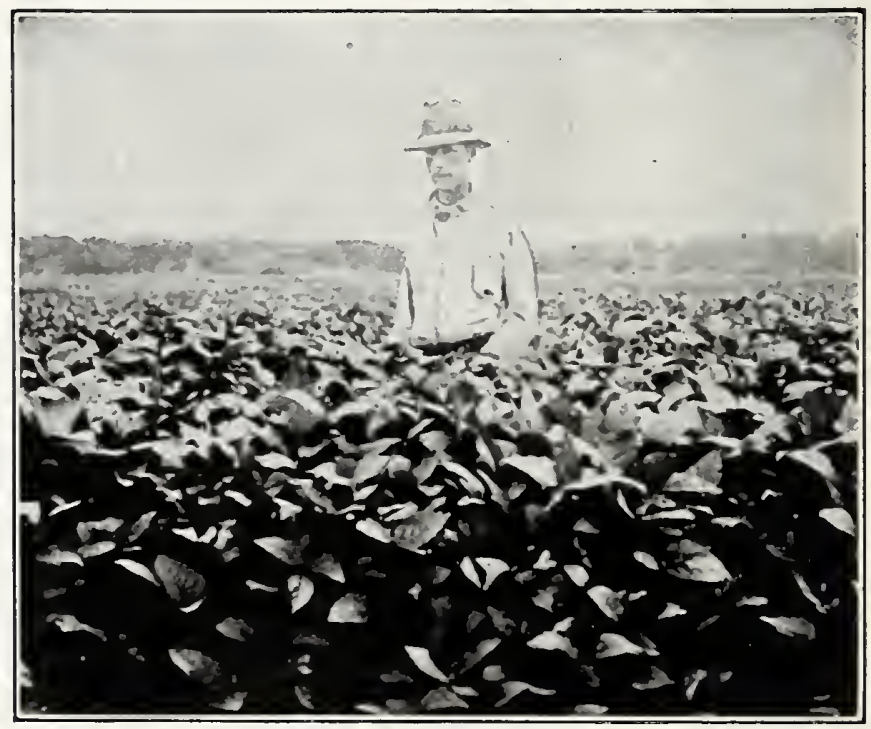

SOWING WITH OTHER CROPS. Soy beans can be grown with other crops, yielding a larger crop and a better balanced ration Soy beans and cowpeas make a good combination. and the vield is nearly always greater than of either crop alone. Plant halfbushel soy beans to one bushel cow peas to the acre. Soy beans and corn is a well-recommended combination, the beans being planted in the hill, or in alternate hills or alternate rows, depending on the proportions wanted in the feed.

Sorghum and a late soy bean make a good combination, probeans give a better balanced feed than Sudan grass alone, as ts protein content is low, while that of soy beans is high.

INOCUIATE. Be sure to inoculate the seeds with soy bean bacteria. Not only will you have assurance of a surer stand
but a better crop and the succeeding crop will have the benefit
stored in the bean roots.

\section{INOCULATE THIS SEED WITH STIMUGERM}

Wilson Early Black -A very prolific variety and one of the sired. Averare height on good land is about three feet. The Delaware State Experiment Farm recommends the Wilson Black as ahead of any as a combination hay and seed variety. It matures in about 115 days. stands up well, makes pods a good distance from the ground and retains its seed. Its fine stem enables it to cure quickly. Its tall growth and absence of lower branches makes it one of the easiest to harrest. By mail post-

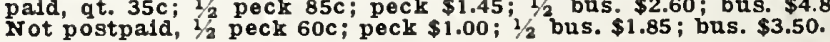

Mammoth Brown -lyakes a large upright growth, standing an abundance of pods. It is a good hay bean, is a proific ylelder of beans, robust and is more disease resistant than most varieties. Probably no variety is so well suited for planting with cow-peas, as they mature nearly together. It is characteristic of Nammoth Brown, and an advantage as well, that the beans remain in the pod long after maturity. They are especially fine for late hog piasture.

Not postpald, $1 / 2$ peck $50 c$; peck 800 ; $1 / 2$ bus. $\$ 1.40$; bus. $\$ 2.60$; 5 -bus. and over $\$ 2.50$ per bus.

Hollybrook Early - Iakes a quicker growth and matures the Mammoth Yellow and makes a large yield, both of forage and pods. It is a sure cropper and a vigorous, quick grower with an abundance of larre leaves. The pods set thickly on stems and branches. If planted thickly it makes fine ensilage, although not as heary a yielder of hay as some of the later kinds. It has special value where an early crop of hay or beans is required. By mall postpald, qt. $30 \mathrm{c} ; 1 / 2$ peck $75 \mathrm{c}$; peck $\$ 1.25 ; 1 / 2$ bus. $\$ 2.15$; bus. $\$ 3.95$.

Not postpajd, $1 / 2$ peck $50 c$; peck $80 \mathrm{c}$; $1 / 2$ bus. $\$ 1.40$; bus. $\$ 2.60$ 5 bus. and over $\$ 2.50$ per bus. 


\section{SOY OR SOJA BEANS-Continued}

Tar Heel Black $\rightarrow$ About ten days earlier than Mammoth The vines stand upright, are not coarse and are well filled with pods. Fully equal to any medium eariy variety for hay and seed production. Makes a growth of $31 / 2$ to 4 feet; hranches close to the ground; has medium thick stalk and abundant $1 / 2$ bus. $\$ 2.15$; bus. $\$ 3.95$.

Not postpaid, $1 / 2$ peck $50 \mathrm{c}$; peck $80 \mathrm{c}$; $1 / 2$ bus. $\$ 1.40$; bus. $\$ 2.60$; 5 -bus. lots $\$ 2.50$ per bus.

Biloxi - An upright variety, growing four to five feet high,coveasily A heavy yielder of beans; the oil and protein contents are high: a fine bean for hogging down, for planting with corn or sorghum and for oil. The pods are less liable to pop than most varieties; in fact, they hardly shatter at all. Late in maturing, requiring a long season, but makes an unusually luxu riant growth. By mail p
$1 / 2$ bus. $\$ 2.30 ;$ bus. $\$ 4.20$.

Not postpaid, $1 / 2$ peck $55 \mathrm{c}$; peck $90 \mathrm{c}$; $1 / 2$ bus. $\$ 1.55$; bus. $\$ 2.85$; 5-bus. lots $\$ 2.75$ per bus.

Mammoth Yellow - The latest, yet the most extensively which it yields in great abundance. It grows more than three feet high, is erect in growth and can be cut with a mower. Particularly valuable for Virginia, and further South for both beans and forage. Mammoth Yellow is one of the largest growers among soy beans, and the most widely grown variety and 70c; peck $\$ 1.20 ; 1 / 2$ bus. $\$ 2.10$; bus. $\$ 3.85$.

Not postpaid, $1 / 2$ peck $45 \mathrm{c}$; peck $75 \mathrm{c}$; $1 / 2$ bus. $\$ 1.35$; bus. $\$ 2.50$; 5 -bus. lots $\$ 2.40$ per bus.

Otootan - Few soy beans can equal Otootan as a hay maker. dant growth-five feet and more in long seasons-its fine stems and abundant foliage, and the fine texture of its hay. It differs from most varieties in having many leafy branches instead of a coarse central stem, making it easy to cut. Recommended for $1 /$ peck $\$ 1.10$; peck $\$ 1.95 ; 1 / 2$ bus. $\$ 3.60 ;$ bus. $\$ 6.85$.

rot postpaid, $1 / 2$ peck $85 \mathrm{c}$; peck $\$ 1.50 ; 1 / 2$ bus. $\$ 2.85$; bus. $\$ 5.50$; 5 -bus. lots $\$ 5.25$ per bus.

\section{FLOWER POTS AND SAUCERS}

Special Prices to Florists Using I arge Quantities. POTS AND SAUCERS CANNOT BE MAIIED.

Charge will be made for packing at $35 \mathrm{cts}$. for orders amounting to $\$ 3.00$ or less. On larger orders add 10 per cent to amount of order. This barely covers the cost. We pack carefully, but will not be responsible for breakage.

\section{FLOWER POTS}

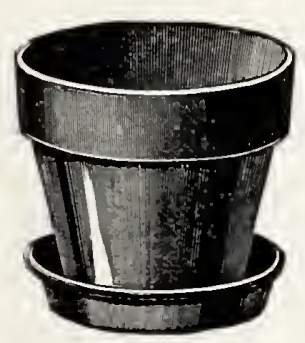

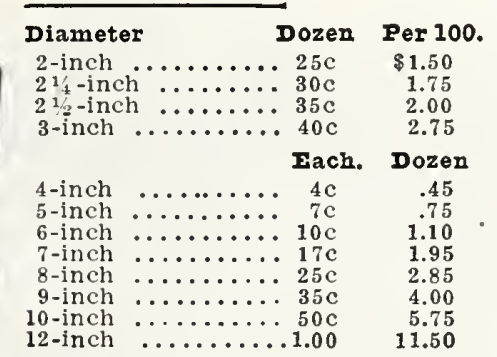

\section{SAUCERS}

Diameter. 


\section{CANADA FIELD PEAS}
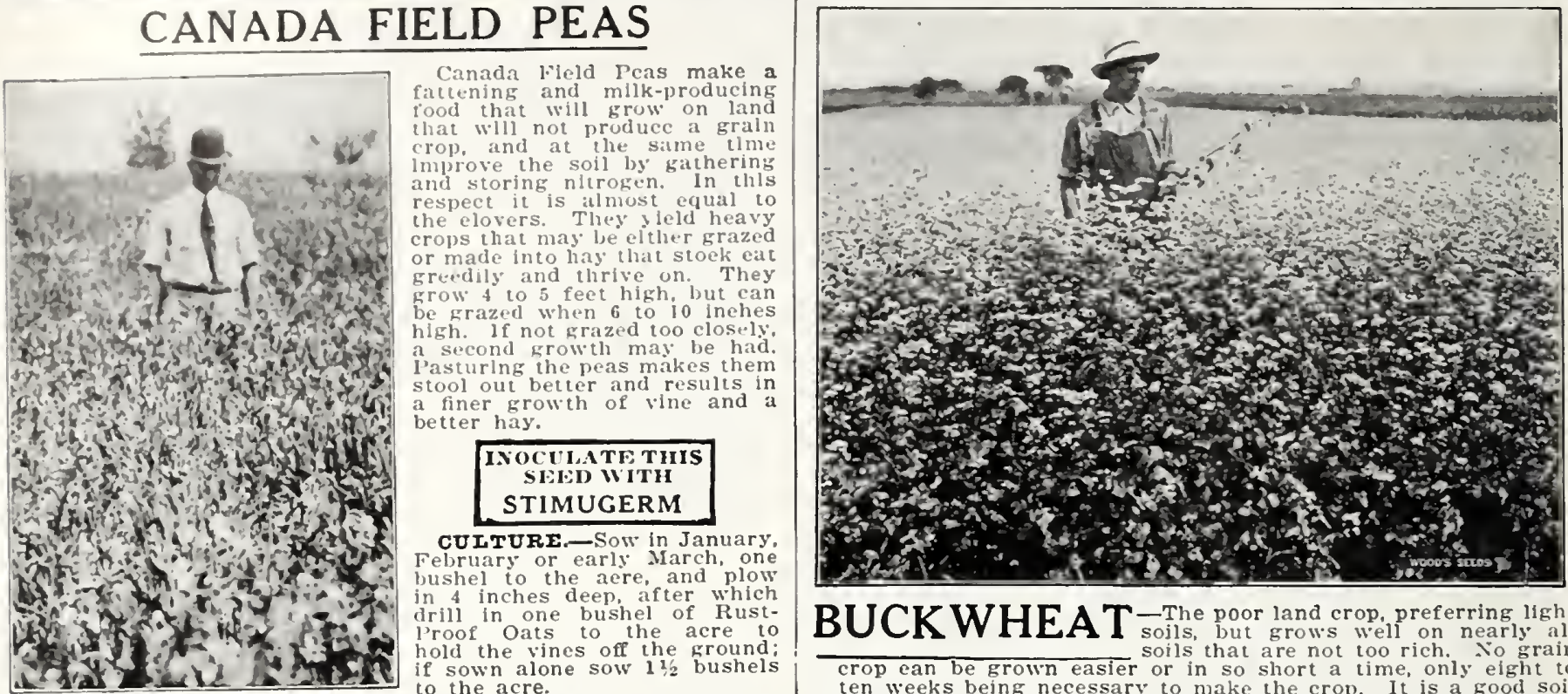

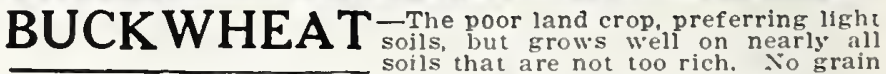
if sown alone sow $1 \frac{1 / 2}{b}$ ushels

3y mall postpala, qt. 25c; $1 / 2$ peck $80 \mathrm{c}$; peck $\$ 1.35 ; 1 / 2$ bushel $\$ 2.35$; bushel $\$ 4.25$.

Not postpald, $1 / 2$ peck 55c; peck 90c; $1 / 2$ bushel $\$ 1.60$; bushel (60 lbs.) $\$ 2.90 ; 5$-bushel lots $\$ 2.85$ per bushel.

Austrian Winter Peas - Grows $2 \frac{1 / 2}{2}$ to 3 fect high; very welght) per aere. Reeommended for fall sowing. By mall post-
pald, 1b. 20c: 5 lbs, $75 c ; 10$ bs. $\$ 1.25 ; 25$ lbs. $\$ 2.55 ; 501 b s . \$ 4.75$.

Not prepaid, 1b. I2c; 5 to 24 lbs. 9 c per 1 b.; 25 to 99 lbs. $71 / 20$ per Ib.; 100 lbs. and over $7 \mathrm{c}$ per lb. No charge for bags.

\section{Vetch $\begin{aligned} & \text { For Fay } \\ & \text { For Grazing } \\ & \text { For Soil Improving }\end{aligned}$} VETCH is a wonderfal nitrogen gatherer and soil

It reseeds itself.

It increases the milk flow.

It saves on the fertizizer blll.

Stock eat it with relish and fatten on it.

It yields a wonderful amount of forage and hay.

Veteh is highly recommended for making a fine grade of hay. for execllent grazing and for turning under to improve the land It milkes a splendid substitute for elover for sections or on lands and cotwon at the last working; eovers the ground during the winIld sow to hold the vines

IXOCULATETHIS
SHED WITI
STIMUGERM

ithout any cxpense in the preparation of the land.

Hairy or Sand Vetch - The hardlest vetel. Fine for hay, im grazing and improving lind. Resow from a produces many branches freBy mall postpaid, 1 b. $25 \mathrm{c} ; 5$ ibs. $95 \mathrm{c}$; 10 lbs. $\$ 1.65 ; 25$ lbs. $\$ 3.55$; 50 lbs. $\$ 6.75$.

Not prepaid, 1b. $16 \mathrm{c} ; 5$ to 24 lbs. $13 \mathrm{c}$ per $1 \mathrm{~b} . ; 25$ to 99 lbs. II $1 / 2 \mathrm{c}$ per lb. ; 100 lbs. and over $11 \mathrm{c}$ per lb. No charge for bags.

WOOD'S SETDS ARE TESTED. The purity and germination of Wood's Seeds are proved before they are allowed to be sold. You ... at $11 \mathrm{berty}$ to send samples to your Commissioner of Agriculture, and if they do not come up to the purity and germination as labelled, your money will be refunded immodintely. 


\section{JERUSALEM ARTICHOKES}

Every hog raiser should grow artichckes, for they come year after year; the hogs will harvest them without cost, will fatten on them, and they will keep the hogs in fine condition-it is claimed that artichokes prevent hog cholera. They are grown inches deep, $1 \overline{3}$ to 18 inches apart in 3 to $3 \frac{1 / 2}{2}$-foot rows. In the fall when they have matured, turn the hogs among them and they will feed on them all winter except when the ground is wet

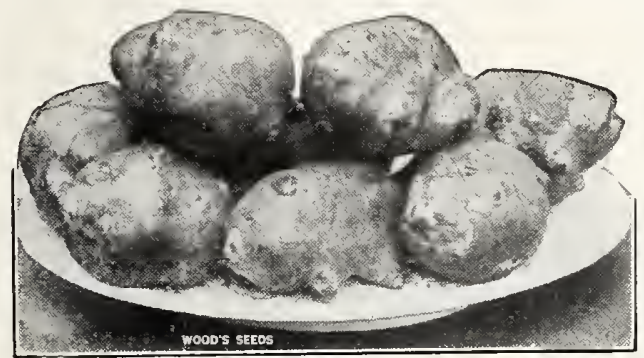
irozen. They ly $\mathrm{grow}$ and more productive than potatoes 700 bushels having been grown on an acre of 300 to 400 bushels is nearer the average crop.

Although grown p rincipally for hogs, the y are fine food for cathorses; for dairy cattle it is claimed they are nearly equal to bran as milk producers. They also make an excellent table dish when boiled or served as a salad, and the best brands of pickles all ccntain artichokes.

Plant during March or April, the earlier the better; they will stand extreme cold, and can be planted earlier than potatoes; they also stand considerable drought. They grow well on any well-drained soil without much attention, and one planting does for several years. By mail postpaid, qt. $30 \mathrm{cts.;} 1 / 2$ peck $65 \mathrm{cts}$.; peck $\$ 1.10$; $1 / 2$ bus. $\$ 1.85$; bushel $\$ 3.30$, bags included.

Not prepaid, qt. 20 cts.; $1 / 2$ peck 40 cts.; peck 65 cts.; $1 / 2$ bus. $\$ 1.15$; bushel $\$ 2.00 ; 5$-bushel lots $\$ 1.90$ per bushel.

\section{CHUFAS Earth Almonds}

With the increasing interest in hog-raising in the South, there should be a corresponding increasing interest in hog-feeding

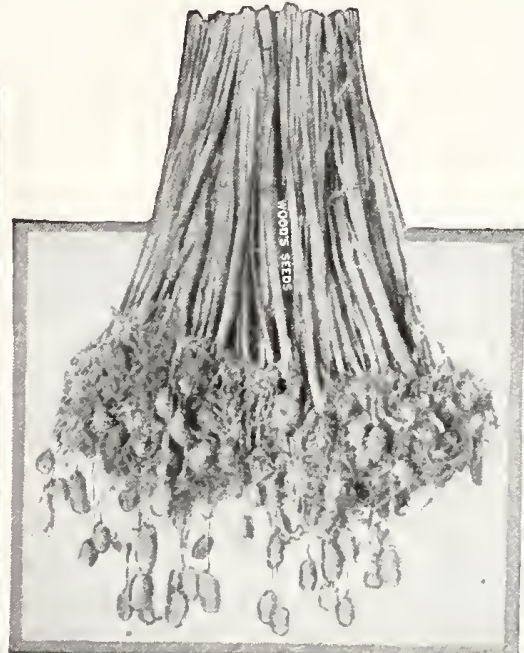
crops that are about and that can be fed r. Hogs not only for quickly on them, but meat is sweeter than equal to ed hogs. or 1 will on light sandy soils
from April 1st till.
in $21 / 2$ to 3 -foot row.
ping three to five

Chufas or Grass Nuts.

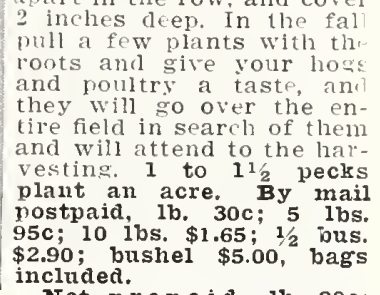
ncluded.

Not prepaid, 1b. 20c; 5 lbs. 70c; 10 lbs. $\$ 1.30$; $1 / 2$ bushel $\$ 2.40$; bushel ( 40

\section{Peanuts}

Any soll that will grow corn or cotton will grow peanuts; on light sandy or loamy soils there are few crops more profitable. In addition to the yield of nuts, the hay is superior to alfalia in fat and almost equal in protein. After the oil is extracted the meal ranks with cottonseed meal and linseed meal in fceding three times as much meat.

CUITURE.--Plant the shelled nut in May or early in June, dropping the nuts 8 to 10 inches apart in cover one to two inches deep. cultivate When harvesting, loosen the roots with a plow, pull the vines with the nuts attached, allow them to dry, and stack around a stake turning the nuts inward. should be set at the foot of the stake to hold the vines off the ground.

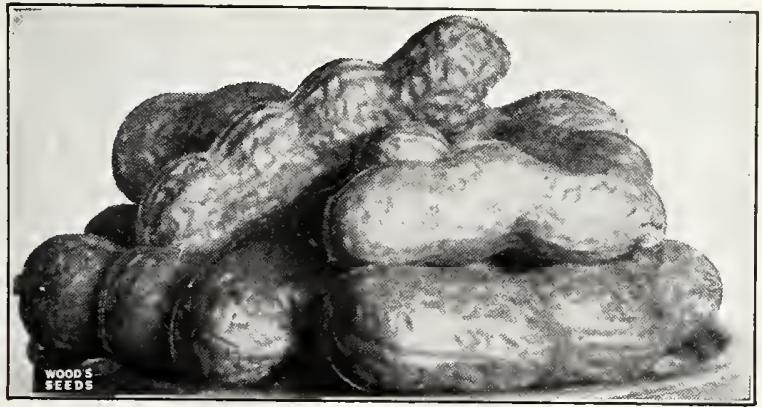

\section{Valencia Peanuts True Stock Grown from}

The Valencia fills the demand for a peanut that is larger and containing more nuts than the common varieties. It is solendidly adapted for growing en the light sandy solls of the South Atlantic Seaboard, where it has yielded uniformly satisfactory crops. The pods are large, well filled, usually containing three ready sale at ton prices. By mail postpaid, 1b. 25c; 5 1bs. $\$ 1.05$ 10 lbs. $\$ 1.85 ; 25$ lbs. $\$ 3.90 ; 501 \mathrm{bs}$. $\$ 7.25$.

Not prepaid, 1b. $18 \mathrm{c} ; 5$ to $24 \mathrm{lbs} .15 \mathrm{c}$ per 1b.; 25 to 99 lbs. 130 per 1b.; $100 \mathrm{lbs}$. and over $12 \mathrm{c}$ per $1 \mathrm{~b}$. No charge for bags.

\section{Spanish Peanuts}

Although not as large as cther kinds, there is no peanut grown that so entirely fills the pod nor can compare with it in stweetness and flavor. There is also a marked freedom from pops, so frequently found in the large varieties when grown under un favorable conditions. They can be grown closer than most varieties, are more easily cultivated and gathered, as the nuts, which are clustered arcund the base of the plant, cling firmly to the
roots, and no peanut is more readily cured. By mail postpaid, 1b. $25 \mathrm{c} ; 5 \mathrm{lbs}$. $95 \mathrm{c} ; 10 \mathrm{lbs}$. $\$ 1.65 ; 25 \mathrm{lbs}$. $\$ 3.75 ; 50 \mathrm{lbs}$. $\$ 6.75$.

Not prepaid, 1b. 16c; 5 to 24 lbs. $13 \mathrm{c}$ per $1 \mathrm{~b}$; 25 to 99 lbs. $11 \mathrm{c}$ per 1b.; $100 \mathrm{lbs}$, and over 10c per lb. No charge for bags.

\section{Virginia Bunch Peanuts}

Wherever they have been grown, Virginia Bunch Peanuts have grown rapidly in popularity. They have several points of decided advantage over the running kinds; they mature about a week eallier; the rows may be closer and the plants nearer together in the rows; they are easier to cultivate and harvest, and 95c; 10 lbs. $\$ 1.65 ; 25$ lbs. $\$ 3.75 ; 50$ lbs. $\$ 6.75$.

Not prepaid, 1b. 16c; 5 to 24 lbs. $13 \mathrm{c}$ per $1 \mathrm{~b} . ; 25$ to 99 lbs. $11 \mathrm{c}$ per 1b.; $100 \mathrm{lbs}$. and over $10 \mathrm{c}$ per $1 \mathrm{~b}$. No charge for bags.

\section{Improved Virginia Peanuts sumioo}

The biggest, brightest peanuts always have preference when peanut you grow. There is will yicld better crops with as small
our selected stock of Improved Virginia

fermly large, and when grown on light sandy land nuts of that bright atractio a $\$ 3.90 ; 50$ lbs, $\$ 7.25$.

Not prepaid, 1b. 18c; 5 to 24 lbs, 15c per 1b.; 25 to 99 lbs, 13c per 1b.; $100 \mathrm{lbs}$. and over $12 \mathrm{c}$ per 1b. No charge for bags.

\section{Tennessee Red Peanuts}

Similar to Spanish in the way the nuts are closely packed in the pod but the pods are longer, usually containing four nuts flavor By mail postpaid, lb. 25c; 5 lbs, 90c; 10 lbs. $\$ 1.55 ; 25 \mathrm{lbs}$. flavor, By mail pos

Not prepaid, 1b. 15c; 5 to 24 lbs. $12 \mathrm{c}$ per $1 \mathrm{~b} . ; 25$ to 99 lbs. $10 \mathrm{c}$ per lb.; 100 lbs. and over 9c per lb. No oharge for bags. 


\section{Sorghum and Sugar Cane}

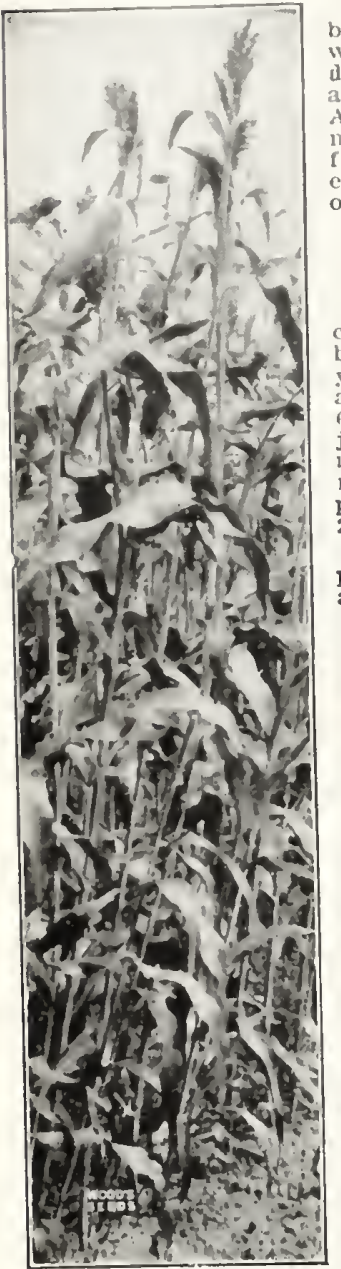

Sugar Driy Sorglum.

Milo Maize

By mail postpaid, $1 \mathrm{~b}$.

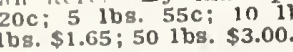

Not propald, 1b. 10c; 5 to 24 bs. 50 per $1 \mathrm{~b}$ : 25 to 99 lbs. $4 \mathrm{c}$ per $1 \mathrm{~b}$; $1001 \mathrm{bs}$, and over $31 / 2 \mathrm{c}$ per ib.

ra
CULTURE.-Piant when the ground celis after corn planting, on a rich, well

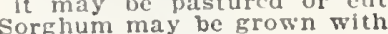

\section{Sugar Drip}

Not prepaid, 1b. $14 \mathrm{c} ; 5$ to 24 lbs. $10 \mathrm{c}$ er 1b.; 25 to 99 lbs. $81 / 2$ c per 1b.; 100 lbs.

\section{Texas Seeded Ribbon} Cane

sugar content of the plants is reater 作 25 1bs, $\$ 2.65 ; 50$ lbs. $\$ 5.00$.

Not prepaid, 2b. 13c; 5 to 24 lbs. $10 \mathrm{c}$ per lb pres to 99 lbs $8 \mathrm{c}$ per lb. 100 lbs. 列

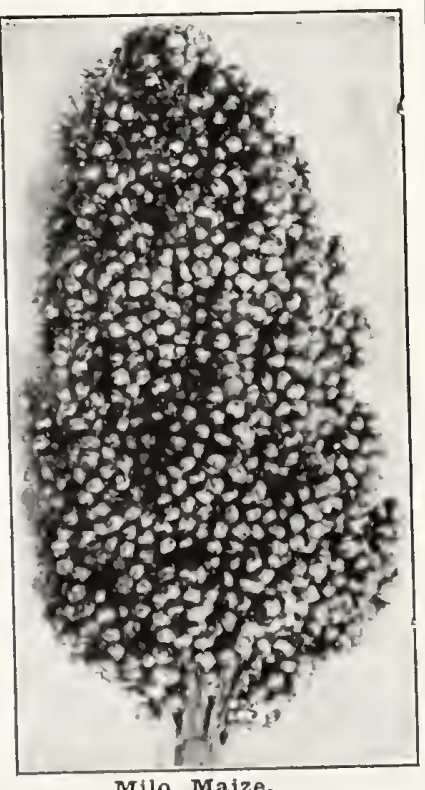

Mulo Maize.

\section{Kaffir Corn}

Kaffir corn vields heavy crops of the very growth, but it starts again with the first rain; its deep root growth than corn alnd pea-rines Kantr corn may' also be grown with soy beans, sowing the grain as

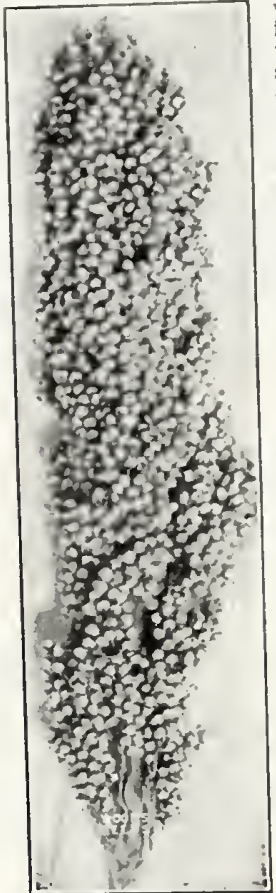

Kaffir Corn.

\section{Early Orange Cane}

About ten days later than Eariy Amber which it ylelds immense crops, frequently two cuttings a season, and stooline may be grown with soy beans and cowpeas in the same prover ane. When sown alone sow 1 to $1 \frac{1 / 2}{2}$ bushels to the acre broadcast. paid 1b. 20c; 5 lbs. $70 \mathrm{c} ; 10 \mathrm{lbs}$. $\$ 1.15 ; 25$ lbs. $\$ 2.15 ; 50$ lbs. $\$ 4.00$.

Tot prepaid, 1b. $12 \mathrm{c} ; 5$ to 24 lbs. $8 \mathrm{c}$ per $1 \mathrm{~b}$; 25 to 99 lbs. $6 \mathrm{c}$ per $1 \mathrm{~b}$.; 100 lbs. and over $5 \frac{1}{2} \mathrm{c}$ per $1 \mathrm{~b}$.

\section{Shallu or Egyptian Wheat}

A non-saccharlne sorghum of special value dry seasons-few forage plants ate moldrougint-rcsistantics frequently come from a single root. Cut when at the dough stage, anco a seond cured mrown as a graind For try platery tihe catte. hor fround it is of high feeding value and will takc the place of corn: the Aotraid, 1b. 25c; 5 lbs. 95c 10 lbs. $\$ 1.65 ; 25$ lbs. $\$ 3.65 ; 50$ lbs. $\$ 7.00$.

Not prepaid, 1b. $16 \mathrm{c} ; 5$ to $24 \mathrm{lbs} .13 \mathrm{c}$ per 1b. 25 to 99 lbs. $12 \mathrm{c}$ per $1 \mathrm{~b}$; ; $100 \mathrm{lbs}$. and over $11 \frac{1}{2} \mathrm{c}$ per lb. No charge for bags.

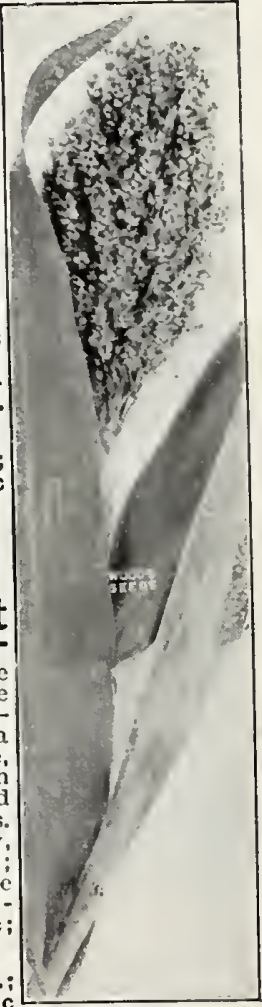

Shaldu. 


\section{JAPANESE, or BARNYARD MILLET}

Called Prosso and Billion Dollar Grass in the West

Distinct from other millets; grows 4 to 6 feet high yielding an enormous crop that in quality is equal to corntodder and is relished by stock. Sow in May, June or July 20 lbs, to the acre broadcast: or sow in 15 -inch drills and cultivate until it is 18 inclies high. When green, feed a moderate quantity at first,

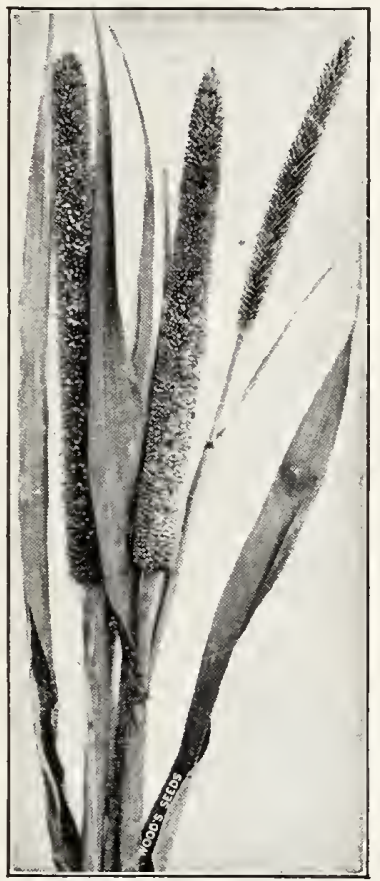

as the animals become accustomerl lbs. $75 \mathrm{c} ; 10$ lbs. $\$ 1.25 ; 25$ lbs. $\$ 2.40$ 50 ibs. $\$ 4.50$.

Not prepaid, 1b. $12 \mathrm{c} ; 5$ to $24 \mathrm{lbs}$. $9 \mathrm{c}$ per $1 \mathrm{~b} . ; 25$ to 99 lbs. $7 \mathrm{c}$ per lb.; $100 \mathrm{lbs}$. and over $61 / 2 \mathrm{c}$ per $1 \mathrm{~b}$. No charge for bags.

\section{PEARL, or CAT-TAIL MILLET}

Also called Pencillaria.

If allowed to attain its full height Peorl willet will grow 10 to 12 feet high, but for the greatest amount 3 to 4 feet high. It will then stool out enormcusly, and during warm weatler will grow with wonderful lings a season and keep on our cuting right up to frost. It dues well even on poor land, and surprisingly well in dry seasons. All kinds of stock eat it creedily and flourish on it: it is highly nutritious. It is a warm weather plant and shculd not be planted till the ground is thoroughly warm otherwise the seeds will not germinate. Flant 5 lbs, to the postpaid, lb, 25c; 5 lbs, $\$ 1.05$; 10 lbs. $\$ 1.85 ; 25$ lbs. $\$ 3.90 ; 50$ lbs. $\$ 7.25$.

Not prepaid, 1b. $18 \mathrm{c} ; 5$ to $24 \mathrm{lbs}$. Pearl or Cat-Tail Millet. $15 \mathrm{c}$ per lb.; 25 to $99 \mathrm{lbs}$. $13 \mathrm{c}$ per lb.; 100 lbs. and over 12c per th. No charge for bags.

\section{GERMAN MILLET}

German Millet makes a quickly grown, easily cured and large sown after wheat is cut, and leaves the land clean and in fine mechanical condition for the folwhen coming into flower, as after that stage the woody tibre forms in the stem and tine liay lis lidlu and time it makes a splendid hay. As summer catch crop it has few equals, for it makes its crop in about sixty days, discing and harrowing wheat or oat land being
only preparation necessary.

Growing millet with an early variety of cow-peas like Whipporwill or New Era is quite popular, three bushel of cow-peas. The crop should be cut when the millet is coming into hloom, regardless of the maturity of the cow-peas, for at this stage the feeding value of the

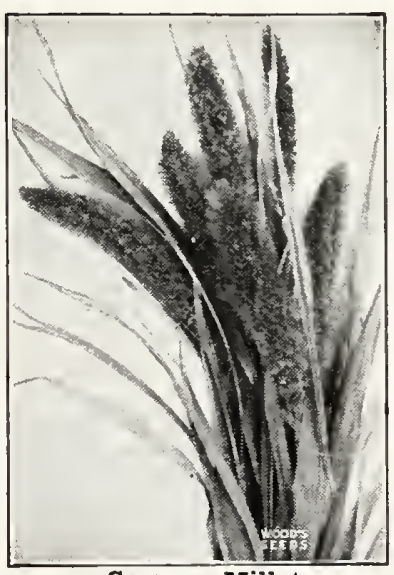

German millet. gether, the yield is larger than when either is grown alone.

To have the finest millet hay sow thickly, not less than a bushel to the acre, from tle niddle of May till the end of July Thin seeding makes coarse stems and a poorer hay.

Warning.-Do not sow common or Western millet. It is not adapted, makes a small growth and is generally disappointing.

TENNESSEE GERMAN MIIIET.-By mail postpaid, 5 lbs. 70c; $10 \mathrm{lbs}$. $\$ 1.15 ; 25 \mathrm{lbs}$. $\$ 2.40$; $50 \mathrm{lbs}$. $\$ 4.50$.

Not prepaid, 1b. $12 \mathrm{c} ; 5$ to 24 lbs. $8 \mathrm{c}$ per $1 \mathrm{~b} . ; 25$ to 99 lbs. $7 \mathrm{c}$ per 1b.; $100 \mathrm{lbs}$. and over $61 / 2 \mathrm{c}$ per $\mathrm{lb}$. No charge for bags.

\section{TEOSINTE}

A single seed producing from thirty to sixty stallis, mous yield may be had froin Teosinte-the Louisiana Ex-

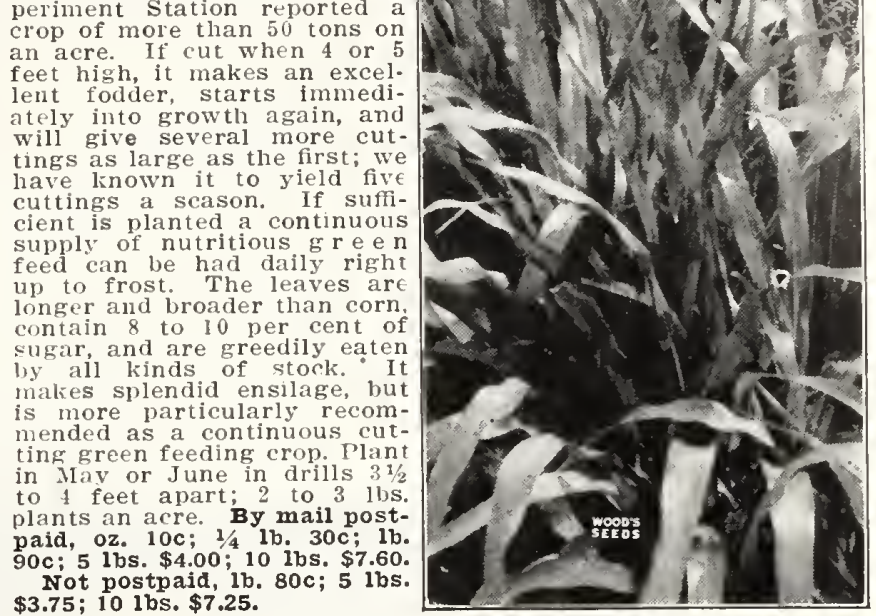

Teosinte.

\section{BROOM CORN}

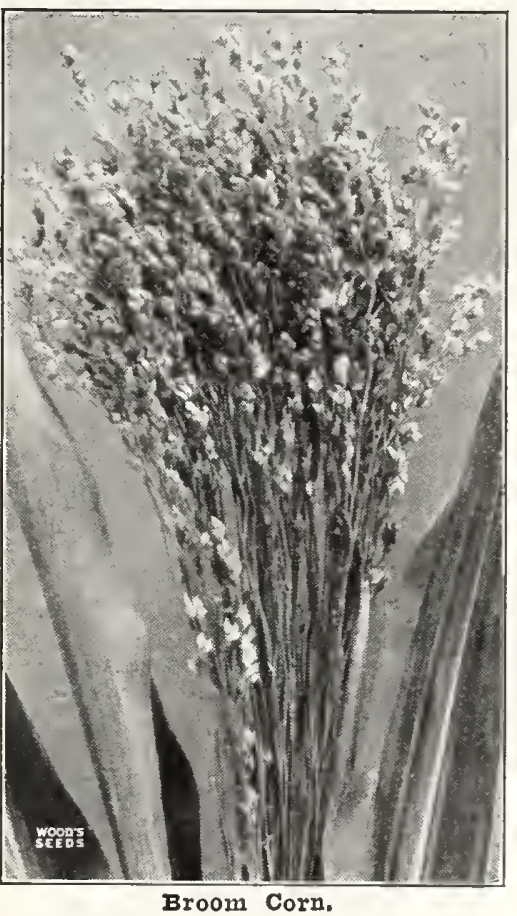

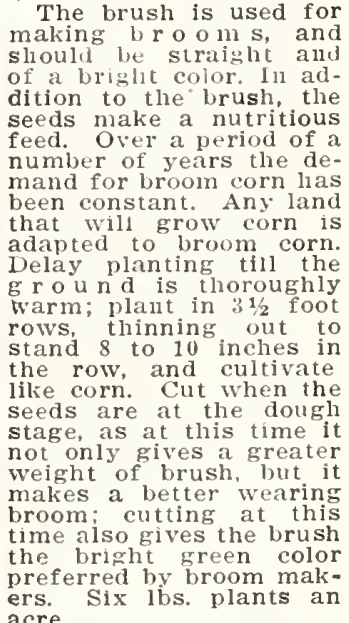

Standard Evergreen

tall

straic

brush. By mail post paid, 1b. 30c; 5 lbs. 1bs. $\$ 4.40 ; 50$ lbs. $\$ 8.25$. Not prepaid, 1b. $20 \mathrm{c} ; 5$ to 24 lbs, $17 \mathrm{c}$ per $1 \mathrm{~b} . ; 25$ to $991 \mathrm{bs} .15 \mathrm{c}$ per 1b.; $100 \mathrm{lbs}$, and over 14c per 1b. No charge for bag's.

Postpaid Prices of Field Seed Apply to Va., N. C., W. Va., POSTAGE TO OTHER STATES: To S. C. Ga. KY Tenn Ohio, Ind., N. Y., New England and Mich., add 2c per pound to postpaid prices.

To Ala., Ark., Fla., Ill., Iowa, La., Miss., Mo. and Wis., add 4c per pound to postpaid prices.

To Texas, Ok1a., Kan. and Neb., add $6 \mathrm{c}$ per pound to postpaid prices. To Cuba add $10 c$ per pound. 


\section{Wood's High-Yielding Early Cotton Seeds} Our cotton seeds are grown at the top of the cotton belt; they weeks earlier than otlier stralns of the same variety-a decided wols advantage in boll werease germination. near to eliming bushels to the acre.

\section{Wood's Ingold Cotton}

As enrly as King; bolls larger than Mexican Big Boll As are wave been brecting hoods ingold to ma

\section{centulled for hish gicid. eariness, length and quality of staple
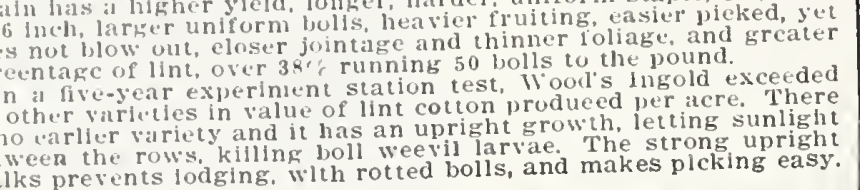

is discasents lodgin

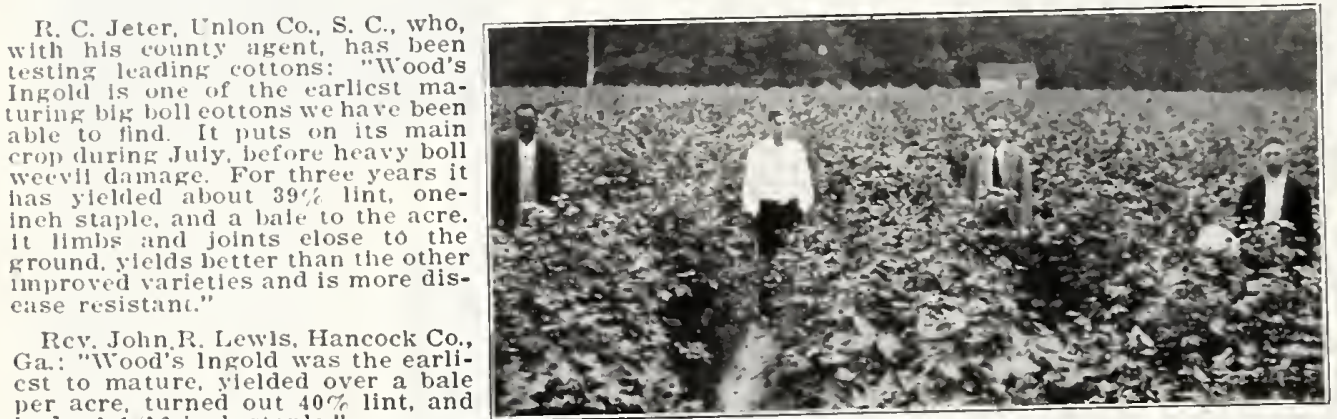

THE VIRGINIA EXPERIMENT STATION SAYS

The boll weevil has become hardy enough to live through virginia winters, and this spring will emerge in time to attack the first squares. It is essential to plant varieties that put on and mature early. Plant Wood's Ingold, Trice and $\mathbf{K i n g}$ on mature two weeks before other varieties. Wood's Inas the will outyield Trice in lint per acre and should be planted gold will outyleld Trint by farmers who seL lint cotton. those who sell cotton in the seed. Both have a full inch staple, Ingold occasionally as high as 118 inches. King has neither the yield nor length of staple as the other two.

\section{Wood's Certified Trice Cotton}

Combines long staple and earliness with big yield; 1 1-16-inch staple; $11-3$ bales per acre.
Certified by the Virginia Crop Improvement Association

"ielded the highest value of lint of ten varieties at the

(the Virginia Holland Experlment chation chith state bigger vield and higher per cent of lint than ordinary Trice. It yields eonsistently 1,800 to 2,000 pounds of seed cotton per aere, has gon as high as 2,700 pounds, and is supply is grown at the Holland Experiment Station ly the original breeder, and is of an improved strain recently developed, having a smaller seed and higher per cent The lint from our Certified Trice was sold to W: D. Rountree "Co., length of your staple measured one inch and was sold at a premium of three-guarters to one cent a pound ver seven-eighth inch eotton.

Mrs. George Jenkins, Martin Co. N. C.: "I found Wood's Certified Cotton all that you elaim in earliness and production.

P.Mery, Warren Co., $\mathrm{N}$. 1540 lbs of seed cotton to the acre in spite of the boll weevil. iIy friends said it was the best in the neighborhood. Trice for me from now on." "Wood's Certified Trice is extra J. I". Harper. Dillon co of other eottons we had.

arly and double the yield of other cottons "Nonster Wortified Lester E. L.ee, Harnett Co., N. C.: "I eonsider poor or rich land. It outyielded other varieties and was ready to piek twelve days carlier. It has large bolls and is the hearek the boll weevil.

No. 128 Registered Mexican Big Boll $11 / 8$-inch staple. Highest yield in N. C. Experiment Station test.

the first to offer this latest outstanding

velopment of the Yorth Carolina Experiment Station, and which is recommended by them above all other cottons. It is a selection from Strain 6-1-9, but is superior in yield, length of staple, un at formity, per cent of lint and money value. $11 / 8$-inch staple, turns the top of all varleties bolls ( 55 to the pound), is medium early, out $38 \%$ lint, has large reslstant, is well branched. open type with medlum follage, and is very" resistant Crop Improvement AssociaOur seeds are registered by the

\section{Wood's Improved Early King}

\section{Coker Cleveland No. 5}

\section{This straln has become very popular because of its $11 / 16-i n c h$}

\section{staple and good yleld.}

\section{PRICES}

wood's Certifled Ingold. .............

Ingold wortified Trice

Wood's Certifled Trice

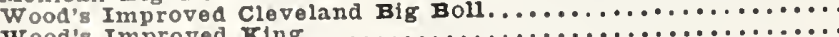

Wood's Improved King.

Coker Cleveland No. 5
Mexican Big Boll.
BY MAII POSTPATD

Peck 1/2 Bus. Bus.

$90 \mathrm{c} 1.45$

$90 \mathrm{c} 150$

$90 \mathrm{c} 1.50$

$85 \mathrm{C} \ldots 1.35$

1.35

1.35
95 c . . . \$1.60 . . \$2.85

$85 \mathrm{c}$
$2.5060 \mathrm{c}$

2.65600

$60 \mathrm{60c}$

\begin{tabular}{l|l}
2.30 & $55 \mathrm{C}$ \\
2.35 & $55 \mathrm{c}$
\end{tabular}

\begin{tabular}{l|l}
2.35 & $55 \mathrm{c}$ \\
2.40 & $60 \mathrm{c}$
\end{tabular}

$2.35 \mid 55 \mathrm{c}$
NOT POSTPAID-F. O. B. RICHMOND 10-Bus. Bus. Bus. 5-Bus. Iots Iots $\$ 1.15$ 1.00 1.05 .

1.05 .

.90 .

.90 . .95 .
$\$ 2.10 \ldots \$ 2.00 \ldots 1.95$

$1.75 \ldots 1.65 \ldots 1.60$

$1.90 \ldots 1.80 \ldots 1.75$

$1.85 \ldots 1.75 \ldots 1.40$

1.55

1.60

1.65

150

150 


\section{Wood's High-Grade Fertilizers}

NOTE.-Prices as noted below are those in effect at time this catalog goes to press. They are subject to change. Such changes will be noted in WOOD'S CROP SPECIAL or will quote prices on request. Our fertilizers are made to conform as closely as possible to the analyses recommended by the Virginia Experiment Station.

\section{Wood's Standard Vegetable Fertilizer} Analysis: 8\% Phosphoric Acid, $4 \%$ Ammonia, $4 \%$ Potash

This fertilizer is made from carefully selected materials containing plant foods known to be best suitcd to vegetable crops and is in perfect condition for distributing. Put up in bags of convenient size for the home and market gardener. Apply 800 to $1,000 \mathrm{lbs}$. to the acre. $50 \mathrm{lbs} . \$ 1.10 ; 100 \mathrm{lbs}$. $\$ 1.85 ; 200-\mathrm{lb}$. bag $\$ 3.40$; ton $\$ 32.50$.

\section{Wood's Market Garden Fertilizer}

Ana?ysis: $8 \%$ Phosphoric Acid, $5 \%$ Ammonia, $5 \%$ Potash

A very popular fertilizer among market growers who wish to get their crops on the market early. The high ammonia content gives vegetables a quick start and pushes them to maturity. The phosphoric acid and potash are in proper proportions to give firmness and good color. This fertilizer is especially adapted for grass and clover after the first cutting to force a quick and heavy growth of the second crop. Apply 800 to $1,000 \mathrm{lbs}$. to the acre for vegetables and 300 to $500 \mathrm{lbs}$. to the acre for grass and clover. $100-1 b$. bag $\$ 2.10$; $200-1 b$. bag $\$ 3.85$; ton $\$ 37.00$

\section{Wood's Standard Corn Fertilizer}

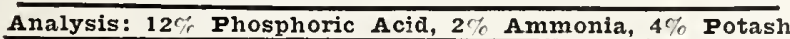

A well balanced mixture of available plant foods especially suit ed to corn. Contains a large percentage of phosphoric acid which is needed to develop a good root system and to hasten the fruiting and maturity of the crop; also ammonia and potash in the rich proportions to produce the vegetative growth and give strength and vigor to the plant Apply 500 to 600 lbs to the acre. $100-1 \mathrm{~b}$. bag $\$ 1.65 ; 200-1 \mathrm{~b}$. bag $\$ 3.05$; ton $\$ 29.00$.

\section{Standard Potato Fertilizer}

Analysis: $7 \%$ Phosphoric Acid, $5 \%$ Ammonia, $7 \%$ Potash

Especially prepared for potatoes and other root crops, which require a liberal supply of potash. Produces smoothness and firmness, and brings crop to early maturity. Also a splendid fertilizer for all general garden crops. Apply 800 to 1,000 lbs. to the acre. $50 \mathrm{lbs}$. $\$ 1.15 ; 100 \mathrm{lbs}$. $\$ 2.05 ; 200-1 \mathrm{~b}$. bag $\$ 3.80 ;$ ton $\$ 36.50$.

\section{Super Standard 16-4-4 Fertilizer}

A highly concentrated mixture to meet the increasing demand of progressive farmers for a high-analysis fertilizer. Especially suited to corn and other grain crops. One ton of this fertilizer is equivalent in plant food to approximately two tons of a low-analysis mixture. Saves handling, freight, etc. In excellent mechanical condition. Apply 300 to 400 ibs, to the acre. $100-1 \mathrm{~b}$. bag $\$ 2.15 ; 200$ lb. bag $\$ 4.05$; ton $\$ 39.00$.

\section{Acid Phosphate or Standard Super-Phosphate Guaranteed 16\% Available Phosphoric Acid}

Acid Phosphate or Superphosphate is recommended for all grain and grass crops, cowpeas, soja beans, and for applying to lands deficient in phosphoric acid. Beneficial results follow the addition of acid phosphate to stable and barnyard manure, the mixture giving a better halanced plant food, including am
Apply 300 to 500 lbs. to the acre. 200-1b. bag $\$ 1.90$; ton $\$ 17.50$.

\section{Wood's Standard Steamed Bone Meal}

Made from pure animal bone thoroughly steamed and pulver ized. Of the finest quality. Recommended for lawns, borders and all garden or farm crops, quickly available and lasting in effects. lined bags. Prices: 50-1b. $\$ 1.35 ; 100-1 b$. bag $\$ 2.50$; ton $\$ 45.00$.

\section{Champion Brand Nitrate of Soda}

The improved modern Chilean Nitrate of Soda, packed in 100-1b. paper lined water proof burlap bags. It is of higher purity and analysis than any other Chilean Nitrate, Drills very easily; doesn't get lumpy. Packed only in $100-1 \mathrm{~b}$. bags. $\$ 3.25$ per $100 \mathrm{lbs}$.

\section{Arcadian Sulphate of Ammonia}

Ammonia $25 \frac{1}{4} \%$, guaranteed. Quickly available; not easily leached from the soil: fine and dry, casily spread by hand or machine. Ideal for top dressing grain, meadows and lawns. Apply lbs. $\$ 3.25$.

\section{Wood's Standard Fair Green Fertilizer}

Analysis: Available Phosphoric Acid $7 \%$, Ammonia $8 \%$,

\section{Potash $5 \%$}

For Golf Courses and Iawns

Produces quickly a fine green turf-it is a complete grass food. Apply 2 lbs per 100 square feet for lawns and greens, For large areas 400 lbs. per acre. $100-1 b$. bag $\$ 3.25$; ton $\$ 60.00$.

\section{Wood's High-Grade Sheep Manure}

The supreme natural fertilizer finely pulverized Vnequaled for lawns, gardens and shrubbery. Supplies all necessary plant elements and improves the fertility of the soil. Fine for mulching or as a liquid manure. A splendid fertilizer for making new lawns or top dressing old lawns. Use $10 \mathrm{lbs}$. to 100 square feet for mixing in soil and half that quantity for top dressing. $25 \mathrm{lbs} .85 \mathrm{c} ; 50 \mathrm{lbs}$. $\$ 1.40 ; 100 \mathrm{lbs} . \$ 2.50$; ton $\$ 45.00$.

\section{Pulverized Limestone}

It is necessary to use lime on all acid soils to sweeten them and render soluble and available as plant food the potash and phosphoric acid already in the soil. Lime combines with the ammonia in manure, and in the soil to make for its fertility. bag; ton $\$ 10.00$.

\section{Imported Basic Slag}

Thomas Phosphate

Analysis: Phosphoric Acid, $18 \%$ : Iime, $45 \%$

A fertilizer, soil conditioner and improver more easily soluble than other mineral phosphates and more readily avallable as plant food. Highly recomment 400 to 600 pounds to the acre, 200-1b. bag $\$ 2.65$; ton $\$ 25.00$.

NOTICE.-In response to the growing demand for a high-analysis fertilizer, we now offer our customers "Wood's SUPER-STANDARD 16-4-4 Fertillzer." One bag of this 1s equal in plant food value to two bags of low-analysis mixture. Try it this year. Offered In 100-1b. and 200-1b. bags. 


\section{Wood's Poultry Foods}

Write for prices in ton lots.

Hollybrook Starting Mash (Buttermllk with Vitamin D). day 5 lbs. 25c; 25 lbs. \$1.10; 100 pald, 5 lbs. $45 \mathrm{c} ; 25$ ibs. $\$ 1.75$.

Hollybrook Chick Grains
Hollybrook Laying Mash (5\% Buttermilk). - This valuable poultry. A combination of the choicest and Lying Ilash and get ing into a nains organic mineral supplentent. By mall postpaid, 10 lbs. $80 \mathrm{c}$.

Not prepaid, 10 lbs. $45 \mathrm{c} ; 50$ lbs. $\$ 1.75 ; 100$ lbs. $\$ 3.25$. Hollybrook Scratching Food Aiming at the needs of those their best fowls, prize winners and such, we offer Hollybrook Scratching Food. Composed of the must desirable trains asedin any scratel, including sunflower and White corn so $10 \mathrm{c} 50 \mathrm{lbs}$. ored for plulnag $\$ 2.70$. Postpald, 10 1bs. $75 \mathrm{c} ; 25$ lbs. $\$ 1.45$.
$\$ 1.55$; 100-1b. bag $\$ 2.85$. Postpald, 10 ibs. $80 \mathrm{c} ; 25$ lbs. $\$ 1.50$

Pamunkey Chick Crains A splendid mixture for general pur50 lbs. $\$ 1.50 ; 100$ lbs. $\$ 2.75$.

Hollybrook Growing Mash (5 is is attermilk). rowing masli whose use produces results and true formula. We urge all poultry $\$ 1.80 ; 100$ lbs. $\$ 3.40$. Postpald, 10 lbs. 85c; 25 lbs. $\$ 1.65$.

Hollybrook Developing Food

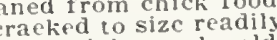
catable by growing chicks of six to eight weeks old. $\$ 2.70$. Postpaid, 10 bs. $75 \mathrm{c}$; 25 lbs. $\$ 1.45$.

Hollybrook Pigeon Mixture Used by the most field peas, hemp, and W ther necresary CORN-Prains for p.o., 10 lbs. 50c; 50 lbs. \$1.90; $100-1 \mathrm{~b}$. bag $\$ 3.60$. Postpaid, 10 lbs. $85 \mathrm{c} ; 25 \mathrm{lbs}$. $\$ 1.65$. WITHOUT CORN-Prices $f$. o. b., $10 \mathrm{lbs}$. 50c; 50 ibs. $\$ 1.90 ; 100-1 \mathrm{~b}$. bag $\$ 3.60$. Postpaid, $10 \mathrm{lbs} .85 \mathrm{c} ; 25 \mathrm{lbs}$ $\$ 1.65$. Wood's Scratch Food Our original mixture.

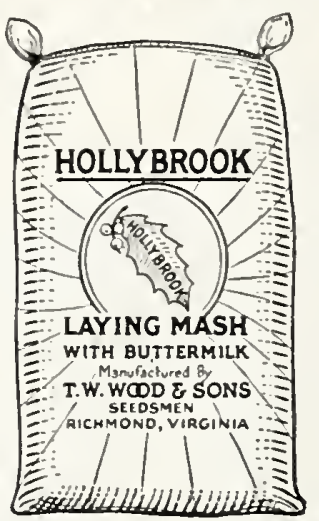
a complete rood. Very popular for general feeding and desirable for laying hens. Contains sunfower and yellow cracked corn. Great p1.35; ralsers. $\$ 2.50$. Postpaid, 10 lbs. $70 \mathrm{c} ; 25 \mathrm{lbs}$. $\$ 1.35$

Pamunkey Scratch Food -A wonderfully good eral purpose feeding. Made of choice, clean grectly white and yellow cracked corn and seeds correctly proportioned to give housands of successful poultry is the favorite of thousand 10 lbs. $35 \mathrm{c}$; 50 lbs. $\$ 1.30$; rao-1b. bag $\$ 2.40$. Postpaid, 10 lbs. $70 \mathrm{c} ; 25 \mathrm{lbs}$. $\$ 1.40$. Pamunkey Laying Mash (1\% Buttermilk). - A

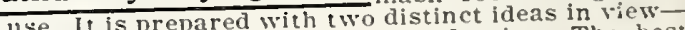
use. Th is preparen west ceneral purpose mash on the market. A moneygeneral por poultry raisers. Contains organic min-

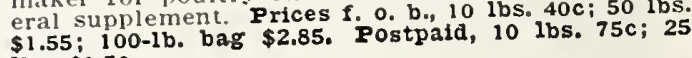
lbs. $\$ 1.50$.

\section{Miscellaneous Feeds}

Pratt's Growing Mash (With Buttermilk),-For g r o w in g feather lullder lngredients: Dried buttermilk, feeding oat ment, corn meal, ground oats, Wheat middlings, Wheat bran (Wy mail postpaid, 10 lbs. $90 \mathrm{c}$.

Not prepaid, 10 lbs. 55c; 25 lbs. $\$ 1.00 ; 50$ lbs. $\$ 1.95 ; 100$

Pratt'5 Baby Chick Food (with Buttermilk) - By mall post-

1bs. $\$ 2.05$.

Not prepaid

100 1bs. \$4.75. Crushed Oyster Shell - Trsential as an egg shell maker By mail postpald, $101 \mathrm{bs}$. 55c.

Not propald, 10 1bs. $25 \mathrm{c}$; 50 ibs. $55 \mathrm{c} ; 100 \mathrm{lbs}$. 95c.

Charcoal - Alds digestion, purifies the blood and promotes Charcoal the health. Thrce rrades-Grade $A$ (fine granuwh hatehed to half-grown chickens, trial package $35 \mathrm{c}$

Not prepaid, trial package 20c; 50-1b. paper lined sack \$1.15. Mica Spar Cubical Grit - Indispensable for digestive pur-

w m mail postpaid, 10 lbs. 50c. Not prepald, $10 \mathrm{lbs}$. $20 \mathrm{c}$; $50 \mathrm{lbs}$. $70 \mathrm{c} ; 100 \mathrm{lbs}$. $\$ 1.15$.

Oberco - An organic mineral s-pplement, the base of which $\frac{\text { Oberco lis lione charcoal. splendirl in mash mixtures. Helps }}{\text { to carry the hens and pullets throngh the laying season in }}$ for hors and dairy cattle. 50 bs. $\$ 1.90 ; 100$ lbs. $\$ 3.50$.

Ep5om Salt5 - By mall postpaid, 10 lbs. $\$ 1.10$.

Ep5om Salt5 Not prepald, 10 lbs. $75 \mathrm{c} ; 50$ lbs. $\$ 2.75 ; 100$ lbs. $\$ 5$. Powdered Sulphur -By mail postpaid, 5 lbs. $65 \mathrm{c}$; 10 lbs: 25 lbs. $\$ 1.65 ; 50$ lbs. $\$ 3.00 ; 100$ lbs. $\$ 5.50$.

Dried Butter Milk (Collis).-Not prepaid, 50 lbs. \$4.75; 100 ibs. $\$ 9.00$.

Nopco Cod Liver Oil-Not prepald, qt. 60c; 2 qts. \$1.10; 1 Nopco Cod Liver Oil gallon, $\$ 2.00 ; 5$ gallons, $\$ 9.50$ "O. K." Sanitary Poultry Litter -Bale $\$ 3.00$.
Green Cut Alfalfa Meal -An all-the-year green feed, high foralue and increases egg production. By mail postpaid, 10 lbs. $70 \mathrm{c}$. Not prepaid, $10 \mathrm{lbs} .35 \mathrm{c} ; 50 \mathrm{lbs}$. $\$ 1.30 ; 100 \mathrm{lbs}$. $\$ 2.40$.

Meat Scrap5 - Except in summer, meat scraps should be in the daily ration of all fowls. Its use in cool weather whits well known content

sary for promoting the lat SCRAPS.-55\% protein. By mail WOODS PREMIER M.

postpaid, 10 lbs. $90 \mathrm{c}$. $50 \mathrm{c} ; 50 \mathrm{lbs}$. $\$ 2.05 ; 100 \mathrm{lbs}$. $\$ 3.90$.

Pin Head Oats -Not postpald, 10 lbs. 50c; 50 lbs. $\$ 1.80 ; 100$ Sunflower for Feeding $\$ 1.25 ; 25$ lbs. $\$ 2.65$. 5 lbs. $75 \mathrm{c} ; 10 \mathrm{lbs}$.

Not prepaid, 5 lbs. 50c; 10 lbs. $90 \mathrm{c} ; 50$ lbs. $\$ 3.50 ; 100$ lbs. $\$ 6.50$.

-By mall postpaid, 5 lbs. $70 \mathrm{c} ; 10$ lbs. $\$ 1.15$.

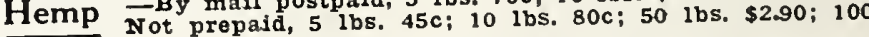
Ibs. $\$ 5.50$.

Buckwheat for Feeding Not prepaid, 10 lbs. $45 \mathrm{c}$; 50 1bs. $\$ 1.70$; 100 1bs. $\$ 3.25$.

Poultry Wheat $-\$ 1.25$ per bashel

Heavy Oat5 for Sprouting -67 c per bashel (32 lbs.).

Canada Field Peas -By mail postpald, 10 lbs. $\$ 1.00$

Canada Field Peas Not prepaid, 10 lbs. 65c; 50 lbs. $\$ 2.50$; 100 Ibs. $\$ 4.75$.

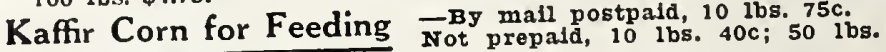
$\$ 1.35 ; 100$ lbs. $\$ 2.50$.

Milo Maize for Feeding $\rightarrow$ By mall postpaid, $10 \mathrm{lbs} 80 \mathrm{c}$. $\$ 1.40 ; 100$ lbs. $\$ 2.60$.

Millet for Feeding - By mall postpaid, 5 lbs. 60c; 10 lbs. 95c. \$2.15; 100 lbs. $\$ 4.00$. Not prepaid, 5 lbs. $35 \mathrm{c}$; $10 \mathrm{lbs} .60 \mathrm{c} ; 50 \mathrm{lbs}$ MEAT FEED CORN (Whole and Cracked) MEA, FEED CORN W. Wite for prices. 


\section{RUST'S}

\section{POULTRY PREPARATIONS}

Rust's Tonic and Appetizer - A general containing only just enough stimulants (less than four per cent) to aid digestion. It will assist in keeping your fowls in robust health, which condition is very necessary if you expect an increase in egg production. It pays the year. When bought in the large size it costs only about two cents a montl to feed each hen. It is equally good for turkeys, geese, or ducks. Although moderate in price, it is one of the best poultry tonics. Full direc postpaid, 1-1b. pkg. 30c;21/2-1b. pkg. 60c;6-1b.

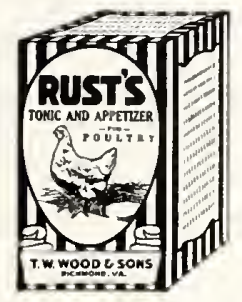
pkg. $\$ 1.20 ; 25-1 \mathrm{~b}$. pkg. $\$ 3.85$.

Not prepaid, $1-1 \mathrm{~b}$. pkg. $25 \mathrm{c} ; 2 \frac{1}{2}-1 \mathrm{~b}$. pkg. 50c; 6-1b. pkg. $\$ 1.00 ; 25-$ 1b. $\mathrm{pkg}$. $\$ 3.25$.

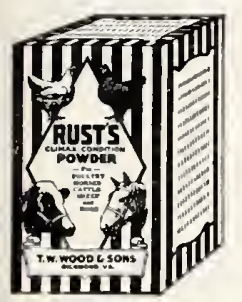

\section{Rust's Climax Condition Powder}

-A tonic and appetizer for poultry, horses, cattle, sheep and hogs. Few realize how much feed animals pass undigested, and how much is thus lost in feed and condition. Rust's Climax Condition Powder assists the digestion thus enabling the fowls and live stock to fatten quickly. As this powder contains no Armal; the benefit is real and lasting. Full direction for feeding contained in each package. Prices postpald, 13-oz, pkg. 3)c; 2-ib. pkg. 60c; 5-1b. pkg. $\$ 1.15 ; 20-1 \mathrm{~b}$. pkg. $\$ 3.70$. Not prepaid, 13-oz. pkg. 25c; 2-1b. plkg. 50c; 5-1b. pkg. $\$ 1.00 ; 20-1$ b. rkg. $\$ 3.25$.

Rust's Lice Powder For Dusting Poultry and tains no naphthalene or other odorous ingredents, it does not affect the flavor of eggs or injure them for hatching. when fowls and nests are dusted with it. When Rust's Iice Powder used, fowls are healthier, have a better appearance, their skin is healthier and their plumage is
brighter. Rust's Lice Powder kills vermin on

fowls, animals or plants, and is very economical to use. Directions on each box.
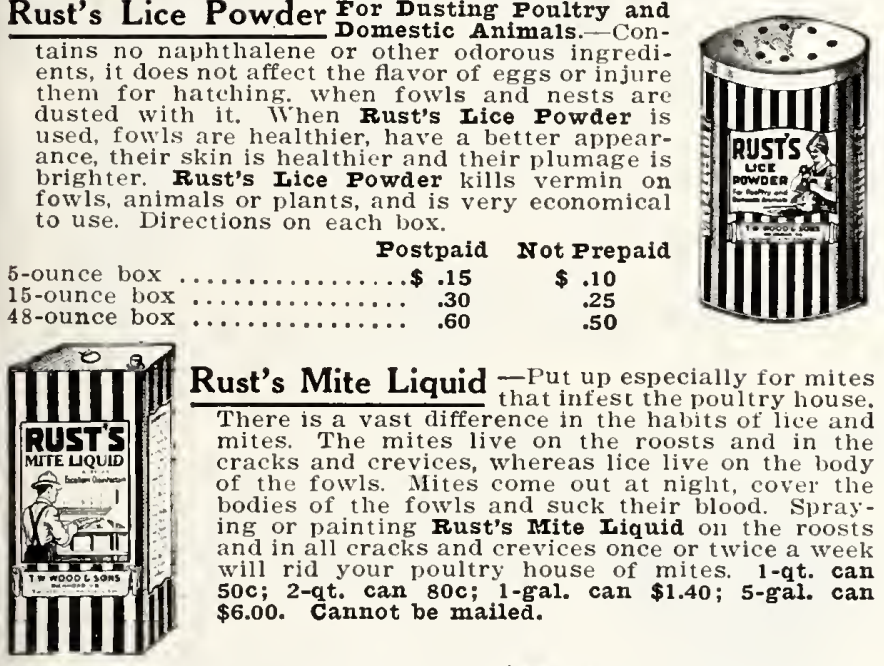

Rust's Mite Liquid -Put up especially for mites There is a vast difference in the habits of lice and mites. The mites live on the roosts and in the cracks and crevices, whereas lice live on the body of the fowls. Mites come out at night, cover the ing or painting Rust's Mite Iiquid oll the roosts ing or painting Rust's Mite Liquid oll the roosts and in all cracks and crevices once or twice a week $50 c$; 2-qt. can $80 c$; 1 -gal. can $\$ 1.40 ; 5$-gal. can $\$ 6.00$. Cannot be mailed.

Rust's Water Glass For Preserving Eggs.-Eggs put away to ten months. One gallon will make enough solution for about fifty dozen eggs. 1-qt. can 40c; 1-gal. can $\$ 1.25$. Cannot be mailed.

Rust's Egg Record For keeping a record of eggs (good for

Carbola - Is infinitely superior to $11 \mathrm{me}$, which loses what to the air. Very much better than kalsomining or whitewash because it paints just as clean and bright a white, but will not chip, scale or peel off. Can be applied with either sprayer or brush. By mail postpaid, 5-1b. pkg. \$1.00; 10-1b. pkg. \$1 60. N
prepaid, 5-1b. pkg. 75 cts.; 10-1b. pkg. $\$ 1.25 ;$ 5C-1b. Tkg. $\$ 5.00$.

"Black Leaf 40" -A new control for poultry lice and mites.

control body-lice Painted on the top-side of the roosts Will Equally effective for mites when applied as a spray. Dilute Equally effective for mites when applied as a spray. Dilute plus 1/2 ounce of ordinary laundry soap. 1-ounce bottle (treats 12 to 15 running feet of roost) $35 \mathrm{c} ; 1 / 21 \mathrm{~b}$. (treats 90 to 120 feet of roost) $\$ 1.25 ; 1-1 b$. bottle (treats 195 to 240 feet) $\$ 2.50 ; 2-1 b$.
tin (treats 385 to 480 feet) $\$ 3.75 ; 5-1 b$. tin (treats 1,000 to 1,200 feet) $\$ 7.00 ; 10-1 b$. tin (treats 1,900 to 2,400 feet) $\$ 11.85$. Cannot be mailed.

CA Worm Capsules CA

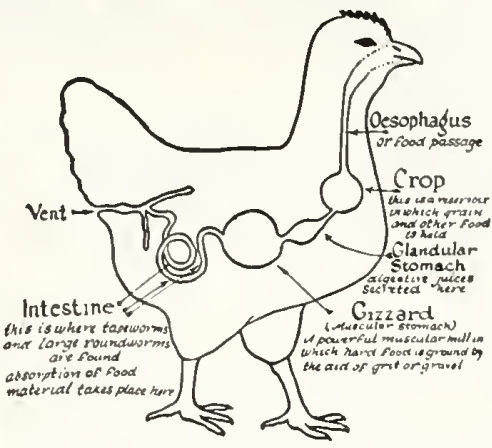

fering

months old order by number. Price: No. 125 Capsules for young birds $35 \mathrm{c}$ per doz., 50 for $9 \mathrm{cc}$, postpaid. No. 196 Capsules for adult birds $45 \mathrm{c}$ per doz., 50 for $\$ 1.25$, postpaid.

NOPCO

\section{Cod Liver Oil}

ure, promo postpaid, 1-qt. can $70 \mathrm{c}$ each. Not prepaid, 1-qt. can $60 \mathrm{c} ; 2-q^{+}$. can $\$ 1.15 ; 1-$ gal. can $\$ 2.25 ; 5$-gal, can $\$ 9.50$ per can.

Walko Tablets - Especially valuable for diar

ble among incubator chicks. They tend to pre-
vent digestive disturbances and should be giv-
en in all drinking water from the time the
chicks are out of the shell. Also recommended
for swellings of roup in the head and simple
catarrh among older birds. Price postpaid.
small size 50c; larger size \$1.00.

Macnair's Barnyard Protector $-\mathrm{S}$

turkeys, guine as and pigeons
ing them small doses of this powder

to direction, and the barnyard enemies that kill

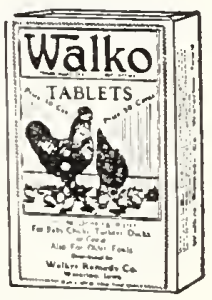

and eat the entire fowl will surely die, By mail postpaid, 7-oz. pkg. 55c; 16-0z. pkg. 85c. Not prepaid, 7-oz. pkg. 50c; 16-oz. pkg. Hackett's Cape Cure

simply lusted over the chicks, and they inhale the dust, which
kills the worms and germs. Price postpaid, 50 cts. each. Not prepaid, $40 \mathrm{cts}$. each.

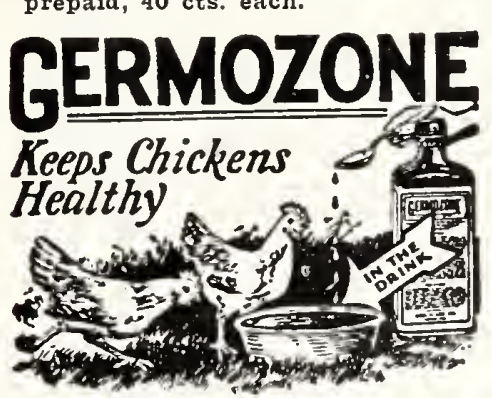

Conkey's Diatex - An

remedy in the drinkin

$50 c$ sizes.

Conkey's Salvo

paid, $25 \mathrm{c}$ and $50 \mathrm{c}$ sizes.

Conkev's Head Lice Oin'ment Price postpaid, 1 -oz. tion. Price postpaid, 30c. Not prepaid, 25c.

Conkey's Old Reliable Powder-Easily given in the drinkhelp themselves. In mild doses it acts as a tonic. Price postpaid, $25 \mathrm{c}$ and $50 \mathrm{c}$ sizes. 
Egg Boxes - Baby Chick Boxes and Shipping Coops

Humpty Dumpty Folding Egg

\section{Crates}

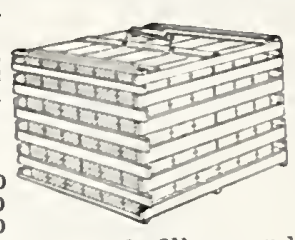

50c. per set, postpaid.

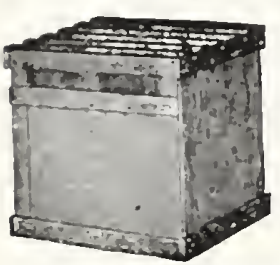

Shipping Coops for Poultry The Best Coop for Shipping Fancy Fowls. - 1 closed eoop inade of light lumber.

(not prepaid $55 \mathrm{c}$. By mall postpaid, 75c each. By mail postpaid, $85 \mathrm{c}$ eacls. Not prepaid, $60 \mathrm{c}$ each; $\$ 6.50 \mathrm{doz}$. Bird size, is inciles long by 21 inches wide hy 21 inches high.

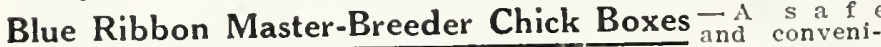

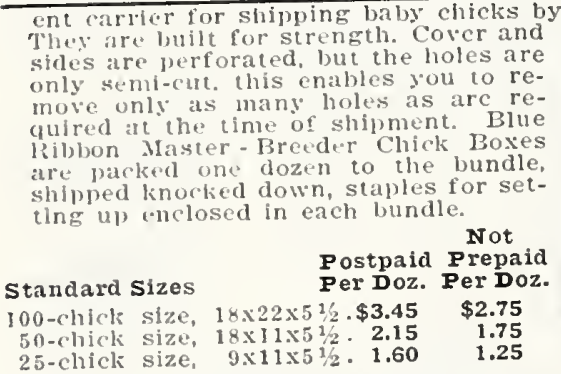

$35 c$ each postpaid.

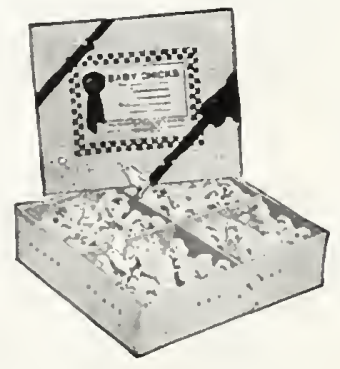

\section{ANDERSONS "HATCHANEGG" BOX}

Speclally made for shlpping valuable eggs for hatching. The maximum of safety is assured. Both body and top are waterproofed on the outside. The strength of the package is approred by shipper thorities. The walls are double thick. ness and the cellular construction no them from excessive heat or cold.

\begin{tabular}{|c|c|c|c|c|}
\hline & \multicolumn{2}{|c|}{ Postpaid } & \multicolumn{2}{|c|}{ Not Prepaid } \\
\hline & & & & \\
\hline & .5 .4 & $\begin{array}{r}\$ 3.90 \\
5.35\end{array}$ & $\begin{array}{l}\text { \$ } .35 \\
.45\end{array}$ & $\begin{array}{r}\$ 3.5 \\
4.7\end{array}$ \\
\hline
\end{tabular}

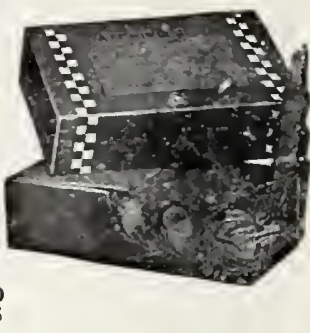

Mew ITodel) For Shipping Eggs by ParMetal Egg Crates cel Post.-. Mrde for continued use, being

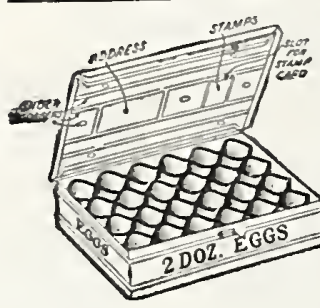
very strongly constructed, but light in weight. The new patemted hape like an cardboard, circllat in shape hetal edges egg) and reinforced with metal edges is a wonder for safety and durability. It is practically" egg-break proof. This new filler is recognized as at permathensity of replacement from time to time. making it both a mone at the old style boxes. These crates do not require outside wrapping for mailing. Descriptive circular mailed on request.

\begin{tabular}{|c|c|c|}
\hline $\begin{array}{l}\text { For Eggs only } \\
\text { Capacity }\end{array}$ & $\begin{array}{c}\text { Postpaid } \\
\text { Eachi }\end{array}$ & Not Prepaid \\
\hline 1 doz. size. & $\ldots \$ 1.10$ & $\$ 1.00$ \\
\hline 116 doz. size & 1.35 & 1.25 \\
\hline 2 doz. size & 1.60 & 1.50 \\
\hline$\overline{3}$ doz. size & 1.90 & 1.75 \\
\hline 4 doz. size & 2.15 & 2.00 \\
\hline 6 doz. size & 2.65 & 2.50 \\
\hline
\end{tabular}

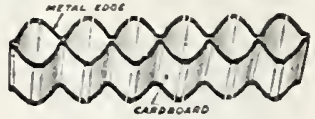

New Model Metal adge Filler
Combination Metal Crates (New Model) For Shipping But-

Combination Metal Crates ter and Eggs by Parcel Post.

$$
\text { Capacity } \begin{gathered}
\text { Postpaid } \\
\text { Each }
\end{gathered}
$$

No. 1 2 los, butter and 1 doz. eggs.......\$1.60 \$1.50

No. 1-2 lbs. butter and 2 doz. eggs........ 2.15

No. 3-4 lbs. butter and 3 doz. eggs.........2.40

No. $4-6$ lbs butter $(32-1$ b containers $) \ldots . .2 .45$

\section{Poultry Fountains and Feeders}

Star Jar Fountain and Feeder - Till nt pt., half Falion Nlason jar. Mianufactured of one unsuldered, teaking impossible. Convenlent. cannet get drowned. Can be used for feed as BY MAIL POSTPAID, $15 \mathrm{cts}$. each; $\$ 1.30$ per doz. NOT PREPAID, $10 \mathrm{cts}$. eacli; $\$ 1.10$ per doz.
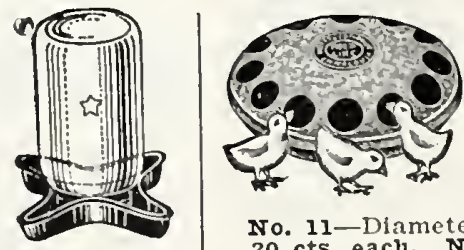

\section{Round Baby Chick Feeder $\bar{s}$}

A great fccd saver, as the chicks cannot upset it or get into it to contaminate the feed. The top fits sningly, yet it can fill easily taken apart for cleaning and fill ing. Made of best quality galvinized in two popular sizes.

No. 11-Dlameter 6 inches with 8 holes. BY MaIl POSTPAID No. 11-DiametroT PREPAID, $10 \mathrm{cts}$. eacli; $\$ 1.10$ per doz. $20 \mathrm{cts}$. eacli. NOT PRE PAID, 35 cts. each. NOT PREPAID, $20 \mathrm{cts}$. each; $\$ 2.25$ per doz

Handy Attachment When attached to it makes i perfect feeder for sour milk butternilk, medicine, water, or small grains. The container ls aluminum, the only metal in which sour nille or medycine tachment is adjustable, simple to operate, lur.able and non-corrosive te his an make of postpaid $35 \mathrm{c}$ each. Not prepaid, $25 \mathrm{c}$ each; $\$ 2.50$ per dozen.

Double Feeding Troughs (For Chicks and Growing Stock)

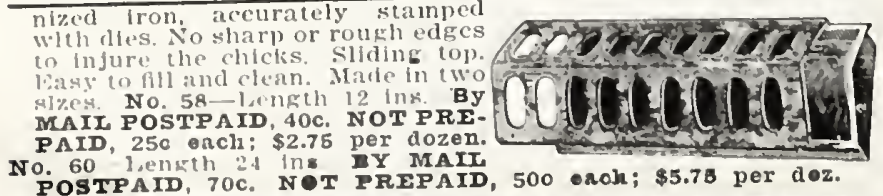

\section{WIITE FOR COPY OF}

Poultry Foods and Poultry Neods, a publieation issucd monthly giving current prlces and valuable information and suggestions for making your poultry raising protitable.-Malled free.

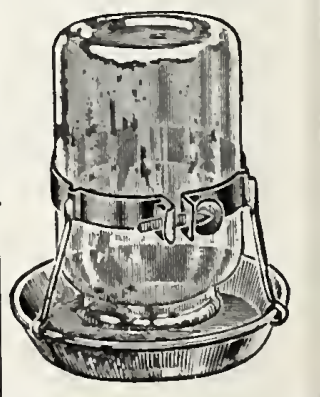




\section{Poultry Fountains and Feeders---Continued}

\section{Round Table Drinking Fountain}

-These fountains provide over four feet of drinking space, fowls can drink from all sides at once. Easily cleaned, can be picked up by handle and carried anywhere. A detachable cone top is provided to prevent fowls from roosting on fountain. Price postpaid, 5-gal. size, \$3.25 each; 8-gal. size, $\$ 3.75$ each. Not prepaid, 5-gal. size, $\$ 2.75$ each; 8-gal. size, $\$ 3.25$ each.
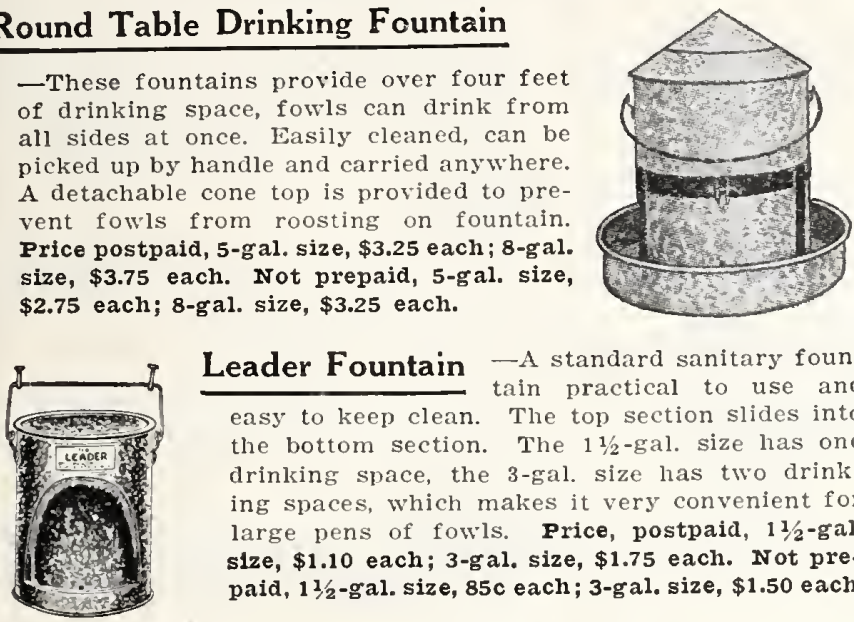

\section{Leader Fountain}

tain easy to keep clean. The top section slides in the bottom section. The $1 \frac{1 / 2}{-g a l}$. size las one drinking space, the 3 -gal. size has two drinking spaces, which makes it very convenient for large pens of fowls. Price, postpaid, 11/2-gal. size, $\$ 1.10$ each; 3-gal. size, $\$ 1.75$ each. Not prepaid, 11/2-gal. size, $85 \mathrm{c}$ each; 3-gal. size, $\$ 1.50$ each.

\section{Duplex Wall Fountain} -The most practical sanitary poultry fountain on the market. This is a double fount, easy to fill, and keeps the water clean a M M I I POSTPAID, 1-gal. size, $\$ 1.30$ each; 2 -gal. size, $\$ 1.60$ each. NOT PREPAID, 1-gal. size, $\$ 1.15$ each; 2 -gal. size, $\$ 1.40$ each.
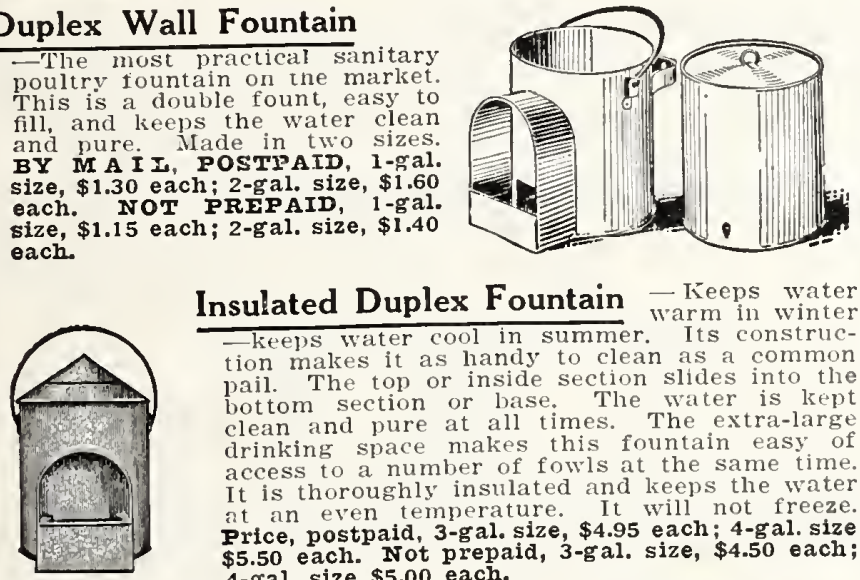

Insulated Duplex Fountain - Teeps water

\section{Handy Fill Chick Fountain}
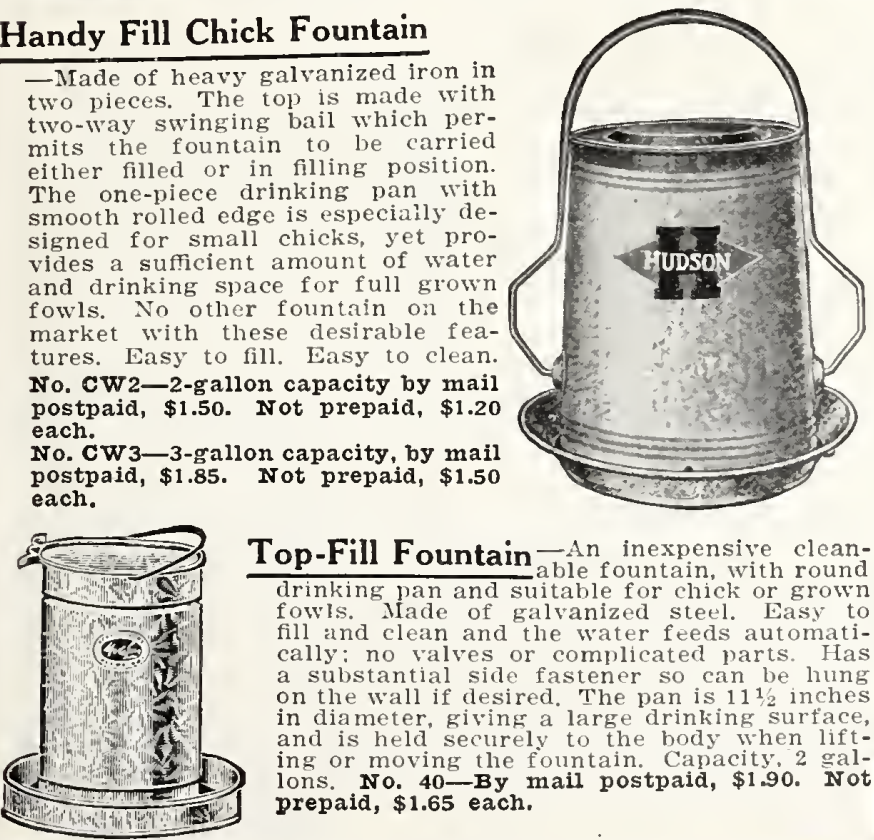
tion makes it as handy to clean as a common pail. The top or inside section slides into the bottom section or lise. The extra-large drinking space makes this fountain easy of access to a number of fowls at the same time. It is thoroughly instlated It vill not freeze. at an even temperature, postpaid, 3 -gal. size, $\$ 4.95$ each; 4 -gal. size $\$ 5.50$ each. Not prepaid, $3-g$ al. size, $\$ 4.50$ each; 4-sal. size $\$ 5.00$ each.

calvanized iron in the top made with two-way swing bail which permits the fountain to be carried The one-piece drinking pan with The is especially deiched for small chick proace fountain on the desirable feaNo. coasy to clean. postpaid, $\$ 1.50$. Not prepaid, $\$ 1.20$

CW each.

Top-Fill Fountain-An inexpensive cleanfowls lade of ralyanized steel Easy to fill and clean and the water feeds automatically: no valves or complicated parts. Has a substantial side fastener so can be liung on the wall if desired. The pan is $11 \frac{1 / 2}{2}$ inches in diameter, giving a large drinking surface, ing or moving the fountain. Capacity. 2 gallons. No. 40-By mail postpaid, $\$ 190$. Not prepaid, \$1.65 each.

\section{Dry Mash Hopper - Easy to fil.}

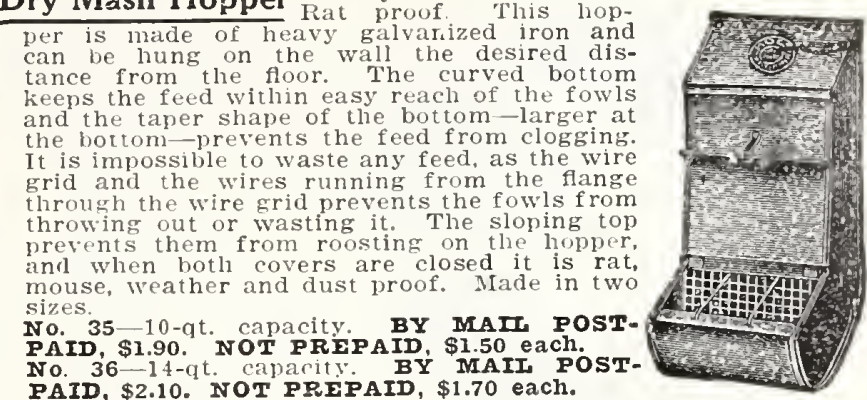
Grit and Shell Box best galvanized iron and
contains three conpartments for food shells
or grit. It can be hung up against the watl
at any height desired, und is a thoroughly firstGrit and class article, practically indestructible, and will Shell hopner" on the market By the use of these Box self-feeding boxes practically every particle of grit, and other materials supplied will be properly used, profits. BY MAIL POSTPAID, 95c each. NOT PREPAID, 750 each.

Large Capacity Feeder

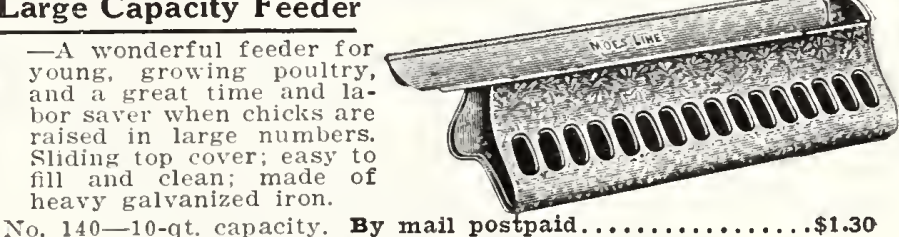

140-10-qt. capacity. By mail postpaid............\$1.30 Not prepaid, \$1.00 each. Not prepaid \$1.60 each.

Wishbone Chick Feeders

\section{The perfect chick feeder. Unob-}

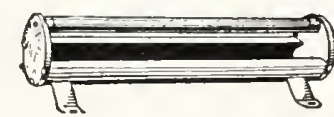

12-inch Chick Feeder

18-inch Chick Feeder

(18-inch

Hudson Insulated Waterer fountain

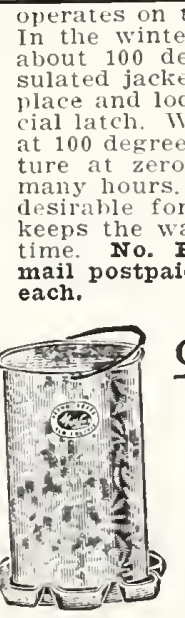

No 158-1- al size by mail postpaid, $70 \mathrm{c}$ each. Tot 2 -gal. size by mail postpaid, $\$ 1.00$ each. Not postpaid, $80 \mathrm{c}$ each; $\$ 9.00$ per dozen. 


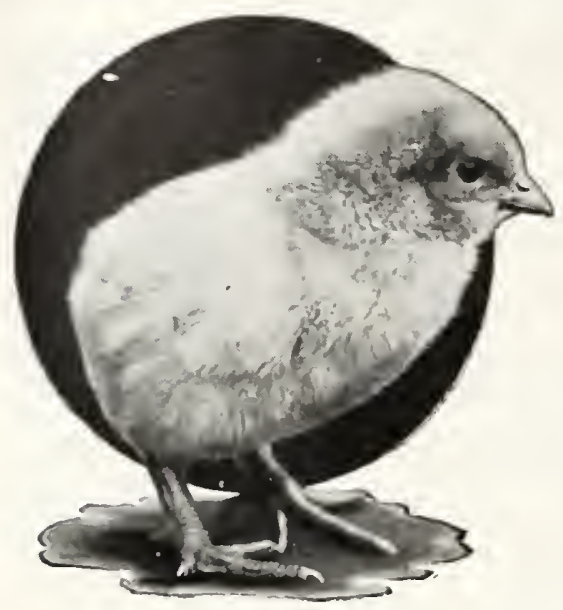

TESTIMONIALS

"I have bought baby chicks all over the country. A lot of Plymouth Rocks bought of hick line 1 ever made."-I. CHAMBERS jOOUE, June 30, 1929, Ilecklenburg Co., Va.

"The 50 Barred Rocks arrived in fine shape. They are fine, strong, healthy ehieks and surely fine chieks."-MISS ROSA JOHNSON, April 20, 1930, Vanee Co., N. C.
WOOD'S BABY CHICKS are vigorous and healthy chieks. They will live, mers for fine laying qualities and breed characteristics. Our shipping days are Monclays and Thursdays. Season begins January 15 th. Customers urged to place order well ahead of wanted shipplng date.

\section{BARRED ROCKS}

Our Barred Rocks are a dual purpose bird, maklng for early maturity and egg-producing quallties. They are dependable for a net profit through the sale of eggs and likewise as broilers will provide a fine income because of reaching the broiler stage at an early date.

\section{SINGLE COMB RHODE ISLAND REDS}

The Rhode Island Red is marked for his healthy rigor and stamina to resist cold. Especially liked for their hlgh egg-produeing qualities during the cold winter months. They are good layers and the eggs are large and brown. Also liked on account of their delicious ftavored meat.

\section{WHITE WYANDOTTES}

Wood's White Wyandottes are noted for their healthy vigor and wonderful egg laying qualities. Also for broilers. Free from pinfeathers, having a yellow skin and easy to prepare for the table. Very popular with housewives.

\section{SINGLE COMB WHITE LEGHORNS}

Above all other breeds the Thite Leghorn exeels in produetion of eggs in proportion to the small amount of feed used. Their large white eggs are always in demand, bringing a premium on most all markets. Whether baekyard flock or a large commercial one Wood's White Leghorns are ready to serve you.

\section{HEAVY MIXED CHICKS FOR BROILERS}

Strongly recommended for broilers, possessing same health and vigor as the purebred sort.

\section{0\% Iive Dellvery Guaranteed Cash with Order}

\begin{tabular}{|c|c|c|}
\hline \multicolumn{3}{|c|}{ Prices Postpaid-Jan. 15th to May 1st. } \\
\hline 25 & 50 & 100 \\
\hline $\begin{array}{r}\$ 4.00 \\
4.00 \\
4.50 \\
3.75 \\
3.75\end{array}$ & $\begin{array}{r}\$ 7.50 \\
7.50 \\
8.50 \\
7.00 \\
7.00\end{array}$ & $\begin{array}{r}\$ 14.00 \\
14.00 \\
16.00 \\
13.00 \\
13.00\end{array}$ \\
\hline
\end{tabular}

A Timely warning: Do not wait too long in ordering Baby Chicks. Anticipate your wants as far ahead as possible to avoid delay in delivery.

\section{Poultry Helps and Appliances}

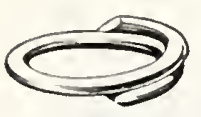

Spiral Celluloid Leg Bands

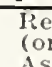

(order by number a Aslatles; No, 2, Flymouth Roek and Rhode Aslatles: No, 2, Plymouth Roek and Rhode
Island lied size; No. 3, Leghorn size; No. 4,
small fowls: No, 5 for baby chicks. No less for pigeuns and small fowls; No. 5 , for baby chicks. No less doz, $10 \mathrm{cts.;} 25$ for $20 \mathrm{cts}$; 50 for $35 \mathrm{cts}$; 100 for $60 \mathrm{cts}$.

Bandetts - Colored celluloid leg bands, lble numbers, They are easily applied single
handed. Made in five colors-blue, red, yellow, handed. Made in five colors-blue, red, yellow, horns: No.11, for Plymouth Rock and Rhode Island Reds, Bandetts so:d on:y in un-
broken gots of 25 in one co:or. By mail postpala, 25 for $60 \mathrm{c}$; 50 for $\$ 1.00 ; 100$ for $\$ 1.75$.
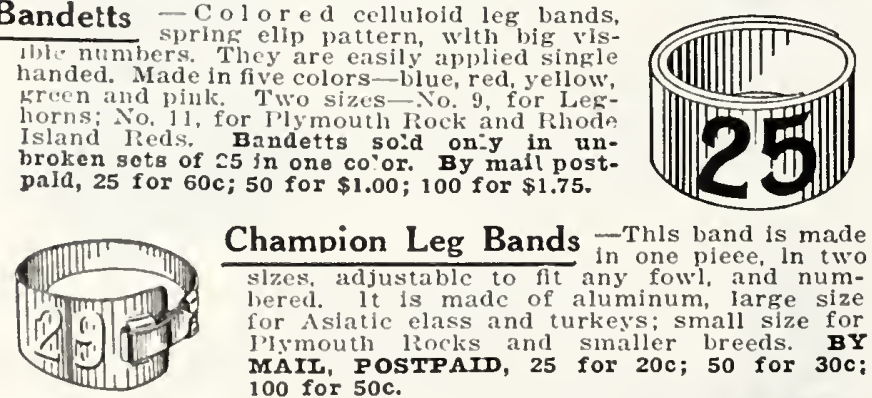

Champion Leg Bands -Thls band is made slzes, adjustable to fit any fowl, and numbered. It is made of aluminum, large size for Aslatic elass and turkeys; small size for MAII, POSTPAID, 25 for 20c; 50 for 30c: 100 for $50 c$.

Perfect Poultry Punch - Simple In eonfhor clear. wlean cut, and does not mutllate NOT PREPAID, 50 cts. each.
Gape Worm Extractor - When gape worms lodge in the If the ehlcken is to reeover. $30 \mathrm{cts}$. each, postpaid.

Tycos Incubator Thermometers The best ineubator manless the thermometer used therein is accurate. The Tyeos thermometer is thoroughly tested before shipped. 75c, postpaid. Incubator Hygrometers -Millions of chicks die in the shell moisture conditions. Incubator Hygrometers do not proper the moisture, but is an indicator, showlng exactly what conaitions are, so that if not eorreet, they may be made so. By mail postpaid, $\$ 1.85$ each.

Philadelphia Caponizing Set -One of the chief advantages sime fow grow raster, the meat sweeter. The operation is very simple, and inctructions are furnished with each set: it ean be
performed in less than ten minutes. \$2.50 each, POSTPAID.

Glass Nest Eggs-Made of first-class fiint glass the same

Glass Nest Eggs size and eolor of a hen's egg. They do not break easlly WIIl last a lifetime. Keep one egg in every neSt, BY MAII, POSTPAID, 40
PAID, 3 for 10 cts.; dozen 30 cts.

Knox Nest Eggs - Keep the nest sweet and pure by plaeing come in contact with the eggs. BY MAII POSTPAID, 10c each; $75 c$ per dozen. NOT PREPAID, 6c each; 65 c per dozen.

The X-Ray Egg Tester-Designed for usc on ordinary lamp These testers are thoroughly praetical, and where sman numbers of eggs are to be tested will answer the purpose well. It will illuminate the interior of the egg and show if the rhick ls allve. BY MAIL, POSTPAID, 350 cts. each. NOT PREPAID, $25 \mathrm{cts}$. 


\section{INSECTICIDES, SPRA.YERS AND TOOLS}

No article on this page can be mailed except those quoted "postpaid"

\section{Antrol \\ Fills All Sweet-Fating Ants. Antrol kill \\ the ant colony in the nest. It contains a mild \\ ly poisonous syrup, attractive to the worker \\ nest. Soon the whole colony is destroyed. Set Cannot be 4 containers and}

Arsenate of Lead - For Ieaf-eating Inleaf better than paris green and remains longer in suspension, requires fewer applications; does not burn the leaf, thus allowing stronger solutions. White in color and shows just where it has been applied. These advantages make it preferable to paris green for destroying leaf-eating in. sects. Use 1 to 2 lbs. to 50 gals. of water general spraying. Lb. 30c; 4-1b. pkg. 85c; case (12 4-1b. pkgs.) \$9.60. Cannot be mailed.

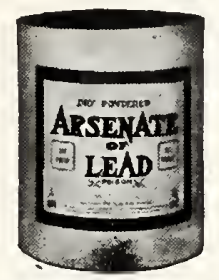

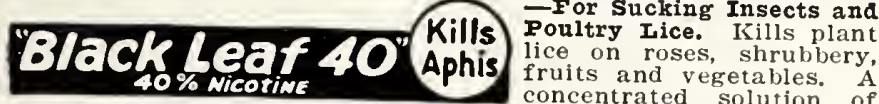
teed to contain not less than nicotine sulphate, guarantion in the proportion of a teaspoonful to a nicotine. A soluwhich add three-fourths ounce of soap (4 Ibs. to each 100 gal lons of solution), will kill the garden pea louse and not injure the vine. Mix with 800 times its bulk of water.

For Poultry Iice paint the top of the roosts and repeat in ten days and your poultry will be completely rid of lice. An ounce bottle paints 12 to 15 feet of roost; 1 lb. paints 190 to 240 feet.

$10-1 \mathrm{~b}$.

Calcium Arsenate (Arsenate of Iime).-For Mexican bean insects. May be applied dry, mixing to 7 parts hydrated (airslaked) lime or land plaster; or in water 2 lbs. to 50 gallons of water. Ib. 20c; 4-1b. pkge. 60c;
case (12 4-1b. pkges.) \$6.50. Cannot be mailed;

Magnesium Arsenate For Bean Beetle and other leaf-eating stations recommend magnesium arsenate for . The various experiment bean beetle, their experiments having for killing the Mexlcan leaf less than other recommended insecticides. For spraying, use 1 pound to 50 gallons of water; for dusting, use 1 pound to drum \$27.00. Cannot be mailed.

Bordeaux Mixture For blights, scab, mildew, etc.-Prevents other fungus di blight, scab, rust, mildew, black-rot and other fungus diseases of plants and fruits and improves the quality and increases the yield. Apply on all vine crops, grapes, pounds to 50 gallons water makes a 4-4-50 mixture ( 3 level tablepkgs.) \$8.75. Cannot be 1 lb. 25c; 4-1b. pkg. 80c; case (12 4-1b.

Bordeaux - Arsenate of Lead-Insecticide and Funglcideof bordeaux mixture and arsenate of lead in the A combination tions to make a combined fungicide to prevent proper proporand insecticide to kill leaf-eating insects. water (2 level tablespoonfuls to 1 gallon). 1-lb. pkg. 35c; 4-1b.
pkg. $\$ 1.00$; case (12 4-1b. pkgs.) $\$ 11.00$.

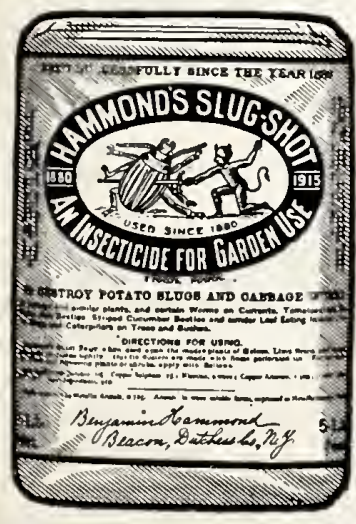

Slug Shot-For leaf-eating insects. and caterpillars on vegetables and house plants, shrubbery, vines, trees, fruits and flowers. Destructive to insects, but harmless to man. beast Apply either dry or in water. $\mathbf{B y}$ mail postpaid, 1 lb. sifter top pkg $30 \mathrm{c} ; 5-1 \mathrm{~b}$. pkg. $75 \mathrm{c}$

Not postpaid, 1 lb. 20c; 5-1b. pkg. $55 \mathrm{c} ; 50$ lbs. $\$ 5.00 ; 100$ lbs. $\$ 9.50$.

Fish Oil Soap (Sometimes called Effectually destroys the mealy bug and almost all lice on both indoor and outdoor plants. Very effective against scale and soft-bodied suck-
ing insects. It penetrates the creving insects. It penetrates the crev-
ices where the eggs and larvae are hidden and destroys them. $\mathbf{B y}$ mall postpaid, lb. $40 \mathrm{c} ; 5$ lbs. $\$ 1.50$. Not postpaid, lb. 30c; 5 lbs. \$1.25.
Kills Insects RED ARROW TON-POISONOUS

can beall beetle, Japanese bectle, striped

dahlia beetles. An ounce makes 6 gallons of spray (a postpaid, oz. bottle 40c; $31 / 2-0 z$. pkg. (1/4 pint) $\$ 1.10 ; 1 / 2$ pint postpaid, oz. $\$ 6.25$.

Not postpaid,

qt. $\$ 6.00$.

\section{"EVERGAREN PROTECT YOUR GARDEN}

ous. For general spraying ( 1 part to 800 ) an ounce makes 6 gal lons; $1 / 2$ pint makes 50 gallons. By mail postpaid, oz. bottle 400 6-0z. bottle $\$ 1.10 ; 16-0 z$. bottle (pint) $\$ 2.15 ; 32-0 z$. (qt.) $\$ 3.75$.
Not postpaid, oz. bottle $35 \mathrm{c} ; 6-$ oz. bottle $\$ 1.00 ; 16-0 z$, bottle $\$ 2.00 ;$ 32-oz. can \$3.50; gallon \$13.00.

Sodium Fluosilicate teffective for killing Mexican bean b

ure to seven parts hydrated or air-slaked lime or plaster
apply with powder duster. $40 \mathrm{c}$ per 1 b.; $\mathbf{5}$ lbs. $\$ 1.65$ postpaid.

Paris Green - For Leaf-eating Insects. It is a strong poison

gallons. On vines and tender vegetables use a larger proporcts.; 1 lb. 45 cts.; 5-1b. pkg. $\$ 2.00$. Cannot be mailed.

Scale Oil (For san Jose Scale.) - A high grade miscible

dormant state. For San Jose scale it is even more effective and spreads better than lime sulphur, and will control other lecanium scale, that are not readily controlled by lime sulphur. spraying old rousl tro evergreens, before the spring growth starts, use one part scale
oil to 25 parts water. Not prepaid, qt. 65 cts.; 2 qts. $\$ 1.00$; gallon $\$ 1.75 ; 5-$ gallons $\$ 6.00$. Cannot be malled.

Lime-Sulphur (For San Jose Scale),-The most generally used DRY IIME-SUIPHUR.

spraying, use 12 to $15 \mathrm{lbs}$. to 50 gallons water. Summer spray5 lbs. $\$ 1.55$; 10 ibs. $\$ 2.65$.

Not postpaid, 1 b. $30 c ; 5$ lbs. $\$ 1.25 ; 10$ lbs. $\$ 2.15 ; 25$ lbs. $\$ 4.25 ; 50$ lbs. $\$ 7.35 ; 100$ lbs. $\$ 13.00$.

IIME-SUIPHUR SOIUTION,-Our solutlon retalns lts strength ndefinitely and does not crystallize if kept from air and freezing. For fall and spring spraying, use 1 gallon to 8 gallons of Qt. $40 \mathrm{c} ; 2$ qts. $65 \mathrm{c}$; gallon $90 \mathrm{c} ; 5$ gals. $\$ 3.00 ; 10$ gals. $\$ 5.00 ; 50-$ gallon barrel \$13.50. (No charge for containers.) Cannot be mailed.

Powdered Sulphur -Use on potatoes when cut for planting and plant mites, $\mathbf{B}$ mail postpald, 5 lbs. 65 cts.; 10 1bs. $\$ 1.15$ Not postpaid, 5 lbs. $45 \mathrm{c} ; 10$ lbs. $75 \mathrm{c} ; 25$ lbs. $\$ 1.65 ; 50$ lbs. $\$ 3.00$; $100-1 \mathrm{~b}$. bag $\$ 5.50$.

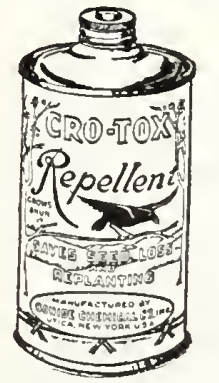

Ceresan

$\$ 3.00 ; 25-1 b$. pkge. $\$ 12.50$. Cannot be mailed.

Cro-Tox

does not clog the planter. By mail postpaid, $\$ 1.10$; large can (treats 2 bushels) $\$ 1.65$. Not postpaid, small can $\$ 1.00$; large can $\$ 1.50$.

Cut Worm Bait - For cut-worms, sow-bugs, grasshoppers, pkge. 25c; 3-1b. pkge. 50c. Cannot be malled. 

$\$ 13.00$. Cannot be mailed. oz. pkg. 50c; 1 1b. pkg. $\$ 2.75 ; 5$ lb. p $;$. Semesan Jr. For Corn.-
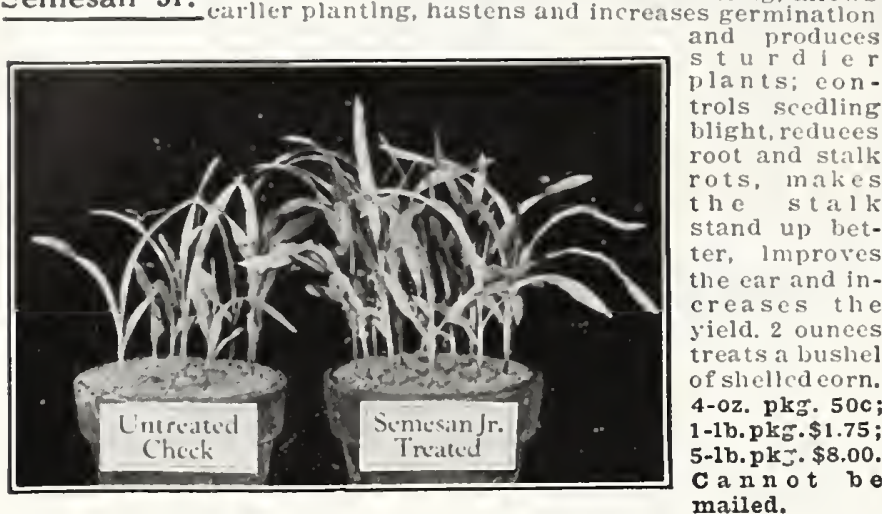

Semesan Bel For Potatoes-Protects potatoes against both seed Therme disenses. produces a better last drop ind will treat many bushels. 4-oz. plig. 50c; 1-1b. pkg. $\$ 1.75 ; 5-1 b$. pkg. $\$ 8.00$. Cannot be mailed.

Para-di-Chloro-Benzene Sometimes called Para; for peach mately $95 \%$ control. Apply in September or Oetober or in the I 00 of the borers: spring applieations 70 to $75 \%$. One pound ington, 1, C.ib. pkge. $\$ 2.50$.
pkge. 60c; 5-1b. pkge. $\$ 2.25$.
Not postpaia, 1-1b. pkge. 50c; 5-1b. pkg main

Thy.Cresol -For Man and Beast; a supply should be consores, siddde-galls, burns and scalds; kills vermin on animals By mail postpaid, 4-oz. bottle 30c; 8-oz. bottle 50c.

Not postpald, 4-oz. bottle $25 \mathrm{c} ; 8-0 z$. bottle $40 \mathrm{c}$; qt. $85 \mathrm{c} ; 2$ qts. $\$ 1.50$; ga1. $\$ 2.50$.

\section{ATLACIDE A WEED KILLER} -300 times the weed-kill-

\section{absolutc}

for two years, and very few weeds appeared the third year By m.

Not postpaid, 1 lb. 50c; $3 \frac{1}{2}-1$ b. pkge. $\$ 1.50$.

Kayso (The caseln spreader and adhesive.) - Makes the spray face Mrad mpakes it stick and makes it cover a greater sur-
only the surtace that ls aeturlly covered is protceted. Kayso

anray, or I lit, for eaeh 100 gallons. By mall postpaid, 2-1b. pkge. Not postpaid, 2-1b. pkge. 50c; 10 lbs. $\$ 2.25$.

Copper Sulphate -Blue Stone or Blue Vitrlol.-Used for

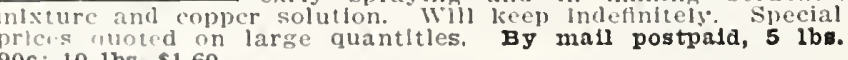
Not postunid, 5 lbs. $65 \mathrm{c} ; 10$ lbs. $\$ 1.25 ; 25$ lbs. $\$ 3.00 ; 50$ lbs. $\$ 5.00$; 100 lbs. $\$ 9.00$.

\section{K I L L S \\ Sulpho- Tobacco Soap. \\ INSECTS}

Sulpho-Tobacco Soap - A wonderful fertillzer for both flowers and regetables. Quickly exterminates insects. Lxeellent for preventing mildew and lice on roses; fulps to grow healthy plants and beautiSure death to plant insects in and out of doors. 3-oz. cake, 15 cts.; 8-oz. cake,
30 cts., postpaid. A $3-0 z$. eake makes 30 cts., postpaid. A $3-0 z$. cake makes
$11 / 2$ gais. of solution; an $8-0 z$. cake makes 4 gals.

Cyanogas

CYANOGAS A DUST.-Kills moles, rats, mlee, eray fish, ground hogs, 5-1b. can $\$ 3.00$. Cannot be mailed.

CYANOGAS G FUMIGANT. For greenhouse, flour mill and grain fumigation. kills whitefly, aphis, moths, weevil, rats and miee. 5 lbs. $\$ 3.00 ; 25-1 b$. tin $\$ 10.00 ; 100-1 b$. drum $\$ 30.00$. Cannot be mailed.

DUSTERS for applying Cyanogas. \$1.25.

Stimuplant $-A$ highly coneentrated, odor-

table and flower garden, shrubs and house

plants. The analysis is guaranteed 11

STIMUPLANT

Makes a
WONDER GARDEN

aeld, 15 per cent potash. an ample amount of each plant food to insure a quick and strons grolv, blooms maturity of garden 100 -tablet pkge. 75c; 1,000-tablet pkge. $\$ 350$, postpaid.

A complete, properly balanced fertilPLANTABBS izer; guaranteed analysis nitrogen ODORLES5 PLANT FOOD TABLETS $20 \%$ hissolves quickly, giving im for all garden planting, especially roses: clean. odorless. easy to use. 30 tablets $25 \mathrm{c} ; 75$ tablets $50 \mathrm{c} ; 200$ tablets $\$ 1.00 ; 1,000$
tablets $\$ 3.50$. Grafting Wax paid, $1 / 2$ lb. 30c; 1b. 50c.

Tree Tanglefoot -A sticliy substance which is applied directind fruit trees to proeffective fully exposed to the weather, for three months. One efiective, fully exposed
coun $70 \mathrm{c} ; 5-1 \mathrm{~b}$. can $\$ 3.00$.

can 70c; 5-1b. can $\$ 3.00$.
Not postpaid, $1-1 \mathrm{~b}$. can $60 \mathrm{c}$; $-1 \mathrm{~b}$. can $\$ 2.75$.

Tree Wound Dressing-Sawed off and pruned limbs of trees

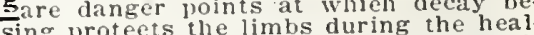
ing period covering the wound with a film and allows the heal ing period, evicring the Wediately. Qt. 75c; gallon $\$ 2.50$. Cannot be mailed.

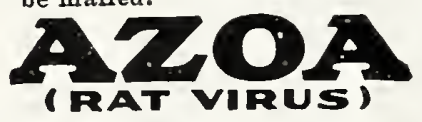

Rat and Mouse Exterminator. Not a poison but the virus of a disease peculiar to rats and mice. After eating Azoa the rats an mice develop a disease which the infected they invariably seek the open air to die. Azoa is no poisonous and is absolutely harmless to domestic animals and
fowls. It is a larle, Davis \& Co. preparation. By mail post paid, 55c. Not postpaid, 50c.

Asparagus Buncher No. 2

Adjustable to size of
bunch and length of stalk.
ulakes bunches 4 to $51 / 2$
inches in diameter, 8 to 12
lnches long. By mail post-
paid, $\$ \mathbf{4 . 2 5}$. Not prepaid $\$ 4.00$.

Asparagus Knife 15 ins. the hlade $1^{1 / 2}$ inches wide.

By mail, postpaid, 40c; $\$ 4.00$ each; dozen $\$ 3.75$. Dibbles $-A$ handy tool for making holes for transplantling. be mailed, add 10 e for postage.

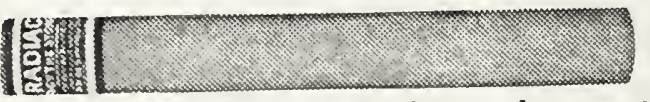

R $A$ D I A C STONE. Puts on a lasting edge with the right "bite" for tough grass and weeds: practieally indestructible. Plant, and Tree Labels
Pot, Plat mail postpatd,

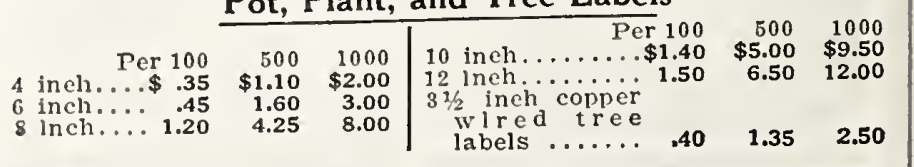


Mole Trap of spring steel and will pierce the mole easily; thoroughly tinned to prevent rusting. By mail, postpaid, \$1.15. Not prepaid, $\$ 1.00$.

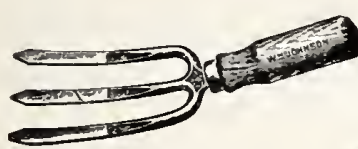

Spading Fork 3 Tine. venient, strong and well made; tines poldle: length, 11 inches. Is mail postpaid, $45 \mathrm{cts}$ Not prepaid, $40 \mathrm{cts}$.

\section{GARDEN TROWELS}
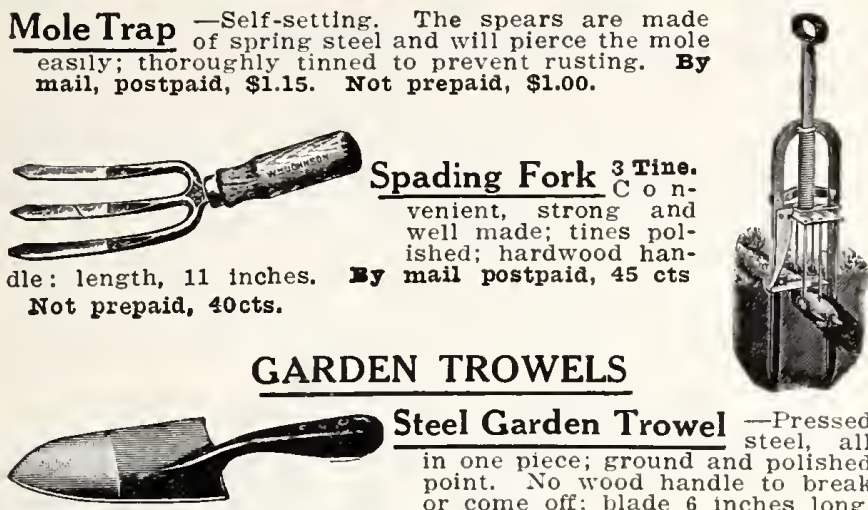

\section{Steel Garden Trowel}

-Pressed

in one piece; ground and polished point. No wood handle to break By mail postpaid, $30 \mathrm{cts}$. Not prepaid, 25 cts.

Galvanized Garden Trowel

-Made of a single piece of heavy

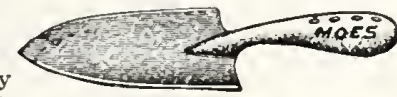

steel; handle and blade in one piece.

By mail postpaid, $25 \mathrm{cts}$. Not prepaid, $20 \mathrm{cts}$.

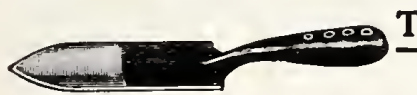

Transplanting Trowel ${ }^{\text {The }}$ is 6 inches long, $13 / 4$ inches wide. piece of pressed steel. By mail postpaid, 30 cts. Not prepaid, 25 cts.

Dandelion Weeder A for getting up deep rooted weeds in the lawn

Lawn Weeder

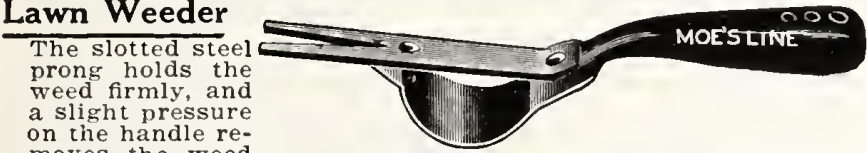
on the handle removes the weed

completely with the root. Easy to use; does not mar the lawn: finished in baked enamel. By mail postpaid, $45 \mathrm{c}$. Not prepaid $40 \mathrm{c}$.

Steel Garden Weeder -One p i e c e finished in black enamel; has five steel fingers: a useful and serviceable weeder.

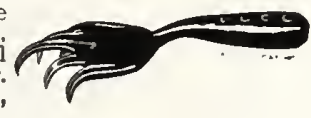
By mail
25 cts.

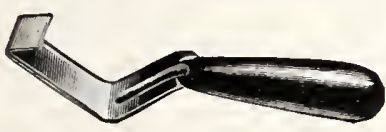

Hand Weeder $-A$ real la b o $r$ hand nicely; made of one piece of hard, stiff steel; ground edges. By mail postpaid, 30 cts. Not pre. paia, 25 cts.

\section{4-Piece Garden Set}

-A garden trowel, a trans. planting trowel, a spading fork and a weeder. All are made of good material. each tool is made of a single piece of heavy pressed steel, handsomely finished. The trowels have is-incl blades with ground and polished points. No wooden handles to come off or break. By mail postpaid. $\$ 1.15$. Not prepaid, $\$ 1.00$.
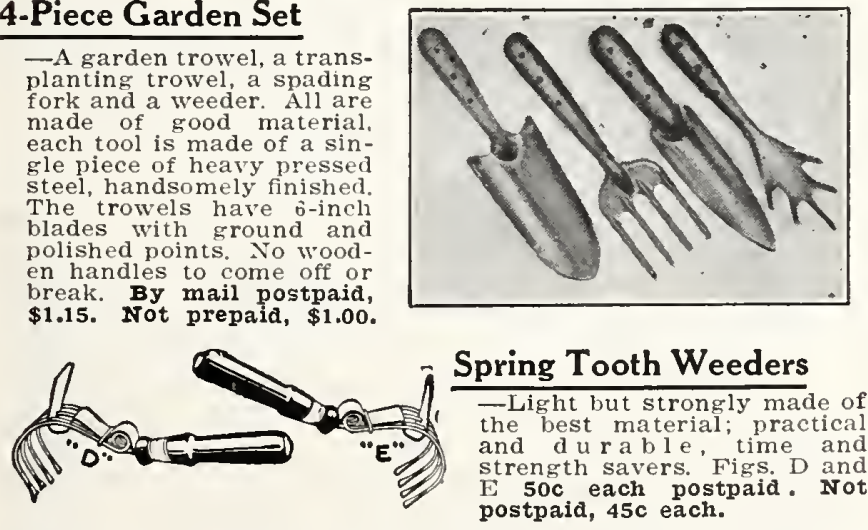

Plant Bed Cloth -For tobacco plant beds, and for vegetable tects the plants plant beds where glass is not necessary. Proallows earlier transplanting; saves time and labor and increases production. Bolts 125 yards long, 36 inches wide. By mail postpaid, $\$ 7.85$ per bolt. Not prepaid, $\$ 7.50$ per bolt.

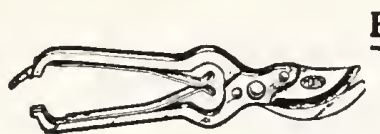

Pruning Shears $\rightarrow$ No 1 .

high-grade tool steel blade

double brass spring. By mail postpaid, $\$ 1.60$.

Not prepaid, \$1.50.

No. 3.-A well-made and satisfactory

pered blade: strong steel coil spring.

By mail postpail, $\$ 1.10$. Not prepaid,
$\$ 1.00$.

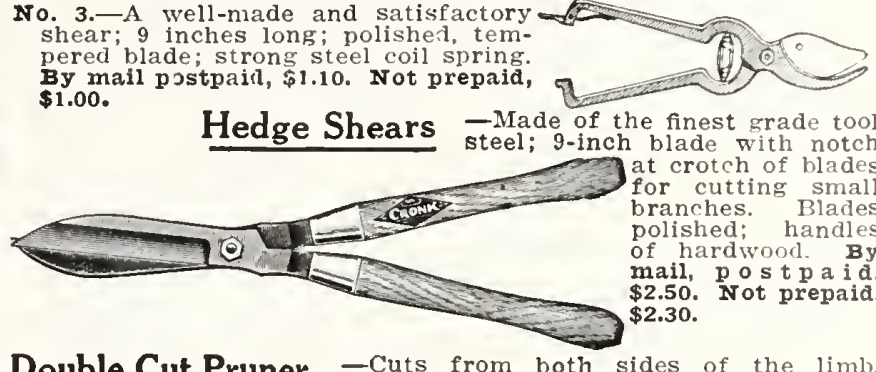

-

Double Cut Pruner - Cuts from both sides of the liml,

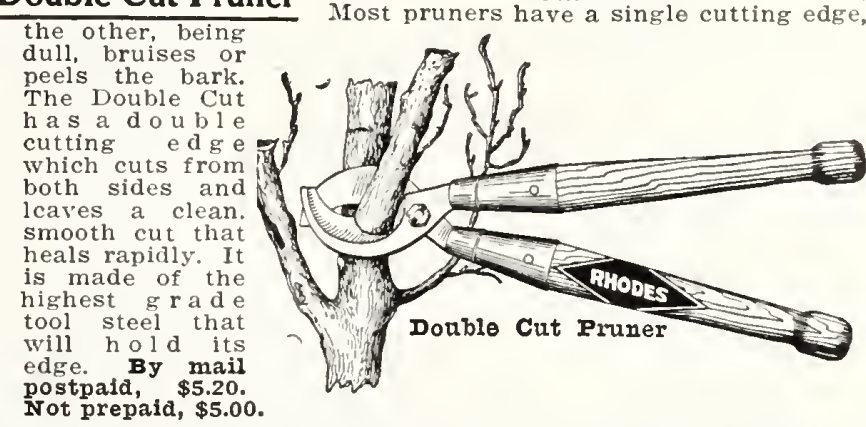

Mulch Paper USE IT TO GROW BIGGER, BETTER AND MARIIER CROPS.

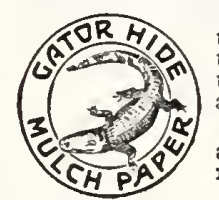

Maper practically eliminates weeds an the labor of cultivating: it conserves the soil mois ture, keeps the ground from crusting: hastens maturity and produces superior crops in size, quality Every crop grown in rows in both the garden and field, except peanuts, can be grown nude mulch paper.

Width By Mail

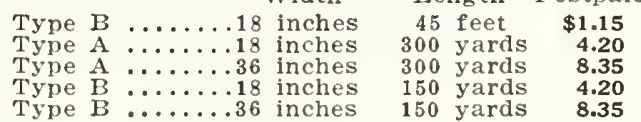

Not Postpaid

\section{GRASS SHEARS}

150 yards $\mathbf{8 . 3 5}$ 3.50 per roll 7.00 per rol (.50 per roll

\section{DoocrIP.-The easiest to} handle as the hand is not turned $\mathrm{sid}$ i w is e when using it. By mail posptpaid, \$1.35. Not postpaid, $\$ 1.25$.
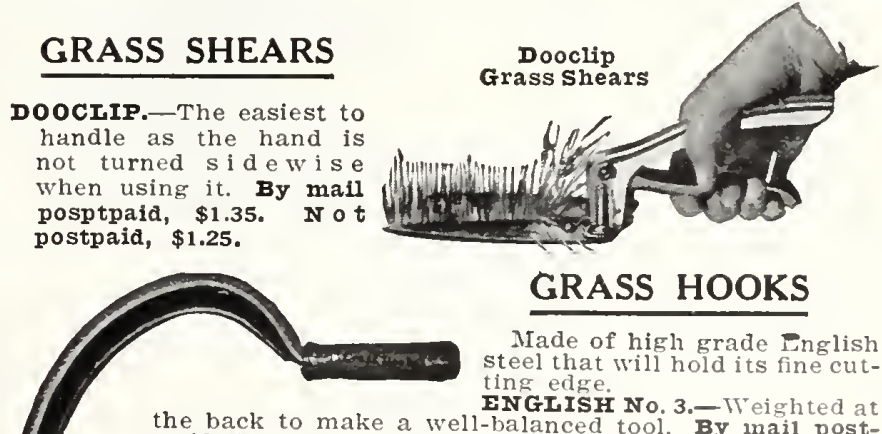

\section{GRASS HOOKS}

Made of high grade English teel that will hold its fine cutINGIISH No. 3.-

l-balanced tool. By mail postDaid, \$1.15. Not prepaid, \$1.00.

postpaia, $\$ 1.40$. Not postpaid, $\$ 1.25$.

Norcross Cultivators

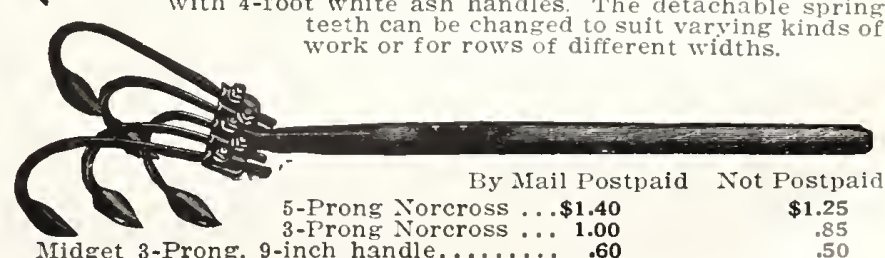

Midget 3-Prong, 9-inch handle....... 
Perfecto Flower Box

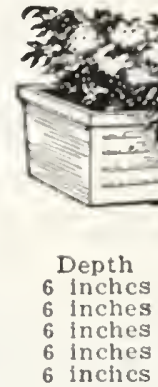

6 inches

\section{LAWN SPRINKLERS}

O UNIVERAI.-Throws the water from the from By mall postpasd, $\$ 2.70$. Not postpaid, $\$ 2.50$. HARTFORD.-1Ia

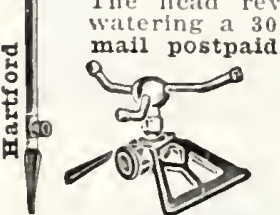
uck in the ground, 2 foot $\$ 1.35 ; 4$ foot $\$ 1.50$. Not prepaid, 2 foot $\$ 1.20 ; 4$ foot $\$ 1.35$. NEW DoIIAR-The smallest of all revolving sprinklers, but a good one; waters a postpaid, \$1.15. Not postpaid, \$1.00.

RING SPRINKIER.-Does not get

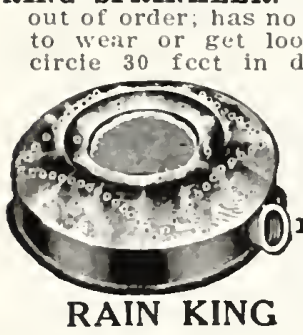

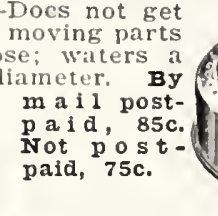

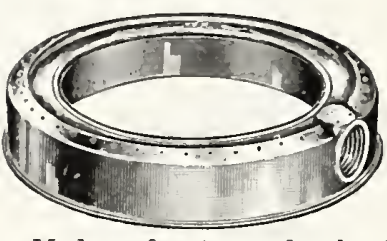

BABY RING.-Made of stamped sheet By mall postpaid, 60c. Not postpaid, 50c.

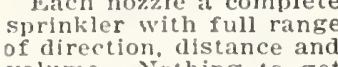

out of order. Built for

hard work and built to

ened and machined to

tantly set for elther

or siow, to cover large pressure. By mail postpaid $\$ 3.50$.

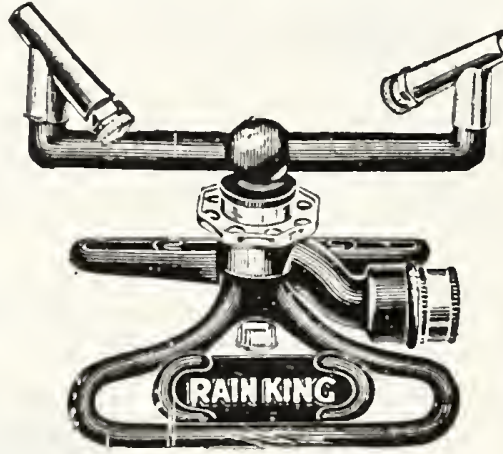

\section{MOULDED RUBBER HOSE} black and red. liffers from ordinary hose in that it is made with Can be supplied in 25 -foot or 50 -foot coupled lengths, /4 inch. UN PROOF-Re
$121 / 2$ c per foot.

CRACKPROOF-Black. 25-foot lengths $12 \frac{1}{2} \mathrm{c}$ per foot; 50-foot lengths $12 \mathrm{c}$ per foot.

\section{WATER BALLAST LAWN ROLLERS}

Ball Bearing Rollers No. 601.--Fill it with watcr to weight it couiplucl with boll bearings, scraper and handle balance. Diamillied, 175 pounds. Price, \$17.00.

No. 604.-Dlameter, 24 inches: lenglh, 32 inches. Weight: cmpty. 130 pounds; filted, 560 pounds. Price, $\$ 26.00$.

Plain Bearing Roller No. 605.- Samc as No. 601, except is balance, Welght: cmpty, 68 lbs, filled, 175 lb.s. Price, \$13.50.

\section{PLANET JR. GARDEN TOOLS}

\section{send for Complete Catalog.}

Do you work your garden with an old-fashioned hoe or with modern tools like a Planet Jr.? If you could see one at work no argument would be necessary to convince you that you fust had to hav" one. We have used them for more than thirty years and could not do without them. Send for complete catalog.

No. 3 Drill sows at any desired depth in continuous rows or plants in hills $4,6,8,12$, or 24 inches apart, covers, rolls, and marks the next row all at a single operation. Price, \$17.50.

No. 4 Drill and Single Wheel Hoe opens the rows, plants the seeds elther in continuous rows or in hills $4,6,8,12$ or 24 inches apart. covers the seeds and marks the next row at one drlll can be detached from the frame and the working tools at3 cultivator teeth Price, $\$ 18.00$.

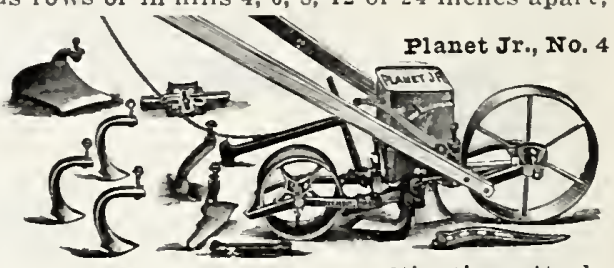

No. 4-D Drill. Exactly like No. 4, but has no cultivating attachments. Price, $\$ 14.25$.

No. 12. Double and Single wheel Hoe. Will straddle the row and work both sides at once, or between the rows as you prefer. Has Price, $\$ 10.75$.

No. 16. Single wheel Hoe, Cultivator, $\boldsymbol{R}$ ake and Plow. Equipped with a pair of 6 . inch hoes, 3 cultivator teeth, a large inch and 7 inch rakes and

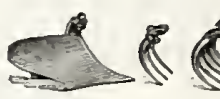

A splendid

ombination. Price, $\$ 9.00$.

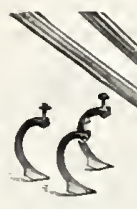$$
0 .
$$

No. 17. Single Wheel Hoe. Exactly like No. 16, but has no rakes. Price, $\$ 7.75$.

No. 19. Garden Plow and Cultivator. Has a cultivating tooth for (10) vating attachment and a plow, 15 -inch wheel, Price, $\$ 5.75$.

No. 119. Has a strong plow, two cultivator teeth, wide and narrow, a reversible attachment with 3 -toothed cultivator and inches high. Price, \$4.75.

Fire Fly Garden Plow. An exceedingly useful tool in the small garden and clicken yard. Price, $\$ 4.25$.

No. 35. Seeder Attachment. Fits any Planet Jr, single and dou. and sows in straight even rows at a uniform depth and covers the seeds. Price, $\$ 6.50$.
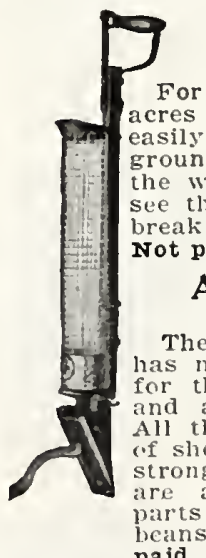

\section{No. 304 POTATO PLANTER}

For the small garden as well as in fields of several acres this is a useful and serviceable tool, light and easily operated. The spring closed jaws enter the Fround easily; it is adjustable for depth of planting: the wre mesh convering tube allows the operator to e that each piece is properly planted; no springs to reak: rustproof steel jaws. By mail postpaid, $\$ 2.25$. Not prepaid, $\$ 2.00$.

\section{ACME CORN PLANTER}

\section{Ilght, Strong and Accurate.}

tome is simple, easy to work, has no dises to get lost, is adjustable for the number of grains to the hill, and adjustable for depth of planting. All the working parts are pressed out of sheet stecl, making the planter light, are adjusted from the outside. All parts are interchangeable. Will plant paid, $\$ 2.25$. Not prepaid, $\$ 2.00$.

Moss -For shipping vegetable plants and for Moss florists. $\$ 4.00$ per bale.

Raffia - For tving up bunches of vegetables, tofor these purposes because it does not cut the stems. By mail postpaid, $1 \mathrm{~b}$. 45c: 5 1bs. $\$ 1.85$. Not prepaid, 1b. 35c; 5 lbs. $\$ 1.60 ; 10$ lbs. $\$ 2.50$.

Jute String For tying up rcgetable bunches, By mail postpaid, 30c per 1b. Not prepaid, 23c per 1b.; 5 1bs. for $\$ 1.00$.

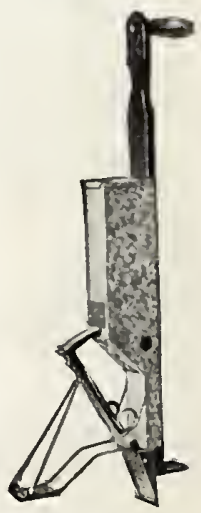




\section{Lawn Mowers}

Pennsylvania Super Roller -Seven 18-inch blades of crucitempered; high speed cylinder. Bearings are all either bull or roller, oil tight and dust proof. Alemite system lubrication, cut gears equipped with roller bearings, running in oil, encased in Mower $\$ 50.00$; Grass Catcher $\$ 8.00$; Transporting Carriage $\$ 5.00$. These may be bought separately.

Cooper Power Mower -Equipped throughout with ball and drive roller; self-sharpening in reverse. Write for descriptive circular. 21 -inch cut $\$ 190.00 ; 27$-inch cut $\$ 285.00$; riding sulky for 27-inch machine $\$ 30.00$.

\section{Grafting, Budding and Pruning Knives}

\section{R1437.}

Grafting and

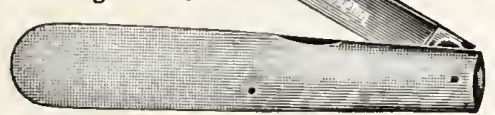

No. R1437. GRAFTIN G AND BUDDING KNIFE Has strong keen cutting edge; highly tempered; white bone handle; length,
closed, 4 inches. Price, \$1.25.

No. 703. PRUNING RNIFE.-Marle of the finest grade of heavy gauge steel; one blade, stag handle, polished steel rat-tail bolster, polished steel rivets and lining. Length, closed, $3 \frac{5}{8}$ ins. Price, $\$ 1.00$.

No. R728. PRUNING KNIFE.--Made to meet the exacting requirements of gardeners, orchardists and nurserymen who must have the finest quality knife. The blade is of the highest quality Steel, hardened and tempered to hold a keen edge: cocobolo Price $\$ 1.75$.

No. R3853. BUDDING AND PRUNING KNIFE. Finest qualit steel; two blades, one for pruning, the other for budding; stas closed, 4 ins. Price, $\$ 1.50$.

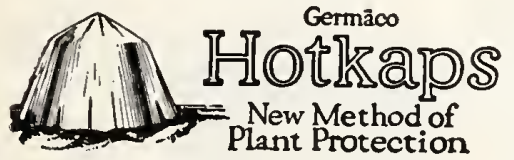
-Protect plants from frost, wind and rain, matures the crops earlier keeps off insects and keeps the soil moist. They are individual miniature greenbase.

By mail postpaid Not postpaid Roll of 1,000 Raps................\$12.20 $\quad \begin{aligned} & \$ 11.50 \\ & 4.00\end{aligned}$ Roll of 250 Kaps.
Roll of 100 Kaps................. 100 and 250 Kap rolls contain a cardboard setter and steel tamper. Extra setters: Metal, $\$ 2.70$ each postpaid. Not postpaid, $\$ 2.50$. Cardboard, 65c each postpaid. Not postpaid, 50c.

5,000 or more Kaps at $\$ 11.00$ per 1,000 .

\section{CYCLONE SEED SOWER}

The Cyclone is a splendid seed sower that will pay for itself in a few days in the time it will sare, besides sowing grass and clover seeds and grain cf all kinds faster and more evenly and uniformly than is possible by
hand. It will sow as fast as you can walk, and the quantity can be regulated to any $\$ 2.00$.

\section{CAHOON BROADCAST SEED SOWER}

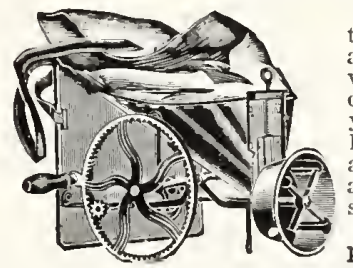

Price, by mail, postpaid, $\$ 510$. Not prepaid, $\$ 4,75$.

\section{Noc-Out Seed and Fertilizer}

\section{Distributor}

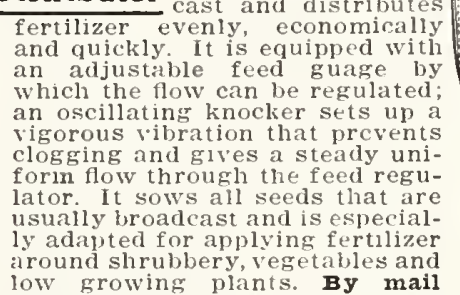
low growing plants. By mail
postpaid, \$1.40. Not postpaid,

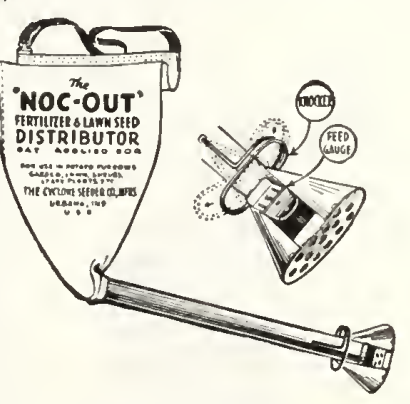

Waterproof Paper Pots - Made

paterproof handle and set up ready for use. May be used over and over. By Mail Postpaid Not Prepaid

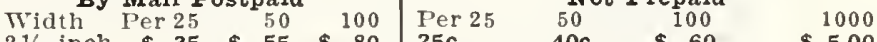

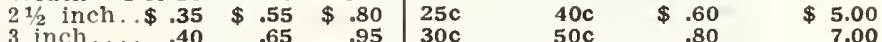

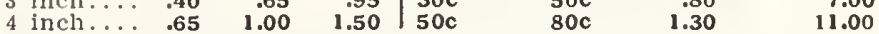

Berry and Fruit Baskets -For shipping and marketing ber1 Pint Size. (Oblong.) By mail postpaid, $\$ 1.40$ per 100 . Not postpaid, $\$ 1.00$ per $100 ; \$ 7.50$ per crate of 1,000

Qnart Size. (Square.) Wood rim. By mail postpaid, \$1.40 per 100 . Not postpaid. $\$ 1.00$ per $100 ; \$ 7.50$ per crate of 1,000 .

Quart Size. (Square.) Metal rim. By mail postpaid, $\$ 1.40$ per 100 . Not postpaid, $\$ 1.00$ per 100; $\$ 15.00$ per crate of 2,000 .

Special prices on lots of 5,000 or more.

\section{Sprayers and Dusters}

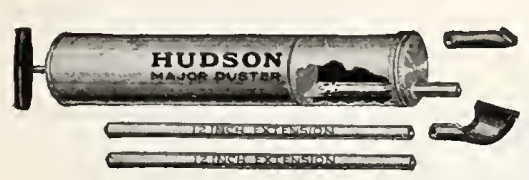

\section{Major Duster}

- Fitted with powder strainer to prevent clogging. The extension pip has two angle nozzles for spreading the dust under the leaves of low-growing plants. Will dust all dry insecticides very efficiently. By mail postpaid, $\$ 1.40$. Not prepaid, $\$ 1.25$.

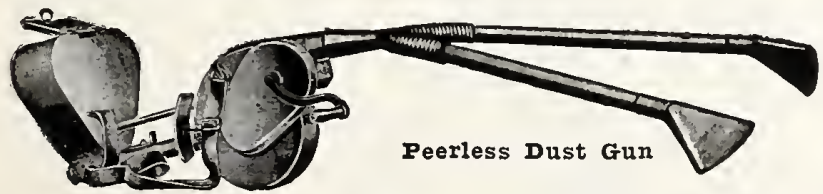

Peerless Dust Gun -A perfectly balanced gun that will not front and rear. The fan revolves on ball bearings in greasepacked housing. Has agitator and brush to break up lumps and insure a constant feed. Dusts two rows at once, to either side of the leaf and can be regulated to apply from almost nothing to $20 \mathrm{lbs}$ to the acre. Handles any dry powdered insecticide. Ideal for dusting tobacco and cotton. By mall postpaid, $\$ 19.50$ Not prepaid, $\$ 19.00$.

\section{Feeny Dust Guns}

Model B.-Double

ing and applie

kinds of powder
secticides and

powders in a cloud to

all parts of the plant.

By mail postpaid, $\$ 1.00$

Not prepaid, $90 \mathrm{c}$.

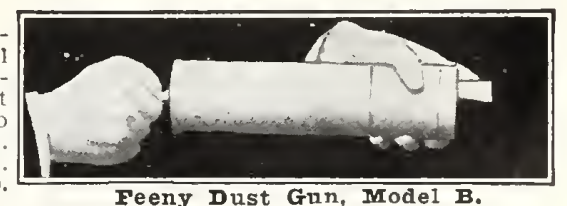

Feeny Dust Gun, Model B.

Model BX.-Iike Model B, except that it has an extension for applying insecticides under the leaves of low-growing plants, $\$ 1.40$. Not prepaia, $\$ 1.25$.

\section{Autocrat Duster}

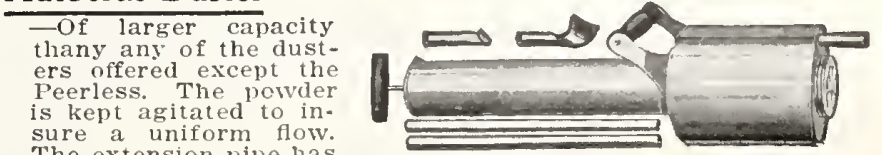

The extension pipe has

two angle nozzles of
different sizes for dusting under low-growing plants; both nozzles will dust under the leaf, the wider nozzle for use when a larger and wider cloud of dust is needed. By mail postpaid, $\$ 3.50$. Not prepaid, $\$ 3.25$. 


\section{SPRAYERS}

Continuous Sprayer

cinu

ulu ind

olls.

angle.

Quart Size

Hand Sprayer

Vers" useful in small for spray ing house

By mall postpald, 65c. Not postpaid, 50c.

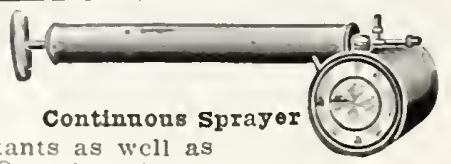

\section{COMPRESSED AIR SPRAYERS}

Self-operating, durable, high pressure sprayers; easy to carry

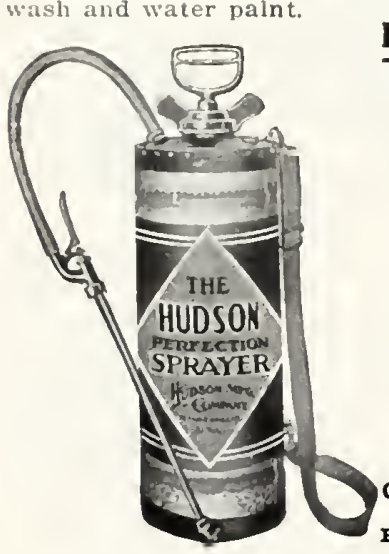

Perfection Sprayers

high pressure sprayer didly bu i it pacity 4 gallons: the tank is made of first quality copper bearing brass or galranized sheets; all seams are rivetted and soldered; the pump cylInder is seamless brass, non-corrosive; has a brass automatic shut-off valve in the nozzle that operates perfectly under all pressures; an efficient and durable automatic brass air valve; equipped wlth 2 plpe. The l'erfection is the best of all compressed alr sprayers; every tank is tested under pressure of 90 to 100 pounds.

Galvanized Steel

Tank $\begin{array}{cc}\text { By mail } & \text { Not } \\ \text { Postpaid. } & \text { Prepaid. }\end{array}$

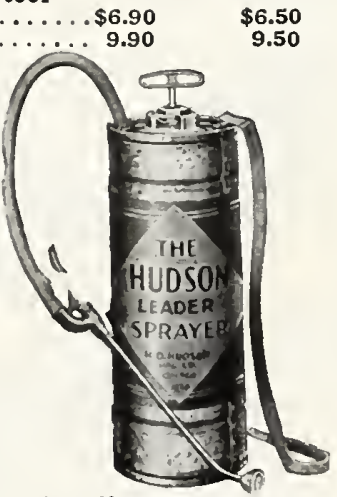

Leader Sprayer -A strong practlwill splay all llquid insecticldes, whitewash, water palnt, etc., and does
splcndid work. Gallanized steel tank, splendid work. Galvanized steel tank,
$33_{i}$ gallons capacity; pump cylinder ls seamless brass locked into tank or reball valve; the tank seam is rivetted and sweat soldered. Equipped with auhose and brass extension pipe. By ma.25.

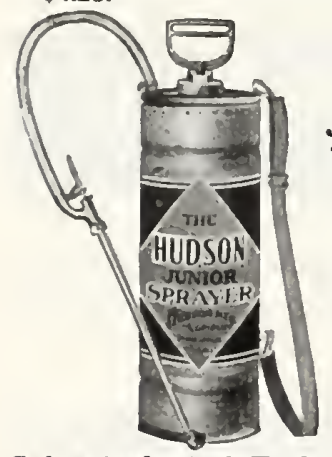

Junior Sprayer -In all respects except

Galvanized Steel Tank. Brass Tank

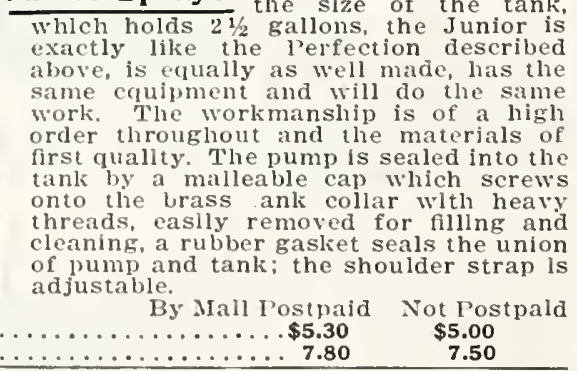

Nozzles, Hose, Etc.

Extra Nozzle for All Compressed Alr Sprayers \$1.75 Postpald. BORDEAUX NOZZLE.- $\$ 1.00$. By mall, $\$ 1.05$.

VERMOREL NOZZLE. $-85 \mathrm{c}$. BY Mall, $90 \mathrm{c}$

RUBBER HOSE. - 3 inch (dinmeter of hole): 120 per foot postpald. Not postpald, 100 per foot. $1 / 2$ inch: $15 \mathrm{c}$ per foot postpaid.
Not postpald, 120 per foot.

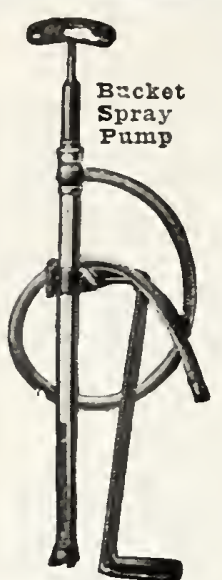

Wheelbarrow Spray

\section{Pump -An ideal out fit}

Bucket Spray Pump $\rightarrow$ A double - acting $1 y$ of brass, except foot rest and handlebrass lesists the corrosive action of spray chemicals, Has brass ball valves, leather packed plunger, the air chamber is large to give a continuous spray and it is easy to operate. A splendid sprayer for general washing vehicles. etc. By mall postpaid, $\$ 4.25$. Not prepaid. $\$ 4.00$.

4-foot extension pipe, for reaching into trees prepald, $40 \mathrm{cts}$.

poultry plants, for ap-

plying spray solutions, disinfectants and whitewash. Its hlgh pressure and easy portability adapt it for all kinds of spraying. The lever operated pump attaches to the tank with two bolts, and bronze ball valves that are accessible without dismantling the pump. All working parts are brass: nozzle discs are reversible, producing any desired spray from a fine mist to a coarse stream. The $12^{1 / 2}$-gallon tank is of heavy copper bearing steel; the wheels 16 inches in diameter, 11/4-inch tire. Equipped with 5 feet of hose, 2 -foot extension pipe and angle spray nozzle. Price, \$15.00.

Auto Spray No. 5

A combination knapsack

and bucket pump that will

throw any kind of spray

solid stream. The pump is

brass, is do u ble acting

practically

pressure. By detacling

pressure. By detaching

ing the strainer you

have a firt - class

bucket pump. Fine for

applying whitewash,

water palnt, insecti-

cides and

KnapsackOutfit-

$\mathrm{Pu} \mathrm{m}, \mathrm{t}$ a $\mathrm{nk}$

and strainer. Price, $\$ 7.50$

Bucket Outfit-Same as the above, but wlthout tank. By mail, postpaid, $\$ 4.70$. Not prepald, $\$ 4.50$.

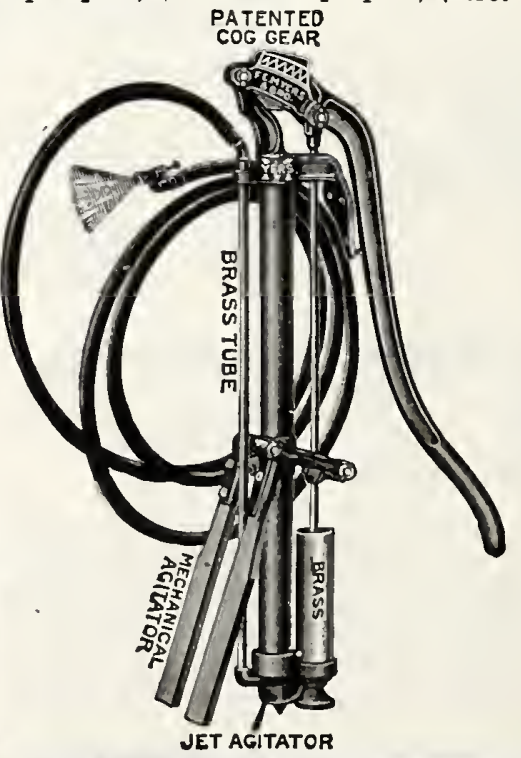

Barrel Spray Pump

- Has bronze ball valves and brass seats: the plunger is self-expanding, the cylinder valves, valve seats and discharge pipes are brass - these metals are not affected by spray chemicals. The air ch a m ber is 32 inches in diameter, insuring in diameter, insuring a uniform, constant erage, is powerful and easily operated. The cog gear head saves and strain on the pump and increases the pumping capacity. rel bolt in the pump rel. bolt in the pump and it is ready to work. inch hose, 8-foot extension pipe and nozzle, $\$ 16.00$. one-third the pumping labor. reduces the wear in the head of the barPump with mechanical 


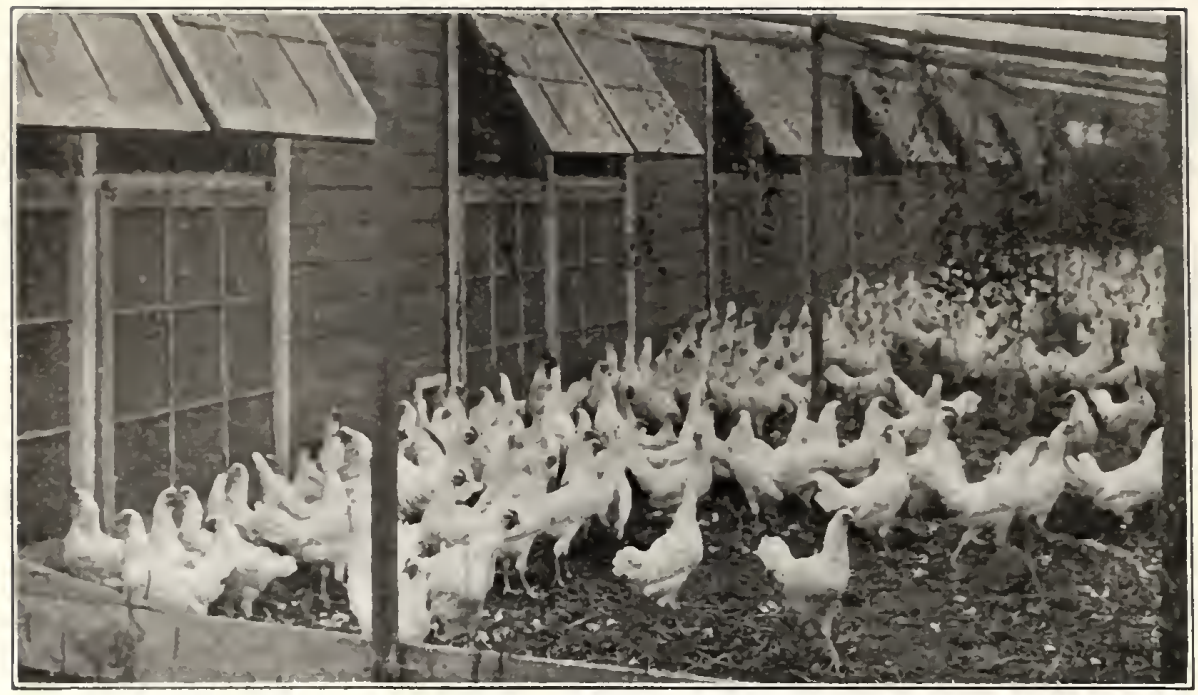

WOOD'S S. C. WHITE LEGHORNS (Left)-If you want a flock of heavy layers that will produce big, chalk-white eggs twelve months out of the year, start with Wood's large S. C. White Leghorns. Get a brood of Wood's healthy, husky. chicks now, and wateh them grow rapidly into early broilers and profitable egg-producers. Wood's White Leghorns inherit their productivity from worldfamous strains noted for their exceptional vield of eggs that bring premium prices. Buy your White Leghorns from $\Pi$ ood and enjoy year-around dividends. Their quick development into broilers will bring you early returns, and their eggs will be a source of profitable income.

WOOD'S BARRED PLYMOUTH ROCKS (Right) - For all-around poultry profits, you cannot find better meatand-egg birds than Wood's quickmaturing Barred Rocks. Their tender, juicy meat commands top prices on the market, and the pullets start laving big brown eggs at an early age. The breeding birds used in the flocks that produce Wood's Barred Rocks are handsome specimens of their varicty, with beatiful, even barring and broad, well-set backs. They are hardy profit-producers that will live and thrive under even the most adverse conditions. Your first market birds will more than repay you for your entire investment.

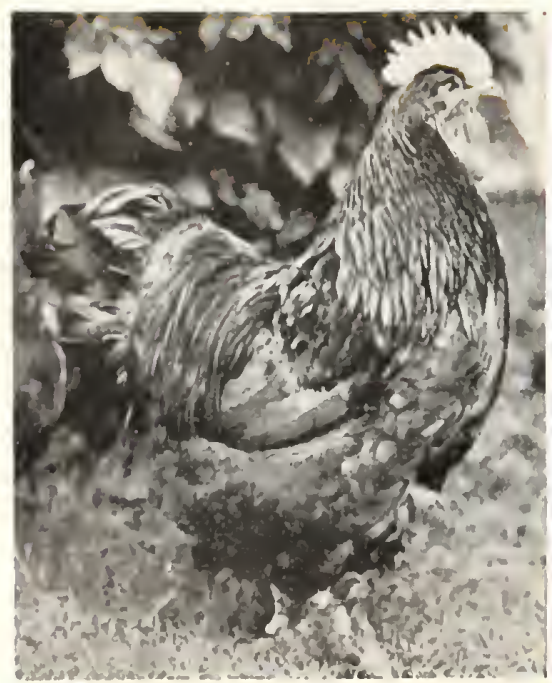

WOOD'S S. C. RHODE ISLAND REDS (Left) - Yitality, ability to withstand cold weather, winter production-those are three outstanding characteristics of the popular Wood's Rhode Island Reds. These full-breasted birds are ideal table fowl, and their generous yield of large brown eggs is a souree of dependable profits.

WOOD'S WHITE WYANDOTTES (Right)-W ood's Wyandottes are supreme winter lavers. Their close feathering protects them against severe weather, and their small rose combs are not susceptible to frost. Wood's IVyandottes are noted as layers, starting at five or six months of age and continuing to produce even during the winter months when egg prices are at their highest. As fryers and roasters, they cannot be excelled.

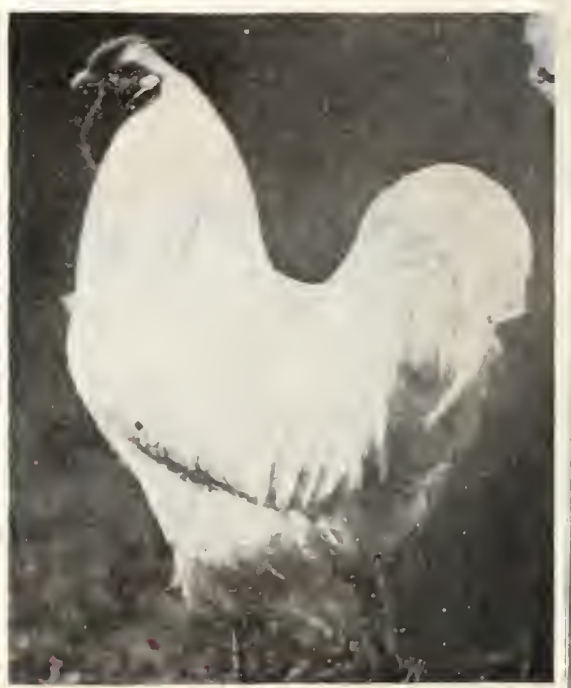


Parcel Post Shipments

We ship by parcel post to any post office in the United States. and prepay the postage at postpaid prices as quoted in this delivered at your door; or if you prefer it, will ship by express charges prepaid.

"By mail postpaid" means we pay the postage.

"Not prepaid" means you pay the cost of transportation.

\section{Parcel Post Rates}

\begin{tabular}{|c|c|c|c|c|c|c|c|c|c|c|}
\hline 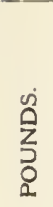 & 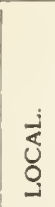 & 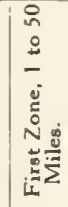 & 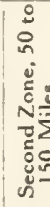 & 20 & & 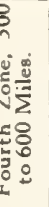 & 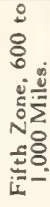 & 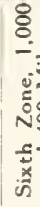 & & 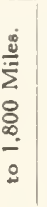 \\
\hline
\end{tabular}

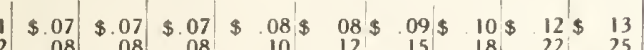

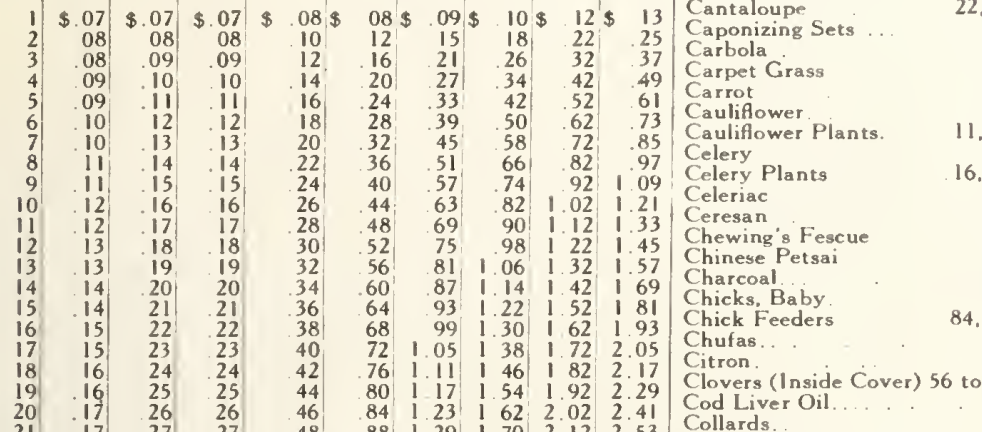

\begin{tabular}{ll|llllll|l|l|l}
19 & 16 & 25 & 25 & 44 & 80 & 1 & 17 & 1.54 & 1.92 & 2.29 \\
20 & .17 & 26 & 26 & 46 & 84 & 1.23 & 1 & 62 & 2.02 & 2.41
\end{tabular}

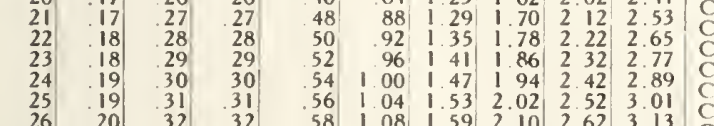

ondition Powder

Conkey's Poultry Rer Shipping
Coops

opper Sulphate.

Corn, Ensilage

Corn, Field.

Corn, Pop.

orn Planters.

Cow Pe

Cro-Tox Crow

\section{Cultivators.}

Cultures. Inoculating.

Cutworm Bait.

Cyanogas

yclone Seed Sower.

Dahlia Bulbs

\section{Dibbles.}

Dusters. Powder.

Egg Boxes and Crates.

\section{Egg. Tester.}

18 Asparagus Roots........5, 38 Evergreen Spra

20 Asparagus Bunchers.

22 Asparagus Knives.

.22 Austrian Winter Peas...

. 26

${ }_{30}^{28}$ Baby Chicks

.32 Bandetts

34 Barley .....

${ }_{38}^{36}$ Baskets, Fruit and Berry

.38 Beans, Garden.

. 42 Beans, Mung

.46 Beans, Soy or Soja Beans. Velvet.

Beets, Stock Feeding

Page Beggar Weed.

81 Bent, Colonial

A cid Phosphate.

59 Bent. South German

57 Bent Grasses .......

82 Bermuda

87 Black Eye Peas.

87 Black Leaf 40......83,87 Grit and Shell Boxes...

Feeders, Poultry

Fish Oil Sors

Flower Boxes

86 Flower Pots.

69 Foods, Poultry.

81 Forks, Spading

Founts and Feeders

Gape Remedies.

75 G Garden Tools.

75 Gherkin

10 Gladioli Bulb

II Gourds.

58 Grafting Knife

59 Grafting Wax

59 Grasses

59 Grass Hooks and Shears.

Alfalfa Meai

Altacide Weed Kille

Antrol.

Arsenate of Lead .

5,77 Blue Stone or Blue Vitriol. 88 Gumbo or Okra.
Page

Index

87 Hackett's Gape Cure

20 Hay Mixtures

85 Head Lice Ointment.

90 Hedge Shears

84 Hemp

79 Herds Grass or Red To

5 Hollybrook Poultry Food.

76 Honey Dew

53 Hoppers, Dry Mash.

82 Hose, Rubber

12, 13, 14 Hygrometers

14. 38

91 Indian Cress

53 Inoculating Cultures

87 Insecticides

76 Italian Rye Grass

${ }_{23} \mathrm{Kaffir}$ Corn

86 Kayso

83 Kentucky Blue Grass

59 Knife, Pruning. Grafting

15 and Budding.

11,38

${ }_{38}^{16}$ L abels, Pot and Tree

38 Lawn Gras

87 Lawn Roller

60 Lawn Sprinklers

14 Lawn Weeder.

82 Leek

86 Leg Bands

84, 85 Lettuce

77 Lettuce Plants

25 Lice Killers

58 Limestone, Pulverized

83 Lime Sulphur

83. MacNair's Barnyard

83 Mrotector

84 Madeira Roots

88 Magnesium Arsenate

8, 19 Mangel Wurzel

64, 65, 66, 67 Meadow Mixture

19 Meat Scrap.

90 Melon, Musk

80 Millet

72. 73 Milo Maize

11 Mite Liquid

87. Mole Tras

89. 91 Mulch Paper

75 Mung. Beans

87 Mustard

88 Nasturtium

33 Nitrate of Soda

Nursery Stock

53

88 Oberco

91 Ointment, Head Lice.

9l Okra or Gumbo

$$
\text { Onion }
$$

Sets

86 Oyster Plant or Salsify.

20 Oyster Shell

87 Paper Pots

84. 85 Paris Green

81 Parsley

90 Paspalum

75 Pasture Mixtures

40 to 52 Peanuts. 82 Pearl Millet

89 Peas. Austrian Winter

84. 85 Peas, Black Eye

Peas, Canada Field

83 Peas, Cow

90 Peas. Crowder.

53 Peas, Gallavant.

63 Pencillaria

20 Pepper

9l Pepper Plants.

88 Perennial Rye Grass

$\begin{array}{lll}59 & \text { to } 63 & \text { Petsai, Chinese. } \\ \end{array}$

89 Phospha

77 Pigeon Food

82 Plantabs

85 Plant Bed Cloth

26 Planet. Jr., Tools

\section{Pag}

Planters, Corn and

otato

60 Pants. Vegetable

60 Plows, Garden.

83 Potatoes

89 Potato Planter

82 Pot Labels

38 Pots. Paper.

82 Poultry Supplies and

23 Remedies

85 Powder Dusters

20, 38 Pratt's Poultry Food

Page

92 Pruners.

91 Pruning Knife

Pumpkin.

26

87. 88 R Raffia.

60 Randall Grass

78 Red Arrow Spray

20 Red Top or Herds Grass.

Rhubarb

61 Rhubarb Roots

Roller. Lawn

91 Rough Stalked Meadow

20 Grass Hoser

88 Rust's Poultry Prepa-

91 Ruta Baga.

90

90 Sage Roots

89 Salsify or Oyster Plant.

20 Scythe Stone

86 Scale Oil

21, 38 Seaside Bent Grass

83 Seed Sowers

81 Semesan

Shears

83 Sheep Fescue

53 Shipping Coops

87 Slug Sho

11 Soda. Nitrate of

60 Sodium Fluosilicate

63 Sorghum

22.23 Soy or Soja Beans

24. 25 Spadins

(a)

78 Sprayers and Dusters.

83 Spray Materials

89 Spring Pasture Mixture

90 Squash or Cymling

89 Stimugerm

73 Stimuplant

6 String, Jute.

26, 47 Sudan Grass

86 Sulphate of Ammonia

81 Sulpho Tobacco Soap

85 Sulpho Tobacco Soap

8 Sunflower for Feeding.

68 Sunflower for Planting.

82 Sweet Peas

83 Sweet Potato Plants

26 Swiss Chard

26 Tall Meadow Oat Grass

60 Teosinte

31 Thermometers.

82 Thy-Cresol

91 Thyme R

88. Tobacco

87 Tomato

26 Tomato Plants

30 Tools, Garden.

59 Trap, Mole.

62. 69 Tree Tanglefoot

77 Tree Wound Diessing...

79 Trowels. Garden

76 Tree Labels

73 Troughs, Feeding. 84, 8

76 Tuberoses.

72. 73 Turnip

73 Vegetable Plants
28, 29 Velvet Beans

79 Vetch

30.38

60 Wa!ko Tablets

14 Water Fountains.

81 Water Glass.

31 Watermelon

82 Wax, Grafting

88 Weeders

89 Weed Killer.

90 Worm Capsules. 


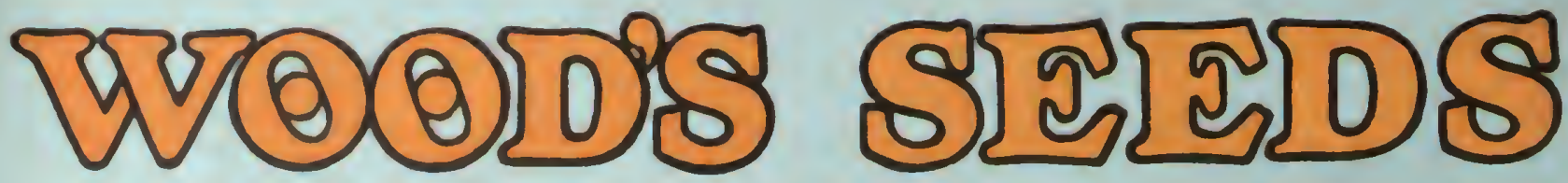 1935}

T.W.WOOD \& SONS

SEEDSMEN SINCE 1879

RICHMOND, VA.

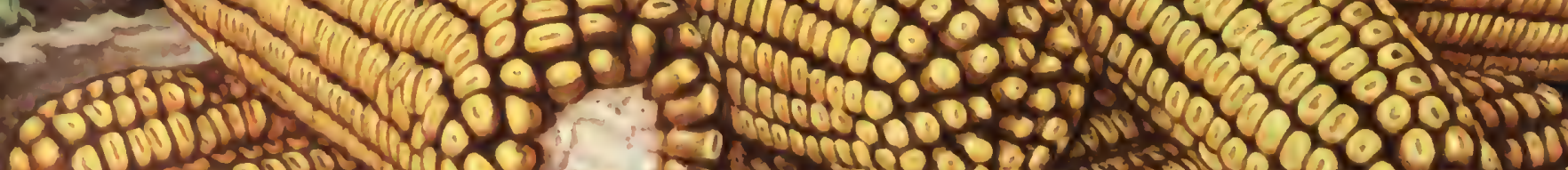
¿240

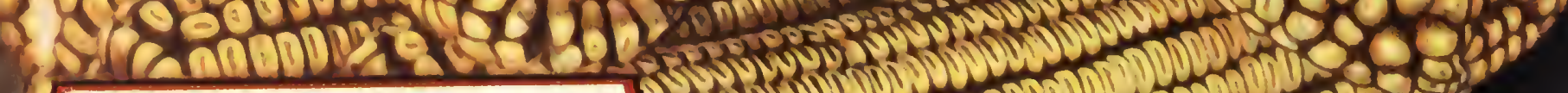

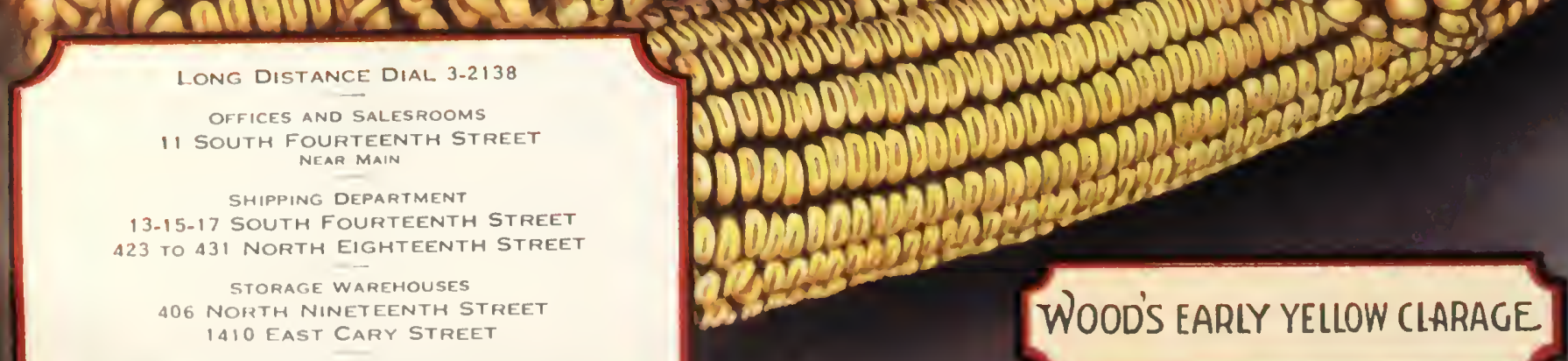

